Mara Angelina Galvão Magenta

\title{
Viguiera Kunth (Asteraceae, Heliantheae) na América do Sul e sistemática das espécies do
} Brasil

Tese apresentada ao Instituto de Biociências da Universidade de São Paulo, como parte dos requisitos necessários à obtenção do título de Doutor em Ciências, Área de Botânica.

Orientador : Prof. Dr. José Rubens Pirani Co-orientador: Dr. David John Nicholas Hind

São Paulo

2006 
Magenta, Mara Angelina Galvão

Viguiera Kunth (Asteraceae, Heliantheae) na América do Sul e sistemática das espécies do Brasil vii +339 páginas + apêndices

Tese (Doutorado) - Instituto de Biociências da Universidade de São Paulo. Departamento de Botânica.

1. Viguiera. 2. Asteraceae. 3. Heliantheae. 4. Taxonomia

5. Palinologia 6. Filogenia 7. América do Sul 8. Biogeografia

Universidade de São Paulo. Instituto de Biociências

Comissão Julgadora:

Prof (a). Dr(a).

Prof (a). Dr(a).
$\operatorname{Prof}(\mathrm{a}) . \operatorname{Dr}(\mathrm{a})$

$\operatorname{Prof}(\mathrm{a}) . \operatorname{Dr}(\mathrm{a})$.

Prof. Dr. José Rubens Pirani

Orientador

Dr. David John Nicholas Hind

Co-orientador 
Aos amados que me geraram, aos amados que gerei, aos amados que me acompanham $e$ aos amados que se foram... 


\section{Agradecimentos}

Ficam aqui expressos meus sinceros agradecimentos às pessoas e instituições que por vias diretas ou indiretas permitiram a realização deste trabalho.

Ao Departamento de Botânica da Universidade de São Paulo, onde foi desenvolvida a maior parte desta tese.

Ao IBAMA, pela concessão das ficenças de coleta em Parques $\mathcal{N a c i o n a i s . ~}$

Aos Herbários: K (Royal Botanic Garden - Kew), e $\mathcal{M}$ (Botanische Staatssammlung München), P (Muséum National d'Histoire Naturele) e BR(Jardin Botanique National de Belgique), pelo acesso às coleções e obras históricas e utilização das instalações e infra-estrutura.

À UNISANTA pelo uso das instalações e do microscópio eletrônico durante o desenvolvimento deste trabalho.

Aos curadores dos herbários visitados ou contatados, pela amabilidade e atenção com que sempre me receberam, e pelo empréstimo das coleções e envio de imagens de tipos.

Ao meu orientador Prof. Dr. José Rubens Pirani, por todo o ensino, pelas palavras de incentivo, e pelas sábias críticas construtivas.

Ao meu co-orientador, Dr. David John $\mathcal{N i c h o l a s ~ H i n d , ~ p e l a s ~ m u i t a s ~ h o r a s ~ d e ~ c o n v e r s a s ~ s o b r e ~ h i s t o ́ r i a ~ d a ~ b o t a ̂ n i c a , ~ i d a s ~ a ̀ ~}$ biblioteca e esclarecimentos sobre nomenclatura e auxífio no acesso a obras raras.

Aos professores Departamento de Botânica da USP, especialmente ao Renato, ao Paulo e à Lúcia.

Aos pesquisadores do Instituto de Botânica de São Paulo, que há muitos anos me recebem com alegria e boa vontade.

Às pessoas ligadas ao Royal Botanic Gardens, que me acolheram, compartifhando seu conhecimento, especialmente a Dra.

Daniela Zappi, por sua sensibilidade no tratamento com os pesquisadores convidados.

À Dra. Vânia Esteves, que, juntamente com sua equipe, nas pessoas de Cláudia Mendonça e Alessandra Junes, conduziu as investigações palinológicas para este trabalho.

À Dra. Cláudia Vecchi, pela co-autoria do capítulo de anatomia e por que "ninguém é amigo à toa".

À Profa. Msc. Verônica Araújo, pela longa amizade e pelos cortes fistológicos e auxílio na coloração das lâminas, a mim concedidos como presentes.

Ao Eugenio, por todo o apoio emocional e logístico durante a tese; impossiveis de enumerar aqui.

Aos meus filhos Leandro (também pelo auxílio na confecção dos mapas de distribuição e impressão da tese), Caio (também pela confecção da capa da tese) e Murilo (por realizar várias tarefas em meu lugar e ler o capítulo), por serem os melhores filhos do mundo em todos os sentidos e pelo apoio recebido na finalização deste trabalho.

Aos meus pais, por suportarem minha ausência.

À Aparecida, minha auxiliar nos serviços domésticos há mais de 20 anos.

Ao Abel è à Elisa, responsáveis pelo processamento e registro das coleções.

Ao Irvandro, da USP, pela metalização das amostras e ao Sr. Wilson, da VNISANTA, pelo auxílio no manejo do M.E.V.

Ao Mateus, à Lígia, a Jucemara e a todos os estagiários do LAPEBIO, da Vniversidade Santa Cecília, pelo apoio logístico especial, durante o desenvolvimento deste trabalho.

À Suzana Martins pela amizade, trabalho em parceria e desprendimento. [

Aos pós-graduandos do departamento de Botânica da USP, pelas trocas de informações e amizade com que me brindaram durante o desenvolvimento desta tese.

Ao colega Pedro Dias, pelo programa de obtenção de georeferências (NNL) e sugestões de leitura de textos sobre filogenia. À Maria Fernanda Cafió por compartilhar dúvidas e conhecimentos e me prestar favores enormes, apesar de tão atarefada. Ao Amauri, pela amizade e auxífio na análise conjunta de dados moleculares e morfológicos.

A Maria Ana pela meiguice e sensibilidade, às vezes tão necessárias durante os momentos críticos e por todas as coisas em que me ajudou.

À Rafaela, pela amizade nunca diminuída, mesmo com a distância.

À amiga Mara Calabrez, em grande parte responsável por minha decisão em seguir a carreira acadêmica.

À Dra. Ana Giulietti, que um dia confiou em minha capacidade, abrindo as portas do mundo acadêmico.

À querida Nanuza, pelo entusiasmo eterno.

À Denise, pelo empenho em digitar as etiquetas das fotos do herbário $\mathcal{N} Y$ e por examinar uma certa planta do Peru...

Ao Leandro, pelas fotografias dos tipos de Rhysolepis, adquiridas no herbário MBM.

Aos queridos olegas Lia, Cristina, Jufiana, Renata, Alexandre (He-man), Benoit, Gledsley (Gepeto), Ivan (Carimbo), Leonardo (Caqui) Luís, Marcelo (Cabeção), Matheus (Bozo)e Rodrigo (Sumo), pela alegria que compartifham todos os dias. À $\mathcal{N} a r a$, pelo abstract do capítulo de biogeografia e à Letícia, pelo auxífio na formatação da chave de identificação.

Ao Klei, que pela sua nobreza de espírito na adaptação de suas lindas ilustrações ao estilo de Emiko Naruto e que, apesar de há tão pouco tempo conhecido, tornou-se uma pessoa muito querida.

Finalmente, a muito querida amiga Emiko Naruto (in memorian) por tantos anos de dedicação de sua maravilhosa arte à ifustração botânica, por sua doçura, sabedoria e amizade, a quem dedico as ilustrações desta tese. 


\section{SUMÁRIO}

Abstract e resumo ............................................................................................................................... vi

\section{Capítulo I}

Introdução geral: O gênero Viguiera Kunth

\section{Capítulo II}

Caracterização morfo-anatômico foliar de espécies sul-americanas do gênero

Viguiera (Heliantheae - Asteraceae) como subsídio a estudos taxonômicos.

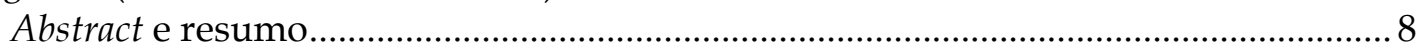

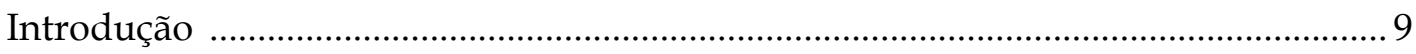

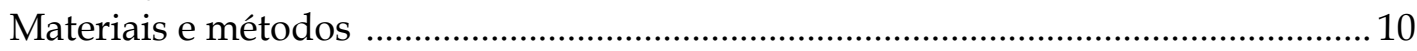

Resultados

Caracterização morfológica

Caracterização anatômica ................................................................................ 14

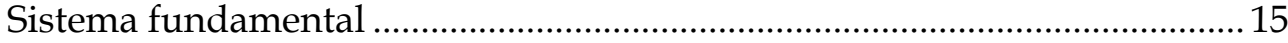

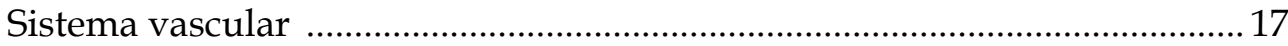

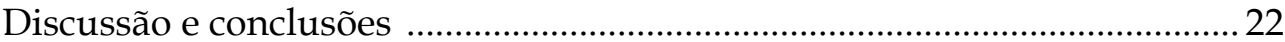

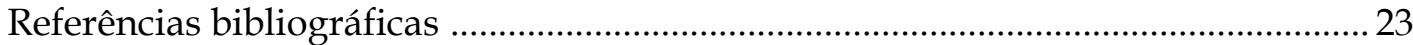

\section{Capítulo III}

Palinotaxonomia de espécies brasileiras de Viguiera Kunth

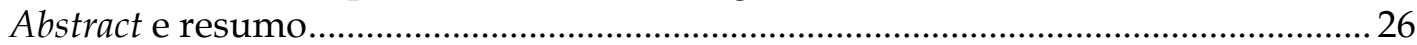

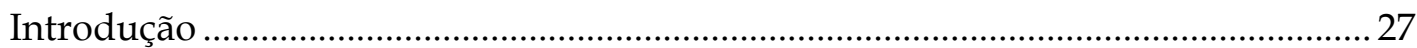

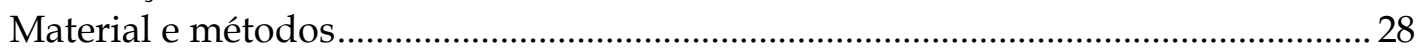

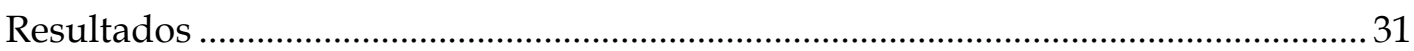

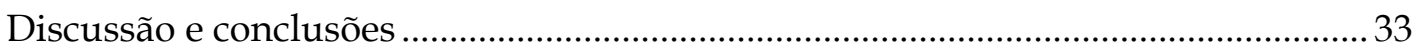

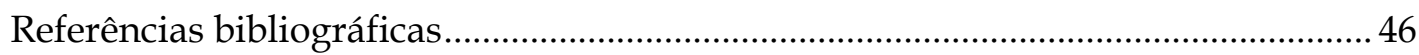

\section{Capítulo IV}

Análise filogenética de Viguiera sensu lato com base em caracteres morfológicos

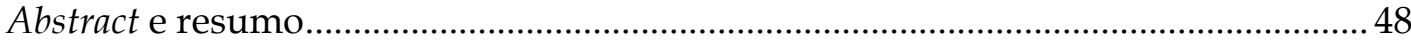

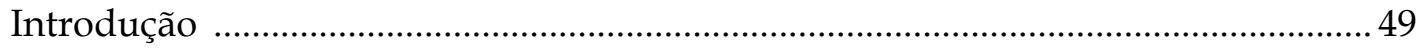

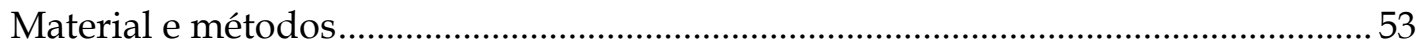

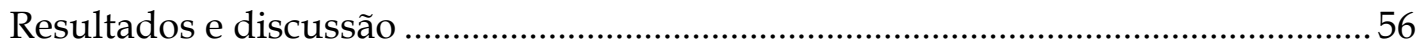

Análise dos caracteres listados na tabela 2 e selecionados para a construção da matriz apresentada na tabela 3; teste das hipóteses filogenéticas propostas em outros trabalhos; Padrões de distribuição.

Conclusões

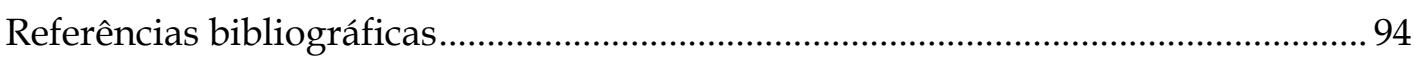

\section{Capítulo V}

Tratamento taxonômico das espécies de Viguiera Kunth da América do Sul com revisão das espécies do Brasil.

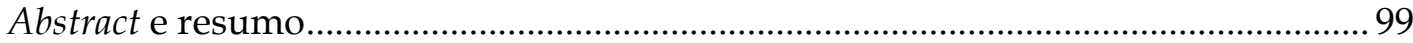

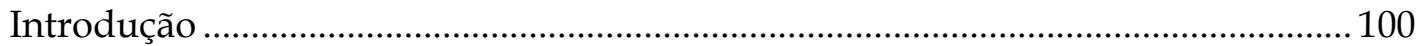

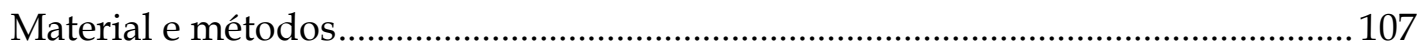

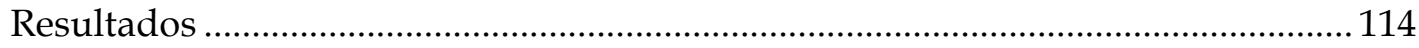

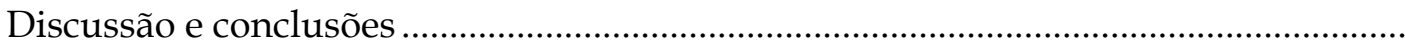

Lectotipificação do basônimo de Viguiera dentata (Cav.) Spreng .................114

Morfologia e outros aspectos das espécies sul-americanas ......................... 115

Chave artificial para separação de Viguiera sul-americanas e táxons morfologicamente relacionados de outras partes americanas .................... 127

Chave artificial para identificação das espécies de Viguiera América do 
Sul 130

Estudo das espécies

1. V. amphychlora

141

2. V. anchusifolia

144

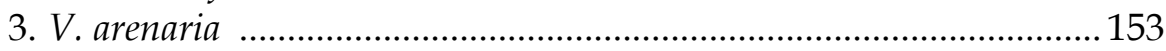

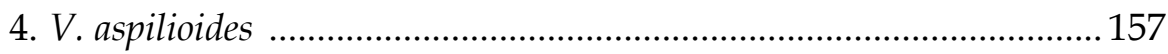

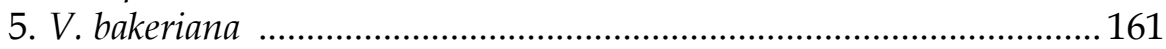

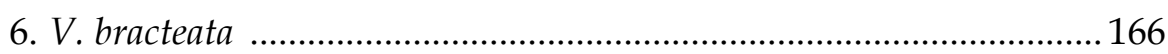

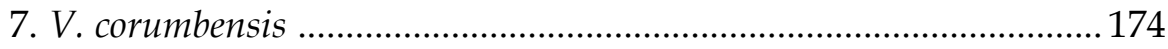

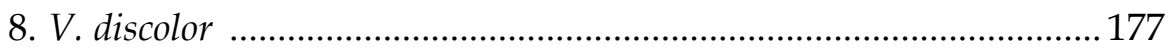

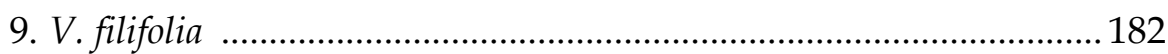

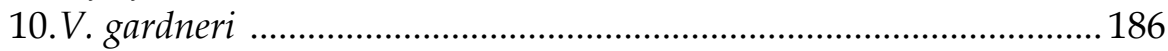

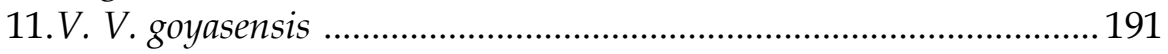

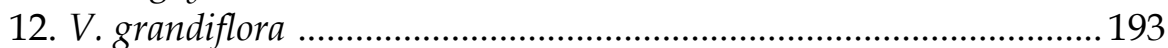

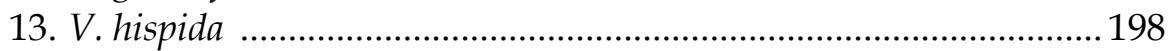

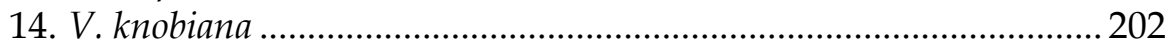

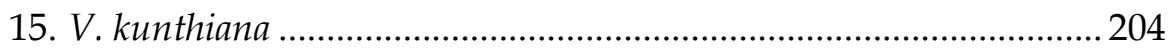

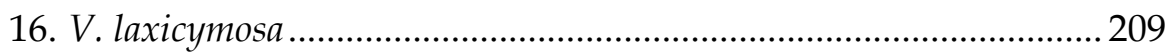

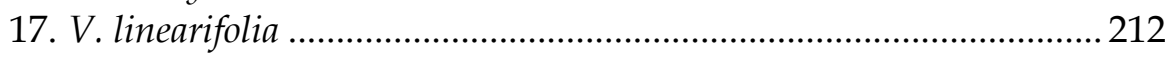

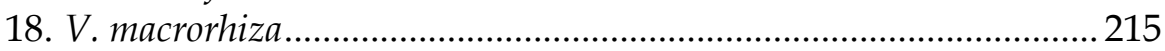

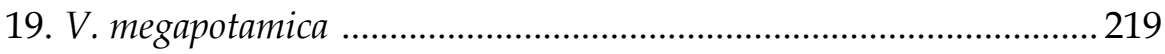

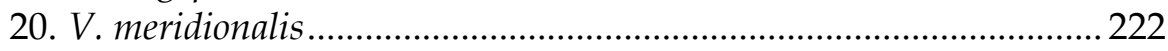

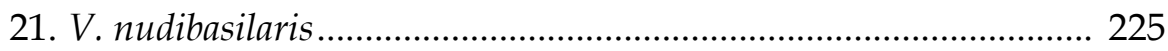

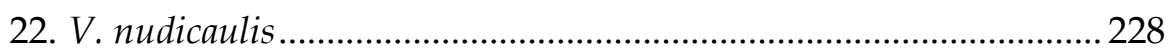

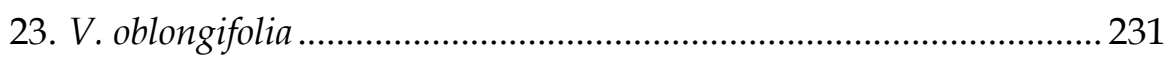

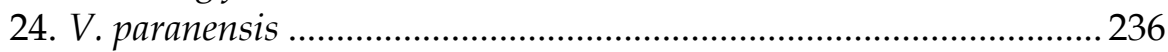

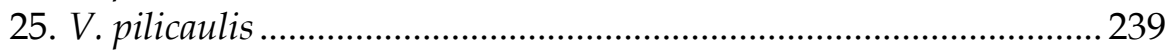

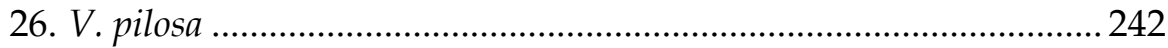

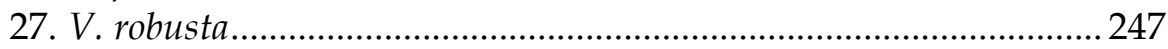

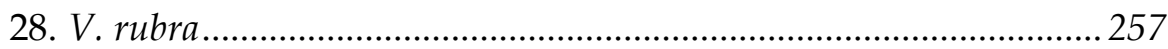

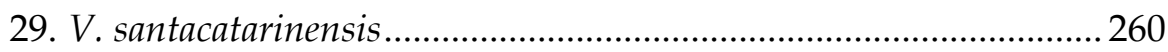

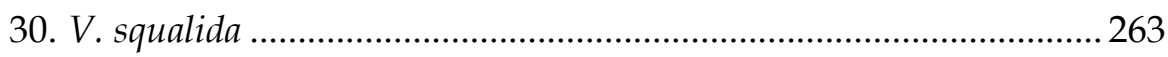

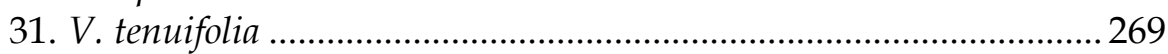

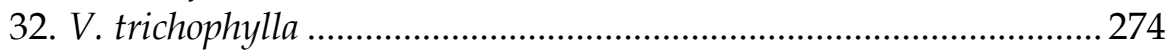

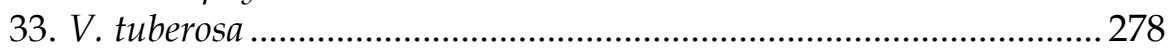

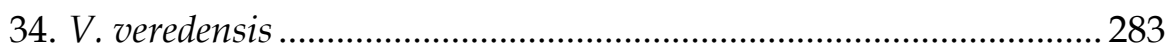

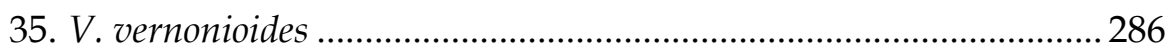

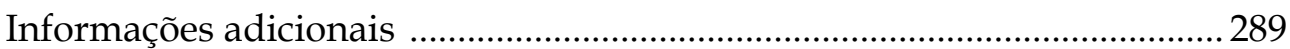

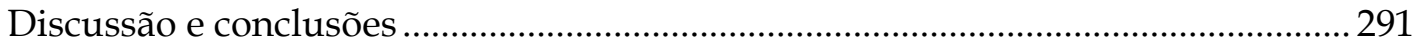

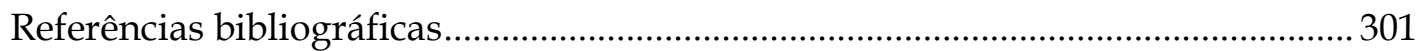

\section{Capítulo VI}

Biogeografia de Viguiera da América do Sul

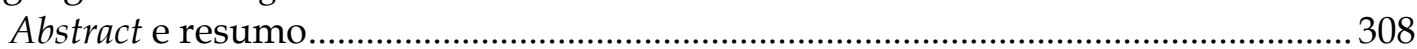

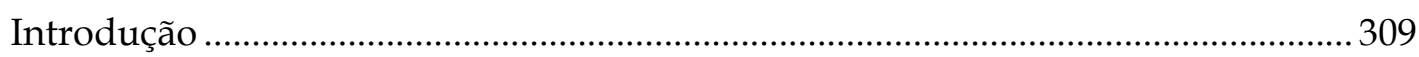

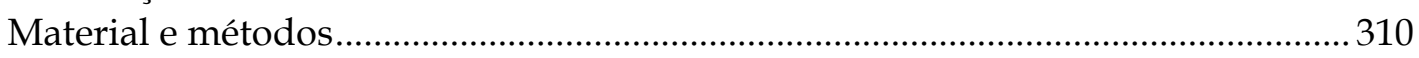

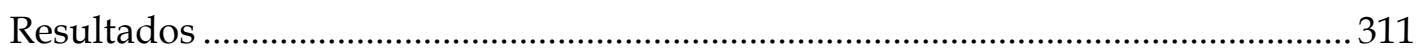

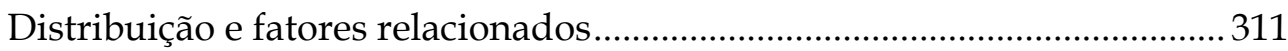

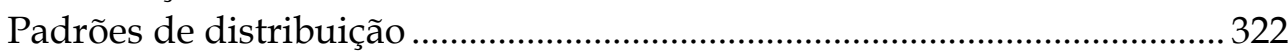


Discussão e conclusões 333

Referências bibliográficas.

\section{Capítulo VII}

Considerações finais e comentários 337

Referências bibliográficas.

\section{Apêndice A}

Índice de coletores e exsicatas

A. Plantas analisadas para a revisão das espécies brasileiras

B. Plantas analisadas para a elaboração da filogenia ou determinação dos padrões de distribuição geográfica

\section{Apêndice B}

Índice de Herbários consultados

\section{ÍNDICE DE FIGURAS E TABELAS}

\section{Capítulo II}

Fig. 1: Nervação padrão do gênero

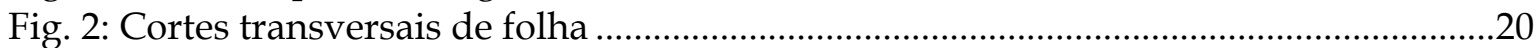

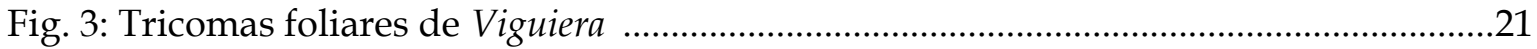

Tab. 1: Lista das espécies analisadas em microscopia de luz e eletrônica de varredura .....12

Tab. 2: Caracteres anatômicos de folhas de Viguiera e Flourensia

\section{Capítulo III}

Fig. I: Imagens 1-35. Fotomicrografias e eletromicrografias de espécies de Viguiera: $V$. amphychlora, V. anchusaefolia, V. aspilioides, V. bakeriana, V. bracteata, V. corumbensis e V. filifolia

Fig. II: Imagens 36-70. Fotomicrografias e eletromicrografias de espécies de Viguiera: $V$. gardneri, V. grandiflora, V. hispida, V. kunthiana, V. macrorhiza, V. megapotamica, $V$. nudibasilaris e $V$. oblongifolia

Fig. III: Imagens 71-105. Fotomicrografias e eletromicrografias de espécies de Viguiera: $V$. oblongifolia (cont.), V. paranensis, V. pilosa, V. robusta, V. rubra, V. santacatarinensis, $V$. squalida, $V$. tenuifolia, $V$. trichophylla, $V$. tuberosa, e $V$. veredensis

Tab. 1: Medidas dos grãos de pólen de espécies de Viguiera em vista equatorial ..............37

Tab. 2: Médias dos grãos de pólen de espécies de Viguiera em vista polar ............................38

Tab. 3: Médias das aberturas e da exina dos grãos de pólen de espécies de Viguiera .........39

Tab. 4: Medidas dos grãos de pólen em vista equatorial dos materiais de comparação .....40

\section{Capítulo IV}

Fig. 1: Parte 1 de 3 da árvore de consenso estrito das 9 árvores igualmente parcimoniosas obtida com a análise morfológica de 143 terminais

Fig. 2: Parte 2 de 3 da árvore de consenso estrito das 9 árvores igualmente parcimoniosas obtida com a análise morfológica de 143 terminais

Fig. 3: Parte 3 de 3 da árvore de consenso estrito das 9 árvores igualmente parcimoniosas obtida com a análise morfológica de 143 terminais

Fig. 4: Parte 1 de 2 da árvore única obtida com a análise morfológica de 106 terminais ....87

Fig. 5: Parte 2 de 2 da árvore única obtida com a análise morfológica de 106 terminais ...88 
Fig. 6: Parte 1 de 2 da árvore de consenso estrito das 2 árvores igualmente parcimoniosas obtida com a análise morfológica de 68 terminais

Fig. 7: Parte 1 de 2 da árvore de consenso estrito das 2 árvores igualmente parcimoniosas obtida com a análise morfológica de 68 terminais

Tab. 1: Quadro sinóptico da classificação de Viguiera Kunth (Blake 1918) e táxons correspondentes, de acordo com propostas recentes.

Tab. 2: Lista de caracteres morfológicos externos e estados de caráter (expressões) utilizados nas análises

Tab. 3: Matriz das expressões de caracteres utilizados nas análises filogenéticas .70

\section{Capítulo V}

Fig. 1: Peças do capítulo de Viguiera e táxons relacionados: $V$. dentata, Rhysolepis palmeri, e

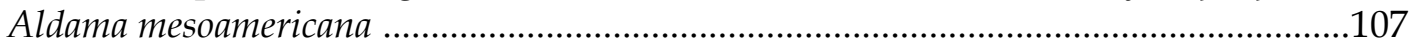

Fig. 2: Sistema subterrâneo com raízes adventícias de $V$. nudibasilaris, $V$. hispida, $V$. oblongifolia, $V$. nudicaulis, $V$. tenuifolia e $V$. aspilioides ..............................................118

Fig. 3: Aspectos da morfologia foliar de $V$. discolor, $V$. tenuifolia, $V$. nudicaulis, $V$. veredensis,

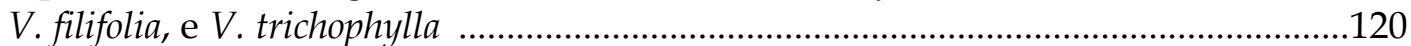

Fig.4: A-H. Esquemas de sinflorescências de Viguiera sul-americanas: $V$. linearifolia, $V$. bracteata, $V$. robusta, $V$. tenuifolia, $V$. anchusifolia......

Fig. 5: Inflorescências de Viguiera do Brasil: V. robusta, V. oblongifolia, V. filifolia, V. gardneri

Fig. 6: Tipos de invólucro do capítulo de V. grandiflora, V. kunthiana, V. rubra, V. veredensis,

$V$. robusta e $V$. trichophylla 124

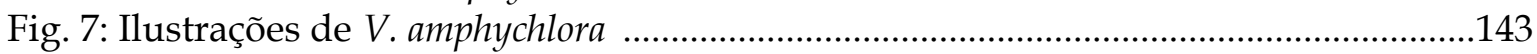

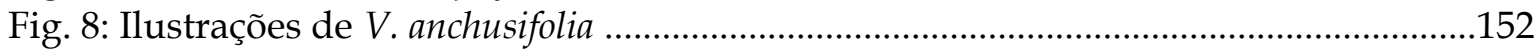

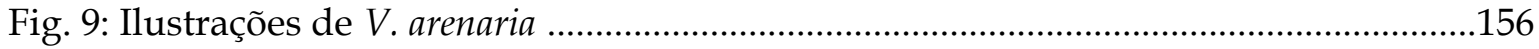

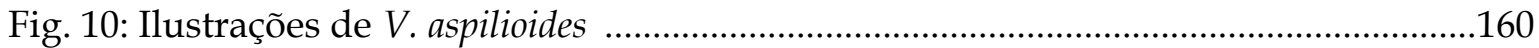

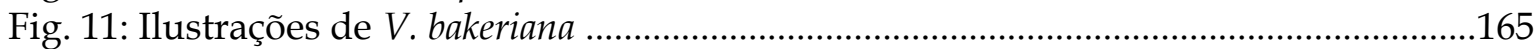

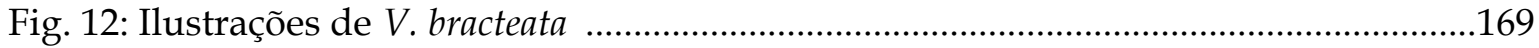

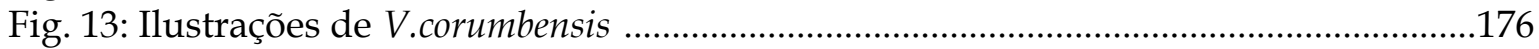

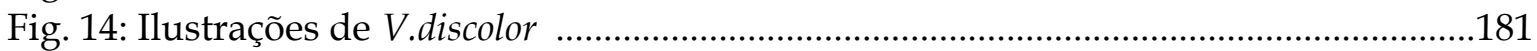

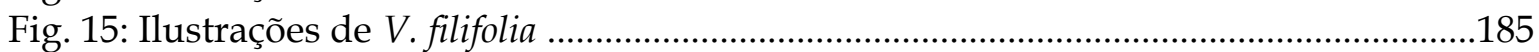

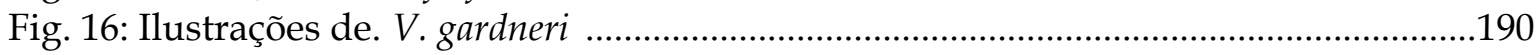

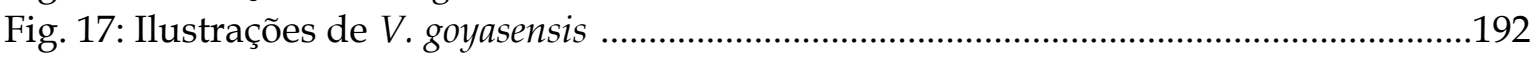

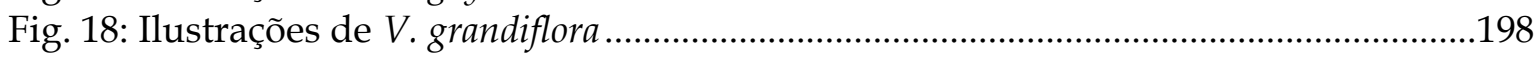

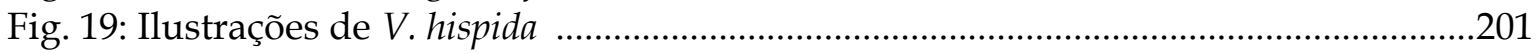

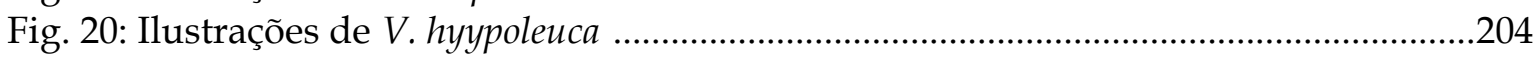

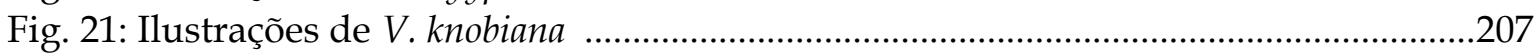

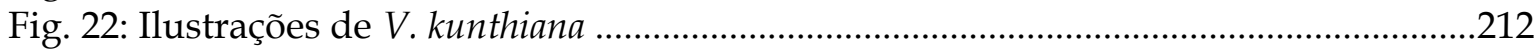

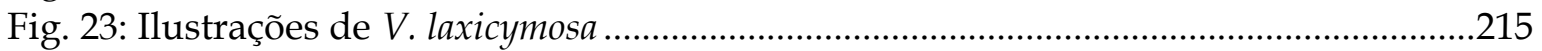

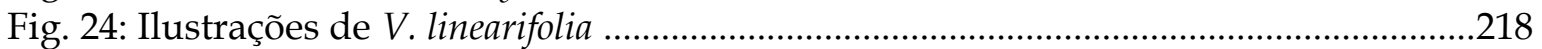

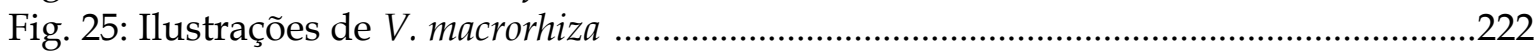

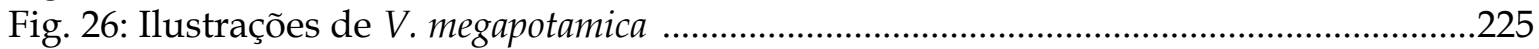

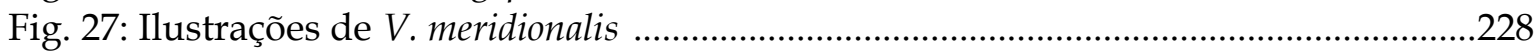

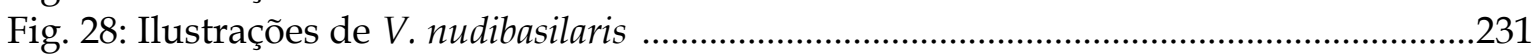

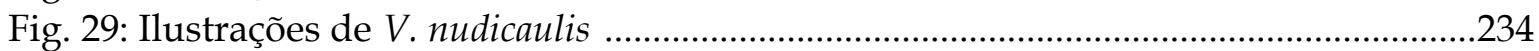

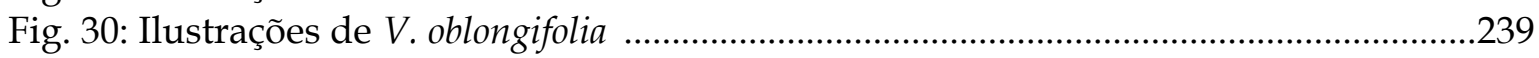

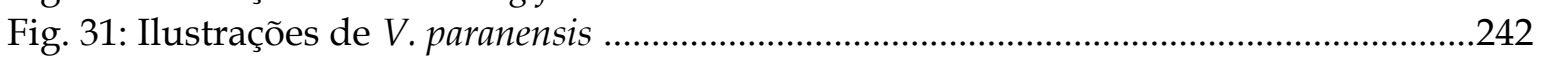

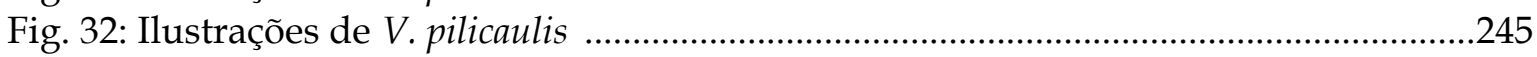

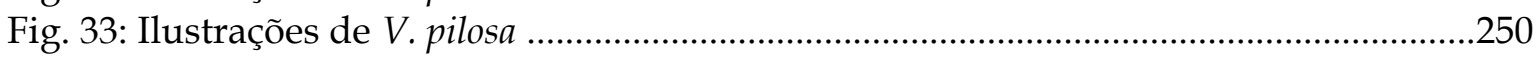

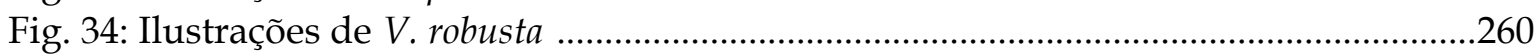




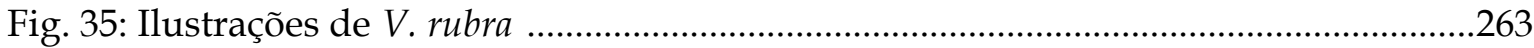

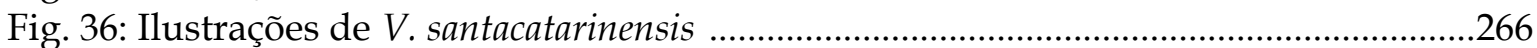

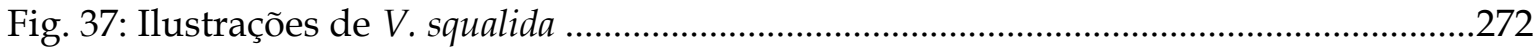

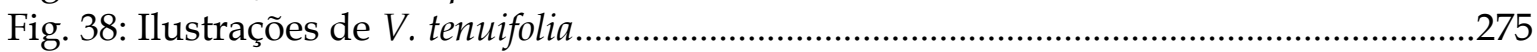

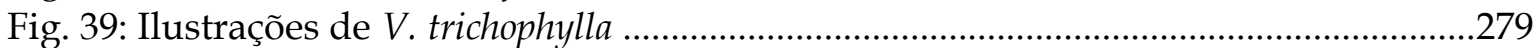

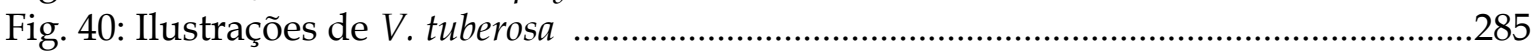

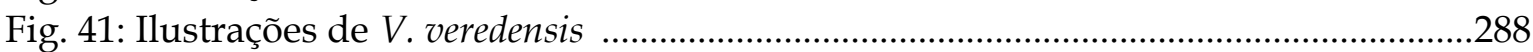

Fig. 42: Mapas 1 e 2 de distribuição de Viguiera no Brasil ..................................................296

Fig. 43: Mapas 3 e 4 de distribuição de Viguiera no Brasil ..................................................297

Fig. 44: Mapas 5 e 6 de distribuição de Viguiera no Brasil .....................................................29

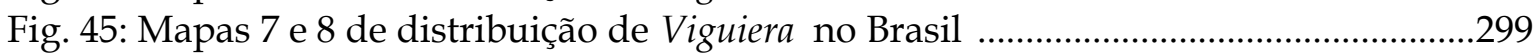

Fig. 46: Mapas 9 e 10 de distribuição de Viguiera no Brasil ....................................................300

Tab. 1: Período e áreas de coletas de materiais por regiões dos estados .............................113

\section{Capítulo VI}

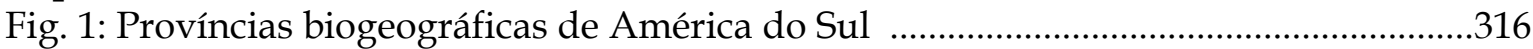

Fig. 2: Correlação entre os sub-padrões do Padrão Cerradense e o clima ..............................326

Fig. 3: Domínios dos Campos de Gramíneas da América do Sul ..........................................328

Fig. 4: Padrões de distribuição do grupo 1 (espécies andinas): Paramense, Desértico, Desértico - Árido - Punense, Atacamense, Coquimbense, e Punense Central-Úmido

Fig. 5: Padrões de distribuição andinos (grupos 1 e 2): Atacamense-Patagônico, Patagônico Central - Prepunense, Padrão contínuo Paramense - Chaquense, Padrão contínuo Yunguense - Chaquense

Fig. 6: Padrões de distribuição do grupo Neotropical: Pampeano, Pampeano - Paranense, Pinheirense, Pinheirense - Atlântico

Fig. 7: Padrões de distribuição do grupo Neotropical: Pampeano - Chaquense, Pantaneiro, Pantaneiro - Cerradense

Fig. 8: Padrão de distribuição Cerradense do grupo Neotropical - espécies brasileiras não exclusivas: $V$. amphychlora, $V$. linearifolia, $V$. pilicaulis e $V$. macrorhiza

Fig. 9: Padrão de distribuição Cerradense do grupo Neotropical - espécies brasileiras exclusivas. A. V. robusta, V. bakeriana, $V$. arenaria

Fig. 10: Padrão de distribuição Cerradense do grupo Neotropical - espécies brasileiras exclusivas. V. hypoleuca, V. oblongifolia, V. gardneri, $V$. goyazensis e V. laxicymosa .332

Fig. 11: Padrões de distribuição do grupo Neotropical - espécies brasileiras exclusivas. $V$. grandiflora, $V$. veredensis, $V$. rubra

Fig. 12: Padrões de distribuição do grupo Neotropical - espécies brasileiras exclusivas: $V$. filifolia, V. kunthiana, V. bracteata

Tab. 1:. Eco-regiões de ocorrência das espécies da América do Sul 
Abstract

This study presents a taxonomic review of the species Viguiera Kunth that occur in Brazil, and includes descriptions, illustrations, distribution maps and comments. Identification keys are also provided for related groups and to the South American species.

The leaf anatomy study supplied new subsidies for the delimitation of the species or of species groups.

The pollinic analysis either presents useful partial information in taxonomy.

An investigation was elaborated on Viguiera sensu lato, through three analyses, involving different numbers of terminal taxa and using morphological data; the first one tried to explain the real taxonomic position of its representative members and the last two sought for a better delimitation of the groups of species in the Continent.

The analysis of the patterns of geographic distribution made possible the delimitation of two groups with different morphological characteristics, and a intermediate one; the first group is exclusive from Andean region, the second not happens in the Andes, and the third do not occur in the Andes, with a few intrusions in other localities. The results also corroborate others author's hypothesis, that the origin of the genus is recent in Brazil. In relation of the edaphic conditions, there are two groups of species in Brazil: the first one is found in regions with climate of the type Cwa and the second in the climate of the type Aw, of the Köpen classification; only 4 species happen in climate Cfa, but they are not exclusively Brazilian.

There was no support for the transfer of the South American species to the genus Rhysolepis.

\section{Resumo}

É apresentada aqui a revisão taxonômica das espécies de Viguiera Kunth que ocorrem no Brasil, com inclusão de descrições, ilustrações, mapas de 
distribuição e comentários. Também são providas chaves de identificação para grupos relacionados e para as espécies sul-americanas.

O estudo da anatomia foliar forneceu novos subsídios para a delimitação de espécies ou grupo de espécies.

As análises polínicas também apresentam informações parciais úteis à taxonomia.

Foi elaborada uma investigação sobre Viguiera sensu lato, através de três análises envolvendo diferentes números de táxons terminais, com uso de dados morfológicos; a primeira visou o esclarecimento da real posição taxonômica de seus representantes e as duas últimas pleitearam uma melhor delimitação dos grupos de espécies no continente.

A análise dos padrões de distribuição geográfica possibilitou a delimitação de dois grupos com características morfológicas distintas, além de um intermediário; o primeiro exclusivo da região dos Andes, o segundo extraandino e o terceiro andino com pequenas intrusões em outras localidades. Os resultados também corroboram a hipótese de outros autores, de que a origem do gênero é recente no Brasil. Em relação às condições edáficas, existem dois grupos de espécies no Brasil; o primeiro encontrado em regiões com clima do tipo Cwa e o segundo no clima do tipo Aw, da classificação de Köpen; apenas 4 espécies ocorrem em clima Cfa, mas não são exclusivamente brasileiras.

Não houve respaldo para a transferência das espécies sul-americanas para o gênero Rhysolepis. 


\section{CAPÍTULO I}

\section{INTRODUÇÃO GERAL}

A família Asteraceae possui cerca de 11000 gêneros e mais de 20000 espécies e é economicamente uma das mais importantes entre as angiospermas. Seus representantes possuem hábito variado; muitas são ser ervas ou subarbustos ou, excepcionalmente, árvores ou epífitas; muitas são escandentes. As folhas são simples, na maioria das vezes alternas, e podem ser opostas em Heliantheae e Eupatorieae ou raramente verticiladas; apresentam-se sésseis ou pecioladas; às vezes são reduzidas, aciculares ou escamiformes.

As inflorescências são do tipo capítulo, involucrado por uma ou mais séries de brácteas, denominadas brácteas involucrais; os capítulos podem estar agregados secundariamente em outros tipos de inflorescências paniculiformes, tirsiformes, corimbiformes, racemiformes, ou mesmo em capítulos de segunda ordem; os capítulos assim agregados são tradicionalmente tratados como conflorescências ou sinflorescências.

A família é aceita como um grupo bem definido, mas a uniformidade dos capítulos dificulta a delimitação das tribos e dos gêneros (Jeffrey 1978). Os paralelismos, presentes com grande freqüência, têm feito a reconstrução filogenética e a circunscrição das tribos tema de grande debate (Bayer \& Starr, 1998).

No conceito de Stuessy (1977), a tribo Heliantheae compreende 15 subtribos, 189 gêneros, e cerca de 2500 espécies. Para Robinson (1981) as subtribos somam 35, com cerca de 3000 espécies distribuídas em 260 gêneros e incluem os representantes de Helenieae (Heliantheae senso lato). Karis \& Ryding (1994) adotaram a definição estrita da tribo, mas admitem sua relação com Helenieae e Eupatorieae. A tribo possui representantes cosmopolitas, sendo principalmente tropical e subtropical, com centro de diversificação no México central (Cronquist 1977). Dos 50 gêneros representados no Brasil, 
poucos são endêmicos. Segundo Robinson (1981), seus representantes primitivos possuem folhas opostas, enquanto os derivados, folhas alternas, inteiras ou partidas, geralmente estrigosas. Os capítulos são geralmente heterógamos radiados, ou às vezes homógamos, com brácteas involucrais fraca a fortemente imbricadas, foliáceas ou membranáceas ou dimórficas nos grupos mais avançados e receptáculo com páleas ou epaleáceo, nas formas mais derivadas. As flores geralmente apresentam pigmento amarelo; sendo do raio são liguliformes, com ápice inteiro ou 1-2-partido; as do disco tubulosas, pentâmeras, com anteras escurecidas e tecas de base obtusa, aguda ou sagitada, que raramente se estendem abaixo do colar filetal; o estilete é 2partido, com linhas estigmáticas paralelas nos ramos de ápice agudo. Possui frutos do tipo cipsela, ou às vezes aquênio, 4-5-gonais ou comprimidos e pápus de páleas ou aristas, raramente plumoso ou ausente.

A subtribo Helianthinae, que inclui o gênero Viguiera, é caracterizada flores do raio neutras, dutos externos às nervuras do estilete e cipselas com paredes estriadas (Karis 1993, Robinson 1981). Esta subtribo é quase inteiramente neo-ártica e neotropical e seus gêneros concentram-se no Continente americano, principalmente no México e nos Estados Unidos. Estudos morfológicos (Robinson 1981, Karis 1993, Bremer 1994) e de dados moleculares (Schilling \& Panero 1991 1996, Schilling et al. 1994)) têm confirmado sua monofilia. No entanto, revelaram um problema taxonômico sério, em relação à delimitação e circunscrição do gênero Viguiera, fato também observado por Karis \& Ryding (1994).

Viguiera é um gênero exclusivamente americano, compreendendo cerca de 180 espécies na sua concepção mais ampla, que o caracteriza pela presença de flores do raio neutras, cipselas estriadas e pápus persistente com duas aristas intercaladas por escamas paleáceas Blake (1918). Desde seu estabelecimento, por Kunth (1820), sofreu várias adições (Bentham 1873, Hemsley 1881, Baker 1884, Baillon 1886) até a publicação do tratamento clássico, elaborado por Blake (1918). Nesta revisão, as espécies foram distribuídas em seções bastante artificiais, incluídas em dois subgêneros, com 
base em caracteres do invólucro, complementados por caracterizações do hábito e informações subjetivas sobre o tamanho do capítulo e morfologia do pápus. Na circunscrição do autor, as espécies sul-americanas estão incluídas nas seções Paradosa e Trichophylla do subgênero Calanticaria e no subgênero Yerbalesia ocorrem no Brasil, Chile, Paraguai, Uruguai e na Argentina.

Nas últimas duas décadas, ressurgiu o interesse pela resolução dos problemas de delimitação do gênero, com inferências a partir de caracteres morfológicos (Robinson 1977, Panero \& Schilling 1988) e moleculares (Schilling \& Jansen 1989, Schilling et al. 1994 2000; Schilling \& Panero 1991, 1996), os quais demonstraram repetidas vezes o parafiletismo de Viguiera sensu lato e indicaram alguns grupos de táxons propostos por Blake (1918) como monofiléticos, os quais Schilling \& Panero (2002) propuseram ser elevados ao nível genérico.

Levantamentos florísticos efetuados no Brasil, como o das Heliantheae do Rio Grande do Sul (Mondin 2004), o das Asteraceae da Serra da Canastra, Nakajima (2000), e as Floras Fanerogâmicas do Estado de São Paulo e do Distrito Federal (Magenta em preparação) também se deparam com problemas de delimitação específica; o estudo de material depositado nos herbários consultados, mostra a ocorrência de espécimes intermediários (observ. pess.) entre várias espécies.

Em 1971, Salgado-Laboriau caracterizou o pólen de espécies de Viguiera e enquadrou-os no padrão Helianthóide (Skvarla \& Turner, 1966). Em 1989, Gonçalves-Esteves e Esteves elaboraram um estudo polínico de 12 espécies ocorrentes no Brasil; a baixa amostragem de espécies nesses trabalhos não permitiu, no entanto, inferências sobre a relação entre as espécies representantes do Brasil.

Não há registros de trabalhos anatômicos relevantes para o grupo em questão, mas existem análises de gêneros da mesma tribo, como os de Clark et al. (1980) e Charest-Clark (1994) que analisaram o gênero Encelia e Machado et al., que trabalharam com sistema subterrâneo de Smallanthus sonchifolius. 
Abordagens sobre biogeografia do gênero também são escassas, conhecidas apenas de comentários em trabalhos filogenéticos (Schilling et al. 2000, Schilling \& Panero 1996 2002).

Importantes descobertas sobre a composição química do grupo vêm sendo efetuadas (Isejima et al. 1991, Da Costa 1996, Schorr et al. 1999, Itaya et al. 1997).

$\mathrm{Na}$ tentativa de estabelecer uma relação filogenética entre as espécies sul-americanas, Schilling et al. (2000) elaboraram uma análise na qual foi utilizado DNA nuclear (ITS), que incluiu nove das espécies brasileiras; não obstante o DNA nuclear ser comprovadamente útil em muitos grupos de Asteraceae (Jansen \& Palmer 1987 1988; Jansen et al. 1990 1991) o método demonstrou baixo nível de variação para as tais espécies, motivo pelo qual os autores sugeriram uma posição derivada do gênero dentro da subtribo Helianthinae e uma origem recente para as mesmas e, ainda com base nos resultados e em outras evidências, uma reavaliação da taxonomia em nível de espécie para as plantas do Brasil.

Argumentando que as Viguiera da América do Sul deveriam ser transferidas para outro gênero, e que os sinônimos providos por Blake (1918) não eram aplicáveis, Robinson \& Moore (2004) transferiram essas plantas para Rhysolepis, sem muitas explicações.

Pelas razões apresentadas, este trabalho objetivou a caracterização da morfologia polínica do gênero, a verificação de correlações entre aspectos anatômicos e a taxonomia do grupo, a revisão taxonômica das espécies representadas no Brasil, com estabelecimento de limites inter e intraespecíficos mais precisos, a tentativa de prover uma melhor delimitação dos grupos de espécies da América do Sul, o empreendimento de esforços na reconstrução da filogenia dos grupos sul-americanos, através da análise dos caracteres morfológicos comparados a um grupo externo (Nixon \& Carpenter 1993, Watrous \& Wheeler 1981), e o esforço em correlacionar a hipótese filogenética com informações de distribuição geográfica, no intuito de contribuir para a compreensão da história biogeográfica do gênero. 


\section{Referências bibliográficas:}

BAILLON, H.E. 1886[1985]. Pp 46-201, in ed. H.E. Baillon, Histoire des Plants vol. 8. Paris, London, Leipzig: L. Hachette \& Cie.

BAKER, J.G. 1884. Compositae IV: Helianthoideae. In C.P. Martius \& A.W. Eichler (eds.). Flora brasiliensis. Monachii. Typografia Regia v. 6, pt. 3. Pp. 135-268.

BAYER, R.J. \& STARR, J.R. 1998. Tribal phylogeny of the Asteraceae based on two non-coding chloroplast sequences, the trnL intron and trnL/F intergenic spacer. Ann. Missouri Bot. Gard. 85: 242-256.

BENTHAM, G. 1873. Compositae. In Bentham, G. \& Hooker, W.J. (eds.). Genera plantarum v. 2, pl. 1. London: Reeve \& Co. Pp. 163-533.

BLAKE, S.F., 1918. A revision of the genus Viguiera. Contr. Gray Herb. 54: 1205.

BREMER, K. 1994. Asteraceae: cladistics and classification. Portland, Oregon: Timber Press. 752 pp.

CHAREST-CLARK, N. 1984. Preliminary scanning electron microscopic study of the peduncle, phyllary, and pale trichomes of Encelia (Asteraceae: Heliantheae). Crososoma 10(4):1-6.

CLARK, C.; THOMPSON, W.C. \& KYNOS, D.W. 1980. Comparative morphology of the leaf trichomes of Encelia (Compositae: Heliantheae). Bot. Soc. Amer., Misc. Publ. 158.

CRONQUIST, A. 1977. The Compositae revisited. Brittonia 29: 137-153.

DA COSTA, F.B.; VICHNEWSKI, W. \& HERZ, W. 1996. Constituents of Viguiera aspilioides and V. robusta. Biochem. Syst. Ecol. 24: 585-587.

GONÇALVES-ESTEVES, V. \& ESTEVES, R. 1989. Contribuição ao estudo polínico da tribo Heliantheae (Compositae) VI. Bol. Mus. Nac., N.S., Bot. 80: 1-9.

HEMSLEY, W.B. 1881. Phanerogamia. Dicotyledones. Gamopetalae. Series I. Inferae. Compositae. Tribe V. Helianthoideae. In W.B. Hemsley (ed.). Biologia Centrali-Americana. Ser. Botanica. Pp. 166 - 189. Disponível em $<$ www.sil.si.edu/web4/ bca/bca>.

ISEJIMA E.M.; FIGUEIREDO-RIBEIRO, R.C.L. \& ZAIDAN, L.B.P. 1991. Fructan composition in adventitious tuberous roots of Viguiera discolor Baker (Asteraceae) as influenced by day length. New Phyt. 199: 149-154.

ITAYA, N.M.; BUCKERIDGE, M.S. \& FIGUEIREDO-RIBEIRO, R.C.L. 1997. Biosynthesis in vitro of high-molecular-mass fructan by cell-free extracts from tuberous roots of Viguiera discolor (Asteraceae). New Phyt. 136: 5360.

JANSEN, R.K. \& PALMER, J.D. 1987. A chloroplast DNA inversion marks an ancient evolutionary split in the sunflower family (Asteraceae) - Proc. Natl. Acad. Sci. U.S.A. 84: 5818-5822.

1988. Phylogenetic implications of chloroplast DNA restriction site variation in Mutisieae (Asteraceae). Amer. J. Bot. 75: 751-764. 
, HOLSINGER, K.E.; MICHAELS, H.J. et al. 1990. Phylogenetic analysis of restriction site data at higher taxonomic levels: an example from the Asteraceae. Evolution 44: 2089-2105.

MICHAELS, H.J. \& PALMER, J.D. 1991. Phylogeny and character evolutions in the Asteraceae based on chloroplast DNA restriction site mapping. Syst. Bot. 16: 98-115.

JEFFREY, C. 1978. (Book review). The biology and chemistry of Compositae. Compositae Newsl. 7:1-6.

KARIS, P.O. 1993. The Heliantheae sensu lato (Asteraceae), clades and classification. Pl. Syst. Evol. 186: 139-195.

\& RYDING, O. 1994. Tribe Heliantheae. In K. Bremer (ed.). steraceae, cladistics and classification. Portland, OR.: Timber Press. Pp. 559624.

KUNTH, A. 1820. Compositae. In Humboldt, Bonpland \& Kunth (eds.). Voyage de Humboldt et Bompland. Sixième Partie. Botanique. Nova Genera et Species Plantarum vol. 4.. Mazi, Paris: Edifolio. Pp. 279-283.

MACHADO, S.R.; OLIVEIRA, M.D.; DIP, M.R. et al. 2004. Morfoanatomia do sistema subterrâneo de Smallanthus sonchifolius (Poepp. \& Endl.) H. Robinson (Asteraceae). Revista Brasil. Bot. 27 (1): 115-123.

MONDIN, C. 2004. Levantamento da tribo Heliantheae Cass. (Asteraceae), sensu stricto, no Rio Grande do Sul, Brasil. Tese de doutoramento. Universidade Federal do Rio Grande do Sul. 349 f.

NAKAJIMA, J.N. 2000. A família Asteraceae no Parque Estadual da Serra da Canastra, Brasil. Tese de doutoramento. Universidade Federal de Uberlândia. $404 \mathrm{f}$.

NIXON, C.K. \& CARPENTER, J.M.N. 1993. On outgroups. Cladistics (9): 413426.

PANERO, J.L. \& SCHILLING, E.E. 1988. Revision of Viguiera sect. Maculatae (Asteraceae-Heliantheae). Syst. Bot. 13: 371-406.

ROBINSON, H. 1977. Studies in Heliantheae (Asteraceae) VIII. Notes on genus and species limits in the genus Viguiera. Phytologia 36(3): 201-215.

1981. A revision of the tribal and subtribal limits of the Heliantheae (Asteraceae). Smith. Contr. Bot. 51: 1-102.

\& MOORE, A.J. 2004. New species and new combinations in Rhysolepis (Heliantheae - Asteraceae). Proc. Biol. Soc. Washington 117 (3): 423-446.

SALGADO-LABOURIAU, M.L. 1971. Contribuição à palinologia dos cerrados. Acad. Bras. Cienc. 5: 67-75.

SCHILLING, E.E., DA COSTA, F.B., LOPES, N.P. et al. 2000. Brazilian species of Viguiera (Asteraceae) exhibit low levels of ITS sequence variation. Edinb. J. Bot. 57(3): 323-332.

SCHILLING, E.E. \& JANSEN, R.K. 1989. Restriction fragment analysis of chloroplast DNA and the systematics of Viguiera and related genera (Asteraceae-Heliantheae). Amer. J. Bot. 76(12): 1769-1778. 
SCHILLING, E.E. \& PANERO, J.L. 1991. Evidence for a close relationship between Iostephane and Viguiera (Asteraceae-Heliantheae). Amer. J. Bot. 78(8): 1054-1062.

SCHILLING, E.E. \& PANERO, J.L. 1996. Phylogenetic reticulation in subtribe Helianthinae. Amer. J. Bot. 83(7): 939-948.

SCHILLING, E.E. \& PANERO, J.L. 2002. A revised classification of subtribe Helianthinae (Asteraceae-Heliantheae). I. Basal lineages. Bot. J. Linn. Soc. 140: 65-76.

SCHILLING, E.E.; PANERO, J.L.; ELIASSON, U.H. 1994. Evidence from chloroplast DNA restriction site analysis on the relationships of Scalesia (Asteraceae-Heliantheae). Amer. J. Bot. 81(2): 248-254.

SCHORR, K.; DA COSTA, F.B.; ZIPPER, R. et al. 1999. Phytochemical study of Viguiera arenaria by trichomes microsampling. Bol. Chim. Farmaceutico 138 (2): LII.

SKVARLA, J.J. \& TURNER, B.L. 1966. Pollen wall structure and its bearing on the systematic position of Blennosperma and Crocidum (Compositae). Amer. J. Bot. 53(6): 555-563.

STUESSY, T.T. 1977 Heliantheae-Systematic review. In V.H. Heywood, J. B. Harborne, and B.L. Turner (eds.). The biology and chemistry of the Compositae. London, UK: Academic Press. Pp. 621-671.

WATROUS, L.E. \& WHEELER, Q.D. 1981. The outgroup comparision method of character analysis. Syst. Zool. 30 (1): 1-11. 
CAPITULO II

CARACTERIZAÇÃO MORFO-ANATOMICO FOLIAR DE ESPÉCIES SULAMERICANAS DO GÊNERO VIGUIERA (HELIANTHEAE-ASTERACEAE) COMO SUBSÍDIO A ESTUDOS TAXONÔMICOS¹

\begin{abstract}
The genus Viguiera Kunth presents many parallelisms in vegetative structures (leaves). In order to identify possible diagnostic characters between species and species groups of South America, an anatomical study of those organs was conducted, including all Brazilian species and some from other South-American countries, from Mexico, besides two species of Flourensia. The mesophyll shown to be extremely useful in the delimitation of species groups, while features of the trichomes were shown to be additional diagnostic characters close species a species groups. Lastly secretory channels were detected; these are typical of several Compositae and in Viguiera are in the most, associated with the vascular system.
\end{abstract}

Resumo: O gênero Viguiera Kunth apresenta vários possíveis paralelismos na morfologia externa das estruturas vegetativas, (e.g. folhas). Com o objetivo de identificar possíveis caracteres distintivos entre as espécies e grupos de espécies da América do Sul, foi realizado o estudo anatômico foliar de todas as espécies brasileiras, e de algumas de outros países sul-americanos, de outras mexicanas e de duas espécies de Flourensia, gênero considerado como próximo de Helianthinae, a subtribo a que pertence Viguiera. Características como a forma da base dos tricomas tectores e a constituição do mesofilo mostraram-se extremamente úteis na delimitação de espécies próximas ou de grupos de espécies Foi detectada a existência de canais secretores, característicos de vários representantes da família que, neste grupo estão, na maioria das vezes, associados ao sistema vascular.

\footnotetext{
${ }^{1}$ Manuscrito a ser submetido ao Boletim de Botânica da Universidade de São Paulo, elaborado em colaboração com Claudia Vecchi.
} 


\section{$\underline{\text { Introdução }}$}

Os paralelismos da variabilidade fenotípica, presentes na família Asteraceae, têm feito a reconstrução filogenética e a circunscrição dos táxons um tema de grande debate (Bayer \& Starr 1998). A ocupação de vários nichos ecológicos repercute nessa variação adaptativa, especialmente nos órgãos vegetativos (Cronquist 1981, Givinish 1987); a questão da convergência adaptativa em órgãos vegetativos tratada por vários autores (Orians e Solbrig 1977, Givnish 19871988 e 1990).

A anatomia de espécies da família Compositae vem sendo caracterizada por vários autores (Metcalfe \& Charlk 1950 1983, Esaú 1974, Fahn 1979, Heywood 1977, Bremer 1994 1996, Machado et al. 2004) e tem sido alvo de interesse de vários pesquisadores (Carquist 1957 1958, Sajo \& Menezes 1986a 1986b, Melo-de-Pinna 2004) e se revelado útil para inferências taxonômicas, como as feitas para o complexo Inuloideae (Drury \& Watson 1966), e delimitação de Encelia (Clark et al. 1980, Charest-Clark 1984).

A tribo Heliantheae é sabidamente portadora de inúmeras semelhanças morfológicas adquiridas por questões ambientais, como folhas cartáceas, indumento geralmente estrigoso e hábito herbáceo perene. Embora Donoghue \& Sanderson (1994) argumentem que as homologias oriundas das oscilações fenotípica não representam um problema nos estudos filogenéticos, partindo do pressuposto que os especialistas são capazes de reconhecê-las e excluí-las das análises, nesta tribo em particular, as análises filogenéticas com base em caracteres morfológicos deixam a desejar.

A subtribo Helianthinae, à qual pertence o gênero Viguiera é bem caracterizada, pela presença de flores do raio estéreis, ramos do estilete das fores do disco com superfície estigmática simples, ductos resiníferos externos às nervuras dos estiletes, resina amarelada e paredes das cipselas estriadas (Robinson, 1981). Porém os limites genéricos são muitas vezes tênues e autores como Schilling \& Panero (1996) já ressaltaram a ineficiência de estudos 
baseados em morfologia externa na taxonomia do grupo, tornando-se necessária a busca de caracteres não exibidos na morfologia externa.

As espécies ocorrentes em áreas de cerrado, caso das plantas aqui estudadas possuem mesofilo comumente compacto, como observaram Handro et al. (1970). Esses autores ressaltaram ainda outros caracteres que consideraram xeromórficos, como a epiderme recoberta por tricomas e apresentando cutícula espessada. Beiguelman (1962) relatou também a ocorrência de fibras do periciclo ramificadas, a partir das nervuras, no interior do mesofilo, como um caráter xeromórfico de plantas de cerrado.

O presente trabalho visa a investigação de caracteres anatômicos ainda não pesquisados para o gênero, que sejam úteis à delimitação de espécies ou grupos de espécies.

\section{Material e métodos}

Os seguintes aspectos anatômicos foram investigados: espessura da cutícula, presença de tricomas tectores, presença posição dos estômatos, presença de hipoderme, tipo e número de camadas de clorênquima, presença e localização de estruturas secretoras e presença de sulcos na epiderme.

Foram analisadas 31 das 35 espécies ocorrentes no Brasil, além de algumas de outros países da América do Sul e de grupos mexicanos relacionados. Foram selecionadas como amostras folhas adultas geralmente localizadas no $3^{\mathrm{o}}$ nó abaixo dos paracládios, das quais foi secionado transversalmente o terço médio da nervura central para os estudos de anatomia de luz e microscopia eletrônica de varredura.

As amostras foram fixadas e em solução formalina (formaldeído 37-40\%, etanol $92^{\circ} \mathrm{Gl} 1: 3: 6, \mathrm{v} / \mathrm{v}$ ) (Johansen 1940, modificado), por 48-72 horas. Após a fixação, as amostras foram estocadas em etanol 70\%.

Para os estudos em microscopia de luz, parte das amostras foi secionada manualmente com auxílio de lâmina de barbear em suporte de isopor, seguindo metodologia usual. O restante da amostra foi desidratado em série etílica (Johansen 1940), pré-infiltradas em óleo de parafina $\left(\mathrm{Nujol}^{\circledR}\right)$, e infiltradas em 
Paraplast $^{\circledR}$ (Lancer-Sherwood Medical, P.F. $56-57^{\circ} \mathrm{C}$ ) em estufa a $60^{\circ} \mathrm{C}$. Os blocos foram secionados em micrótomo rotativo, obtendo-se cortes histológicos com espessuras variando entre 10 e $15 \mu \mathrm{m}$. As fitas de Paraplast ${ }^{\circledR}$ foram afixadas nas lâminas com em gelatina glicerinada (Haupt 1930 apud Kraus \& Arduin 1997), modificada (sem a adição de Fenol) em placa aquecedora a $42^{\circ} \mathrm{C}$, e secas em estufa a $45^{\circ} \mathrm{C}$.

Os cortes histológicos foram corados com azul de alcian (C.I. 74240) 1\% e fucsina básica (C.I. 50240) 0,125\% (9:1, v/v) (Kraus et al. 1998).

As lâminas contendo os cortes histológicos provenientes de seccionamento em micrótomo foram montadas em Entelan ${ }^{\circledR}$ diluído em acetato de butíla $(8: 1$, v/v) e as lâminas com cortes secionados à mão, em glicerina 50\% e vedadas com esmalte incolor (Kraus \& Arduin 1997).

Para as análises de microscopia eletrônica de varredura, foram retiradas amostras de folhas de material herborizado depositado herbário SPF, dos quais foram selecionados pequenos fragmentos (incluindo a nervura central) de 49 táxons (Tabela 1). As amostras foram afixadas com fita adesiva dupla-face em porta amostras e, após metalização com ouro, efetuada no Instituto de Biociências da Universidade de São Paulo, as amostras foram transferidas para a Universidade Santa Cecília, em Santos, avaliadas com uso de microscópio JEOL 25 SII, e fotografadas em filme Fugifilme Neopan 100 acros.

A terminologia foi adotada com base em Metcalfe \& Chalk (1950) . 


\begin{tabular}{|c|c|c|c|}
\hline Espécie & Material examinado & $\begin{array}{c}\text { Microscopia } \\
\text { de luz }\end{array}$ & $\begin{array}{l}\text { Microscopia } \\
\text { eletrônica de } \\
\text { varredura } \\
\text { (MEV) }\end{array}$ \\
\hline \multicolumn{4}{|l|}{ BRASIL } \\
\hline Viguiera amphychora & N. Silveira 9786 (HAS) & $x$ & \\
\hline Viguiera anchusifolia & M. Magenta \& J.E. Magenta Neto 495, 504 (SPF) & $x$ & $x$ \\
\hline Viguiera anchusifolia var. immarginata & $\begin{array}{l}\text { M. Magenta \& C. Mondin } 533 \text { (SPF), M. Magenta E } \\
\text { L.R. Lima } 587 \text { (SPF) }\end{array}$ & $X$ & $\mathrm{X}$ \\
\hline Viguiera arenaria & M. Magenta \& J.E. Magenta Neto 275, 383, 384 (SPF) & $x$ & \\
\hline Viguiera aspilioides & M. Magenta \& J.E. Magenta Neto 477, 478, 479 (SPF) & $x$ & $x$ \\
\hline Viguiera bakeriana & M. Magenta \& J.E. Magenta Neto 291, 485, 493 (SPF) & $\mathrm{X}$ & $\mathrm{X}$ \\
\hline Viguiera bracteata & $\begin{array}{l}\text { M. Magenta \& J.E. Magenta Neto 366, } 641 \text { (SPF), M. } \\
\text { Magenta et al. } 575 \text { (SPF) }\end{array}$ & $X$ & $\mathrm{X}$ \\
\hline Viguiera corumbensis & $\begin{array}{l}\text { A. Pott et al. } 7026 \text { (SPF), G. Hatschbach et al. } 74900 \\
\text { (SPF) }\end{array}$ & $\mathrm{X}$ & \\
\hline Viguiera discolor & M. Magenta \& J.E. Magenta Neto 307, 319, 718 (SPF) & $x$ & $\mathrm{X}$ \\
\hline Viguiera filifolia & $\begin{array}{l}\text { M. Magenta \& J.E. Magenta Neto } 376 \text { (SPF), M. } \\
\text { Magenta et al. } 442,447 \text { (SPF) }\end{array}$ & $\mathrm{X}$ & $\mathrm{X}$ \\
\hline Viguiera gardneri & M. Magenta et al. 441, 457, 656 (SPF) & $\mathrm{x}$ & $x$ \\
\hline Viguiera goyazensis & G. Hatschbach et al. 60230 (MBM) & $x$ & \\
\hline Viguiera grandiflora & $\begin{array}{l}\text { M. Magenta \& et al. } 269 \text { (SPF), M. Magenta \& J.E. } \\
\text { Magenta Neto 310, } 371 \text { (SPF) }\end{array}$ & $x$ & $\mathrm{X}$ \\
\hline Viguiera hispida & M. Magenta \& J.E. Magenta Neto $716,720,722$ (SPF) & $\mathrm{X}$ & $x$ \\
\hline Viguiera hypoleuca & M. Magenta \& J.E. Magenta Neto 460 (SPF) & $x$ & $x$ \\
\hline Viguiera knobiana & J. Knob E S. Bordignon 713 (ICN) & $\mathrm{x}$ & \\
\hline Viguiera kunthiana & M. Magenta \& J.E. Magenta Neto 309, 316, 321 (SPF) & $\mathrm{x}$ & $\mathrm{x}$ \\
\hline Viguiera linearifolia & M. Magenta \& J.E. Magenta Neto 690, 692, 693 (SPF) & $x$ & \\
\hline Viguiera macrorhiza & M. Magenta \& J.E. Magenta Neto 476 (SPF) & $\mathrm{x}$ & $\mathrm{X}$ \\
\hline Viguiera megapotamica & $\begin{array}{l}\text { M. Magenta \& C. Mondin } 502 \text { (SPF), M. Magenta et al. } \\
595 \text { (SPF) }\end{array}$ & $\mathrm{X}$ & $\mathrm{X}$ \\
\hline Viguiera nudibasilaris & M. Magenta \& J.E. Magenta Neto 426 (SPF) & $x$ & $x$ \\
\hline Viguiera nudicaulis & $\begin{array}{l}\text { M. Magenta \& C. Mondin } 503 \text { (SPF), M. Magenta } \mathcal{E} \\
\text { L.R. Lima } 615 \text { (SPF) }\end{array}$ & $\mathrm{X}$ & \\
\hline Viguiera oblongifolia & M. Magenta et al. 339, 340, 352 (SPF) & $\mathrm{x}$ & $\mathrm{x}$ \\
\hline Viguiera pilicaulis & G \& M. Hatschbach et al. 74393 & $x$ & $x$ \\
\hline Viguiera robusta & M. Magenta \& J.E. Magenta Neto 381, 431 (SPF) & $\mathrm{X}$ & $\mathrm{x}$ \\
\hline Viguiera rubra & M. Magenta \& J.E. Magenta Neto 388 (SPF) & $x$ & $x$ \\
\hline Viguiera santacatarinensis & M. Magenta \& J.E. Magenta Neto 410, 706, 707 (SPF) & $\mathrm{X}$ & \\
\hline
\end{tabular}

Tabela 1: espécies analisadas em microscopia de luz e eletrônica de varredura. 


\begin{tabular}{|c|c|c|c|}
\hline Espécie & Material examinado & $\begin{array}{l}\text { Microscopia } \\
\text { de luz }\end{array}$ & $\begin{array}{c}\text { Microscopia } \\
\text { eletrônica } \\
\text { de } \\
\text { varredura } \\
\text { (MEV) }\end{array}$ \\
\hline Viguiera meridionalis & K. Hagelund s.n. (ICN 12804) & $\mathrm{x}$ & \\
\hline Viguiera squalida & $\begin{array}{l}\text { M. Magenta \& T.U. Konno } 675 \text { (SPF), M. Magenta \& } \\
\text { J.E. Magenta Neto 308, } 686 \text { (SPF) } \\
\end{array}$ & $\mathrm{x}$ & $\mathrm{x}$ \\
\hline Viguiera tenuifolia & M. Magenta \& J.E. Magenta Neto 481, 491 (SPF) & $x$ & $x$ \\
\hline Viguiera trichophylla & M. Magenta \& J.E. Magenta Neto 390, 424, 561 (SPF) & $x$ & $x$ \\
\hline Viguiera tuberosa & M. Magenta et al. 600, 603 (SPF) & $x$ & $x$ \\
\hline Viguiera tuberosa var. guaranitica & $\begin{array}{l}\begin{array}{l}\text { M. Magenta \& C. Mondin } 512 ; \text { M. Magenta et al. } 606 \\
\text { (SPF) }\end{array} \\
\end{array}$ & & \\
\hline Viguiera veredensis & M. Magenta \& J.E. Magenta Neto 664, 665 (SPF) & $x$ & \\
\hline Viguiera pilosa & M. Magenta \& J.E. Magenta Neto 406, 415, 535 (SPF) & $x$ & \\
\hline \multicolumn{4}{|l|}{ OUTRAS SUL-AMERICANAS } \\
\hline V. australis & St.G. Beck 875 (LPB) & $\mathrm{x}$ & \\
\hline V. brittonii & N. Angulo \& A. Sagástegui 2597 (LP) & $x$ & \\
\hline V. ellenbergii & A.L. Cabrera 13518 (LP) & $\mathrm{x}$ & \\
\hline \multicolumn{4}{|l|}{ V. fusiformis } \\
\hline V. gayana & A.L. Cabrera 3497 (LP) & $x$ & \\
\hline$V$. gilliesii & H.A. Fabris \& F.O. Zuloaga 8539 (LP) & $x$ & \\
\hline V. lanceolata & R. Guillés 375 (LPB) & $x$ & \\
\hline V. mollis & A.L. Cabrera \& R. Kiesling 24906 (MBM) & $x$ & \\
\hline$V \cdot$ procumbens & V. Coro 19 (LPB) & $x$ & \\
\hline V. revoluta & J. Crisci 427 (LP) & $x$ & \\
\hline V. tucumanensis & E. Bastián 1123 (LPB) & $x$ & \\
\hline \multicolumn{4}{|l|}{ MEXICANA } \\
\hline V. excelsa & D.M. Spooner \& J.L.V. Rios 2520 & $x$ & \\
\hline \multicolumn{4}{|l|}{ GRUPO EXTERNO } \\
\hline Flourensia blakeana & M.A. Farinaccio et al. 661 (SPF) & & \\
\hline F. fiebrisii & G. Beck et al 23836 (SPF) & & \\
\hline Total de táxons analisados & & 49 & 23 \\
\hline
\end{tabular}

Tabela 1 (cont.): espécies analisadas em microscopia de luz e eletrônica de varredura. 


\section{$\underline{\text { Resultados }}$}

\section{Caracterização morfológica}

As folhas de Viguiera são simples, sésseis ou com pecíolo diminuto (Figura 2C) e o formato limbo varia em forma e em tamanho; são cartáceas e estrigosas, especialmente na face adaxial e a nervação é acródroma basal ou supra basal, com três a 5 nervuras de maior calibre (Figura 1).

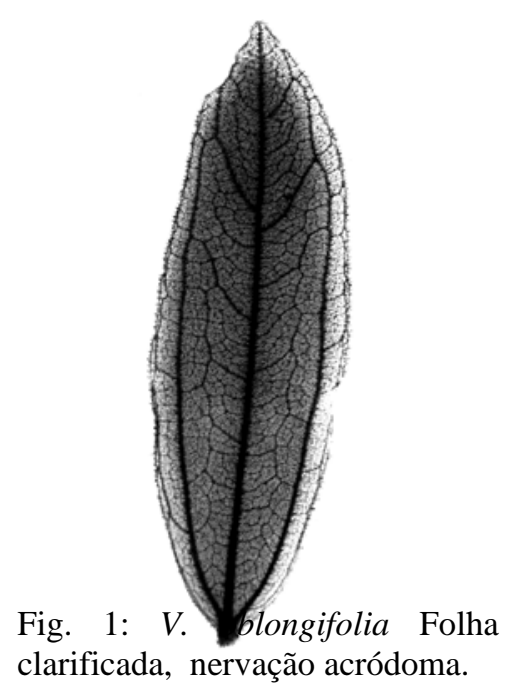

\section{Caracterização anatômica}

$\underline{\text { Sistema de revestimento }}$

A analise das secções transversais das folhas de Viguiera spp. demonstrou que estas apresentam epiderme unisseriada, revestida por cutícula que, na maioria das plantas brasileiras, é delgada (Figura 2A, C e E). Representam exceções $V$. corumbensis, $V$. gardneri, $V$. kunthiana, e $V$. tenuifolia, as quais, como a espécie mexicana analisada ( $V$. excelsa) e a maior parte das sulamericanas extra-brasileras, possuem epiderme com cutícula espessa. A grande maioria é anfiestomática (Figura 2E-F) mas, no Brasil, há sete espécies hipoestomáticas (V. knobiana, V. nudibasilaris, V. pilosa, V. robusta, V. rubra, V. santacatarinensis e $V$. veredensis) e uma epiestomática. As Viguiera analisadas, não ocorrentes no Brasil, são anfiestomáticas, exceto por $V$. mollis, uma espécie epiestomática.

O indumento das folhas é composto por tricomas tectores multicelulares unisseriados (Figura 3A, B, D e F) e tricomas glandulares (Figura 3C-D), presentes em ambas as faces, embora os glandulares sejam mais comuns na face abaxial. Os tricomas tectores apresentam uma a duas células basais maiores que as demais células, com formato cilíndrico ou cônico e a célula terminal apresenta o ápice agudo (Figuras 3A-B). Suas paredes são adornadas com estruturas verrugosas (Figura 3A) conhecidas como bossas (Payne 1978), cuja 
distribuição pode ser ampla (Figura 3C) ou localizada (Figura 3E). É possível a distinção, ao redor da célula basal dos tricomas tectores, de uma a três séries de células concêntricas (Figuras 2D e 3D). O número de camadas dessas células representa um caráter útil na delimitação de espécies morfologicamente semelhantes; assim, os tricomas de $V$. bakeriana são circundados por apenas uma camada de células, enquanto em $V$. discolor observam-se duas a três camadas e, em V. grandiflora, até 4 camadas (Figura 2D). Esse padrão não é exclusivo do gênero e já foi observado anteriormente (e.g. Clark et al., 1980; Charest-Clark, 1984) em outros representantes da tribo Heliantheae.

Existem outras características que representam informações úteis para o reconhecimento de espécies muito próximas. Como exemplo, é possível citar duas espécies freqüentemente confundidas nos herbários: $V$. aspilioides, que apresenta face adaxial foliar com tricomas contendo bossas inconspícuas e $V$. tenuifolia, a qual possui tricomas com bossas conspícuas. Esta última espécie também é morfologicamente próxima de $V$. kunthiana, caracterizada pela presença de tricomas tectores 3-celulares com bossas apenas nas células central e inferior. As espécies citadas no parágrafo anterior, $V$. bakeriana e $V$. discolor, também podem ser diferenciadas por aspectos do ornamento; na primeira, os tricomas da face adaxial da folha apresentam de base cônica e bossas conspícuas; $V$. discolor possui tricomas de base cilíndrica, sem bossas ou com bossas inconspícuas.

Os tricomas glandulares são curtamente pedicelados (Figura 5F), diferenciando-se daqueles sésseis, encontrados em representantes da seção Maculatae S.F. Blake durante a revisão para o grupo (Panero \& Schilling 1988). Estão freqüentemente situados em depressões da epiderme (sulcos), como os encontrados em Richterago Kuntze (Melo-de-Pinna 2004).

\section{Sistema fundamental}

O clorênquima pode ser isomorfo, como em $V$. arenaria, $V$. bracteata, $V$. gardneri e $V$. robusta (Figura 2C), bilateral, como em $V$. bakeriana, $V$. discolor e $V$. 
grandiflora (Figura 2A e F), ou isobilateral, com uma única espécie representante (V. tenuifolia).

O padrão bilateral, onde parênquima paliçádico ocorre em 2-3 (-4) camadas é característico de espécies que possuem capítulos envolvidos por 2-3 séries de brácteas, como $V$. nudibasilaris, $V$. santacatarinensis e $V$. veredensis (grupo A), V. bakeriana, $V$. discolor, $V$. grandiflora e $V$. squalida, (grupo D), $V$. aspiloides, V. linearifolia e V. tuberosa (grupo G).

O padrão isomorfo está dividido em dois outros:

No primeiro (iso A), o parênquima paliçádico ocorre em 3-4(-5) camadas; este padrão é característico de plantas predominantemente herbáceas, delicadas e normalmente flexíveis, como $V$. anchusifolia e $V$. megapotamica, $V$. filifolia e $V$. trichophylla (grupo B).

No segundo (iso B), o parênquima paliçádico tem 6-8 camadas: é encontrado em espécies arbustivas, geralmente com capítulos que apresentam entre 4-6 séries de brácteas involucrais, como $V$. arenaria, $V$. bracteata, $V$. gardneri, V. oblongifolia (grupo E). Há três exceções para essa correlação, pois o padrão ocorre também em $V$. macrorhiza, $V$. nudicaulis e $V$. paranensis, plantas relativamente delicadas e com capítulos portando 2-3 séries de brácteas involucrais.

O padrão isobilateral é foi detectado apenas em $V$. tenuifolia, uma espécie com folhas lineares e capítulos com 2-3 séries de brácteas involucrais; entretanto, houve incertezas na observação da anatomia foliar de V. kunthiana, que apresenta as mesmas características fenotípicas externas.

Os padrões acima corroboram os resultados obtidos com a análise filogenética de Viguiera efetuada nesta tese (capítulo IV).

É válido ressaltar que nas secções transversais das folhas de Viguiera spp. não foi observada a presença de hipoderme contínua, estando esta presente apenas na região do bordo foliar (Figura 2B).

Estruturas secretoras associadas a regiões vasculares são usualmente encontradas, interrompendo regiões de clorênquima (Figura 2B e E). Apenas em $V$. megapotamica e $V$. oblongifolia estas estruturas podem ocorrer em regiões não 
vascularizadas. As estruturas secretoras encontradas são comuns na família Asteraceae (Grotta 1944; Metcalf \& Chalk 1950; Esaú 1960, Heywood 1977 Fahn 1979, Luque 1995, Melo-de-Pinna \& Menezes 2003). A cor vermelha da substância secretada por estes canais, obtida com as técnicas de coloração utilizadas (Figura 2E), indica que sua natureza é ácida.

\section{$\underline{\text { Sistema vascular }}$}

Os tecidos vasculares estão dispostos de forma colateral podendo ser formados por 1 a 5 unidades vasculares na nervura mediana; nas nervuras de menor calibre, apresentam bainha do feixe, estendida até a epiderme (Figura 2A-B). Segundo Fahn \& Cutler (1992), a extensão da bainha é uma das características adaptativas das xerófitas, pois as fibras são condutoras de água. 


\begin{tabular}{|c|c|c|c|c|c|c|c|c|}
\hline 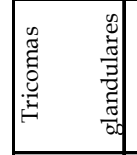 & 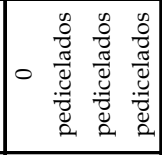 & 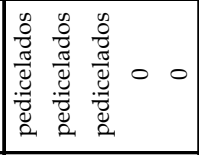 & 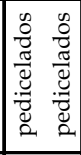 & 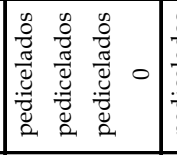 & 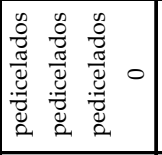 & 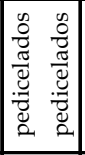 & 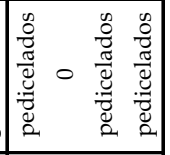 & 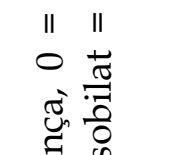 \\
\hline 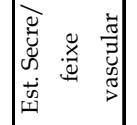 & 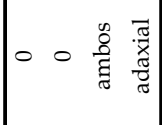 & 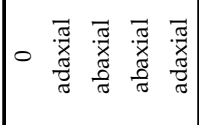 & 00 & 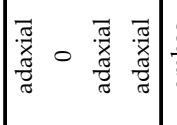 & 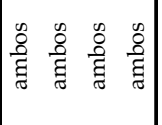 & 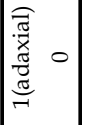 & 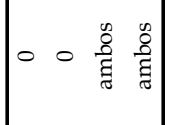 & 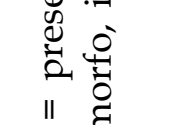 \\
\hline 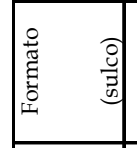 & 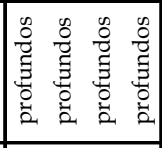 & 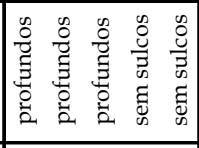 & 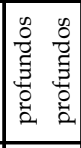 & 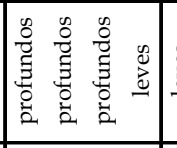 & 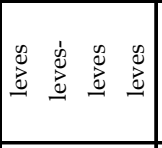 & 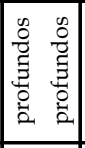 & 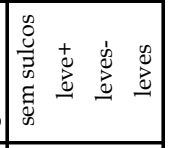 & 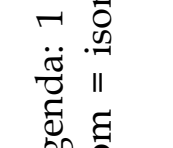 \\
\hline 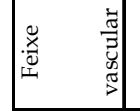 & 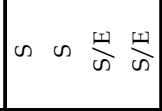 & $\frac{m}{\omega} \frac{m}{\omega} \infty \cdots \cdots$. & $\frac{\omega}{\omega} \frac{w}{\omega}$ & $\frac{m}{\omega} \frac{m}{\omega} \frac{w}{\omega} \frac{w}{\omega}$ & $\frac{w}{\omega} \frac{w}{\omega} \omega \frac{w}{\omega}$ & $\sin$ & $\therefore \cdot \frac{m}{\omega} \cdots \cdot \frac{\pi}{\omega}$ & $\begin{array}{l}0.0 \\
0.0 \\
0 \\
0\end{array}$ \\
\hline 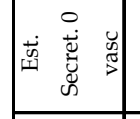 & $\begin{array}{llll}0 & 0 & 0 & 0\end{array}$ & $0 \begin{array}{llll}0 & 0 & - & \cdots\end{array}$ & $\begin{array}{ll}0 & 0\end{array}$ & $\begin{array}{lll}0 & 0 & 0\end{array}$ & $\mid \begin{array}{llll}0 & 0 & 0 & -1\end{array}$ & $\mid \begin{array}{ll}0 & 0\end{array}$ & 00 & 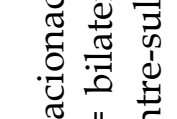 \\
\hline 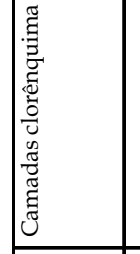 & 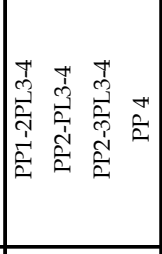 & 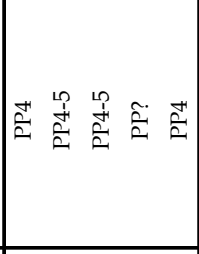 & 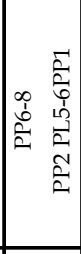 & 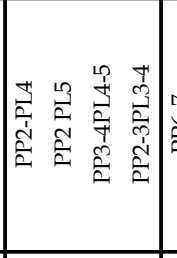 & & 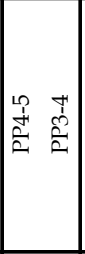 & 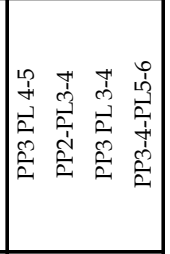 & 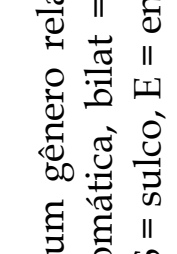 \\
\hline E & 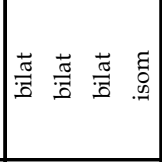 & 鹿 & 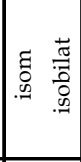 & 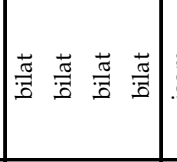 & 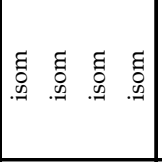 & 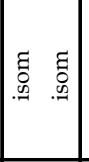 & 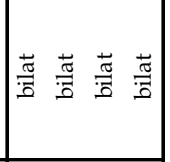 & 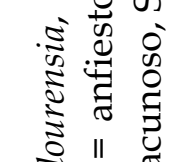 \\
\hline 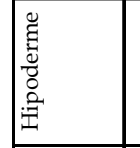 & 100 & $\begin{array}{lll}0 & 0 & 0\end{array}$ & 00 & $\left|\begin{array}{llll}0 & 0 & 0 & 0\end{array}\right|$ & 00 & $\begin{array}{lll}0 & 0\end{array}$ & 00 & 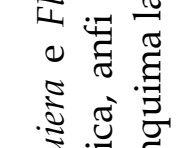 \\
\hline : & $\neg$ & $-r$ & $-r$ & $-H$ & $-\rightarrow$ & $\rightarrow-7$ & & 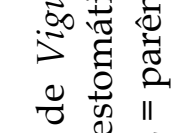 \\
\hline 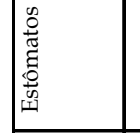 & 粍 : & 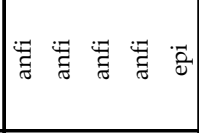 & छี & 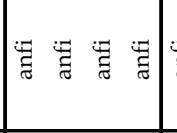 & 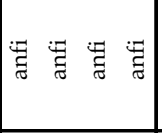 & 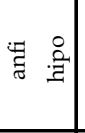 & 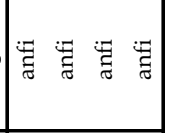 & 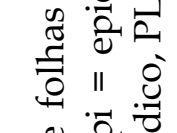 \\
\hline 遏 & -7 & $\neg-$ & $-r-$ & $\rightarrow$ & $H A r r \mid$ & $-\rightarrow$ & \pm & 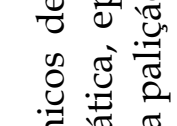 \\
\hline 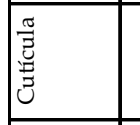 & 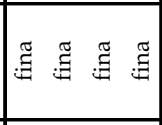 & 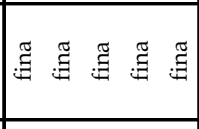 & 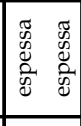 & 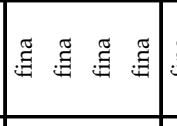 & 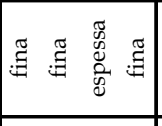 & 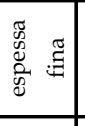 & 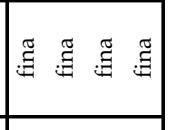 & 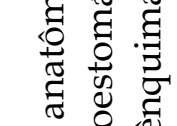 \\
\hline $\mathbb{\mathscr { Z }}$ & 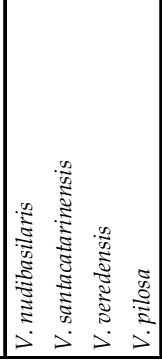 & 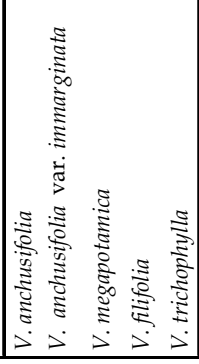 & 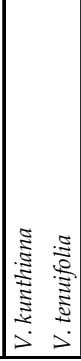 & 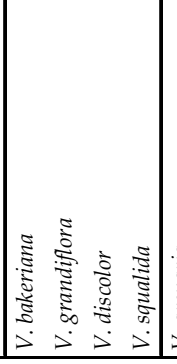 & 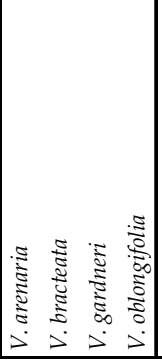 & $\mid$ & 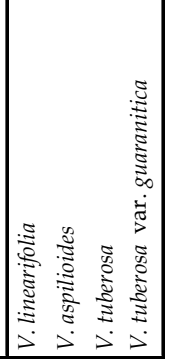 & 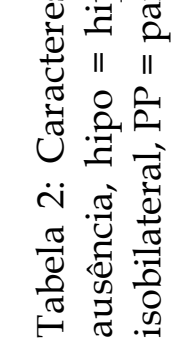 \\
\hline
\end{tabular}




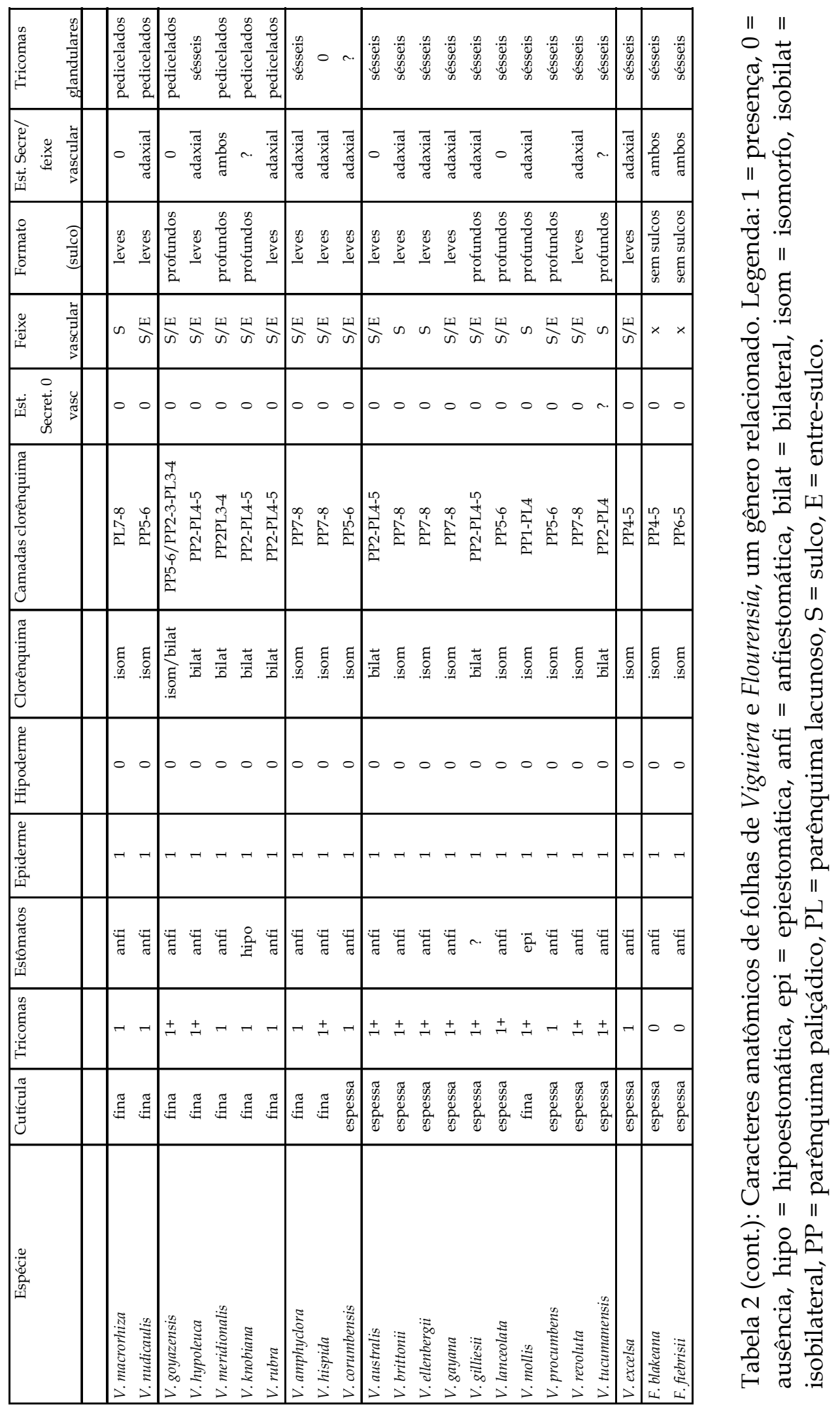



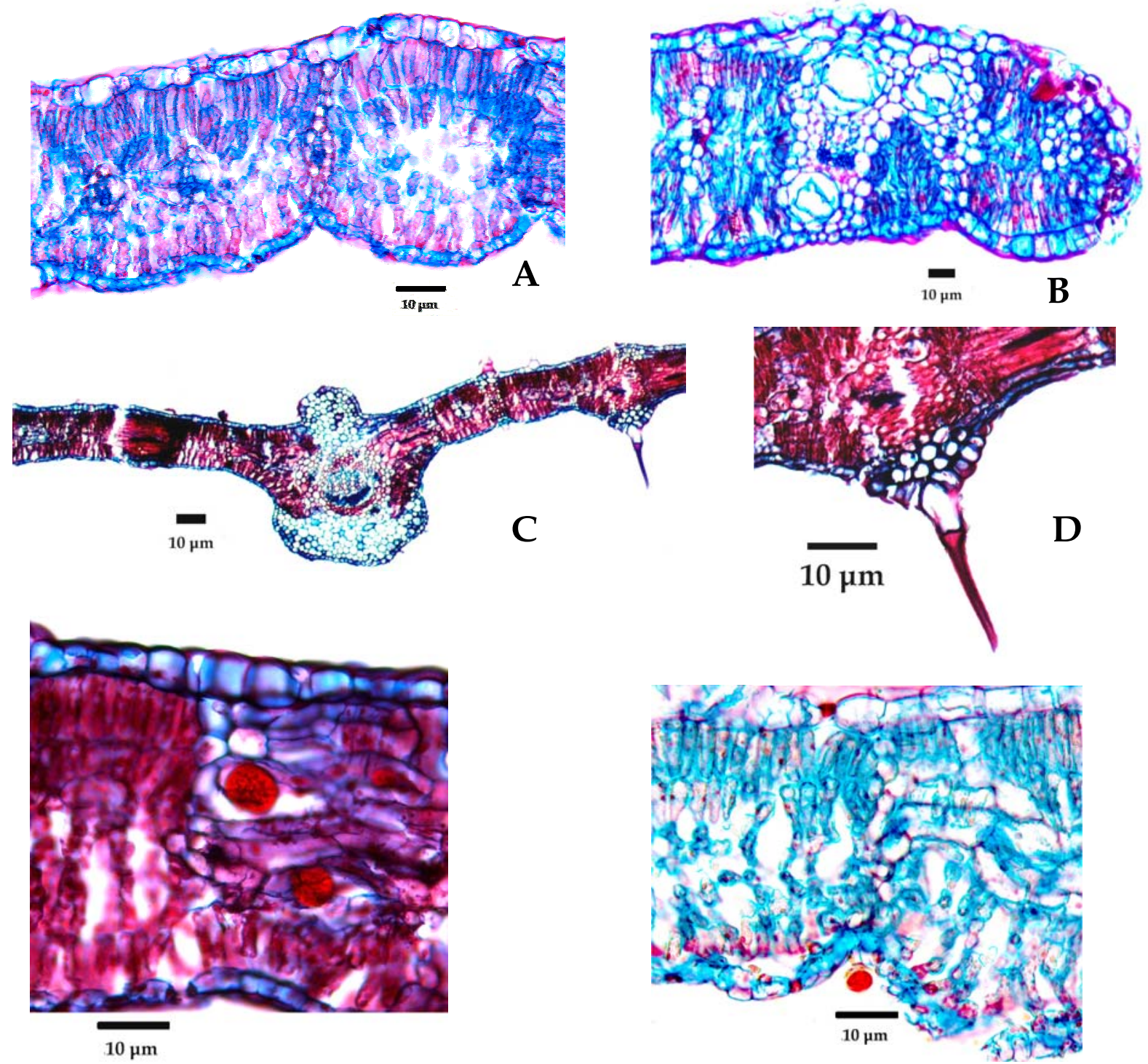

E

$\mathbf{F}$

Fig. 2 A-F. Corte transversal de folha. A e F. V. grandiflora, A. Extensão da bainha do feixe vascular na região dos sulcos, F. Folha anfiestomática, mostrando detalhe da estrutura do tricoma glandular, C-E. V. oblongifolia, C. clorênquima isomorfo, D. Base do tricoma tector cercada por 3-4 séries de células. A e F. M. Magenta \& J. Magenta 371 (SPF); C-E. M. Magenta et al. 352 (SPF). 


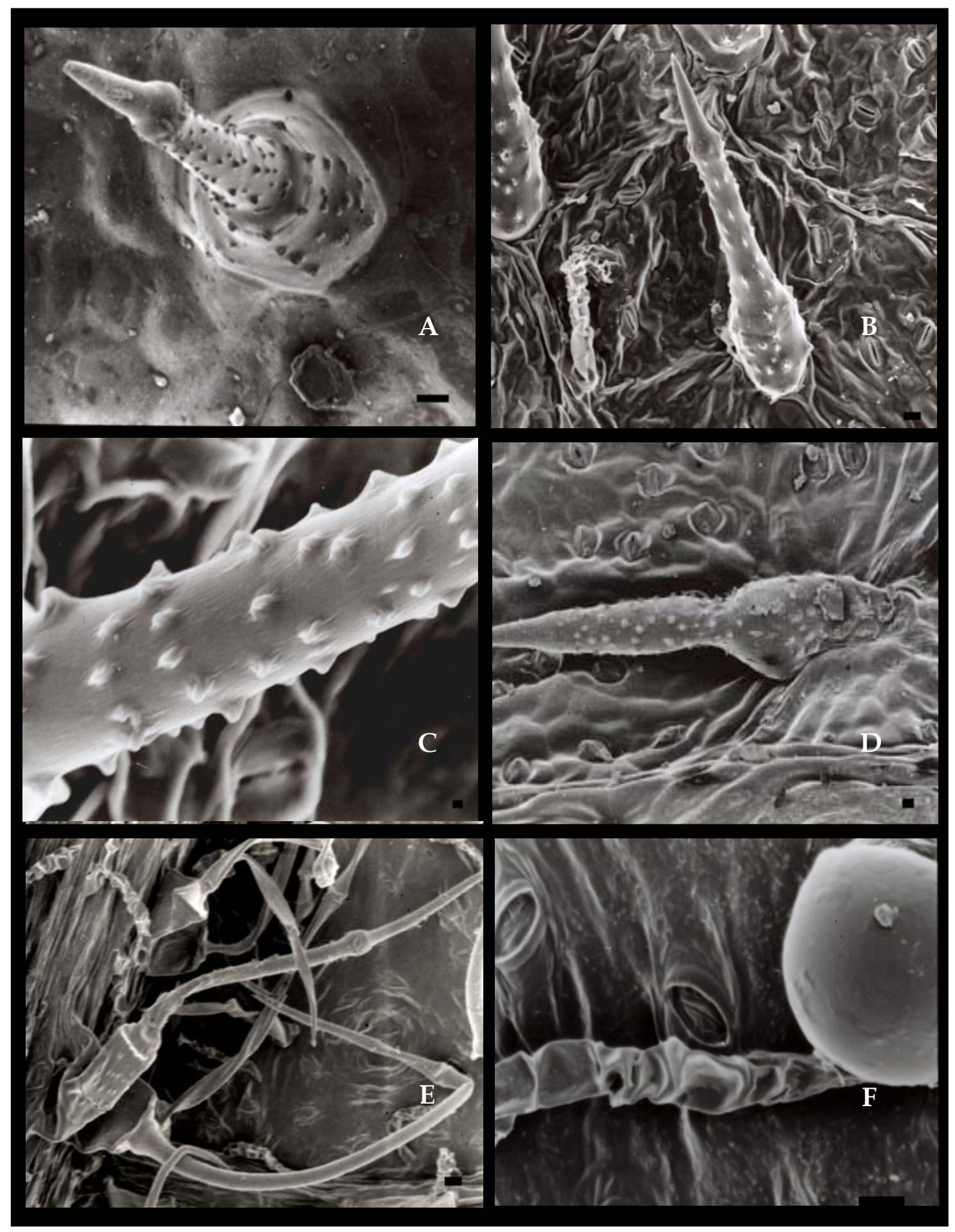

Fig. 3: Tricomas foliares de Viguiera. A-D. Face adaxial. A. V. robusta, tricoma com base largamente cônica, B-C. V. gardneri, B. Tricoma com base cilíndrica, C. Detalhe mostrando as bossas do tricoma. D. V. tenuifolia, mostrando tricoma fortemente apresso, E-F. Face abaxial, $V$. discolor. E. Tricoma com bossas inconspícuas, F. Tricoma glandular pedicelado. A. M. Magenta E J. Magenta 381 (SPF); B-C. M. Magenta et al. 446 (SPF), D-F. M. Magenta \& J. Magenta, D. 491 (SPF), E-F. 295 (SPF). 


\section{Discussão}

A anatomia do gênero Viguiera apresentou características que podem auxiliar nos estudos taxonômicos em nível de delimitação de espécies, tais como o número de células que circunda os tricomas, caráter útil na separação de espécies próximas, como V. bakeriana e $V$. discolor ou a presença de estruturas secretoras fora da região vascular, condição encontrada em V. megapotamica, mas não em $V$. anchusifolia, de morfologia externa muitas vezes extremamente semelhante. Sua maior aplicação, porém, está relacionada à separação de grupos de espécies, através do tipo de clorênquima, e do número de camadas do parênquima paliçádico que o compõe.

Embora não seja possível delimitar grupos de espécies com base em um único caráter, a análise de conjuntos de caracteres é extremamente útil para esse aspecto. Assim, as espécies do Brasil com mesofilo isomórfico, sulcos leves na região do feixe vascular e estruturas secretoras em ambos os lados do feixe vascular constituem o grupo $\mathrm{E}$ ( $V$. arenaria, $V$. bracteata, $V$. gardneri e $V$. oblongifolia), que é representado por plantas com capítulos de invólucro formado por mais de 3 séries de brácteas involucrais; espécies com mesofilo bilateral e folhas hipoestomáticas constituem o grupo A (V. nudibasiliaris, $V$. santacatarinensis e $V$. veredensis), com exceção de $V$. pilosa, que possui mesofilo isomorfo.

Quanto à superfície adaxial foliar, foi detectado um padrão similar para todas as espécies analisadas, com tricomas tectores e glandulares; nos primeiros, a forma das células basais, o número de séries de células que a rodeiam, o tamanho das bossas e sua localização, provêm importante subsídio à taxonomia em nível específico. A presença de uma fina camada de cutícula sobre a epiderme, característica da grande maioria das espécies brasileiras, parece representar um bom caráter para diferenciá-las das espécies que ocorrem nos demais países sul-americanos e no México, as quais possuem cutícula espessa sobre a epiderme. 


\section{Referências bibliográficas}

BAYER, R.J. \& STAR, J.R. 1998. Tribal phylogeny of the Asteraceae based on two non-coding chloroplast sequences, the trnL intron and trnL/F intergenic spacer. Ann. Missouri Bot. Gard. 85: 242-256.

BEIGUELMAN, B. 1962. Fibras do periciclo ramificadas no interior do mesófilo. Oyton 18 (2): 127-131.

BREMER, K. 1994. Asteraceae: cladistics and classification. Portland, Oregon: Timber Press. 752 pp.

1996. Major clades and grades of the Asteraceae. In D.J.N. Hind, \& H.J. Beenje (eds.). Compositae: Systematics. Proceedings of the International Compositae Conference. Kew. 1994 (D.J.N. Hind. Editor-in-Chief), vol 1. Kew: Royal Botanic Gardens. Pp. 1-7.

CARLQUIST, S. 1957. Leaf anatomy and ontogeny in Argyroxiphium and Wilkesia (Compositae). Amer. J. Bot. 44:696-705.

. 1958. Anatomy and Systematic Position of Centaurodendron and Yunquea (Compositae). Brittonia 10(2): 78-93.

CHAREST-CLARK, N. 1984. Preliminary scanning electron microscopic study of the peduncle, phyllary, and pale trichomes of Encelia (Asteraceae: Heliantheae). Crososoma 10(4):1-6.

CLARK, C.; THOMPSON, W.C. \& KYNOS, D.W. 1980. Comparative morphology of the leaf trichomes of Encelia (Compositae: Heliantheae). Bot. Soc. Amer., Misc. Publ. 158.

CRONQUIST, A. 1981. An integrated system of classification of flowering plants. New York, Columbia, University Press. 1261p.

DRURY, D.G. \& WATSON, L. 1966. taxonomic implications of a comparative anatomical study of Inuloideae-compositae. Amer. J. Bot. 53(8): 833-847.

DONOGHUE, M.J. \& SANDERSON, M.J. 1994. Complexity and homology in plants. In B.K. Hall (ed). Homology: the hierarchical basis of comparative biology. EUA. San Diego, CA, Academic Press. Pp. 393-421.

ESAU, K. 1960. Anatomy of seed plants. New York: Wiley International Edition. $729 \mathrm{p}$.

ESAU, K. 1974. Anatomia das Plantas com Sementes. Editora Edgard Blücher Ltda. São Paulo. 293p.

FAHN, A. 1979. Secretory Tissues in Plants. Londres, Academic Press. 302 p.

FAHN, A. \& CUTLER, D.F. 1992. Xerophytes. Berlin, Gerbüderr Borntraeger. $176 \mathrm{p}$.

GIVINISH, T.J. 1987. Comparative studies of leaf form: assessing the relative roles of seletive pressuresand phylogenetic constraints. New phytologist 106 (suppl.): 131-160.

1988. Adaptation to sun vs. shape: a whole-plant perspective. Austr. J. Plant Phys. 15: 63-92. 
1990. Leaf mottling: relation to grown form and leaf phenology, and possible role as camouflage. Funct. Ecol. 6: 463-474.

GROTTA, A.S. 1944. Contribuição ao estudo morfológico e anatômico de Spilanthes acmella L. (compositae). An. Fac. Farm. e odont. USP 4: 130-164.

HANDRO, W., CAMPOS, J.F.B.M. \& OLIVEIRA, Z.M. 1970. Sobre a anatomia foliar de algumas compostas dos campos rupestres. Ciência e Cultura 22(2): 107-127.

HEYWOOD, V.H.; HARBONE, J.B. \& TURNER, B.L. 1977. An overture to the Compositae. In V.H. Heywood, J.B. Harbone and B.L. Turner (eds.). The biology and chemistry of the Compositae. London: Academic Press. Pp. 3-59.

JOHANSEN, D.A. 1940. Plant Microtechnique. New York: McGraw-Hill Book. $523 \mathrm{p}$.

KRAUS, J.E. \& ARDUIN, M. 1997. Manual Básico de Métodos em Morfologia Vegetal. Editora da Universidade Federal Rural do Rio de Janeiro, Seropédica. 198p.

KRAUS, J.E.; SOUSA, H.C.; REZENDE, M.H. CASTRO et al. 1998. Astra Blue and Basic fuchsin double staining of plants materials. Biotec. $\mathcal{E}$ Histoch. 73: 235-243.

LUQUE, R. 1995. Estudo anatômico em espécies de Lycnophora Mart. (Asteraceae) dos campos rupestres do Brasil. Tese de doutoramento, Instituto de Biociências, Universidade de São Paulo.

MACHADO, S.R.; OLIVEIRA, M.D.; DIP, M.R. et al. 2004. Morfoanatomia do sistema subterrâneo de Smallanthus sonchifolius. Rev. Bras.. Bot. 27 (1): 115-123.

MELO-DE-PINNA, G.F. 2004. Anatomia foliar de Richterago Kuntze (Mutisieae, Asteraceae). Acta bot. Bras. 18(3): 591-600. 2004.

\& MENEZES, N.L. 2003. Meristematic endodermis and secretory structures in adventicious roots of Richterago Kuntze (Mutizieae - Asteraceae). Rev. Bras. Bot. 26 (1-10).

METCALFE, C.R. \& CHALK, L. 1950. Anatomy of the Dicotyledons I. Oxford: Claredon Press. 1500 p.

METCALFE, C.R. \& CHALK, L. 1983. Anatomy of The Dicotyledons. $2^{a}$ ed., Vol. 2. Oxford, Clarendon Press. 109p.

ORIANS, G.H. \& SOLBRIG, O.T. 1977. A cost-incom model of leaves ans roots with special reference to arid and semiarid areas. Amer. Nat. 111: 677-690.

PAYNE, W.W. 1978. A glossary of plant hair terminology. Brittonia 30 (2): 239255.

PANERO, J.L. \& SCHILLING, E.E. 1988. Revision of Viguiera sect. Maculatae (Asteraceae-Heliantheae). Syst. Bot. 13: 371-406. 
ROBINSON, H. 1981. A revision of the tribal and subtribal limits of the Heliantheae (Asteraceae). Smith. Contr. Bot. 51: 1-102.

SAJO, M.G. \& MENEZES, N.L. 1986a. Anatomia do rizóforo de espécies de Vernonia Screb. (Compositae) da Serra do Cipó, MG. Rev. Bras. Biol. 46:189196.

SAJO, M.G. \& MENEZES, N.L. 1986b. Origem e crescimento do rizóforo em espécies de Vernonia Screb. (Compositae), da Serra do Cipó, MG. Rev. Bras. Biol. 46:197-202.

SCHILLING, E.E. \& PANERO, J.L. 1996. Relationships in Heliantheae subtribe Helianthinae based on chloroplast DNA restiction site analysis. In D.J.H. Hind \& H.J. Beentje (eds). Compositae: Systematics. Proceedings of the International compositae Conference, Kew, 1994, vol. 1. Kew: Royal Botanic Gardens. Pp. 361-376. 


\title{
CAPÍTULO III
}

\section{PALINOTAXONOMIA DE ESPÉCIES BRASILEIRAS DE VIGUIERA KUNTH (HELIANTHEAE-COMPOSITAE) ${ }^{1}$}

\begin{abstract}
With the aim to get subsidies to the inter-specific delimitation of the genus Viguiera Kunth in Brazil, a palynological analysis was accomplished with 27 taxa, representing around $77 \%$ of species. The samples were obtained from herbarium specimes and the pollen grain was analyzed under light and scanning eletronical microscopy. Characters observed on pollen grain shape, the polar and equatorial diameter, measurements of the aperture, surface ornamentation and exine thickness were registered and compared. The pollen grains are medium $(25-50 \mu \mathrm{m})$, isopolars, oblate-spheroidals (prolate -spheroidals in V. aspilioides Baker). The verified values corroborated the sinonimization of some species and micromorphological differences such as the polar diameter, the dimensions of colpium and endoaperture, confirmed species delimitation obtained in phylogenetic analysis of morphology.
\end{abstract}

Kew words: Asteraceae, Compositae, pollen, taxonomy, Viguiera

Resumo: Com a finalidade de obter subsídios para a delimitação inter-específica do gênero Viguiera Kunth no Brasil, foi efetuado um estudo palinológico com 27 táxons, representando cerca de $77 \%$ das espécies ocorrentes. As amostras foram obtidas de material herborizado e o grão de pólen foi analisado sob microscopias óptica e eletrônica de varredura. Os grãos de pólen foram caracterizados quanto à forma, às dimensões e tipo da abertura, à ornamentação da superfície e à espessura da exina. Os grãos de pólen são médios $(25-50 \mu \mathrm{m})$, isopolares, oblato-esferoidais (prolatoesferoidais em $V$. aspilioides Baker), tricolporados, endoabertura lalongada, sexina espinhosa. Os valores obtidos corroboraram a sinonimização de algumas espécies e diferenças micro-morfológicas, tais como os valores do diâmetro polar, as dimensões do colpo e da endoabertura confirmaram algumas delimitações de espécies obtidas em análises filogenéticas de morfologia.

Palavras-chave: Asteraceae, Compositae, pólen, taxonomia, Viguiera

${ }^{1}$ Manuscrito a ser submetido ao Kew Bulletin, elaborado em colaboração Alessandra de Deus Nunes, Cláudia Barbieri Ferreira Mendonça e Vania Gonçalves-Esteves 


\section{Introdução}

Viguiera senso Blake (1918) é um gênero neotropical com 180 a 200 espécies, pertencente à subtribo Helianthinae (Heliantheae - Asteraceae) e representado do sudoeste da América do Norte ao sul da América do Sul. Nas últimas décadas, várias propostas de desmembramento sugiram, principalmente com base em dados moleculares (Schilling \& Jansen 1989; Schilling \& Panero 1996a, 1996b; Schilling et al. 2002). Esses autores concordam que as espécies do Brasil formam um grupo coeso, juntamente com alguns representantes de outros países sul-americanos. No entanto, são ainda notórios os problemas de delimitação específica e mesmo genérica. Panero (2007) afirmou que, certamente, quando houver mais dados disponíveis, a classificação de Viguiera sofrerá modificações em âmbito de delimitação e das relações filogenéticas com outros gêneros.

As análises palinológicas representam eficientes ferramentas nos estudos taxonômicos da família Asteraceae (Wodehouse 1926, 1928; Wells 1971; Tomb et al. 1974, Feuer \& Tomb 1977; Vezey et al. 1994; Perveen 1999; Qreshi et al. 2002). O grão de pólen apresenta, na tribo Heliantheae, um padrão estrutural que foi denominado Heliantóide (Skvarla \& Larson 1965a, 1965b; Skvarla \& Turner 1966, 1969; Skvarla et al. 1977). Tal padrão é encontrado também nas tribos Eupatorieae, Astereae, Helenieae e Calenduleae e em alguns taxa de Inuleae senso lato, Senecioneae e Anthemideae e é caracterizado por exinas cavadas e forame interno. Vários trabalhos em morfologia polínica apresentam resultados relevantes para a taxonomia de Heliantheae (Wodehouse 1928; Fellipe \& Salgado-Labouriau 1964; Wells 1971; Horner \& Pearson 1978; Melhem et al. 1979). É preciso considerar, porém, quais os melhores caracteres polínicos a serem utilizados na análise da sistemática de cada grupo. Fellipe \& Salgado-Labouriau (1964), por exemplo, trabalhando com grãos de pólen equinados, propuseram a utilização da presença ou ausência de perfurações nos espinhos para diferenciar espécies; no entanto, como os próprios autores observaram, Bidens gardneri Baker pode apresentar os três tipos distinguidos no trabalho (alguns grãos de pólen com uma, outros com duas cavidades e alguns grãos de pólen com espinhos sólidos). Por esse motivo, Skvarla et al. (1977) e Bolick et al. (1984) refutaram a utilidade desse caráter na tribo Heliantheae. Embora seja necessário efetuar estudos 
isolados para os diferentes táxons, as características palinológicas não apenas provêm informações adicionais, mas incrementam as análises para a sistemática (Qreshi et al. 2002).

A única análise para grupos de espécies de Viguiera do Brasil foi feita por Gonçalves-Esteves \& Esteves (1989) com 10 espécies. Nela, os autores enquadram o pólen no tipo 'Aspilia', termo adotado por Salgado-Labouriau (1973) para designar a morfologia do pólen de $V$. robusta Gardner, semelhante ao de Aspilia Thouars (Ecliptinae). O padrão é definido por grãos de pólen oblato-esferoidais a prolatoesferoidais, tricolporados, com exina e sexina separadas por uma cavidade, unidas apenas nas margens das aberturas, e sexina tegilada.

Este estudo visa estabelecer diferenças entre espécies e semelhanças entre grupos de espécies pertencentes ao gênero Viguiera do Brasil.

\section{Material e métodos}

Foram analisados palinologicamente 27 táxons de Viguiera: V. amphychlora S.F. Blake (Fig. 1-3), V. anchusifolia (DC.) Baker (Fig. 4-6), V. arenaria Baker (Fig. 7-9), V. aspilioides Baker (Fig. 10-12), V. bakeriana S.F. Blake (Fig. 13-14), V. bracteata Gardner (Fig. 15-16), V. corumbensis Malme (Fig. 17-18), V. discolor Baker , V. filifolia Sch. Bip., V. gardneri Baker (Fig. 19-20), V. grandiflora Gardner (Fig. 21-22), V. hispida Baker (Fig. 23-24), V. kunthiana Gardner (Fig 25-28), V. macrorhiza Baker (Fig. 29-31), V. megapotamica Malme (Fig. 32-35), V. nudibasilaris Baker (Fig. 36-37), V. oblongifolia Gardner, V. paranensis (Malme) Santos (Fig. 38-40), V. pilosa Baker (Fig. 41-42), V. robusta Gardner (Fig. 43-44), V. rubra Magenta, sp. nov., inéd. (Fig. 45-47), V. santacatarinensis (H. Rob. \& A.J. Moore) Magenta \& Mondin, comb. inéd. (Fig. 50-51), V. squalida S. Moore, V. tenuifolia Gardner (Fig. 52-53), V. trichophylla Dusén (Fig. 5455), V. tuberosa Hassler (Fig. 56-58), V. veredensis Magenta, sp. nov., inéd. (Fig. 59-60).

Material examinado: Viguiera amphychlora - Paraná: Sengés, V.1991, N. Silveira 9786* (HAS). Viguiera anchusifolia - Rio Grande do Sul: Santiago, I.2003, M. Magenta \& C. Mondin 527* (SPF). Viguiera arenaria - São Paulo: Itirapina, II.2002, M. Magenta \& J.E. Magenta Neto 383 (SPF); II.2002, M. Magenta \& J.E. Magenta Neto 384* (SPF). Viguiera aspilioides - Paraná: Palmeira, X.1985, P.I. Oliveira 965 (BR, 
MBM); Ponta Grossa, IX.2002, M. Magenta \& J.E. Magenta Neto 479* (SPF); X.1965, G. Hatschbach 12847 (MBM, P, UB). Viguiera bakeriana - Minas Gerais: Piumhi, X.2002, M. Magenta \& J.E. Magenta Neto 483 (SPF); Lagoa Dourada, X.2002, M. Magenta \& J.E. Magenta Neto 494 (SPF); Santana do Riacho, X.2002, M. Magenta \& J.E. Magenta Neto 488* (SPF). Viguiera bracteata - Distrito Federal: Brasília, XI.2001, M. Magenta \& J.E. Magenta Neto 312* (SPF); Goiás: Alto Paraíso de Goiás, V.2002, M. Magenta et al. 444 (SPF); Minas Gerais: São Roque de Minas, IV.2003, M. Magenta \& J.E. Magenta Neto 631 (SPF); Tapira, IV.2003, M. Magenta \& J.E. Magenta Neto 637 (SPF). Viguiera corumbensis - Mato Grosso do Sul: Miranda, III.1995, A. Pott et al. 7026* (CPAP, SPF). Viguiera discolor - Minas Gerais: Santa Juliana, XI.2001, M. Magenta \& J.E. Magenta Neto 320 (SPF); São Sebastião do Paraíso, X.2001, M. Magenta \& J.E. Magenta Neto 279 (SPF); São Paulo: Cristais Paulista, XI.2001, M. Magenta \& J.E. Magenta Neto 294* (HUFU, K, SPF, TEX). Viguiera filifolia - Goiás: Alto Paraíso de Goiás, I.2002, M. Magenta \& J.E. Magenta Neto 376* (SPF); V.2002, M. Magenta et al. 447 (K, SPF, TEX); V.2002, M. Magenta et al. 452 (HUFU, K, SPF). Viguiera gardneri Goiás: Ipameri, V.2002, M. Magenta et al. 441* (SPF); Santo Antônio do Descoberto, V.2002, M. Magenta et al. 455 (SPF); V.2002, M. Magenta et al. 456 (SPF). Viguiera grandiflora - Distrito Federal: Sobradinho, I.2002, M. Magenta \& J.E. Magenta Neto 371* (SPF). Viguiera hispida - Goiás: Alto Paraíso de Goiás, XII.1988, M.G.L. Wanderley et al. 1764 (SP, SPF); São Paulo: Mogi Guaçu, X.1955, M. Kuhlmann 3695* (SP, TENN). Viguiera kunthiana - Distrito Federal: Brasília, VIII.1990, M. Aparecida da Silva et al. 1005 (HEPH, IBGE, RB, US); Goiás: Campo Alegre de Goiás, XI.2001, M. Magenta \& J.E. Magenta Neto 316* (SPF). Viguiera macrorhiza - Minas Gerais: Paracatu, X.1978, G. Hatschbach \& A. Kasper 41675* (MBM, UEC); São Paulo: Mogi Guaçu, X.2002, M. Magenta \& J.E. Magenta Neto 476 (SPF). Viguiera megapotamica Rio Grande do Sul: Arroio dos Ratos, I.2003, M. Magenta \& C. Mondin 502* (SPF). Viguiera nudibasilaris - Minas Gerais: Camanducaia, III.1976, H.F. Leitão F 1853 (K, UEC); Pouso Alegre, IV.2002, M. Magenta \& J.E. Magenta Neto 430* (SPF); São Paulo: Campos de Jordão, III.1985, M.J. Robim \& J.P.M. Carvalho 256 (D, MBM, SPSF, UEC). Viguiera oblongifolia - Goiás: Piranhas, XII.2001, M. Magenta et al. 349 (SPF); XII.2001, M. Magenta et al. 352 (K, SPF); Mato Grosso: Barra do Garças, XII.2001, M. 
Magenta et al. 340* (HUFU, K, SPF, SPSF, TEX). Viguiera paranensis - Paraná: Ponta Grossa, XI.1987, P.M. Araki s.n.* (HUEPG 3498); IX.1950, J. Vidal \& E.S. Araújo III228 (R). Viguiera pilosa - Rio Grande do Sul: Campestre da Serra, III.2002, M. Magenta \& J.E. Magenta Neto 406* (K, SPF, SPFR); Santana do Livramento, I.2003, M. Magenta \& C. Mondin 511 (SPF). Viguiera robusta - Goiás: Anápolis, I.2002, M. Magenta \& J.E. Magenta Neto 381 (K, SPF); Minas Gerais: Camanducaia, IV.2002, M. Magenta \& J.E. Magenta Neto 428* (K, SPF); São Paulo: Capão Bonito, III.2003, M. Magenta \& J.E. Magenta Neto 566 (SPF). Viguiera rubra - São Paulo: Pirassununga, III.2002, M. Magenta \& J.E. Magenta Neto 388* (K, SPF). Viguiera santacatarinensis Rio Grande do Sul: São José dos Ausentes, 2002, M. Sobral et al. 9495* (ICN, SPF). Viguiera squalida - Mato Grosso: Lago Leo, X.1960, A. Lima 461-68 (IPA); Mato Grosso do Sul: Ribas do Rio Pardo, XI.2003, M. Magenta \& J.E. Magenta Neto 695* (SPF); XI.2003, M. Magenta \& J.E. Magenta Neto 697 (SPF). Viguiera tenuifolia Minas Gerais: Capitólio, X.2001, M. Magenta \& J.E. Magenta Neto 287 (SPF); Itabirito, X.2002, M. Magenta \& J.E. Magenta Neto 491* (SPF); São Roque de Minas, III.2003, M. Magenta \& J.E. Magenta Neto 584 (SPF). Viguiera trichophylla - Paraná: Lapa, I.2003, M. Magenta \& J.E. Magenta Neto 537* (SPF). Viguiera tuberosa - Rio Grande do Sul: Quaraí, IV.2003, M. Magenta et al. 603* (SPF); Santana do Livramento, IV.2003, M. Magenta et al. 604 (SPF); III.2002, C. Mondin \& A. Iob 2588 (HASU, SPF). Viguiera veredensis - Bahia: Cocos, V.2001, R.C. Mendonça et al. 4277* (HEPH, IBGE, US).

Foram retiradas anteras férteis de flores em antese e/ou botões florais bem desenvolvimos, de exsicatas depositadas nos seguintes herbários (acrônimos de acordo com Holmgren et al. 1990): BR, CPAP, D, HAS, HASU, HEPH, HUEPG, HUFU, IBGE, ICN, IPA, K, MBM, P, R, RB, SP, SPF, SPFR, SPSF, TENN, TEX, UB, UEC, US.

Sempre que possível, procurou-se analisar os grãos de pólen de três espécimes de uma mesma espécie. Um deles foi escolhido como padrão (indicado no material examinado por um asterisco), para as mensurações, descrições e ilustrações polínicas; os demais espécimes foram utilizados para comparação dos resultados. Para o estudo sob microscópio de luz, o material polínico foi preparado segundo o método acetolítico de Ertdman (1952); para a obtenção das eletromicrografias em microscopia 
eletrônica de varredura (Zeiss DSM 960), utilizou-se material polínico não acetolisado. Os grãos de pólen foram espalhados sobre suportes metálicos previamente recobertos por fita de carbono e, posteriormente, banhados em uma fina camada de ouro paládio por cerca de três minutos.

Do material padrão, na maioria das espécies, foram mensurados 25 grãos de pólen em vista equatorial (diâmetro polar $=\mathrm{DP}$ e diâmetro equatorial $=\mathrm{DE})$. Com os resultados obtidos, foram efetuados tratamentos estatísticos calculando-se a média aritmética $(\overline{\mathrm{x}})$, o desvio padrão da amostra (s); o desvio padrão da média $\left(\mathrm{s}_{\mathrm{x}}\right)$; o coeficiente de variabilidade (CV\%) e o intervalo de confiança (IC) a 95\%. Para as medidas das demais características, como as do diâmetro equatorial em vista polar (DEVP), do lado do apocolpo (LA), do índice de área polar (IAP), das aberturas e da exina, foi calculada a média aritmética de 10 medidas, o mesmo ocorrendo para as medidas dos diâmetros dos grãos de pólen do material de comparação.

A terminologia adotada e as descrições polínicas seguiram os critérios de Barth \& Melhem (1988) e Punt et al. (1999), levando-se em consideração o tamanho, a forma, o número de aberturas e o padrão de ornamentação da sexina. A denominação da área polar e o tamanho da abertura estão de acordo com a classificação estabelecida por Faegri \& Iversen (1966) para o índice da área polar.

\section{Resultados}

Os grãos de pólen mostraram-se médios $(25-50 \mu \mathrm{m})$, isopolares, oblatoesferoidais, prolato-esferoidais apenas em $V$. aspilioides (Tab. 1), área polar pequena a muito pequena (Tab. 2), âmbito subcircular, tricolporados, sexina espinhosa.

Os menores valores do intervalo de confiança do diâmetro polar, em vista equatorial, foram encontrados em $V$. veredensis $(32,3-33,1 \mu \mathrm{m})$ e os maiores, em $V$. macrorhiza e $V$. oblongifolia $(41,1-42,0 \mu \mathrm{m})$.

Os colpos são longos a muito longos, estreitos, com extremidades agudas, endoabertura acentuadamente lalongada na maioria das espécies (Fig. 16), exceto em $V$. discolor (ca. 2,2x5,5 $\mu \mathrm{m}$ ), onde apresenta extremidades agudas (Fig. 24, 30) e em $V$. aspilioides (Fig. 16), V. bracteata (Fig. 22) e V. pilosa (Fig. 42), que possuem extremidades das endoaberturas obtusas. O colpo mais longo (ca. 18,0 $\mu \mathrm{m}$ ) foi encontrado em $V$. filifolia e o mais curto (ca. 11,3 $\mu \mathrm{m}$ ) em $V$. aspilioides (Tab. 3). Em 
MEV pode-se observar a presença de membrana granulada nos colpos (Fig. 31, 35, $55)$.

A exina é espessa, cavada (a cava mais larga, ca. 1,5 $\mu \mathrm{m}$, é encontrada em $V$. nudibasilaris e a mais estreita, ca. 0,8 $\mu \mathrm{m}$, em V. grandiflora), simplescolumelada, espinhos longos, estreitos, com perfurações na base (Fig. 28, 35, 40), ca. 8,0 $\mu \mathrm{m}$ de distância entre si. A camada de columelas, bem como a cava, são nítidas. A sexina é sempre mais espessa do que a nexina.

Os espinhos podem ser cônicos (Fig. 31) ou apresentar projeções nas bases (Fig. 6, 18, 27), os espinhos mais longos, mais largos (ca. 11,0X6,1 $\mu \mathrm{m}$ ) e com maior distância (ca. 10,4 $\mu \mathrm{m}$ ) foram encontrados em $V$. oblongifolia (Tab. 3). Os espinhos mais curtos (ca. 5,0 $\mu \mathrm{m}$ ) foram encontrados em $V$. veredensis, os mais estreitos, em $V$. rubra (ca. 2,5 $\mu \mathrm{m}$ ) e a menor distância entre eles (ca. 7,1 $\mu \mathrm{m})$, em $V$. amphychlora (Tab. 3).

O confronto dos resultados encontrados nos espécimes de comparação (Tab. 4) com o respectivo material padrão mostra que a forma e as dimensões dos grãos de pólen são constantes, exceto em $V$. aspilioides que apresentou forma variando de prolato-esferoidal (material padrão) a oblato-esferoidal (material de comparação).

Utilizando-se as características polínicas, é possível separar as espécies em quatro grandes grupos, utilizando-se os valores do intervalo de confiança a 95\% do diâmetro polar. No quarto grupo está incluída a maioria das espécies, que foram reunidas em subgrupos, como está discriminado abaixo:

Chave de identificação para grupos de espécies (IC - intervalo de confiança; D. diâmetro)

I - I.C. $95 \%$ D. polar $=41,1-42,0 \mu \mathrm{m}$ : V. macrorhiza, $V$. oblongifolia

II - I.C. 95\% D. polar $=32,3-33,1 \mu \mathrm{m}:$ V. veredensis

III- I.C. 95\% D. polar $=39,3-40,6 \mu \mathrm{m}: V$. aspilioides, $V$. paranensis, $V$. pilosa, $V$. santacatarinensis

IV- I.C. 95\% D. polar $=34,0-39,2 \mu \mathrm{m}$ : demais espécies

IV.1- compr. colpo $=11,3-14,9 \mu \mathrm{m}$ 
a- larg. endoabertura $=5,5 \mu \mathrm{m}: V$. discolor

b- larg. endoabertura $=10,3-11,7 \mu \mathrm{m}$, compr. espinho $=5,0-7,4 \mu \mathrm{m}$

b.1- área polar pequena: $V$. bracteata, $V$. gardneri, $V$. tuberosa

b.2- área polar muito pequena: $V$. bakeriana, $V$. megapotamica, $V$. nudibasilaris

c- larg. endoabertura $=12,0-14,0 \mu \mathrm{m}$

c.1- área polar pequena: $V$. corumbensis, $V$. tenuifolia

c.2- área polar muito pequena: $V$. arenaria, $V$. rubra

IV.2- compr. colpo $=15,8-18,0 \mu \mathrm{m}$

a- larg. endoabertura $=11,3-11,7 \mu \mathrm{m}$

a.1- compr. espinho $=6,0 \mu \mathrm{m}:$ V. grandiflora .

a.2- compr. espinho $=7,4 \mu \mathrm{m}:$ V. trichophylla.

b- larg. endoabertura $=12,0-13,2 \mu \mathrm{m}$; compr. espinho $=5,1-8,2 \mu \mathrm{m}$

b.1- área polar muito pequena: $V$. hispida.

b.2- área polar pequena: $V$. amphychlora, $V$. anchusifolia, $V$. filifolia, $V$. kunthiana, V. robusta, V. squalida.

\section{Discussão e conclusões}

São poucos os dados polínicos de Viguiera na literatura. O gênero pode ser caracterizado, com base nos resultados aqui obtidos, pela presença de grãos de pólen médios, oblato-esferoidais, área polar pequena a muito pequena, tricolporados, colpos longos a muito longos, endoaberturas acentuadamente lalongadas na maioria das espécies, exina espinhosa, com cava nítida. Embora haja discrepâncias entre os grupos obtidos com base em características polínicas e aqueles unidos por similaridades do fenótipo externo, as variações do tamanho dos grãos de pólen (expressas nos valores do intervalo de confiança), das áreas polares e das dimensões das aberturas (colpo e endoabertura), forneceram subsídios parciais à taxonomia do 
gênero mostrando-se extremamente úteis na delimitação de várias espécies.

Viguiera hilairei foi originalmente tratada como espécie válida (Blake 1918). No estudo taxonômico realizado por Magenta (2006) para a re-delimitação das espécies brasileiras, foi constatado que $V$. hilairei deveria ser sinonimizada à $V$. bracteata. A análise polínica aqui desenvolvida corroborou essa posição, o que pode ser constatado no material de comparação de V. bracteata (M. Magenta E E. Magenta Neto 631, 637), inicialmente identificado como V. hilairei.

Viguiera anchusifolia pode apresentar a porção vegetativa com forma similar à de $V$. pilosa; além disso, as duas espécies aparentemente formam híbridos, o que dificulta sua delimitação. Os resultados encontrados mostram que os táxons são polinicamente diferentes, ficando $V$. anchusifolia (IC.95\% do diâmetro polar $=34,8$ 35,2 $\mu \mathrm{m}$ ) no grupo IV.2.b.2, enquanto $V$. pilosa (IC.95\% do diâmetro polar = 39,3-39,7 $\mu \mathrm{m})$, se enquadra no grupo III (grupos polínicos aqui estabelecidos).

Viguiera arenaria, V. gardneri e V. rubra são freqüentemente confundidas nos herbários com $V$. robusta, mas podem ser separadas desta por caracteres polínicos relativos ao diâmetro polar e largura da endoabertura .

Algumas espécies são muito semelhantes morfologicamente, somente sendo possível sua separação após minuciosa observação de caracteres reprodutivos; a largura da endoabertura dos grãos de pólen proveu um novo subsídio para a delimitação de vários desses táxons como nos casos abaixo:

No grupo IV.1 (compr. colpo $=11,3-14,9 \mu \mathrm{m}), V$. discolor é alocada no subgrupo a (larg. endoabertura $=5,5 \mu \mathrm{m}$ ) e V. bakeriana, com largura da endoabertura na faixa de 10,3-11,7 $\mu \mathrm{m}$, no subgrupo $\mathbf{b}$.

No grupo IV.2 (compr. colpo $=15,8-18,0 \mu \mathrm{m}$ ), Viguiera grandiflora se enquadra no subgrupo a (larg. endoabertura $=11,3-11,7 \mu \mathrm{m}$ ) e $V$. squalida no subgrupo b (larg. endoabertura $=12,0-13,2 \mu \mathrm{m})$; neste mesmo grupo, $V$. trichophylla está no subgrupo a e $V$. filifolia no subgrupo b; estas espécies são consideradas como sinônimos por muitos autores.

Outras espécies de difícil delimitação são: Viguiera tenuifolia (grupo IV.1) e $V$. 
kunthiana (grupo IV.2); V. megapotamica (grupo IV.1) e V. anchusifolia (grupo IV.2); V. aspilioides (grupo III) e $V$. tuberosa (grupo IV.1). No presente estudo, esses táxons apresentam características morfo-polínicas distintas.

Fellipe \& Salgado-Labouriau (1964) e Salgado-Labouriau (1973) trataram de espécies de cerrado de Heliantheae (Asteraceae). Dentre elas, Viguiera arenaria e $V$. robusta, que foram incluídas no tipo 'Aspilia'. Esse tipo, segundo os autores, é comum para toda a tribo Heliantheae e se caracteriza, basicamente pela forma dos grãos de pólen (oblato-esferoidal a prolato-esferoidal), pelo âmbito com cerca de 12 espinhos, pelo tipo de abertura (tricolporados) e pela exina espinhosa com cava. Os resultados aqui encontrados para essas espécies são semelhantes aos dos autores, diferindo apenas nos valores dos diâmetros dos grãos de pólen.

Skvarla \& Turner (1966) avaliando as implicações sistemáticas com o uso de microscópio eletrônico de transmissão nos estudos de Asteraceae, utilizaram 184 espécies de 11 tribos e, dentre elas, Viguiera dentata (Cav.) Spreng., à qual pertence o tipo do gênero. Segundo os autores, na tribo Heliantheae a camada basal é sempre muito fina e a presença de cava é comum em todas as espécies. Essas características foram aqui constatadas.

Gonçalves-Esteves \& Esteves (1989) analisaram 10 espécies brasileiras de Viguiera, oito delas objeto do presente estudo. Os autores consideraram os grãos de pólen muito homogêneos, de tamanho médio a grande, espinhos cônicos ou com projeções basilares, "tegilo oco" (atualmente, equivale a espinho com perfuração na base) ou "tegilo simples" (atualmente, equivale a espinho sólido). Os autores concordaram com Salgado-Labouriau (1973) ao enquadrar os grãos de pólen no tipo 'Aspilia'. O atual estudo apresenta resultados diferentes, no que se refere às dimensões dos grãos de pólen e a não citação da existência da cava aqui definida. Concorda-se, porém, com o tipo polínico 'Aspilia', para todas as espécies de Viguiera analisadas.

O grão de pólen, quando considerado no conjunto de seus atributos, revelouse em um caráter diagnóstico importante, principalmente em nível específico onde, 
além das classes de tamanho do intervalo de confiança do diâmetro polar e do tipo de área polar, características como a forma e dimensões das aberturas, puderam ser usadas para identificar espécies e corroborar os resultados encontrados nos estudos taxonômicos de Magenta (2006). 
Tabela 1: Medidas (em $\mu \mathrm{m})$ de grãos de pólen de espécies de Viguiera, em vista equatorial $(\mathrm{n}=25) ; \overline{\mathrm{x}}$ - média aritmética; $\mathrm{s} \overline{\mathrm{x}}$ - desvio padrão da média; $\mathrm{s}$ - desvio padrão da amostra; CV - coeficiente de variabilidade; IC - intervalo de confiança a 95\%; P/E - relação entre o diâmetro polar e o diâmetro equatorial.

\begin{tabular}{|c|c|c|c|c|c|c|c|}
\hline \multirow[t]{3}{*}{ Espécies } & \multicolumn{3}{|c|}{ Diâmetro polar (DP) } & \multicolumn{3}{|c|}{ Diâmetro equatorial (DE) } & \multirow[t]{3}{*}{$\mathrm{P} / \mathrm{E}$} \\
\hline & Faixa de & $\bar{x} \pm s_{x}$ & IC 95\% & Faixa de & $\bar{x} \pm s_{x}$ & IC 95\% & \\
\hline & \multicolumn{3}{|l|}{ Variação } & \multicolumn{3}{|l|}{ Variação } & \\
\hline V. amphychlora & $36,3-38,8$ & $37,3 \pm 0,2$ & $36,9-37,7$ & $38,8-41,3$ & $39,9 \pm 0,1$ & $39,7-40,1$ & 0,93 \\
\hline V. anchusifolia & $33,8-36,2$ & $35,0 \pm 0,1$ & $34,8-35,2$ & $37,5-40,0$ & $38,2 \pm 0,2$ & $37,8-38,6$ & 0,91 \\
\hline$V$. arenaria & $37,5-40,0$ & $38,5 \pm 0,2$ & $38,1-38,9$ & $40,0-43,8$ & $42,2 \pm 0,2$ & $41,8-42,6$ & 0,91 \\
\hline V. aspilioides & $38,8-41,2$ & $40,2 \pm 0,2$ & $39,8-40,6$ & $37,5-41,2$ & $39,8 \pm 0,3$ & $39,1-40,3$ & 1,01 \\
\hline V. bakeriana & $35,0-38,0$ & $36,9 \pm 0,2$ & $36,5-37,3$ & $38,8-41,2$ & $39,8 \pm 0,1$ & $39,6-40,0$ & 0,92 \\
\hline$V$. bracteata & $35,0-37,5$ & $36,2 \pm 0,2$ & $35,8-36,6$ & $37,5-41,2$ & $39,4 \pm 0,2$ & $39,0-39,8$ & 0,91 \\
\hline V. corumbensis & $36,2-40,0$ & $38,4 \pm 0,2$ & $38,0-38,8$ & $40,0-42,5$ & $41,0 \pm 0,2$ & $40,6-41,4$ & 0,93 \\
\hline V. discolor & $37,5-38,8$ & $38,1 \pm 0,1$ & $37,9-38,3$ & $37,5-42,5$ & $39,9 \pm 0,2$ & $39,5-40,3$ & 0,95 \\
\hline$V$. filifolia & $35,5-38,8$ & $36,9 \pm 0,2$ & $36,5-37,3$ & $38,0-41,2$ & $39,7 \pm 0,2$ & $39,3-40,1$ & 0,92 \\
\hline V. gardneri & $37,5-41,2$ & $38,4 \pm 0,2$ & $38,0-38,8$ & $40,5-42,5$ & $41,1 \pm 0,2$ & $40,7-41,5$ & 0,93 \\
\hline V. grandiflora & $35,0-37,5$ & $36,5 \pm 0,2$ & $36,1-36,9$ & $38,0-41,2$ & $40,0 \pm 0,1$ & $39,8-40,2$ & 0,91 \\
\hline V. hispida & $35,0-40,0$ & $37,5 \pm 0,2$ & $37,1-37,9$ & $37,5-43,0$ & $40,5 \pm 0,2$ & $40,1-40,9$ & 0,92 \\
\hline V. kunthiana & $32,5-36,2$ & $34,4 \pm 0,2$ & $34,0-34,8$ & $35,0-38,8$ & $36,8 \pm 0,2$ & $36,4-37,2$ & 0,94 \\
\hline V. macrorhiza & $40,0-42,5$ & $41,5 \pm 0,2$ & $41,1-41,9$ & $42,5-45,0$ & $43,6 \pm 0,2$ & $43,2-44,0$ & 0,95 \\
\hline$V$. megapotamica & $37,5-40,0$ & $38,8 \pm 0,2$ & $38,4-39,2$ & $38,8-42,5$ & $41,0 \pm 0,2$ & $40,6-41,4$ & 0,94 \\
\hline V. nudibasilaris & $35,0-37,5$ & $36,5 \pm 0,2$ & $36,1-36,9$ & $37,5-42,5$ & $40,8 \pm 0,3$ & $40,2-41,4$ & 0,89 \\
\hline V. oblongifolia & $41,2-42,0$ & $41,6 \pm 0,2$ & $41,2-42,0$ & $42,5-46,2$ & $44,7 \pm 0,1$ & $44,5-44,9$ & 0,93 \\
\hline$V$. paranensis & $37,5-41,3$ & $39,8 \pm 0,2$ & $39,4-40,2$ & $42,5-47,5$ & $43,4 \pm 0,2$ & $43,0-43,8$ & 0,91 \\
\hline V. pilosa & $38,8-40,0$ & $39,5 \pm 0,1$ & $39,3-39,7$ & $42,5-45,0$ & $42,8 \pm 0,1$ & $42,6-43,0$ & 0,92 \\
\hline$V$. robusta & $36,2-40,0$ & $37,6 \pm 0,2$ & $37,2-38,0$ & $38,8-42,5$ & $40,4 \pm 0,2$ & $40,0-40,8$ & 0,93 \\
\hline V.rubra & $35,0-37,5$ & $35,9 \pm 0,2$ & $35,5-36,3$ & $36,3-40,0$ & $38,2 \pm 0,2$ & $37,8-38,6$ & 0,93 \\
\hline$V$. santacatarinensis & $37,5-42,5$ & $39,9 \pm 0,2$ & $39,5-40,3$ & $40,0-43,8$ & $41,5 \pm 0,2$ & $41,1-41,9$ & 0,96 \\
\hline V. squalida & $35,0-40,0$ & $38,2 \pm 0,3$ & $37,6-38,8$ & $40,0-42,5$ & $40,9 \pm 0,3$ & $40,3-41,5$ & 0,93 \\
\hline V. tenuifolia & $37,5-40,0$ & $37,9 \pm 0,2$ & $37,5-38,3$ & $37,9-38,7$ & $38,7 \pm 0,2$ & $38,3-39,1$ & 0,91 \\
\hline V. trichophylla & $35,0-38,8$ & $36,8 \pm 0,3$ & $36,2-37,4$ & $37,5-41,2$ & $39,2 \pm 0,2$ & $38,8-39,6$ & 0,93 \\
\hline$V$. tuberosa & $33,8-36,2$ & $35,3 \pm 0,1$ & $35,1-35,5$ & $37,5-41,2$ & $39,1 \pm 0,2$ & $38,7-39,5$ & 0,90 \\
\hline$V$. veredensis & $31,2-33,8$ & $32,7 \pm 0,2$ & $32,3-33,1$ & $33,8-36,2$ & $35,4 \pm 0,2$ & $35,0-35,8$ & 0,92 \\
\hline
\end{tabular}


Tabela 2 - Médias (em $\mu \mathrm{m})$ de grãos de pólen de espécies de Viguiera, em vista polar: diâmetro equatorial (DEVP); lado do apocolpo (LA) e índice da área polar (IAP) de espécies de Viguiera $(n=10)$.

\begin{tabular}{|c|c|c|c|c|c|}
\hline \multirow[b]{2}{*}{ ESPÉCIES } & \multicolumn{2}{|l|}{ DEVP } & \multicolumn{2}{|l|}{ LA } & \multirow[t]{2}{*}{ IAP } \\
\hline & Faixa & $\overline{\bar{x}}$ & Faixa & $\overline{\bar{x}}$ & \\
\hline & Variação & & Variação & & \\
\hline V. amphychlora & $37,5-40,0$ & 38,6 & $10,0-12,5$ & 10,3 & 0,26 \\
\hline$V$. anchusifolia & $37,5-40,0$ & 38,0 & $10,0-12,5$ & 11,2 & 0,29 \\
\hline$V$. arenaria & $40,0-43,8$ & 42,1 & $10,0-10,0$ & 10,0 & 0,23 \\
\hline V. aspilioides & $41,2-43,8$ & 42,2 & $10,0-12,5$ & 12,2 & 0,29 \\
\hline V. bakeriana & $38,8-41,2$ & 40,5 & $7,5-10,0$ & 8,6 & 0,21 \\
\hline V. bracteata & $38,8-40,0$ & 39,6 & $10,0-12,5$ & 11,0 & 0,27 \\
\hline V. corumbensis & $38,8-42,5$ & 39,9 & $10,0-12,5$ & 11,5 & 0,28 \\
\hline V. discolor & $38,0-42,5$ & 40,8 & $7,5-10,0$ & 9,6 & 0,23 \\
\hline V. filifolia & $37,5-40,0$ & 39,1 & $10,0-12,5$ & 11,4 & 0,29 \\
\hline V. gardneri & $38,8-42,5$ & 40,5 & $10,0-12,5$ & 11,7 & 0,28 \\
\hline$V \cdot$ grandiflora & $37,5-41,2$ & 39,9 & $12,5-13,8$ & 12,7 & 0,31 \\
\hline V. hispida & $38,8-41,2$ & 39,9 & $8,8-11,2$ & 10,0 & 0,25 \\
\hline V. kunthiana & $37,5-40,0$ & 38,2 & $11,2-12,5$ & 12,2 & 0,32 \\
\hline V. macrorhiza & $41,2-43,8$ & 42,5 & $10,0-12,5$ & 11,8 & 0,27 \\
\hline V. megapotamica & $40,0-41,2$ & 40,3 & $8,8-11,2$ & 9,9 & 0,24 \\
\hline V. nudibasilaris & $40,0-43,8$ & 41,5 & $10,0-12,5$ & 10,5 & 0,25 \\
\hline V. oblongifolia & $43,8-45,5$ & 44,9 & $10,0-12,5$ & 11,2 & 0,24 \\
\hline$V$. paranensis & $42,5-45,0$ & 43,4 & $10,0-11,3$ & 10,1 & 0,23 \\
\hline$V$. pilosa & $42,5-45,0$ & 43,6 & $12,5-13,8$ & 12,6 & 0,28 \\
\hline$V$. robusta & $37,5-41,2$ & 39,0 & $10,0-12,5$ & 11,9 & 0,30 \\
\hline V. rubra & $36,3-40,5$ & 38,5 & $7,5-10,0$ & 9,6 & 0,24 \\
\hline V. santacatarinensis & $40,0-42,5$ & 41,0 & $10,0-12,5$ & 11,2 & 0,27 \\
\hline V. squalida & $37,5-41,2$ & 40,1 & $10,0-12,5$ & 11,7 & 0,29 \\
\hline V. tenuifolia & $41,2-42,5$ & 42,0 & $10,0-12,5$ & 11,8 & 0,28 \\
\hline V. trichophylla & $37,5-41,2$ & 38,7 & $11,2-13,8$ & 12,5 & 0,32 \\
\hline V. tuberosa & $37,5-41,2$ & 39,4 & $10,0-12,5$ & 10,4 & 0,26 \\
\hline V. veredensis & $32,5-36,2$ & 34,0 & $8,8-10,0$ & 9,6 & 0,28 \\
\hline
\end{tabular}


Tabela 3 - Médias (em $\mu \mathrm{m}$ ) das aberturas e da exina dos grãos de pólen de espécies de Viguiera $(n=10) ;$ * exina total incluindo espinho.

\begin{tabular}{|c|c|c|c|c|c|c|c|c|c|c|}
\hline \multirow[t]{2}{*}{ Espécies } & \multicolumn{2}{|c|}{ colpo } & \multicolumn{2}{|c|}{ endoabertura } & \multicolumn{3}{|c|}{ espessura da exina } & \multicolumn{2}{|c|}{ espinho } & \multirow[b]{2}{*}{ dist. } \\
\hline & 'compr. & larg. & compr. & larg. & exina* & cava & nexina & compr. & larg. & \\
\hline V. amphychlora & 15,8 & 4,3 & 4,3 & 12,6 & 7,1 & 1,0 & 1,0 & 5,1 & 3,0 & 7,1 \\
\hline$V$. anchusifolia & 16,6 & 3,0 & 2,8 & 12,5 & 10,1 & 0,9 & 1,0 & 8,2 & 4,8 & 8,5 \\
\hline$V$. arenaria & 14,0 & 4,5 & 3,0 & 14,0 & 9,4 & 1,1 & 0,9 & 7,4 & 4,5 & 8,4 \\
\hline V. aspilioides & 11,3 & 3,6 & 3,4 & 10,9 & 9,2 & 1,0 & 1,0 & 7,2 & 4,7 & 9,0 \\
\hline V. bakeriana & 11,9 & 3,5 & 3,0 & 10,9 & 8,2 & 1,0 & 1,0 & 6,2 & 3,3 & 9,0 \\
\hline V. bracteata & 13,0 & 3,8 & 3,4 & 11,0 & 8,9 & 1,0 & 1,0 & 6,9 & 4,0 & 8,5 \\
\hline V. corumbensis & 13,4 & 3,6 & 3,5 & 12,4 & 8,1 & 1,1 & 0,9 & 6,1 & 3,6 & 7,7 \\
\hline V. discolor & 14,1 & 3,2 & 2,2 & 5,5 & 9,0 & 1,0 & 1,0 & 7,0 & 3,8 & 8,6 \\
\hline V. filifolia & 18,0 & 3,2 & 2,9 & 13,0 & 8,2 & 1,0 & 1,0 & 6,2 & 3,2 & 8,0 \\
\hline V. gardneri & 14,5 & 4,0 & 3,6 & 10,9 & 6,0 & 1,0 & 0,9 & 6,3 & 4,3 & 8,3 \\
\hline$V \cdot$ grandiflora & 17,2 & 2,3 & 2,4 & 11,3 & 7,7 & 0,8 & 0,9 & 6,0 & 3,0 & 8,0 \\
\hline V. hispida & 16,5 & 3,5 & 3,2 & 12,0 & 7,7 & 1,0 & 0,9 & 5,8 & 2,9 & 9,2 \\
\hline V. kunthiana & 16,1 & 3,9 & 3,4 & 12,5 & 9,1 & 1,0 & 1,0 & 7,1 & 4,9 & 8,0 \\
\hline V. macrorhiza & 12,9 & 4,4 & 4,4 & 12,0 & 8,0 & 0,9 & 1,0 & 6,1 & 3,4 & 8,8 \\
\hline$V$. megapotamica & 14,2 & 3,5 & 2,8 & 11,3 & 7,7 & 1,1 & 0,9 & 5,7 & 3,2 & 8,7 \\
\hline V. nudibasilaris & 13,2 & 4,2 & 3,3 & 10,3 & 8,5 & 1,5 & 0,8 & 6,1 & 2,7 & 7,9 \\
\hline V. oblongifolia & 14,8 & 2,9 & 3,1 & 11,5 & 13,0 & 1,0 & 1,0 & 11,0 & 6,1 & 10,4 \\
\hline$V$. paranensis & 16,5 & 4,0 & 3,5 & 10,7 & 10,0 & 1,0 & 1,0 & 8,0 & 3,3 & 7,3 \\
\hline$V$. pilosa & 16,8 & 2,9 & 2,9 & 14,5 & 10,4 & 1,0 & 0,9 & 8,5 & 6,0 & 9,7 \\
\hline$V$. robusta & 15,8 & 6,3 & 4,8 & 13,2 & 8,3 & 1,0 & 0,9 & 6,4 & 3,3 & 8,6 \\
\hline V. rubra & 14,3 & 5,0 & 4,5 & 12,2 & 7,6 & 1,0 & 1,0 & 5,6 & 2,5 & 7,7 \\
\hline V. santacatarinensis & 14,5 & 4,8 & 3,8 & 12,0 & 8,2 & 1,0 & 1,0 & 6,2 & 3,0 & 8,2 \\
\hline V. squalida & 17,0 & 4,1 & 2,9 & 12,2 & 7,0 & 1,1 & 0,9 & 5,1 & 2,7 & 8,1 \\
\hline V. tenuifolia & 14,2 & 4,0 & 3,2 & 12,6 & 8,1 & 1,0 & 1,0 & 6,1 & 4,3 & 9,0 \\
\hline V. trichophylla & 16,2 & 3,3 & 3,0 & 11,7 & 9,4 & 1,0 & 1,0 & 7,4 & 5,5 & 8,3 \\
\hline V. tuberosa & 13,7 & 3,4 & 2,9 & 11,4 & 8,0 & 1,0 & 0,9 & 6,1 & 3,0 & 10,0 \\
\hline$V$. veredensis & 14,2 & 3,8 & 3,0 & 12,0 & 6,9 & 0,9 & 0,9 & 5,0 & 3,0 & 9,0 \\
\hline
\end{tabular}


Tabela 4 - Médias (em $\mu \mathrm{m}$ ) dos diâmetros dos grãos de pólen em vista equatorial (diâmetro polar, diâmetro equatorial), em vista polar (diâmetro equatorial, lado do apocolpo), relação dos diâmetros polar e equatorial e a forma do material de comparação de espécies de Viguiera $(\mathrm{n}=10) . \bar{x}$ média aritmética; P/E - relação entre o diâmetro polar e o diâmetro equatorial; diâmetro equatorial em vista polar (DEVP); lado do apocolpo (LA).

Espécimes

\begin{tabular}{|c|c|}
\hline Diâmetro & Diâmetro \\
\hline polar & equatorial \\
\hline $\bar{x}$ & $\bar{x}$ \\
\hline
\end{tabular}

\begin{tabular}{|c|c|}
\hline \multirow[t]{2}{*}{ Forma } & $D E \quad L A$ \\
\hline & $V P \quad \bar{x}$ \\
\hline
\end{tabular}

V. arenaria

M. Magenta \& J.E. Magenta 383 36,7

38,8

o,94 oblato- $\quad 39, \quad 8,9$

esferoidal 5

V. aspilioides

P.I. Oliveira 965

42,5

43,1

0,96

oblato-

$45, \quad 12,5$

G. Hatschbach 12847

40,3

42,5

0,95

esferoidal 8

oblato-

$43, \quad 10,9$

esferoidal $\quad 0$

\section{V. bakeriana}

M. Magenta \& J.E. Magenta 483

35,8

39,7

0,90

oblato-

$40, \quad 9,7$

esferoidal 3

M. Magenta \& J.E. Magenta 494

27,2

29,7

$0,91 \quad$ oblato-

$28, \quad 7,3$

esferoidal $\quad 9$

\section{V. bracteata}

M. Magenta et al. 444

37,1

40,2

0,92

oblato-

$40, \quad 10,1$

M. Magenta \& J.E. Magenta 631

37,3

39,5

0,94

esferoida

2

M. Magenta \& J.E. Magenta 637 34,8

37,1

0,93

oblato-

$40, \quad 10,5$

esferoidal 1

oblato-

$36, \quad 10,7$

esferoidal 6

\section{V. discolor}

M. Magenta \& J.E. Magenta 320

37,5

40,7

0,92

oblato-

$40, \quad 9,6$

esferoida

7

M. Magenta \& J.E. Magenta $279 \quad 38,1$

40,9

0,93

oblato-

$41, \quad 10,1$

esferoidal 0

\section{V. filifolia}


Tabela 4 (cont.) - Médias (em $\mu \mathrm{m}$ ) dos diâmetros dos grãos de pólen em vista equatorial (diâmetro polar, diâmetro equatorial), em vista polar (diâmetro equatorial, lado do apocolpo), relação dos diâmetros polar e equatorial e a forma do material de comparação de espécies de Viguiera $(n=10) . \bar{x}-$ média aritmética; P/E - relação entre o diâmetro polar e o diâmetro equatorial; diâmetro equatorial em vista polar (DEVP); lado do apocolpo (LA).

\begin{tabular}{|c|c|c|c|c|c|c|}
\hline Espécimes & Diâmetro & Diâmetro & $P / E$ & Forma & $D E$ & $L A$ \\
\hline & polar & equatorial & & & $V P$ & $\bar{x}$ \\
\hline & $\bar{x}$ & $\bar{x}$ & & & $\bar{x}$ & \\
\hline M. Magenta et al. 447 & 35,9 & 38,1 & 0,94 & oblato- & 37 & 11,5 \\
\hline & & & & esferoidal & 4 & \\
\hline M. Magenta et al. 452 & 36,8 & 38,9 & 0,94 & oblato- & 39, & 12,7 \\
\hline & & & & esferoidal & 0 & \\
\hline V. gardneri & & & & & & \\
\hline M. Magenta et al. 455 & 39,5 & 42,2 & 0,93 & oblato- & 42 & 11,4 \\
\hline & & & & esferoidal & 2 & \\
\hline M. Magenta et al. 456 & 34,9 & 38,0 & 0,91 & oblato- & 37, & 10,2 \\
\hline & & & & esferoidal & 6 & \\
\hline V. hispida & & & & & & \\
\hline Wanderley et al. 1764 & 37,9 & 41,2 & 0,91 & oblato- & 41, & 11,4 \\
\hline & & & & esferoidal & 6 & \\
\hline V. kunthiana & & & & & & \\
\hline M.A. Silva et al. 1005 & 35,4 & 38,2 & 0,92 & oblato- & 38 & 10,0 \\
\hline & & & & esferoidal & 9 & \\
\hline V. macrorhiza & & & & & & \\
\hline M. Magenta \& J.E. Magenta 476 & 38,2 & 40,1 & 0,95 & oblato- & 39, & 11,6 \\
\hline & & & & esferoidal & 1 & \\
\hline V. nudibasilaris & & & & & & \\
\hline H.F. Leitão $\mathrm{F}^{\circ} 1853$ & 36,9 & 39,5 & 0,93 & oblato- & 39,1 & 11,6 \\
\hline & & & & esferoidal & & \\
\hline M.J. Robim \& J.P.M. Carvalho & 36,7 & 40,0 & 0,91 & oblato- & 39,0 & 11,0 \\
\hline 256 & & & & esferoidal & & \\
\hline V. oblongifolia & & & & & & \\
\hline M. Magenta et al. 349 & 28,4 & 31,4 & 0,90 & oblato- & 30,0 & 8,1 \\
\hline & & & & esferoidal & & \\
\hline M. Magenta et al. 352 & 42,2 & 45,1 & 0,93 & oblato- & 44,9 & 11,1 \\
\hline & & & & esferoidal & & \\
\hline
\end{tabular}




\section{V. paranensis}

J. Vidal \& E.S. Araújo III-228 39,0

39,0

40,7

0,96 oblato-

$41,2 \quad 10,6$

esferoidal

\section{V. pilosa}

M. Magenta \& C. Mondin 511

39,5

42,8

0,92

oblato-

43,6

12,6

\section{V. robusta}

M. Magenta \& J.E. Magenta 381

36,5

$0,91 \quad$ oblato-

$36,7 \quad 10,2$

M. Magenta \& J.E. Magenta 566

40,4

42,9

0,94

esferoidal

V. squalida

A. Lima 461-68

33,6

37,1

0,90

oblato-

$36,9 \quad 10,6$

M. Magenta \& J.E. Magenta 697

40,0

42,1

0,95

esferoidal

esferoidal

$41,6 \quad 13,1$

oblato-

$41,4 \quad 11,4$

esferoidal

\section{V. tenuifolia}

M. Magenta \& J.E. Magenta $287 \quad 38,4$

40,9

0,93

oblato-

41,9

12,5

esferoidal

M. Magenta \& J.E. Magenta $584 \quad$ 37,6

41,0

0,91

oblato-

39,7

12,1

esferoidal

\section{V. tuberosa}

M. Magenta et al. 604

38,5

40,75

0,94

oblato-

40,5

10,2

C. Mondin E A. Iob 2588

36,6

39,1

0,93

esferoidal

oblato-

39,7

esferoidal 

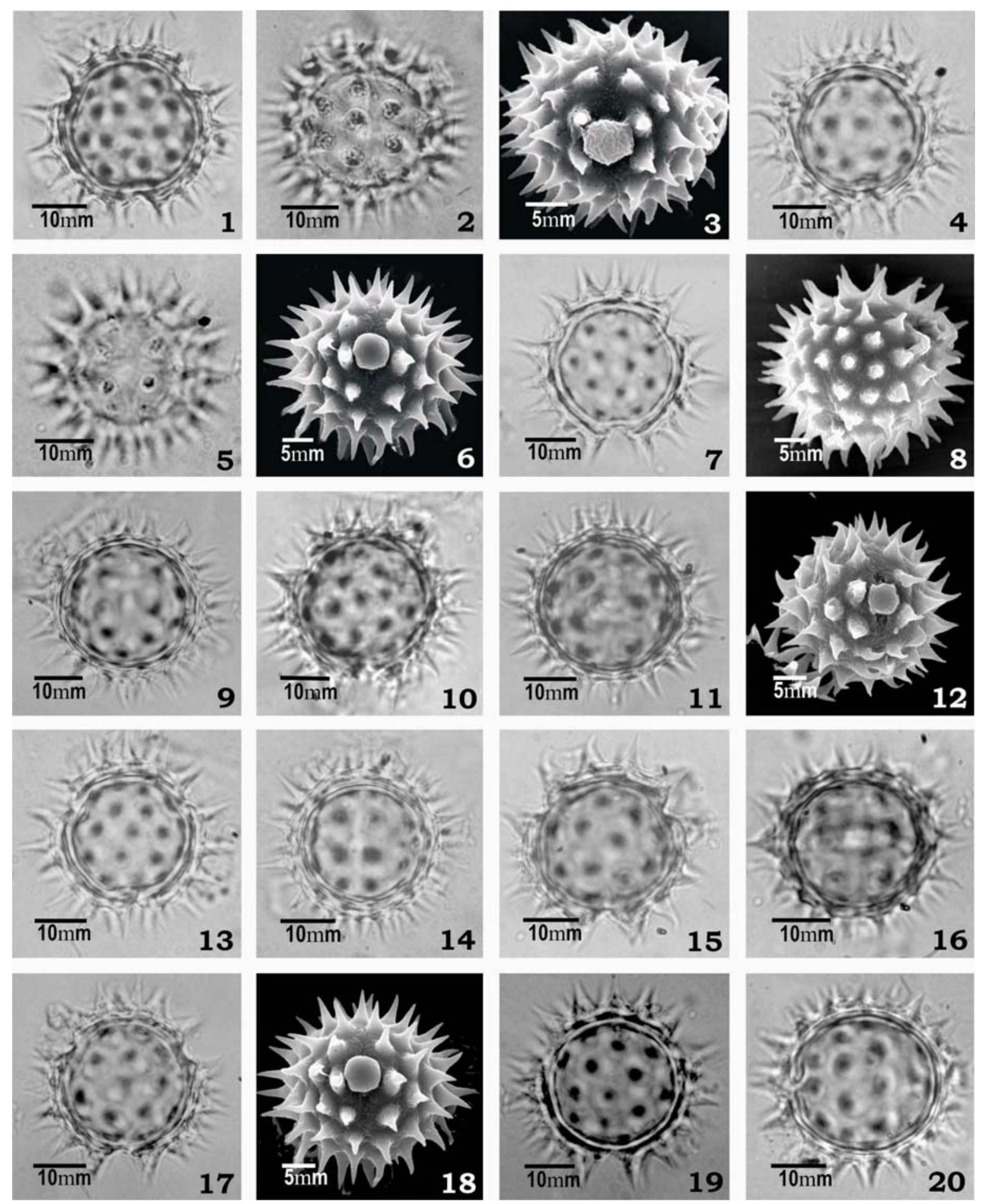

Fig. 1. Fotomicrografias e eletromicrografias de espécies de Viguiera. 1-3. V. amphychlora Vista polar: 1. Corte óptico. Vista equatorial: 2.3. abertura e superfície. 4-6. V. anchusifolia Vista polar: 4. Corte óptico. Vista equatorial: 5.6. Abertura e superfície. 7-9. V. arenaria - Vista polar: 7. Corte óptico. 8. Superfície na região do apocolpo. Vista equatorial: 9. Corte óptico. 10-12. V. aspilioides - Vista polar: 10- Corte óptico. Vista equatorial: 11.12. Abertura e superfície. 13-14. V. bakeriana - Vista polar: 13. Corte óptico. Vista equatorial: 14. Corte óptico. 15-16. V. bracteata - Vista polar: 15. Corte óptico. Vista equatorial: 16. Abertura. 17-18. V. corumbensis - Vista polar: 17. Corte óptico. Vista equatorial: 18. Abertura. 19-20. V. gardneri Vista polar: 19. Corte óptico. Vista equatorial: 20. Corte óptico. 

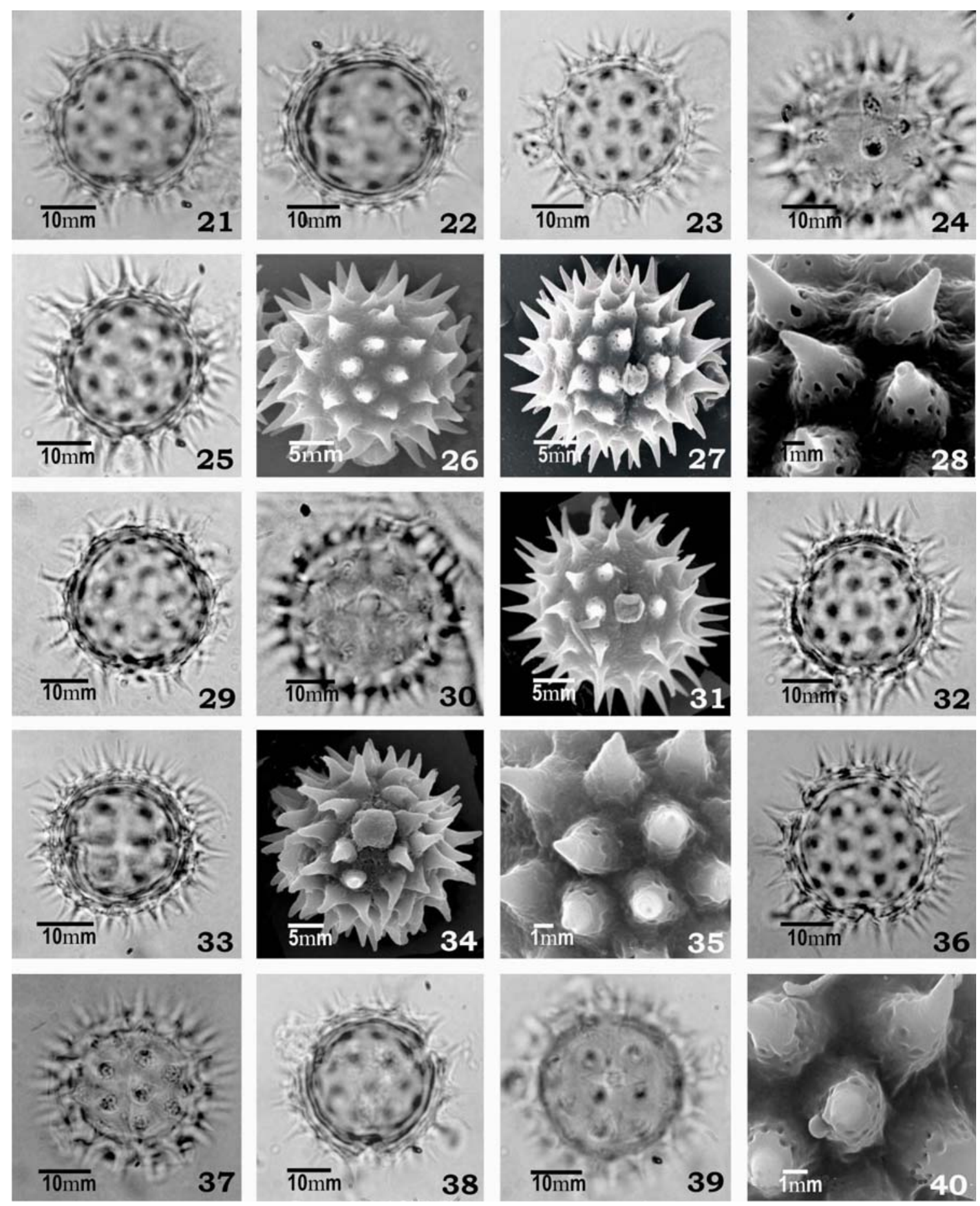

Fig. 2. Fotomicrografias e eletromicrografias de espécies de Viguiera. 21-22. V. grandiflora Vista polar: 21. Corte óptico. Vista equatorial: 22. Corte óptico. 23-24. V. hispida - Vista polar: 23. Corte óptico. Vista equatorial: 24. Abertura. 25-28. V. kunthiana - Vista polar: 25. Corte óptico. 26. Superfície na região do apocolpo. Vista equatorial: 27. Abertura. 28. Detalhe da superfície. 29-31. V. macrorhiza - Vista polar: 29. Corte óptico. 30. Abertura. Vista equatorial: 31. Abertura e detalhe da superfície. 32-35. V. megapotamica - Vista polar: 32. Corte óptico. Vista equatorial: 33.34. Abertura. 35. Detalhe da superfície. 36-37. V. nudibasilaris - Vista polar: 36. Corte óptico. Vista equatorial: 37. Abertura. 38-40. V. paranensis - Vista polar: 38. Corte óptico. Vista equatorial: 39. Abertura. 40. Detalhe da superfície. 

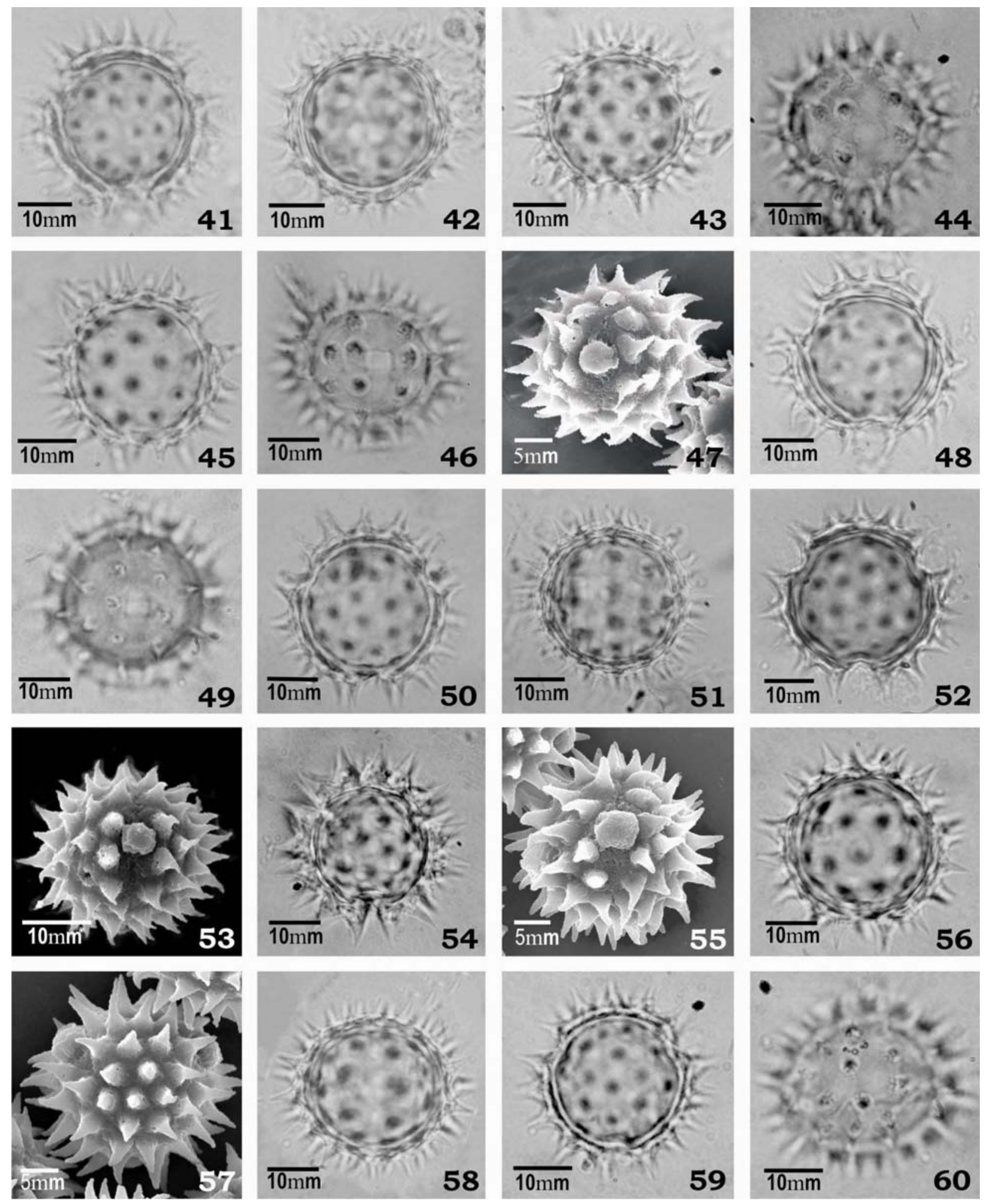

Fig. 3. Fotomicrografias e eletromicrografias de espécies de Viguiera. 41-42. V. pilosa - Vista polar: 41. Corte óptico. Vista equatorial: 42. corte óptico e abertura. 43-44. V. robusta - Vista polar: 43. Corte óptico. Vista equatorial: 44. Abertura. 45-47. V. rubra - Vista polar: 45. Corte óptico. Vista equatorial: 46-47. Abertura e superfície. 48-49. V. santacatarinensis - Vista polar: 48. Corte óptico. Vista equatorial: 49. Abertura. 50-51. V. squalida - Vista polar: 50. Corte óptico. Vista equatorial: 51. Corte óptico. 52-53. V. tenuifolia - Vista polar: 52. Corte óptico. Vista equatorial: 53. Abertura. 54-55. V. trichophylla - Vista polar: 54. Corte óptico. Vista equatorial: 55. Abertura. 56-58. V. tuberosa - Vista polar: 56. Corte óptico. 57. Superfície na região do apocolpo. Vista equatorial: 58. Corte óptico. 59-60. V. veredensis - Vista polar: 59. Corte óptico. Vista equatorial: 60. Abertura. 


\section{Referências bibliográficas}

BARTH, O.M. \& MELHEM, T.S. 1988. Glossário ilustrado de palinologia. Unicamp, Campinas.

BLAKE, S.F. 1918. A revision of the genus Viguiera. Contr. Gray Herb. 54: 1 - 205.

BOLICK, M.R., SKVARLA, J.J. \& TURNER, B.L. 1984. On cavities in spines of Compositae pollen - A taxonomic perspective. Taxon 33: 289 - 295.

ERDTMAN, G. 1952. Pollen morphology and plant taxonomy. Angiosperms. Almquist \& Wiksell, Stockholm.

FAEGRI, K. \& INVERSEN, J. 1966. Textbook of modern pollen analysis. 2a ed. Scandinavian University Books, Copenhagen.

FELIPPE, G.M. \& SALGADO-LABOURIAU, M.L. 1964. POLLEN GRAINS OF THE "CERRADO" - VI - COMPOSITAE - TRIBUS HELIANTHEAE. AN. ACAD. BRAS. CIENC. 36: $85-101$.

FEUER, S. \& TOMB., A.S. 1977. Pollen morphology and detailed structure of family Compositae, tribe Cichorieae II. . Subtribe Microseridinae. Am. J. Bot. 64: 230 245.

GONÇALVES-ESTEVES, V. \& ESTEVES, R.L. 1989. Contribuição ao estudo polínico da tribo Heliantheae (Compositae) VI. Bol. Mus. Nac. 80: 1 -11.

HOLMGREN, P.K.; HOLMGREN, N.H. \& BAINETT, L.G. 1990. Index Herbariorum. Part. 1. The Herbaria of the world. New York Botanical Garden, New York.

HORNER, H.T., JR. \& PEARSON, C.B. 1978. Pollen wall and aperture development in Helianthus annus (Compositae-Heliantheae). Am. J. Bot. 65: 293 - 309.

MAGENTA, M.A.G. 2006. Viguiera Kunth (Asteraceae - Heliantheae) na América do Sul e sistemática das espécies do Brasil. PHd Thesis, Instituto de Biociências, Universidade de São Paulo, Brazil (unpublished).

PANERO, J.L. 2007. HELIANTHEAE. IN: J.W. KADEREIT. \& C. JEFFREY (EDS.): THE FAMILIES AND GENERA OF VASCULAR PLANTS. VOL. 8FLOWERING PLANTS - EUDICOTS. (SERIES EDITOR: K. KUBITZKI). BERLIN HEIDELBERG. SPRINGER.

MELHEM, T.S., SILVESTRE, M.S.F. \& MAKINO, H. 1979. Grãos de pólen de plantas alergógenas. Hoehnea 8: 73 - 100.

PERVEEN, A. 1999. CONTRIBUTIONS TO THE POLLEN MORPHOLOGY OF THE FAMILY COMPOSITAE. TR. J. OF BIOLOGY 23: 523 - 535.

PUNT, W., BLACKMORE, S., NILSSON, S. A. 1999. Glossary of pollen and spore terminology. $\quad 2_{-}^{\text {a }}$ ed. Available at: // http://www.biol.ruu.nl/ palaeo/glossary/glos-int.htm/ [accessed January 2006].

QRESHI, S.J., AWAN, A.G.; KHAN, M.A. \& BANO, S. 2002. PALYNOLOGICAL STUDY OF THE GENUS SONCHUS FROM PAKISTAN. J. BIOL. CIENC. 2: 98 105.

SALGADO-LABOURIAU, M.L. 1973. Contribuição à Palinologia dos Cerrados. Academia Brasileira de Ciências, Rio de Janeiro.

SCHILLING, E.E. \& JANSEN, R.K. 1989. Restriction fragment analysis of chloroplast DNA and the systematics of Viguiera and related genera (Asteraceae-Heliantheae). Am. J. Bot. 76: 1769 - 1778. 
SCHILLING, E.E., JANSEN, R.K. \& PANERO, J.L. 2002. A revised classification of subtribe Helianthinae (Asteraceae-Heliantheae). I. Basal lineages. Bot. J. Linn. Soc. 140: $65-76$.

SCHILLING, E.E. \& PANERO, J.L. 1996a. Relationships in Heliantheae subtribe Helianthinae based on chloroplast DNA restriction site analysis. In: D.J. Hind \& H.J. Beentje, (eds.). Compositae: systematics proceedings of the international Compositae conference, vol. 1, pp 361 - 376. Royal Botanic Gardens, Kew.

SCHILLING, E.E., \& PANERO, J.L. 1996b. Phylogenetic reticulation in subtribe Helianthinae. Am. J. Bot. 83: 939 - 948.

SKVARLA, J.J. \& LARSON, D.A. 1965a. An electron microscopy study of pollen morphology in the Compositae with special reference to Ambrosiinae. Grana Palyn. 9: 50 - 62 .

SKVARLA, J.J. \& LARSON, D.A. 1965b. Interbedded exine components in some Compositae. Soutw. Natural. 10: 65 - 68.

SKVARLA, J.J. \& TURNER, B.L. 1966. Systematic implications from electron microscope studies of Compositae pollen - a review. Ann. MO. Bot. Gard. 3: 220 256.

SKVARLA, J.J. \& TURNER, B.L. 1969. Fine structure of Petrobinae (CompositaeHeliantheae) pollen walls. Am. J. Bot. 56: 418 - 419.

SKVARLA, J.J.; TURNER, B.L., PATEL, V.C. 1977. Pollen morphology in the Compositae and morphologically related families. In: V.H. Heywood, J.B. Barbone \& B.L. Turner (Eds.). The biology and chemistry of the Compositae, pp. 141 - 217. Academic Press, London.

TOMB, A.S., LARSON, D.A. \& SKVARKA, J.J. 1974. Pollen morphology and detailed structure of family Compositae, tribe Cichorieae I. Subtribe Stephanomeriinae. Am. J. Bot. 61: 486 - 498.

VEZEY, E.L., WATSON, L.E., SKVARLA, J.J. 1994. Plesiomorphic and apomorphic pollen structure characteristics of Anthemideae (Asteroideae: Asteraceae). Am. J. Bot. 81: $648-657$.

WELLS, J.R. 1971. Variations in Polymnia pollen. Am. J. Bot. 58: 124 - 130.

WODEHOUSE, R.P. 1926. Pollen grain morphology in classification of Anthemidae. Bull. Torr. Bot. Club 53: 479 - 485.

WODERHOUSE, R.P. 1928. Pollen grains in the identification and classification of plants II. Barnadesia. Bull. Torr. Bot. Club 55: 449 - 462. 


\section{CAPÍTULO IV}

\section{ANÁlise FILOGENÉTICA DE VIGUIERA SENSU LATO COM BASE EM CARACTERES MORFOLÓGICOS ${ }^{1}$}

\section{$\underline{\text { Abstract }}$}

Aiming a phylogenetic test of Viguiera sensu lato, three analysis (1, 2 and 3) were performed, two of them (analysis 1 and 2) containing representatives of all infra-generic taxa proposed in the revision of the genus made by Blake, and a third one (analysis 3) including only the South American species and the genera Aldama and Rhysolepis. Besides, analysis 2 and 3 included some anatomical characters now available for the Brazilian species and three Andean taxa. The results confirm that the genus is not monophyletic, but there are strong support to some of the traditional infra-generic groups as monophyletic assemblages. In all of the analysis, Viguiera dentata, the typical species of the genus, emerge in the basal portion of the cladogram, the same happening with Simsia dombeyana; in the first two, it is also close to members of the series Grammatoglossae. The analyses are partially congruent with previous works, based on data from mutations in restriction site of cpDNA and on sequences of internal transcribed spacer region of nuclear ribossomal DNA (ITS). Morphological characters, not widely explored so far, like the presence and type of glands in the leaves, pales involving total or partially the outlying disk flowers and the shape of cipselas, seem to be consistent with the monophyly of some groups in the molecular analysis.

\section{$\underline{\text { Resumo }}$}

Com a finalidade de buscar uma hipótese filogenética robusta sobre Viguiera sensu lato, foram realizadas três análises (denominadas 1, 2 e 3); as duas primeiras contendo representantes de todos os táxons infra-genéricos, propostos na revisão do gênero efetuada por Blake (1918), e a última com as

\footnotetext{
${ }^{1}$ Manuscrito a ser submetido ao Kew Bulletin.
} 
espécies sul-americanas mais os gêneros Aldama e Rhyzolepis; as análises 2 e 3 tiveram inclusão de características anatômicas das espécies brasileiras e de três andinas. Os resultados confirmam que o gênero é parafilético, mas evidenciam que alguns dos grupos infra-genéricos tradicionais sejam monofiléticos. Em todas as análises, Viguiera dentata, a espécie típica do gênero, emerge na porção basal do cladograma, juntamente com Simsia dombeyana; nas duas primeiras, desponta também junto a membros da série Grammatoglossae. As análises são parcialmente congruentes com trabalhos anteriores, com dados de mutações em sítios de restrição de cpDNA e de seqüenciamento da região do espaçador ribossomal interno ribossômico nuclear (ITS). Caracteres morfológicos até agora pouco explorados, como presença e tipo de glândulas nas folhas, páleas envolvendo total ou parcialmente as flores periféricas do disco e forma da cipsela, parecem prover informações consistentes com as hipóteses de monofilia de alguns grupos nas análises moleculares.

\section{Introdução}

A subtribo Helianthinae, à qual pertence o gênero Viguiera Kunth é caracterizada pela presença de flores do raio neutras, dutos externos às nervuras do estilete e cipselas com paredes estriadas (Robinson 1981). Esta subtribo é quase que inteiramente americana, do Reino Holártico ao Neotropical, e seus gêneros se concentram principalmente no México e nos Estados Unidos; uma única espécie do gênero Sclerocarpus Jacq. parece ser nativa da África (Robinson, 1981). Estudos morfológicos (Robinson 1981; Karis 1993; Bremer 1994) e de dados moleculares (Schilling et al. 1994; Schilling e Panero 1996) têm confirmado a monofilia da subtribo. Esses e outros trabalhos (Robinson 1977; Schilling \& Panero 1991; Karis 1993) constataram, no entanto, um sério problema taxonômico, quanto à delimitação tradicional de Viguiera, com forte evidência de que não se trata de um grupo monofilético.

O tratamento clássico do gênero é o de Blake (1918) no qual o autor incluiu em Viguiera representantes de Bahiopsis, Gymnolomia, Heliomeris e Hymenostephium. Para as classificações infra-genéricas, o autor considerou 


\section{conjuntos de características relativas ao hábito, brácteas involucrais dos capítulos e pápus (ver tabela 1).}

\section{Tabela 1: Quadro sinóptico da classificação de Viguiera Kunth (Blake 1918) e táxons correspondentes, de acordo com propostas recentes (o número de espécies é o constante na revisão de Blake; os nomes das espécies tratadas como sinônimos no capítulo V estão assinalados com *).}

Subgênero Amphilepis: ervas ou arbustos; brácteas involucrais interiores (ao menos na frutificação) com ápice membranáceo arredondado e ampliado, submembranáceo; pápus com 2 aristas e várias escamas ou cipselas sem pápus: México; 12 espécies.

Subgênero Calanticaria (subg. Viguiera Kunth): Brácteas involucrais sem ápice ampliado; pápus 2aristado e com várias escamas escariosas muito menores que as aristas ou sem pápus: dividido em 7 (sete) seções, de acordo com o hábito, forma e margem das folhas e características das brácteas involucrais: Estados Unidos até Argentina e Brasil; 124 espécies.

Seção 1: Hypargyrea: Perenes firmes, simples, com um a poucos capítulos grandes e folhas sésseis muito grandes, lanceoladas ou ovadas, com face abaxial serícea ou tomentosa; brácteas involucrais em 2-3 séries, oblongas a ovado-oblongas, levemente endurecidas na base, pápus sempre presente. México; 3 espécies.

Seção 2: Chloracra

Série A: Maculatae [Seção Maculatae (S.F. Blake) Panero]: Arbustos; capítulos em inflorescências paniculiformes e folhas usualmente ovadas escabrosas; brácteas involucrais em 2-3 séries, com base caniculada e margem paleácea e ápice curtamente foliáceo. México; 7 espécies.

Série B: Grammatoglossae: Ervas a arbustos, folhas ovadas; capítulos médios a grandes; brácteas involucrais em 2-5 séries, com tamanhos similares ou diferentes, base obscuramente endurecida e costada e ápice de textura semelhante à da base. Texas a Guatemala; 11 espécies.

Série C: Dentatae [série Viguiera Kunth; Bahiopsis Kellog - menos V. dentata e V. potosina]: Ervas ou arbustos, usualmente com folhas ovadas denteadas ou laciniadas; capítulos em panículas; brácteas involucrais em 2-3 séries, com base fortemente endurecida e estriada e ápice foliáceo abruptamente linear; raramente sem pápus. Cuba a Estados Unidos; 9 espécies.

Série D: Pinnatilobatae: Arbustos ou raramente ervas, com folhas profundamente pinatilobadas; brácteas involucrais em 2-3 séries, lanceoladas a lanceolado-subuladas, com base fortemente endurecida e costada e ápice foliáceo abruptamente estreitado; corolas ampliadas na base; cipselas sem pápus. Texas ao México; 4 espécies.

Série E: Brevifoliae [gênero Calanticaria (B.L. Rob. \& Greenm.) Schilling \& Panero]: Pequenos arbustos muito ramificados, canescentes, com pubescência fina e apressa; folhas pequenas, ovadas, canescentes ao menos na face inferior; capítulos solitários nos ápices dos ramos; brácteas involucrais em 34 séries, ovadas a oval-oblongas, agudas, estrigilosas, obscuramente costadas, com ápice foliáceo curto e obscuro; cipselas com ou sem pápus: México; 3 espécies.

Seção 3: Diplostichis [atualmente em Hymenostephium Benth, incluindo Haplocalyma e Garcilassa]: Ervas anuais ou raramente arbustos delicados; capítulos pequenos, brácteas involucrais em 2 séries, base estriada e ápice subfoliáceo; cipselas com carpopódio distinto, raramente sem pápus: México, Venezuela e Equador (atualmente Argentina); 7 espécies.

Seção 4: Heliomeris (Heliomeris Nutt.): Ervas anuais ou perenes, delicadas, folhas lineares a linearlanceoladas; invólucro 2-seriado, brácteas levemente diferentes, lanceoladas a linear-lanceoladas, totalmente foliáceas: Montana a Chiapas; uma espécie na Geórgia; 7 espécies . 
Tabela 1 (cont.): Quadro sinóptico da classificação de Viguiera Kunth (Blake 1918) e táxons correspondentes, de acordo com propostas recentes (o número de espécies é o constante na revisão de Blake; os nomes das espécies tratadas como sinônimos no capítulo V estão assinalados com *).

Seção 5: Paradosa: Ervas ou arbustos de hábitos variados; brácteas involucrais em 2-5 séries, lanceoladas ou oblongo-lanceoladas, mais ou menos endurecidas e costadas na base, ápice herbáceo, pápus sempre presente: Equador até Brasil; 63 espécies.

Série A: Tenuifolieae: Ervas perenes com folhas estreitamente lineares ou linear-filiformes; capítulos solitários, brácteas involucrais em 2 séries, lanceoladas ou oblongas, membranáceas, base pouco endurecida: Brasil; 4 espécies

Espécies: V. tenuifolia; V. angustissima*; V. kunthiana; V. aspilioides.

Série B: Revolutae: Arbustos ou ervas perenes com folhas inteiras alternas lanceoladas ou oblongolanceoladas; capítulos grandes solitários, brácteas involucrais em 3-5 séries de tamanhos diferentes, lanceoladas, base levemente endurecida; Chile e Argentina adjacente; 3 espécies.

Série C: Grandiflorae: Ervas perenes; folhas inferiores opostas, as mais baixas reduzidas e freqüentemente escamiformes, sub-remotas, espessadas e fortemente nervuradas, 5-7 nervuras principais, as superiores mais espessadas, muito maiores e alternas; capítulos solitários ou poucos, grandes, freqüentemente longo-pedunculados, terminais, brácteas involucrais em 2-4 séries, de tamanhos semelhantes, lanceoladas ou oblanceoladas, pouco endurecidas: Brasil, Paraguai e Peru; 11 espécies. macropoda*.

Espécies ocorrentes no Brasil: V. obtusifolia*; V. discolor; V. bakeriana; V. squalida; V. grandiflora; $V$.

Série D: Aureae: Ervas ou arbustos perenes, raramente anuais, de hábitos variados; capítulos de tamanho médio, brácteas involucrais em (2-) 3-5 séries, de mesmo comprimento ou não, a maioria lanceolada, base leve ou fortemente endurecida, não bruscamente delimitada do ápice herbáceo: Equador, Argentina e Brasil; 31 espécies.

Espécies ocorrentes no Brasil: V. nudibasilaris; V. pilosa; V. hilairei*; V. anchusaefolia.

Série E: Bracteatae: Ervas perenes, maioria das folhas séssil a subséssil; brácteas involucrais em 3 séries, de tamanhos muito diferentes, fortemente endurecidas e costadas próximo ou até o ápice, com uma ponta herbácea abrupta obsoleta: Brasil e Paraguai; 14 espécies.

Espécies ocorrentes no Brasil: V. arenaria; V. ovatifolia*; V. radula*; V. imbricata*; V. bracteata; $V$. quinqueremis*; V. oblongifolia; V. nervosa*; V. gardneri; V. robusta; V. macrocalyx*.

Seção 6: Leighia: Ervas perenes; brácteas involucrais em 4-7 séries, de tamanhos muitos diferentes, usualmente oblongas, fortemente endurecidas, costadas, com ápice foliáceo abruptamente apendiculado ou estreitado e escarioso: México e Baixa Califórnia; 4 espécies.

Seção 7: Trichophylla: Ervas perenes delicadas virgadas (cheia de hastes longas, sem ramificações), caule simples (ou sub-simples) com muitas folhas lineares a linear-filiformes, revolutas; brácteas involucrais em 3 séries, fortemente costadas na parte inferior, foliáceas na superior. Paraguai e Brasil adjacente; 5 espécies.

Espécies ocorrentes no Brasil: $V$. filifolia; $V$. linearifolia; $V$. trichophylla.

Subgênero Yerbalesia: Perenes ou simples; brácteas involucrais mais ou menos endurecidas na base, foliáceas na parte superior; folhas lanceoladas ou oblongas, raramente ovais; capítulos solitários terminais em pedúnculos longos; cipcelas com papus 2-aristado, aristas membrano-paleáceas, semelhantes às escaminhas, que são unidas em cada lado do aquênio, em escamas membrano-escariosas com muitas nervuras: Uruguai, Paraguai e Argentina adjacente (Brasil); 5 espécies.

Espécies ocorrentes no Brasil: V. hassleriana*; V. guaranítica*; V. macrorhiza; V. nudicaulis; V. tuberosa. 
A primeira proposta de desmembramento da circunscrição de Blake (1918) foi de Yates (1979) que sugeriu o restabelecimento de Heliomeris como gênero, apoiando-se primeiramente no número básico de cromossomos ( $\mathrm{n}=8$, condição única em Viguiera sensu lato). A partir da década de 1980, novas circunscrições foram apresentadas, com base em análises de dados moleculares (Schilling \& Jansen 1989; Schilling \& Panero 1996a, 1996b, 2002). Os resultados de Schilling \& Panero (1996) para análises de sítio de restrição de DNA de cloroplastos, indicaram que Viguiera seria parafilético, com grupos infragenéricos formando clados relativamente bem suportados, ao lado de outros compostos por espécies de outros gêneros de Helianthinae (Alvordia, Iostephane, Lagascea, Helianthus, Pappobolus, Scalesia e Sclerocarpus). Os autores alertaram para pelo menos duas grandes incongruências entre os resultados e a morfologia, ambas envolvendo o que consideraram ser grupos derivados de Helianthinae: Simsia dombeyana, exibindo o mesmo tipo de plastoma do cpDNA de Viguiera da América do Sul e Thitonia, posicionada em dois clados; com Alvordia e Lagascea e com representantes do subgênero Amphilepis. Após a comparação com resultados de DNA ribossomal da região do espaçador interno (ItS), sugeriram que os resultados de cpDNA podem refletir eventos passados de hibridação, envolvendo membros da subtribo relativamente divergentes. Incluindo vários gêneros no grupo - externo, Schilling \& Panero (2002) efetuaram uma nova análise combinada desses dados; mais uma vez, grupos definidos por Blake (1918) como subgenéricos, surgiram em clados mais ou menos delimitados, com algumas exceções. A despeito do consenso entre esses últimos, de que os espécimes brasileiros, juntamente com alguns outros sulamericanos formam um grupo coeso, nenhum trabalho esclareceu as relações dentro desse grupo, como é possível verificar na publicação de Schilling et al. (2000), na qual os resultados de análises de ITS demonstraram uma variação muito pequena nas seqüências, menor que 3,4\% entre as espécies da América do Sul e menor que 4,5 entre estas e $V$. flava, uma espécie do subgênero mexicano Amphilepis Este fato levou os autores a inferirem uma origem recente para Viguiera no Brasil. Com a finalidade de testar as recentes propostas de 
desmembramento de Viguiera sensu lato e avaliar o posicionamento de Robinson \& Moore (2004) que transferiu a maior parte das Viguiera sulamericanas para o gênero Rhysolepis S.F. Blake, uma análise filogenética foi realizada usando, a princípio, caracteres morfológicos.

\section{Material e métodos}

São muitas as discussões existentes sobre o a melhor forma de se delimitar uma espécie, com autores advogando os conceitos Ecológico (Van Valen 1976), Biológico (Mayr 1942, Paterson 1986), de Coesão (Templeton 1989) e os filogenéticos (Brundin 1972; Nelson e Platinick 1981; Cracraft 1983; de Queiroz e Donogue 1988; Nixon e Wheeler 1990, 1992; Ridley 1989). Doze métodos, entre eles os filogenéticos, foram discutidos por Sites \& Marshall (2004) que concluíram haver falhas em todos invariavelmente (ver discussão no capítulo V). Uma severa crítica a estes conceitos, é o fato de não haver grande preocupação com a hibridação (Skála \& Zrzavý 1994) sabidamente significativa na especiação das Asteraceae, especialmente na tribo Heliantheae (ver Yates 1979, Schiling \& Panero 1996a, 1996b; Sossey-Alaoui et al. 1998; Ungerer et al. 1998; Rieseberg 1991, 2000; Schwarzbach et al. 2001). Os dois anos de trabalho em campo permitiram a observação de grande variabilidade de fenótipos em Viguiera e parece haver gradientes de variação contínua e ocorrência de polimorfismo. Este fato tornou inviável uma análise embasada no conceito filogenético de espécie, pois não foi possível coletar grandes amostras de populações e, como notado por Henderson (2005), o material dos herbários é oriundo de coletas pontuais. Durante este trabalho, foi detectada a existência de espécimes transicionais, possivelmente de origem híbrida, entre $V$. pilosa e $V$. anchusifolia; trata-se uma de ocorrência restrita, em relação ao número total de espécies; segundo Rieseberg (1995) os híbridos entre espécies proximamente relacionadas causam pouca ou nenhuma alteração na topologia das análises filogenéticas; porém, a inclusão de híbridos entre espécies com relacionamento distante resulta em mudanças topológicas maiores, exigindo o uso de métodos estatísticos para análises que pretendem inferir a filogenia de grupos com 
evolução reticulada (McDade 1997; Xu 2000; McKenzie et al. 2004).

As unidades operacionais (terminais) do trabalho foram definidas seguindo os critérios e conceitos expressos no capítulo V. Para a análise cladística, foram selecionados os fenótipos mais representativos de cada espécie, evitando-se extremos de variação. Muitos táxons têm número básico de cromossomos conhecidos, mas esta característica não foi utilizada nas análises, principalmente pelo desconhecimento deste número para quase todas as plantas do Brasil. As espécies transferidas para outros gêneros aparecem nos terminais com a nomenclatura atual.

Três avaliações usando apenas dados morfológicos foram efetuadas: a primeiro envolveu 89 caracteres e 143 terminais, representando a maioria das espécies de todos os grupos considerados na revisão do gênero (Blake 1918); as outras duas visaram resultados mais acurados da filogenia, e tiveram acréscimo de 6 caracteres, totalizando 95, com informações de morfologia interna foliar (anatomia) de todas as espécies brasileiras e de três de outros países sulamericanos, e o número de terminais foi reduzido para 106 e 68, respectivamente. Micro-caracteres como a presença e extensão de ductos resiníferos nos ramos do estilete e espessura do carpopódio foram utilizados, com base nos resultados de Scott (1985) para Eupatorieae. Apesar das várias críticas quanto a combinação de dados (Bull et al. 1993; de Queiroz 1993) devido à possibilidade de terem origens filogenéticas diferentes, autores como De Queiroz et al. (1995) e Wiens (1998) propuseram métodos que, segundo eles, permitem a combinação de diferentes tipos de dados, mesmo com origens filogenéticas diferentes. Assim, foi cogitada uma quarta análise, combinando dados morfológicos e de ITs (espaçadores intergênicos) disponíveis no "GenBank". Porém, um teste de incongruência (Incongruence Length Difference - ILD), disponível no programa Winclada versão 2002, e efetuado com 1000 replicações, não obteve resultado favorável à análise combinada $(P=0.0010$ significativamente incongruente), que ainda assim foi testada, resultando em $\mathrm{IC}=0$ e IR=1 e, portanto, definitivamente descartada.

A escolha dos caracteres potencialmente significativos apoiou-se na 
análise de todas as espécies tradicionalmente incluídas em Viguiera e de espécies pertencentes a grupos relacionados. Ao todo, foram examinadas mais de duas mil exsicatas, dos seguintes herbários: BHCB; BM; BOTU; BR; CEN; CESI; CETEC; CTES; CGMS; COR; CPAP; ESA; E; FUEL; HAS; HASU; HEPH; HRB; HRCB; HUCS; HUEFS; HUEPG; HUFU; IBGE; ICN; IPA; K; LP; LPB; M; MBM; P; PACA; PEL; R; RB; SGO; SP; SPF; SPFR; UB; UEC; UFG; UFLA; UFMT; VEN.

Foi utilizado o método do grupo-externo (Watrous \& Wheeler 1981; Nixon \& Carpenter 1993), representado por espécies dos gêneros Encelia e Flourensia (Ecliptinae), que despontam na análise de Jansen \& Palmer (1987) como um grupo próximo da subtribo Helianthinae.

A codificação dos caracteres obedeceu aos critérios de McDowell \& Bremer (1998), que excluem extremos de variação, mas admitem uso de caracteres quantitativos, desde que haja uma clara descontinuidade entre grupos de espécies, quando comparados todos os táxons. Assim, foram utilizados padrões de número de nervuras nas páleas (caráter 40), extensão da porção foliácea das brácteas involucrais (caráter 24), relação entre altura e largura dos lobos das flores do disco (caráter 48) e espessura do carpopódio (caráter 69), por serem bem delimitados nos diferentes grupos. A maioria dos caracteres é binária; os estados polimórficos parciais são tratados por "\$", os polimórficos totais por "*", os desconhecidos por "?" e os caracteres não analisáveis por "_". Os caracteres utilizados e a suas possíveis expressões de estados nos táxons terminais estão listados na tabela 2; suas reais expressões são apresentadas na tabela 3 (matriz) e comentadas no texto do item resultados, onde o número entre parênteses se refere ao da tabela 2 e corresponde ao caráter comentado.

As relações filogenéticas foram analisadas usando máxima parcimônia, implementada no programa Winclada versão 1.0 (Nixon 2002). Dois métodos de busca foram utilizados em cada análise: o heurístico, e o Ratchet (Island Hopper). A busca heurística obedeceu aos parâmetros: máximo de 1000 árvores retidas (hold); $100\left(\right.$ mult $\left.^{*} \mathrm{~N}\right)$ replicações e máximo de 10 árvores retidas em cada 
100 replicações (hold). A busca por Ratchet (Nixon 1999) apresenta, segundo o autor do método, um incremento na eficiência entre 20 a 80 vezes em relação aos métodos estratégicos tradicionais; neste trabalho, as análises utilizaram como parâmetros 200 interações por repetição, 1 árvore inicial de Wagner e cerca de $10 \%$ dos caracteres amostrados, obedecendo aos critérios de Nixon, que recomenda índices de amostragem entre entre 5 e 25\%. O índice de constrição foi de 10\%. Para as buscas, foi empregada a opção TBR+TBR $\left(\right.$ Mult $\left.^{*} \mathrm{Max}^{*}\right)$; caracteres com expressão ambígua sofreram otimização rápida (ACCTRAN), que prioriza conversões ao invés de convergências, quando a escolha é igualmente parcimoniosa. O suporte dos ramos foi verificado com o índice de Jack-knife (Farris 1997), já que o uso de índice de bootstrap (Felsentein 1985) não é confiável em análises com menos de 1000 caracteres (Kitiching et al. 2000). Para cálculo do índice de Jack-knife foram empregadas 1000 replicações e 10 repetições por busca $\left(\mathrm{Mult}^{*} \mathrm{~N}\right)$, com retenção de 1 árvore de Wagner por replicação (hold/).

\section{$\underline{\text { Resultados e discussão }}$}

Análise dos caracteres listados na tabela 2 e selecionados para a construção da matriz apresentada na tabela 3.

\section{a. hábito}

Viguiera Kunth sensu S.F. Blake apresenta uma diversidade de hábitos, incluindo ervas perenes e anuais, arbustos e pequenas árvores. $\mathrm{O}$ autor da revisão não utilizou criteriosamente o hábito como um caráter para a classificação em nível subgenérico, mas reconheceu alguns padrões para os grupos, como ervas perenes delicadas nas seções Tenuifoliae e Trichophylla, diferenciando a segunda pela postura vergada. Panero \& Schilling (1988) destacaram o hábito arbustivo e o arbóreo, este último ignorado por Blake (1918) existente na série Maculatae (elevada à seção pelos autores). O exame in situ dos espécimes no Brasil evidenciou a plasticidade fenotípica, verificada na 
maioria das plantas, que apresenta formas intermediárias entre ervas e arbustos com caule subterrâneo espessado emitindo raízes tuberosas e, sazonalmente, ramos caulinares aéreos; como a literatura não apresenta dados suficientes neste aspecto sobre o restante do grupo, optou-se por utilizar na análise somente aspectos bem conhecidos, como a robustez ou delicadeza das plantas (caráter 0) e a presença de resina (caráter 1), que ocorre no grupo-externo.

\section{b. folhas}

Viguiera sensu lato apresenta cinco padrões de filotaxia: alterna, oposta, folhas basais opostas e superiores alternas, alterna ou mista ou ainda oposta ou mista. Na seção Chloracra, que ocorre dos Estados Unidos à Guatemala, as plantas das séries Grammatoglossae, Dentatae (parcialmente elevada ao gênero Bahiopsis por Schilling \& Panero 2002) e Maculatae apresentam folhas opostas, com variação de opostas a mistas em $V$. pringlei, e exceção de $V$. cordifolia (ser. Grammatoglosae), que apresenta sempre filotaxia mista e B. laciniata e $B$. microphylla, V. adenophylla e V. oaxacana (ser. Maculatae), com filotaxia alterna. A maioria dos representantes do subgênero Amphilepis tem filotaxia variando entre oposta e mista e apenas $V$. latibracteata possui folhas alternas. Também possuem folhas opostas todos os táxons infra-específicos de $V$. dentata. Os representantes da seção Heliomeris (restabelecido como gênero por Yates 1979) apresentam filotaxia mista, podendo variar de mista a alterna em de Heliomeris ciliata, e com V. obscura exibindo folhas opostas. Nas espécies da América do Sul ocorre principalmente a filotaxia alterna, com variações para alterna e mista ocorrendo na mesma espécie; apenas V. knobiana, V. nudibasilaris (Brasil), $V$. nudicaulis (Brasil e Uruguai) e V. gayana (Chile) têm todas as folhas opostas. Assim, parece haver predominância de folhas opostas no Hemisfério Norte e folhas alternas no Sul. Os componentes de Diplostichis (Hymenostephium, gênero resgatado por Schilling \& Panero 2002), ocorrentes do Panamá até a Argentina, têm todos os tipos de filotaxia. Definidos estes padrões, optou-se por sua inclusão nas análises (caráter 2), já que todas as espécies do grupo-externo apresentam apenas folhas alternas. 
A presença de pecíolo conspícuo (caráter 3) é característica de alguns grupos do Hemisfério Norte (séries Dentatae, Grammatoglossae, Maculatae e seção Heliomeris), ou que alcançam a parte oeste da América do Sul (Hymenostephium, V. pussila) e apresentam filotaxia primariamente oposta. Naquele Hemisfério, o subgênero Amphilepis é composto por plantas com folhas sésseis ou subsésseis, assim como a grande maioria das plantas sul-americanas.

A forma das folhas é muito variável, mas folhas deltóides ou triangulares (caráter 4) são restritas a alguns representantes das séries Dentatae, Grammatoglossae, Maculatae e V. pinnatilobata, esta última com lâmina pinatissecta; folhas lineares ou filiformes (caráter 5) são encontradas apenas em uns poucos representantes da seções Heliomeris (EUA, México), Leighia (México) e Paradosa (América do Sul).

Folhas de base cuneada (caráter 7) ocorrem principalmente em representantes da sect. Heliomeris (H. multiflora, H. obscura, H. ovalis), das séries Dentatae (V. dentata), Grammatoglossae (V. rhombifolia, V. semanii, V. sessifolia); e Maculatae ( $V$. oaxacana, $V$. trachyphylla) e no subgênero Amphilepis ( $V$. angustifolia, V. buddleiaformis, V. excelsa e V. hypoclora). A forma do ápice (caráter 8) varia de obtuso a acuminado.

Margens inteiramente denteadas são características de representantes das séries Dentatae (B. deltoidea, B. laciniata, B. parishii, B. subincisa, B. tomentosa e V. dentata), Grammatoglossae e Maculatae, além das seções Diplostichis (Hymenostephium), do Hemisfério Norte e Paradosa, ocorrente na América do Sul, de três espécies da série Aureae ( $V$. mollis, $V$. pussila e $V$. simsioides) e uma da série Grandiflorae (V. peruviana); no Brasil, a característica é observada numa única espécie, descrita por Robinson \& Moore (2004) no gênero Rhysolepis ( $R$. santacatarinensis). Essas margens são observadas ainda em gêneros correlacionados, como Helianthus, Pappobolus e Simsia.

Folhas membranáceas (caráter 9) também são observadas nas seções Diplostichis e Heliomeris e nas séries Dentatae, Maculatae, e Aureae subsérie Pussilae. Nos demais táxons, as folhas, à semelhança das plantas do Hemisfério Sul, variam entre cartáceas e coriáceas, características compartilhadas com 
Rhysolepis senso S.F. Blake, Aldama e Helianthus.

O indumento inclui variações de híspido, estrigoso ou tomentoso; apenas três espécies ( $V$. bicolor, $V$. lanata e $V$. linearifolia) apresentam folhas com indumento lanoso e três (B. microphylla, $V$. potosina e $V$. stenoloba) com indumento seríceo; quanto a este aspecto, optou-se por avaliar apenas se o mesmo é suave ou rijo (caráter 10).

A presença de glândulas na face abaxial das folhas (caráter 11) é uma característica constante nos componentes do grupo-externo e ocorre na maioria dos representantes de secões. Heliomeris e Leighia, e séries Maculatae e Pinnatilobatae e no grupo-externo e gêneros relacionados, mas também ocorre em diversas plantas Sul-americanas.

\section{c. inflorescência}

A maioria dos componentes de Viguiera sensu lato apresenta inflorescência com aspecto geral (caráter 12) paniculiforme, com o grupoexterno apresentando inflorescências curtas, caráter compartilhado principalmente com os representantes da série Maculatae (embora ocorra esporadicamente na seção Hypargyrea, e nas séries Grammatoglossae e Pinnatilobatae) e com poucas plantas da América do Sul que têm, em sua maioria, inflorescências paniculiformes longas. Um terceiro padrão de inflorescência, corimbiforme, foi detectado em um pequeno grupo da série Dentatae (V. deltoidea - Bahiopsis), em V. quitensis (Hymenostephium) e V. seemanii (Gramatoglossae). Inflorescências congestas (caráter 13) são encontradas apenas na série Maculatae (V. quinqueradiata, V. sphaerocephalla e $V$. trachyphylla); a despeito disso, os capítulos podem estar adensados nas inflorescências de última ordem (extremidades, caráter 14), como em certas representantes de Dentatae (Bahiopsis), V. adenophylla e V. maculata (V. eriophora ssp. maculata), e também de Maculatae, Flourensia, Hymenostephium e Rhysolepis.

Normalmente, os paracládios são herbáceos (caráter 15), mas a série Brevifoliae da seção Chloracla compartilha com Flourensia ramos da inflorescência lenhosos. São opostos ou raramente mistos (caráter 16) em Maculatae, V. ensifolia 
(subg. Amphilepis) V. montana (sect. Leighia) e mistos nas séries Brevifoliae (sect. Chloracla) e Gramatoglossae, em Encelia farinosa, Rhysolepis palmeri, espécies representativas de Helianthus e Hymenostephium, e também em $V$. revoluta (Argentina) e $V$. nudicaulis (Brasil e Uruguai). No grupo-externo, os paracládios terminam no mesmo nível do capítulo terminal (caráter 17), como em muitos representantes das séries Dentatae e Maculatae e Hymenostephium; na seção Heliomeris, terminam acima do capítulo terminal e, no sugbênero Yerbalesia, abaixo. Estas expressões de caracteres, no entanto, se mostraram variáveis em outros grupos. No Brasil, os paracládios são geralmente bracteolados (caráter 18), exceto em Yerbalesia, na seção Tricophylla, na série Tenuifoliae, em $V$. anchusifolia, $V$. arenaria, $V$. oblongifolia e $V$. squalida; nos demais países da América do Sul não há uma clara predominância de ramos da inflorescência com bractéolas.

\section{d. brácteas involucrais}

É possível caracterizar pequenos grupos tradicionais de espécies, com base no número de séries das brácteas involucrais (caráter 19); assim, espécies com até 3 séries de brácteas compõem grupos como o subg. Yerbalesia, a sect. Heliomeris, e as sers. Brevifoliae, Dentatae, Grandiflorae e Tenuifolieae. A similaridade na forma (caráter 20) e no tamanho das brácteas involucrais (caráter 21) ocorre com muita freqüência nos grupos acima, em Encelia e Hymenostephium e, às vezes, em outros grupos; já o subgênero Amphilepis é caracterizado por apresentar brácteas de formas e tamanhos diferentes, o que ocorre também em Rhysolepis; em Flourensia, Aldama, Helianthus e Pappobolus a forma das brácteas é diferente, mas estas apresentam tamanhos similares; nos demais grupos, verifica-se uma heterogeneidade neste aspecto. $\mathrm{O}$ ápice das brácteas externas pode ser cirroso a linear-lanceolado, como em Encelia e agrupando a série Pinnatilobatae e muitos representantes de Dentatae, acuminado, como em sect. Heliomeris e ser. Grammatoglossae ou, como na maioria dos táxons, agudo (caráter 22). Essas brácteas geralmente apresentam uma base coriácea (em 1/2 do comprimento ou mais) e um ápice foliáceo, mas 
alguns grupos apresentam-nas totalmente foliáceas, ou foliáceas em cerca de 2/3 do comprimento ou mais (caráter 24). Podem ser apressas, como no subg. Yerbalesia, na maioria dos componentes da sect. Maculatae e na ser. Grandiflorae ou reflexas, como no subgênero Amphilepis, nas séries Bracteatae, Revolutae e a quase totalidade de Aureae. (caráter 23). Quanto à consistência (caráter 25), Heliomeris, muitas Dentatae, Aldama, Hymenostephium, o grupo-externo e os grupos correlacionados (Helianthus, Pappobolus e Simsia) não apresentam brácteas involucrais coriáceas. Em Encelia farinosa e Flourensia monticola, do grupo-externo, as brácteas possuem uma nervura destacada da base ao ápice (caráter 26), o que ocorre em algumas espécies analisadas. $\mathrm{O}$ indumento da face abaxial das brácteas externas pode ser suave ou rijo e esse caráter (27) foi incluído na análise para auxílio na delimitação de algumas espécies; a maioria é ciliada, mas as brácteas dos componentes do grupo externo, das sects. Diplostichis e Heliomeris, e da ser. Dentatae além de algumas espécies isoladas, não apresentam cílios (caráter 28). As brácteas internas são escariosas no subgênero Amphilepis e em Pappobolus (caráter 29).

\section{e. receptáculo}

No grupo-externo, o receptáculo maduro (caráter 30) é plano a levemente convexo e há uma gradação para receptáculo convexo (a maioria) a fortemente convexo ou mesmo cônico (Aldama, Rhysolepis e $V$. aspilioides). As páleas periféricas do disco da espécie típica do gênero ( $V$. dentata) dividem com Aldama, Rhysolepis, Simsia e V. stenoloba a forma bojosa (caráter 31), o envolvimento completo da flor (caráter 32) e o ápice (caráter 33) pungente (ápice variável em $R$. morelensis); as dos dois primeiros gêneros são fortemente corrugadas transversalmente (caráter 35). Também exibem ápice pungente Amphilepis, Heliomeris e Grammatoglossae. O ápice é inflexo em Pappobolus, $B$. microphylla e V. purisimae (caráter 34). Páleas escariosas e translúcidas (caracteres 36 e 37) ocorrem nas seções Heliomeris e Diplostichis, na série Dentatae e no subgênero Amphilepis; estas condições são compartilhadas com o grupoexterno e Pappobolus. No grupo externo, nas seções Diplostichis e Heliomeris, na 
série Dentatae, e na maior parte da série Grammatoglossae (V. cordifolia, V. ovata, $V$. parkinsonii, V. pringlei e V. sessifolia) e nos gêneros Aldama, Helianthus Pappobolus, Rhysolepis e Simsia, as páleas possuem uma porção central rígida e alas largas estramíneas (caráter 38). A maioria das plantas analisadas tem páleas com nervuras imersas em uma região de células diferenciadas (caráter 39), o que não ocorre com o grupo-externo e em Heliomeris e Diplostichis e alguns representantes de outros táxons. As páleas de Dentatae possuem poucas nervuras (4 a 6), com 6 a 8 em $V$. dentata (números também verificados em subg. Heliomeris, sect. Leighia e em diversas espécies de outros táxons); já Aldama, Helianthus, Pappobolus e Rhysolepis compartilham com a seção Diplostichis, a série Revolutae e poucas espécies do México e algumas da América do Sul, a presença de 10 ou mais nervuras nas páleas (caráter 40). V. weberbaueri divide com a também peruana $V$. simsioides a existência de páleas com número mínimo de 14 nervuras; a primeira foi inicialmente descrita no gênero Syncretocarpus, caracterizado por apresentar um espessamento corticoso na margem da cipsela, também observado neste trabalho em V. simsioides. Em Pappobolus, as nervuras são coalescentes no ápice (caráter 41). O grupo-externo tem em comum com Aldama, Rhysolepis e representantes de Dentatae ( $V$. dentata, B. potosina e $B$. subincisa e B.tomentosa) os ductos resiníferos com resina clara (caráter 42), paralelos às nervuras das páleas (embora não seja uma característica exclusiva), enquanto a maioria dos demais táxons apresenta resina escurecida. Com exceção do grupo externo e de Aldama, as páleas têm indumento (caráter 43), que pode ser apenas pubescente ou híspido a estrigoso (caráter 44). São decíduas apenas no grupo externo, em Aldama e em Rhysolepis (caráter 45). Encelia e Flourensia possuem glândulas nas páleas, característica também observada na maioria da sect. Dentatae, das sers. Brevifioliae e Pinnatilobatae, em $V$. weberbaueri e V. simsioides, entre outras poucas espécies (caráter 46).

\section{f. flores}




\section{f.1. flores do disco}

A forma das corolas das flores do disco (caráter 47) pode ser: cilíndricotubulosa (subg. Amphilepis, sects. Heliomeris, Diplostichis e Leighia, ser. Grammatoglossae, a maioria dos componentes das séries Aureae e Dentatae, além de algumas espécies de outros táxons infra-genéricos e Encelia, Aldama, Helianthus e Rhysolepis); cilíncrico-campanulada a cilíndrico-funeiforme (subg. Yerbalesia, sect. Tricophylla, sers. Bracteatae, Grandiflorae e Tenuifoliae, e V. dentata, além de quatro representantes da série Aureae) ou campanulada a levemente urceolada ( $V$. breviflosculosa e Simsia dombeyana). Os lobos da corola podem ter altura maior ou menor que o dobro da largura (caráter 48); lobos mais altos predominam em Heliomeris, sers. Dentatae, Maculatae, na maioria dos representantes da série Bracteatae (Brasil e do Paraguai) e também nas espécies que compõem o grupo-externo, Pappobolus e Simsia. Poucas das espécies analisadas não apresentam indumento no tubo, ou no limbo da corola das flores do disco (caracteres 49 e 50); entre elas estão as do grupo-externo; por outro lado, somente cinco espécies apresentam indumento viloso (caráter 51), e a condição foi inserida na análise com o intuito de melhor delimitar essas espécies. Glândulas são comuns nas flores do raio, mas certos grupos as exibem também nas flores do disco (caráter 52); glândulas sésseis estão presentes nas flores de Encelia, Flourensia, R. palmeri e S. dombeyana; glândulas alongadas ocorrem em vários representantes de Dentatae e glândulas pediceladas em Amphilepis, V. ciliata (Heliomeris), V. densifolia, V. pinnatilobata, V. tenuifolia e $V$. weberbaueri (caracteres 53 e 54). Assim como nas espécies do grupo-externo, as flores de Amphilepis não apresentam tricomas nos lobos (caráter 55), o mesmo ocorrendo com $V$. decurrens e $V$. purissimae (México) e $V$. paranensis (Brasil)A resina das flores é hialina em Encelia e Flourensia (caráter 56) e colorida nas demais (uma das características que excluem as duas primeiras de Helianthinae, aqui utilizada para melhor delimitar o grupo-externo). As anteras são castanhas a marrons na maioria das espécies do grupo interno, mas as de $V$. revoluta, $V$. weberbaueri e $S$. dombeyana são amareladas (caráter 57). Os filetes dos estames de $V$. dentata exibem tricomas como sinapomorfia (caráter 58). No 
grupo interno, os estiletes apresentam um ducto resinífero em toda a extensão, exceto em Heliomeris, no qual os ductos são restritos aos ramos (caráter 59).

\section{f.2. flores do raio}

As flores do raio se apresentam muito semelhantes em toda a subtribo; no grupo analisado, é possível distinguir dois padrões, de acordo com a presença de indumento (caráter 60): um representado por flores glabras ou glabrescentes (subg. Amphilepis, ser. Dentatae, e gêneros Aldama, Encelia, Flourensia, Pappobolus e Rhysolepis, além de espécies de táxons diversos) outro com flores de indumento rijo (sect. Leighia, sers. Pinnatilobatae, Brevifoliae e várias outras).

\section{g. cipselas}

As cipselas possuem pouca variação na forma, mas existem estados bem delimitados: cipselas obtriangulares ou obovóide-triangulares estão presentes principalmente nas séries Dentatae e Maculatae e no grupo-externo; Aldama, Rhysolepis, V. sphaerocephala (México) e V. peruviana (Peru) apresentam cipselas periféricas do disco hemisféricas recurvadas (caráter 61), sendo as dos dois primeiros táxons fortemente assimétricas (caráter 62); as demais espécies possuem cipselas obovóides simétricas ou levemente assimétricas. Encelia e Flourensia possuem cipselas com duas saliências acentuadas (caráter 63), o que também foi verificado em Simsia dombeyana e em duas espécies da ser. Gramatoglossae (V. cordifolia e V. parkinsonii), duas da ser. Dentatae (B. deltoidea e $V$. potosina) e uma de Aureae (V. retroreflexa). Cipselas fortemente compressas, características de Encelia (caráter 64), foram encontrada também em $S$. dombeyana, V. sylvatica e Hymenostephium. mucronatum (Diplostichis) e em quatro espécies de Gramatoglossae (V. cordifolia, V. parkinsonii, V. pringlei e V. seemanii); uma destacada compressão marginal (caráter 65), existente no grupo-externo, foi verificada em Simsia, em Dentatae e em alguns representantes de outros grupos. As células do carpopódio apresentam diferenciação radial em Encelia, Flourensia e V. mucronata (Hymenostephium) e as demais possuem aparente 
diferenciação tangencial (caráter 67). Os carpopódios se apresentaram unilaterais (maioria de subg. Amphilepis, ser. Pinnatilobatae, Aldama, Rhysolepis, $V$. potosina), bilaterais simétricos (Encelia) e bilaterais assimétricos, em todas as demais (caráter 68). O carpopódio pode ser espesso, como em Amphilepis, Heliomeris e em mais da metade de Gramatoglossae (V. grammatoglossa, $v$. parkinsonii, V pringlei, $V$. rhombifolia e $V$. sessifolia), entre outras, ou ser estreito, a condição mais comum (caráter 69). Na sect. Diplostichis (Hymenostephium), o carpopódio possui uma bainha delgada (caráter 70). As cipselas são conspícuamente estriadas (característica de Helianthinae) na maioria das espécies, mas as estrias são leves em Simsia e esta condição também foi encontrada em Flourensia, da subtribo Ecliptinae (caráter 71). Cipselas glabras (caráter 72) são encontradas apenas em Amphilepis, Heliomeris, Pinnatilobatae, duas espécies da ser. Dentatae (B. laciniata e $B$. potosina) e duas da ser. Gramatoglossae (V. ovata e V. parkinsonii), duas da sect. Diplostichis ( $H$. microcephallum e H. quitensis). Parte da série Dentatae (B. deltoidea, B. reticulata, B. subincisa, B. tomentosa e $V$. dentata), a maioria de Maculatae (exceto v. eriophora) e as Grammatoglossae não-glabras, além de algumas espécies isoladas apresentam, assim como as espécies do grupo-externo, uma grande concentração de tricomas no eixo de simetria (caráter 73). O indumento (caráter 74) pode ser classificado em velutino (grupo-externo e muitas Dentatae, Grammatoglossae e Maculatae), cerdoso (Yerbalesia, sect. Trycophylla e a maioria da ser. Bracteateae), pubescente ou estrigiloso a estrigoso (a maioria das demais). Os cílios longos da margem das cipselas de Encelia e Flourensia também ocorrem em algumas Gramatoglossae ( $V$. cordifolia, $V$. ovata e $V$. seemanii) e em algumas espécies de outros táxons, de forma isolada (caráter 75). A série Dentatae é caracterizada ainda por tricomas hialinos brilhantes, mas estes também são encontrados em representantes de Diplostichis e em V. soridoi e V. weberbaueri, além de Encelia e Simsia (caráter 76). As cipselas de Flourensia possuem glândulas e esta condição foi utilizada para reforçar a delimitação do grupo (caráter 77).

\section{g.1. pápus}


O pápus de Viguiera sensu lato é quase sempre formado por aristas, geralmente duas, intercaladas por escamas, livres ou unidas e as peças podem ser persistentes, decíduas ou facilmente destacáveis (caracteres 78 e 79); Os representantes da sect. Heliomeris, dois representantes do subg. Amphilepis (V. hypochlora e V. schultzii), V. potosina (Dentatae) e Hymenostephium. quitensis e $H$. debilis não possuem pápus. As aristas decíduas, consideradas como um forte caráter do gênero Helianthus, são encontradas em Pappobolus, quatro representantes da ser. Dentatae (B. deltoidea, B. laciniata, B. microphylla e $V$. dentata), em V. buddleiaformis (subg. Amphilepis), V. grammatoglossa (ser. Grammatoglossae), V. mollis (ser. Bracteatae), em Hymenostephium microcephallum e em Rhysolepis. Aristas delicadas existem na seção Diplostichis, boa parte das espécies de Brevifoliae, Dentatae e Euaureae e em algumas espécies de outros grupos; podem ser muito longas nas duas primeiras (caráter 80), e em espécies isoladas, e muitos tênues na ser. Dentatae, subs. Euaureae e outras (caráter 81). As aristas de Helianthus, V. eriophora, V. maculata, V. oaxacana, V. trachyphylla (Maculatae), B. laciniata, B. subincisa (Dentatae), V. macrorhiza (Yerbalesia) e $V$. weberbaueri (Grandiflorae) possuem uma ala hialina (caráter 82). Não há escamas no pápus dos componentes do grupo externo e de Simsia, Helianthus, e sect. Heliomeris, além de algumas espécies de outros táxons (caráter 83); em aldama, Rhysolepis e algumas espécies da ser. Dentatae, elas são decíduas e, em espécies andinas, são destacáveis (caráter 84). As escamas são totalmente unidas em Yerbalesia, Brevifoliae (exceto em v. greggii), Tenuifolieae e Trichophylla (exceto em $V$. trichophylla) e algumas espécies de outros táxons (caráter 85) e totalmente livres em Grammatoglossae (exceto em $V$. cordata), em Maculatae (exceto em $V$. sphaerocephalla), $V$. dentata (exceto na var. genuina), além de espécies isoladas (caráter 86). Em Grandiflorae, Grammatoglossae e Tenuifolieae as escamas são conduplicadas (caráter 88); também o são em metade das Euaureae e quatro representantes de Grammatoglossae (V. grammatoglossa, V. pringlei, V. seemanii e V. sessifolia).

Tabela 2: Lista de caracteres morfológicos externos e estados de caráter (expressões) utilizados nas análises: 
00 Plantas robustas ou delgadas: (0) robusta; (1) delgada.

01 Plantas resiníferas ou não: (0) resiníferas; (1) não resiníferas.

02 Filotaxia: (0) alterna; (1) mista; (2) oposta.

03 Presença de pecíolo conspícuo: (0) pecíolo conspícuo; (1) folhas sésseis ou subsésseis.

04 Presença de folhas lineares ou filiformes: (0) ausentes; (1) presentes.

05 Presença de folhas deltóides ou triangulares: (0) presentes; (1) ausentes.

06 Forma do ápice foliar: (0) ápice nunca acuminado; (1) ápice acuminado ( ao menos às vezes ).

07 Forma da base foliar: (0) atenuada (ao menos às vezes); (1) cuneada (ao menos às vezes); (2) outras.

08 Folhas com margem inteiramente denteada; serreada; crenada ou lobada: (0) não; (1) sim.

09 Textura das folhas: (0) cartáceas ou coriáceas; (1) membranáceas.

10 Indumento da face abaxial das folhas: (0) suave; (1) rijo.

11 Presença de glândulas na face abaxial das folhas: (0) com glândulas; (1) sem glândulas.

12 Forma geral da inflorescência: (0) paniculiforme curta; (1) paniculiforme longa ou capítulos solitários; (2) umbeliforme ou corimbiforme.

13 Inflorescências laxas ou congestas: (0) laxas; (1) congestas.

14 Adensamento dos capítulos nas extremidades da inflorescência: (0) adensados; (1) adensados.

15 Ramos ou paracládios lenhosos ou herbáceos: (0) herbáceos; (1) lenhosos.

16 Posição dos paracládios de primeira ordem: (0) mistos ou opostos; (1) alternos ou capítulos solitários.

17 Nível dos paracládios superiores (acima ou abaixo do capítulo terminal): (0) mesmo nível do capítulo terminal; (1) acima do capítulo terminal; (2) abaixo do capítulo terminal ou capítulos solitários.

18 Presença de bractéolas nos paracládios: (0) abracteolados ou com 1-2 pares de bractéolas; (1) conspicuamente bracteolados.

19 Número de série das brácteas involucrais: (0) máximo de três séries; (1) sempre em mais de três séries.

20 Semelhança no tamanho das brácteas involucrais: (0) igual ou muito similar; (1) levemente diferente; 2 conspicuamente diferente.

21 Semelhança na forma das brácteas involucrais: (0) similares; (1) diferentes ou levemente diferentes.

22 Forma do ápice das brácteas involucrais da primeira série: (0) cirroso; oblongo-lanceolado ou linear; (1) acuminado; (2) obtuso ou agudo.

23 Posição das brácteas involucrais externas: (0) apressas ou levemente reflexas; (1) conspicuamente reflexas.

24 Extensão da porção foliácea das brácteas involucrais: (0) totalmente foliáceas ou em 2/3 superiores; (1) foliáceas em $1 / 2$ ou menos superiores.

25 Brácteas involucrais coriáceas ou não: (0) não coriáceas; (1) coriáceas.

26 Presença de uma nervura destacada; da base ao ápice das brácteas involucrais: (0) com nervura destacada; (1) sem nervura destacada.

27 Indumento abaxial das brácteas involucrais externas: (0) suave (hirsuto ou híspido); (1) rijo (setoso ou estrigoso).

28 Presença de cílios nas brácteas involucrais externas: (0) sem cílios; (1) com cílios.

29 Textura das brácteas involucrais internas: (0) não escariosas; (1) escariosas.

30 Forma do receptáculo maduro: (0) plano a levemente convexo; (1) convexo; (2) fortemente convexo a cônico.

31 Forma da páleas periféricas do disco: (0) largas não bojosas; (1) bojosas; (2) estreitas.

32 Abrangência da pálea: (0) envolvendo parcialmente a base dos frutos periféricos; (1) envolvendo totalmente a base dos frutos periféricos.

33 Forma do ápice das páleas: (0) pungente; (1) outras formas.

34 Flexão do ápice das páleas: (0) ereto; (1) inflexo.

Tabela 2 (cont.): Lista de caracteres morfológicos externos e estados de caráter (expressões) utilizados nas análises: 
35 Páleas das flores periféricas do disco corrugadas ou não: (0) não corrugadas; (1) levemente corrugadas; (2) conspicuamente corrugadas.

36 Textura das páleas: (0) páleas escariosas; (1) cartáceas ou cartáceas com margem escariosa; (2) cartáceo-coriáceas.

37 Transparência das páleas: (0) totalmente translúcidas; (1) não totalmente translúcidas.

38 Páleas com porção central rígida e alas estramíneas largas: (0) presente; (1) ausentes.

39 Diferenciação das regiões com nervuras das páleas: (0) em regiões não diferenciadas; (1) em regiões diferenciadas.

40 Padrões no número de nervuras na páleas: (0) entre 4 e 6 nervuras; (1) entre 6 e 8 nervuras; (2) nervuras entre 8 e 10 ou 8 e 12 nervuras; (3) entre 14 e 16 nervuras.

41 Coalescência apical das nervuras das páleas: (0) não coalescentes; (1) coalescentes.

42 Cor das nervuras das páleas: (0) hialinas; paleáceas ou amareladas; (1) nervuras cor de mel; (3) acastanhadas ou vináceas.

43 Presença de indumento nas páleas: (0) gabras; (1) com indumento.

44 Tipo de indumento da face externa das páleas: (0) gabrescentes ou pubescente; (1) com outro tipo de indumento.

45 Páleas das flores periféricas do disco decíduas com o fruto ou persistentes: (0) decíduas; (1) persistentes.

46 Presença de glândulas nas páleas: (0) com glândulas; (1) sem glândulas.

47 Forma da corola das flores do disco: (0) cilíndrico-tubulosa; (1) cilíndrico-campanulada ou cilíndrico-funeiforme; (2) campanulada a levemente urceolada.

48 Relação entre altura e largura dos lobos das flores do disco: (0) altura maior que a largura; (1) altura igual ou menor que a largura.

49 Presença de indumento tector no tubo: (0) glabro ou glabrescente; (1) com indumento.

50 Presença de indumento tector no limbo: (0) glabro ou glabrescente; (1) com indumento.

51 Presença de indumento denso viloso na base do limbo da flor tubulosa: (0) sem indumento viloso; (1) com indumento viloso.

52 Presença de glândulas no tubo das flores do disco: (0) com glândulas; (1) sem glândulas.

53 Forma das glândulas no tubo das flores do disco: (0) glândulas sésseis ou alongadas; (1) glândulas globosas pediceladas.

54 Presença de glândulas na base do limbo das flores do disco: (0) glândulas alongadas ou sésseis; (1) sem glândulas ou com glândulas pediceladas.

55 Presença de indumento nos lobos das flores do disco: (0) glabros; glabescentes ou hispídulos; (1) com outros tipo de indumento.

56 Coloração da resina da corola das flores do disco: (0) resina hialina; (1) resina amarelada.

57 Cor das tecas das anteras: (0) paleáceas ou amareladas; (1) castanhas ou atro-marrons.

58 Presença de tricomas nos filetes da antera: (0) sem tricomas; (1) tricomas.

59 Presença de ductos resiníferos no estilete: (0) sem ductos resiníferos; (1) com ductos resiníferos restritos aos ramos; (2) com ductos resiníferos em toda a extensão.

60 Presença de indumento nas flores do raio: (0) glabras a pubescentes; (1) com indumento rijo (setoso a estrigoso).

61 Forma das cipselas periféricas: (0) obtriangulares a obovóide-obtriangulares; (1) obovóides; (2) hemisféricas recurvadas.

62 Cipselas da periferia do disco simétricas assimétricas: (0) simétricas ou levemente assimétricas; (1) assimétricas.

63 Protuberância da margem superior da cipsela: (0) protuberante; (1) não protuberante.

64 Compressão das cipselas: (0) fortemente compressas; (1) levemente compressas.

65 Cipselas com margem fortemente compressa: (0) com margens fortemente compressas; (1) sem forte compressão marginal.

66 Presenças de margem corticosa nas cipselas: (0) com margem corticosa; (1) sem margem corticosa.

67 Diferenciação aparente das células do carpopódio: (0) radial; (1) tangencial.

68 Simetria do carpopódio: (0) bilateral simétrico; (1) bilateral assimétrico; (2) unilateral.

69 Espessura do carpopódio: (0) largo (com 5 ou mais séries de células); (1) médio a estreito (com 3-4 ou menos séries de células). 
70 Presença de bainha no carpopódio: (0) sem bainha; (1) com bainha.

71 Presença de estrias nas cipselas: (0) não estriadas; (1) com estrias leves; (2) conspicuamente estriadas.

72 Presença de tricomas nas cipselas: (0) com tricomas; (1) sem tricomas.

73 Concentração de indumento no eixo de simetria da cipsela: (0) com muitos tricomas; (1) com poucos tricomas; (2) glabrescente ou cipselas glabras.

74 Tipo de indumento da cipsela: (0) velutinas; (1) cerdosas; (2) com outros tipo de indumento ou glabras.

75 Presença de cílios longos na margem das cipselas: (0) margem de cílios longos; (1) margem de cílios longos.

76 Tricomas hialino brilhantes ou somente translúcidos: (0) hialinos brilhantes; (1) translúcidos opacos.

77 Presença de glândulas nas cipselas: (0) com glândulas; (1) sem glândulas.

78 Persistência das aristas do pápus: (0) aristas persistentes; (1) pápus com aristas destacáveis ou decíduas.

79 Consistência das aristas: (0) pápus com aristas delicadas; às vezes destacáveis; (1) pápus com aristas firmes.

80 Presença de aristas longas e cerdosas; aproximando-se do ápice da flor: (0) sem aristas longas e cerdosas; (1) com aristas longas e cerdosas.

81 Se aristas longas presentes: tênues ou com base endurecida: (0) tênues; (1) endurecidas.

82 Aristas com alas hialinas ou não: (0) com alas hialinas; (1) sem alas hialinas.

83 Presença de escamas do pápus: (0) sem escamas; (1) com escamas ou coroniforme.

84 Persistência das escamas do pápus: (0) decíduas ou destacáveis; (1) persistentes.

85 Presença de escamas totalmente unidas: (0) totalmente unidas; (1) não unidas.

86 Presença de escamas totalmente livres: (0) totalmente livres; (1) escamas não totalmente livres.

87 Escamas do pápus imbricadas ou não: (0) não imbricadas; (1) imbricadas.

88 Escamas do pápus conduplicadas ou não: (0) não conduplicadas; (1) conduplicadas.

89* Espessura da cutícula: (0) espessa; (1) fina.

90* Posição dos estômatos na folha: (0) anfiestomática; (1) hipoestomática; (2) epiestomática.

91* Tipo de clorênquima: (0) isomorfo; (1) isobilateral; (2) bilateral.

92* Presença de sulcos na face abaxial: (0) sem sulcos; (1) com sulcos leves; (2) com sulcos profundos.

93* Presença de canais secretores na região dos feixes vasculares: (0) canais em ambas as faces; (1) canais em uma face; (2) sem canais.

94* Tricomas glandulares: (0) sésseis; (1) pedicelados; (2) sem tricomas glandulares.

Obs.: Caracteres 89 a 94 - anatômicos - incluídos apenas nas análises reduzidas, dos grupos sulamericanos (106 e 68 terminais). 


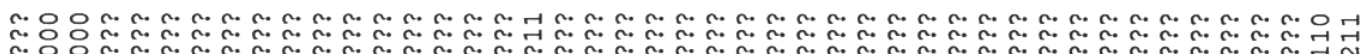
$\cdots$
$\cdots$

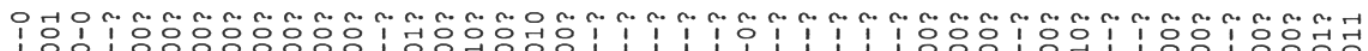

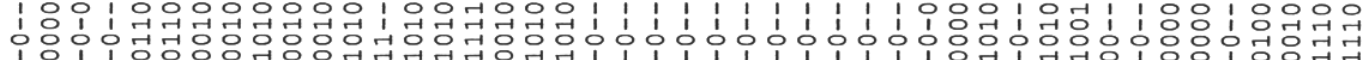

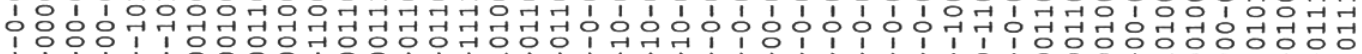

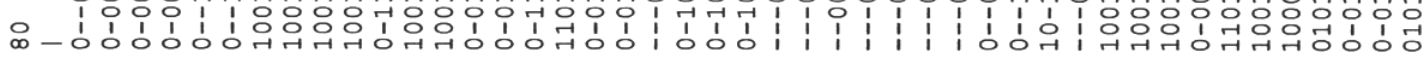

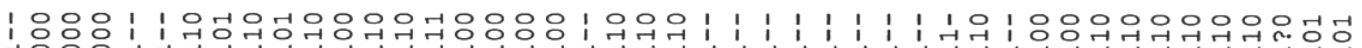

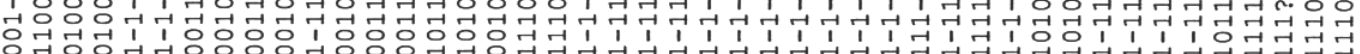

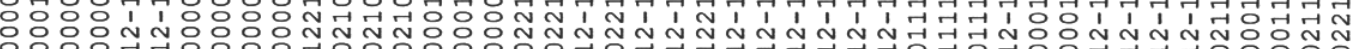

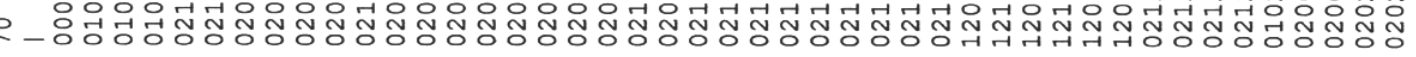

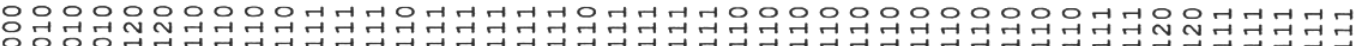

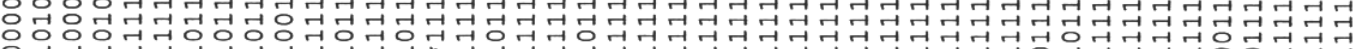

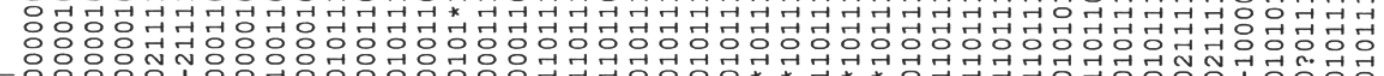

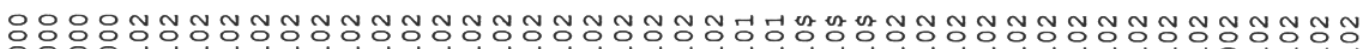

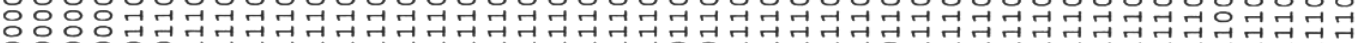

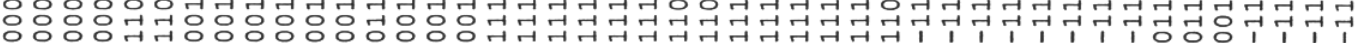

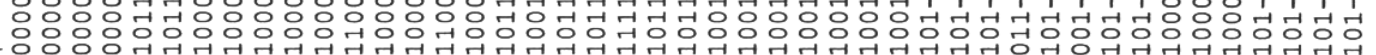

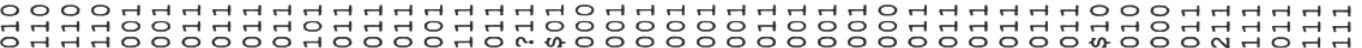

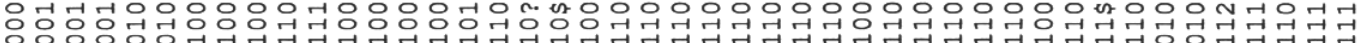

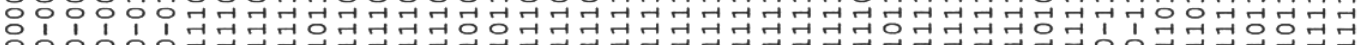

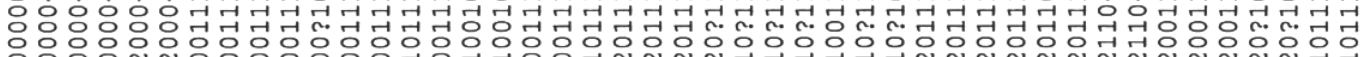

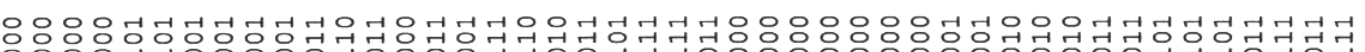

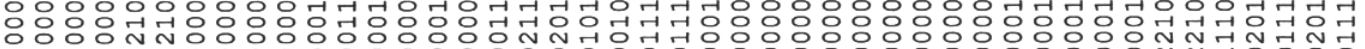

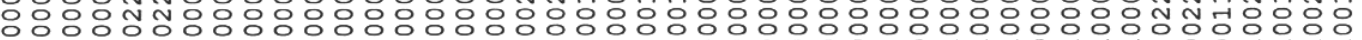

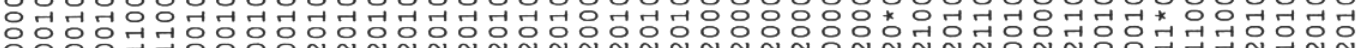

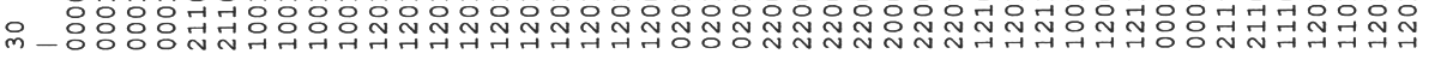

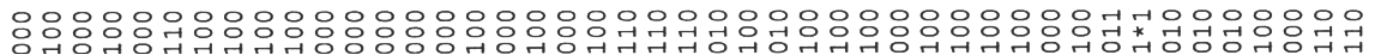

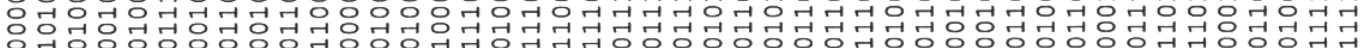

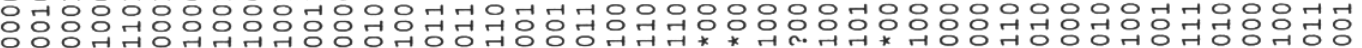

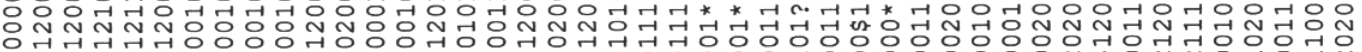

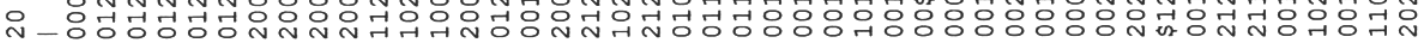

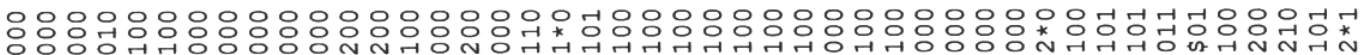

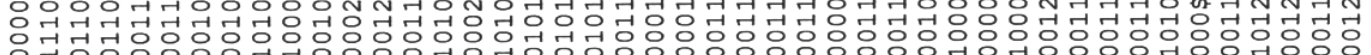

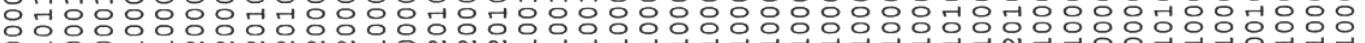

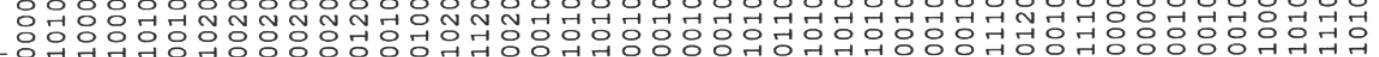

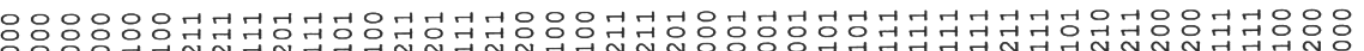

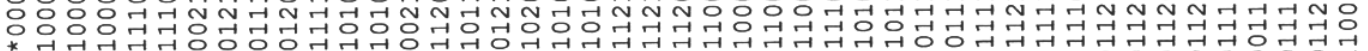

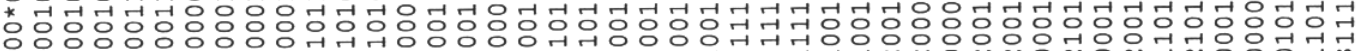

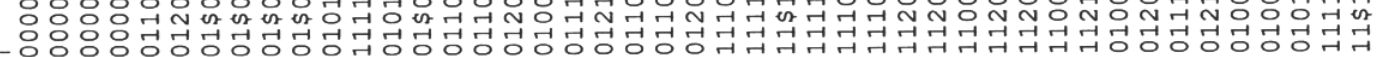

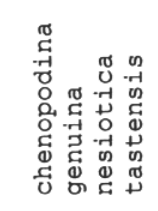

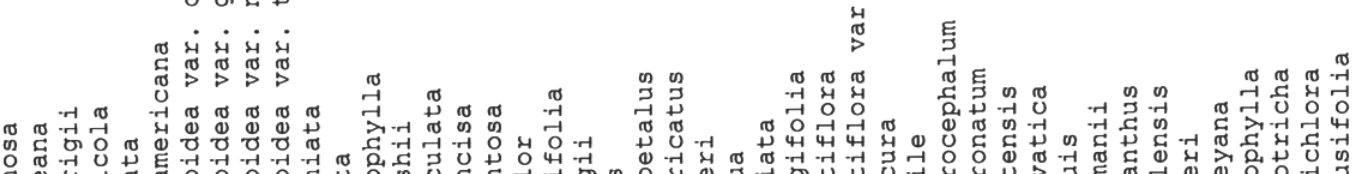

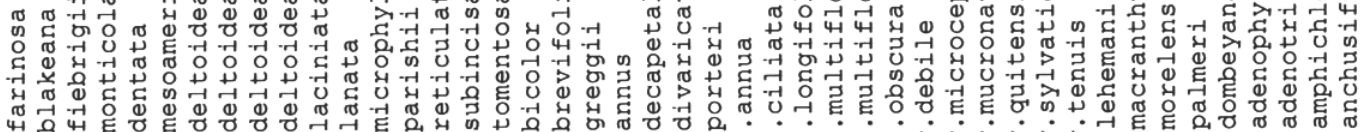

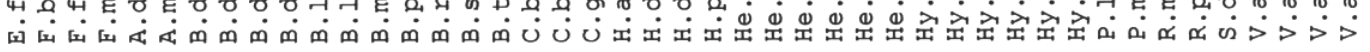




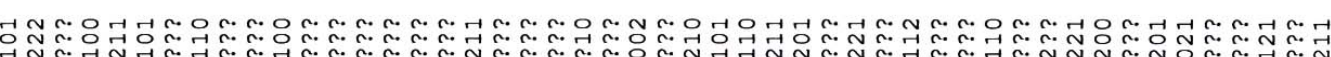

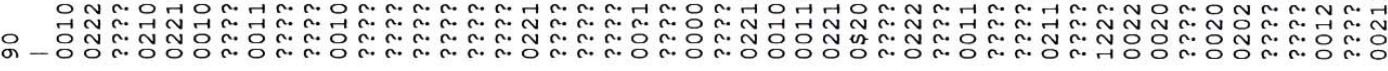

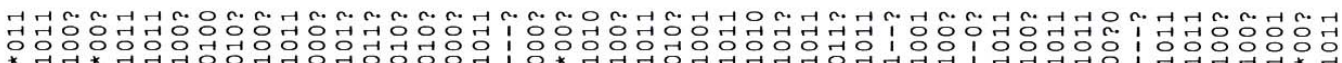

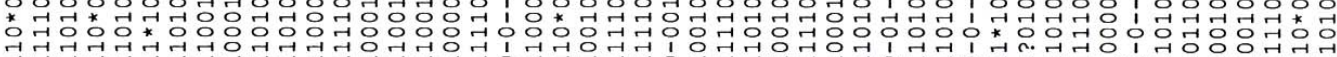

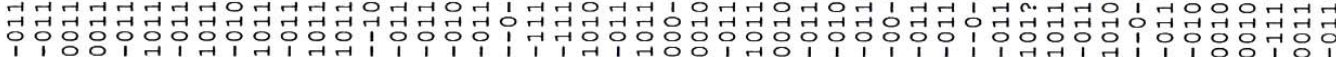

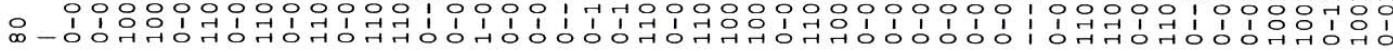

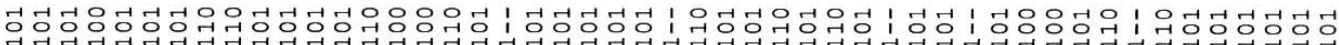

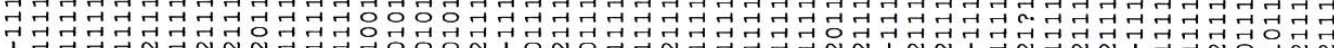

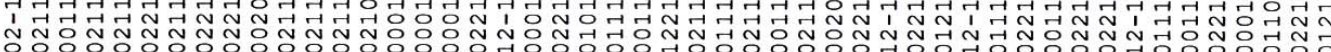

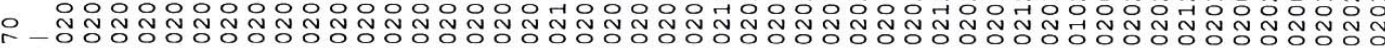

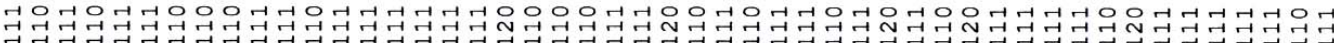

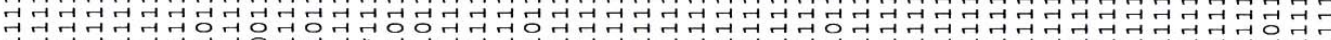

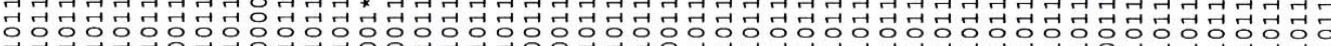

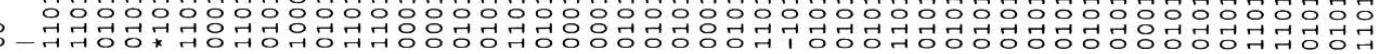
N

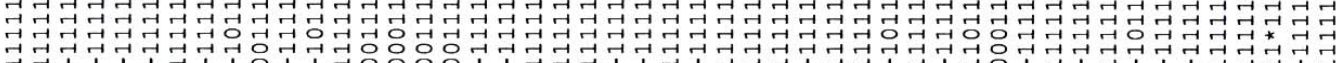

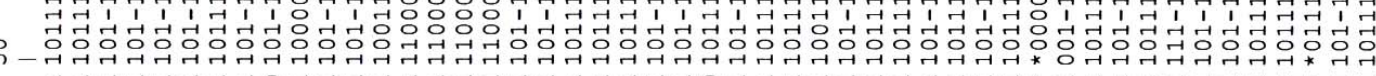

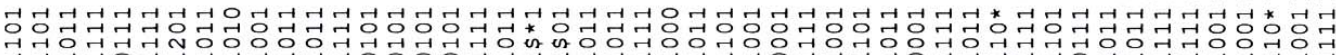

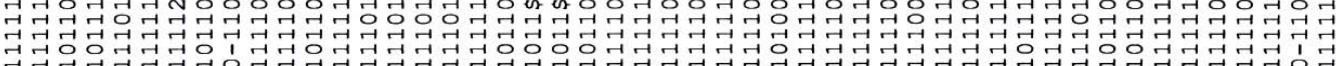

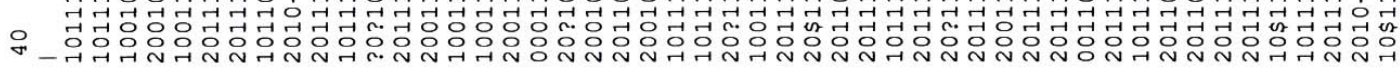

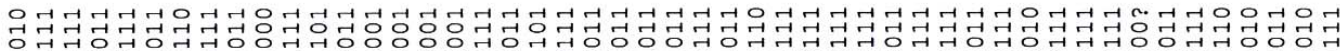

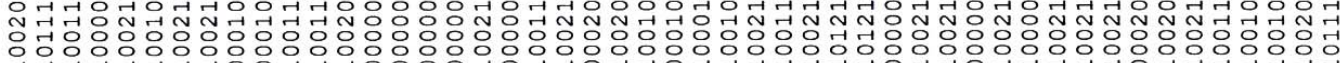

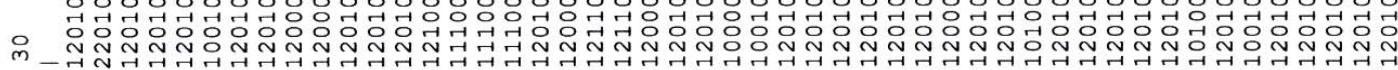

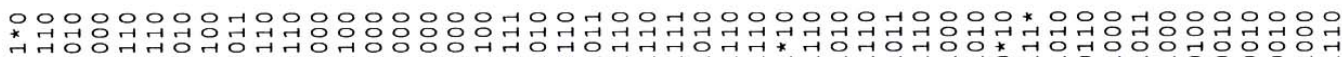

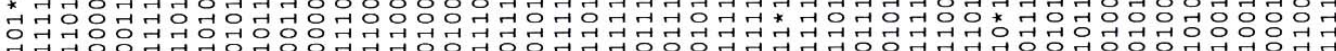

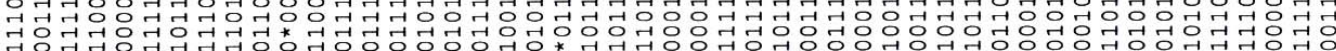

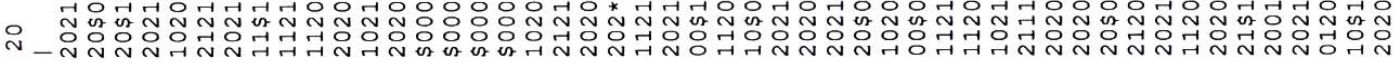

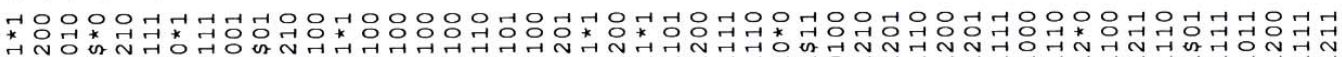

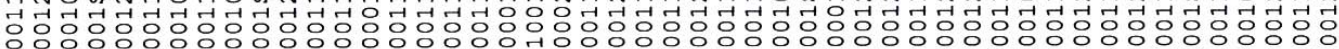

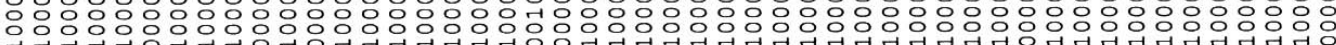

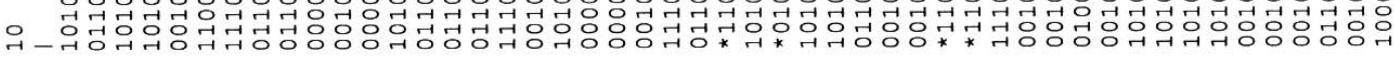
응ㅇㅇㅇㅇㅇㅇㅇㅇㅇㅇㅇㅇㅇㅇㄱㄱㅇㅇㅇㅇㅇㄱㄱㄱㄱㄱㄱㅇㅇㅇㅇㄱㄱㄱㄱㅇㅇㅇㅇㅇㅇㅇㅇㅇㅇㅇㅇㅇㅇㅇㅇㅇㅇㅇㅇㅇㅇㅇㅇㅇㅇㅇㅇㅇㅇㅇㅇㅇㅇㅇㅇㅇㅇㅇㅇㅇㅇㅇㅇㅇㅡ

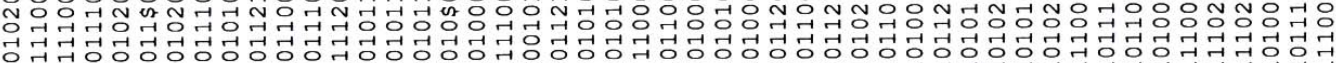

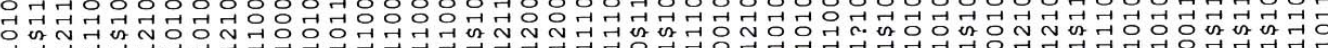
o -

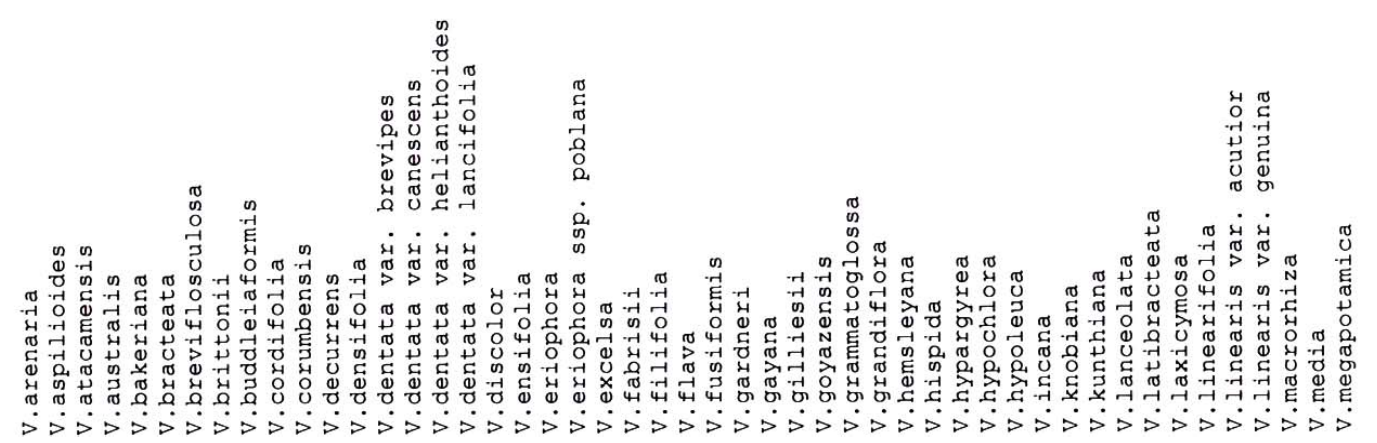




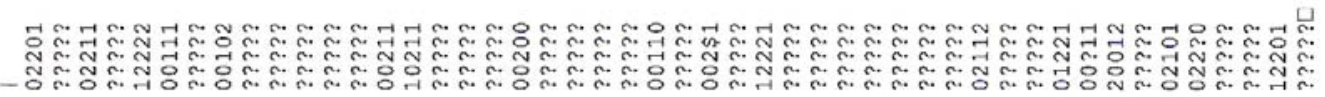

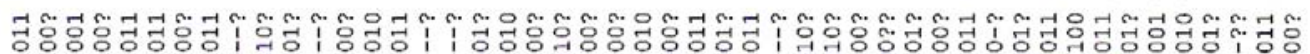

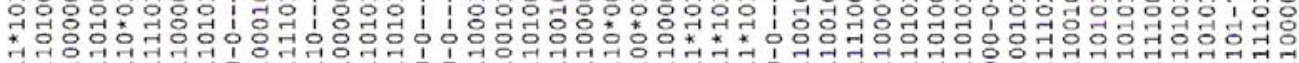

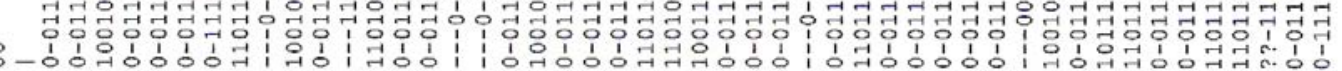

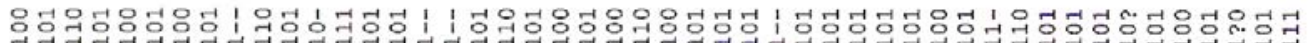

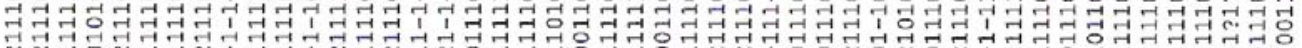

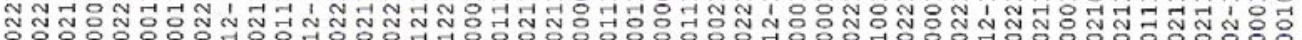

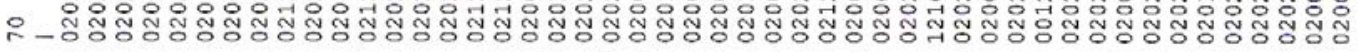

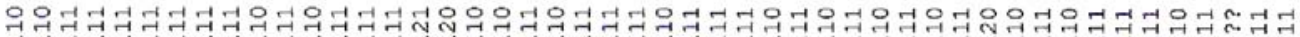

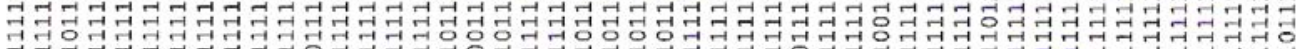

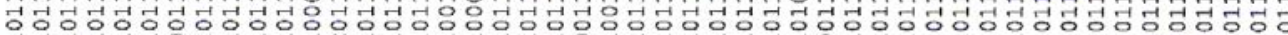

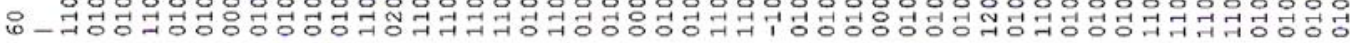

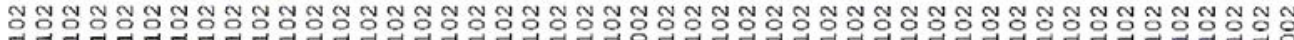

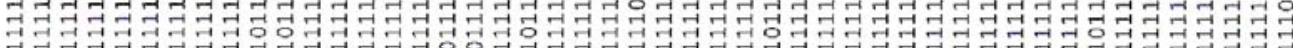

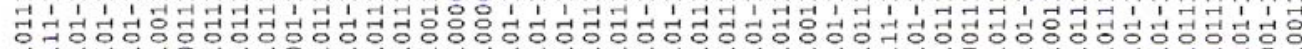

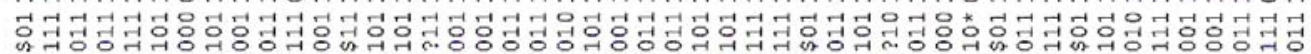

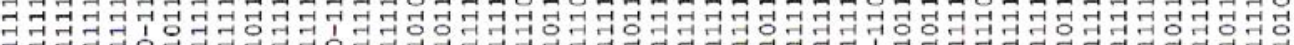

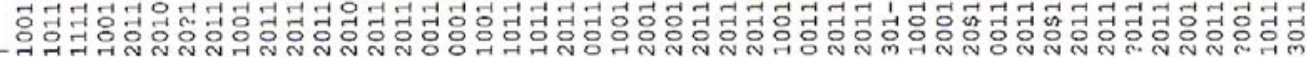

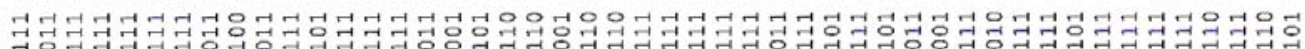

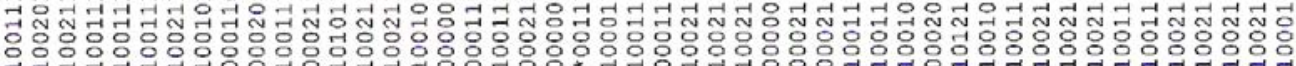

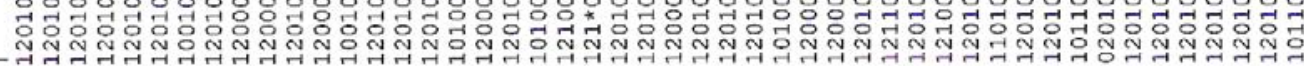

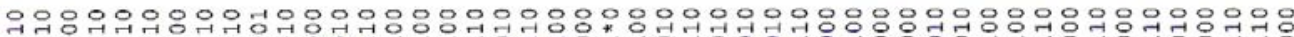

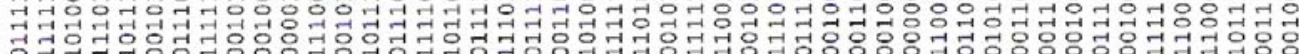

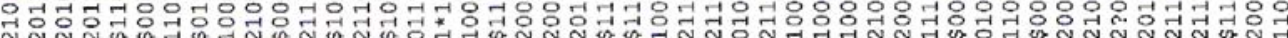
에 -

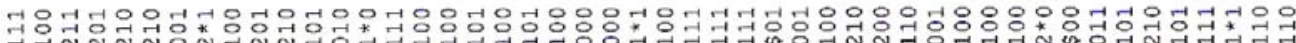

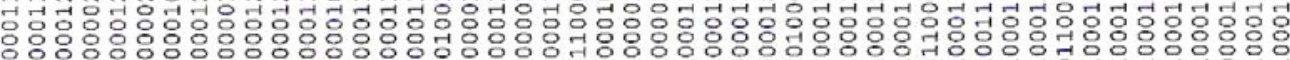

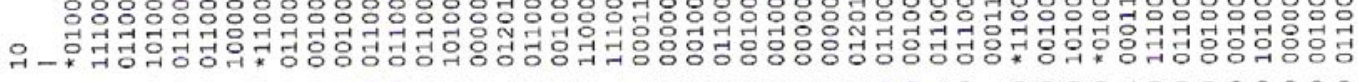

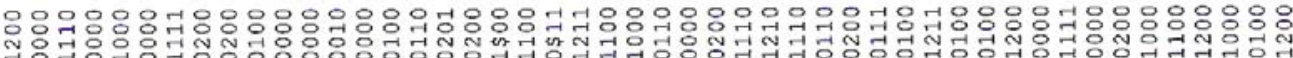

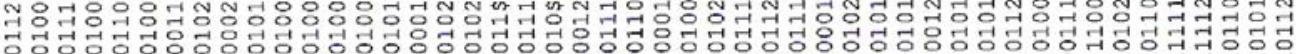

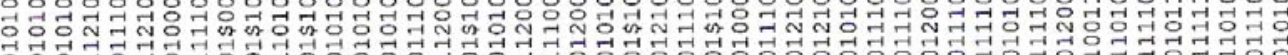

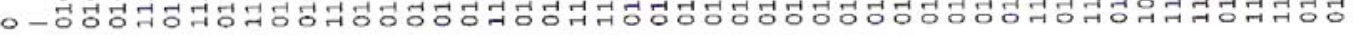


Teste das hipóteses filogenéticas propostas em outros trabalhos

Em todas as análises os dois tipos de busca apresentaram resultados semelhantes e serão detalhados aqui os da busca por Ratchet.

\section{Análise 1 (Figuras 1-3)}

$\mathrm{Na}$ análise envolvendo os 143 terminais, as diferenças entre os métodos analíticos utilizados se detiveram no número de árvores mais parcimoniosas obtido (1000 na busca heurística e 9 na busca por Ratchet) e numa pequena alteração no número de passos (1347 na primeira e 1343 na segunda). Em ambas, os índices de consistência e retenção foram iguais (IC=0,07 e $\mathrm{IR}=0,56)$. Os baixos índices indicam uma grande quantidade de eventos homoplásicos (Sanderson \& Donogue 1989; Kitching et al. 2000). No entanto, para Goloboff (1991a 1991b) grandes quantidades de homoplasia na árvore mais parcimoniosa não implicam dados menos decisivos.

$\mathrm{O}$ alto índice de homoplasias ou reversões aqui observado também foi obtido por Schilling \& Panero (1991) num trabalho comparativo entre caracteres morfológicos de alguns representantes de Viguiera do México e Iostephane. Os presentes resultados não ofereceram solução para a filogenia do grupo como um todo, e provavelmente resultam de paralelismos (Bayer \& Starr 1998) e de hibridações (Rieseberg 1991 2000; Schwarzbach et al. 2001) comuns em Asteraceae.

A obtenção da árvore de consenso estrito implicou no colapso de 78 nós; nela, o grupo interno é definido por 20 sinapomorfias, sendo 7 homoplásticas $(2,7,8,9,20,23,42)$ e 13 não-homoplásticas $(1,30,43,45,49,50,55,56,57,59$, $63,67,83)$.

No setor basal do cladograma (clados $\mathrm{C}$ a E9), estão os representantes da série Dentatae (que não formam um grupo monofilético), com exceção de $V$. potosina, uma espécie da série Gramatoglossae (V. cordifolia) e Simsia dombeyana (Figura 1). Entre as Dentatae, Bahiopsis Kellogg possui hábito lenhoso, (não analisado) e as Viguiera (V. potosina e V. dentata) são herbáceas; Schilling (1990) 
preferiu excluí-las de sua proposta de elevação da maioria dos representantes de Dentatae ao subgênero Bahiopsis (gênero restabelecido por Schilling \& Panero 2002), pelo hábito e pela ausência de glândulas sésseis nas folhas. Nesta análise, $V$. potosina faz parte de um grande clado de posição intermediária no cladograma (E9), contendo, entre outros grupos, algumas espécies andinas de Viguiera. Na análise parcial de sítios, de retrição de cpDNA incluindo representantes do subg. Amphilepis, e da ser. Grammatoglossae (Schilling \& Panero 1996) esta espécie também emerge do contendo espécies da América do Sul.

O clado $\mathrm{E}_{1}$ é formado por três espécies de Bahiopsis, incluindo B. lanata, a espécie típica do gênero, e todos os táxons de $V$. dentata. É definido por 4 sinapomorfias homoplásticas, dois paralelismos - folhas sem glândulas (11) e paracládios terminando abaixo do capítulo terminal (17) e duas reversões folhas com ápice acuminado (6) e páleas do receptáculo com glândulas (46). Bahiopsis possui número básico de cromossomos $n=18$ e $V$. dentata tem $n=17$ (Schilling, E. E. \& Schilling, E. M. 1986), Número básico de cromossomos n=18 é também encontrado em Encelia (Solbrig et al. 1972) Flourensia (Robinson et al. 1981), do grupo-externo. Nas análises combinadas de cpDNA e Its (Schilling \& Panero 2002) as relações entre os representantes de Bahiopsis também não foram bem resolvidas.

No clado $\mathrm{E}_{2}$ estão os quatro táxons quatro de $V$. dentata, atualmente conhecidas como variedades, num clado sustentado por dois paralelismos (32, 51), cinco reversões $(12,17,33,48,86)$ e uma sinapomorfia não-homoplástica (58); a presença de longos tricomas na face posterior da porção superior do filete dos estames (58) é uma autapomorfia de $V$. dentata.

O clado $\mathrm{E}_{8}$ é formado por $V$. cordifolia (Grammatoglossae) e Simsia dombeyana (F1), uma representante de Helianthinae de ampla distribuição nas Américas que, como os representantes do grupo-externo, apresentam cipselas com margens fortemente compressas (65). É definido por oito sinapomorfias homoplásticas: três paralelismos $(28,36$ e 60$)$ e quatro reversões $(26,38,63,65)$. Nas análises de morfologia, cpDNA e ITs (Schilling \& Panero 19911996 2000) 
Simsia também emerge num clado com representantes de Grammatoglossae.

Devido à posição desses táxons fundamentalmente mexicanos na parte basal do cladograma por eles obtido, Schilling \& Panero (1996) sugeriram uma origem mexicana para a subtribo Helianthinae. No entanto, este é um tipo de conclusão criticado por se focar numa leitura unilateral da árvore e não testar múltiplos grupos-irmãos de ambos os nós extremos de uma filogenia (Crisp \& Cook 2005).

Após a cladogênese de Hymenostephium sylvatica que, ao contrário dos outros representantes da seção Diplostichis, possui páleas do receptáculo com glândulas (caráter 46), as demais espécies Viguiera sensu lato emergem, numa grande politomia (clado F, Figura 2), cuja porção basal é constituída por Heliomeris (sect. Heliomeris), demais representantes de Hymenostephium (sect. Diplostichis), subg. Amphilepis, duas representantes da ser. Brevifoliae (V. bicolor e V. brevifolia) algumas Viguiera sul-americanas andinas, Helianthus, Pappobolus, Aldama e Rhysolepis, além de um representante de Dentatae (V.potosina).

Algumas verificações são possíveis:

O clado G é formado pelo gênero Pappobolus (arbustos lenhosos dos Andes) que, por muito tempo, esteve incluso em Helianthus (ervas anuais ou perenes da América do Norte); a proposta de restabelecimento de Pappobolus S.F. Blake foi feita por Panero (1992) para acomodar o grupo que Robinson (1979) chamou de Helianthopsis; o gênero é composto por plantas com folhas de margem serreada (8), brácteas involucrais internas escariosas (29) e páleas do receptáculo com nervuras coalescentes no ápice (41), entre outros caracteres.

O clado J contém as espécies de Helianthus, que têm folhas inteiramente denteadas ou serreadas (8) e membranáceas (9) e receptáculo plano a levemente convexo (37), condições incomuns entre Viguiera, além de pápus decíduo (78 e 84), e compartilhadas com Aldama, Pappobolus, Rhysolepis e algumas Viguiera do Hemisfério Norte.

No clado H, Viguiera potosina, com n=17 (Jones 1970), a única espécie da ser. Dentatae a não emergir junto ao grupo basal, desponta como irmã de Hymenostephium quitensis $(\mathrm{n}=21)$, por compartir dezoito sinapomorfias 
homoplásticas (12 paralelismos e seis reversões); ambas possuem folhas membranáceas com pecíolo conspícuo (caracteres 9 e 3), páleas do receptáculo periféricas largas (31) e são epaposas $(78,83)$. V. potosina, ao contrário dos representantes de Bahiopsis Kellogg, não apresenta brácteas involucrais com ápice abruptamente estreitado (condição não avaliada neste trabalho). No clado $\mathrm{K}$, as espécies da série Pinnatilobatae ( $V$. pinnatilobata e $V$. stenoloba) formam o grupo-irmão de Calanticaria greggi, da série Brevifoliae (elevada ao gênero Calanticaria por Schilling \& Panero 2002), com a qual V. stenoloba tem também em comum paracládios lenhosos (16); são pequenos arbustos muito ramificados (condição não analisada) e apresentam paracládios sem bractéolas 1-2bracteolados (estado não considerado na cladogênese), e ocorrem do México ao sul dos Estados Unidos. As outras espécies que compõem Brevifoliae (C. bicolor e C. brevifolia) estão no clado S, juntamente com $V$. discolor, do Brasil.

O clado L, compartilhado por $V$. decurrens, do México e duas espécies do Peru ( $V$. simsioides e $V$. weberbaueri) que, num fato digno de nota, emergem como espécies-irmãs; ambas apresentam um espessamento corticoso na margem da cipsela e pápus cartáceo (caracteres não analisados), mas foram acondicionadas por Blake (1918) em diferentes séries. Na análise as espécies peruanas $\left(\mathrm{L}_{1}\right)$ foram agrupadas por dois paralelismos (11 e 32) e quatro reversões $(46,73,76$ e 80$)$; a presença de muitos tricomas no eixo de simetria da cipsela (73) não é comum, ocorrendo nas séries Dentatae e Maculatae e nas seções Diplostichis e Leighia; As espécies do clado L apresentam uma sinapomorfia única no grupo: número de nervuras nas páleas variando entre 14 e 16; as demais possuem páleas com no máximo 12 nervuras (caráter 40, não expresso).

No clado $\mathrm{N}$, uma espécie andina ( $V$. adenotricha) emerge com as espécies da ser. Maculatae e definido principalmente pela presença de páleas do receptáculo cartáceo-coriáceas (36) glabrescentes ou pubescentes (44).

Bastante significativa é a constituição do clado $M$, composto pelos gêneros Aldama e Rhysolepis sensu S.F. Blake (JK=95), através do compartilhamento de dezoito caracteres $(20,21,28,30,31,32,33$, 35, 36, 37, 38, $42,45,48,61,62,68$ e 72), dos quais e sete são reversões $(33,38,42,45,69,84$ e 
88) e apenas dois são sinapomorfias não homoplásticas: a presença da páleas do receptáculo transversalmente corrugadas (35) cipselas da periferia do disco fortemente assimétricas (62). A morfologia das páleas de Rhysolepis foi enfatizada por Blake (1917) que, no entanto, não se referiu aos frutos periféricos fortemente assimétricos, ambos presentes em Aldama La Llave \& Lex. As únicas diferenças entre estes dois gêneros concernem à textura das páleas do receptáculo que, em Aldama, se tornam mais coriáceas que as de Rhysolepis na maturação do fruto e no pápus que, neste último, é formado por duas aristas tênues e diminutas escamas intermediárias livres e em Aldama as diminutas aristas e escamas são unidas, conferindo-lhes um aspecto coroniforme; em ambos, o pápus é decíduo. Em Helianthinae, as condições de escamas total ou parcialmente unidas ou livres ocorrem em grupos proximamente relacionados, como em Tithonia e em muitas espécies de Viguiera do Brasil. Desta forma, esses táxons deveriam constituir um único gênero que, de acordo com o Código Internacional de Nomenclatura Botânica em vigência (Saint Louis), deve ser, por prioridade de publicação, Aldama.

Com base na observação da morfologia, Robinson \& Moore (2004) propuseram a inclusão de todas as espécies sul-americanas em Rhysolepis (ignorando o gênero Aldama), alegando que as páleas são apenas "levemente transversalmente corrugadas", o que não distinguiria o grupo como gênero. $O$ termo "levemente" não é cabível, visto que é uma característica acentuada (ver Figura 1 do capítulo V). Em seu trabalho, os autores não fizeram menção à morfologia dos frutos periféricos, que é acentuadamente diferente daquela das plantas da América do Sul, nas quais as cipselas são simétricas ou, excepcionalmente, levemente assimétricas (observadas em V. sphaerocephala ser. Maculatae e V. tucumanensis - Aureae).

O grande clado O abrange vários outros, contendo as espécies da Região Neotropical, algumas andinas e poucas mexicanas.

No clado Q, $V$. amphychlora e $V$. oblongifolia compartilham oito sinapomorfias homoplásicas: sete paralelismos $(0,2,7,10,11,19$ e 24$)$ e duas reversões (18 e 37); o caráter reversivo - presença de páleas totalmente 
translúcidas (37) - é incomum entre as Viguiera da América do Sul.

Formado por $V$. knobiana e $V$. laxyracemosa, está o clado R, definido por uma sinapomorfia homoplásica de paralelismo (brácteas involucrais inteiramente foliáceas ou foliáceas em 2/3 superiores, caráter 24) e quatro reversões $(25,27,73$ e 79$)$; poderia também ser caracterizado pela presença de capítulos com brácteas involucrais de indumento suave (26), apressas (28), flores do raio glabrescentes (60) e cipselas cerdosas (74).

O clado S, formado por $V$. macrorhiza, $V$. nudicaulis, e $V$. paranensis, engloba plantas delgadas (0) de filotaxia oposta (2), podendo ser mista em $V$. macrorhiza, com folhas sem glândulas na face abaxial (11), paracládios terminando abaixo do capítulo terminal (17) brácteas involucrais levemente diferentes (21), e cipselas com escamas do pápus totalmente unidas (85). Sete reversões são observadas neste clado $(20,25,26,27,36,48$ e 73$)$.

O clado $\mathrm{T}$, é definido principalmente pela presença de folhas com ápice acuminado (6) sem glândulas (11) e cipselas cm escamas do pápus totalmente unidas (85). Nele, V. goyazensis, uma espécie ereta com folhas largas, emerge como espécie-irmã de $V$. aspilioides e $V$. tuberosa, plantas decumbentes de folhas estreitas (caracteres não analisados).

O clado U ( $V$. kunthiana, $V$. anchusifolia, e $V$. megapotamica) está representado por plantas delgadas (0) de folhas lineares ou filiformes (4) de indumento abaxial rijo (10), páleas do receptáculo com nervuras variando entre 6 e 8 (40) e cipselas com pápus de escamas totalmente unidas (85). Estas espécies possuem ainda brácteas involucrais totalmente foliáceas ou foliáceas em 2/3 superiores (24), caráter não incluído na cladogênese.

$\mathrm{O}$ clado $\mathrm{V}$ contém $V$. discolor, do Brasil, e duas espécies do gênero Calanticaria (ser. Brevifoliae) que compartilham, principalmente, a ausência de cílios nas brácteas involucrais (28); o clado W é composto por duas espécies sulamericanas ( $V$. breviflosculosa e $V$. squalida) e pela mexicana $V$. hypargyrea (sect. Hypargyrea), unidas principalmente por possuírem folhas de base atenuada (7) e lobos da corola com altura maior que o dobro da largura (48).

O clado X é formado por $V$. linearis (sect. Leighia), do México e $V$. 
tucumanensis var. discoidea, uma espécie andina; são plantas delgadas (0) de filotaxia mista (2) e folhas lineares a filiformes (4) com brácteas involucrais em mais de três séries (19) e conspicuamente reflexas (23), e apresentam como reversões as brácteas com uma nervura destacada da base ao ápice (26), de indumento suave (27), páleas com nervuras em regiões não diferenciadas (39), corola das flores do disco cilíndrico-tubulosa (47), lobos da corola com altura maior que o dobro da largura (48).

No clado $\mathrm{Y}_{1}, V$. corumbensis, uma espécie que ocorre nos Estados do Mato Grosso e Mato Grosso do Sul, próximo a região de fronteira com a Bolívia, emerge como grupo-irmão de espécies andinas ( $V$. soridoi e $V$. truxilensis), principalmente por apresentar corola cilíndrico-tubulosa (47), condição rara entre as espécies da Região Neotropical. Quanto aos caracteres expressos na cladogênese, a espécie brasileira possui brácteas involucrais ciliadas e lobos das flores do disco glabros, e os táxons andinos apresentam brácteas involucrais sem cílios (28) e flores tubulosas com lobos estrigilosos (55).

As demais espécies analisadas da seção Leighia ( $V$. Montana e $V$. purisimae) compartilham o clado Z com cinco espécies da série Grammatoglossae, principalmente pela presença de folhas com base cuneada (7), e duas reversões: paracládios da inflorescência opostos ou mistos (16) e páleas do receptáculo com ápice pungente (33) 


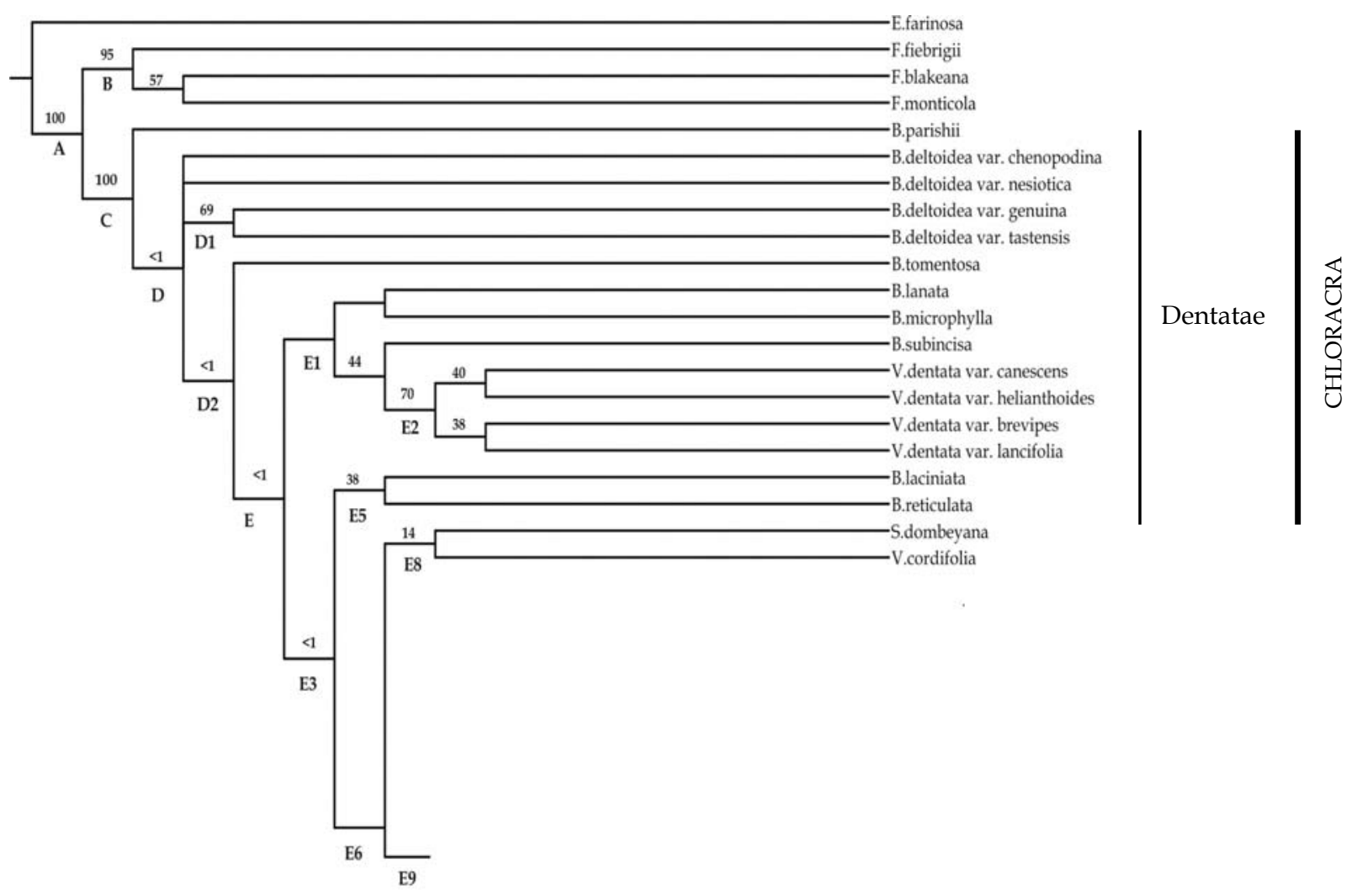

Fig. 1. Parte 1 de 3 , da árvore de consenso estrito das 9 árvores igualmente parcimoniosas (1343 passos, IC=0,07 e IR=0,56) obtida com a análise morfológica de 143 terminais, incluindo a maioria das espécies de Viguiera sensu lato, evidenciando grupos do Hemisfério Norte. Classificação dos subgêneros (maiúscula, negrito), seções (maiúscula) e séries (normal) segundo Blake (1918). Os valores de Jack-knife acima de 10 estão representados na parte superior dos clados. B. - Bahiopsis, E. - Encelia, F. - Flourensia, S. - Simsia, V. Viguiera). 


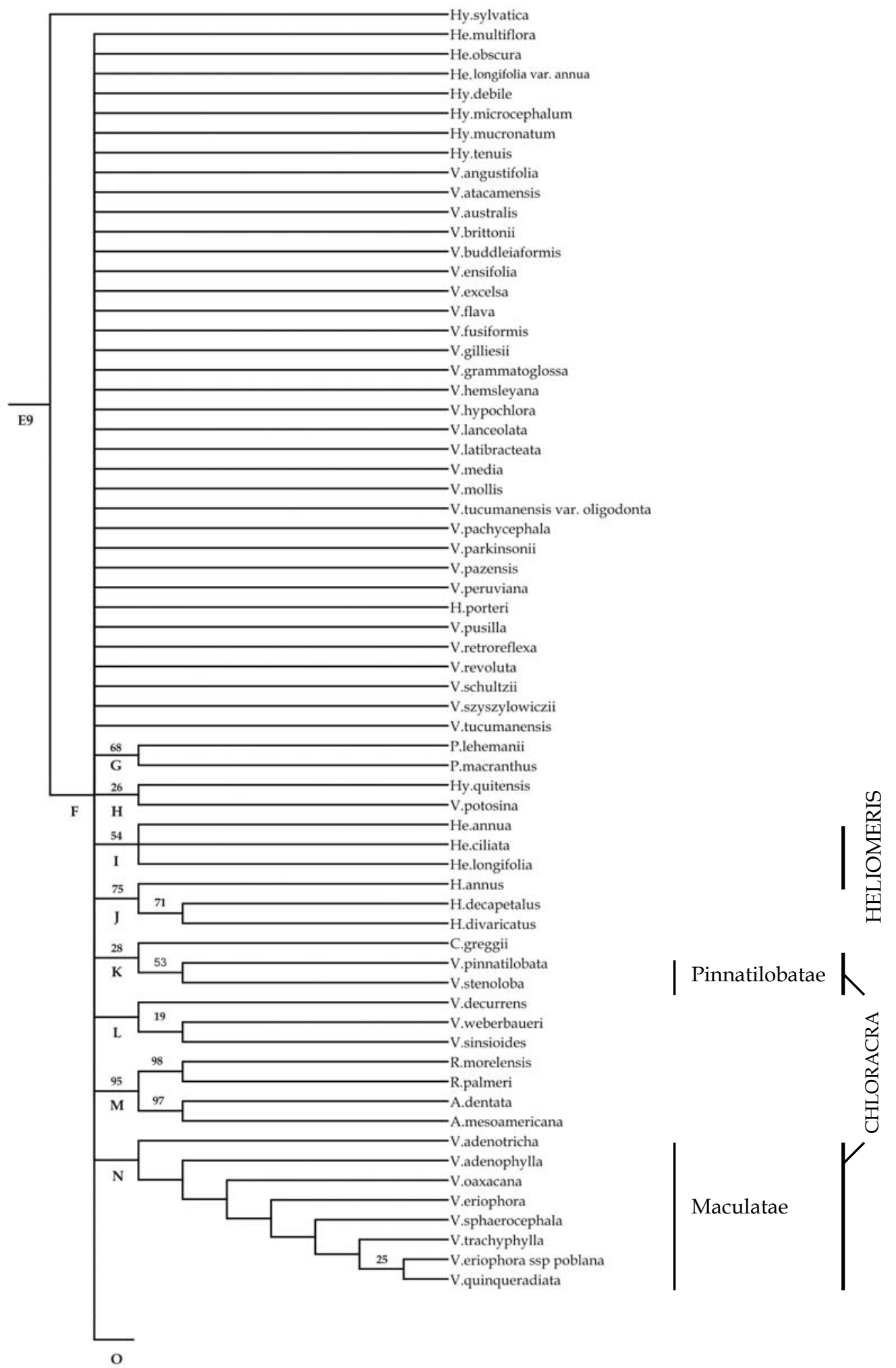

Fig. 2. Parte 2 de 3, da árvore de consenso estrito das 9 árvores igualmente parcimoniosas (1343 passos, IC=0,07 e IR=0,56) obtida com a análise morfológica de 143 terminais, incluindo a maioria das espécies de Viguiera sensu lato, evidenciando grupos do Hemisfério Norte e algumas espécies andinas. Classificação dos subgêneros (maiúscula, negrito), seções (maiúscula) e séries (normal) segundo Blake (1918). Os valores de Jack-knife acima de 10 estão representados na parte superior dos clados. AAldama, C. - Calanticaria, E. - Encelia, F. - Flourensia, H. - Helianthus, He. - Heliomeris, Hy. Hymenostephium, P. - Pappobolus, R. - Rhysolepis, S. - Simsia, V. -Viguiera). 


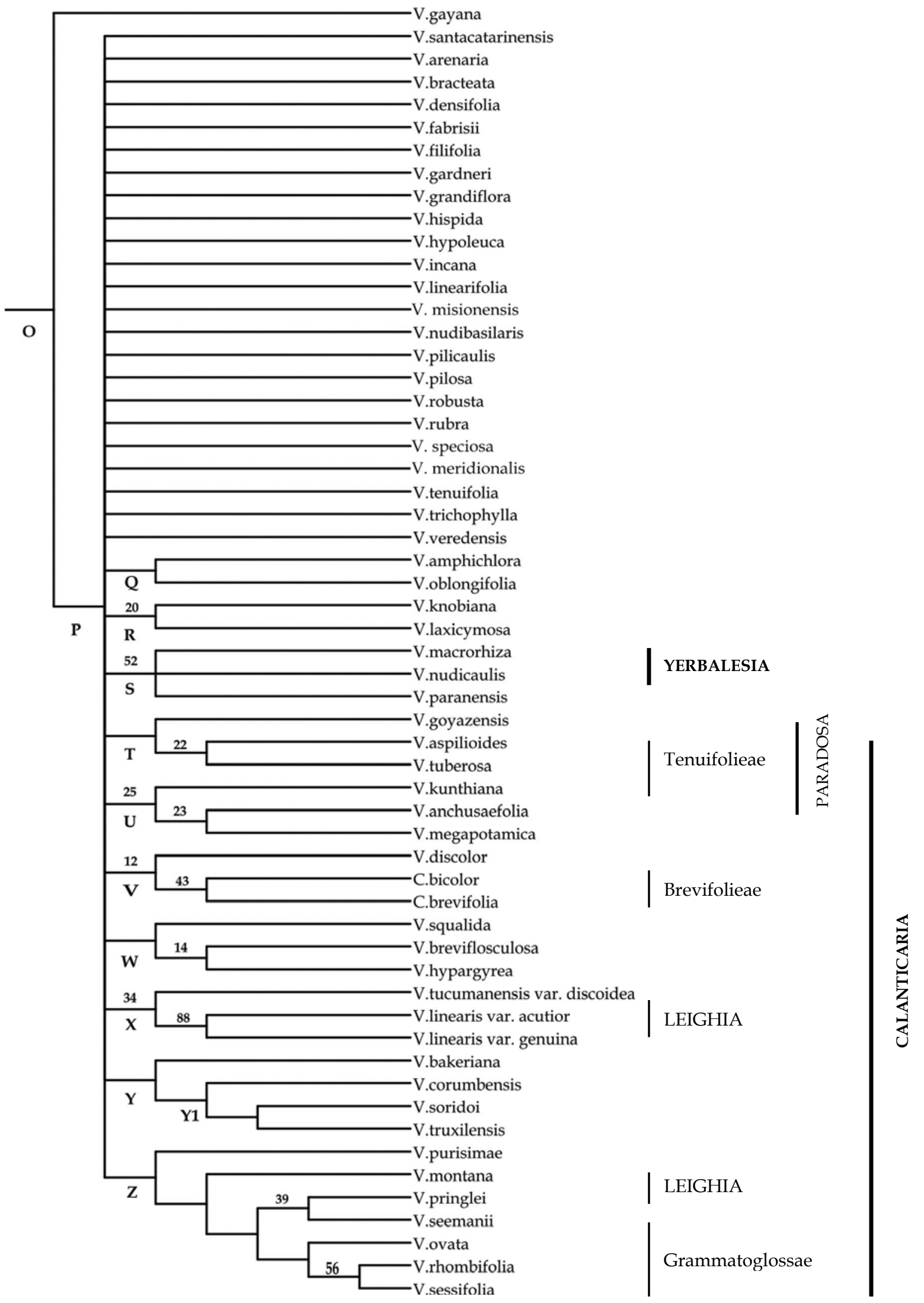

Fig. 3. Parte 3 de 3, da árvore de consenso estrito das 9 árvores igualmente parcimoniosas (1343 passos, IC=0,07 e IR=0,56) obtida com a análise morfológica de 143 terminais, incluindo a maioria das espécies de Viguiera sensu lato, evidenciando grupos derivados da América do Sul e alguns mexicanos. Classificação dos subgêneros (maiúscula, negrito), seções (maiúscula) e séries (normal) segundo Blake (1918). Os valores de Jack-knife acima de 10 estão representados na parte superior dos clados. C. - Calanticaria, V. -Viguiera). 


\section{Análise 2 (Figuras 4-5)}

Na segunda análise, com 106 terminais, as buscas resultaram em 1000 árvores igualmente parcimoniosas na busca heurística, com $C=1081$ e 1 única árvore na busca por Ratchet $(\mathrm{C}=1078)$, ambas com $\mathrm{Ci}=0,10$ e $\mathrm{Ri}=0,51$.

Na porção basal da árvore obtida pelo método de Ratchet (Figuras 4 e 5) emergem, com relações mal estabelecidas, os representantes da série Dentatae (Bahiopsis. deltoidea, B. lanata, Viguiera dentata e $V$. potosina) os das séries Brevifoliae (Calanticaria greggi) e Pinnatilobatae ( $V$. pinnatilobata e $V$. stenoloba), dois representantes de Grammatoglossae (V. ovata e V. grammatoglossa) e Simsia dombeyana, já comentada na análise anterior (clados C a F).

Como na primeira análise, as espécies da série Pinnatilobatae ( $V$. pinnatilobata e V. stenoloba) emergem como grupo-irmão de Calanticaria greggi, da série Brevifoliae (clado E). O clado é delimitado por seis sinapomorfias homoplásicas: quatro do tipo paralelismo (1, 23, 25 e 68) e duas do tipo reversão (22 e 40). O baixo número de nervuras nas páleas do receptáculo (40) é um estado de caráter compartilhado apenas com o gênero Bahiopsis, com uma espécie da ser. Maculatae (V. quinqueradiata), uma da ser. Grammatoglossae (V. seemanii) e V. incana, do Equador.

No cladograma, após o evento de especiação do clado $H$, formado por $V$. procumbens (Argentina, Bolívia, Chile e Peru) e V. retroreflexa, da série Aureae, um grande grupo (I), envolve dois outros (J e R), que são divididos em vários outros.

O clado J engloba plantas com capítulos de brácteas involucrais sem cílios (28) e folhas com sulcos leves na epiderme abaxial (92); é composto de algumas espécies andinas que, juntamente com $V$. decurrens (sect. Hypargyrea México), emergem na porção basal do clado e, no clado interno $M$, os representantes do subgênero Amphilepis, e dos gêneros Aldama, Helianthus, Heliomeris, Hymenostephium e Rhysolepis. Neste, o clado P é compartilhado pelas espécies de Amphilepis (V. ensifolia, V. hemsleyana, V. flava, V. hypochlora, $V$. schultzii) e pelos gêneros Aldama e Rhysolepis, devido à presença de carpopódio 
unilateral (68); $V$. hypoclora e $V$. schultzii têm também em comum com os outros dois gêneros, as páleas do receptáculo envolvendo totalmente as flores periféricas do disco (32) e $V$. schultzii compartilha também com eles a presença de brácteas involucrais com porção foliácea reduzida a 1/2 ou menos (21) e páleas do receptáculo com nervuras paleáceas (42). A emersão de V. flava no mesmo clado que espécies andinas, corrobora os resultados de análises de ITS, efetuados por Schilling et al. (2000)

Os componentes do clado Q apresentam folhas com pecíolo conspícuo (3, reversão) e lâmina membranácea (9) de margem inteiramente denteada (caráter 8, não expresso) e brácteas involucrais com ápice acuminado (22) e indumento rijo (27); nele estão os gêneros Helianthus e Pappobolus, num subclado menor $\left(Q_{1}\right)$, compartilhando a existência de capítulos com receptáculo plano a levemente convexo (30) e carpopódio estreito (69), também comum em Viguiera sul-americanas; e, em outro, Hymenostephium e Heliomeris $\left(\mathrm{Q}_{2}\right)$, que possuem brácteas involucrais com formas similares (21) e páleas do receptáculo com porção central rígida e alas estramíneas (38) e nervuras em regiões não indiferenciadas (39); é preciso observar que as folhas deste último não possuem margens denteadas e o número de cromossomos é $n=8$ (Powell \& Sikes 1970; Keil et al. 1988; Carr et al. 1999; Strother \& Panero 2001), condição única em Viguiera sensu lato. Os registros de número básico de cromossomos para Hymenostephium são poucos (ver Watanabe 2005): H. quitensis $(\mathrm{n}=21)$, H. tenuis $(n=12)$ e H. mucronata $(n=42)$. Os demais táxons do clado possuem $n=17$. A restrição de informações a esse respeito impediu o uso do caráter na análise.

O grande clado S reúne todas as espécies analisadas das seções Leighia, (V. linearis, V. montana e $V$. purissimae) e Maculatae ( $V$. adenophylla e $V$. eriophora), uma da seção Hypargyrea ( $V$. hypargyrea), espécies sul-americanas e três representantes da série mexicana Grammatoglossae (V. parkinsonii, V. pringlei, V. seemanii) e além de uma de série Brevifoliae (Calanticaria bicolor). O clado S é composto, em sua maioria, por espécies com brácteas involucrais em mais de três séries (19).

O clado X é formado por onze espécies da Região Andina e uma 
mexicana ( $V$. linearis, sect. Leighia) e sua principal característica é a presença de flores do disco com corola cilíndrico-tubulosa (47), uma condição não encontrada nas espécies sul-americanas da Região Neotropical. Mais uma vez, $V$. simsioides e $V$. weberbaueri emergem como irmãs, num clado definido por uma sinapomorfia não homoplástica (40) e cinco reversões (32, 38, 46, 65 e 73). O clado $X_{5}$, no qual se encontra a espécie mexicana, junto a duas Chilenas ( $V$. atacamensis e $V$. gilliesii) é delimitado pelas folhas com indumento abaxial suave (10) e sem glândulas (11), além das cipselas com escamas do pápus parcialmente unidas (86).

O cladoY reúne principalmente espécies com brácteas involucrais externas de indumento rijo (27). Os componentes de $Y_{2}$ são plantas robustas com capítulos de brácteas involucrais de forma geralmente similar (caracteres 0 e 21, não expressos) com cipselas geralmente cerdosas (74); nele, apenas as duas espécies da seção mexicana Maculatae têm folhas pecioladas (caráter 3, não expresso) e membranáceas (9). Como espécies irmãs emergem, em $\mathrm{Y}_{3}, V$. grandiflora e V. speciosa, a primeira do Brasil, ocorrendo nos Estados de Goiás, Minas Gerais, Mato Grosso, Mato Grosso do Sul e São Paulo e a segunda do Paraguai, unidas por apresentarem flores do disco de lobos com altura maior que o dobro da largura (48), mas que também são idênticas vegetativamente. $Y_{5}$ é composto por plantas delgadas (0) com folhas de base atenuada (7) sésseis ou subsésseis e brácteas involucrais geralmente apressas (caracteres 3 e 23, não expressos). Dentro deste clado, $\mathrm{Y}_{6}$ é formado por $V$. aspilioides e $V$. tuberosa, duas plantas decumbentes, da Região Sul do País, que emergem como espécies irmãs, devido ao indumento rijo das flores do raio (60), mas compartilham vários caracteres não expressos, pois são delgadas (0), têm folhas de base atenuada (7), brácteas involucrais em duas a três séries (19) de formas similares (21) e tamanhos diferentes (20) e pápus com escamas totalmente unidas (85). No clado $\mathrm{Y}_{8}$, definido apenas por reversões, estão plantas também da Região Sul, com brácteas involucrais de tamanho igual ou similar (20), com indumento suave (27) e folhas sem sulcos na epiderme abaxial (caráter 92, não expresso); duas espécies do Rio Grande do Sul, V. macrorhiza e V. nudicaulis que 
despontam como irmãs; a primeira descrita para o Paraguai, e registrada para o Brasil pela primeira vez no capítulo V, é encontrada também no Paraná e em São Paulo e a segunda, de registro recente para o Brasil (Mondin 2004), foi descrita para o Uruguai, onde aparentemente é conhecida pelo material-tipo; a emersão destas espécies como irmãs, confirma sua estreita relação; o baixo número de coletas impede uma análise mais detalhada, mas é possível tratar-se de uma única espécie.

No clado $Y_{11}$ estão plantas com folhas lineares ou filiformes (92), que apresentam outros caracteres em comum, não expressos na análise: paracládios terminando abaixo ou na altura do capítulo terminal (17), brácteas involucrais de tamanhos diferentes (20), totalmente foliáceas ou em mais de 2/3 superiores (24), estrigilosas ou estrigosas (27); dentro dele, V. linearifolia e V. trichophylla, duas espécies resiníferas (1), com brácteas involucrais fortemente reflexas (23) e epiderme abaxial foliar sem sulcos (92), despontam como espécies irmãs, $V$. kunthiana compartilha outro clado com $V$. anchusifolia e $V$. megapotamica, todas com brácteas involucrais apressas (caráter 23, não expresso), 6-8 nervuras nas páleas do receptáculo (40) e cipselas cerdosas (74). 


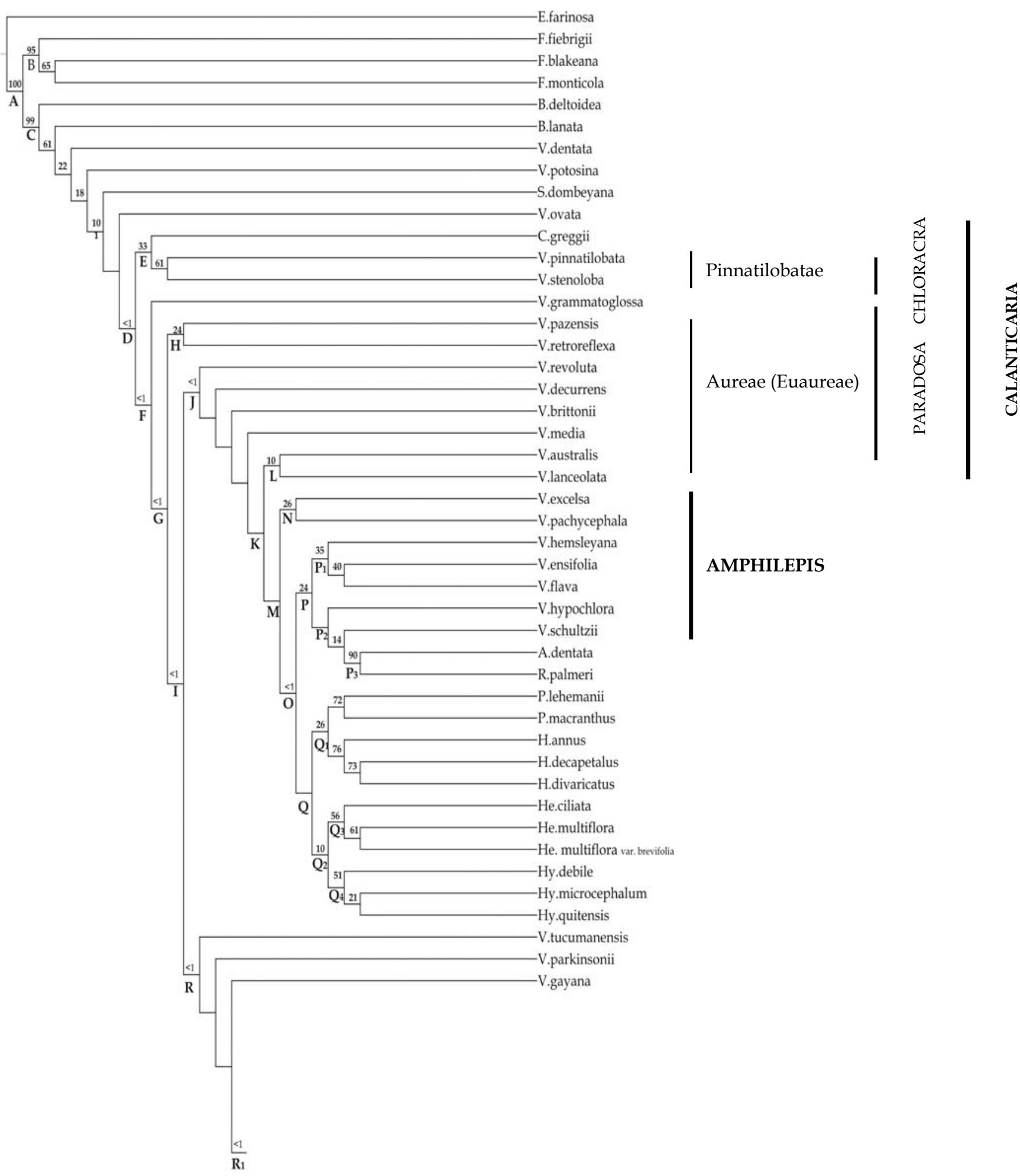

Fig. 4. Parte 1 de 2, da árvore única (1078 passos, $I C=0,10$ e $I R=0,51$ ) obtida com a análise morfológica de 106 terminais, incluindo representantes de todos os táxons infragenéricos de Viguiera sensu lato. Classificação dos subgêneros (maiúscula, negrito), seções (maiúscula) e séries (normal) segundo Blake (1918). Os valores de Jack-knife abaixo de 1 ou acima de 10 estão representados na parte superior dos clados. AAldama, C. - Calanticaria, E. - Encelia, F. - Flourensia, H. - Helianthus, He. - Heliomeris, Hy Hymenostephium, P. - Pappobolus, R. - Rhisolepis, S. - Simsia, V. -Viguiera). 


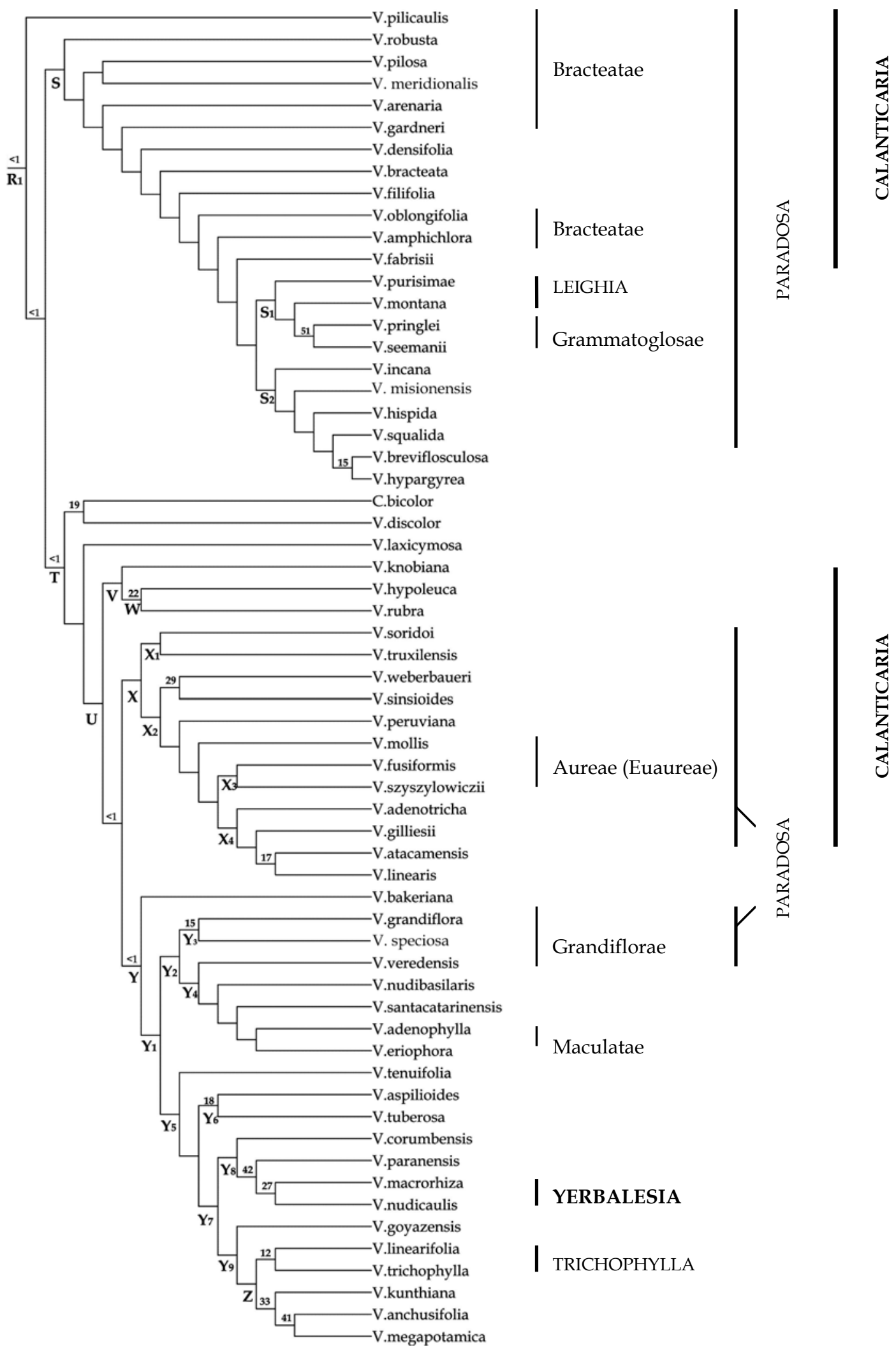

Fig. 5. Parte 2 de 2 , da árvore única ( 1078 passos, $I C=0,10$ e $I R=0,51)$ obtida com a análise morfológica de 106 terminais, incluindo representantes de todos os táxons infra-genéricos de Viguiera sensu lato. Classificação dos subgêneros (maiúscula, negrito), seções (maiúscula) e séries (normal) segundo Blake (1918). Os valores de Jack-knife abaixo de 1 ou acima de 10 estão representados na parte superior dos clados. C. - Calanticaria, V. - Viguiera. 
A análise com 68 táxons, incluindo apenas representantes da América do Sul, Simsia, Viguiera dentata, Aldama e Rhysolepis resultou em 43 (busca heurística) e 7 (Ratchet) árvores igualmente parcimoniosas, com $C=669, \mathrm{IC}=16 \mathrm{e}$ $\mathrm{IR}=50$ nos dois métodos de busca e é congruente com as anteriores; Simsia e $V$. dentata emergem em posições basais do cladograma (A-C) e Rhysolepis e Aldama como grupo irmão das plantas sul-americanas (D), condição definida por 4 caracteres sinapomórficos não homoplásticos (3, 42, 53 e 54), quatro sinapomorfias homoplásticas (10, 23, 36 e 76) e quatro reversões (8, 9, 47 e 69); várias das as relações entre as plantas brasileiras são confirmadas, com acréscimo da emersão de $V$. santacatarinensis e $V$. nudibasilaris como espéciesirmãs (J) .

Na porção basal do clado que contém as espécies sul-americanas, está a maioria das espécies andinas (clados $\mathrm{F}$ a $\mathrm{H})$.

O clado $\mathrm{G}$ ( $V$. adenotricha, $V$. atacamensis e $V$. gilliesii) é formado por espécies chilenas ( $V$. gilliesii ocorre também na Argentina) com páleas do receptáculo pubescentes (44) e eixo de simetria das cipselas com tricomas adensados (73), características aparentemente adquiridas por reversão.

A condição de espécies-irmãs de $V$. simsioides e $V$. weberbaueri é confirmada no clado $\mathrm{H}_{1}$.

O clado J ( $V$. santacatarinensis e $V$. nudibasilaris) é determinado por duas sinapomorfias homoplásticas; estas espécies possuem folha com base atenuada (6), uma condição incomum na América do Sul, brácteas conspicuamente reflexas (23) e apresentam uma aparente reversão, com escamas do pápus totalmente unidas (85).

O clado R é formado por plantas com capítulos de brácteas involucrais conspicuamente reflexas (23), foliáceas em 1/2 ou menos superiores (24) e flores do raio a maioria com indumento rijo (60). Nele, $V$. pilosa, compartilha o clado $S$ com $V$. arenaria, $V$. gardneri, $V$. bracteata, e $V$. densifolia, que possuem brácteas involucrais de formas diferentes (21) páleas do receptáculo translúcidas (37) e epiderme abaxial foliar sulcada (92); as três últimas apresentam também escamas das cipselas totalmente unidas (85). 
No clado T, V. meridionalis, uma espécie nova do Rio Grande do Sul, compartilha com cinco espécies andinas $(V$. procumbens, $V$. retroreflexa, $V$. tucumanensis, $V$. brittoni e $V$. revoluta) a presença dos estados de caráter $6,36,40$, 42, 47, 69 e 79, os seis últimos reversivos e incomuns nas plantas da Região Neotropical.

São confirmadas ainda as seguintes relações de espécies-irmãs: clado K, de $V$. grandiflora e $V$. speciosa (2, 22 e 48); clado M, de $V$. aspiloides e $V$. tuberosa (6, 36 e 60); clado $\mathrm{O}$, com $V$. paranensis compartilhando com $V$. macrorhiza e $V$. nudicaulis o mesmo estado em 11 caracteres $(0,20,21,25,26,27,36,73,85,92$ e 93), clado $Q$, com $V$. kunthiana tendo em comum com $V$. anchusifolia e $V$. megapotamica os estados de caráter de 10, 40 e 74; clado W, de $V$. hypoleuca e $V$. rubra (19 e 26).

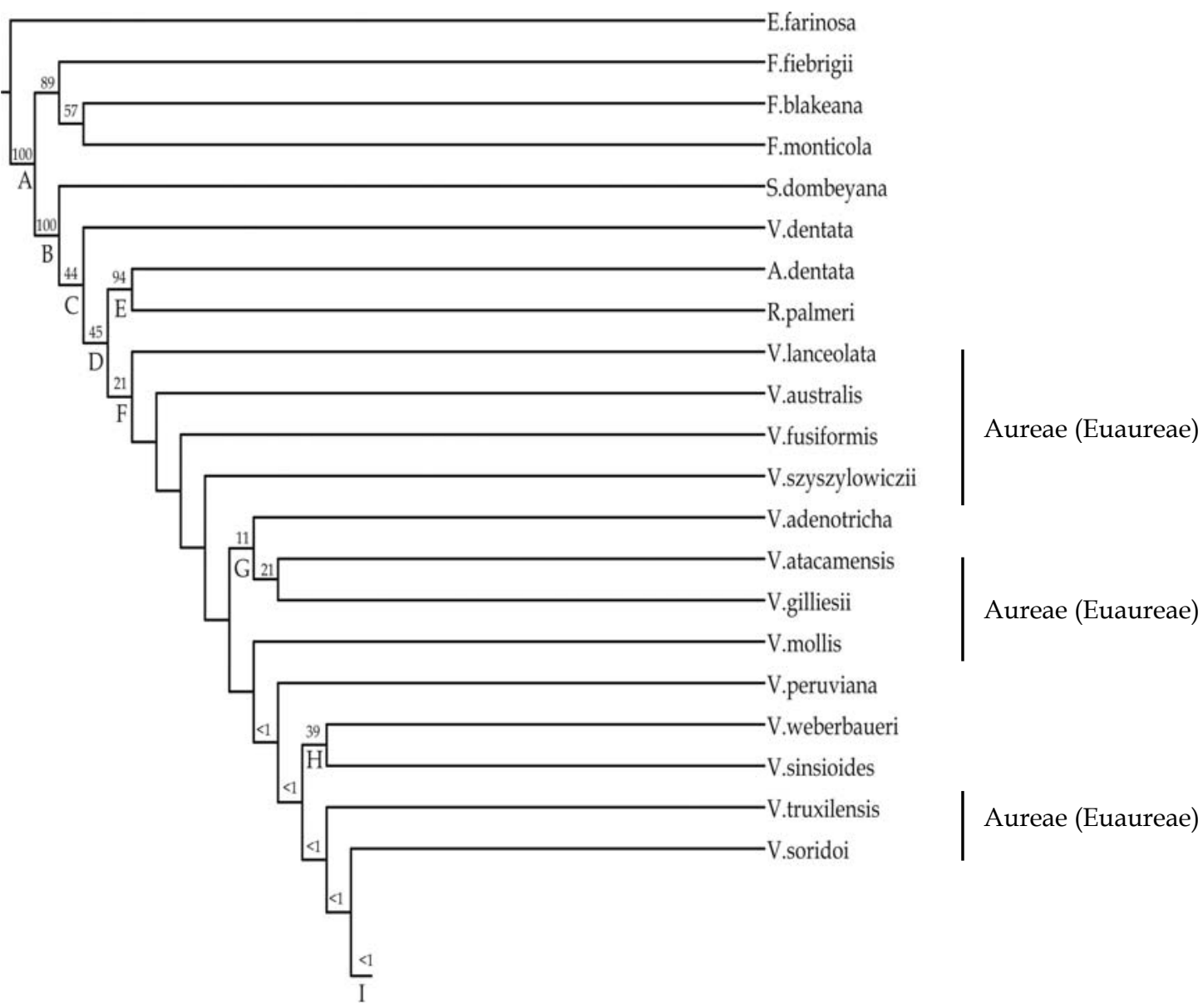

Fig. 6. Parte 1 de 2, da árvore de consenso estrito das 2 árvores igualmente parcimoniosas (669 passos, IC=0,16 e IR=0,50) obtida com a análise morfológica de 68 terminais, incluindo Aldama, Rhysolepis, Simsia e a grande maioria dos representantes sul-americanos Viguiera sensu lato. Classificação dos subgêneros (maiúscula, negrito), seções (negrito) e séries (normal) segundo Blake (1918). Os valores de Jack-knife abaixo de 1 ou acima de 10 estão representados na parte superior dos clados. A- Aldama, E. - Encelia, F. - Flourensia, R. - Rhysolepis, V. -Viguiera). 


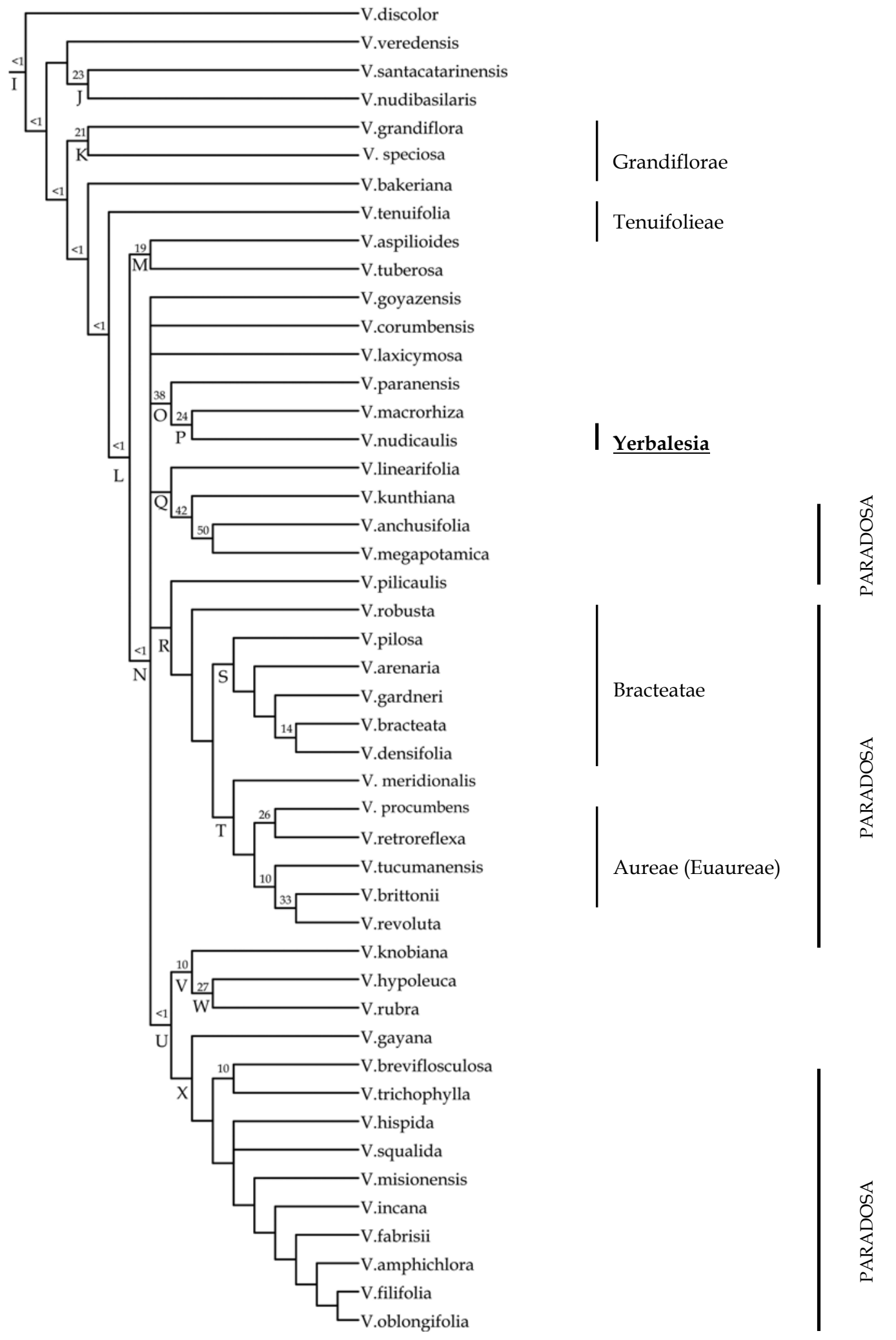

Fig. 7. Parte 2 de 2, da árvore de consenso estrito das 2 árvores igualmente parcimoniosas ( 669 passos, IC $=0,16$ e IR=0,50) obtida com a análise morfológica de 68 terminais, incluindo Aldama, Rhysolepis, Simsia e a grande maioria dos representantes sul-americanos Viguiera sensu lato. Classificação dos subgêneros (maiúscula, negrito), seções (maiúscula) e séries (normal) segundo Blake (1918). Os valores de Jack-knife abaixo de 1 ou acima de 10 estão representados na parte superior dos clados. AAldama, E. - Encelia, F. - Flourensia, R. - Rhysolepis, V. -Viguiera). 


\section{Conclusões}

As análises indicam a provável existência de numerosas homoplasias e reversões na morfologia do grupo, comuns de resto na família Asteraceae. Este fato não permitiu, com exatidão, o estabelecimento da filogenia de Viguiera sensu lato, mas algumas conclusões podem ser inferidas, como o parafiletismo de Bahiopsis (ser. Dentatae, em parte), a estreita relação de $V$. dentata com as espécies tradicionalmente posicionadas nesta série, a monofilia (análise 2) de Heliomeris (ou sect. Heliomeris) e Hymenostephium (ou sect. Diplostichis). Também são evidentes as correlações entre Simsia e a série Grammatoglossae, entre representantes de Brevifoliae e Pinnatilobatae, e entre as espécies andinas e algumas mexicanas, do subgênero Amphilepis, da seção Leighia e das séries Grammatoglossae e Maculatae.

Os resultados são, em parte, congruentes com os de Schilling \& Panero (1996; 2002) com ressalvas para Calanticaria (sect. Brevifoliae) e V. hypargyrea (sect. Hypargyrea) que, nas duas análises onde foi incluída, emergiu como espécie-irmã de $V$. breviflosculosa do Uruguai. Nos trabalhos desses autores, esses grupos emergem numa posição basal do cladograma, juntamente com Bahiopsis e Hymenostephium. Viguiera dentata segundo eles, pertence a um grupo derivado de Helianthinae (que inclui também as Viguiera sul-americanas); de acordo com a morfologia, $V$. dentata está inclusa no grupo basal do cladograma, no mesmo clado que $B$. lanata (espécie típica do gênero Bahiopsis). Segundo Sosef (1997) o surgimento de grupos parafiléticos é inevitável em modelos hierárquicos, quando há evolução reticulada. Corroborando os resultados obtidos por Schilling \& Panero (1996) com análises de sítios de restrição de cpDNA verifica-se, no segundo cladograma (Figuras 4 e 5), a hipótese de Heliomeris e Hymenostephium como grupos-irmãos. Com base em morfologia, este forma o grupo-irmão dos gêneros Helianthus e Pappobolus; tal clado, por sua vez, é irmão de outro com representantes do subgênero Amphilepis, do México, além de Aldama e Rhysolepis; participam ainda deste grande clado algumas Viguiera da Região Andina (de Morrone 1999), além de V. grammatoglossa. As relações entre a ser. Grammatoglossae e o subg. Amphilepis também são expressas 
nos trabalhos de Schilling \& Panero (1996). Poucas inferências podem ser feitas a respeito das espécies do Brasil: todas as análises apontam para forte hipótese de monofilia entre $V$. paranensis, $V$. macrorhiza e $V$. nudicaulis; o mesmo acontecendo com $V$. kunthiana, $V$. anchusifolia e $V$. megapotamica; nas análises reduzidas, isto também é verdadeiro para $V$. grandiflora e $V$. speciosa, $V$. hypoleuca e $V$. rubra, $V$. aspilioides e $V$. tuberosa. A falta de resolução na filogenia das plantas brasileiras também foi comentada por Schilling et al.( 2000), que não puderam encontrar sinapomorfias nas seqüências de ITS que as sustentassem como um grupo monofilético. Esta informação contrasta, segundo os autores, com os resultados de DNA de cloroplasto (Schilling et al. 1994; Schilling \& Panero 1996a), que indicam um mínimo de cinco mudanças sinapomórficas em sítios de restrição.

É importante ressaltar o problema nomenclatural existente no grupo. $\mathrm{O}$ exame dos materiais-tipo das variedades de $V$. dentata, a espécie típica do gênero mostrou que, provavelmente, existem aí três espécies: $V$. dentata (Cav.) Spreng. (var. brevipes), V. lancifolia (S.F. Blake) ?Magenta (var. lancifolia) e $V$. helianhoides H.B.K. (var. helianhoides), da qual $V$. canescens DC (V. canescens) é sinônimo; esses táxons possuem, como sinapomorfias, a páleas do receptáculo bojosas e a presença de longos tricomas na parte posterior da porção superior dos filetes das anteras. Em todas as análises, emergiram próximos de Bahiopsis num clado que abarca apenas espécies do Hemisfério Norte. De acordo com os resultados deste trabalho e com os obtidos a partir de dados de cpDNA (Schilling \& Panero 1996a), os gêneros Aldama La Lave \& Lex. e Rhysolepis S.F. Blake são estreitamente relacionados e não é desprezível a hipótese de serem sinônimos. Da mesma forma, ficou comprovada sua relação com algumas das Viguiera andinas da América do Sul, mas também com várias espécies do México, especialmente do subgênero Amphilepis, e com Helianthus L., gênero descrito setenta anos antes de Aldama e mais de cento e setenta anos antes de Rhysolepis. Mesmo que novos estudos com base em dados moleculares demonstrem que Helianthus é um gênero à parte e que os dois últimos e as espécies sul-americanas são co-genéricos, o nome do gênero, por prioridade, 
deve ser Aldama e a proposta de Robinson \& Moore (2004), com embasamento em constatações subjetivas, de transferir as espécies sul-americanas para Rhysolepis, se constitui também num equívoco nomenclatural.

Diante desses fatos, embora pareça evidente que as espécies sulamericanas não devam pertencer ao gênero Viguiera em uma futura circunscrição monofilética, optou-se nesse momento por persistir (Capítulo V) a usar, no capítulo de tratamento taxonômico das espécies sul-americanas, o nome tradicional do gênero. Espera-se para breve a realização de estudos mais detalhados, com base em marcadores moleculares, ou em análises de evidência total empregando também dados morfo-anatômico, que viabilizem uma visão mais aprimorada e precisa da filogenia em Helianthinae.

\section{$\underline{\text { Referências bibliográficas }}$}

BAYER, R.J. \& STARR, J.R. 1998. Tribal phylogeny of the Asteraceae based on two non-coding chloroplast sequences, the trnL intron and trnL/F intergenic spacer. Ann. Missouri Bot. Gard. 85: 242-256.

BLAKE, S.F. 1917. New and noteworth Compositae, chiefly Mexican. Contr. Gray Herb. 52: 16-39.

1918. A revision of the genus Viguiera. Contr. Gray Herb. 54: 1-205.

BREMER, K. 1994. Asteraceae: cladistics and classification. Oregon, Portland: Timber Press. 752 pp.

BRUNDIN, L. 1972. Evolution, casual biology, and classification. Zoologica Scripta 1: 107-120.

BULL, J.J.; HUESENBEK, J.P.; SWOFFORD, L. et al. 1993. Partitioning and combining data in phylogenetic analysis. Syst. Biol. 42: 384-497.

CARR, G.D.; KING, R.M.; POWELL, A.M. et al. 1999. Chromosome numbers in Compositae, XVIII. Amer. J. Bot. 86 (7): 1003-1013.

CRACRAFT, J. 1983. Species concepts and speciation analysis. Current Ornithology 1: 159-187.

CRISP, M.D. \& COOK, L.G. 2005. Do early branching lineages signify ancestral traits? Trends Ecol. Evol. 20 (3): 122-128.

DAVIS, J.I. 1997. Evolution, evidence, and the role of species concepts in phylogenetics. Syst. Bot. 22(2): 373-403.

DE QUEIROZ, A. 1993. For consensus (sometimes). Syst. Biol. 42:368-372.

\& DONOGUE, M.J. 1988. Phylogenetic systematics or Nelson's version cladistics? Cladistics 6: 61-75.

DONOGUE, M.J. \& KIM, J. 1995. Separate versus combined analysis of phylogenetic evidence. Annu. Rev. Ecol. Syst. 26: 657-681. 
DONOGUE, M.J. 1985. A critique of the biological species concept and recommendations for a phylogenetic alternative. Bryologist 88: 401-418.

FARRIS, J. 1997. The future of phylogeny reconstruction. Zoologia scripta 26: 303311.

FELSEINSTEIN J. 1985. Confidence limits on Phylogeny: An approach using the bootstrap. Evolution 39: 783-791.

GOLOBOFF, P.A. 1991a. Homoplasy and the choice among cladograms. Cladistics 7: 215-232. 395:406.

1991b. Random data, homoplasy and information. Cladistics 7:

HENDERSON, A. 2005. The methods of herbarium taxonomy. Syst. Bot. 30(2): 456-469.

JANSEN, R.K. \& STUESSY, T.S. 1980. Chromosome counts of Compositae from Latin America. Amer. J. Bot. 67 (4): 585-594.

\& PALMER, J.D. 1987. Chloroplast DNA from lettuce and Barnadesia (Asteraceae): structure, gene localization, and characterization of a large inversion. Current genetics 11: 553-564.

JONES, S.B. 1970. Chromosome numbers in Compositae. Bull. Torrey Bot. Club 97: $168-174$.

KARIS, P.O. 1993. The Heliantheae sensu latu (Asteraceae) - clades and classification. Pl. Syst. Evol. 186: 139-195.

KEIL, D.J.; LUCKNOW, M.A. \& PINKAVA, D.J. 1988. Chromosome studies in Asteraceae from the United States, Mexico, the West Indies, and South America. Amer. J. Bot. 75: 652-668.

KITCHING, I.; FOREY, P; HUMPHRIES, C. et al. 2000. Cladistics: The theory and practice of parsimony analysis. The systematic Association Publication 11: 1228.

MAYR, E. 1942. Systematics and the Origin of Species. New York: Columbia University Press. 334P.

MCDADE, L.A. 1997. Hybrids and Phylogenetic Systematic III. Comparison with distance methods. Syst. Bot. 22(2): 669-683.

MCDOWEL, T. \& BREMER, B. 1998. Phylogeny, diversity, and distribution in Exostema (Rubiaceae): implications of morphological and molecular analyses. Pl. Syst. Evol. 212: 215-246.

MCKENZIE, R.J.; WARD, J.M.; LOVIS, J.D. et al. I. 2004. Morphological evidence for natural intergeneric hybridization in the New Zealand Gnaphalieae (Compositae):. Bot. J. Linn. Soc. 145: 59-75.

MONDIN, C. 2004. Levantamento da tribo Heliantheae Cass. (Asteraceae), sensu stricto, no Rio Grande do Sul, Brasil. Tese de doutoramento. Universidade Federal do Rio Grande do Sul. 349 f.

NELSON, G.J. \& PLATINICK, N.I. 1981. Systematic and Biogeography: cladistics and vicariance. Columbia University Press, New York. 345p.

NIXON, C.K. 1999. The parsimony Ratchet, a new method for rapid parsimony analysis. Cladistics 15. 407-414.

2002. Winclada version 1.0 (Computer software manual). Ithaca: distribuído pelo autor. Disponível em: <http/ / www.cladistics.com>. 
\& CARPENTER, J.M.N. 1993. On outgroups. Cladistics (9): 413-426.

NIXON, C.K. \& WHEELER. Q.D. 1990. An amplification of the phylogenetic species concept. Cladistics 6: 211-223.

PANERO, J.L. 1992. Systematics of Pappobolus (Asteraceae-Heliantheae). Syst. Bot. Monogr. 36: 11-95.

\& SCHILLING, E.E. 1988. Revision of Viguiera sect. Maculatae (Asteraceae-Heliantheae). Syst. Bot. 13: 371-406.

PATERSON, H.E.H. 1986. The recognition concept of species. In E. S. Vrba (ed.), Species and Speciation. Pretoria, South Africa: Transvaal Museum Monograph Number 4. Pp. 21-29.

POWELL, A.M. \& SIKES, S. 1970. Chromosome numbers of some Chihuahuan desert Compositae. Southw. Naturalist 15: 175-186.

RIDLEY, M. 1989. The cladistic solution to the species problem. Biol. Phil. 4: 116.

RIESEBERG, L.H. 1991. Homoploid reticulate evolution in Helianthus (Asteraceae): Evidence from Ribossomal genes. Amer. J. Bot. 78(9): 12181237.

1995. The hole of hybridization in evolution: old wine in new skins. Amer. J. Bot. 82(7): 944-953.

1998. Homoploid reticulate evolution in Helianthus (Asteraceae): Evidence from ribosomal genes. Amer. J. Bot. 78(9): 1218-1237.

2000. Crossing relationships among ancient and experimental sunflower hybrid lineages. Evolution 54 (3): 859-865.

ROBINSON, H. 1977. Studies in Heliantheae (Asteraceae) VIII. Notes on genus and species limits in the genus Viguiera. Phytologia 36(3): 201-215.

1979. Studies in Heliantheae (Asteraceae) XVIII. A new genus: Helianthopis. Phytologia 44: 257-269.

1981. A revision of the tribal and subtribal limits of the Heliantheae (Asteraceae). Smith. Contr. Bot. 51: 1-102.

\& MOORE, A.J. 2004. New species and new combinations in Rhysolepis (Heliantheae: Asteraceae). Proc. Biol. Soc. Wash. 117(3): 423-446.

ROBINSON, H.; POWELL, A.M.; KING, R.M. et al. 1981. Chromosome numbers in Compositae, XII: Heliantheae. Smithsonian Contr. Bot. 52: 1-28.

SANDERSON, M.J. \& DONOGHUE, M.J. 1989. Patterns of variation in levels of homoplasy. Evolution 43: 1781-1795.

SCHILLING, E.E. 1990. Taxonomic revision of Viguiera subg. Bahiopsis (Asteraceae - Heliantheae). Madroño 37: 149-170.

1991. Phylogenetic analysis of Helianthus (Asteraceae) based on chloroplast DNA restriction site data. Theor. Appl. Genet. 94: 925-933.

\& JANSEN, R.K. 1989. Restriction fragment analysis of chloroplast DNA and the systematics of Viguiera and related genera (AsteraceaeHeliantheae). Amer. J. Bot. 76(12): 1769-1778.

LINDER, C.R.; NOYES, R.D. et al. 1998. Phylogenetic relationships in Helianthus (Asteraceae) based on nuclear ribosomal DNA internal 
transcribed spacer region sequence data. Sist. Bot. 23: 177-187.

DA COSTA, F.B.; LOPES, N.P. et al. 2000. Brazilian species of Viguiera (Asteraceae) exhibit low levels of ITS sequence variation. Edinburgh J. Bot. 57(3): 323-332.

\& PANERO, J.L. 1991. Evidence for a close relationship between Iostephane and Viguiera (Asteraceae-Heliantheae). Amer. J. Bot. 78(8): 10541062.

PANERO, J.L. \& ELIASSON, U.H. 1994. Evidence from chloroplast DNA restriction site analysis on the relationships of Scalesia (AsteraceaeHeliantheae). Amer. J. Bot. 81(2): 248-254.

\& PANERO, J.L. 1996a. Relationships in Heliantheae subtribe Helianthinae based on chloroplast DNA restriction site analysis. In D.J. Hind \& H.J. Beentje (eds.). Compositae: systematics proceedings of the international Compositae conference, vol. 1. Kew: Royal Botanic Gardens, 361376.

\& PANERO, J.L. 1996b. Phylogenetic reticulation in subtribe Helianthinae. Amer. J. Bot. 83(7): 939-948.

\& PANERO, J.L. 2002. A revised classification of subtribe Helianthinae (Asteraceae-Heliantheae). I. Basal lineages. Bot. J. Linn. Soc. 140: 65-76.

\& SCHILLING, E.M. 1986. Chromosome numbers in Viguiera series Dentatae (Compositae). Syst. Bot. 11: 51-55.

SCHWARZBACH, A.E.; DONOVAN, L.A. \& RIESEBERG, L.H. 2001. transgressive character expression in a hybrid sunflower species. Amer. J. Bot. 88: 270-277.

SCOTT, R.W. 1985. Microcharacters as generic markers in the Eupatorieae. Taxon 24 (1): 26-30.

SITES, J.W. JR. \& MARSHALL, J.C. 2004. Operational Criteria for delimiting species. Annu. Rev. Evol. Syst. 35: 199-227.

SKÁLA, Z. \& ZRZAVÝ, J. 1994. Phylogenetic reticulation and cladistics: discussion of methodological concepts. Cladistics 10: 305-313.

SOLBRIG, O. T.; KYHOS, D. W.; POWELL, A. M. et al. 1972. Chromosome numbers in Compositae VIII: Heliantheae. Amer. J. Bot. 59: 869-872.

SOSEF, M.S.M. 1997. Hierarchical models, reticulate evoltion and the inevitability of paraphyletic supraspecific taxa. Taxon 46: 75-85.

SOSSEY-ALAOUI, K.; SERIEYS, H.; TERSAC, M. et al. 1998. Evidence for several genomes in Helianthus. Theor. Appl. Genet. 97: 422-430.

STROTHER, J.L. \& PANERO, J.L. 2001. Chromosome studies: American Compositae. Amer. J. Bot. 81: 770-775.

STROTHER, J.L. \& PANERO, J.L. 2001. Chromosome studies: Mexican compositae. Amer. J. Bot. 88: 499-502. 
TEMPLETON, A. R. 1989. The meaning of species and speciation: a genetic perspective. In D. Otte and J. A. Endler (eds.). Speciation and Its Consequences. Sunderland. MA, Sinauer Associates. Pp. 3-27.

UNGERER, M.C.; BAIRD, S.J.E.; PAN, J. et al. 1998. Rapid hybrid speciation in wild sunflowers. Proc. Natl. Acad. Sci. India, B. 95: 11757-11762.

VAN VALEN, L. 1976. Ecological species, multispecies and oaks. Taxon 25: 233239.

XU, S. 2000. Phylogenetic analyses under reticulate evolution. Mol. Biol. Evol. 17(6): 897-907.

WATANABE, K. Index to Chromosome numbers in asteraceae. Disponível em <http://www-asteraceae.cla.kobe-u.ac.jp/index>. Acesso em 17.dez.2005.

WATROUS, L.E. \& WHEELER, Q.D. 1981. The outgroup comparision method of character analysis. Syst. Zool. 30 (1): 1-11.

WIENS, J.J. 1998. Combining data sets different with phylogenetic histories. Syst. Bot. 47(4): 568-581.

YATES, W.F. 1979. Synopsis of Heliomeris (Compositae). Proc. Indiana Acad. Sci. 88: 364-372. 


\title{
TRATAMENTO TAXONÔMICO DAS ESPÉCIES DE VIGUIERA KUNTH DA AMÉRICA DO SUL COM REVISÃO DAS ESPÉCIES DO BRASIL ${ }^{1}$
}

\begin{abstract}
$\underline{\text { Abstract }}$
The traditional delimitation of the genus Viguiera Kunth is based on features of the involucre and pappus. Nevertheless, these are probably the result of convergences in many taxa in tribe Heliantheae, since Viguiera does not constitute a monophyletic group in many recent phylogenetic analysis. The present morphological studies didn't provide a solution towards a reliable circumscription of the genera in the group; neither could help improve the controverted nomenclature of the genus in South America. Hence Viguiera is here treated in a conservative way, until future achievement of new phylogenetic studies. The South-American species taxonomic study revealed two major groups which are relatively well delimited: one formed by the species from Andean Region, with cylindric- tubular disc flowers and easily deciduous pappus, like in Helianthus, and the other formed by non-Andean plants with cylindric-campanulate limbs and persistent pappus. On the Brazilian species revision, are proposed three new species and combinations, besides twenty four new synonymies, thirty-two lectotipifications and the neotypification of $V$. aspilioides Baker. The paper yet provides the lectotipification of Helianthus dentatus Cav., basionym of $V$. dentata, the typespecies of the genus.
\end{abstract}

\section{$\underline{\text { Resumo }}$}

A delimitação tradicional do gênero Viguiera Kunth é baseada em características do invólucro e do pápus, mas estas semelhanças provavelmente resultam de convergências adaptativas em muitos táxons em Heliantheae, uma vez que nos vários estudos filogenéticos já realizados Viguiera não emerge como grupo monofilético. As análises morfológicas ora encetadas não ofereceram uma solução para a polêmica questão da circunscrição genérica na América do

\footnotetext{
${ }^{1}$ Manuscrito a ser submetido ao Boletim de Botânica da Universidade de São Paulo, elaborado em colaboração com José Rubens Pirani e David John Nicholas Hind.
} 
Sul e, desse modo, Viguiera é aqui tratado de modo conservador, até que novos estudos filogenéticos sejam efetuados. O estudo taxonômico das espécies sulamericanas evidenciou a existência de dois grandes grupos relativamente bem delimitados: o das espécies que pertencem à região andina, com flores do disco de limbo cilíndrico-tubuloso e pápus facilmente decíduo, como ocorre em Helianthus, e aquele que envolve plantas não andinas, com flores de limbo cilíndrico-campanulado e pápus persistente. Na revisão das espécies do Brasil, são propostas três novas espécies, três combinações novas, vinte e quatro sinonímias, trinta e duas lectotipificações e a neotipificação de $V$. aspilioides. Apresenta-se ainda a lectotipificação de Helianthus dentatus Cav., basinômio da espécie típica do gênero, $V$. dentata.

\section{Introdução}

Viguiera é um gênero de ocorrência exclusiva dos neotrópicos, pertencente à tribo Heliantheae da família Asteraceae (Compositae). Em sua circunscrição inicial (Kunth 1820) era definido pela presença de receptáculo cônico, flores do raio neutras e aquênios (cipselas) com pápus 2-aristado e escamas intermediárias. Após várias adições (Bentham 1873, Hemsley 1881, Baker 1884, Baillon 1886) foi revisto por Blake (1918) que reconheceu 143 espécies, das quais 34 com registros no Brasil, e as dividiu em três subgêneros com sete seções abrangendo várias séries. Robinson (1977) propôs, como características do gênero, a a inclusão de corola das flores do raio com nervuras do mesmo calibre, flores do disco com ramos do estilete possuindo uma única superfície estigmática e cipselas sem cicatriz basal.

Em seu sentido amplo, Viguiera apresenta a maior diversidade de espécies entre os componentes da subtribo Helianthinae (tribo Heliantheae). O gênero tradicional mais próximo é Helianthus L., do qual se diferencia pela presença de pápus 2-aristado persistente com e várias escamas paleáceas entre estas aristas (Helianthus possui aristas decíduas e apenas uma a duas escamas entre elas). Devido à provável evolução convergente, extremamente freqüente na tribo Heliantheae, as plantas menores de Helianthinae são facilmente confundidas 
com representantes de gêneros de outras subtribos (e.g. Aspilia Thouars, Dimmerostema Cass. e Wedelia Jacq.). A correta identificação requer principalmente a observação das cipselas: em Aspilia elas apresentam cicatriz basal e são constritas junto ao pápus; em Dimmerostema são geralmente aladas e têm aristas enrijecidas; Wedelia é diferenciado pela presença de flores do raio pistiladas e cipselas com pápus coroniforme. Vale lembrar que Robinson (1992) considerou os gênero Aspilia como sinônimo Wedelia pois, segundo ele, a presença de flores estéreis no primeiro e férteis no segundo não representa um forte caráter para a separação dos táxons e alguns representantes de Wedelia sensu stricto apresentam constrição na base do pápus. Já as plantas grandes, que atingem mais de dois metros de altura, como $V$. nudibasilaris e $V$. santacatarinensis assemelham-se a representantes do gênero Tithonia Desf. ex Juss., que pode ser distinguido por apresentar paracládios fistulosos junto ao capítulo.

\section{Histórico do gênero}

Em 1820, Kunth descreveu o gênero Viguiera, em homenagem ao médico e botânico francês Alexandri Viguier, no $4^{\circ}$ volume de Nova genera et species plantarum, com base em uma única espécie freqüente em Cuba, Viguiera helianthoides, posteriormente sinonimizada sob V. dentata (Cav.) Spreng., descrita inicialmente como Helianthus dentatus Cav., e então registrada para o México. Inicialmente, gênero foi caracterizado por apresentar invólucro semigloboso, com brácteas de tamanhos similares dispostas em uma série, receptáculo cônico paleáceo, flores amarelas, as do raio várias e neutras, flores do disco numerosas, tubulosas e bissexuadas, aquênio obovado-cuneado, compresso, coroado por muitas escamas e duas aristas decíduas.

Cassini (1818) descreveu Harpalium, para o qual usou o termo "sousgenre" (subgênero em português) de Helianthus, diferenciando-se das demais espécies deste último pelo invólucro em nível inferior ao das flores do disco, formado por brácteas estriadas coriáceas sem apêndice e pela presença de muitas escamas decíduas entre as aristas. No $20^{\circ}$ volume de Dictionnaire des 
Sciences Naturelles (1821) descreveu Leighia, com invólucro superando a altura das flores do disco e formado por brácteas com um grande apêndice foliáceo, além de pápus bi-aristado, com escamas persistentes entre as aristas, tratando-o na mesma categoria de sous-genre. $\mathrm{O}$ autor tratou esses táxons com nomes binomiais (Harpalium rigidum e Leighia elegans, cujo basiônimo seria Helianthus linearis). Em 1825, elevou Harpalium ao nível genérico. Para Cassini, o terceiro grupo, que formaria o subgênero Helianthus, apresenta invólucro superando a altura das flores do disco, com poucas séries de brácteas não estriadas, foliáceas, pelo pápus formado por duas escamas opostas, articuladas, decíduas. Embora Cassini soubesse do uso anterior do nome Leighia por Scopolli (1777), argumentou que este último usou arbitrariamente o nome em substituição ao nome inválido Kahiria Forsskål (1775), sinônimo de Ethulia L.f. (1762) e, assim, Leighia Scopolli deveria ser suprimido.

Lessing (1832) em sua Synopsis considerou Harpalium Cass. e Leighia Cass. como subgêneros de Helianthus, mantendo Viguiera como um gênero distinto.

Em 1836, De Candolle, no 5o volume de Prodromus, tratou Viguiera, Leighia e Harpalium como gêneros, sem maiores explicações, mas sugeriu que estes eram fortemente relacionados e poderiam ser unidos. Também inferiu sua próxima relação com o gênero Helianthus o qual diferenciou pelo pápus decíduo.

Após ter examinado várias plantas de sua coleção obtida no Brasil, Gardner (1848) entendeu que a única diferença entre os três táxons era uma mera modificação no invólucro (sem identificar qual) e, no volume VII de London Journal of Botany, uniu-os em Viguiera, dividindo o gênero em quatro seções, de acordo com as características do invólucro. Porém, três destas continham representantes de outros gêneros (Aspilia e Oyedaea), como conseqüência, das dezessete novas espécies que descreveu para o Brasil, apenas sete se enquadram em Viguiera sensu lato.

Em 1873, Bentham ampliou a circunscrição de Viguiera, considerando como características do gênero o invólucro hemisférico a largamente 
campanulado, as brácteas involucrais em três a muitas séries com base geralmente "seca", ápice ou raramente também a base foliáceos, as interiores delicadas, com ápice ligeiramente dilatado membranáceo, as exteriores apressas ou com ápice ligeiramente esquarroso e o receptáculo convexo a cônico com páleas conduplicadas envolvendo as flores do disco.

Vários autores fizeram observações sobre uma estreita relação entre Viguiera e Helianthus (De Candolle 1836, Gardner 1848, Bentham 1873, Blake 1918, Schiiling \& Jansen 1989, Schiiling \& Panero 1991 1996a) e novas adições ao gênero foram efetuadas por Hemsley (1881) que listou 20 espécies para a América Central, e Baker (1884) que, na Flora Brasiliensis, enumerou 29 espécies para a Argentina, Brasil, Paraguai e Uruguai.

Baillon (1886[1885]), em Histoire des plantes VIII, seguindo a tendência de união de gêneros, sinonimizou Tithonia, Viguiera, Flourensia e Wyethia em Helianthus. Sua proposta não foi considerada por autores posteriores.

Em 1918, Blake publicou uma revisão para o gênero, na qual 143 espécies (34 ocorrentes no Brasil) foram distribuídas em seções bastante artificiais, incluídas em três subgêneros, com base em características do invólucro, complementados por caracterizações do hábito e informações subjetivas sobre o tamanho do capítulo e do pápus. Na circunscrição do autor, as espécies sulamericanas estão incluídas nas seções Paradosa e Trichophylla do subgênero Calanticaria. O autor relacionou Viguiera com Tithonia, Helianthus, Syncretocarpus, Haplocalyma e Hymenostephium.

Robinson (1977) sugeriu que se adotassem as idéias de D’Arcy (1975) publicadas na Flora do Panamá, segundo o qual todas as espécies herbáceas com invólucro 1-3-seriado e com apêndices do estilete curtos, mas distinguíveis, deveriam ser posicionadas em Viguiera, independente da ausência ou presença de pápus 2-aristado e com escamas. Também comentou as peculiaridades de $V$. dentata, como os tricomas existentes nos filetes dos estames, o tamanho da garganta (limbo) da corola do disco menor que o dobro da altura dos lobos e com base densamente "escabrosa", representando uma combinação de características diferentes da maior parte das espécies do gênero. $\mathrm{O}$ autor 
descreveu ainda novas espécies e fez novas combinações, atentando para detalhes como lobos da corola com proporção igual entre altura e largura ( $V$. tenuis), lobos profundos (V. sylvatica) e comprimento da antera, em relação ao colar da antera (V. molinae e $V$. sylvatica).

Com base nas observações de Robinson (1977) e percebendo que nenhum dos sinônimos apresentados por Blake (1918) é aplicável, Robinson \& Moore (2004) sugeriram a transferência das plantas sul-americanas para o gênero Rhysolepis S.F. Blake. Tradicionalmente, espécies desse gênero só ocorrem no Hemisfério Norte, e nelas as páleas do receptáculo apresentam fortes corrugações transversais e ápice pungente, e as cipselas são assimétricas com pápus decíduo.

\section{Trabalhos baseados em dados moleculares}

Em 1989, Schilling \& Jansen efetuaram um estudo com base em sítios de restrição DNA de cloroplastos, com gêneros de Helianthinae, no qual Viguiera sensu lato se mostrou polifilético, mas alguns grupos correspondentes a táxons infragenéricos de Blake (1918) surgiram como monofiléticos. O grupo da Baixa Califórnia (Bahiopsis) apareceu como irmão de um grande clado formado por todos ou outros; Heliomeris Nutt., Viguiera sect. maculatae (Blake) Panero e $V$. dentata, juntos, surgiram como um grupo monofilético; Viguiera aff. ovata surgiu relacionada a Simsia e as demais (dois representantes da seção Paradosa dois da série Grammatoglossae e um membro de Viguiera subg. amphilepis Blake (V. aff. flava) formaram um clado fortemente sustentado, com um índice de "bootstrap" de $100 \%$, no outro extremo do cladograma de consenso estrito. Devido às evidências de grande proximidade de Viguiera com outros gêneros, os autores deduziram que as características morfológicas distintivas refletiriam mais uma divergêngia fenética do que filogenética e que talvez os limites do gênero devessem ser ampliados para englobar os pequenos gêneros relacionados.

Schilling \& Panero (1996a) trabalharam com sítios de restrição de cpDNA, cuja análise apontou a subtribo Helianthinae (15 de 18 gêneros representados) como monofilética e novamente Viguiera como parafilético. 
Nesse trabalho, incluíram, pelas semelhanças morfológicas, os gêneros Aldama, Alvordia, Lagascea, Iostephane, Rhysolepis, Sclerocarpus e Stuessya, até então considerados como não pertencentes à subtribo Helianthinae e estes despontaram nas análises junto aos grupos derivados da mesma, ou seja, próximo a representantes dos táxons infra-genéricos considerados por Blake (1918): Viguiera ser. Gramatoglossae, subgênero Amphilepis S.F. Blake e seções Leighia e Paradosa, na qual estão posicionadas as espécies sul-americanas. No mesmo ano, Schilling \& Panero (1996b) efetuaram um estudo comparativo usando marcadores de cpDNA e de espaçador ribossomal interno (ITS) do DNA ribossômico nuclear para representantes de Helianthinae e obtiveram resultados congruentes com os do primeiro trabalho.

Em 2000, Schilling et al. efetuaram seqüenciamentos dos espaçadores intergênicos (ITS) 1 e 2 do DNA ribossômico para análise e posicionamento de Viguiera sul-americanas entre outras Helianthineae; os resultados apontaram para um baixo nível de variação para tais espécies, motivo pelo qual os autores sugeriram uma posição derivada do gênero dentro da subtribo Helianthinae e uma origem recente dessas plantas e, ainda com base nos resultados e em outras evidências, uma reavaliação da taxonomia em nível de espécie para as plantas do Brasil.

Finalmente, em 2002, Schilling \& Panero publicaram uma revisão da classificação das linhagens basais de Helianthinae (cpDNA + ITS), cuja análise corroborou o trabalho de Yates \& Heiser (1979) propondo a retomada do nível genérico para Heliomeris, o qual Blake (1918) considerava como seção de Viguiera. Obtiveram também respaldo para os resultados de Schiiling (1990) os quais indicaram que Bahiopsis, com número básico de cromossomos n=18, não deveria ser considerado um grupo infra-genérico de Viguiera e, exceto por duas espécies com n=17: $V$. dentata (a espécie típica do gênero, com tricomas na parte posterior do filete das anteras) e $V$. potosina (que, ao contrário das demais, não apresenta brácteas involucrais com ápice abruptamente estreitado), a série Dentatae S.F. Blake foi tratada como gênero Bahiopsis. Além disso, propuseram 
também a inclusão da seção Diplostichis S.F. Blake em Hymenostephium e elevaram a série Brevifoliae ao nível de gênero (Calanticaria).

\section{Justificativa do emprego do nome Viguiera neste trabalho}

Os resultados obtidos nas análises filogenéticas efetuadas neste trabalho (capítulo IV), não corroboram a hipótese de Robinson \& Moore (2004) com Rhysolepis despontando, na análise com 106 terminais, num clado que inclui representantes do gênero Helianthus, do subgênero mexicano Amphilepis e das espécies Andinas da América do Sul ou, juntamente com Aldama, como grupoirmão das Viguiera da América do Sul (análise com 68 terminais). Por outro lado, a espécie típica do gênero, $V$. dentata, surgiu nestes estudos num clado basal, formado por plantas mexicanas como Bahiopsis, Hymenostephium, $V$. cordifolia e Simsia dombeyana.

Morfologicamente, as plantas da América do Sul apresentam várias peculiaridades que as diferem dos táxons até agora propostos para seu posicionamento: o ápice das páleas varia de obtuso a agudo, mas nunca é pungente, como ocorre em Aldama e Rhysolepis e em V. dentata (Figura 1A, F e I); os filetes glabros também as diferenciam de $V$. dentata, na qual todos os táxons apresentam longos tricomas na porção superior do filete (Figura 1C e D); as cipselas periféricas simétricas, com carpopódio bilateral assimétrico e pápus persistente são diferentes das encontradas em Aldama e Rhysolepis, que são assimétricas, com carpopódio unilateral e pápus decíduo (Figura 1H e K).

Mesmo que análises mais completas, incluindo novos dados moleculares, venham a fornecer subsídios para a separação de Helianthus (Linnaeus 1754) e a união dos demais táxons em um só gênero, Aldama La Lave (1874) emergiu, nas análises efetuada por Magenta (2006), como gênero-irmão de Rhysolepis S.F. Blake (1917) e, por prioridade, seria o nome a ser corretamente aplicado. Tais fatos impedem qualquer tomada de decisão satisfatória, no sentido de redelimitação taxonômica na subtribo. Por isso, decidiu-se conservar por enquanto, o nome tradicional do gênero no tratamento taxonômico das espécies da América do Sul. 

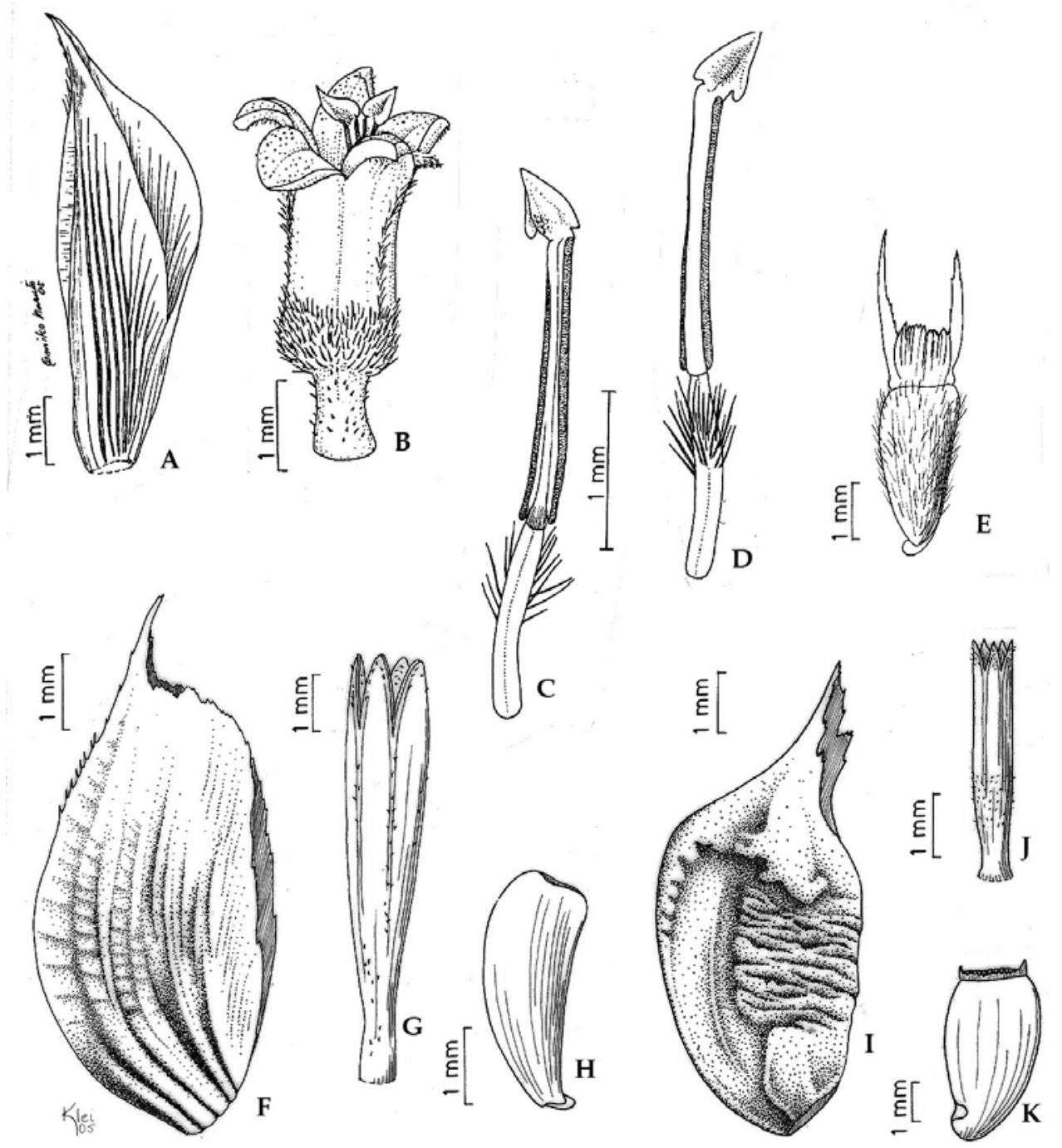

Fig. 1: A-K. Peças do capítulo de Viguiera e táxons relacionados. A-E. V. dentata, A. Pálea do receptáculo, B. Flor do disco, C-D. Estames, E. Cipsela. F-H. Rhysolepis palmeri, F. Pálea do receptáculo transversalmente corrugada, G. Flor do disco, H. Cipsela, I-K. Aldama mesoamericana, Pálea do receptáculo, com fortes corrugações transversais, J. Flor do disco, K. Cipsela. A-E. K. Landon 780 (LP), F-H. Pringle 2314 (K), I-K. Palmer 582 $(\mathrm{NY})$.

\section{Material e métodos}

O tratamento taxonômico foi baseado principalmente no estudo de exemplares herborizados e na observação de populações no campo. A observação de forte variabilidade morfológica, incluindo evidentes casos de polimorfismo nas populações in vivo, representou auxílio crucial na tomada de certas decisões taxonômicas. A análise filogenética baseada em características 
morfológicas trouxe apenas subsídios pontuais e parciais para as decisões taxonômicas tomadas.

Existe uma gama de discussões e propostas de conceitos sobre a forma mais abrangente possível para delimitação de espécies, como o Conceito Ecológico, que considera as pressões ambientais (Van Valen 1976), o Conceito Biológico (Mayr 1942, Paterson 1986), que prioriza o isolamento reprodutivo, o Conceito de Coesão, que combina isolamento reprodutivo, seleção ecológica e compatibilidade reprodutiva (Templeton 1989), além de vários outros com embasamento filogenético, como os que advogam o critério da monofilia para a delimitação de grupos naturais (Brundin 1972, Ridley 1989, Donogue 1985, de Queiroz \& Donogue 1988), criticados por muitos sistematas (Sosef 1997), por menosprezarem a hibridação, e os conceitos filogenéticos ampliados (Nelson e Platinick 1981, Cracraft 1983, Nixon \& Wheeler 1990) que reconhecem espécies como sistemas populacionais divergentes, evidenciados por combinações fixas ou diagnósticas de caracteres, não necessariamente autapomórficas (Davis 1997).

Sites \& Marshall (2004) discutiram doze dos métodos operacionais existentes para delimitação de espécie, considerando os tipos de dados aos quais cada um pode ser aplicado e as limitações de cada um. Para estudos morfológicos, referem os seguintes:

- Matrizes de distância correlacionadas (Corr-D), Puorto et al. (2001): usa dados moleculares combinados aos de morfologia, sumarizando os resultados morfológicos em uma matriz de distâncias Euclideanas e comparando-os com as distâncias de mtDNA. Limitações: dados moleculares e morfológicos devem estar disponíveis para a mesma espécie; o teste pode ser circular se as espécies em questão forem simpátricas.

- Agrupamentos morfo-genotípico (M/GC), Mallet (1995): agrupa entidades monotípicas ou politípicas, de acordo com morfologia e caracteres genéticos, em grupos de indivíduos com pouco ou nenhum 
contato intermediário. Limitações: a variabilidade entre as espécies é maior do que dentro delas; a introgressão é limitada ou ausente.

- $\quad$ Análise de Agregação de Populações (PAA), Davis \& Nixon (1992): o método é baseado em dois princípios - (a) todos os indivíduos coletados em uma população são assumidamente conspecíficos; (b) atributos de caracteres divididos entre indivíduos de populações diferentes provêm evidências de serem da mesma espécie. Limitação: não considera possibilidade de espécies diferentes na mesma população; a fixação dos caracteres é difícil de mostrar em níveis convencionais $(\alpha=0,05)$ de confiança.

- Métodos filogenéticos baseados em construção de árvores (PCT): terminologia de Brooks \& McLennan (1999) para designar várias versões de métodos filogenéticos, como os baseados em apomorfias (Rosen 1979), em diversificação de linhagens e em conceitos de espécies compostas (Kornet 1993). Limitações: algumas versões reduzem a especiação a uma única substituição de caráter, outras requerem uma forte rejeição à priori, de alguns modelos de especiação ou anagênese.

- $\quad$ Teste de coesão de Templeton (TTC), Templeton (2001): inclui testes operacionais e de limites de espécie; estabelece estatisticamente, a correlação entre genótipo, fenótipo e distribuição geográfica das espécies e testa duas hipóteses: (a) todos os organismos provêm de uma única linhagem evolutiva, (b) populações de linhagem separadas identificadas pela rejeição de (a) os indivíduos permitem fluxo gênico e/ou são ecologicamente intercambiáveis. Limitações: as inferências podem ser falsas por amostragem insuficiente; (b) os resultados nunca podem ser completamente falsos; a escolha dos traços podem ser subjetiva.

Sites \& Marshal (2204) chegaram à conclusão de que todos os métodos falham em delimitar as fronteiras das espécies apropriadamente ou fornecem resultados conflitantes e que todos requerem, em algum nível, uma avaliação 
qualitativa por parte dos pesquisadores. Assim, o subjetivismo parece estar sempre implícito, seja a partir da seleção da amostragem ou do estabelecimento de um hipotético grupo de espécimes. Mesmo a divisão dos atributos em traços ou características pode ser afetada por uma visão pessoal.

Após o exame detalhado de várias populações durante as observações em campo e de exemplares herborizados, foi observada uma grande variabilidade de fenótipos, aparentemente com casos de gradientes de variação contínua e casos de polimorfismo. Tal padrão, dentro de cada população, inviabiliza uma abordagem filogenética criteriosa até mesmo para a revisão das espécies do Brasil já que, como também notado por Henderson (2005) os exemplares encontrados nos herbários são oriundos de localidades dispersas, sem um número suficiente de amostras de cada população. Além disso, não haveria tempo hábil para tais coletas, considerando a distribuição do gênero no Brasil e que algumas espécies aqui estudadas ocorrem também em países vizinhos. Em acréscimo, a despeito dos inúmeros e conflitantes conceitos, a complexidade no agrupamento de espécies de origem simpátrida, surgidas muitas vezes por meio de hibridação, raramente é assunto de discussões filosóficas em sistemática filogenética (Skála \& Zrzavý 1994). No entanto, muitos trabalhos com a família Asteraceae, especialmente na tribo Heliantheae (Yates 1979, Schiling \& Panero 1996a, 1996b; Sossey-Alaoui et al. 1998; Ungerer et al. 1998, Rieseberg 1991 2000, Schwarzbach et al. 2001) indicam a hibridação como um fator crucial na evolução dos grupos. O estudo dos exemplares herborizados, aliado ao efetuado em campo, mostrou a existência de alguns indivíduos transicionais, possivelmente de origem híbrida (e.g.: V. pilosa $\times V$. anchusifolia). A detecção de híbridos não é um trabalho fácil: segundo Rieseberg (1995) os conceitos simplistas utilizados para isso no passado como "morfologicamente intermediários", "morfologia menos definida que a dos parentais" ou "associação de caracteres" levam a interpretações equivocadas; por isso, esta investigação foi postergada a um trabalho futuro.

Como conjecturou Rapini (2000), não há como determinar a quantidade de apomorfias, quais os caracteres diagnósticos, ou ainda o nível de fluxo 
gênico e/ou diferenciação do nicho ecológico necessários para o rompimento da coesão de uma determinada população, afim de que dois táxons possam ser reconhecidos como espécies diferentes.

Refletindo sobre a grande profusão de conceitos de espécie, Mallet (1998) lembrou que eles representam atualmente um grande atraso para o estudo da diversidade biológica e seu uso em estratégias de conservação e investigação evolutiva. Argumenta ainda que os biólogos não se preocupam tanto com os "conceitos de célula" ou "conceitos de gene", presumivelmente porque os conceitos de célula como unidades de tecidos e DNA como material genético são largamente compreendidos, e que continuamos a discordar sobre os conceitos de espécie por não entendermos espécie muito bem.

Neste trabalho é adotado o Conceito Taxonômico de Espécie, no qual espécie é uma categoria que permite o agrupamento de indivíduos. Foram tratados como espécies os táxons que apresentam descontinuidade morfológica entre si (Stace 1980, Snaydon 1984). Dentro deste conceito, muitos táxons descritos no passado, com base no conceito tipológico, não foram aqui aceitos.

Por não ter sido possível o estabelecimento da filogenia completa do grupo (capítuloIV), as espécies são apresentadas em ordem alfabética; o material examinado é citado em ordem de país, estado ou província, município ou distrito e sobrenome do coletor.

As descrições e ilustrações das espécies brasileiras e outras utilizadas para comparação de morfologia, foram adequadas às normas do Boletim de Botânica da Universidade de São Paulo e elaboradas a partir do exame de espécimes herborizados e/ou fixados em solução Transeau (Bicudo \& Bicudo 1970). As medidas gerais de material herborizado e das peças florais reidratadas por fervura foram tomadas com paquímetro. Para avaliação e ilustração dos detalhes, foi utilizado estereomicroscópio com câmara clara e escala micrométrica acopladas. Foram examinados materiais dos seguintes herbários: BHCB; BM; BOTU; BR; CEN; CESJ; CETEC; CTES; CGMS; COR; CPAP; ESA; E; FUEL; HAS; HASU; HEPH; HRB; HRCB; HUCS; HUEFS; HUEPG; HUFU; IBGE; ICN; IPA; K; LP; LPB; M; MBM; NY; P; PACA; PEL; R; RB; SGO; SP; SPF; 
SPFR; SPSF; UB; UEC; UFG; UFLA; UFMT; VEN. Os materiais-tipo foram estudados, com exceção de $V$. aspilioides, do qual foi encontrado apenas um esboço, depositado no herbário K. As siglas de herbários dos tipos analisados são seguidas pelo símbolo !; aqueles materiais dos quais se avaliou imagens digitais têm a sigla de herbário seguida por *; para as duplicatas de tipos não vistas são citadas apenas as siglas.

Os termos usados para designar as estruturas morfológicas seguiram as definições de Radford et al. (1974), Payne (1978), Weberling (1989) e Bremer (1994). A abreviatura das "obras princeps" seguiu Stafleu e Cowan (1976-1988), o nome dos periódicos foi abreviado segundo Bridson e Smith (1991) e o dos autores (no texto) segundo Brummit e Powell (1992).

Para a observação das variações fenotípicas nas populações, vinte e três incursões a campo foram efetuadas, cobrindo grandes áreas de 8 estados brasileiros (Tabela 1). Para confirmação da morfologia do sistema subterrâneo, foram coletadas no mínimo três exemplares de cada espécie, crescendo em diferentes tipos de solo.

A distribuição geográfica foi obtida com base nas citações das etiquetas afixadas nas exsicatas e em bibliografia especializada e o sistema de regiões considerado é o de Morrone (1999). O autor divide a América do Sul em duas grandes regiões: A Região Neotropical, restrita a uma parte da Região Neotropical de outros autores como Cabrera e Willink (1973), é incluída no Reino Holotropical e a Região Andina equivale ao sub-reino Andino de RivasMartinez e Tovar (1983) unido ao domínio subantártico de Cabrera e Willink (1973) e está associada ao Reino Austral, sensu Kuschel (1964). Os mapas foram plotados com uso do programa ArcView 3.2, cujos mapas de fundo foram obtidos no Instituto Geográfico Militar de Quito, no Equador; a base de dados para a plotagem foi efetuada no programa de georeferências NL (Dias 2004).

Ressalte-se que nenhum dos nomes e combinações constantes nesta tese devem considerados efetivamente publicados aqui; eles serão publicados em revistas de boa circulação. 
Tabela 1: Período e áreas de coletas de materiais por regiões dos estados:

\begin{tabular}{|c|c|}
\hline 1 - Janeiro 2001 & São Paulo: nordeste. \\
\hline 2 - Outubro de 2001 & $\begin{array}{l}\text { Minas Gerais: sudoeste. } \\
\text { São Paulo: nordeste, norte. }\end{array}$ \\
\hline 3 - Novembro 2001 & $\begin{array}{l}\text { Goiás: leste, sudoeste, sul. } \\
\text { Minas Gerais: oeste, sudoeste. } \\
\text { São Paulo: norte. }\end{array}$ \\
\hline 4 - Dezembro 2001 & $\begin{array}{l}\text { Goiás: leste, oeste, sudoeste, sul. } \\
\text { Mato Grosso do Sul: sudeste. } \\
\text { Minas Gerais: oeste. } \\
\text { São Paulo: nordeste. }\end{array}$ \\
\hline 5 - Janeiro 2002 & $\begin{array}{l}\text { Goiás: leste, norte, nordeste, sudeste. } \\
\text { Minas Gerais: oeste. } \\
\text { São Paulo: norte. }\end{array}$ \\
\hline 6 - Fevereiro 2002 & São Paulo: nordeste, norte. \\
\hline 7 - Março de 2002 & São Paulo: nordeste. \\
\hline 8 - Março de 2002 & $\begin{array}{l}\text { Paraná: leste, sudeste, sul. } \\
\text { Rio Grande do Sul: leste, nordeste, norte. } \\
\text { Santa Catarina: nordeste, oeste, sudeste, } \\
\text { sul. }\end{array}$ \\
\hline 9 - Abril 2002 & $\begin{array}{l}\text { Minas Gerais: sudoeste. } \\
\text { São Paulo: nordeste. }\end{array}$ \\
\hline 10 - Maio 2002 & $\begin{array}{l}\text { Goiás: leste, norte, nordeste, noroeste, } \\
\text { sudeste, sul. } \\
\text { Minas Gerais: oeste. } \\
\text { São Paulo: nordeste. }\end{array}$ \\
\hline 11 - Maio 2002 & $\begin{array}{l}\text { Goiás: sudoeste. } \\
\text { Mato Grosso: sudeste, sul. } \\
\text { Mato Grosso do Sul: leste, nordeste, } \\
\text { norte, sudeste. } \\
\text { São Paulo: noroeste. }\end{array}$ \\
\hline 12 - Agosto 2002 & $\begin{array}{l}\text { Goiás: leste, noroeste, sudoeste. } \\
\text { Minas Gerais: oeste. } \\
\text { São Paulo: nordeste. }\end{array}$ \\
\hline 13 - Setembro 2002 & Paraná: leste, nordeste. \\
\hline 14 - Outubro 2002 & São Paulo: nordeste. \\
\hline
\end{tabular}


Tabela 1 (cont.): Período e áreas de coletas de materiais por regiões dos estados:

\begin{tabular}{|l|l|}
\hline 15 - Outubro 2002 & $\begin{array}{l}\text { Minas Gerais: leste, sudeste, sudoeste, } \\
\text { sul. } \\
\text { São Paulo: nordeste. }\end{array}$ \\
\hline 16 - Janeiro 2003 & $\begin{array}{l}\text { Paraná: leste, sul. } \\
\text { Rio Grande do Sul: noroeste, norte, oeste, } \\
\text { sudeste, sudoeste, sul. } \\
\text { Santa Catarina: sudeste, sul, noroeste, } \\
\text { norte. }\end{array}$ \\
\hline 17 - Março 2003 & $\begin{array}{l}\text { Paraná: nordeste. } \\
\text { São Paulo: sudoeste. }\end{array}$ \\
\hline 18 - Março 2003 & $\begin{array}{l}\text { Minas Gerais: sudoeste. } \\
\text { São Paulo: nordeste. }\end{array}$ \\
\hline 19 - Abril 2003 & $\begin{array}{l}\text { Paraná: leste, sudeste. } \\
\text { Rio Grande do Sul: leste, nordeste, sul. } \\
\text { Santa Catarina: norte, sul. }\end{array}$ \\
\hline 20 - Abril 2003 & $\begin{array}{l}\text { Minas Gerais: noroeste, norte, oeste, } \\
\text { sudoeste. } \\
\text { São Paulo: nordeste, norte. }\end{array}$ \\
\hline 21 - Novembro de 2003 & $\begin{array}{l}\text { Mato Grosso do Sul: leste, oeste, } \\
\text { sudoeste, sul. } \\
\text { São Paulo: noroeste. }\end{array}$ \\
\hline 22 - Dezembro de 2003 & $\begin{array}{l}\text { Rio Grande do Sul: leste, nordeste. } \\
\text { Sinas Gerais: nordeste, oeste. } \\
\text { São Paulo: norte. }\end{array}$ \\
\hline
\end{tabular}

\section{$\underline{\text { Resultados e discussão }}$}

Lectotipificação do basiônimo de Viguiera dentata (Cav.) Spreng

A despeito de vários trabalhos efetuados com a espécie típica do gênero, sua lectotipicação não foi feita até o momento. Dentre os síntipos do basiônimo da espécie, Helianthus dentatus Cav., foi aqui estabelecido um lectótipo, após a observação das imagens digitalizadas dos tipos, da descrição e das ilustrações de Cavanilles (1794). 
Viguiera dentata (Cav.) Spreng., Syst. 3: 615. 1826.

Basiônimo: Helianthus dentatus Cav. Icon. 3: 10. 1794. Tipos: Habitat in império Mexicano proppe Hapam. Ч [Perene]. Colitur in Regio Matritense, Cav. s.n.: Lectótipo, aqui designado: Cavanilles s.n. MA* (MA 475778 ex horto R. Matritense); (Remanescentes dos sintipos originais: Cavanilles s.n MA* MA 475777) - 2x; Cavanilles s.n: MA* (MA 475779 ex horto Reg Matr. anno 1808).

Nota nomenclatural: A escolha do material MA 475788 é justificada por ele conter a etiqueta de campo manuscrita por Cavanilles, com nome da obra de publicação. Trata-se de planta cultivada no Horto de Madri, a partir de amostra oriunda do México.

\section{Morfologia e outros aspectos das espécies sul-americanas}

Embora Viguiera tenha sido caracterizado por diferentes autores (Kunth 1820, De Candolle 1834, Gardner 1848, Bentham 1873, Blake 1918) cada um o fez segundo sua própria circunscrição. Assim, é apresentada aqui uma caracterização morfológica para as espécies da América do Sul, que compartilham vários caracteres, alguns deles prováveis sinapomorfias morfológicas em relação a certos grupos das Américas Central e do Norte, indicando uma origem comum.

\section{Hábito}

Como demonstrado no capítulo IV, três táxons infra-genéricos estabelecidos por Blake (1918) possuem parte de seus representantes morfologicamente similares às plantas sul-americanas: as séries Maculatae e Grammatoglossae e subgênero Amphilepis. A atual seção mexicana Maculatae (S.F. Blake) Panero \& Schilling é composta de arbustos muito robustos e ramificados ou até mesmo arborescentes; Grammatoglossae é constituída por ervas a arbustos, perenes ou não; Amphilepis é formado por ervas a subarbustos, na maioria perenes. Assim como as plantas sul-americanas podem às vezes apresentar hábito arbustivo com ramos herbáceos, variam de 0,4 a $3 \mathrm{~m}$ de altura, são geralmente eretas, cespitosas ou raramente solitárias. Estas últimas podem 
ser resiníferas ( $V$. gardneri, $V$. filifolia, $V$. trichophylla e $V$. vernonioides), caráter encontrado nos gêneros Encelia e Flourensia que, de acordo com estudos moleculares de Jansen \& Palmer (1987) em conjunto são considerados grupoirmão da subtribo Helianthinae.

O sistema caulinar das plantas do Brasil inclui uma parte aérea geralmente delgada e herbácea e uma subterrânea, geralmente lenhosa. Em pelo menos numa espécie (V. arenaria Baker), estudos preliminares indicam tratar de um xilopódio (Rocha, com. pess.), tipo de sistema subterrâneo reportado também para outros gêneros de Heliantheae, como Calea e Isostigma, o que leva à possibilidade de ampla ocorrência entre muitas outras Viguiera com aspecto macro-morfológico semelhante. Assim, embora dotadas de lenhosidade na porção subterrânea, as plantas de Viguiera são comumente descritas na literatura como ervas, quando a porção aérea não apresenta partes lenhosas, termo conservado neste trabalho.

O sistema subterrâneo é composto por um caule espessado, que emite raízes que geralmente apresentam tuberosidades em graus e porções diferentes. Esse tipo de sistema foi comentado pela primeira vez por Lindman (1906) que, ao trabalhar com plantas do sul do país, verificou que ele exercia um papel importante na regeneração da porção vegetativa aérea das plantas. $\mathrm{O}$ autor denominou o caule subterrâneo de xilopódio, um termo ainda hoje amplamente empregado. Sistemas semelhantes foram encontrados em Smallanthus sonchifolius (Machado et al. 2004) e em espécies de Vernonia (Sajo \& Menezes 1986a, b) que os descreveram como rizóforos, diferenciando-os de rizomas por sua origem a partir de gemas cotiledonares (Vernonia) ou do espessamento do hipocótilo, como observado em Rhizophora mangle e, por essa razão, apresentam um sistema bipolar de ramificação caulinar. Os rizomas são originados a partir da plúmula e constituem um sistema monopolar de ramificação (Apezzato-daGlória 2003).

\footnotetext{
* Rocha, R. (Tese de Doutoramento: Morfo-anatomia de sistemas subterrâneos de espécies de Asteraceae do Cerrado do Estado de São Paulo, junto ao PPG em Ciências Biológicas, Área Botânica, Instituto de Biociências da UNESP, Botucatu, SP, sob orientação de Beatriz Apezzato-da-Glória).
} 
Algumas espécies apresentam um forte desenvolvimento desse sistema como $V$. nudibasilaris, $V$. hispida e $V$. tenuifolia (Figura 2A-B e E), enquanto em outras ele é moderado, como em $V$. oblongifolia, $V$. robusta e $V$. vernonioides (Figura 2C). Sua disposição é geralmente vertical (Figura 2A e C-F) como em $V$. aspilioides, V. nudibasilaris, V. nudicaulis e V. oblongifolia, mas pode ser horizontal, como em $V$. hispida (Figura 2B).

As raízes adventícias apresentam diferentes tipos de espessamentos, que são bons caracteres para diferenciar táxons próximos em nível específico; por exemplo, em $V$. tenuifolia as raízes adventícias apresentam tuberosidade acentuada na porção central e, em $V$. aspilioides, são delgadas, com tuberosidade na porção terminal (Figura 2F). Raízes sem tuberosidade ou com tuberosidade discreta ocorrem em $V$. grandiflora, uma espécie de ampla distribuição, coletada em todos os tipos de cerrado nos Estados de Bahia, Goiás, Mato Grosso Minas Gerais e Tocantins; em V. vernonioides, do Mato Grosso, encontrada em cerrado aberto e à meia sombra de cerrado típico e em $V$. paranensis, endêmica do Parque Estadual de Vila Velha, no Paraná.

A porção caulinar aérea é formada por ramos alongados sem lenhosidade aparente (verdes desde a base) ou, em algumas espécies, com fraca lignificação basal. Na maioria das vezes, a planta tem um aspecto cespitoso e a compreensão do sistema caulinar torna-se relativamente simples. Porém, quando a planta aparentemente apresenta um caule aéreo solitário, como em indivíduos de $V$. anchusaefolia, $V$. kunthiana, $V$. immarginata e $V$. tenuifolia, somente a observação do sistema subterrâneo permite determinar o tipo de sistema. Os pseudocaules são sempre caniculados e os paracládios repetem o mesmo padrão. Alguns apresentam lenticelas, como em $V$. trichophylla e $V$. vernonioides. 


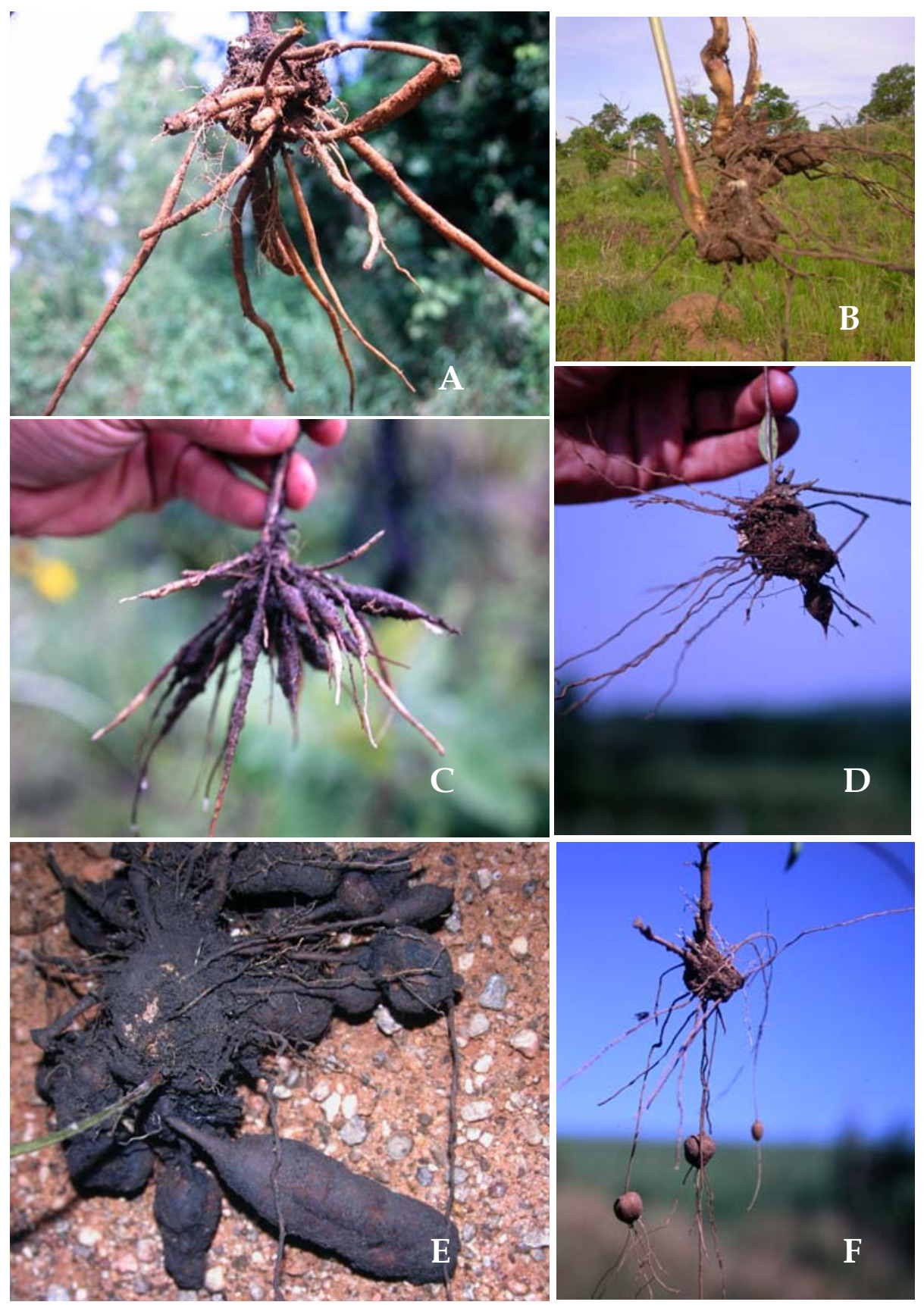

Fig. 2: A-F. Sistema subterrâneo com raízes adventícias. A. V. nudibasilaris, caule subterrâneo vertical e raízes com tuberosidade uniforme, B. $V$. hispida, caule subterrâneo horizontal, C. V. oblongifolia, raízes com tuberosidade fusiforme, D. $V$. nudicaulis; caule subterrâneo vertical com tuberosidade apenas na raíz principal, E. $V$. tenuifolia, raízes com tuberosidade acentuada na porção mediana. F. $V$. aspilioides, raízes com tuberosidade globosa na porção terminal. A, B, D e F: M. Magenta \& J. Magenta A. 426 (SPF), B. 720 (SPF), D. 503 (SPF), F. 478 (SPF); C. M. Magenta \& C. Mondin C. 340 (SPF); E. M. Magenta et al. 584 (SPF). 


\section{Folhas}

As folhas das Viguiera da América do Sul são sésseis ou pecíolo muito curto, um caráter que as diferencia dos seguintes grupos de Blake (1918): seção Diplostichis e séries Dentatae e Maculatae, da seção Chloracra, do Hemisfério Norte. A filotaxia é alterna ou com folhas opostas ocorredo preferencialmente na porção basal do caule aéreo, e a forma das folhas (Figura 3A-F) é bastante variável, podendo haver espécies com folhas primariamente lineares (e.g. $V$. aspilioides, V. linearifolia, $V$. tenuifolia), oblongas (V. gardneri, V. nudicaulis, $V$. oblongifolia), ovais, largamente ovais ou orbiculares (V. discolor, V. grandiflora). A margem varia de inteira a levemente denteada ou serreada, geralmente na porção superior; apenas $V$. simsioides, do Peru, e duas espécies conspicuamente pecioladas, uma do Equador (hoje considerada como Hymenostephium quitensis) e V. pusilla, também do Peru e com fortes similaridades a este último, apresentam folhas totalmente denteadas. $\mathrm{O}$ indumento predominante é o estrigoso, mas as espécies andinas e $V$. aspiloides, $V$. macrorhiza, $V$. nudicaulis e $V$. paranensis possuem folhas híspidas. A nervação, proeminente ao menos na face abaxial, é acródroma basal ou suprabasal perfeita ou imperfeita. 

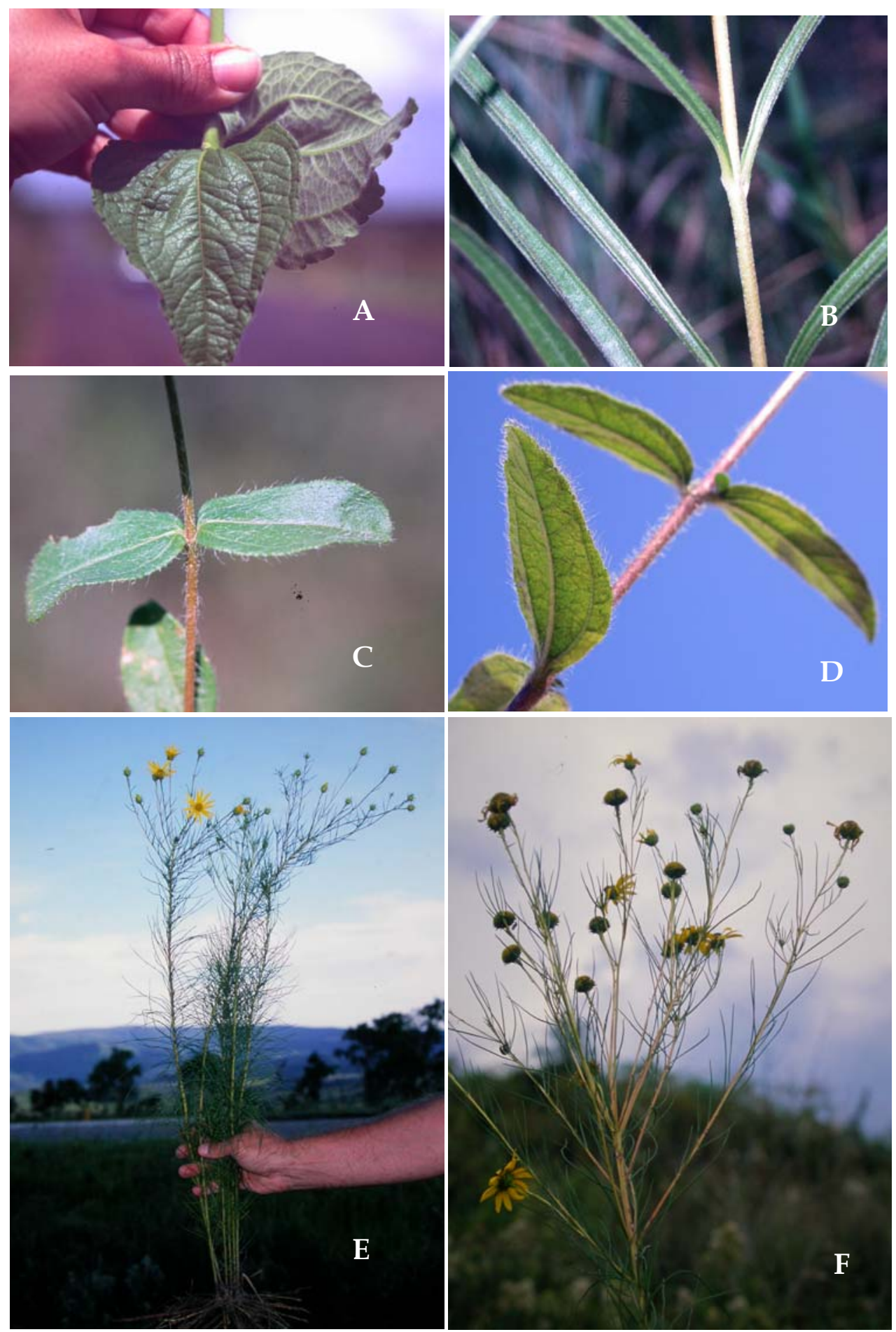

Fig. 3: A-F. Aspectos da morfologia foliar. A. V. discolor, com folhas largamente ovais, cartáceas, discolores, B. V. tenuifolia, mostrando folhas lineares. C. V. nudicaulis, evidenciando folhas subsésseis. D. $V$. veredensis, folhas com pecíolo curto, E-F. Folhas filiformes. E. V. filifolia, F. V. trichophylla. A-B e D-F. M. Magenta \& J. Magenta A. 307 (SPF), B. 280 (SPF) D. 664 (SPF); E. 376 (SPF), F. 561 (SPF). C. M. Magenta \& L.R. Lima 615 (SPF). 


\section{Arranjo dos capítulos}

De acordo com sistema de Weberling (1989) a inflorescência em Viguiera pode ser enquadrada nos tipos tirsóide (quando a ramificação ocorre exclusivamente na axila de profilos) ou botrióide (quando a ramificação ocorre em pontos destituídos de profilos), ou ainda ser constituída de ambos, paracládios (eixos que repetem a estrutura do eixo central) monocasiais ou apenas os terminais raramente dicasiais, assumindo um aspecto obpiramidal (Figuras 4A-H e 5A-D). Os paracládios de primeira ordem são, na maioria, alternos (Figura 5A e C), ou às vezes mistos (Figura 5B) em $V$. discolor, $V$. oblongifolia e $V$. squalida; em $V$. filifolia e $V$. trichophylla pode ocorrer concrescimento do caule e paracládios superiores, resultando num aspecto verticilado (Figura 5C). Panero \& Schilling (1988) verificaram um padrão tirsóide para as inflorescências da Seção Maculatae; no entanto, nela os paracládios são opostos, exceto em $V$. oaxacana; os autores detectaram ainda um padrão anômalo em $V$. adenophylla, com os paracládios resultando do crescimento contínuo de um eixo simpodial.

Os capítulos são, em sua grande maioria, radiados; sua forma varia de estreitamente campanulada a campanulada ou semiglobosa e é definida de acordo com o número de flores do disco, como constataram Panero \& Schiling (1988), mas também com a altura destas flores e com a posição das brácteas involucrais (apressas ou reflexas). Assim, espécies com menos de 100 flores e brácteas involucrais apressas de tamanho semelhante apresentam capítulos campanulados, como V. grandiflora e V. kunthiana (Figura 6A-B); espécies com menos de 100 flores e brácteas involucrais apressas, as internas gradativamente maiores que as externas, possuem capítulos estreitamente campanulados, como $V$. rubra e $V$. veredensis (Figura 6C-D) e espécies com mais de 100 flores e brácteas involucrais internas gradativamente maiores que as externas exibem capítulos largamente campanulados a semiglobosos, como $V$. robusta e $V$. trichophylla (Figura 6E-F). As brácteas involucrais apresentam, na maioria das vezes, base coriácea estriada e ápice foliáceo, em diferentes proporções. 
O receptáculo varia de levemente convexo a convexo na grande maioria das espécies e pode ser fortemente convexo a cônico em uma mesma espécie ( $V$. aspilioides), com páleas que envolvem apenas parcialmente a flor e são naviculares, carenadas, cartáceas a cartáceo-coriáceas, com ápice agudo, ou às vezes obtuso ou truncado, mas nunca pungente, foliáceo ou muitas vezes coriáceo; apresentam nervuras longitudinais e raramente leves corrugações junto à carena.
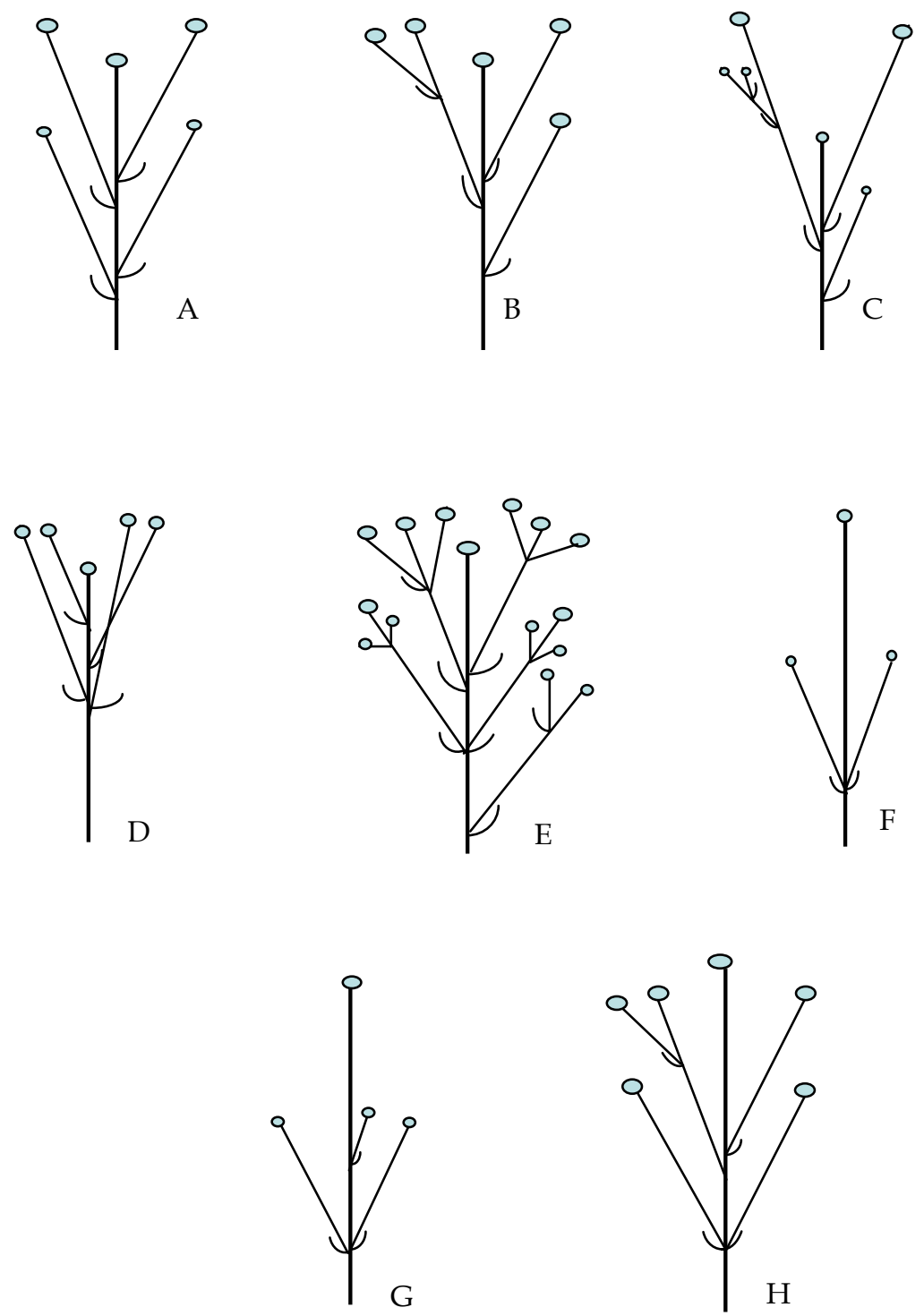

Fig.4: A-H. Esquemas de inflorescências de Viguiera sul-americanas. A-D. Tirsóides com paracládios alternos, os superiores terminando acima do capítulo terminal, A. Paracládios em uma só ordem ( $V$. linearifolia), B. Paracládios em duas ordens $(V$. bracteata), C. Paracládios em três ordens ( $V$. rubra), D. Paracládios espiralados $(V$. robusta), E. Inflorescência mista com paracládios de primeira ordem opostos e alternos (V. pilicaulis), F-H. Inflorescências tirsóides com paracládios superiores terminando 
abaixo do capítulo terminal, F-G. Paracládios de uma só ordem ( $V$. tenuifolia), H. Paracládios em duas ordens (V. anchusifolia).
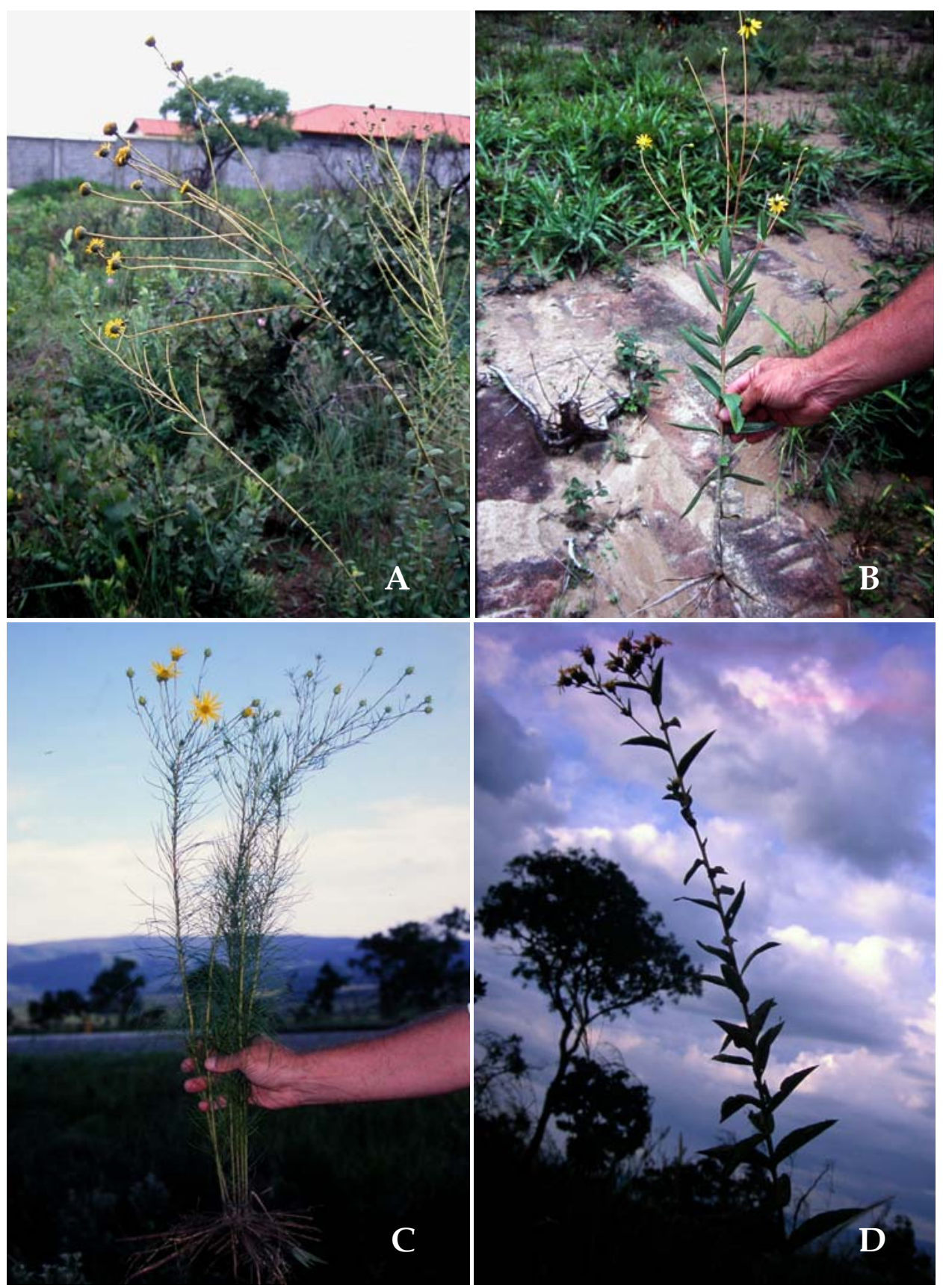

Fig. 5: A-D. Inflorescências de Viguiera do Brasil. A. V. robusta, B. V. oblongifolia, C, V. filifolia, D. V. gardneri. A e C: M. Magenta \& J. Magenta, A. 311 (SPF), C. 376 (SPF); B e D: M. Magenta et al. B. 352 (SPF), D. 457 (SPF). 

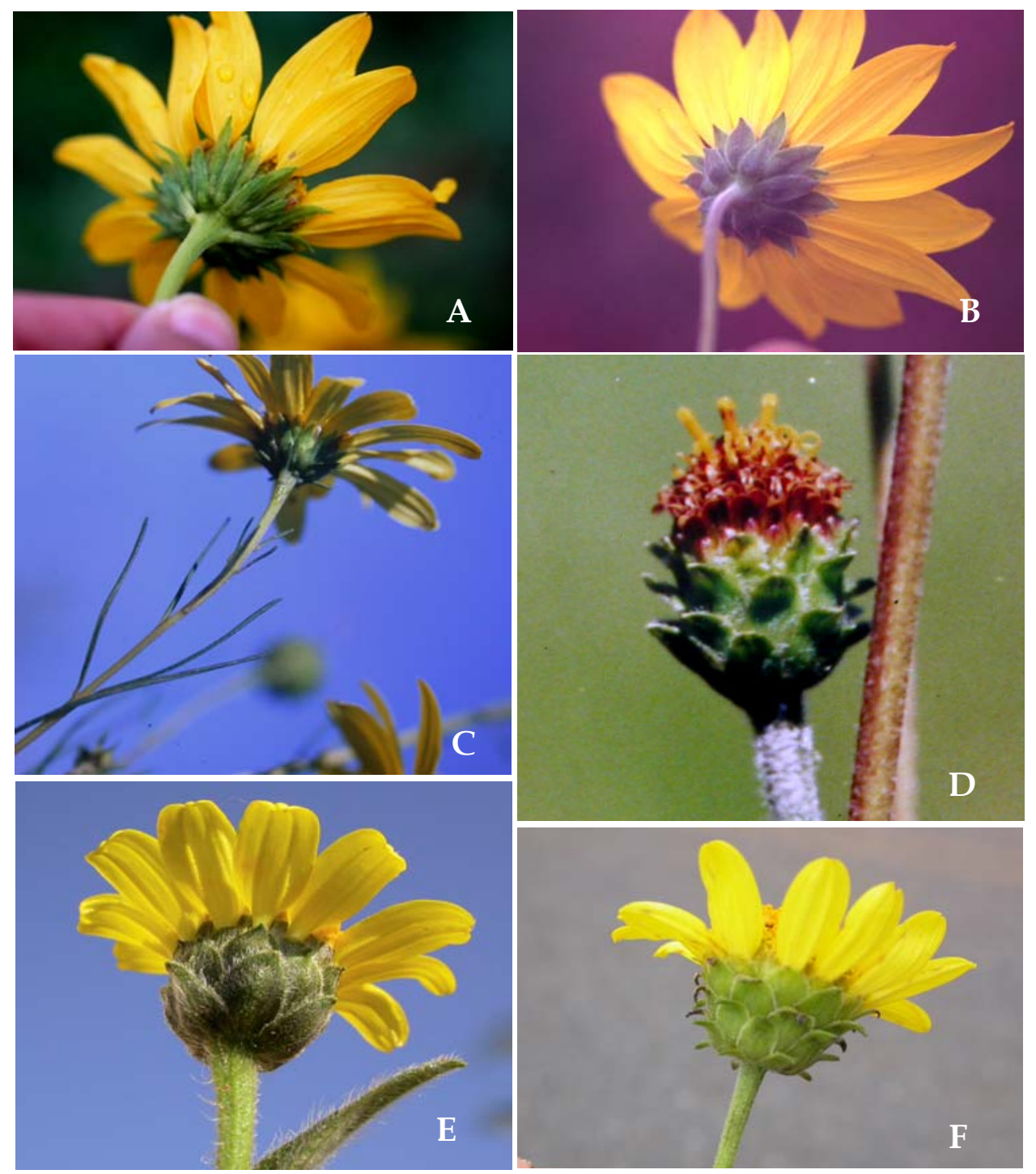

Fig. 6: Tipos de invólucro do capítulo. A-C. campanulado, A. V. grandiflora, B. V. kunthiana, C. V. trichophylla. D. estreitamente campanulado, V. rubra, E. semigloboso, $V$. veredensis, F. largamente campanulado, V. robusta. A-F: M. Magenta \& J. Magenta A. 310 (SPF), B. 309 (SPF), C. 424 (SPF), D. 388 (SPF), E. 664 (SPF), F. 661 (SPF).

\section{Flores}

As flores do raio são neutras, liguliformes, com ápice curtamente 2-3partido e possuem base tubulosa geralmente com indumento híspido a estrigoso; apresentam ductos resiníferos amarelados acompanhando as nervuras, que variam de dez a dezoito e partem do tubo, confluindo no ápice dos lobos. As flores do disco são tubuloso-campanuladas (com exceção daquelas das espécies andinas, que divide com o subgênero Amphilepis (Hemisfério Norte) a presença flores tubulosas), pentâmeras, com lobos 
triangulares, de altura e largura semelhantes, tubo e limbo distintos; usualmente o indumento concentra-se na base, nos lobos e nas nervuras, mas pode se estender por todo o limbo, como em $V$. linearifolia, onde este é recoberto por indumento lanoso antes da antese. Os estames são adnatos à porção basal do limbo, com filetes glabros e anteras atro-marrons. O estilete apresenta alargamento basal geralmente cônico ( $V$. macrorhiza, $V$. trichophylla, $V$. vernonioides), às vezes piriforme ( $V$. bracteata, $V$. kunthiana, $V$. robusta) fusiforme (V. gardneri), semigloboso (V. anchusifolia, V. corumbensis, V. filifolia, V. knobiana e $V$. tuberosa) ou globoso ( $V$. amphychlora, $V$. aspilioides, $V$. meridionalis); está fixado num nectário usualmente chamado estilopódio (Bremer 1994) de largura maior que a altura.

\section{Cipselas}

As cipselas são obovóides e estriadas, com carpopódio bilateral assimétrico delgado (espesso em algumas espécies andinas). O pápus é persistente, constituído de duas aristas triangulares ou lanceoladas, com dois a cinco pares de escamas entre si. O pápus apresenta-se marginal, como em $V$. liearifolia ou intramarginal, como em $V$. hispida e as aristas podem ser unidas às escamas laterais, como em $V$. amphychlora e $V$. bakeriana ou livres, como em $V$. aspilioides e $V$. corumbensis; as escamas podem estar parcialmente unidas ( $V$. bakeriana, V. grandiflora, $V$. hispida, , V. knobiana, V. pilosa, V. squalida, $V$. veredensis, $V$. vernonioides e outras), totalmente unidas ( $V$. amphychlora, $V$. anchusifolia, V. aspilioides, V. filifolia, V. macrorhiza, V. nudicaulis, V. paranensis, V. tenuifolia e $V$. tuberosa) ou variáveis, de parcial a totalmente unidas ( $V$. bracteata, $V$. meridionalis, $V$. robusta, $V$. santacatarinensis). As aristas podem estar posicionadas marginal ou intra-marginalmente. Apenas as espécies andinas possuem pápus destacável ou às vezes decíduo.

\section{Pólen}

O pólen apresenta o padrão heliantóide, estabelecido por Sckvarla (1965), caracterizado por exina cavada e forame interno. Num âmbito mais restrito 
segue o tipo Aspilia (Salgado-Laboriau 1964), com grãos oblato-esferoidais a prolato-esferoidais, 3-colporados, exina e sexina separadas por uma cavidade, unidas apenas nas margens das aberturas e sexina tegilada.

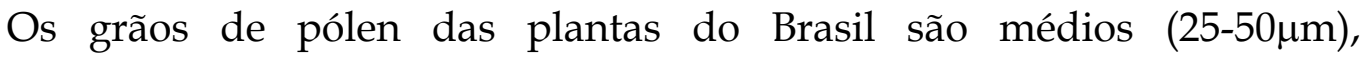
isopolares, oblato-esferoidais na maioria das espécies, prolato-esferoidais apenas em $V$. aspilioides; a área polar é pequena a muito pequena, de âmbito subcircular, 3-colporados, com colpos longos, estreitos, com extremidades agudas; a exina é muito espessa e espinhosa, a sexina é sempre mais espessa que a nexina (ver estudo palinológico no capítulo III).

\section{Cromossomos}

O número básico de cromossomos é 17 (Robinson 1977, 1981); entretanto, Watanabe (2005) em sua grande listagem com as informações sobre número de cromossomos de Asteraceae, encontrou vários registros de $n=34$ para espécies andinas ou de regiões adjacentes ( $V$. britonii, $V$. lanceolata, $V$. procumbens, $V$. sodiroi, $V$. tucumanensis) ou de regiões adjacentes ( $V$. pilosa, V. tuberosa). Poucos estudos foram efetuados para as espécies exclusivamente brasileiras, sendo conhecido apenas $n=17$, de $V$. trichophylla (Carr et al. 1999) e V. robusta (Turner et al. 1979). Segundo a listagem de Watanabe, a espécie sul americana com maior variação nesse número é $V$. anchusifolia $(28,34,16-17)$, sendo que estas condições se traduzem na variação morfológica da espécie. Durante este trabalho obteve-se a germinação de frutos de várias espécies, e as plântulas foram enviadas à Dra. Mariana Esteves da Unicamp, juntamente com cipselas não-germinadas; porém houve dificuldades em levar a cabo a contagem cromossômica, detectando-se apenas $\mathrm{n}=17 \mathrm{em} V$. trichophylla.

\section{Química}

As plantas desse grupo do Brasil têm sido alvo de interesse de pesquisadores das áreas de química e farmácia. A variação da química (Da Costa et al. 1996b 2001) vem sendo estudada e as lactonas sistematicamente classificadas (Da Costa et al. 1996a, Spring et al. 2001 2003, Schorr et al. 2002); os 
frutanos também são investigados (Isejima \& Figueiredo-Ribeiro 1993, Isejima et al. 1991, Itaya et al. 1997 1999). No aspecto medicinal, certos compostos também exercem atividades bactericidas (Da Costa et al. 1998) e, segundo Itaya*, as inulinas de cadeia longa são eficazes no combate ao câncer.

\section{Distribuição geográfica}

Na América do Sul, as espécies de Viguiera distribuem-se da linha do equador até cerca de $40^{\circ} \mathrm{S}$; as espécies que ocorrem ao longo da Cordilheira dos Andes normalmente possuem folhas enegrescidas e pápus destacável ou decíduo, às vezes decíduo e as demais apresentam folhas verde-claras, com pápus firme, persistente. Uma análise mais pormenorizada sobre a distribuição geográfica das espécies é apresentada no capítulo VI.

\section{Chave artificial para separação de Viguiera sul-americanas e táxons morfologicamente relacionados de outras regiões americanas (com adoção das propostas nomenclaturais atuais)}

1. Cipselas com pápus decíduo ou facilmente destacável.

2. Plantas exclusivas do Hemisfério Norte; páleas periféricas do disco bojosas, de ápice pungente ou agudo com acúmen, envolvendo totalmente as flores.

3. Cipselas periféricas simétricas.

4. Ervas a arbustos pouco ramificados; paracládios herbáceos; corola das flores do disco geralmente urceolada; base do limbo hirsuta; filetes com tricomas longos $V$. dentata (sér. Dentatae)

4. Arbustos muito ramificados; paracládios com base lenhosa; corola das flores do disco tubulosa a tubuloso-campanulada; base do limbo esparsamente estrigosa, filetes sem tricomas

V. stenoloba (sér. Pinnatilobatae)

3. Cipselas periféricas fortemente assimétricas.

\footnotetext{
* ITAYA, N. (Instituto de Botânica de São Paulo). Comunicação pessoal, 2002.
} 
5. Pápus formado por duas aristas tênues e diminutas, escamas intermediárias livres Rhysolepis

5. Pápus coroniforme, formado por diminutas aristas, escamas unidas .... Aldama

2. Plantas ocorrentes nos dois Hemisférios; páleas periféricas do disco não bojosas, de ápice obtuso a agudo, envolvendo parcialmente as flores.

6. Arbustos muito ramificados; páleas de ápice inflexo.

7. Plantas mexicanas com paracládios lenhosos

Calanticaria (antiga sect. Brevifolieae)

7. Plantas com paracládios herbáceos.

8. Plantas andinas velutino-seríceas; paracládios alternos; páleas de nervuras convergentes

Pappobolus

8. Plantas mexicanas pubescentes a hirsutas; paraclácios opostos; páleas sem nervuras convergentes

V. sect. Maculatae (S.F. Blake) Panero (em parte)

6. Ervas ou arbustos pouco ramificados; páleas de ápice ereto.

9. Ervas do Hemisfério Norte.

10. Folhas membranáceas com pecíolo conspícuo Helianthus

10. Folhas cartáceas V. buddleiaformis (do subg. Amphilepis)

9. Ervas a arbustos do Hemisfério Sul

Viguiera sul-americanas da Região Andina de Morrone (1999) - em parte.

1. Cipselas com pápus persistente.

11. Brácteas involucrais internas escariosas com ápice expandido lateralmente $V$. angustifolia (do subg. Amphilepis)

11. Brácteas involucrais internas foliáceas a cartáceas ou coriáceas, sem expansão apical.

12. Cipselas com carpopódio espesso (células em 5 ou mais séries)

sér. Grammatoglossae; V. gayana (sp. recente) e V. media (ser. Aureae)

12. Cipselas com carpopódio delgado (células em 4 ou menos séries). 
13. Plantas mexicanas; folhas com pecíolo conspícuo, membranáceas; margem sem partes inteiras

V. sect. maculatae (S.F. Blake) Panero (em parte)

13. folhas sésseis ou subssésseis, cartáceas a coriáceas; margem total ou parcialmente inteira.

14. Flores do disco tubulosas

Viguiera sul-americanas da Região Andina de Morrone (1999) em parte.

14. Flores do disco tubuloso-campanuladas

Viguiera sul-americanas da Região Neotropical de Morrone (1999) - em parte.

\section{O gênero Viguiera Kunth na América do Sul}

Ervas geralmente perenes, subarbustos ou arbustos pouco ramificados, tricomas glandulares curtamente pedicelados, capitados e tricomas tectores com base alargada, ramos caulinares aéreos canaliculados; sistema subterrâneo espessado, raízes adventícias geralmente tuberosas em diferentes níveis. Folhas alternas na porção superior, geralmente opostas na porção inferior, ovais a lanceoladas, às vezes orbiculares ou lineares. Inflorescência botrióide ou tirsóide, paracládios em uma a três ordens; capítulos radiados, campanulados ou semi-globosos, brácteas involucrais em 2-5(-6) séries, as externas menores ou similares às internas, geralmente lanceoladas ou oval-lanceoladas, raramente lineares, base geralmente estriada e ápice foliáceo ou inteiramente foliáceas, ou internas às vezes com ápice escarioso ou totalmente escariosas; receptáculo levemente convexo a convexo ou muito raramente cônico, páleas firmes, naviculares, totalmente escariosas ou apenas na base, geralmente carenadas. Flores do raio 8-25(-30), liguliformes, neutras, ápice 2-3-partido; flores do disco tubulosas a tubuloso-campanuladas, tubo curto, limbo longo infundibiliforme, 5-lobado, lobos papilosos na face interna; anteras marrons, de base curtamente sagitada ou raramente auriculada, apêndices ovais com glândulas; estilete sobre estilopódio, ramos longos, levemente recurvados, face superior papilosa, face 
inferior hispídula, apêndices agudos. Cipselas levemente 3-4-gonais, levemente compressas, inteira ou parcialmente hispídulas, estrigilosas ou raramente velutinas; pápus (1-)-2-aristado, persistente ou destacável, raramente decíduo, aristas agudas a acuminadas e com escamas intermediárias escariosas, parcial ou totalmente unidas, ou às vezes livres, raramente ausentes.

\section{Chave artificial para identificação das espécies de Viguiera América do Sul}

1. Flores do disco tubulosas; plantas da Região Andina de Morrone (1999).

2. Cipselas com pápus decíduo ou facilmente destacável.

3. Folhas escuras discolores; páleas glabrescentes; carpopódio de largura variável.

4. Cipselas com carpopódio delgado (5-6 séries de células de altura).

5. Capítulos com brácteas involucrais em 3 séries.

6. Folhas lanceoladas com base cuneada, inteiras, face abaxial pubescente, com glândulas; brácteas involucrais sem cílios; flores do raio com nervuras vilosas $V$. adenotricha

6. Folhas ovais com base arredondada a atenuada, denteadas, face abaxial híspida, sem glândulas; brácteas involucrais ciliadas; flores do raio com nervuras glabrescentes

V. peruviana

5. Capítulos com brácteas involucrais em (4-)5 séries .... V. revoluta

4. Cipselas com carpopódio espesso (8 ou mais séries de células de altura).

7. Folhas ovais; paracládios com mais de 3 bractéolas ...... V. brittonii

7. Folhas oval-lanceoladas, oblongo-lanceoladas ou lanceoladas, paracládios ebracteolados ou com 1-2 bractéolas.

8. Folhas lanceoladas largas (1,5-3,5 cm larg.); cipselas obtriangulares.

9. Brácteas involucrais lanceoladas V. lanceolata

9. Brácteas involucrais agudas V. mollis 
8. Folhas lanceoladas estreitas (0,5-12 mm larg); cipselas obovais.

10. Folhas estrigosas, brácteas albo-vilosas V. emaciata

10. Folhas e brácteas involucrais híspidas V. gilliesii

3. Folhas claras concolores; páleas estrigilosas; carpopódio espesso.

11. Plantas decumbentes de até $30 \mathrm{~cm}$ de altura; páleas totalmente escariosas V. fusiformis

11. Plantas eretas, atingindo mais de 1m de altura; páleas cartáceas com margem escariosa.

12. Brácteas involucrais externas totalmente foliáceas ou com base coriácea e 2/3 superiores foliáceos, híspidas, ciliadas

$V$. procumbens

12. Brácteas involucrais externas com base coriácea e $1 / 2$ superior foliáceo, estrigosas, sem cílios. V. szyszylowiczii

2. Cipselas com pápus persistente.

13. Cipselas setosas a estrigosas.

14. Brácteas involucrais com face abaxial híspida a vilosa; cipselas fortemente estriadas.

15. Receptáculo com páleas de 10-12 nervuras, glabras; corola do disco tubo estrigoso; cipselas com carpopódio espesso (5 ou mais células de altura) e tricomas amarelados translúcidos $V$. media

15. Receptáculo com páleas de 6-8 nervuras; corola do disco com tubo setoso; cipselas com carpopódio delgado (menos de 4 células altura) e tricomas hialinos brilhantes $V$. sodiroi

14. Brácteas involucrais com face abaxial estrigosa; cipselas levemente estriadas.

16. Folhas com face abaxial vilosa; paracládios 1-bracteolados

$V$. incana

16. Folhas com face abaxial híspida; paracládios conspicuamente bracteolados V. ellenbergii

13. Cipselas finamente cerdosas a velutinas.

17. Cipselas com tricomas adensados no eixo de simetria. 
18. Folhas concolores obovais a ovais, denteadas, membranáceas; receptáculo com páleas de 14-16 nervuras; cipselas com margem corticosa fortemente compressa.

19. brácteas involucrais em duas séries; cipsela com cílios curtos na margem; carpopódio com bainha fina na porção superior V. simsioides 19. brácteas involucrais em três séries; cipselas com cílios longos na margem; carpopódio sem bainha

V. weberbaueri

18. Folhas discolores lineares, inteiras, cartáceas; receptáculo com páleas de 6-8 nervuras; cipselas sem margem corticosa e compressa V. atacamensis

17. Cipselas sem tricomas adensados no eixo de simetria.

20. Brácteas involucrais ciliadas; páleas com 10-12 nervuras.

21. Folhas concolores glaucas V. gayana

21. Folhas discolores escuras V. tucumanensis

20. Brácteas involucrais sem cílios; páleas com 6-8 nervuras.

22. Cipselas com margem superior protuberante, levemente tetragonais $V$. retroreflexa

22. Cipselas sem protuberâncias, trígonas.

23. Folhas com base cuneada e ápice acuminado; capítulos em inflorescências botriódes ou tirsóides; brácteas involucrais foliáceas em 1/2 superior, com uma nervura destacada da base ao ápice $V$. australis

23. Folhas com base arredondada e ápice agudo; capítulos solitários; brácteas involucrais 
totalmente foliáceas, sem nervuras destacadas $V$. truxilensis

1. Flores do disco tubuloso-campanuladas; plantas da Região Neotropical de Morrone (1999). Obs.: as espécies que não ocorrem no Brasil são antecedidas por $" * * "$.

24. Folhas levemente discolores a discolores, lâmina atingindo mais de $9 \mathrm{~cm}$ de comprimento, lanceolada, com base cuneada ou atenuada.

25. Folhas com ápice acuminado; cipselas com tricomas restritos à porção apical.

26. Filotaxia oposta; pecíolo com 5-8mm de comprimento; brácteas involucrais em 2 séries, foliáceas em 1/3 superior, levemente reflexas na floração; aristas $0,8-1,2 \mathrm{~mm}$ de altura ...21. V. nudibasilaris

26. Filotaxia alterna; pecíolo com 1-2mm de comprimento; brácteas involucrais em 3-4 séries, totalmente foliáceas ou em 3/4 superiores, fortemente reflexas na floração; aristas 2,5-4mm de altura

29. V. santacatarinensis

25. Folhas com ápice agudo ou raramente obtuso; cipselas com tricomas em todo o corpo 26. V. pilosa

24. Folhas sem o conjunto de caracteres

27. Plantas delicadas, a maioria com ramo aéreo flexível.

28. Brácteas involucrais em 2-3 séries, sempre apressas; pápus com escamas totalmente unidas ou unidas até muito próximo ao ápice ou, se unidas apenas até o meio, lâminas das folhas superiores muito estreitas.

29. Brácteas involucrais de tamanhos similares.

30. Plantas fortemente decumbentes; capítulos sempre solitários.

31. Brácteas involucrais com uma nervura fortemente destacada, da base ou ápice; cipselas com 7-7,7mm, carpopódio prolongando-se nas laterais

18. V. macrorhiza 
31. Brácteas involucrais sem uma nervura fortemente destacada, cipselas com cerca de $4 \mathrm{~mm}$, sem prolongamento do carpopódio...... 24. V. paranensis

30. Plantas eretas ou semi-eretas; capítulos em botrióides ou tirsóides laxos ou muito raramente solitários.

32. Folhas medianas com lâmina elíptica, oval, levemente oboval ou largamente oblonga

22. V. nudicaulis

32. Folhas medianas com lâmina estreita, linear a lanceolada.

33. Lâmina foliar longamente ciliada, com face abaxial densamente albo-híspida; paracládios densamente híspidos ou estrigosos; brácteas involucrais com face abaxial geralmente híspida; pápus sem manchas 13. V. hispida

33. Lâmina foliar sem cílios, com face abaxial estrigosa a híspida; paracládios esparsamente híspidos; brácteas involucrais com face abaxial estrigilosa a estrigosa; pápus com manchas vináceas 31. V. tenuifolia

29. Brácteas involucrais de tamanhos diferentes, as externas gradualmente menores.

34. Brácteas involucrais totalmente foliáceas ou foliáceas em $3 / 4$ superiores.

35. Lâmina foliar com face abaxial estrigosa; flores do raio com nervuras pubescentes a híspidas; cipselas com carpopódio delgado, pápus amarelo-dourado, escamas unidas até a metade 15. V. kunthiana

35. Lâmina foliar com face abaxial hirsuta a híspida; flores do raio com nervuras estrigilosas a estrigosas; cipselas com carpopódio espesso, pápus 
com manchas vináceas, escamas totalmente unidas 4. $V$. aspilioides

34. Brácteas involucrais foliáceas em $1 / 3$ superior

33. V. tuberosa

28. Brácteas involucrais em 3-4 séries, apressas ou reflexas.

36. Plantas resiníferas; lâmina foliar filiforme ou, se linear, com face abaxial albo-lanosa.

37. Pápus com aristas livres das escamas laterais.

38. Lâmina foliar com face abaxial lanosa; brácteas involucrais foliáceas em $2 / 3$ superiores

17. $V$. linearifolia

38. Lâmina foliar com face abaxial estrigilosa a estrigosa; brácteas involucrais foliáceas em 1/2 superior

9. V. filifolia

37. Pápus com aristas unidas às escamas laterais.

39. Folhas 1-3 mm larg., face adaxial estrigilosa, face abaxial híspida; brácteas involucrais em 5 séries...... ${ }^{*} V$. densifolia

39. Folhas 0,5-0,8mm larg., glabras; brácteas involucrais em 4 séries 32. V. trichophylla

36. Plantas sem resina, lâmina foliar de outras formas $u$, se linear, sem indumento albo-lanoso na face abaxial.

40. Pecíolo expandido na base, lâmina com base arredondada a obtusa, ciliada; número de nervuras das páleas variando entre 8 ou 10 ...23. V. oblongifolia

40. Pecíolo sem expansões, lâmina com base atenuada ou cuneada, sem cílios; número de nervuras das páleas variando entre 6 ou 8.

41. Folhas discolores, de base atenuada, às vezes lineares, face abaxial com glândulas; cipselas setulosas a setosas, escamas unidas até o meio. 
42. Plantas eretas, folhas com 3 nervuras principais; paracládios flexuosos; páleas de ápice agudo a obtuso .............. 2. V.anchusifolia

42. Plantas decumbentes; folhas uninervuradas; paracládios eretos; páleas de ápice apiculado . 19. V. megapotamica

41. Folhas concolores, de base truncada ou cuneada, nunca linerares, face abaxial com glândulas; cipselas cerdosas, escamas unidas até o ápice.

43. Planta delgada; lâmina foliar estreitamente lanceolada, base truncada, coriácea; brácteas involucrais foliáceas em $1 / 2$ superior

1. V. amphychlora

43. Planta robusta; lâmina foliar lanceolada a oblongo-lanceolada, base cuneada, cartácea; brácteas involucrais totalmente foliáceas

${ }^{*} V$. fabrisii

27. Plantas robustas com ramo aéreo ereto.

44. Brácteas involucrais em 2 a 3 ou raramente 4 séries, apressas ou às vezes apenas levemente reflexas na floração.

45. Brácteas involucrais de tamanhos similares, ao menos as duas primeiras ou duas últimas séries.

46. Pápus com aristas largamente triangulares, naviculares, porção basal gibosa.

47. Caule subterrâneo com espessamento leve; folhas com base levemente atenuada a cordada e face abaxial tomentosa ou híspida; brácteas involucrais com face abaxial vilosa, estrigosa ou setosa; anteras terminando na base do colar filetal; pápus com arista marginal fortemente recurvada

8. V. discolor 
47. Caule subterrâneo fortemente espessado, folhas com base obtusa e cuneada, glabras a esparsamente estrigosas a estrigosas, hirsutas ou setosas; brácteas involucrais com face abaxial esparsamente estrigilosa a estrigilosa; anteras terminando acima da base do colar filetal; pápus com arista geralmente intramarginal, ereta

30. V. squalida

46. Pápus com aristas estreitamente triangulares a triangulares, sem base gibosa.

48. Lâmina foliar com base oblíqua; brácteas involucrais com uma nervura central destacada; páleas de ápice agudo; cipselas com menos de $5 \mathrm{~mm}$ e pápus com manchas vináceas

5. V. bakeriana

48. Lâmina foliar sem base oblíqua; brácteas involucrais sem nervura central destacada; páleas de ápice acuminado; cipselas com mais de $5 \mathrm{~mm}$ e pápus sem manchas.

49. Capítulos reunidos em inflorescências botrióides ou tirsóides laxas; flores do raio com nervuras esparsamente hispídulas; receptáculo com páleas de 8-10 nervuras

12. V. grandiflora

49. Capítulos solitários; flores do raio com nervuras pubescentes; receptáculo com páleas de 10-12 nervuras ${ }^{*} V$. speciosa

45. Brácteas involucrais de tamanhos diferentes, as externas gradativamente menores.

50. Lâmina foliar com face abaxial vilosa; a maioria dos capítulos com páleas de ápice truncado ou obtuso. 
51. Planta resinífera, brácteas involucrais foliáceas em 1/3 superior, com nervuras proeminentes; flores do raio cerca de 8; pápus maduro vináceo; escamas cerca de 3 pares 35. V. vernonioides

51. Planta sem resina; brácteas involucrais inteiramente foliáceas, com nervuras imersas; flores do raio 10 a 12; pápus maduro estramíneo; escamas 6-7 pares ..... 34. V. veredensis

50. Lâmina foliar com outros tipos de indumento na face abaxial ou, se indumento viloso, páleas de ápice agudo. 52. Folhas opostas; brácteas involucrais em 2 séries; lobos das corolas do disco com altura igual ou maior que o dobro da largura 14. V. knobiana

52. Folhas alternas ou mistas; brácteas involucrais em 3 séries; lobos das corolas das flores do disco com altura igual à largura.

53. Folhas sésseis; base levemente cordada e ápice obtuso a arredondado ${ }^{*} V$. breviflosculosa

53. Folhas pecioladas; base com outras formas e ápice agudo a acuminado.

54. Paracládios terminando abaixo do capítulo terminal; brácteas involucrais com uma nervura destacada da base ao ápice, foliáceas em $2 / 3$ superiores

7. V. corumbensis

54. Paracládios terminando acima do capítulo terminal; brácteas involucrais sem uma nervura destacada da base ao ápice, foliáceas em $1 / 2$ superior.

55. Lâmina com face abaxial vilosa; brácteas involucrais externas ciliadas com face 
abaxial estrigosa; flores do raio 14-15; corolas do disco glabras; cipselas glabrescentes 11. V. goyazensis

55. Lâmina com face abaxial estrigosa; brácteas involucrais externas sem cílios e com face abaxial hispídula; flores do raio cerca de 18; corolas do disco estrigilosas; cipselas seríceas. 16. V. laxicymosa

44. Brácteas involucrais em 4 a 5 ou raramente 3 ou 6 séries, geralmente conspicuamente reflexas, ou pelo menos com ápice totalmente reflexo na floração.

56. Lâmina foliar escura, face abaxial híspida e nervuras estrigosas; brácteas involucrais foliáceas em mais de 1/2; páleas com nervuras amareladas; cipselas com carpopódio espesso (8 ou mais séries de células de altura) 20. V.meridionalis

56. Lâmina foliar clara, sem a combinação de indumentos; brácteas involucrais foliáceas em até $1 / 2$; páleas com nervuras cor de mel a castanhas; cipselas com carpopódio delgado (5-6 séries de células de altura).

57. Lâmina lanceolada a linear; brácteas involucrais com formas diferentes em cada série, foliáceas em 1/5 superior; lobos das flores do disco menores que o dobro da corola; aristas longas e cerdosas, com base endurecida 6. V. bracteata

57. Lâmina de outras formas, largas; brácteas involucrais com formas iguais, foliáceas em $1 / 4$ superior ou mais; lobos das flores do disco iguais ou maiores que o dobro da corola; aristas de outros tipos.

58. Páleas com no mínimo 6 nervuras, imersas em regiões indiferenciadas, cipselas glabras ou 
estrigilosas; pápus sem escamas ou com escamas livres

3. V. arenaria

58. Páleas com no mínimo 8,10 ou 12 nervuras, imersas em regiões diferenciadas; cipselas com indumento cerdoso ou raramente setoso; pápus com escamas ao menos parcialmente unidas.

59. Plantas resiníferas; carpopódio simétrico

10. V. gardneri

59. Plantas sem resina; carpopódio assimétrico.

60. Capítulos discóides, brácteas involucrais com face abaxial híspida; flores do disco jovens com ápice vináceo 28. V. rubra

60. Capítulos, radiados, brácteas involucrais com face abaxial estrigosa; flores do disco jovens totalmente amarelas.

61. Folhas concolores, base arredondada a levemente atenuada; brácteas involucrais fortemente reflexas na floração; flores do raio $17-17 \mathrm{~mm}$ alt.; base das anteras terminando muito abaixo da base do colar filetal; aristas unidas às aristas unidas às escamas laterais 25. $V$. pilicaulis

61. Folhas discolores a levemente discolores, base arredondada, levemente auriculada e geralmente cuneada; brácteas involucrais levemente apressas com ápice fortemente reflexo na floração; flores do raio 8,5-12 $\mathrm{mm}$ alt.; base das anteras terminando acima da base do colar filetal; aristas livres ....27. V. robusta 


\section{Estudo das espécies ocorrentes no Brasil}

1. Viguiera amphychlora S.F. Blake, Contr. Gray Herb. 54: 166. 1918. Tipo: Paraguay: In regiones Yerbalium de Maracayú. Paraguaria Euro-austra 1898-99, Hassler 5160 (holótipo: BM!, fotografia do holótipo: K!, SPF!; isótipos: G*, GH .).

Figura 7

Erva ereta 1-1,8m alt., ramo aéreo ereto ou flexível, cilíndrico canaliculado, esparsamente hispídulo; entrenós $10-15 \mathrm{~cm}$ compr.; sistema subterrâneo desconhecido. Folhas verde-claras, inferiores opostas ou raramente verticiladas, superiores alternas ou o par abaixo da inflorescência oposto, remotas, 7,5-18x0,5-1cm, sésseis; lâmina estreitamente lanceolada, revoluta, base atenuada, levemente alargada junto ao caule, ápice agudo a acuminado mucronado, inteira, coriácea, nervação acródroma basal perfeita, face adaxial estrigosa, tricomas tectores 3-celulares, com bossas conspícuas de base cônica, cercada por 2 séries de células, face abaxial estrigilosa a estrigosa, tricomas tectores 3-celulares, com bossas conspícuas, base cônica cercada por 2-3 séries de células; às vezes com folhas pequenas nas axilas. Inflorescências tirsóides laxas $15-60 \mathrm{~cm}$ alt., paracládios eretos, superiores terminando levemente acima do capítulo terminal, estreitamente canaliculados, esparsamente estrigilosos, com bractéolas esparsas 0,5-1,5cm compr., lineares; 1a ordem alternos, 7-28cm compr., 2a ordem raros, 4-5cm compr.; pedúnculo terminal 7-23cm compr. Capítulos 5-6cm diâm., radiados, às vezes subtendidos por 1-2 bractéolas lineares, invólucro 1,2-1,5cm diâm., campanulado, brácteas involucrais levemente apressas na floração, em 3-4 séries, base caniculada, duas nervuras salientes, foliáceas em 1/3 superior, ápice oblongo-lanceolado,, longamente mucronado, coriáceas, das duas primeiras séries oval-lanceoladas, cilioladas, face adaxial glabra, face abaxial estrigosa, 1a série 5-6mm, 2a série 5-9mm, das outras séries 6,5-11mm, oblongo-lanceoladas, porção superior ciliolada, face abaxial esparsamente estrigilosa; receptáculo convexo, páleas 6-6,5mm, obovais, ápice obtuso, mucronado, 6 ou 8 nervuras salientes imersas em região diferenciada, cartáceo-coriáceas, translúcidas, carena conspícua esparsamente 
estrigilosa. Flores do raio 12-16, em 1 verticilo, corola 15-22x4-4,2mm, tubo 1,5$2 \mathrm{~mm}$ alt., limbo estreitamente oblongo, obtuso, irregularmente 3-partido, face abaxial estrigilosa a setosa, com tricomas glandulares, nervuras ca. 11; tubo hispídulo; flores do disco 55 a 65, corola ca. 4mm alt., lobos alt. e larg. semelhantes, face externa de lobos glabros ou com nervuras estrigilosas, base do limbo e tubo esparsamente estrigilosos; tubo 0,6-1,2mm alt., anteras de base auriculada, terminando na base do colar filetal; estilete com pequeno alargamento basal globoso, estilopódio 0,10-0,12x0,24-0,30 mm. Cipselas ca. $4 \mathrm{~mm}$ alt., largamente obovóides, levemente trígonas, canaliculadas, ângulos laterais esparsamente estrigosos, carpopódio delgado; pápus amarelado 2aristado, aristas intramarginais levemente desiguais, unidas às escamas laterais, maior ca. $3 \mathrm{~mm}$ alt., menor ca. $2,8 \mathrm{~mm}$ alt., oblongas ou a parte superior expandida, ápice longamente acuminado, esparsamente estrigilosas, escamas ca. 2 pares 1,8mm alt., unidas até o ápice eroso.

Embora originalmente descrita para o Paraguai, o único espécime encontrado nos herbários procedente desse país foi o material-tipo. É aqui registrada pela primeira vez para o Brasil, onde foi coletada apenas no nordeste do Estado do Paraná e sul de São Paulo FIG. 43B , em locais antropizados, com flores e frutos de fevereiro a maio. DISJUNÇÃO De acordo com os critérios da IUCN, é uma espécie vulnerável, por distribuição restrita e tamanho populacional reduzido; o táxon pode ser afetado por atividades antrópicas ou eventos estocásticos em período muito curto de tempo, podendo assim tornarse criticamente em perigo ou mesmo extinto.

Identificada em muitos herbários brasileiros como $V$. aspilioides, dela se diferencia pelas folhas coriáceas estrigosas, brácteas involucrais coriáceas em 34 séries, com porção foliácea apenas em um terço superior, e pápus com 1-2 pares de escamas. $V$. aspilioides, por sua vez, possui folhas cartáceas hirsutas, 2-3 séries de brácteas involucrais levemente cartáceas, ou internas levemente estramíneas, com porção foliácea nos três quartos superiores ou em toda a bráctea e pápus com 3-4 pares de escamas. 
Material examinado: BRASIL: Paraná: Arapoti, Rio das Cinzas, Barra do Perdizes, 26.II.1961 (fl, fr), G. Hatschbach 7769 (MBM, RB); Fazenda do lobo,

Telêmaco Borba, Monte Alegre, 22.II.1953, G. Hatschbach 2997 (SP). São Paulo: Capão Bonito, 26.III.1915 (fl, fr), Dusén 16875 (BM). PARAGUAI: departamento indefinido, Sierra de Maracayú, 1898/99 (fl), E. Hassler 5160 (BM).

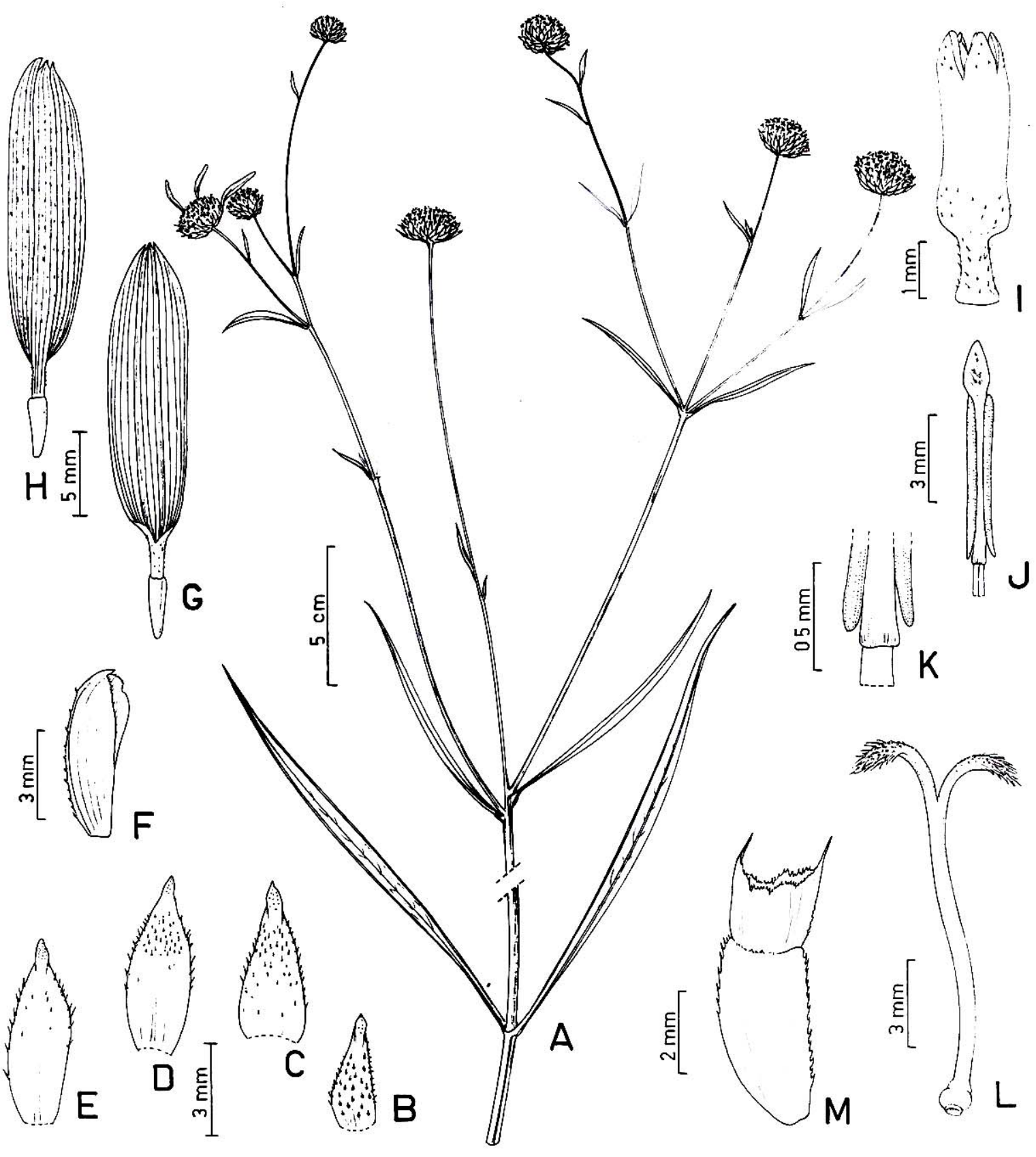

Fig. 7: V. amphychlora. A. Segmento de ramo com sinflorescência, B-E. Brácteas involucrais, F. Pálea do receptáculo, G-H. Flores do raio, I. Corola do disco, J-K. Antera, K. Detalhe com tecas de base auriculada, terminando acima da base do colar filetal, L. 
Estilete com alargamento basal cônico compactado, M. Cipsela com escamas unidas. AM. N. Silveira 9786 (HAS).

2. Viguiera anchusifolia (DC) Baker in Martius, Fl. bras. 6 (3): 222. 1884, "anchusaefolia". Tipo: citado sob a var. anchusifolia.

Figuras $4 \mathrm{H}$ e 8

Ervas, subarbustos a arbustos 1-2(-3)m alt., ramos aéreos flexíveis, cilíndricos, canaliculados, setosos a estrigosos; entrenós 1,5-5cm compr.; caule subterrâneo fortemente espessado, raízes de tuberosidade fusiforme longa ou curta, em diferentes porções. Folhas levemente discolores, alternas ou o par basal oposto, sésseis ou pecíolo 1-3mm, estrigoso, lâmina decorrente no pecíolo, a das inferiores $5,5-10 \times 0,3-1 \mathrm{~cm}$, superiores $3-6 \times 0,2-0,3 \mathrm{~cm}$, lineares, estreitamente oblongas, elípticas ou inferiores oval-lanceoladas ou elíptico-lanceoladas, inteiras ou inferiores esparsamente denteadas na porção superior, geralmente revolutas, base levemente atenuada, ápice agudo mucronado, nervação acródroma suprabasal imperfeita, 3 nervuras principais, cartáceas, face adaxial com nervação proeminente, estrigosa a setosa, tricomas tectores 3-celulares de base levemente cônica, adpressa, cercada por 2-3 séries de células dispostas radialmente; face abaxial setosa, tricomas tectores com bossas de base cilíndrica a levemente cônica, adpressa, cercada por 1 série de células, às vezes com tricomas glandulares. Inflorescência botrióide ou tirsóide laxa, candelabriforme, $15-45 \mathrm{~cm}$ alt., paracládios flexuosos, superiores terminando acima ou abaixo do capítulo terminal, cilíndricos a levemente tetragonais, canaliculados, esparsamente setosos a setosos, geralmente bracteolados, bractéolas 1-5cm compr, foliáceas; 1a ordem alternos, $12-35 \mathrm{~cm}$ compr., 2a ordem 5-20cm compr.; pedúnculo terminal 7-26cm compr. Capítulos 3-5,5cm diâm., radiados, invólucro campanulado $8-15 \mathrm{~mm}$ diâm., brácteas involucrais levemente apressas a apressas em (3-)4 séries, oblongas, espatuladas ou ovais a oval-lanceoladas, coriáceas, base levemente canaliculada, uma nervura saliente, ápice obtuso a agudo, foliáceas em 2/3 superiores, face adaxial esparsamente estrigilosa, face abaxial setosa a estrigosa, tricomas fortemente adpressos; esparsamente ciliadas a ciliadas, externas menores, 2,5-5mm alt., centrais 4,5- 
8mm alt., internas 7-10mm alt.; receptáculo fortemente convexo, páleas 5-7 $\mathrm{mm}$, oblongas, cartáceas, margem escariosa, carenadas, ápice obtuso a agudo, fimbriado, mucronado, 6 ou 8 nervuras imersas em regiões diferenciadas, porção superior da margem e carena esparsamente estrigilosas. Flores do raio (12-)13-14(-20), corola 8-18×3,5-5mm, limbo oblongo a elíptico, ápice curtamente 2-partido, nervuras 11-13, face adaxial papilosa, face abaxial com nervuras hirsutas; tubo 1-1,5mm alt., às vezes com pistilódio; flores do disco ca. 50, corola 4-4,5mm alt., lobos alt. e larg. semelhantes, face externa com base do limbo e tubo estrigilosos, tubo 0,8-1mm alt.; anteras de base curtamente sagitada, terminando na base do colar filetal; estilete com base semi-globosa, estilopódio 0,14-0,16x0,30-0,32mm. Cipselas 3,5-4mm alt., levemente obovóides, compressas, estriadas, setosas a seríceas, carpopódio delgado; pápus geralmente vináceo ou às vezes amarelado, 2-aristadas; aristas intramarginais livres, iguais ou levemente desiguais, 1,5-3mm alt., lanceoladas, acuminadas, esparsamente estrigilosas, escamas em 3-4pares, 1-1,7mm alt., unidas até o meio ou próximo ao ápice fimbriado, estrigilosas.

Ocorre na Argentina, no Paraguai, no Uruguai e no Brasil, onde é comum nos Estados de Paraná, Santa Catarina e Rio Grande do Sul (fig. 42B), em cerrados, bordas de mata, beira de estrada e capoeiras. Floresce durante a primavera e o verão ou raramente no outono.

Blake (1918) distinguiu duas variedades, com base na forma das folhas: a que chamou de var. genuina, com folhas de lâmina estreitamente oblonga ou oblongo-lanceolada e a var. immarginata, com folha de lâmina linear ou oblongo-linear. Apesar da existência de uns poucos materiais com características intermediárias, é possível delimitar as duas variedades.

A variedade típica, apresenta certa variabilidade morfológica, certamente associada aos diferentes hábitats de ocorrência. Plantas encontradas em solos mais férteis apresentam folhas maiores, com alguns espécimes assemelhandose, em estado vegetativo, a $V$. pilosa, da qual se diferencia principalmente por apresentar brácteas involucrais externas bem menores que as internas, com ápice geralmente agudo e pápus com aristas com alturmenor que o dobro da 
altura das escamas, enquanto a segunda possui brácteas de tamanho similar e pápus com aristas maiores que o dobro da altura das escamas; as convergências entre essas espécies levaram Mondin (2004) a considerá-las como sinônimos. Na análise filogenética efuada no capítulo IV, essas espécies emergiram em clados diferentes (ver pág. 88). Os espécimes encontrados em regiões úmidas e relativamente sombreadas do Parque Nacional dos Aparados da Serra apresentam folhas mais largas, com ápice truncado e os coletados em alto de Cerros do Rio Grande do Sul, em solo pedregoso, apresentam folhas oblongas muito escabrosas, como ocorre com a espécie-tipo de $V$. anchusifolia. A variedade immarginata assemelha-se a $V$. megapotamica (ver comentário sob a descrição da espécie), que surgiu, no estudo filogenético, como irmã da primeira. Também são grandes as semelhanças morfológicas de $V$. anchusifolia e V. kunthiana, mas esta múltima apresenta brácteas involucrais apressas.

Não está descartada a possibilidade de formação de híbridos entre elas, mas a confirmação deste fato depende de estudos futuros, que deverão analisar estatisticamente (ver Freeman et al. 1999 e Rieseberg 1995 2002) uma amostragem significativa das duas espécies; uma provável zona de hibridação foi detectada, estendendo-se do sudoeste ao sudeste do Rio Grande do Sul, em áreas perturbadas. Os espécimes encontrados em regiões úmidas e relativamente sombreadas do Parque Nacional dos Aparados da Serra apresentam folhas mais largas, com ápice truncado e os coletados em alto de Cerros do Rio Grande do Sul, em solo pedregoso, apresentam folhas oblongas muito escabrosas, como ocorre com a espécie-tipo de $V$. anchusifolia. A variedade immarginata assemelha-se a $V$. megapotamica (ver comentário sob a descrição da espécie).

\section{Chave para as variedades}

1. Plantas com folhas de lâmina oblonga a oblongo-lanceolada ou as superiores lineares V. anchusifolia var. anchusifolia

1. Plantas com todas as folhas de lâmina linear ... V. anchusifolia var. immarginata 
2.1. Viguiera anchusifolia (DC) Baker var. anchusifolia. Leighia anchusifolia DC, Prodr. 5: 580. 1836. Viguiera anchusaefolia (DC) Baker var. genuina S.F. Blake, Contr. Gray Herb. 54: 156. 1918. Rhysolepis anchusifolia (DC) H. Rob. \& A.J. Moore, Proc. Biol. Soc. Wash. 117(3): 425. 2004. Tipo: Rio Grande do Sul, Herb. Imp. Brésil 875 (holótipo: P!; fotografia do holótipo: K!, SPF!; isótipo: G - DC; fotografia de isótipo de B [destruído]: F!).

?Rudbeckia densifolia Sm. in Rees, Encyc. 30 (10). 1819. Tipo: não citado.

Leighia lomatoneura DC., Prodr.: 581. 1836. Tipo: Brazil, Rio Grande do Sul, Herb. Imp. Brésil 878 (holótipo: P!; fotografia do holótipo: GH, K, SPF; isótipo: $\mathrm{G}-\mathrm{DC})$.

Leighia baldwiniana Nutt., Trans. Amer. Philos. Soc. Ser. 2, 7: 365. 1841. Tipo: South America, s.l., s.d., Baldwin s.n. (holótipo: BM!, fotografia do holótipo: K!, SPF!; GH - esboço).

Leighia dissitifolia DC, Prodr.: 581.1836. Tipo: Rio Grande do Sul, Herb. Imp. Brésil 881 (holótipo: P!; fotografia do holótipo: GH; isótipo: G - DC).

Material examinado: ARGENTINA: Buenos Aires, Rincontieduna, III.1934 (fl), E. Ringuelet 399 (LP); Bagre Flaco, 19.III.1942 (fl), A.L. Cabrera 7488 (LP); Atucha, 22.I.1947, A. Krapovickas 3288 (SPF, SP); [Buenos Aires], San Pedro, 19.IV.1940 (fl), A.L. Cabrera 6415 (LP); Partido de San Nicolás, Barrancas del Paraná, 6.III.1941 (fl), A.L. Cabrera 7149 (LP, SP); entre La Plata e S. Vicente del Tuyu, beira de estrada, 14.III.1951 (fl), G.A. Black \& Boelcke 51-1122 (RB); Entre Rios, Paraná, verano,1930, J.F. Salellas 1422 (LP); La Paz, Distrito Alcatraz, 25.I.1960 (fr), A. Burkart \& N.M. Bacigalupo 21443 (LP); Gualeyguaychú, 27.II.1970 (fr), A. Burkart \& N.S. Troncoso 27887 (RB); Misiones, Candelaria, Santa Ana, 26.XI.1945, J.E. Moules 1502 (RB); Salta, Rosario de Lerma, Santa rosa de Tastil, arroyo al SE del caserio, 7.IV.1987 (fl, fr), L. Novara 6451 (M). Província indefinida, s.d. s.c. s.n. (LP 11803); s.d. s.c. s.n. (LP 70988). BRASIL: Paraná: Campo Mourão, 625 m.a.m., 14.X.1965 (fr), G. Hatschbach 13009 (UB); Catanduvas, Barra do Guarani, 10.X.1974 (fl), G. Hatschbach \& P. Pelanda 35138 (MBM); Horizonte, rodovia BR 280, caminho de Palmas, 1400 m.a.m., 27.I.1985 (fl, fr), A. Krapovickas \& C.L. Cristóbal 39702 (CTES, LP); Reserva do Iguaçu,

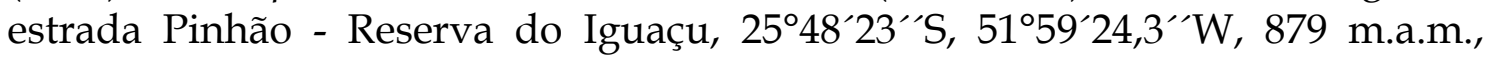
29.III.2002 (fl, fr), M. Magenta \& J. Magenta 421 (SPF); idem, 2548’21,2”S, 51 59`27,7’W, 854 m.a.m., 29.III.2002 (fl, fr), M. Magenta \& J. Magenta 422 (K,

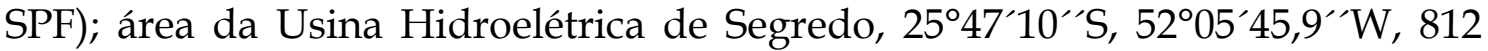
m.a.m., 29.III.2002 (fl, fr), M. Magenta \& J. Magenta 423 (K, SPF). Rio Grande do Sul: Arroio dos Ratos, rodovia BR 290 km 159,5, sentido Arroio dos Ratos -

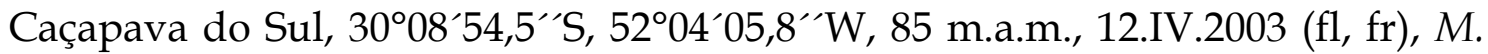
Magenta et al. 597 (K, SPF); Barra do Ribeiro, Barra do Ribeiro para Porto Alegre, 
5.IV.1950 (fl, fr), B. Rambo s.n. (PACA 46631); Bom Jesus, Fazenda Caraúna, 10.II.1937, Dutra 1442 (ICN); Cachoeira do Sul, Cerro dos Peixoto, no topo do morro, 30.IV.1985 (fl, fr), M. Sobral 3787 (ICN, MBM); Cambará do Sul, Cambará para São Francisco de Paula, III.1948 (fl), B. Rambo s.n. (PACA 36529); na Fortaleza, no alto do morro, 27.III.1987 (fl), J.R. Mattos et al. 30968 (HAS); idem, 27.III.1987 (fl), J.R. Mattos et al. 31004 (HAS); na Fortaleza, 28.III.1989 (fl), N. Silveira 6645 (HAS); na saída da cidade, rodovia para São Francisco de Paula, 13.II.2002 (fl), C. Mondin \& A. Iob 2554 (HASU, SPF); Parque Nacional dos Aparados da Serra, Serra Geral, próximo estrada dos pesquisadores,

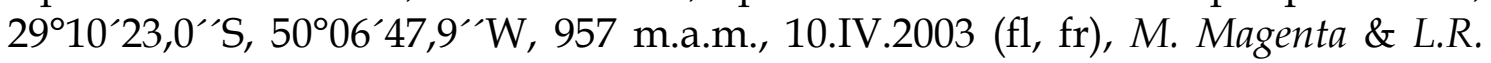

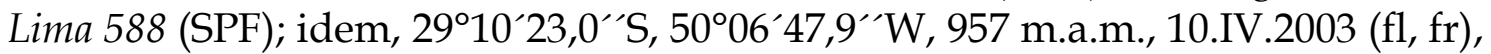
M. Magenta \& L.R. Lima 589 (SPF); idem, 29¹0`23,0“'S, 5006`47,9”W, 957 m.a.m., 10.IV.2003 (fl, fr), M. Magenta \& L.R. Lima 590 (SPF); idem, 29¹0`23,0`S, 5006`47,9”'W, 957 m.a.m., 10.IV.2003 (fl, fr), M. Magenta \& L.R. Lima 591 (SPF);

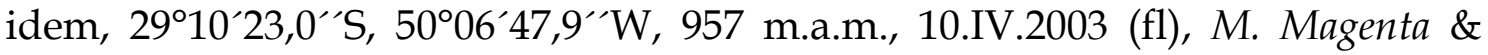
L.R. Lima 592 (SPF); estrada p/ o Parque Nacional dos Aparados da Serra a 11 $\mathrm{km}$ da portaria, 10.XII.2003 (fl), M. Magenta \& J. Magenta 700 (SPF); idem, 10.XII.2003 (fl, fr), M. Magenta \& J. Magenta 702 (SPF); idem, 10.XII.2003 (fl), M. Magenta \& J. Magenta 703 (SPF); Canela, estrada Passo do Inferno para Canela, 10.II.1941, B. Rambo s.n. (PACA 4670); Cruz Alta, Rincão dos Vales, próximo a Cruz Alta, Fazenda Cruz Alta, 20.IV.1893, G.O.A. Malme 794B (R, S); rodovia BR

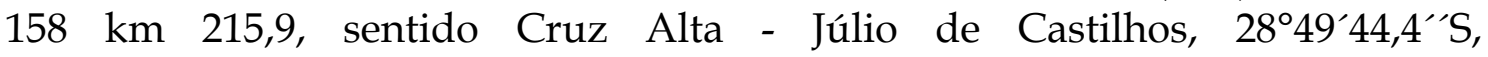
53³6`43,3“W, 387 m.a.m., 25.I.2003 (fl, fr), M. Magenta \& C. Mondin 530 (SPF); Eldorado do Sul, rodovia BR 116 km 290, 12.IV.1995 (fl, fr), N.I. Matzenbacher s.n. (ICN 106400); BR 290, 23.III.2002 (fl), C. Mondin \& A. Iob 2610 (HASU, SPF); Esmeralda, Estação Ecológica Aracurí, 920 m.a.m., 29.III.1982, L.A. Cestaro s.n. (HAS 28492); Lajeado, rodovia RST 453, entre Lajeado Grande e Tainhas, 30.XI.2002 (fl, fr), C. Mondin 2849 (HASU, SPF); rodovia RST $453 \mathrm{~km} \mathrm{207,5,}$ 9.XII.2002 (fl, fr), C. Mondin 2856 (HASU, SPF); idem, km 231, 9.XII.2002 (fl), C. Mondin 2857 (HASU, SPF); Muito Capões, rodovia BR $285 \mathrm{~km} \mathrm{142,} \mathrm{sentido}$

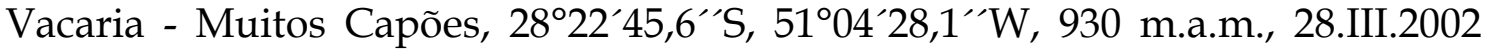
(fl), M. Magenta \& J. Magenta 413 (SPF); Nonoai, estrada Monoai para Uruguai, III.1945 (fl), B. Rambo s.n. (PACA 28329); Osório, 1.V.1950 (fl, fr), B. Rambo s.n. (ICN, PACA 46991); no topo do morro em frente a cidade, III.1987 (fl, fr), $M$. Sobral et al. 5700 (ICN); Palmeira das Missões, Palmeira para Uruguai, 30.I.1952 (fl), B. Rambo s.n. (PACA 51953, S); 13.XII.1966 (fl), J.C. Lindeman \& S. Haas 3637 (MBM); Porto Alegre, Fazenda Tristesa, 13.II.1902, G.O.A. Malme 1502 (S); idem, 13.III.1902, G.O.A. Malme 1503 (LP, S, UPS); Fonte Menino de Deus, 20.III.1902 (fl), G.O.A. Malme 1517 (GH, LP, R, S, UPS); $4 . I V .1941$ (fl, fr), Schultz 534 (ICN); Montesserrate, V.1941 (fl), W. Emmerich s.n. (ICN 32125); morro da Vila Manresa para Porto Alegre, X.1944 (fl, fr), B. Rambo s.n. (LP, PACA 27042); estrada Espírito Santo para Porto Alegre, 24.XII.1948 (fl), B. Rambo s.n. (PACA 39171); idem, 24.XII.1948 (fl), B. Rambo s.n. (PACA 39148); morro da Polícia para Porto Alegre, 27.XII.1948 (fl), B. Rambo s.n. (PACA 39214); estrada Vila Mansera para Porto Alegre, 3.III.1949 (fl), B. Rambo s.n. (PACA 40527); Morro Tapera, acesso pela estrada Juca Batista, 8.V.1979 (fl), O. Bueno 1376 (HAS); Morro Tapera, 
entrada para pedreira, 15.IV.1980 (fl), O. Bueno 2409, 2422 (HAS); Poá, Morro da Polícia, 26.III.1993 (fl, fr), C. Mondin 743 (ICN); Morro Teresópolis, Bairro de São

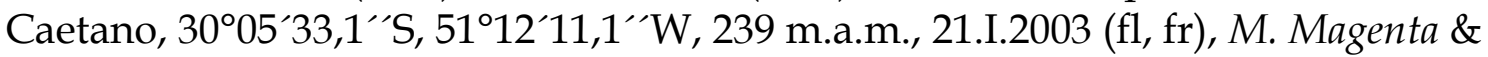
C. Mondin 504 (SPF); Santa Maria, estrada Silvicultura - Santa Maria, 10.III.1956 (fl, fr), O. Camargo 18 (PACA); Santana do Livramento, rodovia para Rosário do Sul, 18.XI.2001 (fl, fr), C. Mondin et al. 2508 (HASU, SPF); Cerro Paloma, 2.III.2002 (fl, fr), C. Mondin \& A. Iob 2586 (HASU, SPF); rodovia BR 158, próximo ao Cerro Paloma, 15.XI.2002 (fl, fr), C. Mondin \& A. Iob 2812 (HASU, SPF); rodovia BR $158 \mathrm{~km} \mathrm{543,6,} \mathrm{sentido} \mathrm{Caçapava} \mathrm{do} \mathrm{Sul} \mathrm{-} \mathrm{Santana} \mathrm{do} \mathrm{Livramento,}$ $30^{\circ} 21^{\prime} 36,8^{\prime \prime} \mathrm{S}, 53^{\circ} 28^{\prime} 04,4^{\prime \prime} \mathrm{W}, 132$ m.a.m., 23.I.2003 (fl), M. Magenta \& C. Mondin

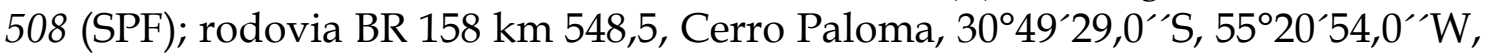
132 m.a.m., 23.I.2003 (fl), M. Magenta \& C. Mondin 511 (SPF); Santiago, estrada entre Bossoroca e Santiago, 28 $8^{\circ} 50^{\prime} 44,0^{\prime \prime} \mathrm{S}, 54^{\circ} 42^{\prime} 43,5^{\prime \prime} \mathrm{W}, 328$ m.a.m., 24.I.2003 (fl, fr), M. Magenta \& C. Mondin 527 (SPF); Santo Antônio da Patrulha, rodovia RS $030 \mathrm{~km}$ 61, sentido Santo Antonio - Glorinha, 14.XII.2003 (fl, fr), M. Magenta \& J. Magenta 708 (SPF); São Francisco de Paula, rodovia RS 20 km 125, 13.III.2002 (fl, fr), C. Mondin \& A. Iob 2595 (HASU, SPF); São Gabriel, Quaraí, Estância do Jarau, Fazenda Santa Cecília, I.1944 (fl, fr), B. Rambo s.n. (LP, PACA 26110); rodovia BR 290 km 289, 5.XII.1978 (fl, fr), A. Krapovickas \& C.L. Cristóbal 34175 (K); São Jerônimo, rodovia BR 290 km 140, 13.XII.2002 (fl, fr), C. Mondin 2859 (HASU, SPF); São José dos Ausentes, Serra da Rocinha, sentido São José

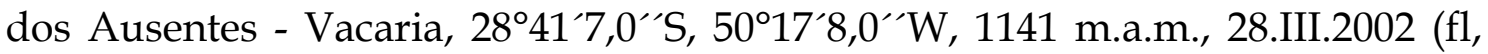
fr), M. Magenta \& J. Magenta 412 (K, SPF); estrada São José - Bom Jesus a $26 \mathrm{~km}$ de São José, 10.XII.2003 (fl), M. Magenta \& J. Magenta 704 (SPF); São Leopoldo, 5.III.1934 (fl), B. Rambo s.n. (PACA 549); 3.IV.1935 (fl), B. Rambo s.n. (PACA 1962); 21.IV.1937 (fl, fr), Dutra 1562 (ICN, LP); III.1941 (fl, fr), S.J.J. Eugênio 2620 (SP); III.1942 (fl, fr), S.J.J. Eugênio 108 (R, RB); Monserrato, 11.IV.1942 (fr), Irm. Augusto s.n. (ICN 19236); 30.III.1967 (fl, fr), F. Recena s.n. (ICN 50223); Torres, I.1939 (fl), J. Vidal s.n. (R 75773); Tupancireta, estrada entre Bossoroca e Jóia, $28^{\circ} 50^{\prime} 47,5^{\prime \prime} \mathrm{S}, 54^{\circ} 08^{\prime} 12,5^{\prime \prime} \mathrm{W}, 466$ m.a.m., 24.I.2003 (fl, fr), M. Magenta \& C. Mondin 528 (SPF); Vacaria, 27.II.1946 (fl), B. Rambo s.n. (PACA 32359); rodovia BR 116 km 08, sentido Lages - Vacaria, Serra Geral, 28¹6`19,1“'S, 5047’37,9”'W, 987 m.a.m., 27.III.2002 (fl), M. Magenta \& J. Magenta 405 (K, SPF, SPSR); Viamão, Lomabs para Viamão, 17.IV.1950 (fl, fr), B. Rambo s.n. (PACA 46888); Morro da Grota, caminho para ponta de Itapoã, 19.III.1980 (fl, fr), O. Bueno 2214 (HAS, R); município indefinido, Lagoa da Pinguela para Osório, 27.III.1955 (fl), B. Rambo s.n. (PACA 46578). Santa Catarina: Capão Alto, rodovia BR $116 \mathrm{~km} \mathrm{290,} \mathrm{sentido}$

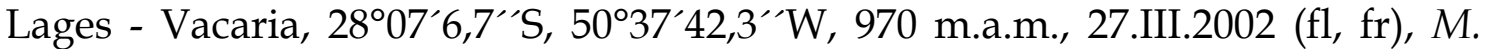
Magenta \& J. Magenta 403 (HUFU, K, SPF, SPFR); idem, 2808`47,6“'S, 50³9`31,7`W, 1040 m.a.m., 27.III.2002 (fl), M. Magenta \& J. Magenta 404 (SPF); Correia Pinto, rodovia BR $116 \mathrm{~km} \mathrm{227,} \mathrm{sentido} \mathrm{Correia} \mathrm{Pinto} \mathrm{-} \mathrm{Vacaria,}$ 27³8`35,7”S, 50²0`16,2”W, 957 m.a.m., 27.III.2002 (fl, fr), M. Magenta \& J. Magenta 397, 398 (SPF); Lages, rodovia BR 116 km 254,5, sentido Lages - Capão

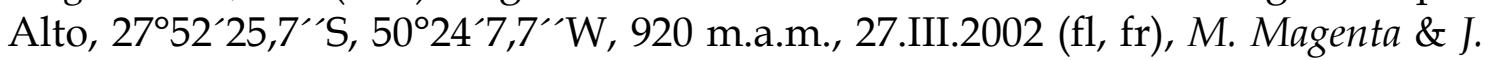
Magenta 401 (K, SPF); estrada que liga a Rodovia BR 116 a Lages, 14.IV.2003 (fl, fr), M. Magenta \& L.R. Lima 621 (SPF); idem, 14.IV.2003 (fl), M. Magenta \& L.R. 
Lima 622 (SPF); Santa Cecília, rodovia BR 116 km 141, Serra do Espigão, sentido São Cristovão do Sul - Ponte Alta do Norte, 2658`29,9”`S, 50²3’55,2”W, 1200 m.a.m., 27.III.2002 (fl), M. Magenta \& J. Magenta 394 (SPF); rodovia BR $116 \mathrm{~km}$

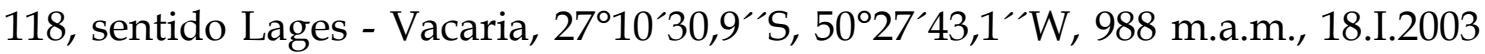
(fl, fr), M. Magenta \& J. Magenta 495 (SPF); Sombrio, Sombrio para Araranguá, Curralinho, 7.XII.1944 (fl, fr), R. Reitz C890 (LP, PACA, RB). Município indefinido, Cachoeira do Capivani, na Serra Geral, s.d. (fl), A. Glaziou 1499 (P). Sem indicação de estado, V.1887, A. Glaziou 16170 (K); s.d. (fl, fr), Sello 2509 (K). PARAGUAI: Caaguazu, $5 \mathrm{~km} \mathrm{E}$ de Caaguazú, rota 2, 8.II.1966 (fl), A. Krapovickas et al. 12519 (LP). Departamento indefinido, s.d. (fl), s.c. s.n. (LP 10229). URUGUAI: Colonia, Riachuelo, IV.1935 (fl), A.L. Cabrera 3302, 3333 (LP); Cunapirú, Cunapirú para Rivera, 12.I.1941 (fl), B. Rambo s.n. (PACA 4686); Montevideo, II.1926 (fl, fr), Herter 290 (M); Soriano, 28.III.1931 (fl), Herter 1109a (M). Departamento indefinido, III.1874 (fl, fr), Fruchard 196 (P); Frai Bentos, I.1877 (fl), Fruchard 31 (P).

2.2. Viguiera anchusifolia (DC) Baker var. immarginata S.F. Blake, Contr. Gray Herb. 54. 1918. Leighia immarginata DC, Prodr. 5: 581. 1836. Viguiera anchusaefolia var. immarginata (DC) S.F. Blake, Contr. Gray Herb. 54. 1918. Viguiera immarginata (DC) Herter, Revista Sudamer. Bot. 7 (6/8): 236. 1943. Tipo: Brésil. Province de Rio-Grande. Herb. Imp. Brés. 1052 (holótipo: P!; fotografia do holótipo: K!, SPF!).

Leighia stenophylla Hook. \& Arn., London J. Bot. 3: 313. 1841. Viguiera stenophylla (Hook. \& Arn.) Griseb., Abh. Königl. Ges. Wiss. Göttingen. 24: 193. 1879 [Symb. Arg.: 193. 1879]. Tipo: Buenos Ayres and Montevideo (síntipos: Tweedie 870 e 875: K!; fotografia dos síntipos: K!, SPF!). Obs.: os dois materiais estão na mesma exsicata, com mais três plantas de coletores e locais diferentes.

Helianthus angustifolius Spreng. ex Baker in Mart., Fl. bras. 6(3): 221. 1884, nom. nud. pro syn.

Helianthus montevidensis Spreng. ex Baker in Mart., Fl. bras. 6(3): 221. 1884, nom. nud. pro syn.

Material examinado: ARGENTINA: [Buenos Aires], La Plata, Elijalde, junto a via férrea, 2.IV.1929 (fr), A.L. Cabrera 779 (SP). BRASIL: Paraná: Laranjeiras do Sul, 85 km SW de Guarapuava, Fazenda da Reserva, Rio Reseva, 13.III.1967 (fl, fr), J.C. Lindeman \& S. Haas 4807 (K, MBM). Rio Grande do Sul: Barreiro, próximo Lagoa Vermelha, 28.I.1964 (fl), E. Pereira 8697 (RB); Bom Jesus, Fazenda Caraúna, III.1936 (fl, fr), Dutra 1281 (ICN, S); 15.I.1942 (fl), B. Rambo s.n. (PACA 8793); arredores de Capoeira Grande, 16.I.1942 (fl, fr), B. Rambo s.n. (PACA 
9008); perto de Vargem, na divisa com Santa Catarina, 29.XI.1977, J.R. Mattos \& N.F. Mattos 17731 (HAS); estrada para fazenda do Cilho, 1100 m.a.m., 15.III.1998 (fl, fr), R. Wasum s.n. (HUCS 12386, MBM); rodovia RS-110 km 8, 1000 m.a.m., 20.III.1999 (fl, fr), M. Rossato \& R. Wasum 99 (HUCS, MBM); Cambará do Sul, estrada para a Fortaleza, a $4 \mathrm{~km}$ da cidade, na copeira, 18.III.1983, N. Silveira \& R. Frosi 595 (HAS); Faxinal, III.1986 (fl), M. Sobral et al. 5063 (ICN); na rodovia para São Francisco de Paula, $12 . I I .1987$ (fl, fr), N. Silveira 4019 (HAS); idem, 10.III.1987 (fl), N. Silveira 7064 (HAS); em beira da estrada, 930 m.a.m., 10.III.2000 (fl, fr), R. Wasum 524 (HUCS, MBM); Cruz Alta, rodovia Santa Maria - Passo Fundo km 222, 28.IV.1988 (fl), J.R. Mattos 31561 (HAS); Esmeralda, 23.II.1983 (fl), G. Hiltll 1410 (HAS); Ijuí, 14.I.1977, J.R. Mattos \& N.F. Mattos 16652 (HAS); Ijuisinho, Ijuisinho para Tupanciretã, 30.I.1942, B. Rambo s.n. (PACA 10036); idem, 30.I.1942 (fl), B. Rambo s.n. (PACA 10056); Itaimbezinho, Itaimbezinho para São Francisco de Paula, 21.II.1951 (fl), B. Rambo s.n. (PACA 50062); 5.VI.2003 (fl), C. Mondin 2959 (HASU, SPF); Júlio de Castilhos, estrada para Santo Antão, no Passo do Felício, a 9 km da BR 158, 29¹9’37,5“'S, 533’38,8`'W, 435 m.a.m., 25.I.2003 (fl, fr), M. Magenta \& C. Mondin 532 (SPF); idem, Passo do Felício, ca. $15 \mathrm{~km}$ a SE da cidade, 15.II.1994 (fl), C. Mondin 830 (ICN); estrada para Santo Antão, no Passo do Felício, a $1 \mathrm{~km}$ da BR 158, 29¹6’06,1”S, 53³9`38,4”W, 491 m.a.m., 25.I.2003 (fl, fr), M. Magenta \& C. Mondin 533 (SPF); Porto Alegre, morro da Vila Manresa para Porto Alegre, 5.VII.1948 (fl), B. Rambo s.n. (PACA 37406); 26.III.1949 (fl), B. Rambo s.n. (PACA 40655); Bairro Serraria, Morro das Abertas, 26.III.1980 (fl, fr), O. Bueno 2289 (HAS, R); Morro Santana, no topo, 20.V.1980 (fl), O. Bueno 2493 (HAS, M); 30.III.1985 (fl, fr), J.R. Stehmann 593 (ICN); morro da Polícia, encosta sul, acesso para torre da Embratel, 17.IV.1986 (fl, fr), E.R. Chini 17 (HAS); Morro Santana, 10.XII.1993 (fl), N.I. Matzenbacher s.n. (ICN 103631); Morro do Osso, 17.I.1996 (fl), R.S. Rodrigues 56 (ICN); Santo Ângelo, 17.XI.1952 (fl), B. Rambo s.n. (PACA 53004); São Francisco de Paula, rodovia RS 20, Serra Geral, entre São Francisco de Paula e Tainhas, $29^{\circ} 25^{\prime} 07,5^{\prime \prime}$ S, 50²9’01,2”W, 941 m.a.m., 10.IV.2003 (fl), M. Magenta \& L.R. Lima 587 (SPF); estrada para Cambará do Sul, saída para a estrada da floresta do IBAMA, 15.II.2005 (fl), M.L.O. Trovó et al. 121 (SPF); São Gabriel, Fazenda Santa Cecília para São Gabriel, I.1944, B. Rambo s.n. (PACA 25775); São José dos Ausentes, Cascata da Rocinha, 10.XII.1994 (fl), N.I. Matzenbacher et al. s.n. (ICN 106240); Tupanciretã, 29.I.1942 (fl), B. Rambo s.n. (PACA 9794); Vacaria, Estação Experimental de Vacaria, 22.I.1967 (fl), A. Pott 67 (RB); margem do Rio Pelotas, Encanados, II.1997 (fl), M. Sobral et al. 8228 (MBM); na Estação Experimental, a $7 \mathrm{~km}$ na rodovia de Vacarias para bom Jesus, 23.II.1977 (fl), J.R. Mattos \& N.F. Mattos 16690 (HAS); quase na descida para o Vale do Rio Pelotas, 11.I.1978 (fl, fr), J.R. Mattos s.n. (HAS 65070). Município indefinido: Azulega para São Francisco de Paula, 15.II.1946 (fl), B. Rambo s.n. (PACA 32238). Santa Catarina: Curitibanos, $10 \mathrm{~km}$ oeste de Curitibanos, na estrada para Campos Novos, 850 m.a.m., 9.II.1957 (fl), L.B. Smith \& R. Klein 11128 (RB); Lages, rodovia BR 116, 5 km N de Lages, 940 m.a.m., 10.III.1976 (fl, fr), G. Davidse \& W.G. D’Arcy 11114 (SP); rodovia BR 116, 19 km N de Lages, direção a Porto Alegre, 960 m.a.m., 11.III.1976 (fl), G. Davidse 
\& W.G. D’Arcy 11136 (SP); km 50 na rodovia Lajes - Vacaria, 23.II.1977, J.R. Mattos \& N.F. Mattos 16794 (HAS); São Joaquim, Invernadinha, Fazenda Velha, III.1953 (fl), J.R. Mattos 1297 (HAS); Mantiqueira, Fazenda de Celso Vieira, 1.II.1958 (fl), J.R. Mattos 5470 (HAS). URUGUAI: Montevideo, Marzo.1875 (fl), Arechavelata 4115 (K); III.1875 (fl), E. Gilbert s.n. (LP 36265); Paysandú Tacuarembó, 3.III.1991 (fl), V. Eden 15672 (CTES, MBM); Soriano, Juan Jackson para Soriano, IV.1941 (fl), B. Rosengurtt PE 4776 (LP, PACA). Departamento indefinido: Fray Bentos, II.1877 (fl), Arechavelata 4167 (K).

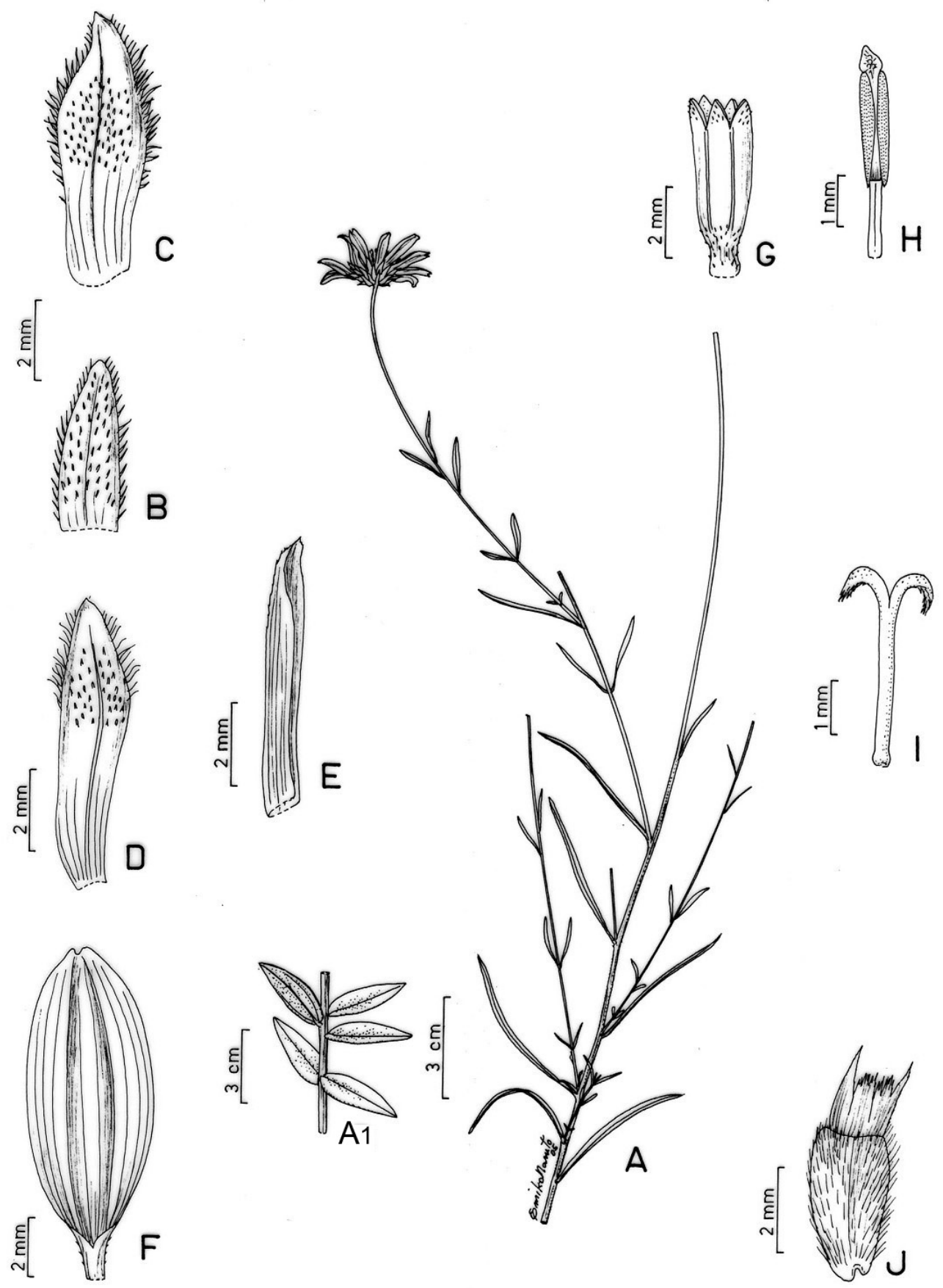


Fig. 8: V. anchusifolia A. var. immarginata, segmento de ramo com sinflorescência, A1. Var. anchusifolia, segmento da base do ramo, B-D. Brácteas involucrais, E. Pálea do receptáculo, F. Corola do raio, G. Corola do disco, H. Antera com tecas de base curtamente sagitada, terminando pouco abaixo da base do colar filetal, I. Estilete com alargamento basal semigloboso, J. Cipsela com escamas maiores que a metade do tamanho das aristas. A-J. $M$. Magenta \& J. Magenta 403 (SPF).

3. Viguiera arenaria Baker in Martius, Fl. bras. 6 (3): 226. 1884. Rhysolepis arenaria (Baker) H. Rob. \& A.J. Moore, Proc. Biol. Washington 117(7): 425. 2004. Tipo: Brasil, Santi Pauli, prope Arraial do Cajuru. Mar. 1857, Regnel III. $771^{x}$ (lectótipo aqui designado: BR!; fotografia do lectótipo: K!, SPF!; isolectótipos: S!, $\mathrm{US}^{*}, \mathrm{GH}$ - frag.) .

Figura 9

Erva cespitosa a subarbusto $0,8-3 \mathrm{~m}$ alt., ramos aéreos eretos, cilíndricos, esparsamente canaliculados a caniculados, esparsamente estrigosos a estrigosos e/ou setosos ou raramente vilosos; entrenós 2,5-4,5cm; caule subterrâneo fortemente espessado, raízes de tuberosidade fusifome na porção central ou próximo à extremidade. Folhas alternas verde-claras, sésseis ou pecíolo até $1 \mathrm{~mm}$, lâmina 2,5-12x1,7-7,5cm, oblonga, elíptica, oval, levemente oboval ou raramente largamente oval, base obtusa a arredondada, às vezes cuneada, ápice obtuso a agudo, levemente cartácea, inteira, ou muito esparsamente denteada, nervação acródroma basal perfeita, com 3(-5) nervuras primárias emersas, face adaxial com nervuras estrigosas, tricomas tectores 2-3-celulares de base cilíndrica geralmente apressa cercada por 1 série de células, tricomas glandulares, face abaxial com nervuras setosas, tricomas tectores 3-celulares, sem bossas ou com bossas inconspícuas, base cilíndrica ereta cercada por 1-3 séries de células, nervuras quaternárias com tricomas glandulares. Inflorescência laxa botrióide ou tirsóide, $15-13 \mathrm{~cm}$ alt., paracládios eretos a ascendentes, alternos, superiores terminando levemente acima do capítulo terminal, 1,5-12(-13)cm compr., esparsamente canaliculados, setosos, ebracteolados ou com bractéolas foliáceas 8-22x3-10mm; pedúnculo terminal 36cm compr. Capítulos radiados, 4,5-5,5cm diâm.; invólucro 10-14mm diâm., campanulado a levemente cilíndrico; brácteas involucrais 4-5 séries, geralmente reflexas na floração, coriáceas, base fortemente canaliculadas, 3 nervuras 
destacadas, foliáceas em 1/3 ou 1/2 superiores, face adaxial glabra, 1a série 2$7 \mathrm{~mm}$ alt., ovais a oblongas, ápice agudo mucronado, margem glabra ou ciliada, face abaxial com nervuras e ápice estrigosos, 2a série $4-7 \mathrm{~mm}$ alt., ovais, oblongas ou obovais, ápice agudo mucronado, cilioladas, face abaxial com nervuras setosas, superfície com glândulas, 3a série ovais,, oblongas ou obovais, cilioladas, face abaxial glabra ou raramente híspida, 4a e 5a séries 8$10 \mathrm{~mm}$ alt., ovais a oblongas, ápice agudo a obtuso, cilioladas ou ciliadas, face abaxial glabra ou raramente híspida; receptáculo convexo, páleas 7-8mm alt., obovais, cartáceo-coriáceas, translúcidas, carena estreita esparsamente estrigilosa, ápice obtuso a arredondado, curtamente denteado, 6 ou 8 nervuras.. Flores do raio ca. 12, em 1 verticilo, corola 11-18x4-6,5mm, tubo ca. 1,5mm alt., estrigiloso, limbo oblongo a elíptico, ápice curtamente 2-3-partido, face adaxial glabra ou híspida, com glândulas, face abaxial esparsamente estrigilosa a estrigosa, com glândulas, nervuras ca. 12; flores do disco ca. 35, corola ca. $5 \mathrm{~mm}$ alt., tubo 0,5-1mm alt., lobos com altura igual ou maior que o dobro da largura, limbo com face externa esparsamente hispídula a esparsamente setosa, lobos estrigosos, principalmente nas nervuras, tubo muito esparsamente estrigiloso; anteras de base curtamente sagitada, terminando acima ou na base do colar filetal, estilete com alargamento basal levemente fusiforme, estilopódio 0,120,14x0,34-0,40mm. Cipselas 4,5-5mm alt., levemente obovóides e tetragonais, curvas, estriadas, glabras a estrigilosas, carpopódio delgado; pápus estramíneo 2-aristado, aristas marginais ou levemente intramarginais, levemente desiguais, menor ca. 3mm alt., maior ca. 3,5mm alt., triangulares, porção basal alargada, ápice agudo, nervura estrigilosa, escamas 2 pares ca. $1 \mathrm{~mm}$ alt., unidas na base ou às vezes livres ou sem escamas.

Concentra-se principalmente no centro-leste do Estado de São Paulo, com poucas ocorrências no sudoeste de Minas Gerais (fig. 44B), em cerrados degradados e campos sujos. Floresce no verão e frutifica do verão ao outono.

Compartilha com $V$. gardneri e $V$. robusta a presença de brácteas involucrais em até cinco séries, com base fortemente canaliculada, e se diferencia pela textura mais delicada das folhas, de coloração verde-clara, pelas 
flores do raio maiores, com até $18 \mathrm{~mm}$ de comprimento, e pelo pápus com apenas dois pares de escamas muito pequenas ou sem escamas; as outras possuem lígulas com até $12 \mathrm{~mm}, V$. gardneri possui pápus com três a quatro pares de escamas e $V$. robusta com quatro a seis pares.

Nota nomenclatural: A escolha do lectótipo pauta-se no fato de que apenas o material depositado no BR apresenta identificação manuscrita por Baker, com as informações citadas no protólogo da espécie.

Material examinado: BRASIL: Minas Gerais: São Roque de Minas, Parque Nacional da Serra da Canastra, $14 \mathrm{~km}$ após portaria do Sacramento, 11.I.1998 (fl, fr), F.B. Costa et al. 57 (SPF, SPFR); Parque Nacional da Serra da Canastra, estrada para a Cachoeira do Fundão, 20 $15^{\prime} 15,8^{\prime \prime} \mathrm{S}, 46^{\circ} 37^{\prime} 30,9^{\prime \prime} \mathrm{W}$, 1366 m.a.m., 17.IV.2003 (fl, fr), M. Magenta \& J. Magenta 632 (SPF); Termópolis, balneário de Águas Quentes, IV.1945 (fr), J. Vidal I-731 (R). São Paulo: Altinópolis, Morro do Forno, 14.I.1993, W. Marcondes-Ferreira et al. 529, 530 (SPFR); idem, 14.I.1993 (fl, fr), W. Marcondes-Ferreira et al. 541 (SPFR); idem, 12.III.1993, W. Marcondes-Ferreira et al. 585, 586 (SPFR); idem, 17.III.1994 (fl, fr), W. Marcondes-Ferreira et al. 745 (SP, SPF); Araraquara, 26.I.1963 (fl), A.S. Grottas 289 (MBM, SPF); Cajurú, Province Saint Paulo. Cajurú, 18.III.1957 (fl, fr), A.F. Regnell III.771x (S); Corumbataí, 20.II.1978, J.C. Toledo 10 (HRCB); 22.II.1983, C.M. Beltrati 4 (HRCB); 5.III.1985, L.C. Saraiva 44 (HRCB, SPF); II.1996 (fl), V.T. Rampin 834 (HRCB, SPF); Itirapina, próximo a cidade, 18.I.1983 (fl, fr), H.F. Leitão Filho et al. 14447 (RB, UEC); Estrada de Graúna, 2.II.1993 (fl, fr), F. Barros 2521 (SP, TENN); 24.III.1993 (fl, fr), V.C. Souza \& L. Ferraro 2592 (ESA); estrada

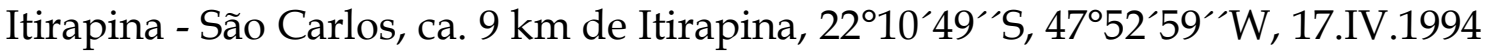
(fr), V.C. Souza et al. 5788 (ESA, SPF, UEC); Rodovia Anhanguera km 264, 13.V.1994 (fr), W. Vichnewski et al. 31638, 31639 (UEC); rodovia de acesso a Itirapina, próximo a Rodovia Wasghinton Luis, 13.V.1994 (fr), W. Vichnewski et al. 31649 (UEC); próximo ao pedágio, Represa do Broa, 22¹0`52,3”S, 4752`48,6“'W, 8.XII.1994 (fl, fr), K.D. Barreto et al. 3362 (ESA); rodovia BR 225 $\mathrm{km} \mathrm{107,} \mathrm{Bairro} \mathrm{do} \mathrm{Lobo,} \mathrm{ao} \mathrm{lado} \mathrm{do} \mathrm{posto} \mathrm{Siriema,} \mathrm{em} \mathrm{frente} \mathrm{a} \mathrm{Fazenda} \mathrm{Siriema,}$ 23.XII.2001 (fl, fr), M.A. Farinaccio \& A.A. Araújo 486 (SPF); vicinal da estrada Itirapina - Ubá, $22^{\circ} 16^{\prime} 58^{\prime \prime} \mathrm{S}, 47^{\circ} 48^{\prime} 08,9^{\prime \prime} \mathrm{W}, 760$ m.a.m., 11.II.2002 (fl), M.

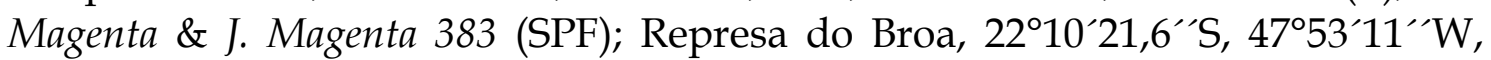
794 m.a.m., 11.II.2002 (fl), M. Magenta \& J. Magenta 384 (SPF); Luís Antônio, Estação Ecológica de Jatão, 2.II.1993, M.R. Mechi \& S. Mateus 173 (SPFR); Mogi Guaçu, 24.III.1994, M.F. Tertuliano 36 (RB, SP); Porto Ferreira, 14.II.1954 (fl, fr), R. Wasicky s.n. (SPF 15244); Santa Rita do Passa Quatro, Cerrado Pé-de-Gigante, 6.II.1996, M. Silva et al. 1008 (SP); A.R.I.E. Cerrado Pé-do-Gigante, 21³6-44'S, 47³4-41'W, 7.I.1997 (fl, fr), M.A. Batalha 1571 (SPF); idem, 10.I.1997, S.A.P. Godoy 793 (SPFR); idem, 16.I.1998, S.A.P. Godoy et al. 1263 (SPFR); idem, 12.I.1998, V.L. Weiser 16, 17 (SPFR); A.R.I.E. Cerrado Pé-do-Gigante, Parque

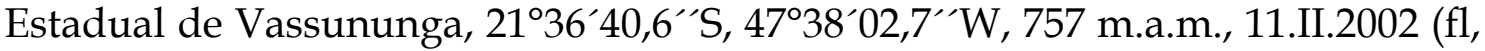

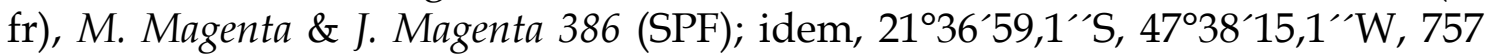


m.a.m., 11.II.2002 (fl, fr), M. Magenta \& J. Magenta 387 (K, SPF); São Carlos, Rodovia Washington Luiz km 222, estrada para Analândia, 25.III.1963, G.M. Felippe 170 (RB, SP); Represa do Broa, 1.X.1980 (fl, fr), J. Semir et al. 11560 (UEC); Rodovia Wasghinton Luís entre São Carlos e Itirapina, 13.V.1994 (fr), W. Vichnewski \& F.B. Costa 31640 (UEC); Rodovia Washington Luiz, Itirapina - São Carlos 1 km Posto Castelo, 2204'49,1”'S, 4750'20,2"W, 793 m.a.m., 13.XI.1996, F.B. Costa \& W. Lopes 1 (SPFR); idem, 7.III.1997 (fl), F.B. Costa et al. 7 (SPFR); Rodovia Washington Luiz, III.1999, F.B. Costa 93 (SPFR); Rodovia Washington Luiz, Itirapina - São Carlos 1 km Posto Castelo, 2204'49,1"'S, 4750'20,2"W, 793 m.a.m., III.2000, F.B. Costa 103 (SPFR); Rodovia Washington Luiz km 223,5, sentido São Carlos - Itirapina, 26.I.2001 (fl), M. Magenta \& J. Magenta 275 (SPF); idem, 2204'49,1“S, 47050`20,2”W, 793 m.a.m., 26.I.2001, M. Magenta \& J.

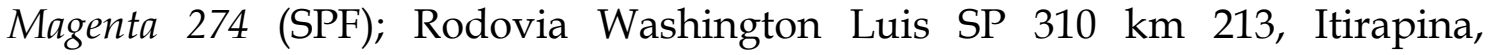
23.XII.2001 (fl), M.A. Farinaccio \& A.A. Araújo 487 (ESA, SPF, UEC); São Simão, Horto Florestal, junto à Estação Bento Quirino, 22.V.1957 (fr), M. Kuhlmann 4100 (RB, SP); Fazenda Aritozina, 29.I.1982 (fl, fr), H.F. Leitão Filho et al. 13264 (UEC); s.d. (fl, fr), H. Sartori 28 (SP). 


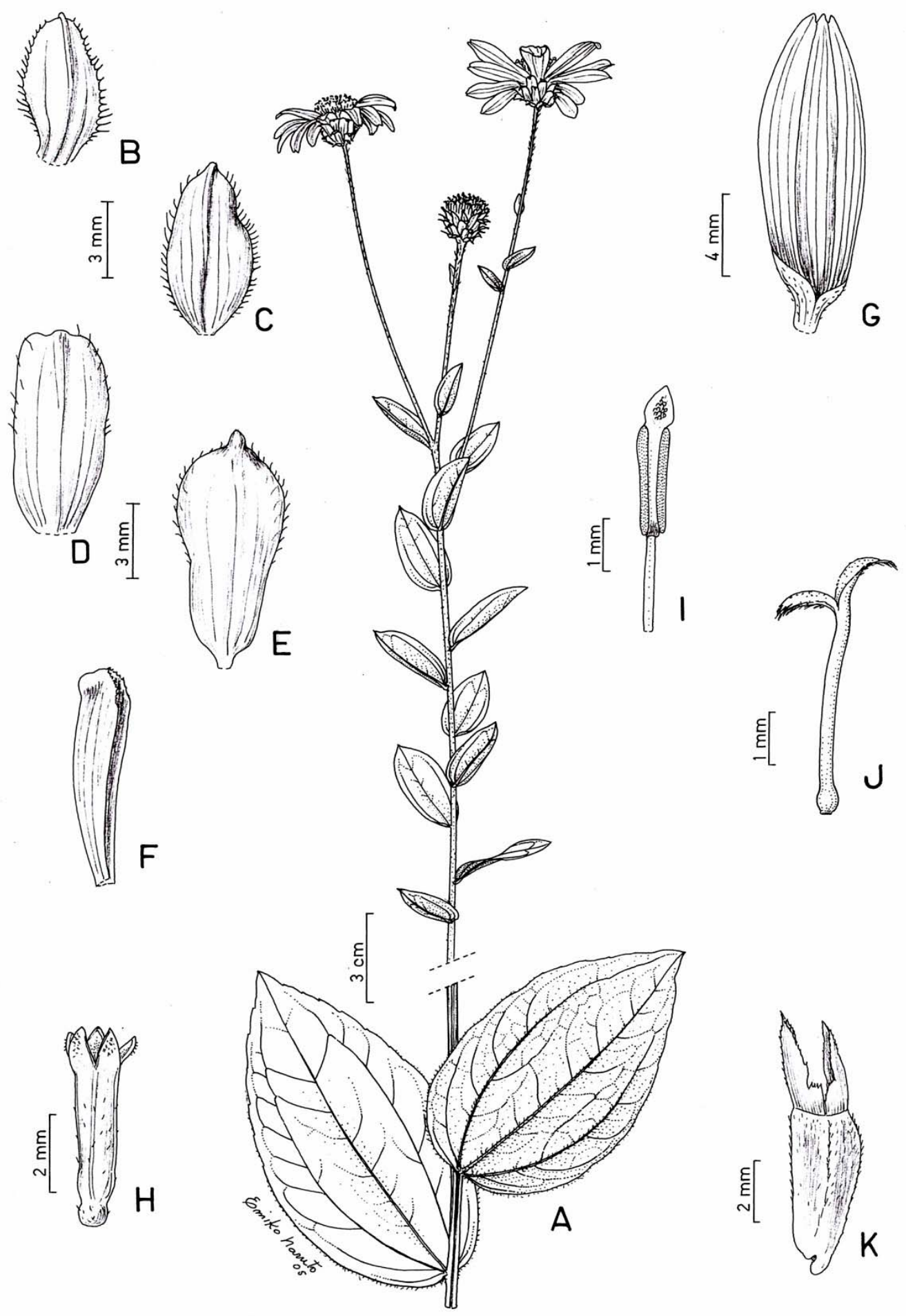

Fig. 9: V. arenaria. A. Segmento de ramo com sinflorescência, B-E. Brácteas involucrais, F. Pálea do receptáculo, G. Corola do raio, H. Corola do disco, I. Antera com tecas de base curtamente sagitada, terminando levemente acima da base do colar filetal, J. Estilete com base levemente fusiforme. K. Cipsela . A-J. A. M. Magenta \& J. Magenta 383 (SPF). 
4. Viguiera aspilioides Baker in Martius, Fl. bras. 6 (3): 228. 1884. Wedelia aspilioides (Baker) B.L. Turner, Phytologia 72(5): 391. 1992. Rhysolepis aspilioides (Baker) H. Rob. \& A.J. Moore, Proc. Biol. Washington 117(7): 425. 2004. Tipo: Brasil. Facienda de Santa Anna, Sello 669 [provavelmente B, destruído] (neótipo aqui designado: Sello s.n. K! - esboço; fotografia do neótipo: SPF!). VER TL-2

Figuras $2 \mathrm{~F}$ e 10

Erva a arbusto 0,4-1m, ramos aéreos delicados, flexíveis, cilíndricos, estreitamente canaliculados, hirsutos; entrenós 2-8cm; caule subterrâneo levemente espessado, raízes adventícias delgadas, com grande tuberosidade globosa na porção terminal. Folhas verde-claras ou levemente discolores, opostas, ou inferiores raramente alternas, medianas $8-19 \mathrm{~cm}$, inferiores reduzidas, sésseis, lâmina estreitamente elíptica, revoluta; base atenuada, ápice acuminado ou agudo, mucronado, cartácea, inteira, muito esparsamente denticulada ou esparsamente serreada na porção superior, nervação acródroma suprabasal imperfeita, 3 nervuras principais, hirsuta a híspida, tricomas tectores multicelulares, sem bossas ou com bossas inconspícuas de base cônica a cilíndrica apressa, cercada por uma série de células, axilas às vezes com folhas jovens. Capítulos solitários ou raramente em inflorescência botrióide, $20-50 \mathrm{~cm}$, paracládios alternos ebracteolados ascendentes terminando abaixo do capítulo terminal; freqüentemente vináceos, estriados, seríceos próximo ao capítulo; pedúnculo terminal $15-50 \mathrm{~cm}$. Capítulos $5-8 \mathrm{~cm}$ diâm., radiados, às vezes subtendidos por 1-2 bractéolas 1-2cm, lineares, hirsutas; invólucro 1,2-2cm diâm., campanulado, brácteas involucrais levemente apressas na floração, em 23 séries, elíptico a oboval-lanceoladas, totalmente foliáceas ou em 3/4 superiores, base às vezes levemente caniculada, uma nervura destacada, ápice agudo a acuminado mucronado, margem ciliada, cartáceas ou internas levemente estramíneas, face adaxial glabra ou com ápice estrigoso; 1 a série 9$12 \mathrm{~mm}$, face abaxial híspida e estrigosa, 2a série $12-18 \mathrm{~mm}$, face adaxial glabra, 3a série 10-12mm; receptáculo fortemente convexo a cônico, páleas $8-9 \mathrm{~mm}$, oblongas, 6 ou 8 nervuras, cartáceas, carena estreita estrigilosa, ápice agudo ou 
arredondado denteado, mucronado. Flores do raio 13, em 1 verticilo, corola 2530x6-8mm, tubo ca. $2 \mathrm{~mm}$, limbo oblongo a levemente elíptico, ápice curtamente 3-partido, face adaxial glabra, face abaxial com 11-12(-13) nervuras estrigilosas e tubo híspido; flores do disco 50-130, corola ca. 5mm; tubo ca. 1mm, delicado, lobos com altura igual ou maior que o dobro da largura; face externa com base esparsamente pubescente e lobos e tubo estrigilosos; antera de base curtamente sagitada, terminando na base do colar filetal; estilete com alargamento basal semigloboso, estilopódio 0,10-0,12x0,24-0,28mm. Cipselas 4,5-5mm estreitamente obovóides, levemente tetragonais, estriadas, seríceas, carpopódio espesso; pápus amarelo-dourado com pontos vináceos, 2-aristadas, aristas marginais levemente desiguais, livres, 2,5-3mm, parte inferior oval, ápice acuminado, nervura estrigilosa, escamas ca. 4 pares, 1,5-2mm, unidas até o ápice eroso.

Ocorre isolada ou em pequenas populações, no sudeste do Paraná, em regiões próximas a Ponta Grossa (fig. 43A), em campos limpos secos, em beira de estradas, indicando risco de extinção, segundo os critérios da IUCN (distribuição restrita e tamanho populacional reduzido). Floresce durante a primavera e o verão.

Freqüentemente confundida com $V$. tenuifolia, mas esta espécie apresenta raízes muito delgadas, com uma grande tuberosidade globosa na região terminal, indumento hirsuto com tricomas multisseriados sem bossas ou com bossas inconspícuas, e escamas do pápus de ápice eroso, enquanto $V$. tenuifolia apresenta raízes com tuberosidade fusiforme nas porções basal ou central, indumento estrigoso, com tricomas 3-seriados de bossas conspícuas na célula central e escamas do pápus com ápice eroso fimbriado. A semelhança entre as duas espécies levou Robinson (1984) a comentar que Aspilia linearifolia (na verdade, $V$. tenuifolia) Baker seria evidentemente Viguiera aspilioides Baker. Assim como esta última, A. linearifolia está representada por um desenho do tipo, no herbário K, com referência a um número de coletor (Sello 1053) que, de acordo com o trabalho de Herter \& Rambo (1953) teria sido coletado em Minas Gerais, onde a espécie encontrada é $V$. tenuifolia. 
Na revisão para o gênero, Blake (1918) referiu o tipo como pertencendo ao Estado do Mato Grosso, certamente desconhecendo o itinerário percorrido por Sello (Herter \& Rambo 1953) e a "Facienda de Santa Anna" existente no Paraná, na época em que a espécie foi descrita, e ligando o nome a cidade de Santa Anna da Chapada, atual Chapada dos Guimarães.

Não foi possível localizar o material-tipo ou qualquer espécie de imagem desta espécie em nenhum dos seguintes herbários: B, BR, BM, F, G, GOET, HAL, K, M, MO, NY, P, W. O material-tipo foi provavelmente depositado em Berlim, e destruído durante a $2^{\mathrm{a}}$ guerra mundial; também não consta nos registros fotográficos do herbário do Field Museum onde existe, citada como fotografia de tipo, a imagem de um espécime sob o número Sello 1095. O único material encontrado analisado por Baker (com sua caligrafia) é um desenho de uma coleção de Sello, no herbário K, da mesma localidade do tipo, mas sem número e sem indicação do material utilizado para sua confecção; na ausência de outro material representativo examinado nos herbários europeus visitados ou consultados, o esboço foi considerado como neótipo, já que o holótipo está desaparecido.

Material examinado: BRASIL: Paraná: Colombo, Rio Canguiri, 3.X.1967 (fl), G. Hatschbach 17257 (LP, MBM); Palmeira, Rio do Salto, 10.XI.1951 (fl), G. Hatschbach 2693 (MBM); Rio dos Papagaios, 14.X.1966 (fl), J.C. Lindeman \& S. Haas 2672 (MBM); Ponta do Papagaio, 22.IX.1982 (fl), G. Hatschbach 45454 (MBM); Rio dos Papagaios, 15.X.1985 (fl), P.I. Oliveira 965 (BR, MBM); Pinhão, Rio Reserva, salto da Fazenda Reserva, 24.II.1996 (fl), G. Hatschbach et al. 645 (MBM); Ponta Grossa, Vila Velha, 17.XI.1964 (fl), E. Santos \& J.C. Sacco 2111 (R, RB); idem, 17.XI.1964 (fl, fr), E. Santos \& J.C. Sacco 2124 (PEL, R); Fazenda Barrozinha, 1.X.1965 (fl), G. Hatschbach 12847 (MBM, P, UB); anfiteatro, 27.IX.1973 (fl), G. Hatschbach 32583 (MBM); estrada que liga BR 376 a Itaiaoca, 2507`43,8`S, 5001`57,6`W, 1016 m.a.m., 21.IX.2002 (fl), M. Magenta \& J. Magenta 477, 478 (SPF); estrada que liga Ponta Grossa a PR 151, 2502’33,9’S, 50¹4`17,7`W, 960 m.a.m., 21.IX.2002 (fl, fr), M. Magenta \& J. Magenta 479 (SPF); Porto Amazonas, Recanto dos Papagaios, Rodovia BR 277, 5.X.2001 (fl, fr), J.M. Silva \& O.S. Ribas 3485 (MBM). Município indefinido: Capão Grande, 18.XII.1903 (fl), P.H. Davis 2784 (R). 


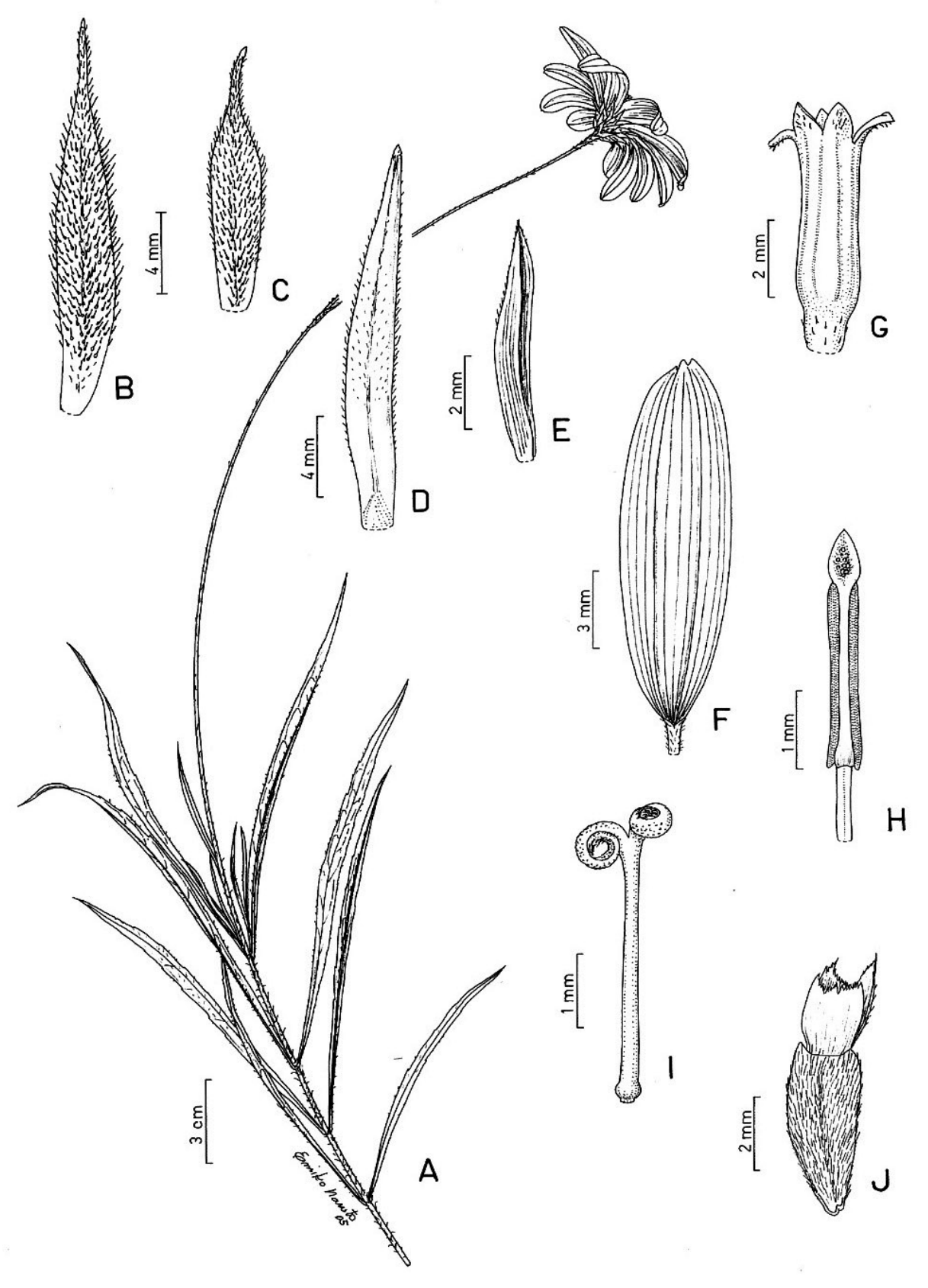

Fig. 10.: V. aspilioides. A. Segmento de ramo portando pedúnculo ebracteolado com capítulo solitário, B-D. Brácteas involucrais, E. Pálea do receptáculo, F. Corola do raio, G. Corola do disco, H. Antera com tecas de base curtamente sagitada, terminando na base do colar filetal, I. Estilete com alargamento basal semigloboso, J. Cipsela com aristas intramarginais e escamas do pápus unidas. A. M. Magenta \& J. Magenta 477 (SPF), B-J. Idem, 479 (SPF). 
5. Viguiera bakeriana S.F. Blake, Contr. Gray Herbarium n. ser. 54: 131. 1918. Rhysolepis bakeriana (S.F. Blake) H. Rob. \& A.J. Moore, Proc. Biol. Washington 117(7): 425. 2004. Tipo: Brasil, 'Environs de Rio de Janeiro et Ouro Preto, 188384', Glaziou 15007 [Minas Gerais, entre Barbacena \& Sitio, 15.Nov.1884 (P)] (lectótipo aqui designado: K!; fotografia do lectótipo: K!, SPF!; isolectótipos: P!, $\mathrm{GH}$ - frag., $\mathrm{NY}^{*}$.).

Tridens varius Pohl ex Baker, Fl. bras. 6(3): 225. 1884, nom. nud., pro syn.

Viguiera subdentata S.F. Blake, Contr. Gray Herb. 54: 131. 1918. Tipo: Brésil. Province de Minas Geraes. 1816 a 1821, A. St.-Hil. 1160. Rhysolepis subdentata (S.F. Blake) H. Rob. \& A.J. Moore, 1.c.: 432. 2004 (holótipo: P!; fotografia do holótipo: GH!; isótipo: $\left.\mathrm{US}^{*}\right)$. Syn. nov.

Figura 11

Ervas a subarbustos $30-80 \mathrm{~cm}$ alt., ramos aéreos eretos cilíndricos, canaliculados, setosos e com glândulas; entrenós 3-7cm compr.; caule subterrâneo fortemente espessado, raízes de tuberosidade fusiforme curta na região central. Folhas verde-claras, inferiores opostas, reduzidas, superiores opostas ou alternas, sésseis ou pecíolo 1-1,5mm compr.; lâmina 5,5-9,5x1,5-3(-4)cm, oblonga, largamente oblonga, elíptica, levemente oboval ou oval, base obtusa, levemente oblíqua, ápice obtuso, agudo ou raramente truncado e denteado, geralmente mucronado, porção superior denteada a serreada, nervação acródroma basal perfeita, com 3-5 nervuras principais, face adaxial híspida a estrigosa nas nervuras, tricomas tectores 3-4-celulares com bossas nas células centrais, de base cônica levemente apressa, cercada por 1 série de células, face abaxial com nervuras híspidas a hirsutas, tricomas tectores 3-celulares com bossas na célula central, tricomas glandulares esparsos; entrenós de tamanho alternado, os maiores 2,5-11cm compr., os menores 2-12mm compr. Inflorescência botrióide ou tirsóide laxas, $5-50 \mathrm{~cm}$ alt., paracládios eretos, , superiores terminando acima do capítulo terminal, $7-45 \mathrm{~cm}$ compr., canaliculados, estrigosos a densamente estrigosos próximo ao capítulo, com bractéolas 15-25mm compr., lineares ou elípticas; pedúnculo terminal $5-38 \mathrm{~cm}$ compr. ou capítulos solitários. Capítulos 3-5cm diâm., radiados, invólucro 1,5-2cm diâm., campanulado; brácteas 
involucrais levemente apressas na floração, em 2-3 séries, elíptico a ovallanceoladas, uma nervura levemente destacada, ciliadas, face adaxial estrigilosa, face abaxial estrigosa, 1a série $6,5-13 \mathrm{~mm}$ alt., ápice acuminado, cartáceas, totalmente foliáceas, com glândulas, 2a e 3a séries $8-14 \mathrm{~mm}$ alt., base estriada, foliáceas em $1 / 2$ superior ou às vezes totalmente foliácea, ápice geralmente estramíneo, às vezes com glândulas; receptáculo convexo, páleas 9$10 \mathrm{~mm}$ alt., oblongas a estreitamente oblongas, ápice agudo mucronado, curtamente lacerado, sem carena ou com carena muito estreita, 6 ou 8 nervuras, estrigilosas e com tricomas glandulares. Flores do raio 10-12(-15-16), em 1-2 verticilos, corola $20-25 \times 5-9 \mathrm{~mm}$, tubo ca. $1 \mathrm{~mm}$ alt., limbo elíptico a largamente elíptico, ápice curtamente 2-partido, face adaxial glabra a esparsamente hispídula, face abaxial com glândulas e 15-18 nervuras híspidas a estrigosas, tricomas adensados na base; flores do disco 65-70, corola 4-4,5mm alt., tubo ca. 0,5mm alt., face interna com glândulas, face externa estrigilosa, tricomas adensados nos lobos, anteras de base curtamente sagitada terminando acima ou na base do colar filetal, estilete com alargamento basal curtamente cilíndrico a curtamente cônico, estilopódio 0,4-0,8x0,38-0,40mm. Cipselas 4-4,5mm alt., obovóides, comprimidas, levemente tetragonais, estreitamente estriadas, ápice estrigoso, carpopódio médio; pápus amarelo-dourado, geralmente com manchas vináceas, 2-aristado, aristas intramarginais 2-3mm alt., estreitamente triangulares a triangulares, base estrigosa, ápice agudo a acuminado, geralmente unidas às escamas laterais; escamas ca. 4 pares, 1,5-1,8mm alt., unidas até o meio, livres ou raramente unidas até próximo ao ápice lacerado.

Ocorre principalmente nas regiões noroeste, centro-oeste e sudoeste do Estado de Minas Gerais (fig. 44B), em cerrados íntegros ou degradados, campo sujo, campos pedregosos, afloramentos rochosos, mas conhecem-se dois registros de outros estados: um em Santa Catarina (A. St.-Hil., 1816-1821), aparentemente um engano, já que não há coletas no Estado de São Paulo, e outro em Ilhéus, no leste do Estado da Bahia (Silveira, Ago. 1894). Floresce e frutifica de setembro a dezembro, com picos em outubro e novembro. 
As plantas coletadas na Serra do Cipó, encontradas em cerrado argiloso pedregoso, possuem folhas muito escabrosas, com nervação saliente na face abaxial. Diferencia-se de $V$. discolor pelas brácteas involucrais externas inteiramente foliáceas, com ápice acuminado e pápus com aristas intramarginais eretas, sem carena ou com carena inconspícua; $V$. discolor apresenta brácteas involucrais externas com base canaliculada, com 1 a 3 nervuras muito salientes e ápice agudo ou obtuso e pápus com aristas marginais recurvadas, robustas, com carena conspícua.

Blake (1918) cometeu um erro, ao relacionar esta espécie ao nome $V$. dissitifolia Baker que, na verdade, corresponde a $V$. anchusifolia (DC) Baker. Isso certamente ocorreu por Baker (1984) ter citado muitos materiais pertencentes de fato a espécie descrita acima, na lista de materiais examinados.

Nota nomenclatural: A escolha do lectótipo pauta-se no fato de que somente o espécime depositado no herbário K possui identificação manuscrita por S.F. Blake, com as informações citadas no protólogo da espécie, numa indicação de ser o material usado pelo autorn para sua descrição.

Material examinado: BRASIL: Bahia: Ilhéus, VIII.1894 (fl), A. Silveira 205 (R). Minas Gerais: Alpinópolis, rodovia Alpinópolis - Carmo do Rio Claro, $3 \mathrm{~km}$ antes Alpinópolis, 17.X.1997 (fl, fr), F.B. Costa et al. 27, 28 (SPF, SPFR); idem, 3 $\mathrm{km}$ após Alpinópolis, alto do morro, X.1998, F.B. Costa \& N.L. Lopes 92 (SPF, SPFR); idem, km 536, 2052`44”'S, 46²4`22”W, 907 m.a.m., 21.X.2001 (fl, fr), M. Magenta \& J. Magenta 291 (K, SPF); Belo Horizonte, 2.XII.1924 (fl, fr), A. Lutz 1678 (R); XII.1929, s.c. s.n. (RB 4848); Parque Vera Cruz, 20.XI.1932 (fl), MelloBarreto 4138 (BHCB); Serra do Taquaril, 20.XII.1932 (fl), Mello-Barreto 4140 (BHCB, R); Pampulha, 28.XII.1948 (fl), Palacios et al. 3733 (R); Carandaí, entre Carandaí e Brejão de Minas, 28.XI.1946 (fl), A.P. Duarte 692 (RB); Carandaí Brejão, 28.XI.1946 (fr), A.P. Duarte 715 (RB, SPF); Carandaí - Santa Cecília, 26.X.1952 (fr), A.P. Duarte s.n. (RB 85092); Carrancas, Cachoeira da Fumaça, Serra da Carrancas, 9.XII.1983 (fl, fr), H.F. Leitão Filho et al. 15422 (UEC); Congonhas, rodovia BR 383 km 08, entre a BR 040 e São João Del Rei, Serra da Moeda, 22.X.2002 (fl, fr), M. Magenta \& J. Magenta 492 (SPF); Divinópolis, Bairro Belverede, 672 m.a.m., 28.XII.1989, F.N. de Oliveira 151 (UFLA); Entre Rios de Minas, rodovia BR 383 km 46, sentido Entre Rios - São João Del Rei, 22.X.2002 (fl), M. Magenta \& J. Magenta 493 (SPF); Esmeraldas, Fazenda Paraíso, 3.IX.1979 (fl, fr), D.S . Rocha 10565 (UEC); estrada que vai de Esmeraldas para Ribeirão das Neves, km 07, 20.X.2002 (fl, fr), M. Magenta \& J. Mag enta 485 (SPF); Lagoa Dourada, rodovia BR $383 \mathrm{~km}$ 73, sentido Lagoa Dourada - São João Del Rei, 205`39,2”S, 4407’10,2`W, 1130 m.a.m., 22.X.2002 (fl, fr), M. Magenta \& J. 
Magenta 494 (SPF); Lagoa Santa, XI.1915 (fl, fr), F.C. Hoehne 6480 (R); Lapa Vermelha sobre o Maciço, 17.X.1977, J.L. Pedersolli \& P. Prous 95 (BHCB); Lassance, Serra do Cabral, 9.XII.1919 (fl), A. Lutz 1572 (R); Lavras, um pouco a leste de Lavras, 13.X.1941 (fl, fr), G. Black 472 B2 (BHCB); estrada Lavras - São João Del Rey, km 123, 4.X.1978 (fl, fr), S.J. Sarti 8481 (UEC); Paraopeba, Horto Florestal de Paraopeba, 13.XII.1956 (fr), E.P. Heringer 5461 (RB, UB); Pedra do Indaiá, rodovia MG $050 \mathrm{~km}$ 165, sentido Divinópolis - Pimenta, 20¹7`47,2’S, $45^{\circ} 11^{\prime} 09,1^{\prime} \mathrm{W}, 900$ m.a.m., 20.X.2002 (fl, fr), M. Magenta \& J. Magenta 484 (SPF);

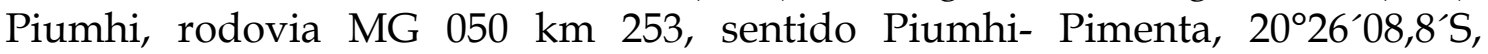
455ㄴ $37,8^{\prime}$ W, 902 m.a.m., 20.X.2002 (fl, fr), M. Magenta \& J. Magenta 483 (SPF); Santa Luzia, Fazenda da Chiaca, 1100 m.a.m., 25.X.1945 (fl), V. Assis 24 (RB); Fazenda da Chiaca, 1100 m.a.m., 20.XI.1945 (fl, fr), V. Assis 153 (GH, LP, RB); Santana do Riacho, Serra do Cipó, rodovia Belo Horizonte - Conceição do Mato Dentro, km 105, 6.X.1981 (fl, fr), I. Cordeiro et al. CFSC 7549 (SPF, UEC); Parque Nacional da Serra do Cipó, trilha para Cachoeira do Gavião, 19²0 35,3”S, 43³5'16,3"W, 822 m.a.m., 21.X.2002 (fl), M. Magenta \& J. Magenta 487 (SPF); idem, trilha para Cachoeira do Gavião e Bandeirinhas, 19 21'42's, 43³4'28,4"W, 1030 m.a.m., 21.X.2002 (fl, fr), M. Magenta \& J. Magenta 488 (SPF); rodovia MG $010 \mathrm{~km} \mathrm{104,} \mathrm{sentido} \mathrm{Santana} \mathrm{do} \mathrm{Riacho} \mathrm{-} \mathrm{Conceição} \mathrm{do} \mathrm{Mato}$ Dentro, 19¹7'55,6“'S, 4336'08,6"W, 1072 m.a.m., 21.X.2002 (fl, fr), M. Magenta \& J. Magenta 490 (SPF); São João del Rey, 8.I.1965 (fl, fr), A.P. Duarte 8711 (RB); X.1969 (fl, fr), L. Krieger, Pe. 7412 (CESJ, RB, SPF); Sete Lagoas, 14.XII.1948 (fl, fr), Palacios et al. 3691 (R); CNPMS, Embrapa, 28.X.1982 (fl), R.C.F. de Carvalho 92 (BHCB); Várzea da Palma, Fazenda Mãe D’Agua, 21.XI.1962 (fr), A.P. Duarte 7424 (RB). Município indefinido: Minas Geraes, Brésil, Ouro Preto, 1844 (fl, fr), M. Weddell 1573 (P); XI.1905 (fl, fr), A.J. Sampaio 260 (R); Province de Minas Geraes, Brésil, 1916-1921 (fl), A. St.-Hil. 1282, 1283 (P); Serra do Cipó, 12.XI.1959 (fl), E.P. Heringer 7287 (RB); Brésil, s.d. (fl), A. Glaziou 12806 (P); Brésil, s.d. (fl, fr), A. Glaziou 14006 (P). [Minas Gerais]: Município indefinido: in campis "sieccis" próximo Lagoa Santa, X.1824 (fl), Riedel 733 (P). Santa Catarina: Município indefinido: Province de Sainte Catherine, 1816-1821 (fl), A. St.-Hil. $1790(\mathrm{P})$. 

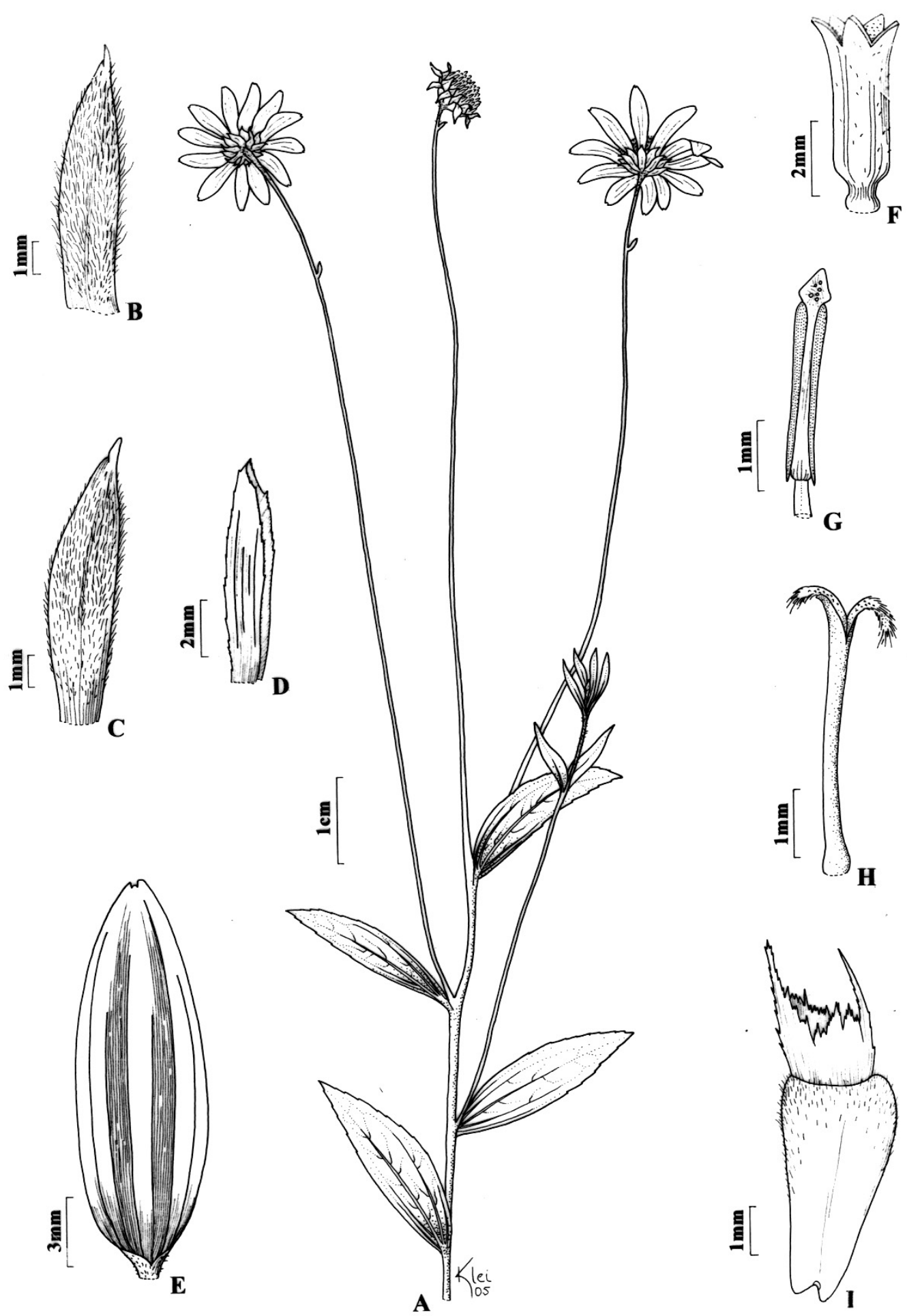

Fig. 11: V. bakeriana. A. Segmento do ramo com inflorescência, B-C. Brácteas involucrais, D. Páleas do receptáculo, E. Flor do raio, F. Corola do disco híspida, G. Antera com tecas de base curtamente sagitada, terminando na base do colar filetal, $\mathrm{H}$. Estilete com alargamento basal curtamente cônico; I. Cipsela. A-J. M. Magenta \& J. Magenta 488 (SPF). 
6. Viguiera bracteata Gardner, London J. Bot. 7: 404. 1848. Tipo: Brazil, Goyaz: dry upland campos, between Arrayas and San Domingos, May 1840, Gardner 4234 (lectótipo aqui designado: K! ex Herb. Hookerianum; fotografia do lectótipo: K!, SPF!; isolectótipos: BM!, K! ex Herbarium Benthamianum, US* 2x , G - frag.; fotografia de isolectótipo[G!])

Viguiera imbricata Baker in Mart., Fl. bras. 6 (3): 220. 1884. Tipo: Brasil, s.l., Pohl 584 (holótipo: K!, isótipo: G - frag., W*; fotografia de isolectótipo de B [destruído]: F!). syn. nov.

Viguiera hilairei S.F. Blake, Contr. Gray Herbarium n. ser. 54: 153. 1918. Tipo: Brazil, Minas Geraes, 1816-21, A. St.-Hil. 1208 [C1 415] (lectótipo aqui designado: P!; isolectótipo: P!). syn. nov.

Viguiera quinqueremis S.F. Blake, Contr. Gray Herb. 54: 168. 1918. Tipo: Brazil: Minas Gerais: 1816 - 21, A. St.-Hil. 1218 [B1 1129 (P!)] (holótipo: P!; fotografia do holótipo: K! SPF!). syn. nov.

Figuras 4B e 12

Erva cespitosa, subarbusto ou arbusto 0,4-2m alt.; ramos aéreos eretos, cilíndricos, estreitamente canaliculados, estrigilosos; entrenós 1-6cm compr.; caule subterrâneo fortemente espessado, raízes adventícias tuberosas na porção mediana. Folhas verde-claras, alternas, sésseis, lâmina 10-27cm×3-18mm, lanceolada a linear, base atenuada a cuneada, ápice agudo a acuminado, inteira ou esparsamente denticulada ou raramente crenada, nervação perfeita, 3 nervuras principais proeminentes na face abaxial, cartáceas, escabrosas, esparsamente estrigilosas a estrigosas, tricomas tectores 3-celulares, com bossas medianas, base cilíndrica apressa, cercada por 1 série de células, face abaxial às vezes com tricomas glandulares. Inflorescência botrióide ou tirsóide, (3,5-)20$50 \mathrm{~cm}$ alt., paracládios eretos, superiores terminando acima do capítulo terminal, cilíndricos, canaliculados, estrigilosos a estrigosos; 1a ordem 3,5-50cm compr., 2a ordem 3,5-17cm compr., 3a ordem raros, 1-3cm compr., bracteolados, bractéolas 1,5-4cm, foliáceas; pedúnculo terminal 2,5-9cm compr. Capítulos 11,8cm diâm., radiados, subtendidos por 1-2 brácteas foliáceas ca. 1cm compr., invólucro 8-15mm diâm., campanulado a estreitamente campanulado, brácteas 
involucrais leve a fortemente desiguais em 4-5(-6) séries, levemente apressas a reflexas na floração, foliáceas em $1 / 4$ a $1 / 2$ superior, as das 4 primeiras séries coriáceas, as outras estramíneas, base caniculada, 3 nervuras destacadas, face adaxial glabra ou estrigilosa próximo ao ápice; 1a série 5-8,5 $\mathrm{mm}$ alt., lanceoladas, ápice foliáceo agudo, mucronado, face abaxial esparsamente estrigilosa ou estrigilosa, cilioladas a esparsamente cilioladas; $2 a$ série $7-11 \mathrm{~mm}$ alt., lanceoladas, ápice foliáceo agudo a acuminado, mucronulado; demais com face abaxial glabra a esparsamente estrigilosa, 3a série 9-15mm alt., ovallanceoladas, ápice agudo a acuminado, mucronulado; 4a série 10-15mm alt., oval-lanceoladas a oblongo-lanceoladas, ápice agudo a acuminado, mucronulado, ápice às vezes setoso, cilioladas, interiores $10-12 \mathrm{~mm}$ alt., ovallanceoladas a oblongo-lanceoladas, escariosas; receptáculo convexo, páleas ca. $8 \mathrm{~mm}$, levemente obovais, ápice expandido obtuso a truncado, ligeiramente lacerado, 8, 10 ou 12 nervuras, carena estreita, estrigosa, margem hialina. Flores do raio 12-20, em 1 verticilo, corola 15-20x5,5-5mm, tubo ca. $2 \mathrm{~mm}$ alt., limbo estreitamente elíptico a elíptico, ápice obtuso a agudo, 2-3-partido; nervuras 1012, face adaxial glabra, face abaxial estrigilosa; flores do disco 55 a 100, corola 45,5mm alt., tubo 0,8-1,2mm, face externa com tubo, base do limbo e lobos esparsamente estrigilosos; anteras de base curtamente sagitada, terminando acima ou na base do colar filetal; estilete com alargamento basal levemente cônico, estilopódio 0,15-0,20x0,30-0,36mm. Cipselas 3,5-4,5mm alt., obovóides a estreitamente obovóides, comprimidas, levemente 4-gonais, estriadas, griseo a dourado-setosas ou raramente esparsamente gríseo-setosas, carpopódio delgado, pápus estramíneo a amarelo-dourado 1-2-aristado, aristas marginais levemente desiguais 2,5-3,5mm alt., livres, estreitamente triangulares, nervuras estrigosas, escamas ca. 4 pares, 1,2-2mm alt., unidas até a metade, ou até próximo ao ápice lacerado ou livres.

Ocorre nas regiões nordeste e sudeste do Estado de Goiás, no Distrito Federal, sudoeste e centro-oeste de Minas Gerais, com um registro em Corumbá, no extremo- oeste do Mato Grosso do Sul (fig. 45B). É encontrada em altitudes acima de 700 m.s.m., em campos sujos e limpos, secos e úmidos, em 
borda de cerrado típico, veredas, afloramentos rochosos e beira de estrada. Floresce e frutifica de janeiro a maio, com picos de floração e frutificação no outono; excepcionalmente pode florescer no inverno ou na primavera.

A variação no número de séries de brácteas involucrais e forma das folhas levaram Baker (1884) a descrever V. imbricata, e Blake (1918) a apresentar como espécies novas $V$. hilairei e $V$. quinqueremis; o formato dessas brácteas também varia, possuindo ápice agudo quando os capítulos estão imaturos e ápice longamente acuminado na maturidade. A maioria dos espécimes com folhas mais largas e capítulos maiores ocorre em Minas Gerais, na Cadeia do Espinhaço, nas Serras do Cipó e do Cabral, e a oeste, na Serra da Canastra, onde pode apresentar um fenótipo peculiar, com folhas e inflorescências muito adensadas, descrito por Blake como $V$. hilairei; o exame detalhado das estruturas reprodutivas mostrou que se trata apenas de variabilidade fenotípica de $V$. bracteata. A espécie também é encontrada em Goiás, na Serras da Gibóia e em Alto Paraíso de Goiás na Chapada dos Veadeiros, em altitudes acima de 1300 m.a.m.

Nota nomenclatural: A escolha do lectótipo baseou-se no fato de que apenas o material depositado no herbário $\mathrm{K}$, originário do Herbarium Hookerianum, apresenta as etiqueta de campo e da exsicata manuscritos por Gardner, com as informações citadas no protólogo. 


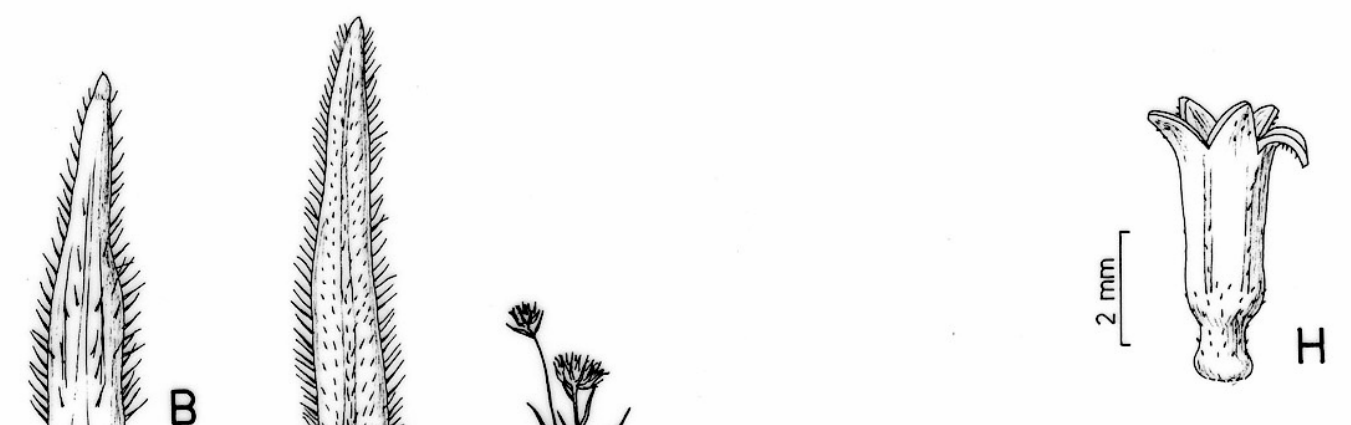

c
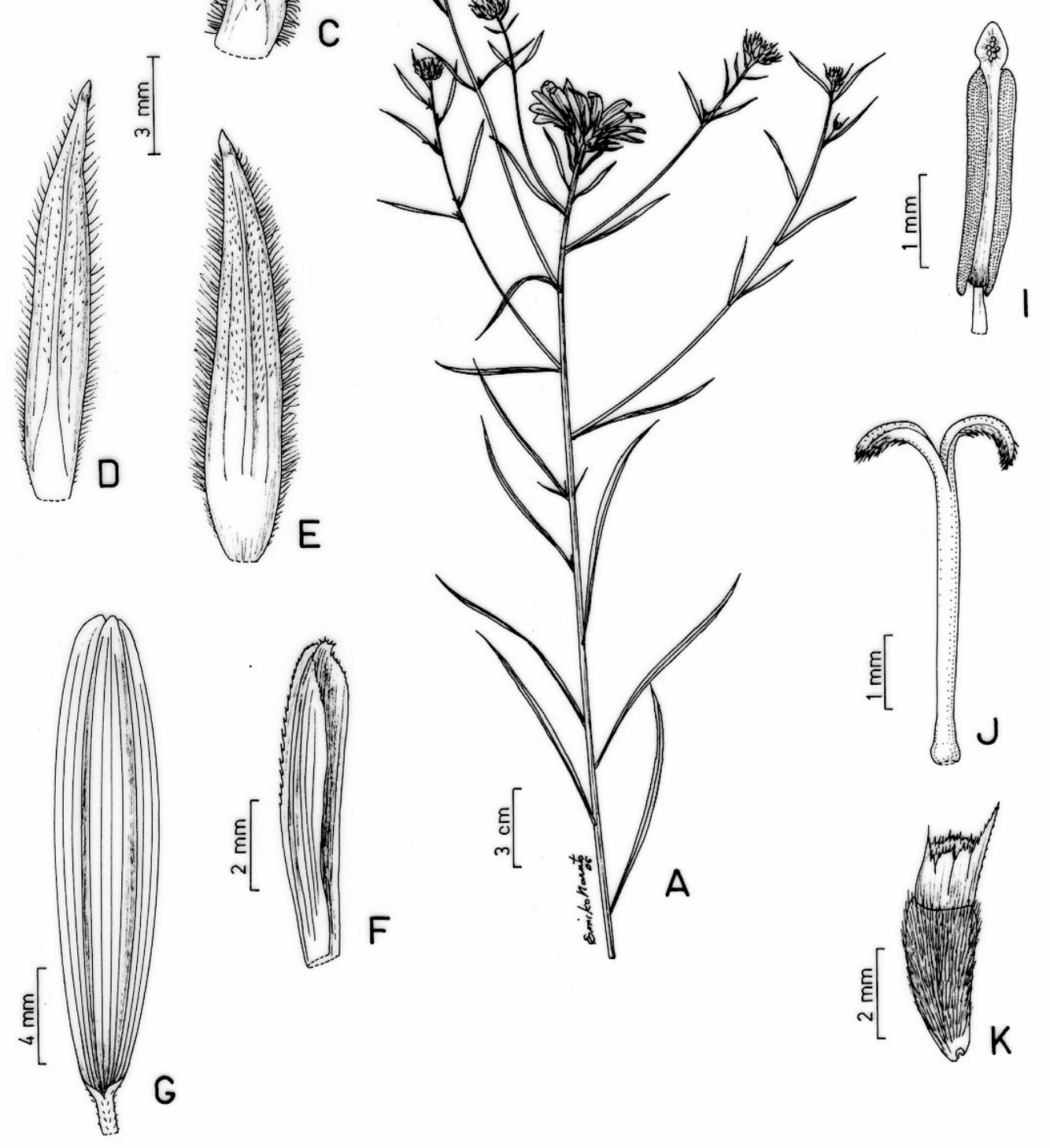

Fig 12: V. bracteata. A. Segmento de ramo com sinflorescência, B-E. Brácteas involucrais, F. Pálea do receptáculo, G. Corola do raio, H. Corola do disco, I. Antera com tecas de base curtamente sagitada, terminando abaixo da base do colar filetal, J. Estilete com base fusiforme. K. Cipsela setosa. A-K. M. Magenta et al. 378 (SPF). 
Material examinado: BRASIL: Distrito Federal: Brasília, Papuda, 17.III.1961 (fl), E.P. Heringer 8084/278 (RB, UB); Horto do Guará, 28.VIII.1961 (fl), E.P. Heringer 8619/813 (LP, RB, UB); Parque Nacional do Gama, 25.V.1965 (fl, fr), D. Sucre 298 (UB); próximo Córrego Taquarí, este da Lagoa Paranoá, 975 m.a.m., 28.IV.1966 (fl), H.S. Irwin et al. 15401 (NY, UB); Parque Nacional do Gama, 15.VI.1968, E. Onishi 132 (UB); Chapada da Contagem, $4 . I .1974$ (fl, fr), E.P. Heringer 13077 (HEPH, IBGE, RB, UB, UEC); Chapada da Contagem, 17.II.1975 (fl, fr), G. Hatschbach et al. 36225 (MBM); Fazenda Água Limpa, Estação Experimental da Universidade de Brasília, próximo a Vargem Bonita, 1.IV.1976 (fl), J.A. Ratter \& S.G. Fonseca 2857 (K, UB); Barragem do Paranoá, 19.V.1976 (fl, fr), E.P. Heringer 15803 (HEPH, IBGE, RB, UB); Fazenda Água Limpa, estação da Universidade de Brasília, $18 \mathrm{~km} \mathrm{~S}$ da torre de TV, 13.V.1976 (fl, fr), J.A. Ratter 3032 (K, UB, UEC); 10 km S, 1100 m.a.m., 10.VII.1976 (fl, fr), P.H. Davis \& G.J. Shepherd D.60081 (UEC); área de inundação da Barragem São Bartolomeu, 30.IV.1979 (fl), E.P. Heringer et al. 1248 (IBGE, UEC); Bacia do Rio Bartolomeu, quadricula 155, 26.III.1980 (fl), E.P. Heringer et al. 4083 (HEPH, IBGE); idem, 3.IV.1980 (fl), E.P. Heringer et al. 4228 (HEPH, UEC); Bacia do Rio Bartolomeu, 1.IV.1981 (fl, fr), E.P. Heringer et al. 6700 (HEPH, IBGE, K, NY, RB); idem, 22.IV.1981 (fl, fr), E.P. Heringer et al. 6820 (HEPH, IBGE, K, MG, MO, NY, US, UEC); Lago Paranoá Norte, margem direita próximo das ilhotas, 20.IV.1982 (fl, fr), B.A.S. Pereira et al. 227 (HEPH, IBGE, K, MO); área isolada, Sítio Novo à margem do Rio Maranhão, 22.IV.1982 (fl, fr), M.V.L. Soares 14 (UB); Jardim Botânico de Brasília, 1552’S, 4751’W, 1035 m.a.m., 7.V.1987 (fl), Equipe do JBB 895 (HEPH); Bacia do Rio Bartolomeu, Córrego Gavião, 20.V.1987 (fl, fr), T.S. Filgueiras 1266 (HEPH, IBGE, RB); Reserva Ecológica do IBGE, 1556 47"'S, 4752'35"W, 28.IV.1988 (fl), D. Alvarenga 24 (HEPH, IBGE, MG, RB, UEC); A.R.I.E. do Capetinga, lado esquerdo da estrada ferro Centro-Oeste, próximo Catetinho, 8.VI.1988 (fl), M.A. Silva 707 (HEPH, IBGE, US); área do Cristo Redentor, 5.VI.1991 (fl), M.L.M. Azevedo \& D. Alvarenga 966 (HEPH, IBGE, US);

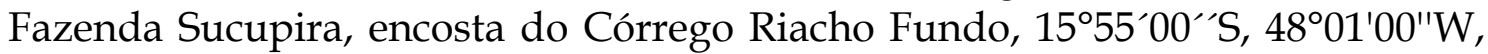
22.IV.1999, J.G. Faria et al. 17 (CEN); Fazenda Sucupira, área no entorno do

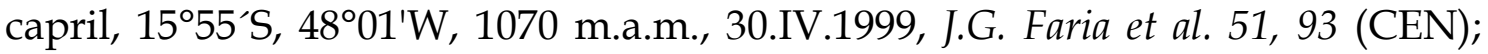
idem, 1555'S, 4801'W, 1070 m.a.m., 30.IV.1999 (fl, fr), J.G. Faria et al. 98 (CEN); Fazenda Água Limpa divisa com o Cristo Redentor (JBB) e o IBGE,

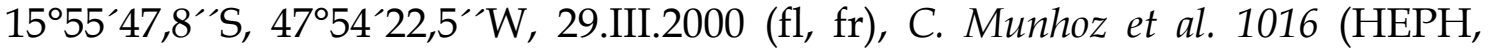
HUFU, IBGE); 2 km trevo do Colorado, em direção à Brazlândia, 16.III.2001 (fl, fr), M.D. Moraes 568 (UEC); Lago Sul, próximo ao Jardim Botânico de Brasília, no Cond. Ecológico Vilage III, 1552`02,2”S, 4748`53,2”W, 4.XI.2001 (fl), M. Magenta \& J. Magenta 312 (SPF); Sobradinho, próximo da Represa Saia Velha, 1602`S, 4756`W, 1100 m.a.m., 11.IV.1983 (fl, fr), J.H. Kirkbride Jr. 5210a (IPA, K, MBM, RB, UB). Goiás: Água Fria de Goiás, rodovia GO 118, Torre Repetidora de Roncador, 8.V.2000 (fl), G. Hatschbach et al. 70640 (CTES, MBM); Alto Paraíso de Goiás, Chapada dos Veadeiros, 1000 m.a.m., 8.III.1969 (fl), H.S. Irwin et al. 24030 (NY, RB); aos pés das montanhas, 20 km S de Alto Paraíso, 1000 m.a.m., 20.III.1969 (fl), H.S. Irwin et al. 24696 (NY, RB); ca. 3 km leste de Alto Paraíso, na estrada para Nova Roma, 1350 m.a.m., 7.III.1973 (fl), W.R. Anderson 6594 (NY, 
RB); 10 km após Alto Paraíso, 18.III.1976 (fl), J. Semir s.n. (K, UEC 2827); rodovia GO 118, ca. 29 km N de Alto Paraíso, margem direita, 21.IV.1998 (fl, fr), F.B. Costa et al. 71 (SPF, SPFR); $10 \mathrm{Km}$ da cidade em direção a São João da Aliança, 11.IV.2001 (fl, fr), M.D. Moraes 646 (CEN, UEC); rodovia BR 118 km 118, Chapada dos Veadeiros, 1401'47,3”S, 47³1'47,2”W, 1506 m.a.m., 24.I.2002 (fl, fr), M. Magenta \& J. Magenta 378 (SPF); rodovia GO 118, sentido Alto Paraíso de

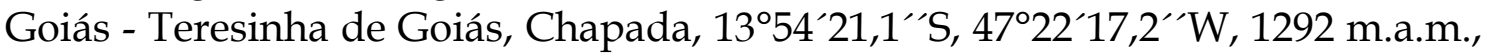
6.V.2002 (fl, fr), M. Magenta et al. 444 (SPF); Anápolis, estrada de Anápolis - DF, 19.V.1961 (fl), E.P. Heringer 8365/559 (HEPH, UB); Caldas Novas, alto da Serra de Caldas Novas, 23.V.1970 (fl), J.A. Rizzo \& A. Barbosa 5232 (UFG); Serra de Caldas Novas, 26.II.1974 (fl, fr), E.P. Heringer 13092 (HEPH, IBGE, RB, UB, UEC); termas do Rio Quente, Reserva Ecológica do Roncador, 14.V.1980 (fl, fr), E.P. Heringer 17807 (HEPH, IBGE); Campo Alegre de Goiás, rodovia BR $050 \mathrm{~km}$

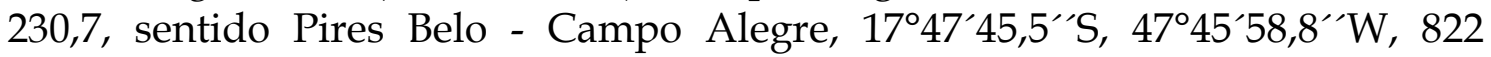
m.a.m., 20.I.2002 (fl), M. Magenta \& J. Magenta 358 (SPF); rodovia BR $050 \mathrm{~km}$

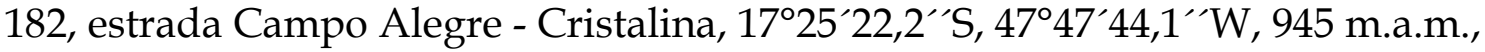
20.I.2002 (fl), M. Magenta \& J. Magenta 363 (SPF); Catalão, rodovia BR 050 km 233, divisa Catalão - Campo Alegre, 7.V.2000 (fl), G. Hatschbach et al. 70586 (BHCB, CTES, MBM); Cavalcante, estrada para Araí, engenho II, Kalunga,

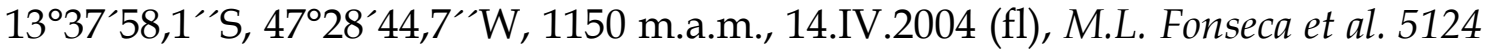
(IBGE, SPF); Cristalina, 23.III.1963 (fl), E.P. Heringer 9223/1436 (HEPH, RB, UB); Serra dos Cristais, $5 \mathrm{~km} \mathrm{~S}$ de Cristalina, 17º , 48 ${ }^{\circ} \mathrm{W}, 1200$ m.a.m., 5.III.1966 (fl), H.S. Irwin et al. 13564 (NY, UB, UEC); Serra Topázio, $20 \mathrm{~km}$ antes de Cristalina, rodovia Brasília - Belo Horizonte, 28.III.1973 (fl), J.A. Rizzo 8926 (UFG); 10 km N de Cristalina, 1080 m.a.m., 3.IV.1973 (fl), W.R. Anderson 8047 (RB); Cristalina Cubículo, 9.IV.1981 (fl, fr), G. Hatschbach 43717 (MBM, SPF); rodovia BR 040, Brasília - Cristalina, $1 \mathrm{~km}$ antes de Cristalina, 4.IV.1985 (fl, fr), C. Proença \& M.F. Bean 461 (CEN, HEPH, UB); estrada para o Salto do Arrojado, 10.II.1990 (fl), G. Hatschbach et al. 53753 (HUCS, MBM, SPF); rodovia BR 040, Paracatu Cristalina, $2 \mathrm{~km}$ antes de Cristalina, 21.IV.1998 (fl, fr), F.B. Costa 68 (SPFR); rodovia BR 040 km 67-68, Cristalina - Paracatu, IV.1998, F.B. Costa 112, 113 (SPFR); rodovia BR $040 \mathrm{~km} \mathrm{72-73,} \mathrm{Paracatu} \mathrm{-} \mathrm{Cristalina,} 2 \mathrm{~km}$ antes de Cristalina, IV.1998, F.B. Costa 114 (SPFR); rodovia BR 050 km 132-133, Cristalina - Catalão, IV.2000, F.B. Costa 116 (SPFR); Serra dos Cristais, $5 \mathrm{~km} \mathrm{~S}$ de Cristalina, em direção a Brasília, 15.IV.2001 (fl, fr), M.A. Silva et al. 4986 (HEPH, IBGE, K, RB,

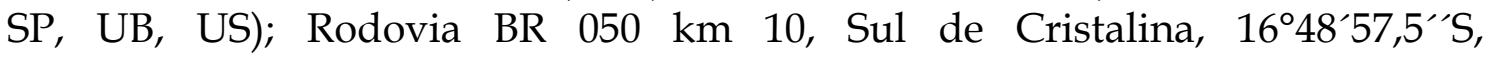

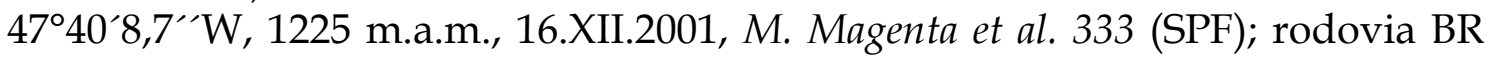

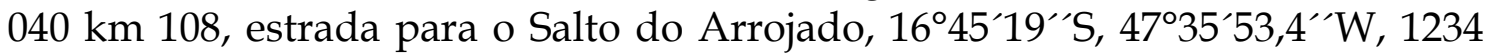
m.a.m., 21.I.2002 (fl, fr), M. Magenta \& J. Magenta 366 (SPF); Ipameri, rodovia BR

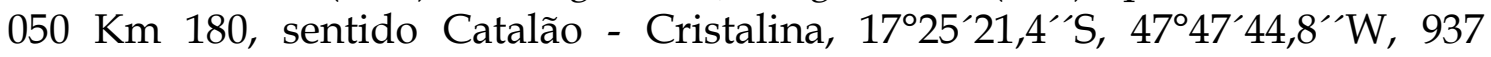
m.a.m., 5.V.2002 (fl, fr), M. Magenta et al. 440 (K, SPF); Morrinhos, Chapadão, 22.III.1976 (fl), G. Hatschbach \& R. Kummrow 38227 (MBM); Pirenópolis, alto da Serra de Pireneus, na base dos 3 picos, 8.XI.1970 (fl), J.A. Rizzo \& A. Barbosa 5711 (UFG); Planaltina de Goiás, Águas Emendadas, 21.IV.1972 (fl, fr), M.B. Ferreira 1334 (HEPH); idem, 15.V.1972, M.B. Ferreira 1417 (HEPH); idem, 30.V.1972, M.B. Ferreira 1193, 1237 (HEPH); 40 km de Brasília, Águas Emendadas, 1200 m.a.m., 
21.I.1978 (fl, fr), A. Gentry 21415 (MO, UB); Reserva Biológica de Águas Emendadas, 40 km NE Brasília, 15³5’S, 47³5'W, 1080 m.a.m., 13.V.1982 (fl, fr), C.M. Maury 126 (HEPH, UEC); São João d'Aliança, Serra Geral do Paraná, 15.III.1971 (fl, fr), H.S. Irwin et al. 31826 (NY, RB, UEC); $7 \mathrm{~km}$ sul da rodovia de São João, 1100 m.a.m., 22.III.1973 (fl), W.R. Anderson 7644 (RB); município indefinido, Between Arrayas \& Sañ Domingos, V.1840 (fl, fr), G. Gardner 4234 (BM, BR); Rio Corumbá, 23.IV.1967 (fl, fr), E.P. Heringer 11205 (UB); Serra da Jibóia, 16³9’S, 4946'W, 900 m.a.m., 1.III.1978 (fl), H. Magnago 27 (HRB, RB). Mato Grosso do Sul: Corumbá, 10.IV.1967, E.P. Heringer 11407 (RB). Minas Gerais: Abadia dos Dourados, Rodovia MG 040 km 198, entre Monte Carmelo e Abadia dos Dourados, $18^{\circ} 30^{\prime} 18,7^{\prime \prime} \mathrm{S}, 47^{\circ} 24^{\prime} 45,6^{\prime \prime} \mathrm{W}, 834$ m.a.m., 22.IV.2003 (fl), M. Magenta \& J. Magenta 671 (SPF); Araxá, 5.II.1956 (fl, fr), A. Macedo 4248 (K,

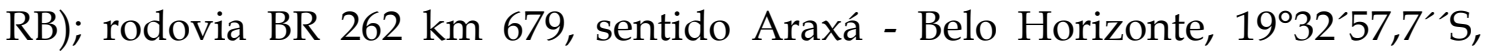
46 50`57,4”W, 936 m.a.m., 18.IV.2003 (fl, fr), M. Magenta \& J. Magenta 641 (SPF); idem, km 678,5, 19³2`53,7’'S, 4650`51,0``W, 941 m.a.m., 18.IV.2003 (fl, fr), M.

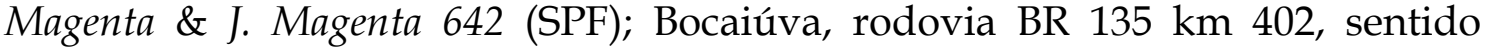
Bocaiúva - Montes Claros, 1702’13,9”S, 4350`24,2”W, 953 m.a.m., 20.IV.2003 (fl, fr), M. Magenta \& J. Magenta 657 (SPF); Coromandel, Chapadão do Pau da Terra, Rodovia MG-040 km 292, entre Guarda-Mor e Coromandel, 1807’21,7’'S, 4705’01,7`'W, 930 m.a.m., 22.IV.2003 (fl), M. Magenta \& J. Magenta 667, 668, 670

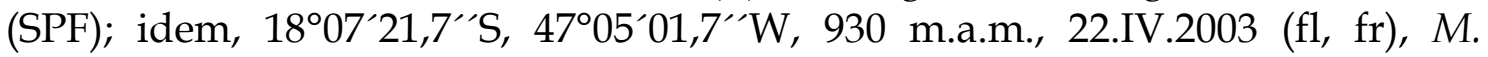
Magenta \& J. Magenta 669 (SPF); Curvelo, rodovia BR 259 km 511, Curvelo Gouveia, IV.2000, F.B. Costa 108 (SPFR); idem, km 509, IV.2000, F.B. Costa 109 (SPFR); idem, km 472, IV.2000, F.B. Costa 110 (SPFR); idem, km 508, IV.2000, F.B.

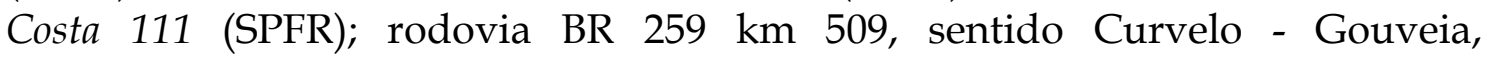
$18^{\circ} 35^{\prime} 50,5^{\prime \prime} \mathrm{S}, 46^{\circ} 57^{\prime} 12,9^{\prime \prime} \mathrm{W}, 1116$ m.a.m., 18.IV.2003 (fl, fr), M. Magenta \& J.

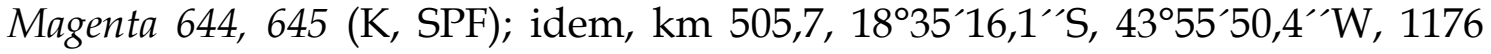
m.a.m., 19.IV.2003 (fl, fr), M. Magenta \& J. Magenta 646 (SPF); Datas, rodovia

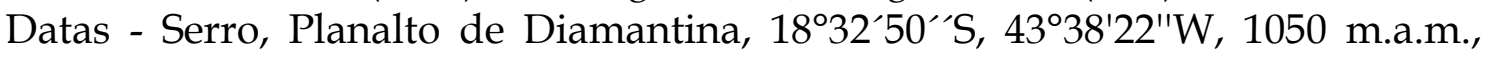
1.III.1998 (fl, fr), J.R. Pirani et al. 4056 (K, SPF, US); Diamantina, Olaria Brush \& Lopes, 13.V.1931 (fl, fr), Y. Mexia 5840 (BM, K); Serra do Espinhaço, ca. $10 \mathrm{~km}$ de São João da Chapada, 1200 m.a.m., 27.III.1970 (fl, fr), H.S. Irwin et al. 28414 (NY, RB); estrada Diamantina - Datas, 9 km de Diamantina, 25.IV.1978 (fl), E.C. Tenório 78-1535 (CETEC); rodovia BR 259 km 475, Diamantina - Gouveia, 20.IV.1998 (fl, fr), F.B. Costa et al. 64 (SPF, SPFR); idem, km 497, 20.IV.1998 (fl, fr), F.B. Costa et al. 65 (SPF, SPFR); estrada para Conselheiro Mata km 166, 2.V.2003 (fl, fr), F.N. Costa \& L.G. Lessa 694 (DIA, SPF); Gouveia, estrada Gouveia - Serro km 467,7, a $300 \mathrm{~m}$ do trevo da BR 259, 18²5’13,7’`S, 43ํ41'18,3"W, 1176 m.a.m., 19.IV.2003 (fl, fr), M. Magenta \& J. Magenta 647 (K, $\mathrm{SPF})$; Itacambira, Serra de Itacambira, beira estrada para Juramento, $17^{\circ} 04^{\prime} 57^{\prime \prime} \mathrm{S}$, 4318'45"W, 17.V.1998 (fl, fr), J.R. Pirani et al. 4377 (BHCB, SPF, US); Jaboticatubas, Serra do Cipó, Chapéu de Sol, 1940'S, 435'W, 1000 m.a.m., 29.IV.1952 (fl, fr), L.B. Smith 7009 (R, US); rodovia Lagoa Santa - Conceição do Mato Dentro - Diamantina km 112,5, 1020 m.a.m., 15.IV.1972, A.B. Joly et al. 1432 (UEC); idem, km 113, 1080 m.a.m., 15.IV.1972 (fl), A.B. Joly et al. 1526 (UEC); Joaquim Felício, Serra do Cabral, 16.IV.1981 (fl, fr), L. Rossi et al. 1031 (SPF); 
Serra do Cabral, $8 \mathrm{~km}$ na estrada para torre de TV, Fazenda Bocaína,

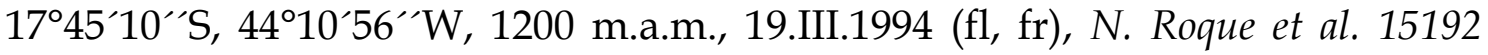
(ESA, SPF); Serra do Cabral, 900 m.a.m., 14.IV.1996 (fl, fr), G. Hatschbach et al. 64675 (MBM); idem, 1200 m.a.m., 15.IV.1996 (fl, fr), G. Hatschbach et al. 64761 (CTES, MBM); Serra do Cabral, estrada para Francisco Dumont a $3 \mathrm{~km}$ da ponte

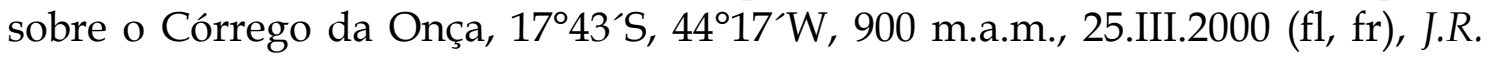
Pirani et al. 4653 (K, SPF); Serra do Cabral, 2.IV.2000 (fl, fr), E.L. Borba 564 (UEC); Montes Claros, estrada para Juramento, 15.V.1977 (fl), P. Gibbs et al. 5147 (UEC);

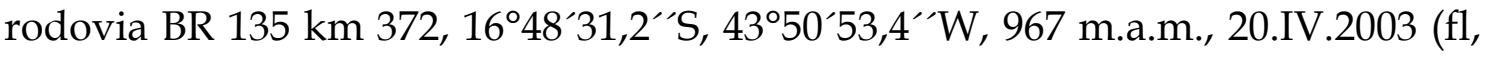
fr), M. Magenta \& J. Magenta 658 (SPF); estrada Montes Claros - Juramento km $10,16^{\circ} 45^{\prime} 44,5^{\prime \prime} \mathrm{S} 43^{\circ} 45^{\prime} 31,8^{\prime \prime} \mathrm{W}, 726$ m.a.m., $20 . \mathrm{IV} .2003$ (fl, fr), M. Magenta \& J. Magenta 660 (SPF); rodovia BR $135 \mathrm{~km} \mathrm{345,} \mathrm{sentido} \mathrm{Montes} \mathrm{Claros} \mathrm{-} \mathrm{Mirabela,}$ 16³6'15,7”S, 4355'49,9”'W, 849 m.a.m., $20 . I V .2003$ (fl, fr), M. Magenta \& J. Magenta 661 (SPF); Palácio Serra do Cipó, km 131, 1110 m.a.m., 23.IV.1950 (fl), A.P. Duarte 2615 (RB, SPF); Paracatu, rodovia BR 040, Paracatu - Cristalina, 68 km de Paracatu, 21.IV.1998 (fl, fr), F.B. Costa et al. 67 (SPF, SPFR); Perdizes, divisa com João Alonso, Unidade de Conservação de Galheiro, CEMIG, 25.V.1994 (fl), E. Tameirão Neto \& M.S. Werneck 1294 (BHCB); Presidente Kubitschek, estrada Gouveia - Serro Km 440,3, 18³4`38,3“'S, 43³4'38,0"W, 1211 m.a.m., 19.IV.2003 (fl, fr), M. Magenta \& J. Magenta 648 (K, SPF); Santana do Riacho, Serra do Cipó, 1400 m.a.m., 10.V.1974 (fl, fr), G. Martinelli 265 (RB); Chapéu de Sol, Serra do Cipó, 1150 m.a.m., 12.V.1990 (fl, fr), T.S.M. Grandi s.n. (BHCB 18394); Santana do Rio Claro Serra do Cipó, atalho entre km 115 e a estrada da usina, 2.V.1993, V.C. Souza \& C.M. Sakuragui 3400 (ESA); São João Batista da Canastra, Parque Nacional da Serra da Canastra, estrada que liga São Roque a Sacramento $47 \mathrm{~km}$ da portaria de São Roque, 20 09'42,1'`S, 46² 42 40,7”W, 1347 m.a.m., 17.III.2003 (fl, fr), M. Magenta \& J. Magenta 580 (SPF); São Roque de Minas, idem, próximo a estrada para o Retiro das Pedras, 18.III.1995, J.N. Nakajima et al. 886 (HUFU); idem, 21.III.1996 (fl, fr), J.N. Nakajima \& R. Romero 1889 (HUFU, SPF); idem, estrada para o Retiro das Pedras, 18.IV.1997 (fl), J.N. Nakajima et al. 2378 (HUFU, SPF); Parque Nacional da Serra da Canastra, estrada São Roque para Sacramento, 20¹4`38,8“'S, 46³2’01,7”W, 1428 m.a.m., 16.III.2003 (fl, fr), M. Magenta et al. 575, 577, 578 (SPF); idem, estrada São Roque a Sacramento, a $34 \mathrm{Km}$ portaria de São Roque, 20¹2'37,9' 'S, 46³9’50“W, 1398 m.a.m., 17.IV.2003 (fl), M. Magenta \& J. Magenta 630, 631 (SPF); Serro, estrada Serro - Milho Verde a $7 \mathrm{~km}$ da BR 259, 18³2`04,8“'S, 43²6’26,7’`W, 1060 m.a.m., 19.IV.2003 (fl), M. Magenta \& J. Magenta 649 (SPF); estrada Milho Verde - São Gonçalo do Rio das Pedras a $7 \mathrm{~km}$ de Milho Verde, $18^{\circ} 26^{\prime} 12,9^{\prime \prime} \mathrm{S}, 4^{\circ} 29^{\prime} 02,6^{\prime \prime} \mathrm{W}, 1171$ m.a.m., 19.IV.2003 (fl, fr), M. Magenta \& J.

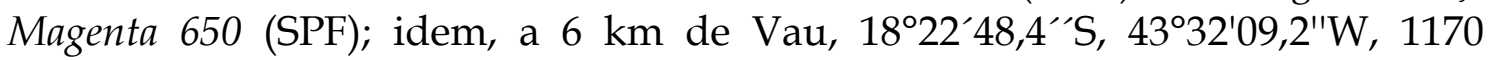
m.a.m., 19.IV.2003 (fl, fr), M. Magenta \& J. Magenta 651 (SPF); Tapira, Serra da Canastra, estrada São João para Itapira, ca. 6,5 Km de Tapira, 1957’20,3“'S, 46²6`25,9”'W, 1227 m.a.m., 18.IV.2003 (fl, fr), M. Magenta \& J. Magenta 637 (SPF); idem, estrada Tapira para Araxá, 1948’54,4”'S, 4650’34,5”W, 1141 m.a.m., 18.IV.2003 (fl, fr), M. Magenta \& J. Magenta 640 (SPF); município indefinido, Province de Minas Geraes, Brésil, 1816-1822 (fl, fr), A. St.-Hil. 1216 
(P); rodovia MG 10, Serra do Cipó, 19.IV.1998 (fl, fr), F.B. Costa \& N.L. Lopes 63 (SPF, SPFR). Município indefinido: 1816 - 21, A. St.-Hil. 1216 [B1 1125 (P!)] (parátipo de V. quinqueremis: P!).

7. Viguiera corumbensis Malme, Ark. Bot. 24A (8): 45. 1931. Tipo: Brasil, Mato Grosso do Sul, Corumbá, in silva clara, loco interdum inundato, 11 Abr 1903, Malme II. s.n. (lectótipo aqui designado: S! [S - S 04-931]); fotografia do lectótipo: K!, SPF!; isolectótipos: S! (R 6475 e S 04 -925).

Rhysolepis hatschbachii H. Rob. \& A. J. Moore, Proc. Biol. Soc. Washington 117(3): 438. Tipo: Brasil, Mato Grosso do Sul, Rodovia Bonito, Campo dos Índios, próximo de Três Morros (Mun. Bonito); encosta do morro; solo calcário, 10 Mar 2003, G. Hatschbach et al. 74469 (holótipo: MBM*; isótipo: US*). syn. nov.

Figura 13

Ervas a subarbustos 1,5-2m alt., ramos aéreos eretos, cilíndricos, estriados, porção inferior com lenticelas, esparsamente híspidos, entrenós 3,5$4 \mathrm{~cm}$ compr.; sistema subterrâneo desconhecido. Folhas alternas levemente discolores, pecíolo 2-4mm, alado, lâmina 5-14x1-4,5cm, elíptica a elípticolanceolada, base atenuada, ápice acuminado, esparsamente serreada, serrilhos mucronados, cartáceas, nervação acródroma suprabasal perfeita, 3 nervuras principais, face adaxial estrigosa, tricomas tectores 3-celulares com bossas, base estreitamente cônica, cercada por 2 séries de células, face abaxial híspida com muitas glândulas amareladas, tricomas tectores 3-celulares com base cilíndrica, cercada por uma série de células. Inflorescência botrióide, $20-60 \mathrm{~cm}$ alt., paracládios ascendentes, superiores terminando abaixo do capítulo terminal, 10-50cm compr., canaliculados, esparsamente hispídulos, com bractéolas opostas 6-7x1-2cm, foliáceas; pedúnculo terminal 14-36cm compr. Capítulos 4,5-6cm diâm, radiados, subtendidos por uma bractéola linear 8-10mm compr., invólucro 1,5-2cm diâm., campanulado; brácteas involucrais levemente apressas na floração, 3 séries, oblongas a oblongo-lanceoladas, base levemente caniculada, foliáceas em 2/3 superiores, ápice agudo a obtuso, cartáceas, face adaxial com ápice estrigiloso, face abaxial densamente setosa a densamente estrigosa, 2a e 3a série às vezes somente na porção superior, margem ciliada a 
esparsamente ciliada, 1a série 6-10mm alt., 2a série 13-15mm alt., 3a série 14$15 \mathrm{~mm}$ alt.; receptáculo levemente convexo, páleas $7-9 \mathrm{~mm}$ alt., estreitamente oblanceoladas, carenadas, ápice agudo a acuminado, mucronado, estrigiloso, 6 ou 8 nervuras, escariosas. Flores do raio ca. 12, em 1 verticilo, corola 15-17x55,5mm, tubo ca. 1,5mm alt., limbo oblongo, ápice obtuso 2-partido, face abaxial com 15-17 nervuras, 2 mais destacadas, hispídulas; flores do disco 70-80, corola 6-6,5mm alt., tubo (0,5-)1,5-2mm alt., face externa com base do limbo e tubo estrigilosos, lobos com tricomas esparsos; antera de base curtamente sagitada, terminando na base do colar filetal ou levemente abaixo, estilete com alargamento basal semigloboso, estilopódio 0,8-0,10-0,14-0,18mm. Cipselas 4,5$5 \mathrm{~mm}$ alt., obovóides, comprimidas, levemente trígonas, estriadas, cerdosas junto ao ápice, carpopódio delgado, pápus amarelado 2-aristado, aristas levemente intramarginais e levemente desiguais, livres, 3-3,5mm alt., estreitamente triangulares, base alargada, margem fimbriada, escamas em 4 pares ca. 0,8mm alt., livres, ápice lacerado.

Espécie rara, ocorrendo apenas no oeste do Estado de Mato Grosso do Sul NÃO FOI PLOTADA!. De acordo com os critérios da IUCN, está "em risco de extinção" por apresentar distribuição restrita e tamanho populacional reduzido. Coletada com flores e frutos nos meses de março e abril. É morfologicamente próxima de $V$. procumbens, uma espécie andina, diferenciando-se pelas brácteas involucrais com base levemente caniculada e ápice foliáceo, pelas flores liguliformes em número aproximado de 12 e com até $17 \mathrm{~mm}$ de comprimento e pelas cipselas trígonas; $V$. procumbens possui brácteas involucrais inteiramente foliáceas, com base levemente caniculada, apresenta raio com 14 a 20 flores de até $25 \mathrm{~mm}$ de comprimento e cipselas compressas.

Nota nomenclatural: Justifica-se a escolha do lectótipo pelo fato de que na introdução do trabalho onde a espécie foi descrita, Malme citou o herbário de destino de suas coletas; o material S 04-931 contém as informações citadas no protólogo, manuscritas por Malme.

Material examinado: BRASIL: Mato Grosso do Sul: Corumbá, caminho de Urucum, IV.1963 (fl, fr), G.M. Barroso s.n. (PEL 5138, RB 117480, SPF); Miranda, Reserva da Escola, secção morada nova, Fazenda Bodoquena, 1956'S, 
5701`W, 350 m.a.m., 17.III.1995, (fl), A. Pott et al. 7026 (CPAP, SPF); Fazenda Lagoão Fechado, 18.III.2003 (fl, fr), G. Hatschbach et al. 74900 (MBM, SPF); município indefinido, estrada para bancada laterítica da Fazenda Toia Caturchi, 29.XI.2000 (fl, fr), M.D. Moraes \& G. Damasceno Jr. 558 (UEC).

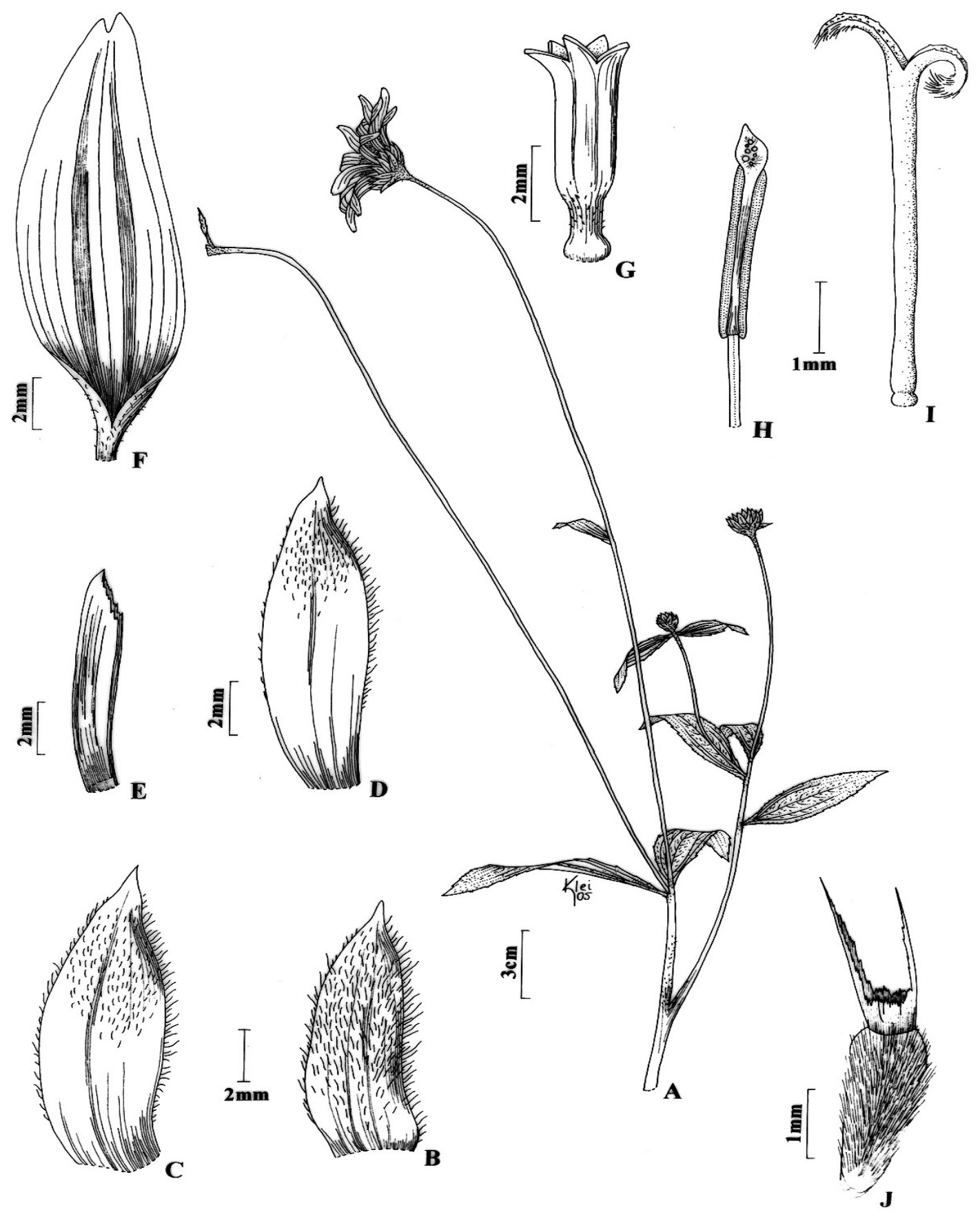

Fig. 13: V. corumbensis A. Segmento da inflorescência. B-D. Brácteas involucrais, E. Pálea do receptáculo, F. Corola do raio, G. Corola do disco, H. Antera com tecas de base curtamente sagitada, terminando levemente abaixo da base do colar filetal, I. Estilete com alargamento basal semigloboso, sobre estilopódio, J. Cipsela com aristas longas e delgadas. A-J. A.Pott 7026 (SPF). 
8. Viguiera discolor Baker, in Martius, Fl. bras. 6(3): 228. 1884. Tipo: [Brasil]. In prov. Minas Geraes, in campis ad Caldas, [18/9/964] Regnel III.771 (lectótipo aqui designado: S! [S 04-923]; fotografia do lectótipo: K!, SPF!; isolectótipos: BR! 2x, GH - esboço, ex. herb. Stockholm, R!, RB!, S! [R 6476 e S 04-922], US*; fotografia de isolectótipo de B [destruído]: F!).

Viguiera obtusifolia Baker in Mart., Fl. bras. 6 (3): 226. 1884. Rhysolepis obtusifolia (DC) H. Rob. \& A.J. Moore, Proc. Biol. Washington 117(7): 430. 2004. Tipo: Brasil, s.l., s.d., Pohl 581 (lectótipo aqui designado: K!, fotografia do lectótipo: K, SPF; isolectótipos: BR!, C, F* , GH - frag.). syn. nov.

Figuras 3A e 14

Ervas a arbustos 0,3-1(-1,6)m alt., ramos aéreos eretos, cilíndricos, canaliculados, híspidos, base glabrescente, entrenós (0,5-)1-5(-10)cm compr.; caule subterrâneo levemente espessado, raízes adventícias delgadas com pequena tuberosidade fusiforme ou obpiriforme próximo à extremidade. Folhas geralmente discolores, alternas ou inferiores opostas, sésseis ou pecíolo 1,5-2mm compr.; lâmina 4,5-7(-11)x1-6cm, oval a largamente oval, elíptica a largamente elíptica ou orbicular, base levemente atenuada a cordada, ápice agudo, obtuso ou arredondado, irregularmente crenada, denteada ou serreada, nervação acródroma basal perfeita, 3(-5) nervuras principais, face adaxial esparsamente híspida, tricomas tectores 3-5-celulares, sem bossas ou com bossas inconspícuas, base cônica ereta, cercada por 2-3 séries de células, face abaxial tomentosa ou híspida, tricomas tectores 1-3-celulares de base cilíndrica, sem bossas ou com bossas inconspícuas, com muitas glândulas amareladas translúcidas. Inflorescência botrióide ou raramente trisóide, terminal, (12-)15$30(-40) \mathrm{cm}$ alt., paracládios eretos, superiores geralmente terminando na altura do capítulo terminal ou raramente acima deles, $8-25 \mathrm{~cm}$ compr., canaliculados, híspidos com bractéolas foliáceas, lineares, estreitamente ovais ou elípticas, esparsamente denteadas, ou capítulos solitários. Capítulos $5-8 \mathrm{~cm}$ diâm., radiados, invólucro 1-2cm diâm., campanulado; brácteas involucrais levemente apressas ou apenas levemente reflexas na floração, em 2-3 séries, ovais, ovallanceoladas, ou oblongo-lanceoladas, base coriácea caniculada a fortemente 
caniculada, 1-3 nervuras destacadas, ápice agudo ou às vezes obtuso, foliáceas em 1/2 superior, face adaxial com ápice estrigiloso, face abaxial vilosa, setosa ou raramente estrigosa, às vezes com glândulas, 1 a série $7-12 \mathrm{~cm}$ alt., 2 a série 8$12 \mathrm{~cm}$ alt., 3a série $9-15 \mathrm{~cm}$ alt.; receptáculo convexo, páleas 7,5-8mm alt., oblongas, carena estreita, ápice agudo, obtuso ou truncado, mucronulado a mucronado, esparsamente ciliolado a ciliado, 6 ou 8 nervuras, margem hialina, base esparsamente hispídula, carena e porção superior estrigosas. Flores do raio 15-20(-25), em 1-2 verticilos, corola 15-30x4-8mm, tubo 0,5-0,8mm alt., limbo elíptico, ápice 2-partido, face abaxial híspida com glândulas, ca. 15 nervuras híspidas; flores do disco 85-90, corola 4,5-5mm, tubo 0,3-0,5mm, face interna glabra, face externa do limbo com base e nervuras estrigilosas, lobos estrigilosos ou às vezes setosos, tubo glabro a esparsamente estrigiloso; anteras de base curtamente sagitada ou levemente auriculada, terminando na base do colar filetal; estilete com alargamento basal cônico a semigloboso, estilopódio (0,12),14-0,18x0,28-0,30mm. Cipselas 5-7mm alt., obovóides a largamente obovóides, levemente recurvadas, comprimidas, estriadas, ápice hispídulo, ângulos laterais ciliolados, carpopódio médio, pápus vináceo, especialmente no ápice, 2-aristada, aristas marginais, desiguais, menor 2-3mm alt., maior 2,5$3,5 \mathrm{~mm}$ alt., livres ou unidas às escamas laterais, largamente triangulares, naviculares, porção basal gibosa, recurvadas, com carena conspícua, base levemente hispídula, ápice agudo, escamas ca. 3 pares, 1-2mm alt., unidas até o ápice eroso ou raramente sem escamas.

Ocorre no nordeste e oeste de Minas Gerais e parte do sudeste de São Paulo, ou mais raramente no sul de Goiás (fig. 44B), em cerrados típicos, campos sujos, campos rupestres e cerrados degradados. Pode florescer o ano todo, com picos de floração e frutificação na primavera.

O epíteto específico está relacionado à cor esbranquiçada da face abaxial foliar de grande parte dos espécimes, conferida pelo indumento albotomentoso; no entanto, quando o indumento é híspido, a espécie é confundida com $V$. bakeriana, da qual se diferencia principalmente por características do invólucro, das páleas e do pápus (ver comentários de V. bakeriana). Possui 
hábito e cipselas muito semelhantes aos de V. squalida, mas diferencia-se pelo caule subterrâneo com espessamento leve, pelas folhas com base levemente atenuada a cordada e face abaxial tomentosa ou híspida, pelas brácteas involucrais com face abaxial vilosa, estrigosa ou setosa, pelas anteras terminando na base do colar filetal e pelo pápus com arista marginal, enquanto a segunda apresenta caule subterrâneo fortemente espessado, folhas com base obtusa cuneada e glabras a esparsamente estrigosas a estrigosas, hirsutas ou setosas, brácteas involucrais com face abaxial esparsamente estrigilosa a estrigilosa, anteras terminando acima da base do colar filetal e o pápus é, geralmente, intramarginal. $\mathrm{O}$ tipo de $V$. obtusifolia apresenta folhas arredondadas de ápice obtuso, variação observada diversas vezes numa mesma população de $V$. discolor durante este trabalho.

Nas etiquetas dos isolectótipos depositados no herbário $S$ a cidade e a data de coleta são diferentes ("Uberava, Sept. 1848"). Neste herbário há também um material numerado como Regnel III. 77 1a (S!, GH - esboço ex herb. Stockholm), com a localização do lectótipo ("Territ. Caldense, prov. Minarum", 1864).

Nota nomenclatural: A lectotipificação seguiu dois critérios: quanto ao herbário onde o material depositado (Baker descrevia suas espécies principalmente a partir de materiais dos herbários BM, BR e K) e com base no protólogo da descrição da espécie. A despeito de haver materiais coletados em dois locais diferentes, Baker citou a cidade de Caldas.

Material examinado: BRASIL: Goiás: Caldas Novas, margem esquerda do Córrego Gameleira, 1705’S, 48²7’W, 560 m.a.m., 22.IX.1993 (fl, fr), G. P. Silva et al. 1935 (CEN, SPF, UEC); Campo Alegre de Goiás, rodovia BR 050,

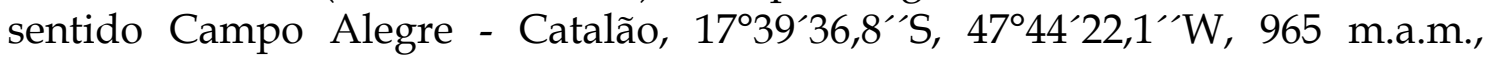

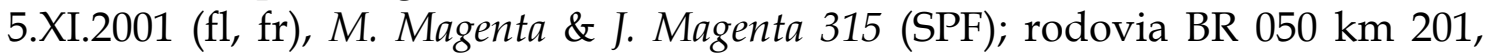

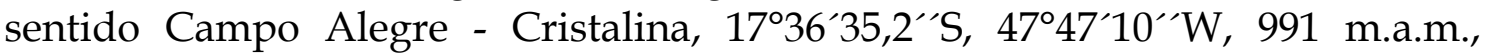
16.XII.2001 (fl, fr), M. Magenta \& J. Magenta 330 (SPF, UEC). Minas Gerais: Araxá, rodovia BR 428 km 41,5, Araxá - Franca, 1942’19,3”S, 4706’0,9”`W, 1133 m.a.m., 6.XI.2001 (fl, fr), M. Magenta \& J. Magenta 322 (SPF); rodovia BR 428, sentido Araxá - Franca, 1941’12,2”S, 47¹0`53,4”W, 1076 m.a.m., 6.XI.2001 (fl), M. Magenta \& J. Magenta 324 (K, SPF); Ituiutaba, 14.XI.1948 (fl), A. Macedo 1378 (RB); 28.X.1956 (fl), s.c. s.n. (RB 96544); rodovia BR $365 \mathrm{~km} \mathrm{433,} \mathrm{sentido} \mathrm{Ituiutaba}$

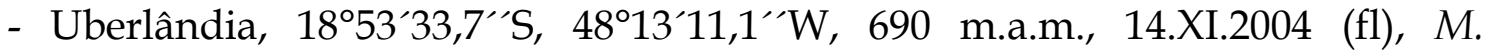


Magenta \& J. Magenta 723 (SPF); João Pinheiro, entre João Pinheiro e Paracatu, 21.XI.1966 (fl, fr), A.P. Duarte 9955 (RB); Monte Alegre de Minas, rodovia BR 365, sentido Monte Alegre - Ituiutaba, 1852`44,6“'S, 4858`56,9”`W, 742 m.a.m., 3.XI.2001 (fl, fr), M. Magenta \& J. Magenta 307 (K, SPF); Paracatu, 14.X.1965 (fl), A.P. Duarte 9274-A (RB); Poços de Caldas, XI.1881 (fl, fr), J. Motta s.n. (R 155997); 26.I.1919 (fl, fr), F.C. Hoehne 2914 (SP); X.1949 (fr), J. Vidal III-5 (R); Alto de Santa Cruz, 10.X.1964 (fl), A.R.A. Roppa 285 (RB); Campo do Saco, 4.IX.1980 (fl), H.F.

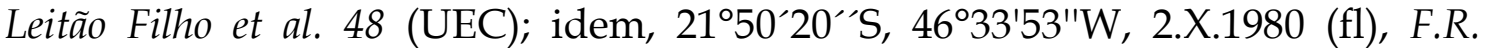
Martins et al. 228 (FUEL, HUM, RB, UEC); idem, 21 50`20“S, 46 33’53“W, 30.X.1981 (fl, fr), H.F. Leitão Filho et al. 1358 (UEC); área próxima ao Hotel Presidente, 21 50`20`S, 46 33’53”W, 3.XII.1982 (fl, fr), H.F. Leitão Filho et al. 1930 (UEC); próximo à estação ferroviária, junto ao Morro das Camisinhas, 21 50`20”S, 46 33`53”W, 9.III.1983 (fl, fr), H.F. Leitão Filho et al. 2049 (UEC); Prata,

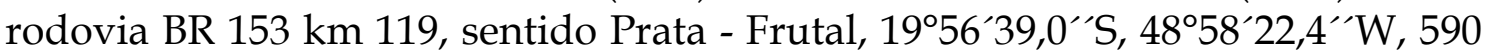
m.a.m., 13.XI.2004 (fl), M. Magenta \& J. Magenta 713 (SPF); rodovia BR 153 km

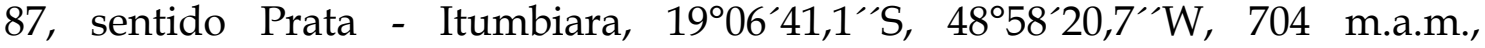
13.XI.2004 (fl), M. Magenta \& J. Magenta 715 (SPF); idem, 1857’08,9”S, 4901`36,9``W, 639 m.a.m., 13.XI.2004 (fl), M. Magenta \& J. Magenta 717, 718 (SPF); Santa Juliana, rodovia BR 452 km 246, sentido Uberlândia - Araxá,

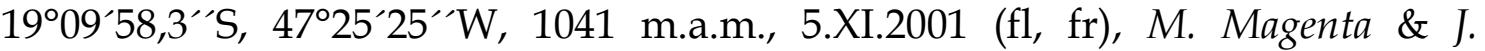
Magenta 320 (SPF); São Roque de Minas, Serra da Canastra, estrada para o Retiro das Pedras, XII.1994, R. Romero et al. 1550 (HUFU); idem, 13.X.1999 (fl, fr), R.C. Mota 77 (BHCB, SPF); São Sebastião do Paraíso, rodovia MG 050, Altinópolis - São Sebastião, atrás da rodoviária, lado direito, 16.X.1997 (fl, fr), F.B. Costa et al. 25 (SPF, SPFR); idem, 9.IX.1998 (fl, fr), F.B. Costa \& N.L. Lopes 88

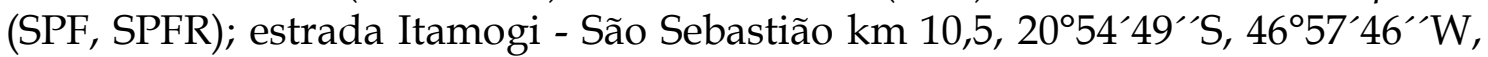
980 m.a.m., 20.X.2001 (fl, fr), M. Magenta \& J. Magenta 279 (SPF); Uberaba, Curralinho, XI.1916 (fl, fr), L. Brito 51 (R); rodovia BR 050 15-20 km Oeste de Uberaba, 13.X.1990 (fl, fr), G. Hatschbach et al. 54358 (BHCB, BR, CTES, K, MA,

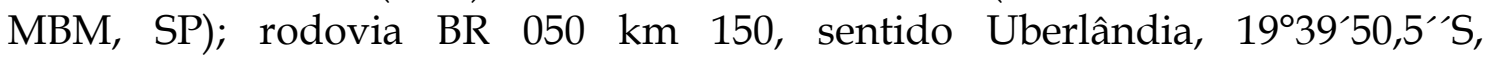
4800`02,2”W, 700 m.a.m., 2.XI.2001 (fl, fr), M. Magenta \& J. Magenta 300 (K, SPF, SPFR); idem, 19³9'50,5”S, 4800`02,2”W, 700 m.a.m., 2.XI.2001, M. Magenta \& J. Magenta 300-A (SPF); rodovia BR $050 \mathrm{~km} \mathrm{148,} \mathrm{sentido} \mathrm{Uberlândia} \mathrm{-}$ Uberaba, 2.XI.2001 (fl), M. Magenta \& J. Magenta 304 (SPF, SPFR, UEC); rodovia BR 050 km 117, sentido Uberaba - Uberlândia, 19¹6’22,2”'S, 4807’29,7’”W, 1000 m.a.m., 2.XI.2001 (fl, fr), M. Magenta \& J. Magenta 306 (HUFU, K, SPF); Uberlândia, 6.XI.1991 (fl, fr), G. Hatschbach \& M. Hatschbach 55800 (BR); Estação Ecológica do Panga, 16.X.1992 (fl), G.M. Araújo et al. 313 (HUFU, RB, UEC); idem, 6.XI.1992 (fl, fr), G.M. Araújo et al. 383 (HUFU, SPF, UEC); idem, 14.X.1995, A.A. Arantes \& R. Scabbia 445 (HRCB, SPF); idem, 14.X.1995, A.A. Arantes \& R. Scabbia 446 (HRCB); rodovia BR 050 km 131, Uberlândia - Uberaba, em frente ao Sítio Ana Branca, 9.XI.1997, F.B. Costa 48 (SPFR); idem, XII.1999, F.B. Costa 100 (SPFR); rodovia BR 452 km 146, sentido Uberlândia - Araxá, 18 56 $06^{\prime \prime}$ S, $48^{\circ} 11^{\prime} 0,3^{\prime \prime W}, 975$ m.a.m., 5.XI.2001 (fl, fr), M. Magenta \& J. Magenta 319 (SPF); idem, 18 ${ }^{\circ} 58^{\prime} \mathrm{S}, 4^{\circ} 07^{\prime} \mathrm{W}, 975$ m.a.m., 5.XI.2001 (fl, fr), M. Magenta \& J. Magenta 319-A (SPF); rodovia BR 050 km 09, 19¹2`07,4”S, 4808`53,5”W, 910 


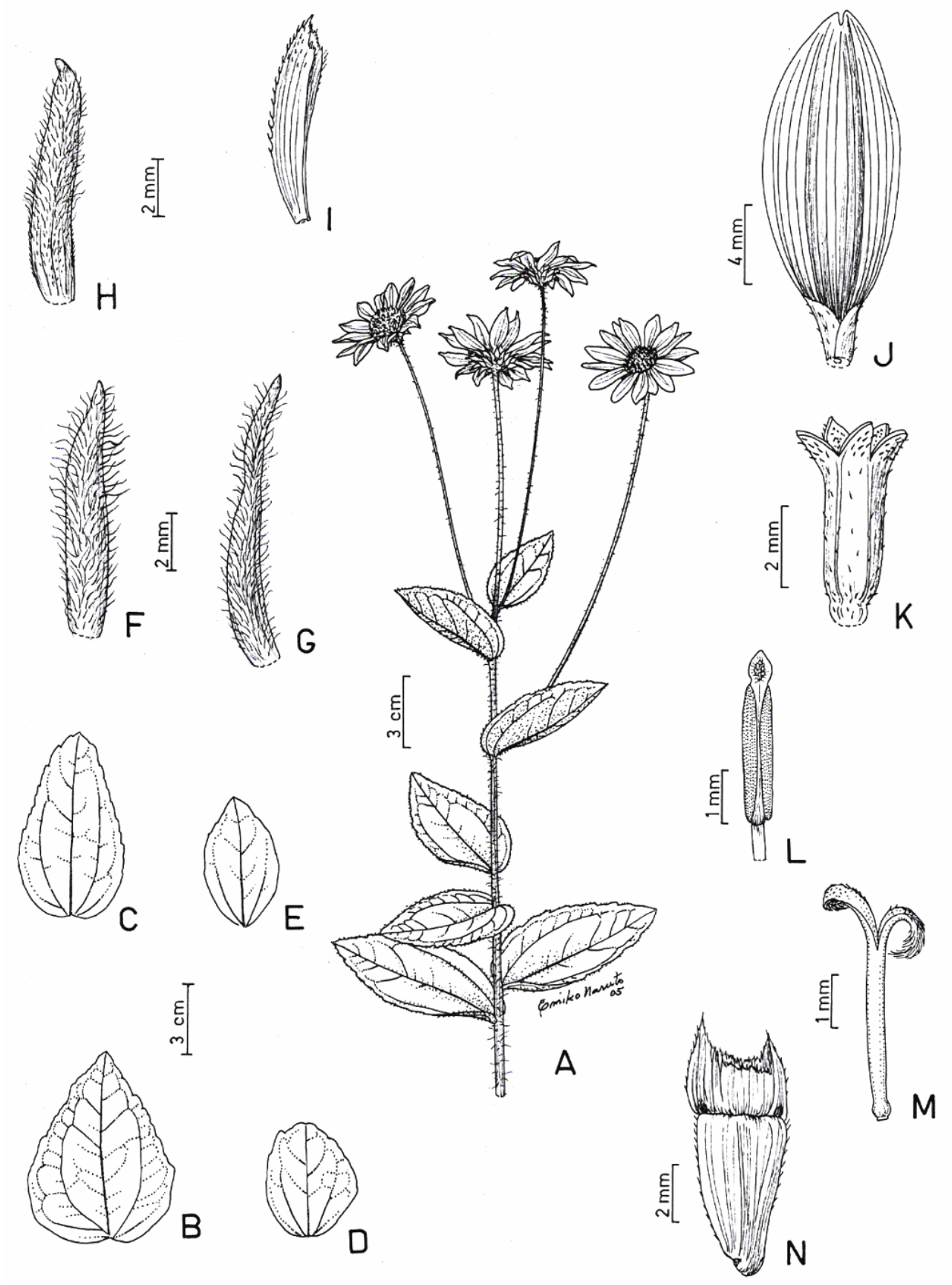

Fig. 14: $V$. discolor. A. Segmento de ramo com sinflorescência, B-D. Folhas, variação na forma, G-H. Brácteas involucrais, I. Pálea do receptáculo, J. Corola do raio, K. Corola do disco, L. Antera com tecas de base levemente auriculada terminando na base do colar filetal, M. Estilete com alargamento basal semigloboso, N. Cipsela com aristas marginais bojosas recurvadas. A-J. M. Magenta \& J. Magenta 307 (SPF). 
m.a.m., 14.XI.2004 (fl), M. Magenta \& J. Magenta 725, 726 (SPF); rodovia BR 050

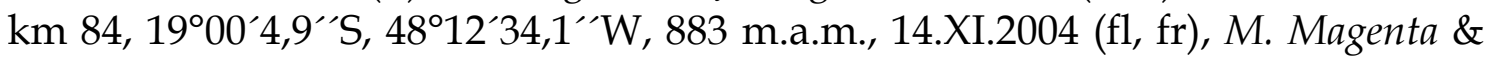
J. Magenta 727 (SPF); município indefinido, 14.X.1965, E. Pereira 10184 (UB); Ad patrocínio et Bambuia, Brésil, s.d. (fl, fr), Pohl 670 (P). São Paulo: Altinópolis, Morro do Forno, 19.XI.1992 (fl), W. Marcondes-Ferreira et al. 507 (SPFR); Cajuru, Fazenda Santa Carlota, 9.X.1989 (fl), A. Sciamarelli \& J.V.C. Nunes 312, 313 (SPFR); Cristais Paulista, rodovia Cândido Portinari km 416-418, próximo a Cristais Paulista, 12.IX.1998 (fl, fr), F.B. Costa \& N.L. Lopes 91 (SPF, SPFR); Estrada Franca - Pedregulho 1,5 km da entrada Cristais, 20 23'24,8' $\mathrm{S}$, 4746’01,8”W, 1025 m.a.m., 1.XI.2001 (fl, fr), M. Magenta \& J. Magenta 294 (HUFU, K, SPF, TEX); Estreito, próximo da Fazenda Três Irmãos, 5.XI.1997 (fl, fr), W. Marcondes-Ferreira et al. 1447 (ESA, HRCB, K, SPF, UEC); área da Usina

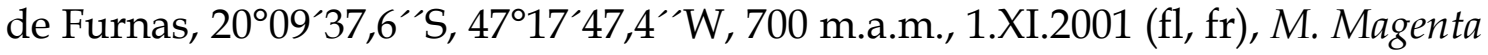
\& J. Magenta 299 (K, SPF, SPFR); Franca, Estrada Franca - Pedregulho 14 km de

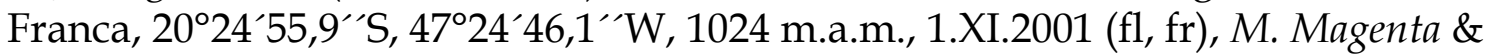
J. Magenta 295 (SPF, TEX); Igaçaba, Morro Solteiro, mata de encosta em morro de arenito, 7.XI.1997 (fl, fr), W. Marcondes-Ferreira et al. 1682 (K, SPF, UEC); Ilha Solteira, município de Selviria, 6.IX.1984 (fl, fr), F.R. Martins et al. 16316 (UEC); Itirapina, 26.II.1920 (fl, fr), A. Gehrt s.n. (SP 3654); 13.XI.1984 (fl, fr), S.N. Pagano 582 (HRCB, SPF); Mogi Guaçu, Fazenda Campininha, III.1996, F.B. Costa 6 (SPFR); Pedregulho, Parque Estadual das Furnas do Bom Jesus, Núcleo Santa Luzia, 24.I.1993 (fl, fr), J.R. Guillaumon s.n. (SPSF 16084); Parque Estadual das Furnas do Bom Jesus, 19.VII.1993 (fl, fr), J.R. Guillaumon s.n. (SPSF 18022); perto da cidade, 12.XI.1994 (fl, fr), W. Marcondes-Ferreira et al. 990 (HRCB, SP, SPF, SPFR, UEC); Parque Estadual de Furnas do Bom Jesus, $20^{\circ} 13^{\prime} \mathrm{S}, 4^{\circ} 26^{\prime} \mathrm{W}$, 4.X.1997 (fl), E.E. Macedo 55 (SPSF); São Carlos, X.1953 (fl, fr), O. Handro 356 (SP, $\mathrm{SPF}) ; 1$ a 2 km do Jockey Club, 2.IX.1961 (fl, fr), J.M. Freitas Campos 29-A (SP). Sem indicação de estado, Catalogos Geographycus Plantarum Brasiliae Tropicale, 1870 (fl), W.J. Burchell 5887 (P); nos cerrados da região do Maranhão sem névoa, IX.1892 (fl), A. Glaziou 27 (P).

9. Viguiera filifolia Sch. Bip. ex Baker in Martius, Fl. Bras. 6 (3): 219. 1884. Tipo: [Brasil]. Cinza, in graminosis pr. Cinza, Mar.1826, Riedel 1444 (lectótipo aqui designado: P!; fotografia do lectótipo: K!, SPF!).

Figuras 3E, 5C e 15

Erva cespitosa 0,6-2m alt., com resina odorífera; ramo aéreo ereto, levemente vináceo, cilíndrico, canaliculado, esparsamente estrigiloso ou glabro, com lenticelas na porção basal; entrenós 0,8-3cm compr.; caule subterrâneo moderadamente espessado, raízes adventícias estreitamente tuberosas. Folhas alternas, verde-claras, adensadas, sésseis, lâmina 55-140x0,6-0,8mm, filiforme, fortemente revoluta, ápice agudo, inteira, 1 nervura proeminente especialmente 
na face abaxial, cartácea, estrigilosa a estrigosa, tricomas tectores 2-3-celulares, com bossas conspícuas, base cilíndrica apressa, circundada por 2 séries de células. Inflorescência botrióide ou tirsóide, $20-40 \mathrm{~cm}$ alt., paracládios eretos, superiores terminando acima do capítulo terminal; 1 a ordem $5-30 \mathrm{~cm}$, 2a ordem 5-16cm compr., 3a ordem raros, ca. $3 \mathrm{~cm}$ compr., cilíndricos a levemente tetragonais, canaliculados, glabros ou esparsamente pubérulos, ebracteolados ou bracteolados, bractéolas 2-7,5cm compr., lineares, pedúnculo terminal 3$30 \mathrm{~cm}$ compr. Capítulos 1,5-2,5cm diâm., invólucro 8-15mm diâm., campanulado a estreitamente campanulado, brácteas involucrais reflexas na floração, levemente desiguais, 3(-4) séries, coriáceas, base caniculada, 3 nervuras destacadas, inteiramente foliáceas ou foliáceas em 1/2 superior, face adaxial com porção superior esparsa a densamente híspida a estrigosa, com glândulas, face abaxial glabra, ou nas internas esparsamente estrigosa, cilioladas a ciliadas, estriadas, membranáceas, lanceoladas a linear-lanceoladas, oval-lanceoladas, ou raramente ovais, ápice agudo a acuminado, mucronado, externas 4,5-16 $\mathrm{mm}$ alt., 2a série 5-18mm alt., 3a série 6-20 $\mathrm{mm}$ alt., e internas 5,5-15mm alt.; receptáculo levemente convexo; páleas 5-8mm alt., geralmente vináceas, oblongas ou levemente obovais, ápice obtuso a agudo, irregular, às vezes esparsamente ciliado, 6 ou 8 nervuras, carena esparsamente estrigilosa. Flores do raio (8-10-)12-20, em 1 verticilo, corola 15-25x2,5-5mm, tubo 1-1,2mm alt., limbo estreitamente elíptico a elíptico, ápice obtuso a agudo, inteiro a curtamente 2-partido, face adaxial glabra; face abaxial com 9-10 nervuras hispídulas; tubo esparsamente estrigiloso; flores do disco ca. 50, corola 4-5mm alt., tubo ca. 0,8mm alt.; face externa com base, tubo e lobos estrigilosos; anteras de base curtamente sagitada, terminando na base do colar filetal ou um pouco abaixo; estilete com alargamento basal semigloboso, estilopódio 0,8-0,12-x0,300,34mm. Cipselas 3,5-4,5mm alt., estreitamente obovóides a obovóides, comprimidas, levemente 4-gonais, estriadas, densamente setosas, carpopódio delgado, pápus geralmente vináceo, 2-3(-4)-aristadas, aristas marginais desiguais, livres, menor 2-2,5mm alt., maior 2,5-3,5mm alt., estreitamente 
triangulares, escamas desiguais, ca. 4 pares, 1,5-2mm alt., unidas até próximo ao ápice lacerado.

Embora descrita originalmente com base em sintipos provenientes da Bahia e Minas Gerais, todas as coletas recentes examinadas dessa espécie são de Goiás (45B), especificamente em Alto Paraíso, em campo arenoso e pedregoso, com flores no final do verão e no outono. Segundo os critérios da IUCN, é uma espécie vulnerável (distribuição restrita e tamanho populacional reduzido), e pode ser afetada por atividades antrópicas ou eventos estocásticos em período muito curto de tempo, podendo assim tornar-se criticamente em perigo ou mesmo extinto.

Espécie morfologicamente próxima de $V$. trichophylla, mas pode ser diferenciada pelo indumento estrigiloso nos lobos das corolas do disco, cipselas com até quatro aristas estreitamente triangulares e escamas com 1,5 a $2 \mathrm{~mm}$ de altura; V. trichophylla possui corolas do disco com lobos glabros, cipselas com 2 aristas de base alargada e escamas com 0,4 a 0,6mm de altura. $\mathrm{Na}$ análise filogenética apresentada no capítulo IV, as espécies emergem em clados diferentes.

Nota nomenclatural: Na mesma exsicata de Riedel 1444, foi montada outra coleta (Riedel 1396), a qual será considerada como sintipo, já que as localidades são quase idênticas, mas Schultz Bipontinus determinou como $V$. filifolia a coleta número 1444. Os dois outros materiais citados no protólogo representam outras espécies; as coleções de Martius, de Serro Frio e Caitité, correspondem a $V$. bracteata Gardner (da qual se diferencia pelo pela presença de indumento híspido e glândulas nas brácteas involucrais, pela forma do alargamento basal do estilete e pela existência de até 4 aristas o pápus) e a coleção de Riedel [s.n.], de Rio Pardo correspondem a V. linearifolia Chodat (uma espécie com folhas de face abaxial densamente albo-lanosa).

Material examinado: BRASIL: Bahia: In campis altis ad Caitété: Martius! (M!, remanescente do síntipo original). Goiás: Alto Paraíso de Goiás, Chapada dos Veadeiros, 1800 m.a.m., 21.XII.1968 (fl), G.M. Barroso et al. 549 (UB); Chapada dos Veadeiros, 21.XII.1968 (fl), R.M. Harley et al. 11384 (K); 35 km N de Veadeiros, 1000 m.a.m., 15.III.1969 (fl), H.S. Irwin et al. 24403 (NY, RB); ca. 15 km da Chapada dos Veadeiros, 1000 m.a.m., 15.III.1969, H.S. Irwin et al. s.n. (RB 


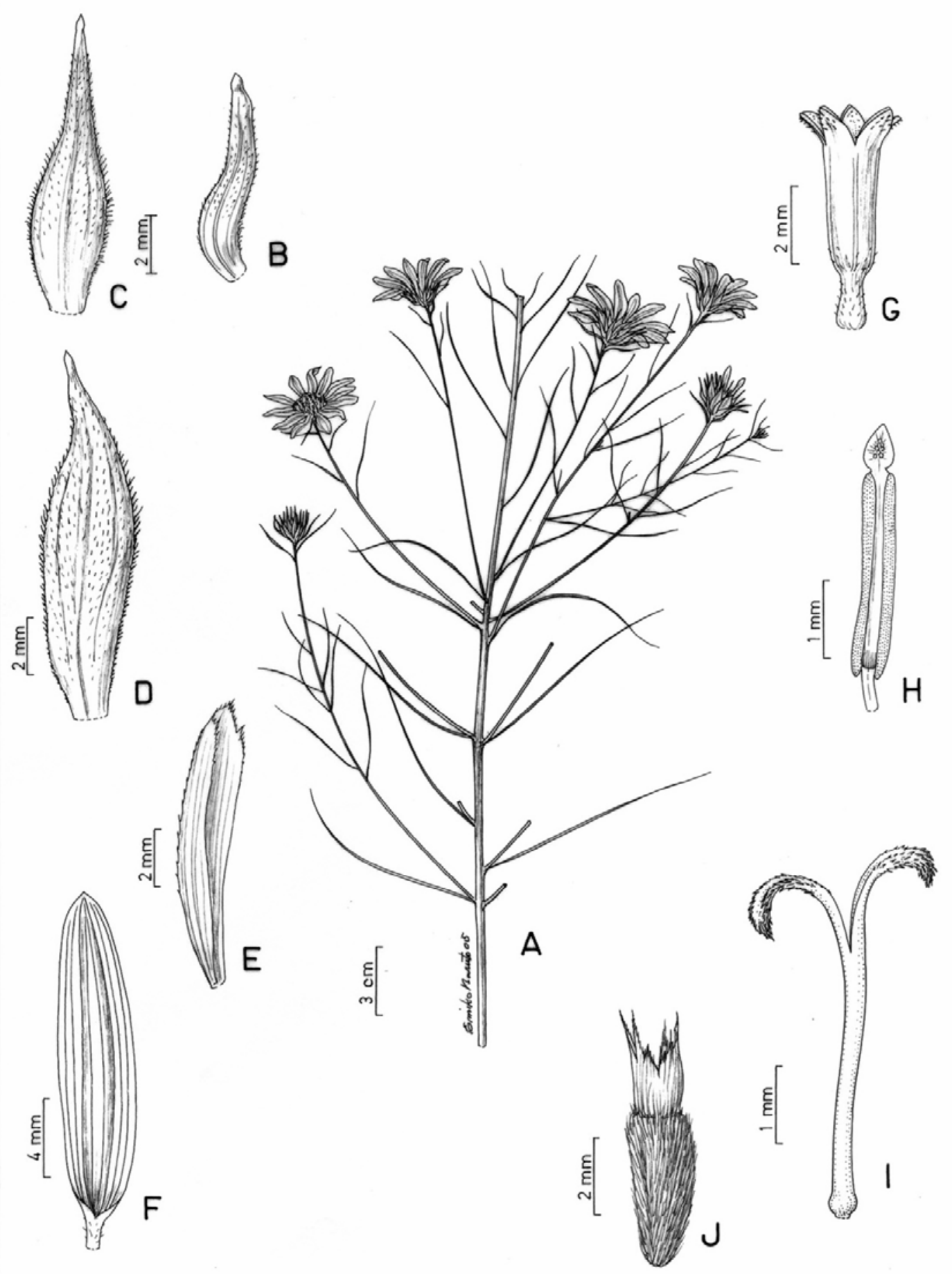

Fig. 15: V. filifolia. A. Segmento da inflorescência (as bractéolas repetem o padrão das folhas caulinares), B-D. Brácteas involucrais, E. Pálea do receptáculo, F. Corola do raio, G. Corola do disco (notar lobos estrigilosos), H. Antera com tecas de base curtamente sagitada, terminando abaixo do colar filetal, I. Estilete com alargamento basal semigloboso, J. Cipsela 4-aristada. A-I. M. Magenta \& J. Magenta 376 (SPF), J. idem 442 (SPF). 
177404); 16 km sul de Alto Paraíso, 1000 m.a.m., 21.III.1969 (fl), H.S. Irwin et al. 24761 (NY, RB); ca. 19 km N de Alto Paraíso, 1250 m.a.m., $20 . I I I .1971$ (fl, fr), H.S. Irwin et al. 32791 (NY, RB, UEC); Chapada dos Veadeiros, $4 . I I .1972$ (fl), J.A. Rizzo 7570 (UFG); idem, 6.IV.1972 (fl), J.A. Rizzo 7918 (UFG); Chapada dos Veadeiros a $10 \mathrm{~km}$ depois de Alto Paraíso, 18.III.1976 (fl), J. Semir s.n. (HEPH 40373, IBGE, UEC 2628); rodovia GO 118, Chapada dos Veadeiros, $18-19 \mathrm{~km} \mathrm{~N}$ de Alto Paraíso, 1350 m.a.m., 24.I.1980 (fl), R.M. King \& F. Almeda 8277 (K, MBM, UB); Chapada dos Veadeiros, estrada Alto Paraíso - Teresina de Goiás, 29.V.1994, S. Bridgewater et al. S-204 (UFG); idem, $14^{\circ} 07^{\prime} \mathrm{S}, 47^{\circ} 28^{\prime} \mathrm{W}, 29 . \mathrm{V} .1994$ (fl), S. Bridgewater et al. S-206 (HUFG, UB, UFG); rodovia GO 118, ca. $8 \mathrm{~km} \mathrm{~N}$ de Alto Paraíso, margem direita, $1^{\circ} 04^{\prime} \mathrm{S}, 4^{\circ} 30^{\prime} \mathrm{W}, 1485$ m.a.m., $21 . I V .1998$ (fl, fr), F.B.

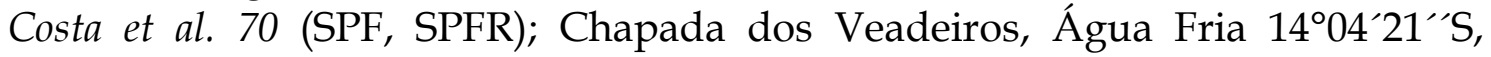
47³0`33”W, 1530 m.a.m., 26.IV.1998 (fl), C. Munhoz et al. 718 (HEPH, UB); rodovia GO 118, Chapada dos Veadeiros, $10 \mathrm{~km} \mathrm{~N}$ de Alto Paraíso, 8.V.2000 (fl, fr), G. Hatschbach et al. 70682 (CTES, MBM); rodovia BR 118 km 117, Chapada

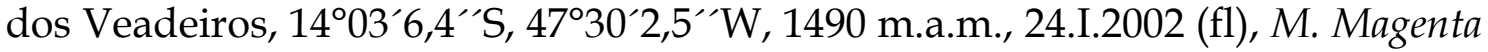
\& J. Magenta 376 (SPF); rodovia GO 118 km 182, sentido Alto Paraíso de Goiás -

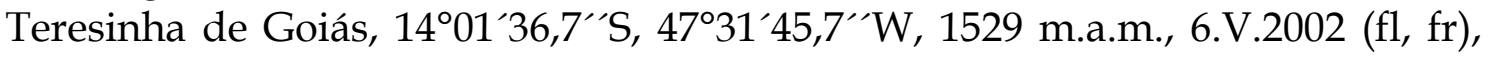
M. Magenta et al. 442 (SPF); rodovia GO 118, sentido Alto Paraíso de Goiás -

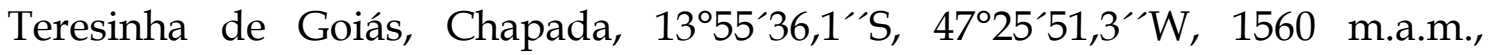
6.V.2002 (fl, fr), M. Magenta et al. 447 (K, SPF, TEX); sentido Alto Paraíso de

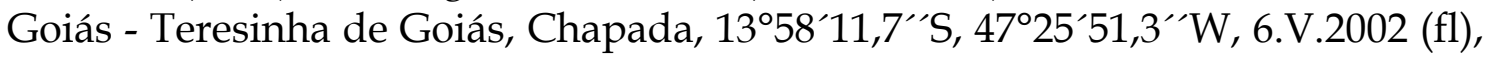
M. Magenta et al. 452 (HUFU, K, SPF). Minas Gerais: Habitat in prov. Minas Geraës, in campis Serro Frio: Martius (remanescente do síntipo original: M!) In campis graminosis montosis pr. Cinza, Febr. 1826, Riedel 1296 (remanescente do síntipo original: P!).

10. Viguiera gardneri Baker in Martius, Fl. bras. 6 (3): 224. 1884. Tipo citado sob a var. gardneri.

\section{Figuras 5D e 16}

Erva a subarbusto com resina, 1-2,5m alt., ramos aéreos eretos, cilíndricos, escabrosos, híspidos a setosos, entrenós 0,8-15mm compr.; caule subterrâneo raízes adventícias tuberosas na porção mediana. Folhas verdeclaras a discolores, 1-2 pares basais opostos, superiores alternas; pecíolo 0,31,2mm compr.; lâmina 3,5-12x0,8-4cm, oblonga a largamente oblonga, elíptica, oval-lanceolada ou raramente oval, base arredondada, obtusa ou atenuada, ápice agudo, mucronulado, inteira ou esparsamente denteada a esparsamente serreada na porção superior, cartácea, nervação acródroma basal a suprabasal, imperfeita a perfeita, 3 nervuras principais, face adaxial esparsa a densamente estrigosa, tricomas tectores 2-celulares com bossas, base cilíndrica levemente 
apressa, cercada por 1-2 séries de células, face abaxial esparsa a densamente estrigosa a vilosa, tricomas tectores 2-3-celulares, com bossas, às vezes com tricomas glandulares. Inflorescência botrióide ou tirsóide, $20-50 \mathrm{~cm}$ alt., paracládios eretos a flexuosos, superiores terminando acima do capítulo terminal estreitamente canaliculados, estrigosos, com bractéolas foliáceas ou sem bractéolas, , ou raramente próximo a ele; 1a ordem 10-30cm compr., 2a ordem 4,5-8cm compr.; pedúnculo terminal 1,5-11cm compr. Capítulos 3-4cm diâm., radiados, invólucro 8-12mm diâm., campanulado a semigloboso, subtendido por 1-2 bractéolas 3-10mm compr., ovais, estrigosas, brácteas involucrais reflexas na floração, 4-5 séries, oblongas, largamente oblongas ou lanceoladas, base estriada, 3 nervuras levemente destacadas, foliáceas em 1/3 superior, ápice agudo mucronado, ciliadas, coriáceas, face adaxial glabra a híspida, com ou sem glândulas, 1a série 4-5(-10)mm alt., face abaxial estrigosa a vilosa na porção superior, 2a série 6-8(-11)mm alt., face abaxial estrigilosa na porção superior, 3a e $4 \mathrm{a}$ séries $8-13 \mathrm{~mm}$ alt., face abaxial esparsamente estrigilosa na porção superior; receptáculo levemente convexo, páleas 7-10mm alt., oblongas a levemente obovais, ápice expandido truncado ou obtuso, geralmente mucronado, , 8, 10 ou 12 nervuras, a principal estrigosa, carena estreita estrigosa. Flores do raio 12-16, em 1 verticilo, corola 9-12x2-3mm, tubo 1,5-2mm alt., limbo oblongo, ápice curtamente 2-partido, face adaxial glabra, face abaxial com 8-10 nervuras estrigilosas; tubo estrigiloso a estrigoso; flores do disco 80-150, corola 6-7mm alt., tubo 1-1,2mm alt., face externa estrigilosa, antera de base curtamente sagitada, terminando acima ou na base do colar filetal, estilete com alargamento basal fusiforme, estilopódio 0,16-0,18x0,380,40 mm. Cipselas 3-4,5mm alt., estreitamente obovóides, estriadas, jovens seríceas, maduras glabrescentes, carpopódio delgado, pápus estramíneo a amarelado com manchas vináceas, 1-2-aristado, aristas marginais iguais a desiguais 1,5-2,5mm alt., livres, delicadas, estreitamente triangulares, margem lacerada, escamas 3-4 pares, 0,7-1,5mm alt., unidas até próximo ao ápice lacerado. 
Ocorre no Distrito Federal e ao sudoeste do Estado de Goiás (fig. 46A). Floresce e frutifica nos meses de abril e maio.

Morfologicamente próxima de $V$. vernonioides, mas com raio composto por 12-16 flores e com 80 a 150 flores no disco, enquanto a segunda apresenta raio com 8 flores e disco com mínimo de 40 e máximo de 85 flores. Assemelhase a $V$. arenaria e $V$. goyasensis, das quais se diferencia por características das folhas e do fruto, além de flores do raio menores do que as de $V$. arenaria (ver comentários das espécies). A fixação de certas características vegetativas em um grupo de espécimes de regiões próximas ao Distrito Federal, permite o reconhecimento de duas variedades.

Nota nomenclatural: Justificativa de escolha do lectótipo: O material depositado no herbário K, oriundo do herbário Hookerianum, apresenta a etiqueta manuscrita por Gardner.

\section{Chave para as variedades de $V \cdot$ gardneri}

1. Folhas com lâmina oblonga a largamente oblonga, elíptica, oval-lanceolada; brácteas involucrais com cílios curtos....... Viguiera gardneri Baker var. gardneri

1. Folhas e bractéolas ovais a largamente ovais; brácteas involucrais com cílios longos Viguiera gardneri Baker var. ovatifolia

10.1. Viguiera gardneri Baker var. gardneri. Rhysolepis gardneri (Baker) H. Rob. \& A.J. Moore, Proc. Biol. Washington 117(7): 426. 2004. Tipo: Brazil, Goyaz, dry upland campos between Arrayas and Sañ Domingos, May 1840, Gardner 4233 bis (lectótipo aqui designado: K!, ex Herb. Hookerianum; fotografia do lectótipo: $\mathrm{K}$ !, SPF!; isolectótipos: $\mathrm{BM}$ !, $\mathrm{K}$ !, GH - frag.).

Rhysolepis subtruncata H. Rob \& A.J. Moore, Proc. Biol. Soc. Wash. 117(3): 442. Tipo: G. Hatschbach et al. 72008 (Brasil, Goiás, Chapada dos Veadeiros, ca. $42 \mathrm{~km} \mathrm{~N}$ of Alto Paraíso, ca. $125 \mathrm{~m}$ elev., riacho margin in cerrado, on rock slopes and adjacent campo, 25 Mar 1971, Irwin, Harley \& G. L. Smith 33151A (holótipo US*; isótipos: $\mathrm{NY}^{*}, \mathrm{UB}$ ). syn. nov.

Material examinado: BRASIL: Distrito Federal: Brasília, Bacia do Rio Bartolomeu, 15.IV.1980 (fl, fr), E.P. Heringer et al. 4387 (HEPH, IBGE); A.R.I.E. 
do Capetinga, lado esquerdo da estrada ferro Centro-Oeste, próximo Catetinho, 8.VI.1988 (fl), M.A. Silva 687 (HEPH, IBGE, RB); área do Cristo Redentor, 16.V.1990 (fl, fr), M.L.M. Azevedo \& D. Alvarenga 548 (HEPH, IBGE, RB, US); Planaltina Águas Emendadas, 21.IV.1972 (fl), M.B. Ferreira 1331 (HEPH); Sobradinho, Granja Ruy Malta, 21.IV.1963 (fl, fr), J.M. Pires et al. 9365 (P, RB). Goiás: Águas Lindas, rodovia BR 070 km 46, Águas Lindas - Cocalzinho de Goiás, margem direita, 24.IV.1998 (fl, fr), F.B. Costa 82 (SPF, SPFR); Alto Paraíso de Goiás, rodovia GO 118, 29 km N de Alto Paraíso, na margem direita, 135'ㄴ, 47²5'W, 1630 m.a.m., 21.IV.1998 (fl, fr), F.B. Costa et al. 72 (SPF, SPFR); rodovia GO 118 km 200, Chapada dos Veadeiros, 9.V.2000 (fl, fr), G. Hatschbach et al. 70725 (CTES, MBM); rodovia GO 118 km 182, sentido Alto Paraíso de Goiás -

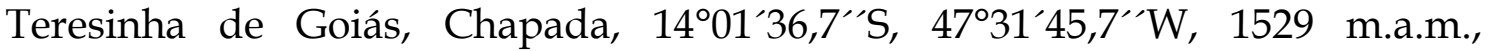
6.V.2002 (fl), M. Magenta et al. 443 (SPF); idem, km 211, 1352’19,1“'S, 47²0`2,6”'W, 1250 m.a.m., 6.V.2002 (fl, fr), M. Magenta et al. 445 (HUFU, K, SPF); rodovia GO 118, sentido Alto Paraíso de Goiás - Teresinha de Goiás, Chapada,

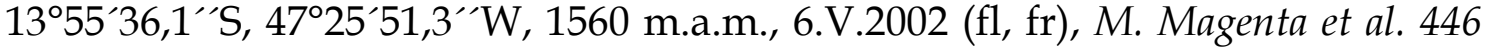
(HUFU, K, SPF); rodovia GO 118 km 144, sentido Alto Paraíso de Goiás - São

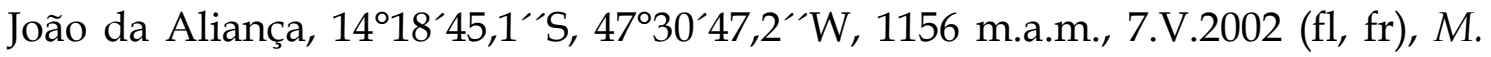
Magenta et al. 453 (SPF); Cavalcante, estrada terra entre Cavalcante e Araí, 133`30,0“S, 47³1'23,2”W, 1135 m.a.m., 13.IV.2004 (fl, fr), R.C. Mendonça et al. 5514 (IBGE, SPF); Cocalzinho de Goiás, estrada Cocalzinho - Pirenópolis, Serra dos Pirineus, 28.V.1998 (fl), R.C. Forzza et al. 892 (CEN, SPF); rodovia BR 070 km 46,5, sentido Águas Lindas - Cocalzinho, 1545`20,6”S, 48³4`56,6”W, 1096 m.a.m., 7.V.2002 (fl, fr), M. Magenta et al. 457 (SPF); Formoso, alto da Serra Grande, Formoso para Campinaçu, $18 . I I I .1972$ (fl, fr), J.A. Rizzo 7900 (UFG); Formoso, Formoso para Campinaçu, alto da Serra Grande, 13.IV.1972 (fl, fr), J.A. Rizzo 8036 (UFG); Ipameri, rodovia BR $050 \mathrm{Km} \mathrm{180,} \mathrm{sentido} \mathrm{Catalão} \mathrm{-} \mathrm{Cristalina,}$

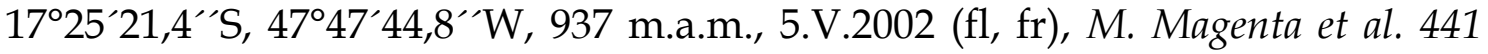
(SPF); Niquelândia, $1 \mathrm{~km}$ da entrada da Fazenda da Níquel Tocantins, próximo a Codemin, $14^{\circ} 05^{\prime} \mathrm{S}, 48^{\circ} 22^{\prime} \mathrm{W}, 440$ m.a.m., 15.IV.1992 (fl, fr), B.M.T. Walter et al. 1394 (CEN, RB, SPF); $4 \mathrm{~km}$ após a ponte de madeira, reserva do IBAMA,

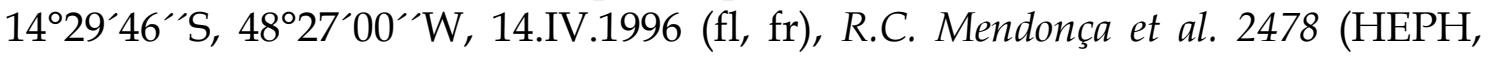
IBGE, RB); Santo Antônio do Descoberto, 27.III.1980 (fl), A.E.H. Salles 134 (HEPH, IBGE); rodovia BR 060, estrada que liga BR 060 a Santo Antonio do Descoberto, km da BR, 7.V.2002 (fl, fr), M. Magenta et al. 455, 456 (SPF); município indefinido, V.1840 (fl, fr), G. Gardner 2133bis (BM); Between Arrayas \& Sañ DomingosDry, upland campo (18114), V.1848 (fl, fr), G. Gardner 4233, bis (BM, K); ponto 09, RADAMBRASIL, próximo a Chapada das Mangabeiras, 1043'S, 46²'1'W, $30 . I V .1978$ (fl, fr), C.A. Miranda 194 (HRB, RB). Minas Gerais: Olhos-d'Água, rodovia MG 451 km 61, 17³2’26,5”`S, 43³1'55,7"W, 764 m.a.m., 20.IV.2003 (fl), M. Magenta \& J. Magenta 655, 656 (SPF); Capitólio, Morro do Chapéu, 1200 m.a.m., 22.VII.1985 (fl, fr), G. Martinelli et al. 11261 (BHCB, NY, $\mathrm{RB})$. 


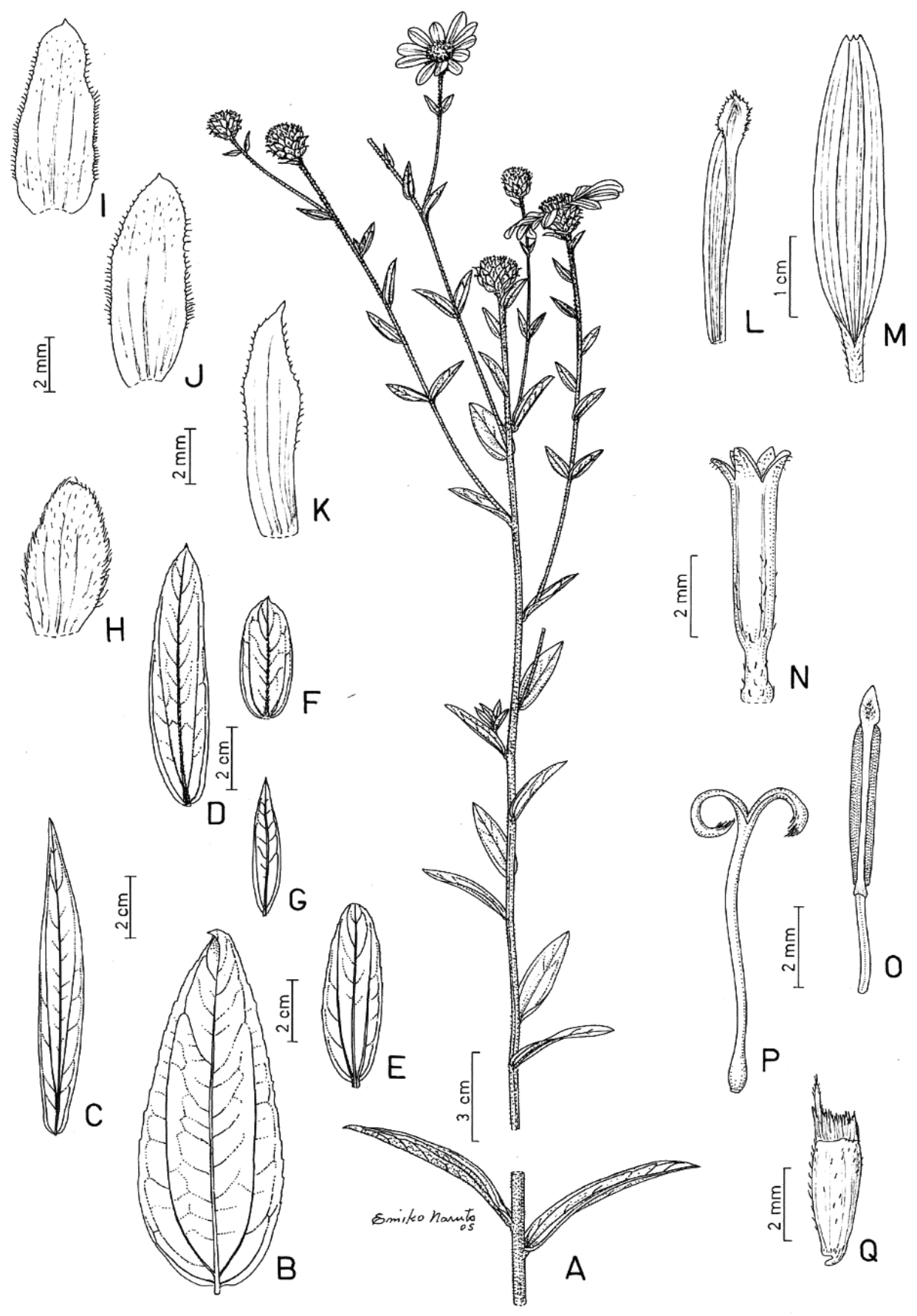

Fig 16: V. gardneri. A. Segmento de ramo com sinflorescência, B-G. Folhas, variação na forma, H-K. Brácteas involucrais, L. Pálea do receptáculo, M. Corola do raio, N. Corola do disco, $\mathrm{O}$. Antera com tecas de base curtamente sagitada, terminando acima da base do colar filetal, P. Estilete com base fusiforme. Q. Cipsela . A-Q. M. Magenta et al. 455 (SPF). 
10.2. Viguiera gardneri Baker var. ovatifolia Magenta, var. nov. Tipo: Santo Antônio do Descoberto, morro a 1 km em direção a Cidade Eclética, 9.IV.1984, B.A.S. Pereira 994 (holótipo: IBGE!; isótipos: HEPH!, RB!, SP!, US!)

Material examinado: BRASIL: Goiás: Itiquira, 16.III.1980 (fl, fr), A.E.H. Salles 160 (HEPH, IBGE); Luziânia, Santo Antonio do Descoberto, 27.III.1980 (fl), E.P. Heringer 17691 (HEPH, IBGE); estrada de terra entre Santo Antonio e

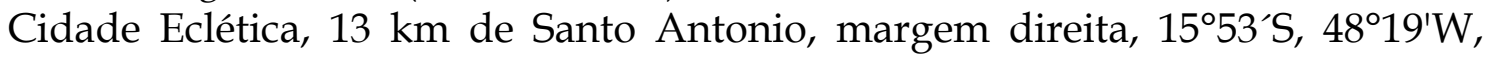
1120 m.a.m., 24.IV.1998 (fl, fr), F.B. Costa 81 (SPF, SPFR).

11. Viguiera goyasensis (H. Rob. \& A.J. Moore) Magenta comb. nov. Rhysolepis goyasensis H. Rob. \& A.J. Moore, Proc. Biol. Soc. Wash. 117(3): 436. Tipo: Goiás. Serra Geral do Paraná, ca. 3km S. of São João da Aliança, near Riacho, ca. 850m, gallery forest and adjacent cerrado, 15 Mar 1971, H.S. Irwin et al. 31821 (holótipo: US*; isótipos: MBM!, NY*, UB, US*).

Figura 17

Subarbusto ca $1 \mathrm{~m}$ compr., ramos áereos eretos, cilíndricos, híspidos entrenós 0,8-15mm; caule subterrâneo levemente espessado, raízes adventícias sem tuberosidade. Folhas verde-escuras alternas, superiores reduzidas; pecíolo 12mm compr.; lâmina 0.6-6,5xx0,3-2,1cm, oblongo-elíptica ou oval-lanceolada, base arredondada, obtusa ou atenuada, ápice agudo a levemente acuminado, inteira, cartácea, nervação acródroma basal a suprabasal, imperfeita a perfeita, 3 nervuras principais, densamente híspidas, tricomas 3-4-celulares de base cilíndrica ereta cercada por 1-2 séries ce células. Inflorescência ou tirsóide, 11,5-30cm alt., paracládios eretos, superiores terminando levemente acima do capítulo terminal, 3,5-20cm compr., canaliculados, densamente híspidos, com bractéolas foliáceas 0,7-10 $\mathrm{mm}$ compr., pedúnculo terminal 5-10cm compr. Capítulos 2,5-3cm diâm., radiados, invólucro 10-15mm diâm., brácteas involucrais apressas a levemente reflexas na floração, ca. de 3-4 séries, oblongas, largamente oblongas a oblongo-lanceoladas, base levemente estriada, ápice agudo a levemente acuminado, totalmente foliáceas ou foliáceas em 2/3 superiores, coriáceas, face adaxial glabra a híspida, 1a série 6-8mm, densamente híspida, 2a série 10-12mm alt., face abaxial densamente híspida na 
porção superior, 3a 10-15mm alt., face abaxial híspida na porção superior, 4a série, quando presentes, 6-7mm alt., ciliadas; receptáculo levemente convexo, páleas 8-10mm alt., oblongas a elípticas, ápice agudo a levemente acuminado, geralmente mucronado, 8, 10 ou 12 nervuras, glabras ou muito esparsamente estrigilosas, carena larga. Flores do raio 14-15, em 1 verticilo, corola ca. Xxx mm partido, face adaxial glabra e face abaxial com 10-12 nervuras pubescentes; tubo pubescente; flores do disco ca. 50, corola 5-6mm alt., tubo 0,7-1mm alt., glabras, antera de base curtamente sagitada, terminando acima da base do colar filetal, estilete com alargamento basal semigloboso a cônico, estilopódio 0,160,18x0,38-0,40mm. Cipselas ca. 3mm, estreitamente obovóides, estriadas, glabrescentes, carpopódio delgado, pápus estramíneo a amarelado 2-aristado, aristas marginais iguais a desiguais $2-3,1 \mathrm{~mm}$ alt., unidas às escamas laterais, lanceoladas, margem e nervura estrigilosas; escamas 3-4 pares, 1,1-1,7mm alt., unidas até próximo ao ápice lacerado.

Coletada apenas no município de São João da Aliança, no sudoeste do Estado de Goiás (fig. 46A), em simpatria com $V$. gardneri, da qual se diferencia principalmente folhas oblongo-elípticas a oval lanceoladas com margem inteira, invólucro densamente viloso e aristas do pápus unidas às escamas laterais; a outra tem folhas oblongas a largamente oblongas, geralmente com dentes esparsos, invólucro estrigoso ou viloso apenas na porção superior e pápus com aristas livres. Floresce e frutifica nos meses de fevereiro e março.

A existência de poucos exemplares levou a considerar o táxom como espécie, mas estudos futuros, com marcadores moleculares, poderão mostrar que se trata apenas de um extremo de variedade fenotípica de $V$. gardneri.

Material examinado: BRASIL: Goiás: São João d'Aliança, estrada para Vãozinho, 9.II.1994 (fl), G. Hatschbach et al. Silva 60230 (parátipos: BR, CTES, K, MBM); Corrente, 20.II.2000 (fl), G. Hatschbach et al. 70471 (parátipo: MBM). 

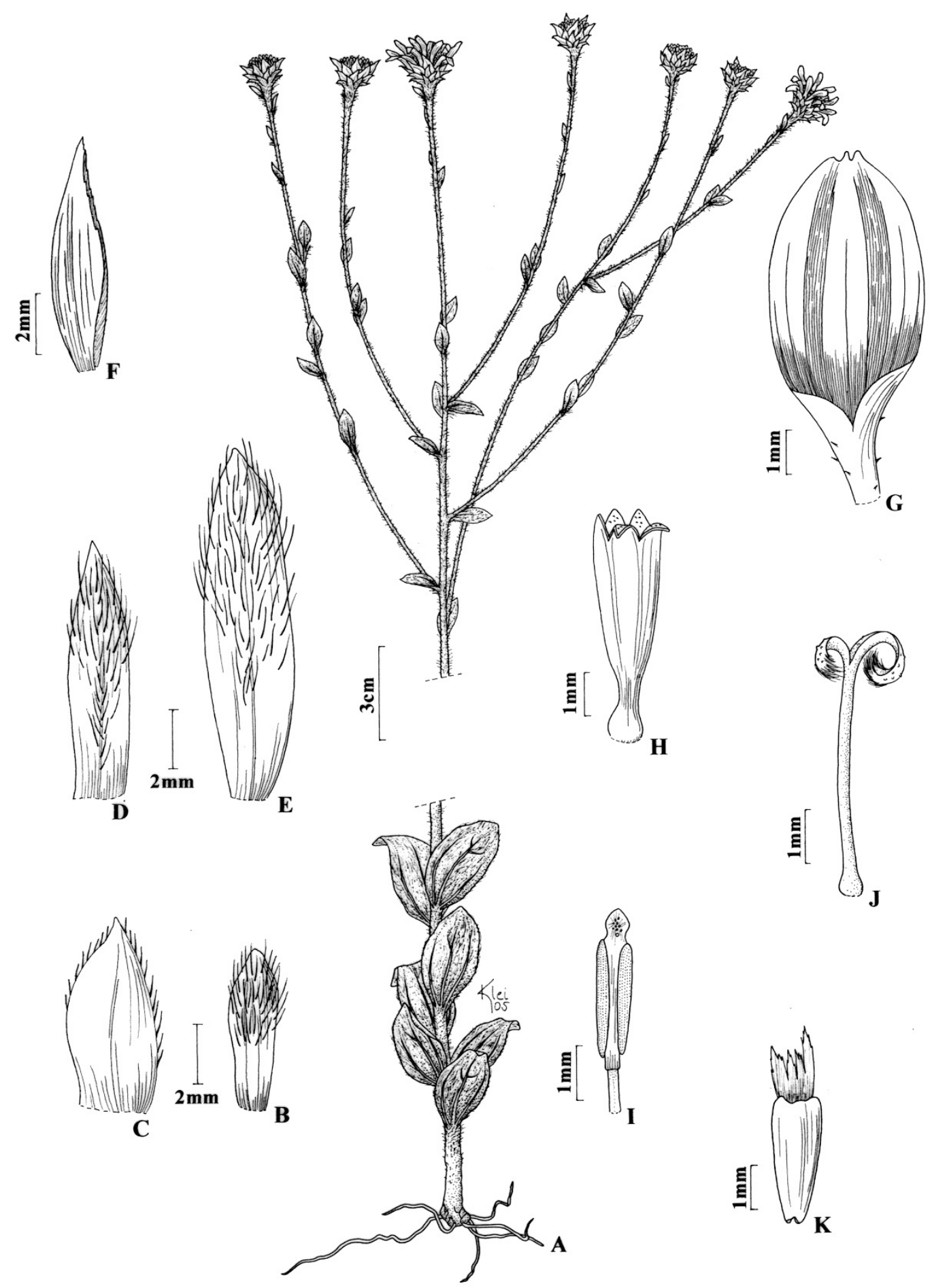

Fig. 17: V. goyasensis: A. Segmento de hábito com sinflorescência, B-E. Brácteas involucrais, F. Pálea do receptáculo, G. Corola do raio, H. Corola do disco, I. Antera com tecas de base curtamente sagitada, terminando acima da base do colar filetal, P. Estilete com base cônica. K. Cipsela. A-QK G. Hatschbach et al. 60230. 
12. Viguiera grandiflora (Gardner) Gardner, London J. Bot. 7: 404. 1848. Leighia grandiflora Gardner in Field \& Gardn., Sert. P1. 54-55. 1844. Viguiera grandiflora f. typica S.F. Blake, Contr. Gray Herb. 54: 127. 1918. Viguiera grandiflora f. latifolia (Baker) S.F. Blake, Contr. Gray Herb. 54: 127. 1918. Tipo: [Brazil. Goyaz.] Dry Hills near Mission of Duro, Oct. 1839, Gardner 3288 (holótipo: OXF, isótipos: BM!, GH - frag., K! - 2x, NY*, P!, RB!; fotografia de isótipo de B [destruído]: F!).

Viguiera macrantha Glaziou, Bull. Soc. Bot. Fr. 57. Mém. 3: 413, nom. nud. pro syn.

Viguiera grandiflora var. latifolia Baker in Mart., Fl. bras. 6(3): 224. 1884. Tipo: Brazil, Goyaz, dry wooded campos, Missione of Duro, Oct. 1839, Gardner 3288 (bis) (lectótipo aqui designado: K!, fotografia do lectótipo: K!, SPF!).

Viguiera macropoda S.F. Blake, Contr. Gray Herb. 54: 128. 1918. Tipo: Brésil, province de Minas Gerais, A. St.-Hil. 1157 (holótipo: P!; fotografia do holótipo: K!, SPF!). syn nov.

Figuras 6A e 18

Erva a subarbusto 0,6-1m alt., eretos; ramos aéreos eretos, cilíndricos a levemente tetragonais, profundamente canaliculados, hirsutos, raramente também estrigosos; entrenós 2,5-9cm compr.; caule subterrâneo levemente espessado, raízes adventícias sem tuberosidade. Folhas verde-claras ou ligeiramente escuras, alternas ou inferiores raramente opostas, sésseis, lâmina 5$15 \times 1-9 \mathrm{~cm}, 2-3$ pares inferiores reduzidos, orbicular, elíptica a largamente elíptica, oblonga a largamente oblonga, oboval, largamente oboval ou lanceolada, base arredondada, cuneada ou raramente atenuada, ápice arredondado, agudo ou raramente acuminado, crenada a crenado-denteada, cartácea, levemente escabrosa; nervação acródroma basal perfeita, 3-5 nervuras principais, face adaxial hirsuta a setosa, tricomas tectores levemente apressos, 23-celulares de base cônica a levemente cônica, cercada por 2-3 séries de células, face abaxial hirsuta nas nervuras, tricomas tectores 3-4-celulares, de base cônica a cilíndrica, cercada por uma série de células, e tricomas glandulares. Inflorescência botrióide laxa, $8-70 \mathrm{~cm}$ alt., paracládios eretos ou levemente flexuosos, superiores terminando acima do capítulo terminal, 5-26cm compr, 
canaliculados, híspidos a hispídulos, com 1-2 bractéolas 5-8mm compr, lineares, estrigilosas; pedúnculo terminal 4-20cm compr., ou capítulos solitários. Capítulos 5-10cm diâm., radiados, invólucro 20-25mm diâm., campanulado, brácteas involucrais levemente apressas na floração, em 2-3 séries, 8-18mm alt., linear-lanceoladas, base caniculada, 3-5 nervuras destacadas, foliáceas em 3/4 superiores, ápice agudo a acuminado, esparsamente cilioladas, cartáceas, face abaxial estrigosa a densamente estrigosa, glândulas esparsas; 1a série com face adaxial estrigilosa e com glândulas, 2a série com face adaxial glabra; receptáculo convexo, páleas 10-12mm alt., lanceoladas, ápice acuminado, 8, 10 ou 12 nervuras, estrigilosas e com glândulas, especialmente no ápice, carena estreita. Flores do raio ca. 12, em 1 verticilo, corola $25-45 \times 4-10 \mathrm{~mm}$, tubo 22,5mm alt., limbo oblongo a elíptico, ápice agudo, curtamente 2-3-partido, face adaxial glabra, face abaxial com glândulas esparsas, nervuras 18-16, esparsamente hispídulas; tubo hispídulo, às vezes com pistilódio e, mais raramente, estaminódios; flores do disco ca. 80, corola 5,5-6mm, tubo ca. 1,5mm alt., lobos com altura igual ou maior que o dobro da largura, face externa com base do limbo estrigilosas, tubo e nervuras esparsamente hispídulos, lobos estrigilosos e com glândulas; antera de base curtamente sagitada, terminando na base ou levemente abaixo do colar filetal; estilete com alargamento basal cônico a semigloboso, estilopódio 0,14-0,18x0,36-0,37mm. Cipselas 6,5-8,5mm alt., estreitamente obovóides, comprimidas, levemente 4-gonais estriadas, sulcadas, densamente setulosa próximo ao ápice, carpopódio médio, pápus amarelado 2-aristado, aristas levemente intramarginais iguais ou levemente desiguais, 0,8-2,5mm alt., livres, firmes, porção inferior triangular alargada, ápice longamente acuminado, esparsamente laceradas, estrigilosas, escamas 4-6 pares, 0,3-0,8mm alt. alt., unidas na base, até o meio ou próximo ao ápice lacerado.

Ocorre no Distrito Federal, norte de Mato Grosso do Sul, noroeste e nordeste de Goiás, noroeste de Minas Gerais e Sul da Bahia (fig. e 46B), em cerrados típicos e campos. Floresce e frutifica na primavera ou raramente no verão. 
São plantas tolerantes a diferenças de intensidade luminosa, condições refletidas na variação da forma e da cor da lâmina foliar; as heliófilas geralmente apresentam um maior número de folhas orbiculares e mais claras. A observação em campo demonstrou que as diferenças de forma foliar, utilizadas por Blake para separar a espécie em duas formas distintas, não procedem; a forma das folhas varia numa mesma população e até num único indivíduo (ex.: R.M. Harley 4296, A.P. Duarte 10313). Esta espécie apresenta indivíduos muito semelhantes a certos espécimes de $V$. squalida, sendo às vezes impossível diferenciá-las em estado vegetativo. A distinção se dá com facilidade por meio da observação do capítulo, cujas brácteas involucrais são sempre linearlanceoladas com face abaxial estrigosa a densamente estrigosa, e do fruto, que é geralmente longo e estreito e apresenta aristas livres, com ápice longamente acuminado, enquanto $V$. squalida possui capítulos com brácteas involucrais elíptico-lanceoladas a oval-lanceoladas ou raramente oblongo-lanceoladas, com face abaxial glabra a esparsamente estrigilosa e cipselas menores e mais largas, com aristas unidas às escamas laterais. Outra espécie de aspecto similar é $V$. simulans, do Paraguai; mas esta esta possui brácteas involucrais lanceoladas com face abaxial híspida, e cipselas de formato semelhante às de V. grandiflora.

Na descrição da espécie, Baker citou apenas o número 3288, no qual inclui a variedade típica e a variedade latifólia. No entanto Baker anotou 3288 (bis) com o nome var. latifolia; este foi aqui selecionado como seu lectótipo.

Material examinado: BRASIL: Bahia: Rio de Contas, Pico do Itabira, 1322'07'S, 4153'03"W, 1800 m.a.m., 15.XI.1996 (fl, fr), R.M. Harley et al. 4296 (ALCB, HRB, HUEFS, SPF); estrada para Serra da Calambola, ca. $25 \mathrm{~km}$ de Rio de Contas, 14.XI.1998 (fl), R.P. Oliveira et al. 71 (HUEFS). Distrito Federal: Brasília, 16.XI.1958 (fl), E. Pereira \& Pabst 4746 (RB); Convênio Florestal, 29.IX.1961 (fl, fr), E.P. Heringer 8703/897 (PEL, K, RB, UB); Paranoa, X.1964 (fl, fr), G.M. Barroso s.n. (RB 124550); ca.15 km leste de Brasília, 1000 m.a.m., 17.VIII.1965, H.S. Irwin et al. 7805 (NY, UB); Rio Descoberto, 28.X.1966 (fl), A.P. Duarte 9966 (RB); Córrego Cabeça de Veado, ca. 11,5 km sudoeste torre de tv Brasília, 27.VIII.1976 (fl, fr), J.A. Ratter et al. 3496 (CPAP, K, UB, UEC); Reserva Ecológica do IBGE, picada R-6, 7.XI.1977 (fl), E.P. Heringer et al. 249 (HEPH, IBGE, RB); próximo Escola Fazendária, 18.X.1978 (fl), E.P. Heringer et al. 17150 (HEPH, K); Fazenda Água limpa, near Vargem Bonita, $18 \mathrm{~km}$ SSW of TV tower, 3.XI.1978 (fl, fr), J.A. Ratter et al. R.427 (K); Fazenda Santa Prisca, 17.IX.1979 (fr), E.P. Heringer et al. 2015 (IBGE, K); Bacia do Rio Bartolomeu, 3.VI.1980, E.P. 
Heringer et al. 4978 (HEPH); Fazenda Água Limpa, Córrego da Onça, 1557'S, 4754"W, 1070 m.a.m., 3.IX.1980 (fl), M.A.G. Barros \& H. Alves 92 (UB); Torre de microondas, sul, 25.IX.1980, E.P. Heringer 17810 (HEPH); próximo Córrego Rajadinha, 5.X.1983 (fl), B.A.S. Pereira 816 (HEPH, UEC); próxima Cabeça de Veado, 5.X.1984 (fl, fr), T.S. Filgueiras 1150 (HEPH, RB, UEC); arredores do Jardim Botânico, ca. 9 km sudoeste do centro de Brasília, 24.X.1987, G. Eiten \& J. Pruski 16000A3527 (NY, UB); Reserva Ecológica do IBGE, entre a estrada e a mata Córrego Taquara, 21.VIII.1990 (fl, fr), M.A. Silva et al. 1009 (HEPH, IBGE, RB, UEC, US); idem, próximo Fazenda Água Limpa, 4.IX.1990, A.L. Brochado \& T.S. Filgueiras 59 (HEPH, UEC); Cristo Redentor, Campo Limpo, 10.X.1990 (fl), A.L. Brochado 70 (HEPH, IBGE, RB); Cachoeira do Cariru, próximo a PADEF, 9.XI.1991, G. Pereira da Silva et al. 896 (CEN, K, SPF); Reserva Ecológica do IBGE, projeto fogo, 9.XII.1991 (fl, fr), M.F. Landim de Souza 83 (HEPH, IBGE, US); Reserva Ecológica do IBGE, 1556“41“'S, 4753`07”W, 1150 m.a.m., 7.XI.1994 (fl, fr), M.A. Silva et al. 2457 (HEPH, IBGE, US); rodovia BR 010, após trevo Planantina para Alto Paraíso de Goiás, XI.1997, F.B. Costa 40 (SPFR); Cristo Redentor, 1557'07'`S, 4753'37"W, 19.X.1988 (fl), M.L.M. Azevedo 180 (HEPH, IBGE, RB); próximo a entrada para Riacho Fundo, 29.IX.1999 (fl, fr), K. Calago et al. 313 (CEN, UEC); Reserva Ecológica do IBGE, próximo Córrego Taquara, 1555`55”S, 4783’08”W, 1015 m.a.m., $20 . I X .1999$ (fl, fr), M.L. Fonseca \& D. Alvarenga 2106 (HEPH, IBGE, UEC); Reserva Ecológica do Jardim Botânico de Brasília, 20.IX.2000 (fl, fr), C.E. Rodrigues Jr. 1423 (HEPH); Península Norte, 1000 m.a.m., s.d. (fl), V.C. Anjos 11 (UB); campus da Universidade de Brasília, s.d. (fl), L.Q. Cobra \& J.O. Oliveira 227-A (RB, UB); idem, s.d., L.Q. Cobra \& J.O. Oliveira 227-B (UB); Gama, Ponte Alta - Gama, 6.XI.1976 (fr), A.Allem 287 (CEN, $\mathrm{RB})$; Sobradinho, rodovia DF $01 \mathrm{~km} \mathrm{9,} \mathrm{sentido} \mathrm{Paranoá} \mathrm{-} \mathrm{Sobradinho,}$

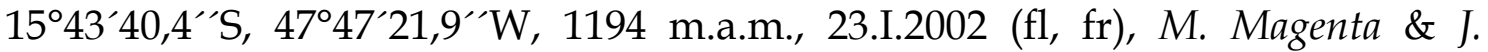
Magenta 371 (SPF). Goiás: Abadiânia, rodovia BR 360 km 17, sentido Alexânia -

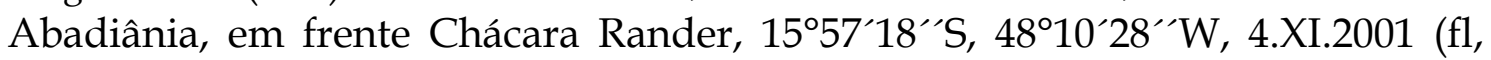
fr), M. Magenta \& J. Magenta 310 (K, SPF, SPFR); Alto Paraíso de Goiás, Chapada dos Veadeiros, estrada para Calvacante km 24, 1400 m.a.m., 15.X.1980 (fl), G. Martinelli et al. 7528 (RB); rodovia GO 118 km 18, Planaltina - Alto Paraíso de Goiás, XI.1997, F.B. Costa 41 (SPFR); idem, km 63, XI.1997, F.B. Costa 42 (SPFR); estrada para Colinas do Sul, ca. $35 \mathrm{~km}$ de Alto Paraíso de Goiás, próximo ao

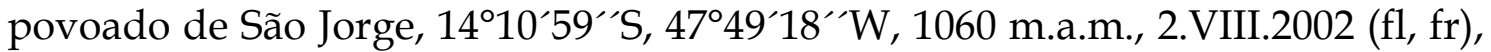
M. Magenta et al. 271 (K, SPF, TEX); Cavalcante, Fazenda Horta, 1348`41'`S, 47²6'54"W, 22.X.1997, C.D. Tosta et al. 35 (HEPH); Colinas do Sul, arredores da cidade, ca. $75 \mathrm{~km}$ de Alto Paraíso de Goiás, $14^{\circ} 11^{\prime} 45^{\prime \prime} \mathrm{S}, 48^{\circ} 05^{\prime} 56^{\prime \prime} \mathrm{W}, 620$ m.a.m., 2.VIII.2002 (fl, fr), M. Magenta et al. 269 (HUFU, K, SPF); Formosa, 20.X.1965 (fl), A.P. Duarte \& E. Pereira 9402 (K, RB); 20.X.1965 (fl), A.P. Duarte \& E. Pereira 10313 (RB); Rio Tiqueira, 25.V.1967 (fl), E.P. Heringer 11448 (M, UB); Goiânia, junto ao Morro Santo Antonio, 5.XII.1978, J.A. Rizzo \& A. Barbosa 2972 (UFG); Luziânia, rodovia para Brasília, 6.X.1980, E.P. Heringer 17886 (HEPH); Niquelândia, 14 km S de Niquelândia, 21.I.1972, H.S. Irwin et al. 34712 (UB); Fazenda Engenho, ca. $11 \mathrm{~km}$ de Niquelândia em direção a Dois Irmãos,

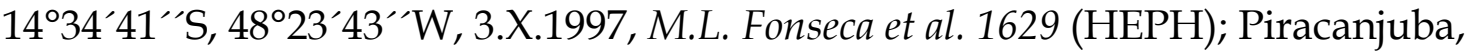




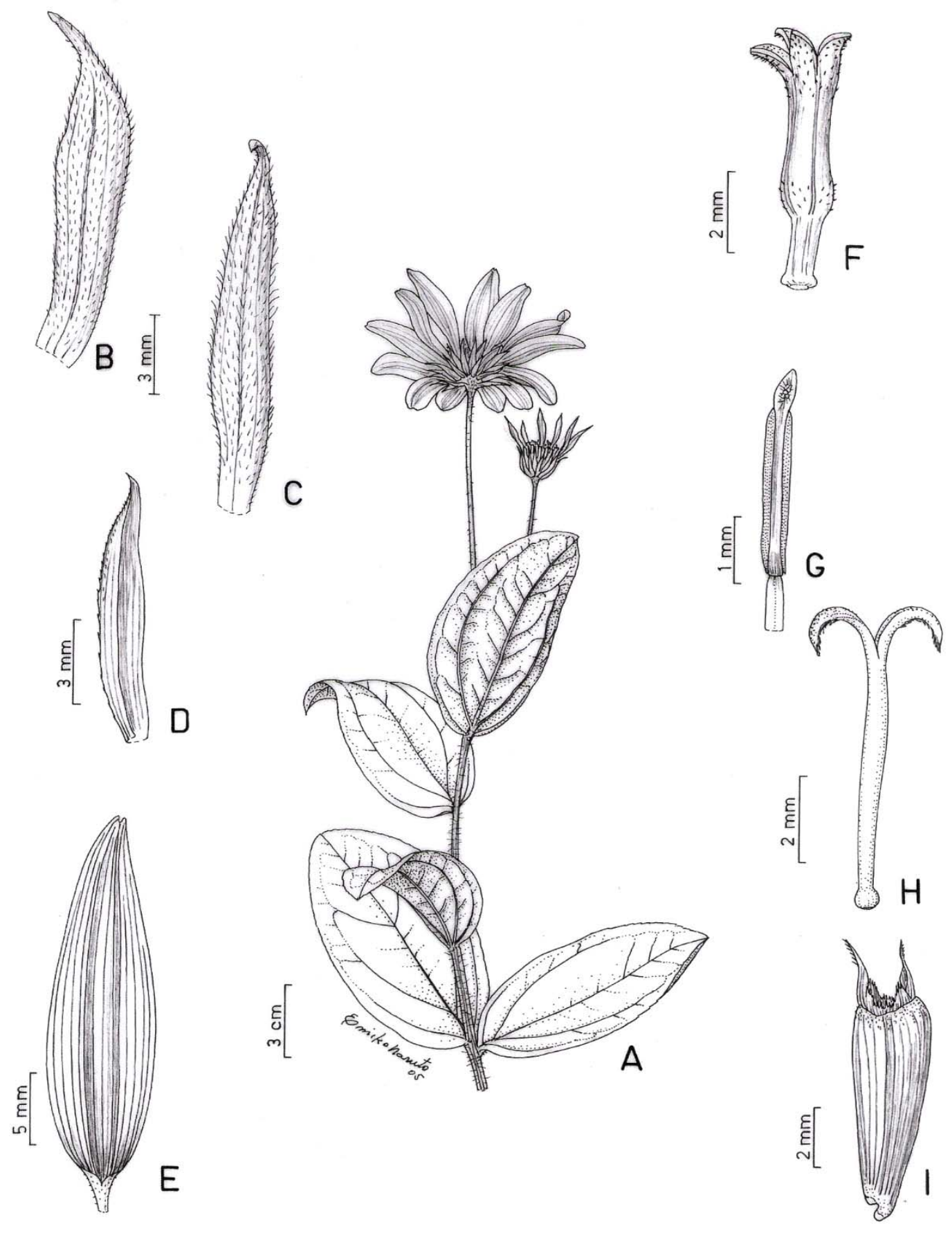

Fig. 18: V. grandiflora. A. Segmento de ramo com sinflorescência (as bractéolas repetem o padrão das folhas caulinares), B-C. Brácteas involucrais, D. Pálea do receptáculo, E. Corola do raio, F. Corola do disco, G. Antera com tecas de base curtamente sagitada, terminando na base do colar filetal, $H$. Estilete com alargamento basal semigloboso, I. Cipsela alongadas, com escamas muito curtas. AJ. M. Magenta \& J. Magenta 371 (SPF). 
Rochedo, 25.IX.1975 (fl), G. Hatschbach 37174 (LP, MBM); Planaltina, 14 km de Planaltina, 5 km da Lagoa Formosa, 600 m do Córrego Maranhão, 1150 m.a.m., 9.X.1992 (fl), J. Fontella \& J.E. Paul 2855 (RB); município indefinido, 1896 (fl, fr), A. Glaziou 21536 (K); s.d. (fl), G. Gardner 3288 (bis) (K). Mato Grosso: Alto Araguaia, 74 km Alto Araquaia para Goiânia, 930 m.a.m., 30.IX.1963, J.M. Pires 56977 (UB); São Vicente, rodovia BR 364, Serra de São Vicente, ca. $60 \mathrm{~km}$ de Cuiabá, 26.X.1981 (fl), F. Sonoda \& N. Menezes 20 (UFMT). Mato Grosso do Sul: Alcinópolis, Fazenda Água Limpa, sub-bacia do Córrego Água Limpa, 18¹3`S, 535`W, 450 m.a.m., 28.X.1999 (fl, fr), A. Pott \& V.J. Pott 8137 (CPAP, SPF);

Bandeirantes, rodovia BR 163, São Pedro, 6.XI.1996 (fl), G. Hatschbach et al. 65352 (MBM). Minas Gerais: Babilônia, Babilônia - São João Batista da Glória sentido Delfinópolis, X.1997, F.B. Costa 35 (SPFR); Buenópolis, Serra do Cabral, 8 km

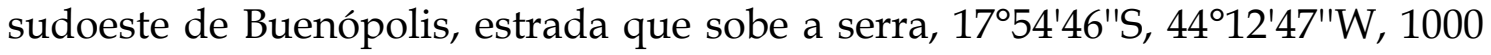
m.a.m., 21.IX.1998 (fl), H.P. Bautista \& S. Ortiz 2791 (HRB); Buritizeiro, ponto 279, RADAMBRASIL, $17^{\circ} 15^{\prime} S, 4^{\circ} 12^{\prime} \mathrm{W}, 750$ m.a.m., 17.XI.1981 (fl, fr), O.A. Salgado 239 (HPR, HRB, HUEFS); Paracatu, estrada Paracatu-Cristalina, 14.I.1965 (fl, fr), E. Pereira \& A.P. Duarte 9290-A (HB, K, RB, SPF); 14.X.1965, E. Pereira \& A.P. Duarte 10200 (UB); São Roque de Minas, Serra da Canastra, estrada para a Serra da Chapada, 14.X.1997 (fl), R. Romero et al. 4603 (HUFU, UEC); Unaí, Fazenda São Miguel, Grupo Votarantim, próximo Ribeirão Bebedouro, 1555’S, 4640'W, 950 m.a.m., 8.XI.1993 (fl, fr), M. Silva et al. 1694 (HEPH, IBGE, US). Tocantins: Arraias, $5-10 \mathrm{~km}$ da rodovia para Paranã, Tocantins, 500 m.a.m., 10.XI.1991 (fl), G. Hatschbach et al. 56012 (BR, CTES, HUEFS, MBM); Dianópolis, X.1839 (fl, fr), G. Gardner 3288 (BM, K, RB); IV.1841 (fl), G. Gardner 3858 (K). Sem indicação de estado, between Baú and Campo Aberto, 4.X.1827 (fl), W.J. Burchell 6083 (K); idem, between Campo Alegre and Urú, 1.XI.1827 (fl), W.J. Burchell 6418 (K).

13. Viguiera hispida Baker in Martius, Fl. bras. 6(3): 220. 1884. TIPOS: Brazil, Goyaz, s.d., Pohl 578 (lectótipo aqui designado: K! [ex Herb. Mus. Hist. Nat. Vindobon]; fotografia do lectótipo: K!, SPF!; isolectótipos: K!, P! [ ex Herb. Mus. Hist. Nat. Vindobon], GH - frag.; fotografia dos isolectótipos de B (destruído) e $\mathrm{W}: \mathrm{F} !)$.

Tridens longifolius Pohl ex Baker in Mart., Fl. bras. 6(3): 220. 1884, nom. nud. pro syn.

Figuras 2B e 19

Subarbusto a arbusto $0,4-1 \mathrm{~m}$ alt., ramos aéreos eretos ou flexíveis, cilíndricos, canaliculados, híspidos; entrenós 1-6cm compr.; caule subterrâneo fortemente espessado, raízes adventícias com tuberosidades nodosas ou sem tuberosidade. Folhas levemente discolores alternas ou par basal oposto, sésseis 
ou pecíolo até $1 \mathrm{~mm}$ compr., inferiores reduzidas; lâmina das folhas medianas 811x0,3-1cm, linear-lanceolada ou das inferiores elíptica a elíptico-lanceolada, base atenuada, ápice agudo a curtamente acuminado, mucronado, inteira, revoluta, longamente ciliada, cartáceas, nervação acródroma suprabasal,imperfeita a perfeita, 3 nervuras principais, coriácea, face adaxial estrigosa a híspida, tricomas tectores 3-4-celulares, com bossas inconspícuas e base cônica levemente apressa, cercada por duas séries de células, face abaxial densamente cinéreo-híspida, tricomas tectores multicelulares, células inferiores com bossas inconspícuas, base cônica, cercada por uma série de células. Inflorescência de capítulos solitários ou botrióide a trisóide, 3-30cm alt., paracládios 4-25cm compr., eretos, superiores terminando abaixo do capítulo terminal, canaliculados, híspidos a estrigosos, 1-2 bractéolas filiformes; pedúnculo terminal $10-20 \mathrm{~cm}$ compr. Capítulos $5-6 \mathrm{~cm}$ diâm., radiados, invólucro 12-18mm diâm., campanulado, brácteas involucrais em 2(-3) séries, apressas na floração, lanceoladas a estreitamente oval-lanceoladas, base canaliculada, duas nervuras destacadas, foliáceas em 2/3 superiores, ápice agudo mucronado, coriáceas, face adaxial com ápice estrigiloso, face abaxial híspida ou às vezes estrigosa, 1a série 7-10mm alt., ciliadas, 2a série 9-11mm alt., cilioladas a ciliadas; receptáculo convexo, páleas 8-9mm alt., obovais, ápice arredondado a agudo, mucronulado, 8, 10 ou 12 nervuras, estrigilosas e com glândulas, carena estreita esparsamente estrigilosa. Flores do raio 12-14, em 1 verticilo, corola 20-30x7-8mm, tubo ca. 1mm alt., limbo elíptico, ápice obtuso, face adaxial glabra ou com tricomas muito esparsos, face abaxial com tricomas glandulares esparsos, nervuras ca. 16, 2-3 fortemente destacadas, pubescentes; tubo hispídulo; flores do disco 75-100, corola 5-5,5mm alt., lobos com altura igual ou maior que o dobro da largura, face externa com tubo, base do limbo e lobos e nervuras estrigilosos; tubo ca. $0,8 \mathrm{~mm}$ alt., base da antera curtamente sagitada, terminando na base do colar filetal; estilete com alargamento basal semi-globoso, estilopódio 0,14-0,16x0,28-0,30mm. Cipselas 5-6mm alt., estreitamente obovóides, levemente tetragonais, fortemente canaliculadas, esparsamente setulosas, especialmente próximo ao ápice carpopódio médio, 
pápus amarelado, 2-aristado, aristas intramarginais levemente desiguais 2-3mm alt., unidas às escamas laterais, triangulares, esparsamente estrigilosas, escamas 4-5 pares 0,5-1,5mm alt., estrigilosas, unidas até próximo ao ápice eroso ou lacerado.

Espécie rara, coletada no sudeste de São Paulo, sudoeste de Minas e sudoeste e nordeste de Goiás (fig. 45A), com flores e frutos na primavera.

No material depositado no herbário P, o número de coleta (Pohl 578) é seguido por letra " $\mathrm{d}$ " minúscula; na etiqueta há uma referência ao nome Tridens hispidus Pohl, in herb. Vindob. A análise da imagem digital do material depositado no herbário W, com este nome, mostrou tratar-se de V. kunthiana Gardner.

Material examinado: BRASIL: Goiás: Alto Paraíso de Goiás, $52 \mathrm{~km}$ de Alto Paraíso, em direção a Teresina de Goiás, 1.XII.1988 (fl, fr), M.G. Wanderley et al. 1764 (IPA, SP, SPF); Jataí, Fazenda Matalta, ca. 22 km da estrada Jataí Caiapônia, 2.X.1968 (fl), Sidney \& E. Onish 1015 (RB); município indefinido, s.d. (fl), Pohl 578 (K). Minas Gerais: Ituiutaba, Serra de São Vicente, 6.XII.1943 (fl, fr), A. Macedo 109 (SP, SPF); Serra da Aroeira, 10.XI.1948 (fl), A. Macedo 1344 (RB); idem, 11.XI.1948 (fl), A. Macedo 1354 (RB); Serra de São Vicente, 12.XI.1948 (fl), A. Macedo 1365 (RB); Serra da Aroeira, Ituiutaba - Cachoeira Dourada km

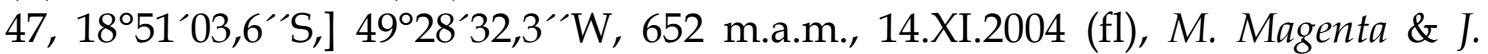

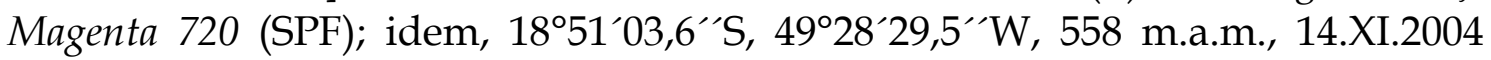
(fl), M. Magenta \& J. Magenta 722 (SPF); Prata, rodovia BR $153 \mathrm{~km} \mathrm{87,} \mathrm{sentido}$ Prata - Itumbiara, 1857’08,9”S, 4901`36,9”W, 639 m.a.m., 13.XI.2004 (fl), M. Magenta \& J. Magenta 716 (SPF); município indefinido, Minas Prov. Minarum, ad Caldas, 1867 (fl), A.F. Regnell III.773 (BR). São Paulo: Itirapina, Morro Pelado, VI.1904, G. Edwall s.n. (SP 16811); Mogi Guaçu, Fazenda Campininha, próximo a Pádua Sales, ceudos da várzea do Rio Mogi, 27.X.1955 (fl, fr), M. Kuhlmann 3695 (SP, TENN); idem, 2 km de Pádua Sales, $18 . X I .1960$ (fl, fr), J.R. Mattos \& N.F. Mattos 8534 (HAS, SP). Município indefinido, ad fazenda do Ferro, prope Uberaba [16.XII.1848, BR!], Regnel III.773 (remanescentes do síntipo: BR!, S! ex Museum Bot. Upsaliense). 

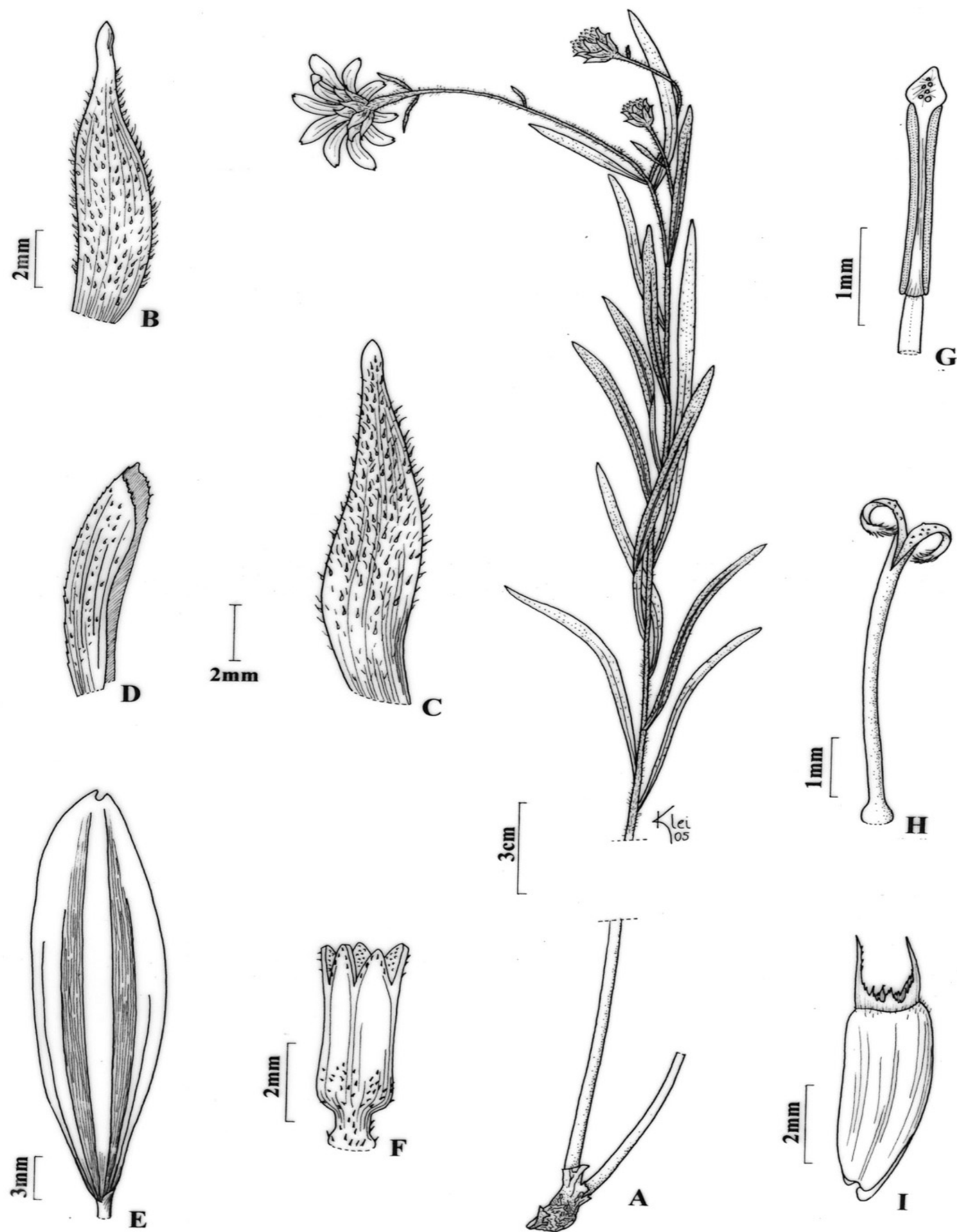

Fig. 19: V. hispida. A. Ramo com inflorescência, B-C. Brácteas involucrais, D. Pálea do receptáculo, E. Corola do raio, F. Corola do disco (notar lobos e base do limbo híspidos), G. Antera com tecas de base curtamente sagitada, terminando na base do colar filetal, H. Estilete com alargamento basal semigloboso, I. Cipsela com escamas do pápus unidas. A. M. Magenta \& J. Magenta 721 (SPF), B-I. Macedo 109 (SP). 
14. Viguiera knobiana Mondin, sp. nova inédita. Tipo: Brasil, Rio Grande do Sul, Toropi, estrada para Jarí, 9 Abr 2002, J. Knob \& S. Bordignon 7163 (holótipo: ICN!; fotografia do holótipo: SPF!; isótipo LA SALLE).

Figura 20.

Erva a subarbusto ca. $80 \mathrm{~cm}$ alt., ramos aéreos cilíndricos, canaliculados, híspidos; entrenós 4-5cm; sistema subterrâneo desconhecido. Folhas verdeclaras opostas, sésseis ou pecíolo 0,2mm compr., lâmina $6-9 \times 2,5-4,5 \mathrm{~cm}$, oval a elíptica, base obtusa a arredondada, ciliada, ápice agudo, esparsamente denteada na porção superior, membranáceas a cartáceas, nervação acródroma suprabasal perfeita, uma nervura principal, híspidas, tricomas tectores levemente apressos, 3-4-celulares, com bossas inconspícuas, base curtamente cônica, circundada por 2 séries de células, face abaxial com muitas glândulas nas nervuras quaternárias. Inflorescência botrióide, ca. $30 \mathrm{~cm}$ alt., paracládios 8,5-20cm compr., canaliculados, eretos, superiores terminando acima do capítulo terminal, híspidos, com 1-2 pares de bractéolas foliáceas ou sem bractéolas,; pedúnculo terminal ca. $3 \mathrm{~cm}$. Capítulos ca. 2,5cm diâm., radiados, invólucro ca. 10mm diâm., campanulado; brácteas involucrais levemente apressas na floração, em 2 séries, às vezes com 3 nervuras evidentes em toda a extensão, foliáceas em $1 / 2$ superior, ápice agudo a acuminado, margem longamente ciliada, cartáceas, face adaxial com ápice hispídulo, face abaxial híspida com glândulas $1^{\mathrm{a}}$ série $6-7 \mathrm{~mm}$ alt., estreitamente lanceoladas, $2^{\mathrm{a}}$ série 7,5-9mm alt., lanceoladas; receptáculo convexo, páleas 6,5-8,5mm alt., oblongas, ápice obtuso expandido com acúmen, 8, 10 ou 12 nervuras, porção apical estrigilosa, carenadas. Flores do raio ca. 8, em 1 verticilo, corola 15-20x5mm, tubo ca. 0,8mm alt., limbo oblongo a levemente elíptico, ápice curtamente 2-3partido, face adaxial glabra, face abaxial com muitas glândulas; nervuras ca. 12, muito esparsamente hispídulas; flores do disco 40-45, corola 4-5mm alt., tubo 0,7-1mm alt., lobos com altura igual ou maior que o dobro da largura, face externa com base do limbo, lobos e tubo estrigilosos, nervuras esparsamente estrigilosas; antera de base curtamente sagitada, terminando acima do colar filetal; estilete com alargamento basal semigloboso, estilopódio 0,10x0,20- 
0,22mm. Cipselas 3,5-4mm alt., obovóides, estriadas, seríceas, tricomas levemente dourados, carpopódio médio, pápus estramíneo, 2-aristado, aristas levemente desiguais, menor 2-2,5mm alt., maior ca. $3 \mathrm{~mm}$ alt., estreitamente lanceoladas, nervura e margem com tricomas curtos antrorsos, escamas ca. 4 pares, ca. 0,8mm alt., unidas até o meio, ápice curtamente lacerado.

A única localidade conhecida é a tipo (fig. 42A).

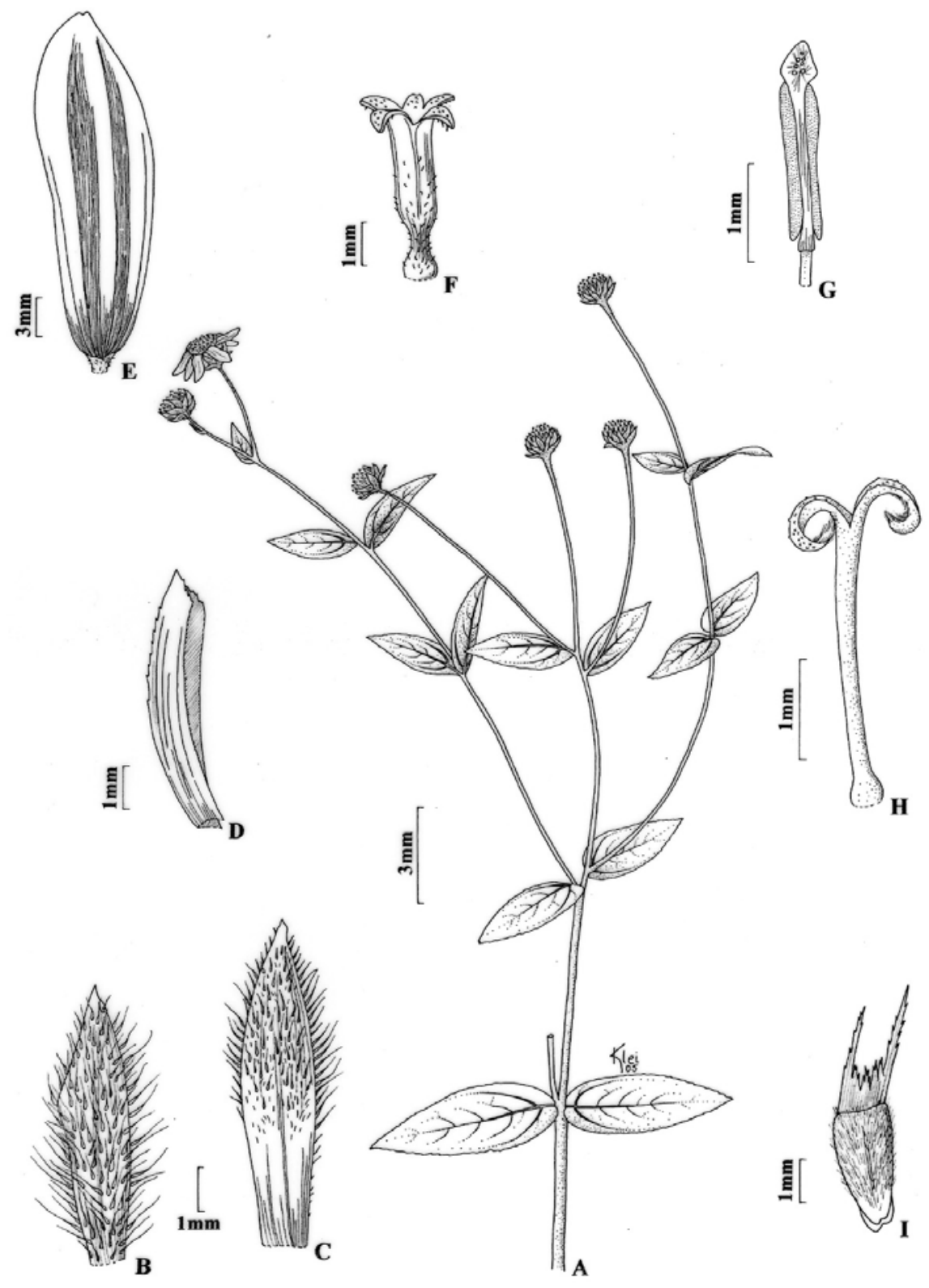

Fig. 20: V. knobiana. A. Ramo com sinflorescência, B-C. Brácteas involucrais, D. Pálea do receptáculo, E. Corola do raio, F. Corola do disco (notar limbo e tubo estrigilosos, G. Antera com tecas de base curtamente sagitada, terminando acima da base do colar filetal, H. Estilete com alargamento basal semigloboso, I. Cipsela serícea com escamas do pápus unidas até o meio. A-I. J. Knob \& S. Bordignon 7163 (MBM). 
15. Viguiera kunthiana Gardner, London J. Bot. 7: 399. 1848. Rhysolepis kunthiana (Gardner) H. Rob. \& A.J. Moore, Proc. Biol. Washington 117(7): 427. 2004. Tipo: Brazil, Goyaz, dry upland campos, Mission of Duro, Oct. 1839, Gardner 3285 (lectótipo aqui designado: K! ex Herb. Hookerianum; fotografia do lectótipo: K!, SPF!; isolectótipos: BM!, K! ex Herb. Benthamianum, NY* ex Herb. Mus. Hist. Nat. Vindobon, GH - frag. e esboço).

Ichthyothere dubia Glaziou, Bull. Soc. Bot. France 57. Mém. 3(d). 409. 1910, nom. nud. pro syn.

Viguiera angustissima S.F. Blake, Contr. Gray Herbarium 54: 118. 1918. Tipo: Brazil, Goyaz, campo between Rajadinha e Paranauna, Glaziou 21561 (lectótipo aqui designado: K!; fotografia do lectótipo: F!, K!, SPF!; isolectótipos: BR!, G, GH - frag., US*). syn. nov.

Figuras 6B e 21

Erva 0,3-1m alt., ramo aéreo flexível, cilíndrico, canaliculado, esparsamente setoso, entrenós $2-17 \mathrm{~cm}$, caule subterrâneo moderadamente espessado, raízes adventícias tuberosas na porção terminal ou sem tuberosidade. Folhas verde-claras, a maioria alterna, 1-3 pares basais opostos, sésseis, lâmina das medianas $90-140 \times 3-8 \mathrm{~mm}$, lâmina das basais 35-90x6-10mm; linear a estreitamente lanceolada, base atenuada, ápice agudo, mucronulado, inteira, cartácea, nervação acródroma basal, perfeita, 3 nervuras principais, estrigosa, tricomas tectores 3-celulares com bossas, base cilíndrica apressa, cercada por 1 série de células, face abaxial com tricomas glandulares. Inflorescência botrióide ou tirsóide, $7-60 \mathrm{~cm}$ alt., paracládios eretos, superiores terminando acima do capítulo terminal, híspidos ou vilosos próximo ao ápice, com ou sem bractéolas, 1a ordem 15-31cm compr., 2a ordem 9-10cm compr.; pedúnculo terminal 4-31cm compr., ou raramente solitários. Capítulos 2-6cm diâm., radiados, invólucro 10-15mm diâm., campanulado; brácteas involucrais levemente apressas na floração, em 2-3 séries, base levemente canaliculada, totalmente foliáceas, uma nervura levemente destacada, margem ciliada, duas séries externas oval-oblongas, elípticas, oblanceoladas, ou raramente lanceoladas, ápice agudo, mucronulado, coriáceas, face adaxial estrigilosa no 
ápice, com glândulas, face abaxial estrigosa; 1a série 6-9mm alt., 2a série 7$11 \mathrm{~mm}$ alt., $\quad 3 a$ série $7-9 \mathrm{~mm}$ alt., oblanceoladas, ápice agudo a curtamente acuminado, mucronulado, membranáceas; receptáculo fortemente convexo a levemente cônico, páleas 6-6,5mm, obovais, carenadas, ápice expandido, agudo, mucronulado, 6 ou 8 nervuras, esparsamente estrigiloso, ciliado, carena estrigosa. Flores do raio 10-12, em 1 verticilo, corola 15-28x5-6mm, tubo 11,5mm alt., limbo elíptico, ápice profundamente 2-partido, face abaxial ca. 10 nervuras pubescentes, tubo estrigiloso; flores do disco 65-75, corola 3,5-4mm alt., tubo ca. 0,5mm alt.; tubo, base do limbo e lobos esparsamente pubescentes; antera de base curtamente sagitada a levemente auriculada, terminando na base do colar filetal; estilete com base piriforme, estilopódio 0,6-0,7x0,22-0,26mm. Cipselas 3-4mm, largamente obovóides, compressas, levemente tetragonais, estriadas, ápice estrigiloso, ciliadas, carpopódio delgado, pápus amarelodourado, 2-aristado, aristas marginais desiguais, unidas às escamas laterais, menor 2-2,5mm alt., maior 2,5-3mm alt., triangulares, porção basal geralmente alargada, estrigilosas, escamas ca. 4 pares, 1,5-2mm alt., unidas até o meio ou até o ápice lacerado.

Ocorre no norte, noroeste e na porção central de Goiás, no noroeste e sudoeste de Minas Gerais e no Distrito Federal (fig. 45B), em campos sujos, campos limpos secos ou úmidos, campos rupestres, brejos com murundus, e borda de matas e de córregos. Floresce de setembro a outubro e frutifica de outubro a novembro.

A espécie se assemelha a $V$. tenuifolia e $V$. aspilioides, das quais se diferencia por apresentar brácteas involucrais menores, com até $11 \mathrm{~mm}$ de altura, geralmente oval-oblongas com ápice agudo, enquanto as outras possuem brácteas que alcançam mais de $17 \mathrm{~mm}$ de altura e são lanceoladas ou elípticolanceoladas com ápice geralmente acuminado. Pode ainda ser distinguida de $V$. tenuifolia pelo receptáculo fortemente convexo a levemente cônico.

Blake (1918) descreveu $V$. angustissima, diferenciando-a de V. kunthiana por possuir folhas mais estreitas, canescentes e com uma só nervura. O trabalho de campo, aliado à observação dos materiais-tipo, demonstrou que o 
indumento e a largura da lâmina foliar são variáveis e, quando esta é estreita, apenas uma nervura é visível com facilidade.

Notas nomenclaturais: Para a escolha do lectótipo de $V$. kunthiana, foi selecionado o espécime que contém a etiqueta de identificação manuscrita por Gardner, proveniente do Herbário Hookerianum em Kew. Como lectótipo de $V$. angustissima, escolheu-se a exsicata do herbário K que contém uma informação manuscrita por Baker, de doação de capítulos e folhas da mesma ao autor da espécie.

Material examinado: BRASIL: Distrito Federal: Brasília, 14.XI.1958, E. Pereira \& Pabst 4688 (RB); Córrego Vicente Pires, Zoobotânico, 18.IV.1963 (fl), J.M. Pires et al. 9222 (RB, UB); limite Parque do Gama e Goiás, 15.X.1963, J.M. Pires 57085 (SPF, UB); X.1964 (fl), G.M. Barroso 519 (RB, UB); X.1964, G.M. Barroso 599 (RB); Parque do Gama, 16.X.1965 (fl), A.P. Duarte 9327-A (RB); em frente ao Zoobotânico, 26.X.1965 (fl, fr), D. Sucre 873 (RB); Chapada da Contagem, ca. 15 km NE de Brasília, ladeira, 1110 m.a.m., 26.X.1965 (fl), H.S. Irwin et al. 9553 (UB); Rio Descoberto, 28.X.1966 (fl), A.P. Duarte 9967 (RB, UB); campus da Universidade de Brasília, 3.II.1968 (fl), R.P. Belém 3917 (UB); Fazenda Água Limpa, perto de Vargem Bonita, 3.XI.1978 (fl), J.A. Ratter et al. 4266 (K, SPF, UB); Bacia do Rio Bartolomeu, 15.IV.1980, E.P. Heringer et al. 4385 (HEPH, IBGE); trevo do Inaí, 14.X.1980, E.P. Heringer \& A.F.H. Salles 17938 (HEPH, IBGE, K); próximo do Córrego Chapadinha e BR 05, 15³1'S, 4802'W, 22.X.1980, J.H. Kirkbride Jr. 22 (UB); idem, 15³1'S, 4802'W, 22.X.1980, J.H. Kirkbride Jr. 3716 (UB); Córrego Capão da Erva, 10.XI.1981 (fl), A.L.V. Atta 16 (UB); Córrego Capão da Erva, 1545’S, 4743'W, 1000 m.a.m., 10.XI.1981 (fl), E.A. Costa 21 (SPF, UB); Capão da Erva, 10.XI.1981 (fl), M.F. Luz 12 (UB); Córrego Capão da Erva, 15²5’S, 4743'W, 1000 m.a.m., 10.XI.1981 (fl), M.L. Batista \& M.P. Valle 17 (UB); Córrego Fazendinha, 15²47’S, 47²4'W, 1000 m.a.m., 11.X.1983 (fl), J.R.S. Mendes 13 (SPF, UB); Reserva Ecológica do IBGE, 3.X.1986 (fl), R.C. Mendonça \& M. Ribeiro 682 (HEPH, RB); arredores do Jardim Botânico de Brasília, ca. 9km SSE do centro, 24.X.1987 (fl), G. Eiten \& J. Pruski 16002 A3529 (NY, SPF, UB); Reserva Ecológica do IBGE, entre a estrada e a mata Córrego Taquara, 21.VIII.1990 (fl), M.A. Silva et al. 1005 (HEPH, IBGE, RB, US); Parque Nacional de Brasília, 1553’S, 47o56'0"W, XI.1990 (fl), P.C.M. Ramos 289 (UB); Reserva Ecológica do Guará, 1548'S, 4758'W, 1035 m.a.m., 26.VIII.1993 (fr), G. Pereira da Silva et al. 1725 (CEN, SPF); Reserva Ecológica do IBGE, próximo viveiro, 27.VII.1994 (fl, fr), F.C.A. Oliveira \& M.L. Fonseca 28 (HEPH, IBGE, RB); estrada da Fazenda Sucupira, $1^{\circ} 51^{\prime} \mathrm{S}, 4^{\circ} 02^{\prime} \mathrm{W}, 13 . X \mathrm{XI} 1998$ (fl, fr), A.J. Sampaio 275 (CEN, UEC); Reserva Ecológica do IBGE, brejo próximo ao

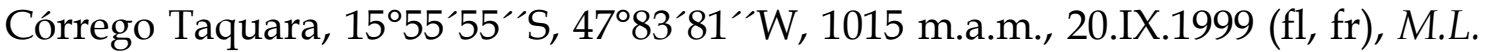
Fonseca \& D. Alvarenga 2114 (HEPH, IBGE, UEC); Brazlândia, 16.XI.1975 (fl, fr), F.H.F. Oldenburguer \& V.V. Mecenas 1792 (CTES, K, RB, U); Gama, $3 \mathrm{~km}$ na estrada Gama - Goiânia, 1602’S, 4806'W, 1220 m.a.m., 1.X.1986 (fl, fr), E.A. 
Nascimento 108 (UB); idem, 1602`S, 4806'W, 1200 m.a.m., 1.X.1986 (fl), M.S. Rossi 4 (SPF, UB); Córrego Gama, between Gama and Brasília, near road to Anápolis, s.d. (fl), H.S. Irwin \& R. Santos 8676 (K); Samambaia, Parque Boca da Mata, 3.XI.1995 (fl, fr), J.M. Rezende 192 (CEN, SPF, UEC). Goiás: Abadiânia, rodovia BR 360 km 58, sentido Alexânia - Abadiânia, 3.XI.2001 (fl, fr), M. Magenta \& J. Magenta 309 (K, SPF); Águas Lindas, 3 km antes de Águas Lindas, Barragem do Descoberto, 9.XI.1997, F.B. Costa 47 (SPFR); Alto Paraíso de Goiás, rodovia GO 118 km 63, Planaltina - Alto Paraíso de Goiás, 8.XI.1997, F.B. Costa 43 (SPFR); estrada para Colinas do Sul, ca. $35 \mathrm{~km}$ de Alto Paraíso de Goiás,

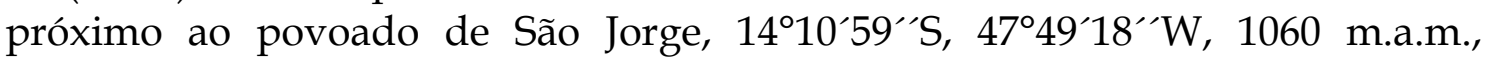
2.VIII.2002 (fl, fr), M. Magenta et al. 272 (SPF); Caiapônia, Serra do Caiapó, ca. 50

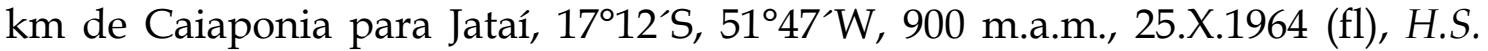
Irwin \& T.R. Soderstrom 7239 (UEC); Caldas Novas, 20.XII.1951 (fl), A. Macedo 3533 (RB); margem direita Rio Corumbá, próximo a alternativa 9, 17²4'S, 48³2'W, 720 m.a.m., 27.X.1993 (fl), R.F. Vieira et al. 1679 (CEN, HEPH, SPF, UEC); Campo Alegre de Goiás, rodovia BR 050, sentido Campo Alegre Catalão, 1758`39,8`S, 4747`45,3”W, 865 m.a.m., 5.XI.2001 (fl, fr), M. Magenta \& J. Magenta 316 (SPF); Corumbá de Goiás, $15 \mathrm{~km}$ Oeste de Corumbá de Goiás para Pirenópolis, 1553’59”S, 4852’03”W, 1038 m.a.m., 27.X.2003 (fl, fr), R.C. Forzza et al. 2457 (RB, SPF, US); Goianira, Fazenda Louzandira, 17.X.1979, J.A. Rizzo \& A. Barbosa 5602 (UFG); Ipameri, Serra da Arnica, 5.X.1976 (fl, fr), G. Hatschbach 38943 (CTES, LP, MBM); Minaçu, estrada de terra Minaçu, Serra da

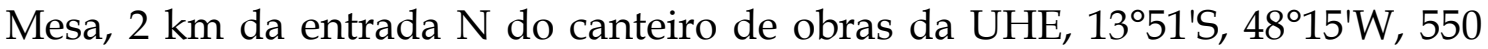
m.a.m., 20.XI.1991 (fl), B.M.T. Walter et al. 781 (CEN, K, SPF); Mossâmedes, Divisa Mossâmedes - Goiás, área da Universidade Federal de Goiás, 1.IX.1969, J.A. Rizzo 445 (UFG); idem, Serra Dourada, 8.XI.1969 (fl), J.A. Rizzo 4536 (UFG); Serra Dourada, 1969 (fl), J.A. Rizzo 4539 (UFG); Serra Dourada, reserva da Universidade Federal de Goiás, alto da serra, 7.X.1994, C.H. Monteiro 66 (UFG); Niquelândia, Usina Níquel Tocantins, estrada a direita da mina, 18.X.1996, $R$. Marquete et al. 2656 (HEPH); Companhia Níquel Tocantins, 14²3'48"S, 48²5’59”W, 19.X.1996, M.L. Fonseca et al. 1220 (UFG); Niquelândia -

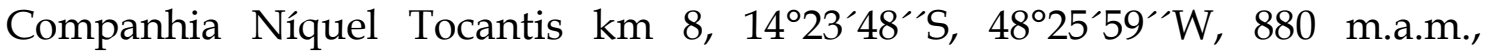
19.X.1996, M.L. Fonseca et al. 1240 (HEPH); trevo de acesso a Macedo Velho, 14²1`30”S, 48²5`10”W, 30.IX.1997, M.L. Fonseca et al. 1565 (HEPH); Fazenda Engenho, ca. $11 \mathrm{~km}$ de Niquelândia em direção a Dois Irmãos, 14³4'41"'S, 48²3“43”'W, 19.XI.1997, M.L.M. Azevedo et al. 1123 (HEPH); em direção à Usina Níquel Tocantins, entrada para Angiquinho, 25.X.2000 (fl), M.D. Moraes \& R.C. Oliveira 532 (UEC); Pirenópolis, alto da Serra de Pireneus, na base dos 3 picos, 2.X.1971, J.A. Rizzo \& A. Barbosa 7048 (UFG); Serra de Pireneus, 1350 m.a.m., 7.XII.1987 (fl), J. Semir 20506 (UEC); Planaltina, Reserva Biológica de Águas

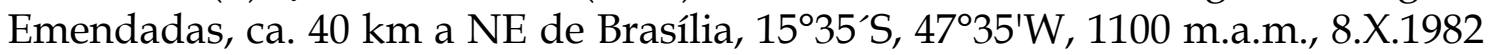
(fl), C.M. Maury 242 (UEC); Uruaçu, Fazenda Macaco, margem esquerda Córrego Vermelho, 6.X.1992 (fl, fr), S.P. Cordovil et al. 50 (CEN, SPF, UEC). Município indefinido: Goyaz, s.l., s.d., Pohl (como Tridens hispidus, $W^{*}$ ). Minas Gerais: Araxá, rodovia BR 428 km 27, sentido Araxá - Franca, 194247"'S, 4659`26,4”W, 6.XI.2001 (fl, fr), M. Magenta \& J. Magenta 321 (SPF); Babilônia, 


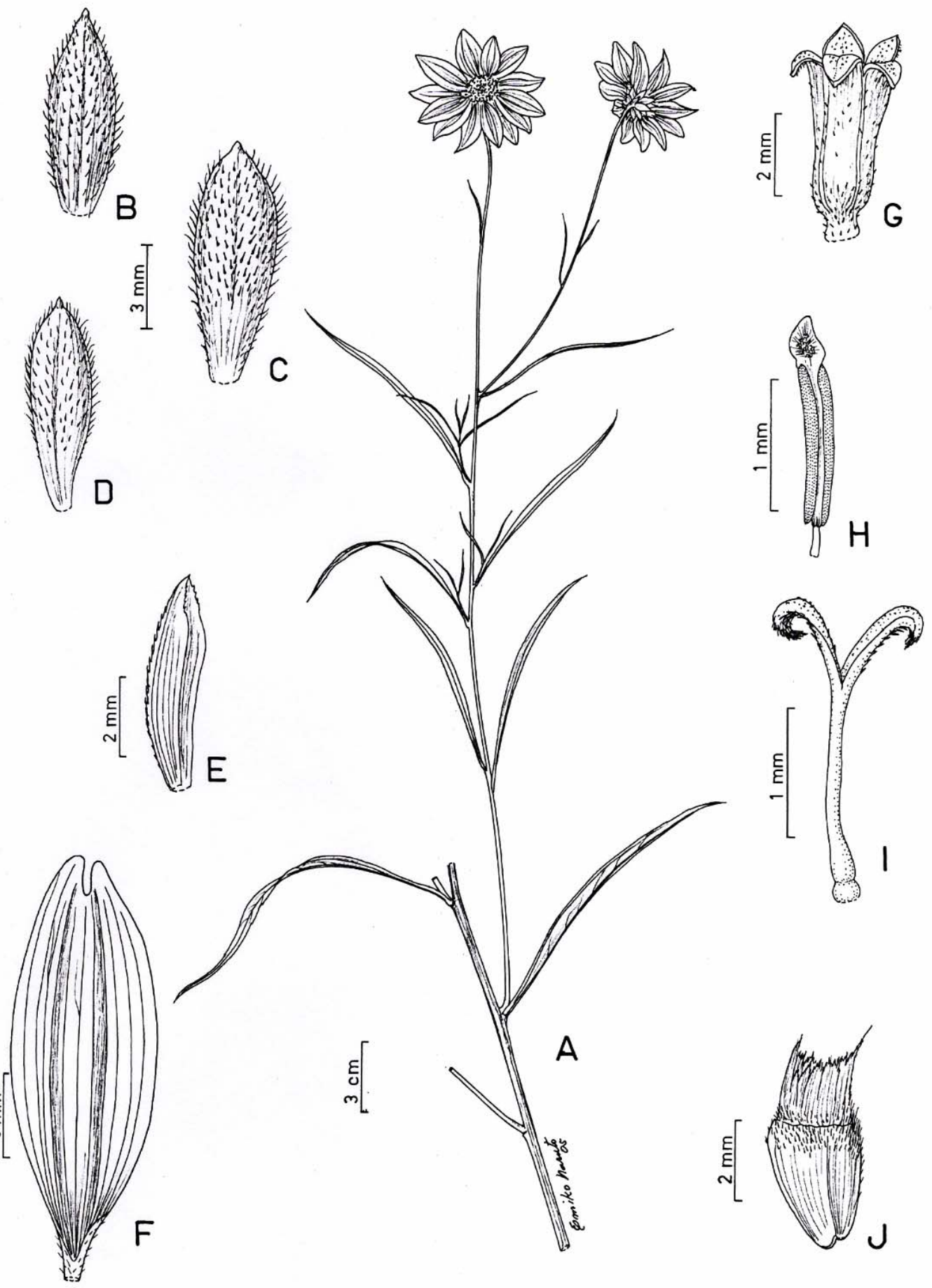

Fig. 21: V. kunthiana. A. Segmento da sinflorescência, B-D. Brácteas involucrais, E. Pálea do receptáculo, F. Corola do raio, G. Corola do disco (notar corola estrigilosa), H. Antera com tecas de base curtamente sagitada, terminando na base do colar filetal, I. Estilete com alargamento basal piriforme, sobre estilopódio, J. Cipsela pequena em relação ao pápus. A-J. M. Magenta \& J. Magenta 309 (SPF). 
Babilônia - São João Batista da Glória, X.1997, F.B. Costa 32 (SPFR); Santa Bárbara, estrada Rio Acima, Fazenda Gandarela, 14 km Rio Acima, $31 . X .1966$ (fl, fr), A.P. Duarte 958 (M); Unaí, Fazenda São Miguel, Grupo Votarantim, próximo ao Ribeirão Bebedouro, 1555'S, 4640'W, 8.XI.1993, M.A. Silva et al. 1688, 1691 (HEPH); município indefinido, Aug.-Apr.1840 (fl, fr), P. Claussen 576 (K). Tocantins: Dianópolis, Mission of Duro, X.1841 (fl, fr), G. Gardner 3285 (BM, K, P); Natividade, Serra de Natividade, XII.1839, G. Gardner 3284 (K, P); Palmeirópolis, Serra Dourada, 12.II.1991 (fl), G. Hatschbach \& M. Hatschbach 56100 (BR); Ponte Alta do Tocantins, Macedo, in midle of Tocantins Ultramatic Complex, $1.8 \mathrm{~km}$ along S Ridge road towards Ponte Alta, 22.VI.1990, R.R. Brooks \& R.D. Reeves TMEX 652 (K). Sem indicação de estado, between Meia Ponte and Caipára, 23.X.1827 (fl), W.J. Burchell 6311 (K); between Ribeiral dos Macácos and Olhos d'Agoa, 2.IX.1828 (fl), W.J. Burchell 7519 (K).

16. Viguiera laxicymosa (H. Rob. \& A.J. Moore) Magenta, comb. nov. Rhysolepis laxicymosa H. Rob. \& A.J. Moore, Proc. Biol. Washington 117(7): 440. 2004. Tipo: Brasil. Minas Gerais: Serra do Cabral, estrada para Francisco Dumont (Mun. Joaquim Felício). Campo rupestre, 950m, 16 Mai 2001, G. Hatschbach et al. 72088 (holótipo: MBM!; fotografia do holótipo: SPF; isótipo: US*).

Figura 22

Erva a arbusto $0,5-1 \mathrm{~m}$ alt., ramos aéreos eretos, cilíndricos, hispídulos, híspidos a setosos; entrenós 0,8-15mm compr.; sistema subterâneo desconhecido. Folhas verde-escuras a discolores, alternas ou basais opostas; pecíolo ca. $1 \mathrm{~mm}$; lâmina $3,7 \times 1,5 \mathrm{~cm}$, oblongo-elíptica ou oval-lanceolada, base arredondada ou obtusa, ápice agudo, mucronulado, inteira ou esparsamente denteada a esparsamente serreada, cartácea, nervação acródroma basal a suprabasal, imperfeita a perfeita, 3 nervuras principais, face adaxial estrigosa, tricomas tectores 2-celulares com bossas, base cônica apressa, cercada por 1 série de células, face abaxial híspida a estrigosa ou serícea, nervuras densamente estrigosas, tricomas tectores 2-3-celulares, com bossas, com tricomas glandulares. Inflorescência botrióide ou tirsóide, $20-50 \mathrm{~cm}$ alt., paracládios 15-25cm compr., delicados, eretos a flexuosos, superiores terminando acima do capítulo terminal, estreitamente canaliculados, estrigosos, com bractéolas foliáceas 3-7mm compr.; pedúnculo terminal $10-15 \mathrm{~cm}$ compr. Capítulos 1,5-2,5cm diâm., radiados, invólucro 5-6mm diâm., campanulado a 
semigloboso, subtendido por 1-2 bractéolas 3-10mm, ovais, estrigosas, brácteas involucrais levemente apressas a levemente reflexas na floração, ca. 3 séries, oblongas a ovais, base estriada, 3 nervuras levemente destacadas, foliáceas em 1/2 superior, ápice obtuso a agudo, mucronado, coriáceas, face adaxial glabra a híspida, face abaxial gríseo-serícea na porção superior, 1a série $4-5 \mathrm{~mm}$ alt., 2a série 6-7mm alt., 3a série 7-8mm alt.; receptáculo levemente convexo, páleas ca. $7 \mathrm{~mm}$ alt., lanceoladas a oblongas ápice agudo, mucronado, 10 a 12 nervuras, com glândulas, carena estreita, base e ápice estrigilosos. Flores do raio ca. 18, em 1 verticilo, corola $6,5-7,5 \times 1,8-3 \mathrm{~mm} \times 2-3 \mathrm{~mm}$, tubo ca. $1,2 \mathrm{~mm}$ alt., limbo largamente oblongo, ápice curtamente 3-partido, face adaxial glabra, face abaxial com 8-10 nervuras pubérulas; glabro a estrigiloso; flores do disco 30-50 corola ca. $4 \mathrm{~mm}$ alt., tubo ca. $1 \mathrm{~mm}$ alt., lobos com altura menor que o dobro da largura, face externa estrigilosa, antera de base curtamente sagitada, terminando na base do colar filetal, estilete com alargamento basal levemente fusiforme, estilopódio 0,12-0,14x0,20-0,22mm. Cipselas ca. 3,5mm alt., estreitamente obovóides, estriadas, seríceas, carpopódio médio, pápus estramíneo 2-aristado, aristas marginais iguais a desiguais 1,5-2,5mm alt., unidas às escamas laterais, delicadas, estreitamente triangulares, margem lacerada, escamas 3-4 pares, 0,7-1,5mm alt., unidas até próximo ao ápice lacerado.

Aparentemente endêmica da Serra do Cabral, em Minas Gerais (fig. 46A), onde ocorre em campo cerrado e campo rupestre; coletada com flores e frutos jovens em maio.

Robinson \& Moore (2004) descreveram as folhas como alternas, mas no material depositado no herbário MBM as folhas basais são opostas. Diferenciase de $V$. robusta e $V$. gardneri pelo tamanho reduzido dos capítulos e flores e pelos paracládios delicados e, de V. rubra, pela presença de flores liguliformes.

Material examinado: BRASIL. Minas Gerais: Joaquim Felício, Serra do Cabral, próximo do Rio Embaiassaia, 06.V.2004, G. Hatschbach et al. 77443 (MBM); idem, 07.V.2004, G. Hatschbach et al. 77447 (MBM); idem 77478(MBM). 


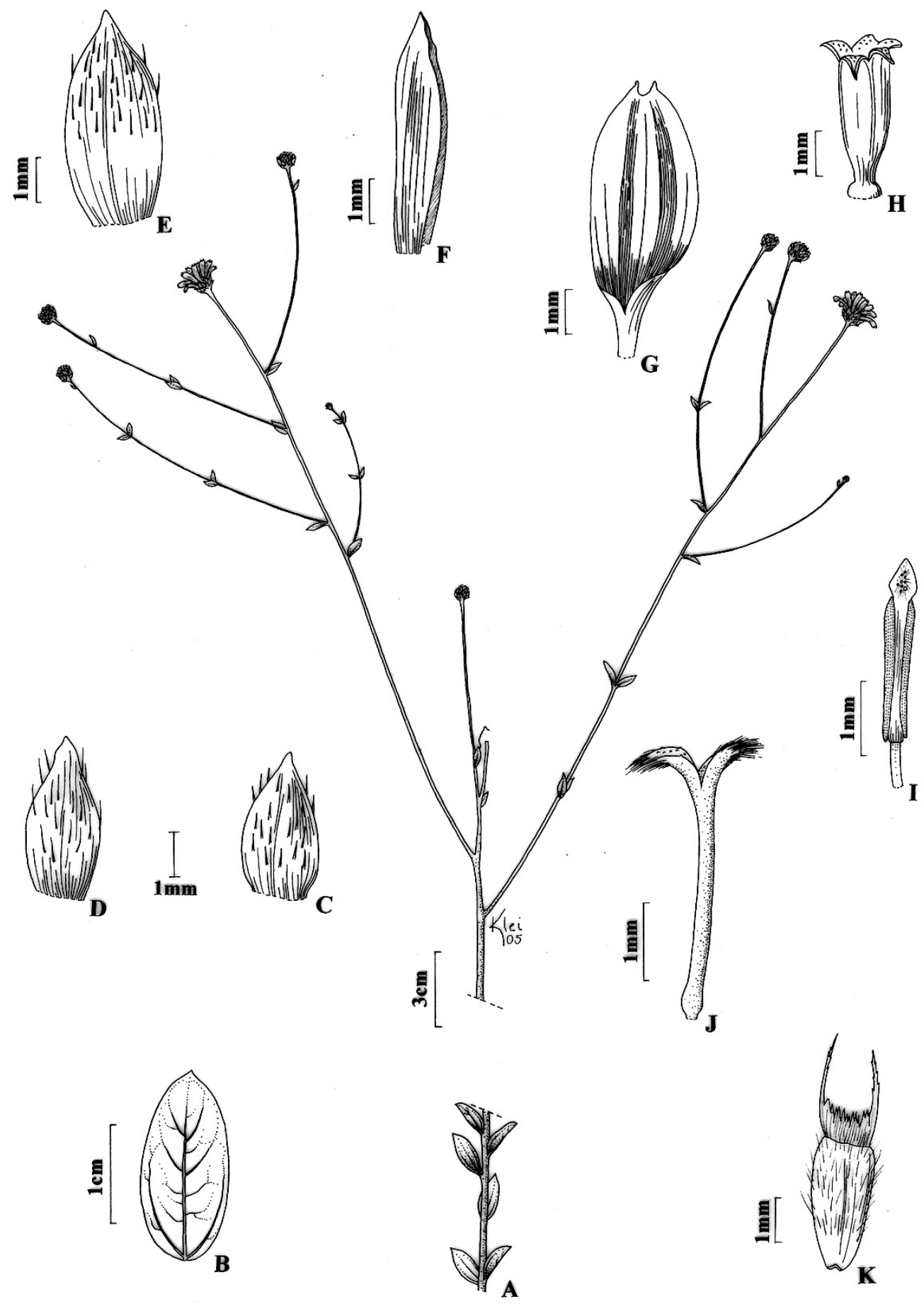

Fig. 22 V. laxicymosa. A. Segmento de ramo com sinflorescência, B. Nervação acródoma, C-E Brácteas involucrais, F. Pálea do receptáculo, G. Corola do raio, H. Corola do disco, I. Antera com tecas de base curtamente sagitada, terminando na base do colar filetal, J. Estilete com alargamento basal levemente fusiforme, $\mathrm{K}$. Cipsela serícea com escamas do pápus unidas até o meio. G. Hatschbach 77447 (MBM). 
17. Viguiera linearifolia Chodat, Bull. Herb. Boissier ser. 2 (2): 392. 1902. Rhysolepis linearifolia (Chodat) H. Rob. \& A.J. Moore, Proc. Biol. Washington 117(7): 429. 2004. Tipo: Paraguay, in campo pr. Ipê-hú, Oct. Hassler 4959 [in autoplanities et decliviis Sierra de Maracayú (K!)] (holótipo: $G^{*}$; fotografia do holótipo: F!, K!, SPF!; isótipos: BM!, $\mathrm{G}^{*}, \mathrm{GH}, \mathrm{K}$ !, P!, S!, $\mathrm{W}^{*}$ ).

Viguiera rojasii S.F. Blake. Contr. Gray Herb. 54: 179. 1918. Tipo: Paraguay: plateau and declivities of the Sierra de Amambay, April 1907-08, Rojas (distr. Hassler) 10367 (holótipo: BM!, GH - frag. e foto). syn. nov.

Figuras $4 \mathrm{~A}$ e 23

Arbusto 1-2m alt., ramo aéreo ereto, cilíndrico, canaliculado, glabro a esparsamente estrigiloso, entrenós 0,8-2,5cm compr.; caule subterrâneo fortemente espessado, raízes adventícias com tuberosidade fusiforme na porção central e/ou na extremidade. Folhas adensadas, discolores, alternas, às vezes com aparência verticilada, sésseis, lâmina $8-20 \mathrm{~cm}$, linear, ápice agudo, base levemente atenuada, fortemente revoluta, cartácea, inteira, 1-nervurada, face adaxial estrigilosa, tricomas 2-3-celulares, com bossas na célula central, base cilíndrica apressa, cercada por 2-3 séries de células, face abaxial albo-lanosa, tricomas multicelulares, sem bossas, tricomas glandulares pedicelados; Inflorescência botrióide, laxas, $20-50 \mathrm{~cm}$ alt., paracládios ascendentes, superiores terminando próximo ao capítulo terminal, cilíndricos a levemente tetragonais, canaliculados, esparsamente estrigilosos, raramente bracteolados, bractéolas, 4-6cm, foliáceas; 1a ordem $15-25 \mathrm{~cm}$ compr., 2a ordem $6-8 \mathrm{~cm}$ compr.; pedúnculo terminal 12-15cm compr. Capítulos 3,5-6cm diâm., radiados, invólucro 2-2,5cm diâm., campanulado, brácteas involucrais desiguais, levemente apressas na floração, 4 séries, oval-lanceoladas, lanceoladas, cartáceas, base canaliculada, uma nervura destacada, foliáceas em 2/3 superiores, ápice longamente acuminado, mucronado, coriáceas, face adaxial com ápice híspido, face abaxial jovem lanosa, madura estrigilosa a estrigosa, especialmente nas nervuras, margem inteira, 1a série $4-12 \mathrm{~mm}$ alt., ápice agudo a cirroso, às vezes mucronado, reflexas na maturidade, 2a série 5,5-14mm alt., 3a e 4a séries 12-15mm alt., ápice cirroso; receptáculo convexo; páleas 10-11mm alt., largamente oblongo-lanceoladas, carena conspícua, ápice obtuso 
mucronado, lanoso, 10 a 12 nervuras. Flores do raio 10-20, em 1(-2) verticilos, corola 25-35x4-12mm, tubo ca. 1,2mm alt., limbo elíptico, ápice obtuso, curtamente 3-partido, tubo esparsamente estrigiloso, nervuras 13-15, face abaxial esparsamente lanosa, tricomas glandulares esparsos ou adensados; às vezes apresentando pistilódio e, mais raramente, também estaminódio; flores do disco $80-85$, corola 5-7mm alt., tubo 1,1-1,2mm alt., as jovens recobertas por indumento albo-lanoso; face externa com limbo e tubo estrigosos, lobos lanosos; anteras de base auriculada, terminando abaixo da base do colar filetal, estilete com alargamento suprabasal cônico, estilopódio 0,16-0,18x0,48-0,56mm. Cipselas 4-5,5mm alt., obovóides, comprimidas ou não, levemente 3-4-gonais, esparsa a densamente setosas, margem ciliada, tricomas vináceos, carpopódio delgado, pápus amarelado ou às vezes vináceo, 2-(3-4)-aristadas, aristas levemente intramarginais, desiguais, livres, menor 2,5-3,5mm alt., maior 3,54,5mm alt., oval-lanceoladas a lanceoladas, base alargada, ápice acuminado, margem superior erosa, esparsamente estrigosas, escamas desiguais ca. 2 pares, 1,5-2mm alt., unidas até próximo ao ápice lacerado.

Descrita com base em material do Paraguai, é aqui referida pela primeira vez para o Brasil, encontrada recentemente apenas na região de Ponta Porã no Mato Grosso do Sul (fig. 43B), em área pedregosa. Coletada com flores do final da primavera ao verão e frutos apenas em novembro.

Foi confundida por Baker (1884) e Blake (1918) com V. filifolia, da qual difere pela face abaxial lanosa nas folhas, flores do disco jovens e páleas recobertas por indumento lanoso alvo e pápus com aristas de base muito alargada e ca. 2 pares de escamas; a segunda não apresenta indumento lanoso e possui pápus com aristas estreitamente triangulares e pápus com ca. 4 pares de escamas. Está ameaçada de extinção por distribuição restrita e população reduzida (segundo critérios da IUCN).

Material examinado: BRASIL: Mato Grosso do Sul: Ponta Porã, rodovia para Antonio João km 22, 9.II.1993 (fl), G. Hatschbach et al. 58730 (BHCB, BR, K, MA, MBM, PEL, SP); estrada Ponta Porá - Vista Alegre a 3,5 km trevo para João Antonio, na ferrovia, $22^{\circ} 18^{\prime} 32,6^{\prime \prime} \mathrm{S}, 5^{\circ} 41^{\prime} 58,1^{\prime \prime} \mathrm{W}, 691$ m.a.m., 21.XI.2003 (fl, fr), 


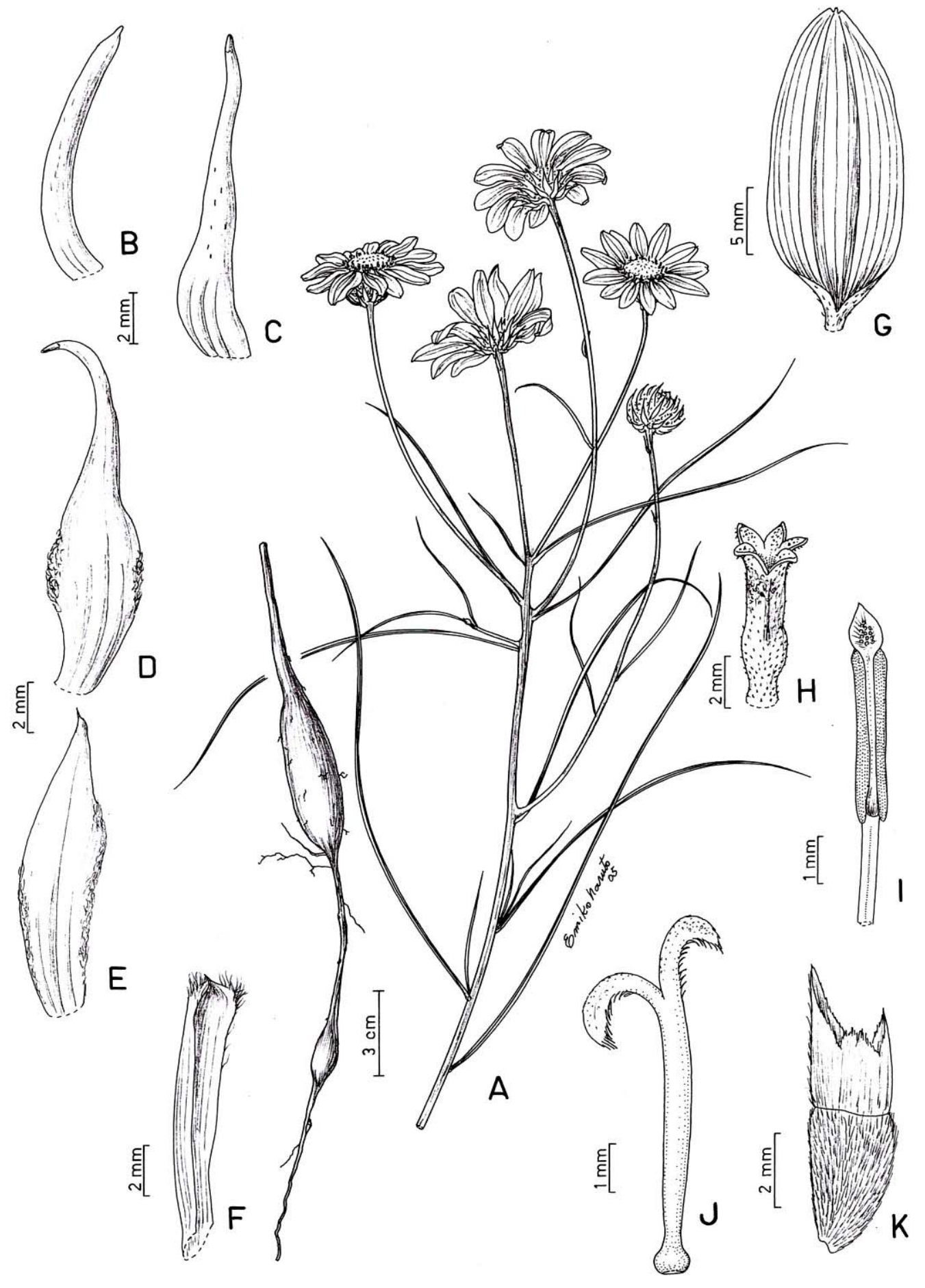

Fig. 23: $V$. linearifolia. A. Segmento de ramo com sinflorescência, B-E. Brácteas involucrais (notar indumento viloso na margem de D e E), F. Pálea do receptáculo, G. Corola do raio, H. Corola do disco estrigilosa, I. Antera com tecas de base curtamente sagitada, terminando abaixo do colar filetal, J. Estilete com alargamento basal cônico, K. Cipsela com escamas do pápus unidas. A-K. M. Magenta \& J. Magenta 690 (SPF).

Canindeyú, 18.XI.1996 (fl), B. Jiménez 1714 (BM); Reserva Natural del Bosque Mbaracayú, 5.XII.1997 (fl), A. Schinini \& M. Dematteis 33327 (CTES, MBM); Pedro Juan Cabalero, Fazenda El Buracon, 30 km de Pedro Juan Cabalero, 
15.XII.1983 (fl, fr), G. Hatschbach \& R. Callejas 47271 (MBM); San Pedro, Yagareté Forest (sustainable Forests Systems site), 2347'46"S, 56²1'41"W; 27.V.1997 (fl, fr), E.M. Zardini \& S.Zavala 46819 (K); Yagareté Forest (sustainable Forests Systems site), 23ํำ'46"S, 56²12'41"W; 27.V.1998 (fl, fr), E.M. Zardini \& S.Zavala 46820 (K); Yagareté Forest (sustainable Forests Systems site), 234ㄱ'46"S, 56²12'41"W; 27.V.1999 (fl, fr), E.M. Zardini \& S.Zavala 46827 (K).

18. Viguiera macrorhiza Baker in Martius, Fl. Bras. 6(3): 225. 1884. Rhysolepis macrorhiza (Baker) H. Rob. \& A.J. Moore, Proc. Biol. Washington 117(7): 429. 2004. Tipo: Habitat in Paraguay in Campos de Caaguazú: [16 Nov. 1874] Balansa 848 (lectótipo aqui designado: K!; fotografia do lectótipo: K!, SPF!; isolectótipos: G, $\mathrm{NY}^{*}$, P!; fotografia de isolectótipo de G: F!).

Viguiera hassleriana Chod., Bull. Herb. Boissier ser. 2(3): 274. 1903. Viguiera macrorhiza f. hassleriana (Chod.) Hassler, Repert. Spec. Nov. Regni Veg. 14: 269. 1916. Tipo: Paraguai, in regions fluminis Tapiraguay, campo, VIII.190102, Hassler 4306 (lectótipo aqui designado: G*; fotografia do lectótipo de G: F; isolectótipos: BM! - 2x, P!; fotografia dos isolectótipos: $\mathrm{K}, \mathrm{SPF}$ !).

Figuras 24

Subarbusto a arbusto $40-80 \mathrm{~cm}$ alt., ramos aéreos decumbentes, cilíndricos, canaliculados, híspidos; entrenós 4,5-12cm compr.; caule subterrâneo levemente espessado, raízes adventícias de tuberosidade fusiforme na região central. Folhas verde-claras, opostas ou superiores raramente alternas, sésseis ou pecíolo 1-1,5mm; lâmina das folhas medianas 4-14×3-5(-7,5$8,5) \mathrm{cm}$, largamente elíptica a oboval, base atenuada, arredondada ou às vezes levemente auriculada, ápice agudo, obtuso ou arredondado, mucronado, inteira ou obscuramente denteada na porção superior, cartácea, nervação acródroma basal a suprabasal, 3 nervuras principais emersas, reticulação evidente, híspidas, tricomas tectores 4-5-celulares de base cilíndrica a cônica, cercada por 1-2 séries de células. Capítulos 3-4,5cm diâm., solitários, terminais, pedúnculos 10-38cm compr., canaliculados, híspidos, flexuosos, sem bractéolas; invólucro 15-25mm diâm., campanulado; brácteas involucrais apressas na floração, 2-3 séries, oblongas, oblongo-lanceoladas, elíptico-lanceoladas ou oval-lanceoladas, uma nervura destacada até o ápice, base levemente canaliculada, foliáceas em 2/3 superiores ciliadas, cartáceas, face adaxial com ápice esparsamente 
hispídulo, face abaxial híspida, 1a série 8-13mm alt., ápice agudo, 2a e 3a séries 14-16mm alt., ápice agudo a acuminado; receptáculo convexo, páleas 6-10mm alt., oblongas, carena estreita hispídula, 8 ou 10 nervuras, escariosas. Flores do raio 12 , em 1 verticilo, corola $20-30 \times 4-5 \mathrm{~mm}$, tubo ca. $1 \mathrm{~mm}$ alt., limbo oblongo a estreitamente oval, ápice agudo 2-3-partido, face adaxial glabra, face abaxial esparsamente híspida, geralmente com glândulas, nervuras 10-12, tubo estrigiloso; flores do disco 50-80, corola 4,5-5mm alt., tubo 0,8-1mm alt., enlarguecido próximo à base, limbo com face externa glabra ou com lobos, nervuras e base do limbo hispídulos, tubo glabro ou esparsamente hispídulo; antera de base curtamente sagitada, terminando abaixo ou na base do colar filetal, estilete com alargamento basal obclavado a cônico, compactado, estilopódio 0,14-0,16x0,28-0,30mm. Cipselas 7-7,5mm alt., obovóides, compressas, levemente tetragonais, base estriada, seríceas, carpopódio prolongando-se nas laterais, delgado a médio, pápus amarelo-dourado, às vezes com ápice levemente vináceo, 2-aristado, aristas marginais desiguais, livres, menor 2,5-3,5mm alt., maior 4-4,5mm alt., base oval, margem escariosa, ápice agudo, nervura estrigilosa, escamas 3-4 pares 2,5-3mm alt., unidas até próximo ao ápice eroso.

Espécie descrita originalmente do Paraguai e aqui citada pela primeira vez para o Brasil, onde é encontrada no Paraná (VER REGIÃO) nas regiões central e sudeste de São Paulo, alcançando regiões nordeste e central de Minas Gerais e possui três registros com mais de 50 anos para outros estados: um da região sudoeste do Paraná, em Laranjeiras do Sul, onde está localizada a Represa de Salto, e dois do Mato Grosso do Sul (fig. 43B), em locais próximos ao Rio Paraná (material examinado???). Talvez isto indique uma origem brasileira para a espécie, em Minas Gerais, já que esse rio resulta da confluência dos Rios Parnaíba e Grande, na divisa dos Estados de Minas, São Paulo e Mato Grosso e poderia servir como rota de dispersão. Atualmente, V. macrorhiza parece estar restrita a áreas de preservação, onde floresce na primavera ou raramente no inverno e frutifica no verão. 
Nota nomenclatural: Os lectótipos foram selecionados de acordo com a observação de etiquetas manuscritas e com o herbário de origem dos autores dos táxons.

Material examinado: BRASIL: Mato Grosso do Sul: Três Lagoas, Retiro das Telhas, 12³0’S, 40²9'W, 22.X.1964 (fr), J.C. Gomes 2397 (SP); município indefinido, Rio Salobra, XI.1941 (fl), N. Santos s.n. (R 36962). Minas Gerais: Brasilândia, Fazenda Brejão, Mannesmann Florestal, 30.XI.1999 (fl, fr), A.A. Azevedo 176 (BHCB); Joaquim Felício, Serra do Cabral, estrada para torre de TV,

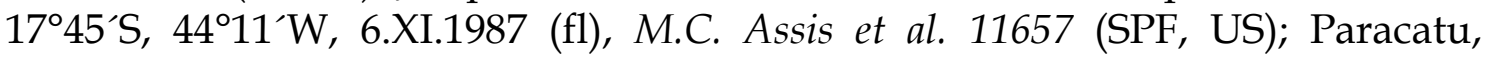
Córrego Rico, 24.X.1978 (fl), G. Hatschbach \& A. Kasper 41675 (MBM, UEC). Paraná: Palmeiras, Rio dos Papagaios, 14.X.1966 (fl), J.Lindeman \& H. Haas 3672 (MBM). São Paulo: Águas de Santa Bárbara, Estação Ecológica de Santa Bárbara, 9.X.1990 (fl), J.A.A. Meira Neto et al. 669 (UEC); Agudos, ca. 4km da cidada e mais próximo do Posto Chapadão, 11.VI.1976 (fl), H.F. Leitão Filho et al. 2149 (BM, UEC); Angatuba, Instituto Florestal de São Paulo, 2327’S, 48²5’W, 19.XI.1983 (fl), J.A. Ratter \& G.C.G. Argent 4912 (UEC); Botucatu, rodovia São Manuel - Piracicaba, a $18 \mathrm{~km} \mathrm{~N}$ de Botucatu e $14 \mathrm{~km}$ de São Manuel, 22 ${ }^{\circ} 45^{\prime} \mathrm{S}$, 48²5’W, 550 m.a.m., 31.VIII.1972, I.S. Gottsberger 24-31872 (BOTU, RB, UB); estrada São Manuel - Piracicaba, perto estação 13 de maio, 22 ${ }^{\circ} 45^{\prime}$ S, 48 $8^{\circ} 25^{\prime} \mathrm{W}$, 550 m.a.m., 19.IX.1974 (fl), I.S. Gottsberger \& C.J. Campos 128-19974 (BOTU, UB); Itapetininga, Chácara Ayres, 6.XI.1880 (fl), A. Löfgren 329 (R, RB); Mogi Guaçu, Reserva Biológica da Fazenda Campininha, próximo a Pádua Sales, 27.X.1955 (fl, fr), M. Kuhlmann 3692 (SP); Campo das Sete Lagoas, 6,6 km de Pádua Sales, 22¹1-18`S, 477-10`W, 650 m.a.m., 22.IX.1960 (fl), G. Eiten \& L.T. Eiten 2393, 2395 (SP); Reserva Biológica da Fazenda Campininha, 3,4 km NNW do Bairro Pádua Sales, 23.IX.1960, J.R. Mattos \& N.F. Mattos 8371 (SP); Fazenda

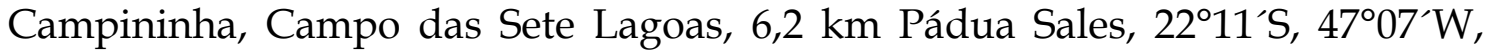
575 m.a.m., 4.XII.1961 (fl, fr), G. Eiten 3528 (K, RB, UB); 21.I.1977, V. Carnielli et al. 4 (UEC); Fazenda Campininha, 21.X.1977 (fl), V. Carnielli et al. 6526 (MBM, RB, UEC); Reserva Biológica da Fazenda Campininha, Bairro Pádua Sales, 14.XI.1979 (fl, fr), W. Mantovani 267 (SP); Reserva Biológica da Fazenda Campininha, 6.II.1980 (fl), W. Mantovani 465 (SP); idem, $15 . I X .1980$ (fl, fr), W. Mantovani 961 (SP); idem, 14.X.1980 (fl), W. Mantovani 1094 (SP, SPF, TENN);

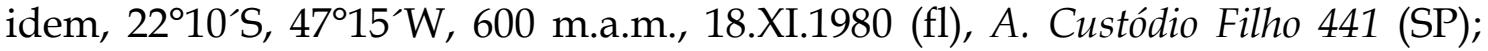
idem, estrada do pesqueiro a $4 \mathrm{~km}$ da entrada para viveiro, $22^{\circ} 12^{\prime} 13,1^{\prime} \mathrm{S}$, 47¹1'18,6’W, 585 m.a.m., 1.X.2002 (fl), M. Magenta \& J. Magenta 476 (SPF);

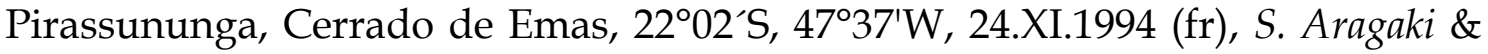
M. Batalha 174 (SP); Ribeirão Preto, Canteiro da Faculdade de Ciências e Farmácia de Ribeirão Preto, 17.IX.1997 (fl), F.B. Costa 24 (SPFR). PARAGUAI: [Caaguazu], in Campos de caaguazuú: [16.XI.1874] Balanza 1139 (remanescente do síntipo original de V. macrorhiza: K!); ídem, in vicinis Caaguazú, s.d. (fl), E. Hassler 9228 (K). Município indefinido: Rio Carimbatay, campos, IX.1901-02, Hassler 4578 (remanescentes do síntipo original de V. hasleriana: G*: BM!, GH frag.). 


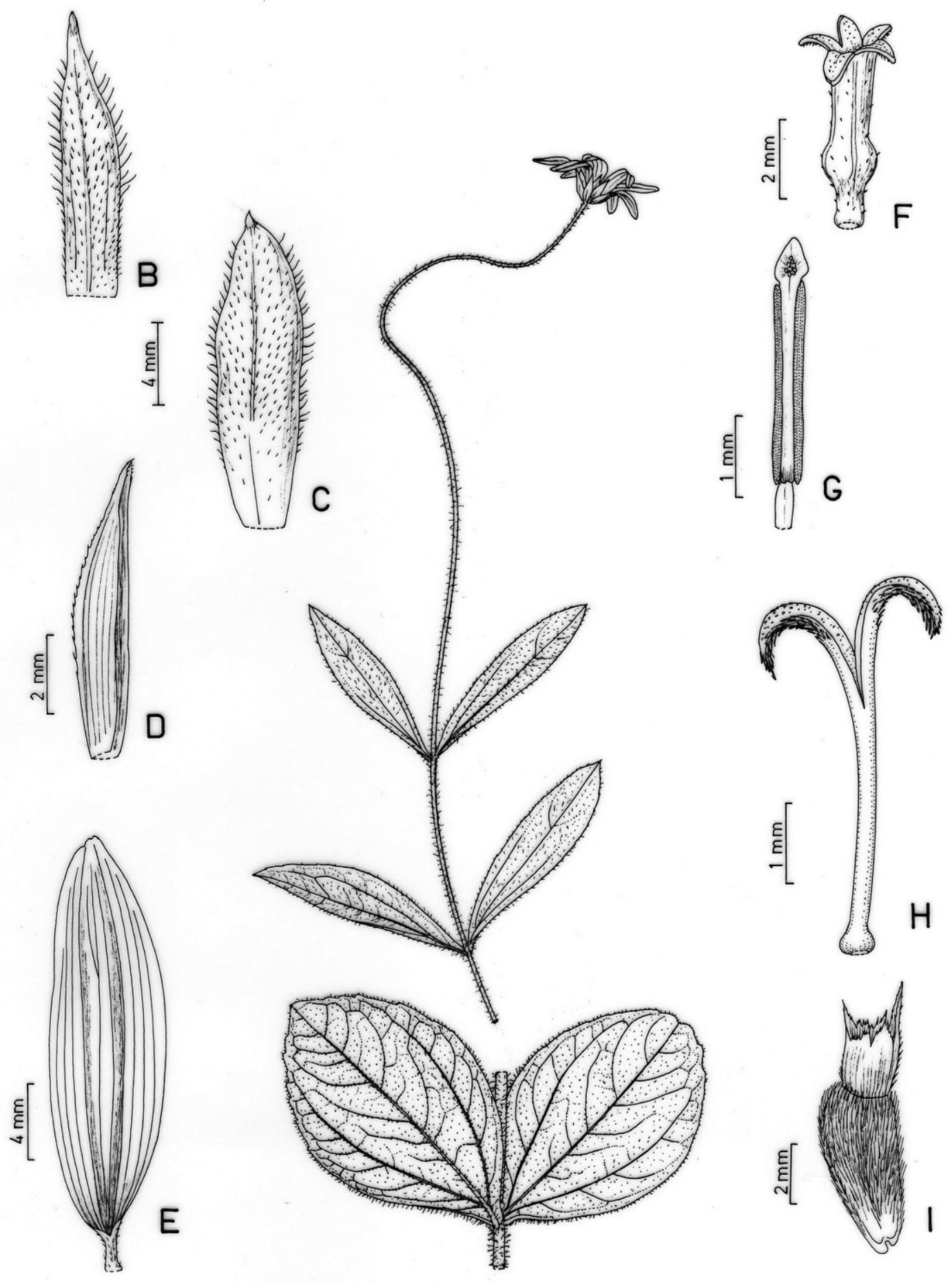

Fig. 24: V. macrorhiza. A. Base e ápice de ramo, a segunda com pedúnculo flexível, portando capítulo solitário, B-C. Brácteas involucrais, D. Pálea do receptáculo, E. Corola do raio, F. Corola do disco. G. Antera com tecas de base curtamente sagitada, terminando na base colar filetal, I. Estlete com alargamento basal cônico compactado, J. Cipsela com escamas do pápus unidas. A-J. M. Magenta \& J. Magenta 476 (SPF). FALTA ESCALA NO HÁBITO 
19. Viguiera megapotamica Malme, Ark. Bot. 24A (6): 68. 1931. Tipos: [Brasil: Rio Grande do Sul,] Cruz Alta, in campo graminoso, 5 Jan 1902; Malme II 52 2a [92 2a - ver comentários] (lectótipo aqui designado: UPS*; isolectótipos GH, LP!, $\mathrm{R} !, \mathrm{S} !)$.

Figura 25

Subarbusto 0,4-0,8m alt.; ramos aéreos decumbentes, cilíndricos, canaliculados, esparsamente setosos, entrenós $1-4 \mathrm{~cm}$, caule subterrâneo levemente espessado, raízes adventícias com tuberosidade fusiforme na porção central. Folhas verde-claras, alternas, sésseis, lâmina 30-80x1-1,5mm, linearfiliforme, fortemente revoluta, ápice obtuso a agudo, inteira, mucronado, uninervurada, nervura imersa na face adaxial, proeminente na face abaxial, cartácea, setosa a estrigosa, tricomas tectores 3-celulares, com bossas conspícuas, base cilíndrica adpressa, circundada por 1 série de células, sésseis. Inflorescência botrióide ou tirsóide, paracládios eretos, superiores terminando acima do capítulo terminal, 1a ordem $11-35 \mathrm{~cm}$ compr., 2a ordem $12-22 \mathrm{~cm}$ compr., 3a ordem raros, $15-16 \mathrm{~cm}$ compr., cilíndricos a levemente tetragonais, canaliculados, setosos a densamente setosos, bracteolados, bractéolas foliáceas, 1,3-3cm; pedúnculo terminal 7-15cm compr. Capítulos 2-2,5cm diâm., radiados, invólucro 5-10mm diâm., campanulado, brácteas involucrais reflexas na floração em 3-4 séries, ovais a oval-lanceoladas ou obovais, cartáceas, base canaliculada, foliáceas em 3/4 superiores, uma nervura destacada, ápice obtuso a agudo, mucronado, coriáceas, face adaxial estrigilosa ou nas internas esparsamente estrigilosa, face abaxial densamente gríseo-estrigosa ou nas internas estrigosa, cilioladas a ciliadas, externas 2-4 $\mathrm{mm}$ alt., ápice obtuso, centrais 4-7mm alt., internas 6-9 $\mathrm{mm}$ alt., mucronado; páleas 7-7,5mm alt., oblanceoladas, apiculadas, 6 ou 8 nervuras, geralmente carenadas, carena estrigosa. Flores do raio 10-12, em 1 verticilo, corola 13-20x4-6mm, tubo 11,5mm alt., limbo oblongo a oboval, ápice obtuso curtamente 2-3-partido, tubo estrigoso; face adaxial glabra, face abaxial com 13-16 nervuras estrigosas; flores do disco 20-45, corola 4-5 mm alt., tubo ca. $1 \mathrm{~mm}$ alt., lobos com altura igual ou maior que o dobro da largura, face externa com nervuras e tubo estrigosos e lobos estrigilosos; anteras de base auriculada, terminando acima ou na base do 
colar filetal, com glândulas, estilete com alargamento basal cônico, estilopódio 0,12-0,14x0,26-0,30mm. Cipselas 4-4,5mm alt., oblongas a levemente obovóides, comprimidas ou não, levemente tetragonais, estriadas, esparsamente setosas, ângulos densamente setosos, carpopódio delgado, pápus estramíneo, 2-4aristado, aristas livres, levemente intramarginais, iguais ou desiguais, 2-3mm alt., estreitamente triangulares, escamas ca. 4 pares, 0,7-1mm alt., unidas até a metade, ápice eroso.

Coletada apenas na região central do Rio Grande do Sul (fig. 42A), em campo sujo degradado, em beiras de rodovias. Floresce e frutifica do final da primavera ao início do outono.

É morfologicamente semelhante a $V$. anchusifolia var. immarginata, mas se diferencia pelas folhas linear-filiformes, pelos paracládios eretos e pelos capítulos e escamas do pápus menores.

Nota nomenclatural: Como os sintipos de Berlin (herbário citado no início do trabalho onde a espécie foi descrita) foram, evidentemente, perdidos durante a 2a guerra mundial, escolheu-se para lectótipo o espécime Malme II 92 2a. No protólogo são citados os números de coleta Malme II.522 e II 52 2a, o que certamente é um erro tipográfico, já que as etiquetas manuscritas por Malme apresentam os números 922 e 92 2a, respectivamente. Há uma anotação "lectótipo", nesta última, feita por C. Mondin, mas este não foi designado explicitamente em sua tese de doutoramento, embora lá também haja o termo "lectótipo". (Mondin 2004).

Material examinado: BRASIL: Rio Grande do Sul: Arroio dos Ratos, rodovia BR 290 km 160, 23.III.2002 (fl), C. Mondin \& A. Iob 2611 (HASU, SPF); idem, km 159,5, 14.XII.2002 (fl, fr), C. Mondin 2870 (HASU, SPF); rodovia BR 290

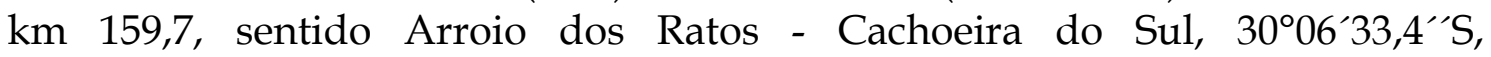
5148`27,6”'W, 94 m.a.m., 21.I.2003 (fl, fr), M. Magenta \& C. Mondin 502 (SPF);

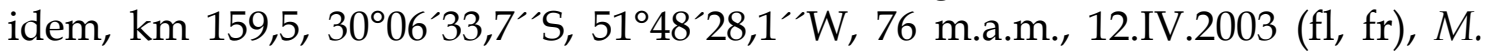
Magenta et al. 595, 596 (K, SPF, TEX); 'Cachoeira, in campo aprico, 3 Jan. 1902, Malme II. 522 [922 - veja comentários] remanescentes do sintipo: GH, LP, R!, S!, UPS); 20 Jan. 1902 (GH*, S!), Malme II: s.n. (remanescente do sintipo: ?S); Cachoeira do Sul, 3.I.1902 (fl), G.O.A. Malme 922 (R); $18 . I I .1948$ (fl), PalaciosCuezzo 1151 (LP); estrada Cachoeira do Sul - Santana de Boa Vista, IV.1995 (fl), M. Sobral \& Jarenkow 7874 (ICN); Rio Pardo, faz. Esperança, Apr. 1924 (n. 76) [(B)], faz. Itacolomy, Mai. 1924 (n.92) [(B)], João Rodrigues, Mart. 1927 (n. 272) [(B)]; Santa Maria, 22.IV.1935 (fl), s.c. s.n. (R 156023); estrada Silvicultura - Santa 
Maria, 2.I.1956 (fl), O. Camargo 125 (PACA); idem, 10.IV.1956 (fl), O. Camargo 492 (PACA). Santa Catarina: Curitibanos, 1 km de Lebon Regis, 900 m.a.m., 16.III.1957 (fl, fr), L.B. Smith \& R. Klein 12199 (RB).

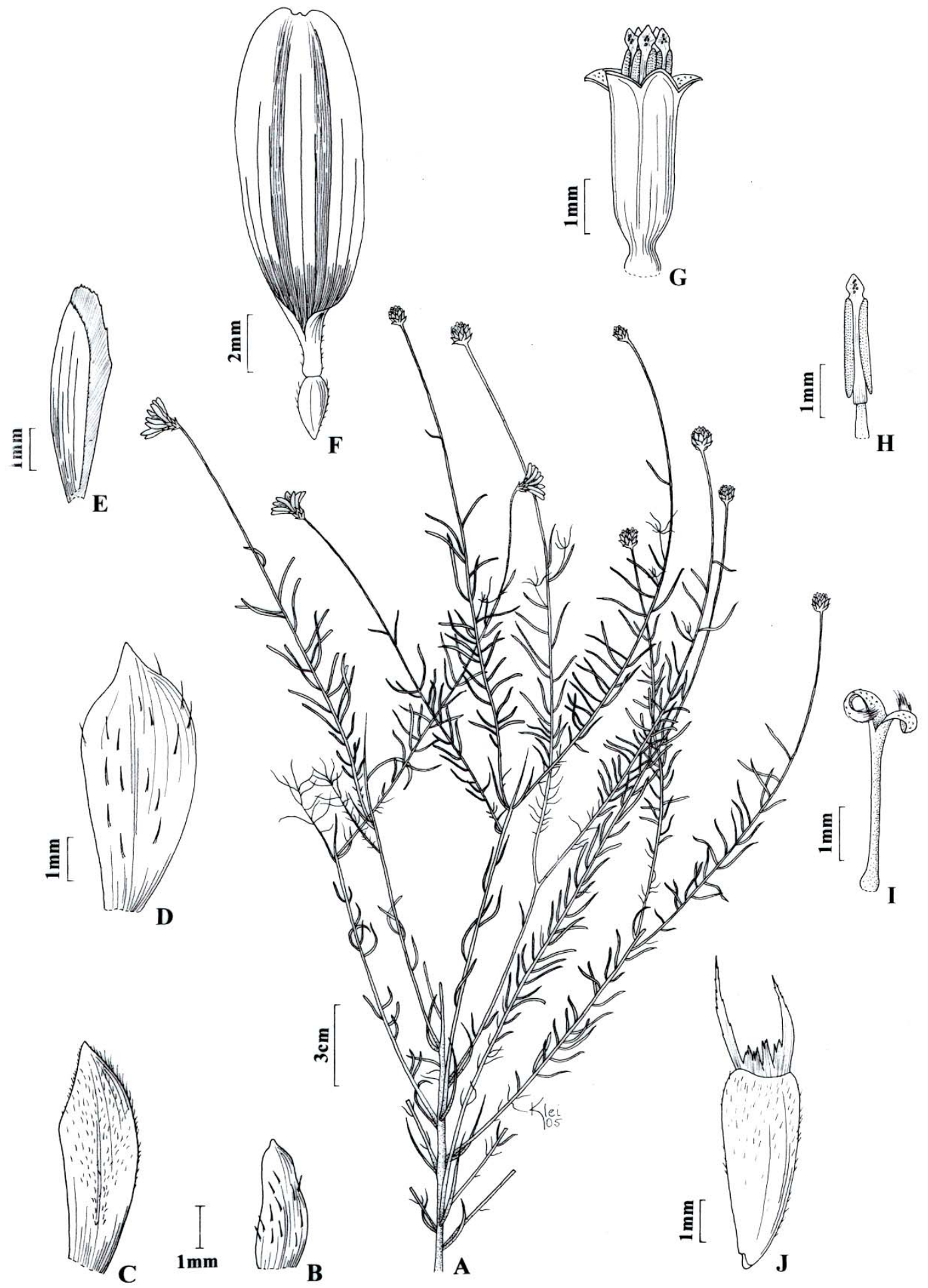

Fig.25: V. megapotamica A. Segmento de ramo com inflorescência, B-D. Brácteas involucrais, E. Pálea do receptáculo, F. Flor do raio, G. Corola do disco, H. Antera com tecas de base curtamente sagitada, terminando acima da base do colar filetal, I. Estilete com alargamento basal cônico J. Cipsela com escamas bem menores que as aristas. A-J. M. Magenta \& C. Mondin 502 (SPF). 
20. Viguiera meridionalis Magenta sp. nov. Tipo: Brasil. Rio Grande do Sul, Soledade, 2.4.1979, K. Hagelund s.n. (holótipo: ICN 12804!; fotografia do holótipo: SPF!).

Figura 26

Ervas perenes a subarbustos, ca. $1 \mathrm{~m}$ alt., ramos aéreos eretos, cilíndricos a levemente tetragonais, estriados, esparsamente estrigosos, entrenós $0,5-4 \mathrm{~cm}$; sistema subterrâneo desconhecido. Folhas alternas, sésseis ou pecíolo 1-5mm compr., viloso, lâmina 3-6x2-3cm, oval, base arredondada a obtusa, às vezes levemente cuneada, ápice agudo a acuminado, mucronulado, porção superior irregularmente serreada, escabrosas, nervação acródroma suprabasal perfeita, 3 nervuras principais, face adaxial estrigosa, tricomas tectores 3-celulares com bossas inconspícuas, base cônica cercada por 2 séries de células, face abaxial híspida, nervuras estrigosas, tricomas tectores 3-4-celulares, com bossas inconspícuas, base estreitamente cônica cercada por uma série de células, com tricomas glandulares. Inflorescência botrióide ou tirsóide, $40-45 \mathrm{~cm}$ alt., paracládios ascendentes, superiores terminando acima do capítulo terminal, estriados, vilosos, bractéolas foliáceas, alternas ou opostas, com glândulas curtamente pediceladas, na face abaxial, 1a ordem $6-40 \mathrm{~cm}$ compr., 2a ordem 1,5-cm compr.; pedúnculo terminal ca. 3,5cm compr. Capítulos ca. $3 \mathrm{~cm}$ diâm., radiados, subtendidos por uma bractéola linear, 3-5mm compr., invólucro ca. 10mm diâm., campanulado; brácteas involucrais reflexas na floração, 3-4 séries, 1a série $5-7 \mathrm{~mm}$ alt., lanceoladas a oval-lanceoladas, foliáceas em 3/4 superiores, coriáceas, face abaxial com base estriada estrigosa, ápice agudo, mucronado, estrigiloso, cilioladas a ciliadas, demais lanceoladas ou oblongas com base estriada, ápice foliáceo, agudo a longamente acuminado, mucronado, estrigiloso, ciliadas, $2 \mathrm{a}$ série $7-8 \mathrm{~mm}$ alt., 3a e 4 a séries $8-9 \mathrm{~mm}$ alt., lanceoladas ou oblongas; receptáculo convexo, páleas 7-9mm alt., oblongas, 6 ou 8 nervuras, carenadas, ápice agudo, escariosas, estrigilosas na porção superior externa. Flores do raio ca. 12, em 1 verticilo, corola ca. 10x4-5mm , limbo oblongo, ápice curtamente 2-partido, glabro, nervuras ca. 10, esparsamente setosas, tubo ca. $1 \mathrm{~mm}$ alt., viloso, flores do disco com corola $4,5-5 \mathrm{~mm}$, tubo ca. $8 \mathrm{~mm}$ alt., lobos 
com altura igual ou maior que o dobro da largura, face externa com tubo, base, nervuras e lobos estrigilosos; anteras de base curtamente sagitada, terminando um pouco acima ou na base do colar filetal; estilete com espessamento suprabasal largamente fusiforme, estilopódio 0,08-0,1x0,16-0,20mm. Cipselas 3,5-4mm alt., obovóides, levemente trígonas, estriadas, seríceas a setosas, carpopódio espesso, pápus amarelado 2-aristado, aristas desiguais, firmes, unidas às escamas laterais, menor $1-1,5 \mathrm{~mm}$ alt., maior 1,5-3mm alt., estreitamente triangulares, com carena estrigilosa, escamas 4-6 pares, 0,5-1mm alt., unidas na base ou até próximo ao ápice lacerado.

Conhecida apenas pelo material tipo coletado em abril (fig. $42 \mathrm{~A}$ ), com flores passadas e frutos. É possível que esteja extinta, pois não foi encontrada em nenhuma das quatro incursões efetuadas ao Estado do Rio Grande do Sul.

Espécie morfologicamente parecida com $V$. procumbens, das quais se diferencia pelas brácteas involucrais internas agudas a longamente acuminadas e pelas aristas do pápus, que são robustas, carenadas, e unidas às escamas laterais, enquanto em $V$. procumbens todas as brácteas possuem ápice agudo e as aristas do pápus são delicadas e livres. 

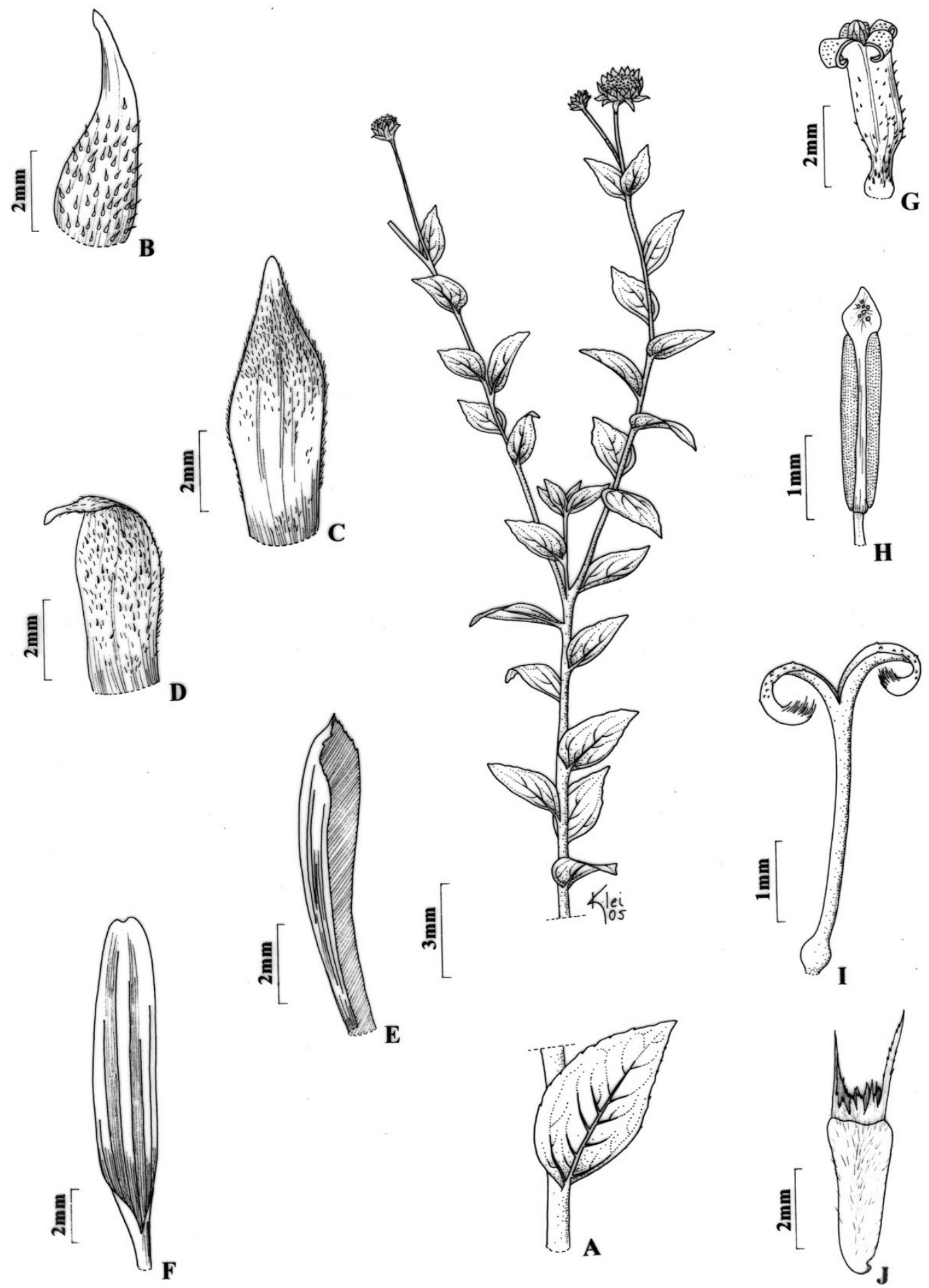

Fig. 26: V. meridionalis: A. Segmento do ramo com sinflorescência, B-D. Brácteas involucrais, E. Páleas do receptáculo, F. Flor ligulada, G. Flor tubulosa híspida, H. Antera com tecas de base levemente auriculada, terminando próximo à base do colar filetal, I. Estilete com alargamento basal largamente fusiforme; J. Cipsela com aristas longas e tênues. A-J. Hugelund s.n. (ICN 124881). 
21. Viguiera nudibasilaris S.F. Blake, Contr. Gray Herbarium 54: 149. 1918. Rhysolepis nudibasilaris (S.F. Blake) H. Rob. \& A.J. Moore, Proc. Biol. Washington 117(7): 429. 2004. Tipo: Brasil, Minas Gerais, Caldas, 1827/346, Widgren s.n. [230 (BR)] (holótipo: K!; fotografia do holótipo: K!, SPF; isótipos: BR!, M!, R!).

Viguiera tuberculata S.F. Blake, Contr. Gray Herbarium 54: 151. 1918. Rhysolepis tuberculata (S.F. Blake) H. Rob. \& A.J. Moore, Proc. Biol. Washington 117(7): 432. 2004. Tipo: Brasil, Minas Gerais, A. St.-Hil. 1212 (holótipo: P!; fotografia do holótipo: K!, SPF!). syn. nov.

Figuras $2 \mathrm{~A}$ e 27

Arbusto 1,5-2,5m alt., ramos aéreos flexíveis, cilíndricos, canaliculados, híspidos, entrenós 1-4cm compr.; caule subterrâneo levemente espessado, raízes adventícias inteiramente tuberosas fusiformes. Folhas levemente discolores, alternas; pecíolo 5-8mm compr., lâmina 5-10x1,5-2cm, lanceolada, base atenuada, decorrente, ápice acuminado mucronado, cartácea, nervação acródroma suprabasal perfeita, 3 nervuras principais, esparsamente denteada, híspidas, face adaxial com tricomas tectores 3-5-celulares, com bossas diminutas, base cilíndrica, ereta cercada por 1-2 séries de células, face abaxial com tricomas tectores sem base delimitada, eretos, base cercada por 1 série de células. Inflorescência botrióide ou tirsóide, 30-50 cm alt., paracládios eretos, superiores terminando próximo ao capítulo terminal, canaliculados, híspidos, bractéolas foliáceas opostas, 1a ordem 9-25cm compr., 2a ordem 5,5-8,5cm compr.; pedúnculo terminal 2,5-6cm compr. Capítulos 4-6cm diâm., radiados, invólucro 1,2-2cm diâm.; brácteas involucrais reflexas na floração, 2 séries, lanceoladas, base caniculada, foliáceas em 1/3 superior, ápice acuminado mucronado, margem com cílios longos, cartáceas, face adaxial glabra a esparsamente estrigilosa, face abaxial estrigosa, 1a série 4-8mm alt., 3-5 nervuras destacadas, 2a série 7-10mm alt; receptáculo convexo, páleas 7,58,5mm alt., oblongas, carena estreita a larga, 8 ou 10 nervuras, ápice estrigiloso agudo mucronado. Flores do raio 10-14, em 1(-2) verticilos, corola 20-35x5$6 \mathrm{~mm}$, limbo oblongo a elíptico com ápice emarginado, tubo 1-2mm alt., face adaxial glabra, face abaxial estrigosa a híspida, com glândulas, nervuras 13-14; flores do disco 100-120, corola 4,5-7mm alt., tubo 1,5-2mm alt., face externa com 
base e nervuras estrigilosas e híspidas, lobos estrigosos, tubo estrigiloso a estrigoso, antera de base curtamente sagitada, terminando na base do colar filetal, estilete com alargamento basal semigloboso a cônico , estilopódio 0,140,2x0,28-0,3 mm. Cipselas 2,5-3,5mm alt., obovóides a estreitamente obovóides, estriadas, carpopódio médio, pápus amarelo-dourado, estrigilosas próximo ao ápice, 2-aristadas, aristas intramarginais, livres, iguais ou levemente desiguais, 0,8-1,2mm alt., cartáceas; escamas ca. 4 pares, $0,3-0,8 \mathrm{~mm}$ alt., unidas até o meio, ápice eroso.

Coletada no nordeste do Estado de São Paulo e sul de Minas Gerais (fig. 42B) em beiras de mata e campo sujo, com flores e frutos de fevereiro a abril, com um registro de maio (Glaziou 15080).

De morfologia similar a $V$. pilosa, diferencia-se desta pelo invólucro 2seriado, pelas flores do disco maiores e em maior número e pelo pápus com aristas e escamas muito menores. As características utilizados por Blake (1918) para estabelecer $V$. tuberculata, relativos ao indumento das brácteas involucrais, ao tamanho das flores do disco e das aristas do pápus, mostraram-se variáveis em capítulos de um mesmo espécime e, portanto, o nome foi considerado como sinônimo de $V$. nudibasilaris..

Material examinado: BRASIL: Minas Gerais: Barbacena, III.1941 (fl), F. de Laueo s.n. (R 35073); Camanducaia, a $15 \mathrm{~km}$ da Vila de Monte Verde, $15 . I I I .1976$ (fl, fr), H.F. Leitão Filho 1853 (K, UEC); a 6 km de Monte Verde, 16.III.1976 (fl), H.F. Leitão Filho et al. 1819 (UEC); Monte Verde, 7.IV.1988 (fl, fr), H.F. Leitão Filho \& T. Lewinsohn 20187 (UEC); estrada para Monte Verde a $1 \mathrm{~km}$ de Camanducaia, $23^{\circ} 06^{\prime} 53,2^{\prime \prime}$ S, 46 $01^{\prime} 16,7^{\prime \prime} \mathrm{W}, 851$ m.a.m., 6.IV.2002 (fl, fr), M. Magenta \& J. Magenta 426 (K, SPF, SPFR); Delfim Moreira, PCH Ninho de Águia, IV.2000 (fl, fr), L.V. Costa s.n. (BHCB 52511); Passa Quatro, 9.IV.1929 (fl), A.J. Sampaio 6148 (R); Poços de Caldas, $30 . \mathrm{I} .1919$ (fl, fr), F.C. Hoehne s.n. (SP 2942); Campo do Saco, 7.IV.1967 (fl, fr), A.R.A. Roppa 1027 (RB); Pouso Alegre, rodovia MG $390 \mathrm{~km} \mathrm{8,}$

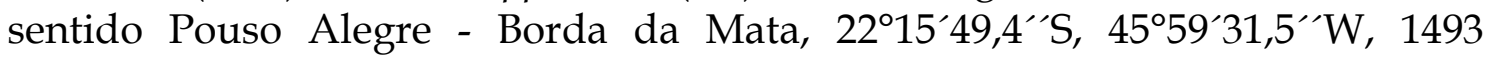
m.a.m., 6.IV.2002 (fl), M. Magenta \& J. Magenta 430 (SPF); São Lourenço, estrada São Lourenço - Carmo de Minas, II.1966 (fl, fr), A. Mattos Filho 441, 449 (EPAMIG, RB, SPF); município indefinido, Prov. Minarum Ad Caldas, 18.III.1865 (fl), A.F. Regnell III.772 (BR, K); Congonhas do Campo, Brésil, 8.VI.1884 (fl, fr), A. Glaziou 15080 (BR,P, K); Brésil, $30 . X I I .1886$ (fl, fr), A. Glaziou 16164 (P); ou Rio de Janeiro? (anotaçao do coletor) II. 1898 (fl, fr), Lindberg 4 e 5 (P); Brasilien, s.d. (fl, fr), Widgren 229 (BR). São Paulo: Campos de Jordão, Instituto Florestal, Região do Canhambora, trilha de equitação, 27.III.1985 (fl, 
fr), M.J. Robim \& J.P.M. Carvalho 256 (D, MBM, SPSF, UEC); parque estadual, trilha do Rio Sapucaí, 17.III.1987 (fl, fr), M.J. Robim 443 (SPF, SPSF, UEC).
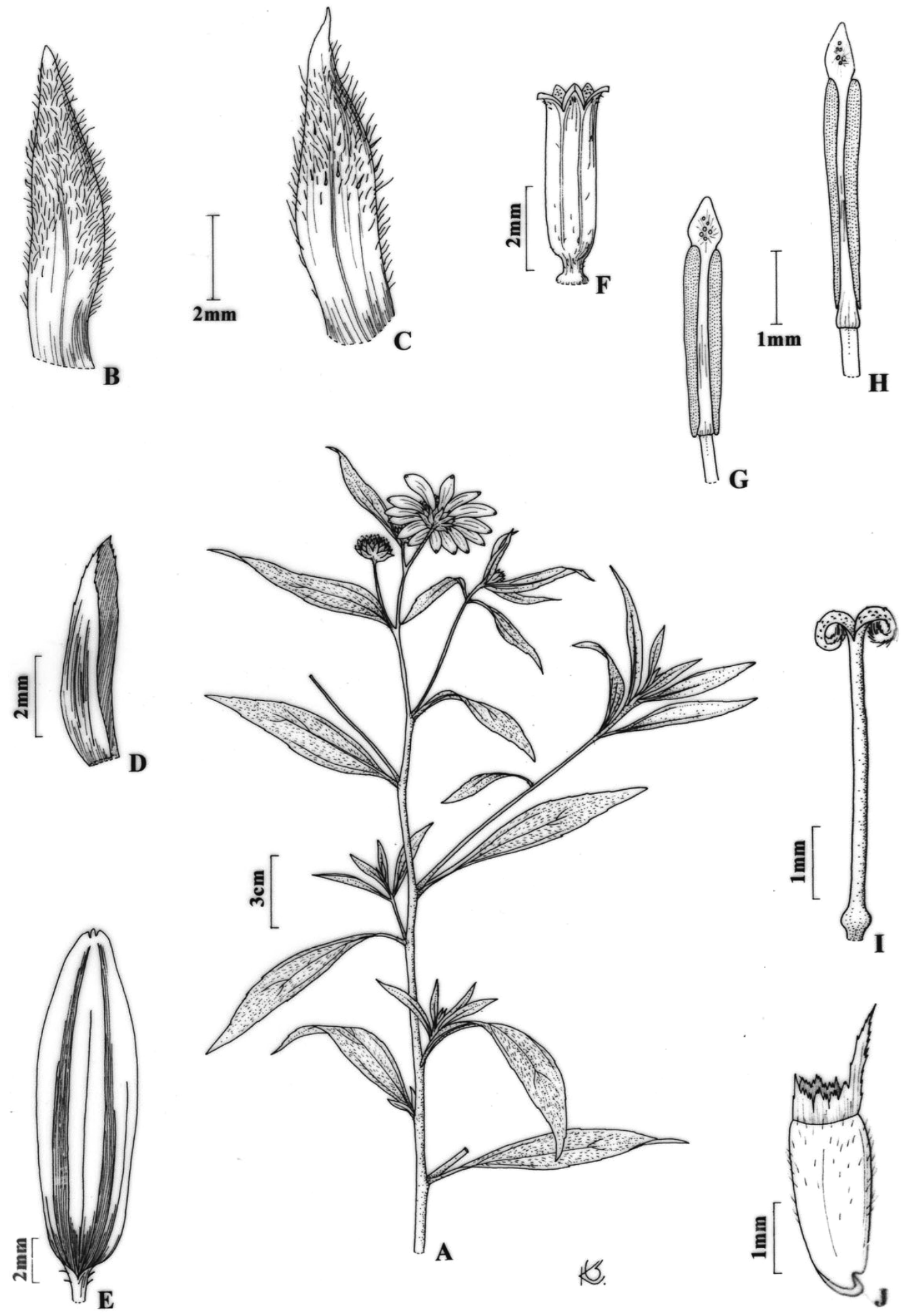

Fig. 27: V. nudibasilaris A. Segmento de ramo com sinflorescência, B-C. Brácteas involucrais, D. Pálea do receptáculo, E. Corola do raio, F. Corola do disco, G-H. Antera, com tecas de base curtamente sagitada; G. Tecas terminando na base do colar filetal; H. Tecas terminando acima da base do colar filetal, I. Estilete com alargamento basal semigloboso, J. Cipsela com aristas desiguais. A. Magenta 430; B-J. M. Magenta \& J.Magenta 426 (SPF). 
22. Viguiera nudicaulis Baker, in Martius Fl. bras. 6(3): 228. 1884. Rhysolepis nudicaulis (Baker) H. Rob. \& A.J. Moore, Proc. Biol. Washington 117(7): 429. 2004. Tipo: Uruguai, Maldonado, 1826-30, Cap. King 40 (holótipo: K!, US - frag.; fotografia do holótipo: K!, SPF).

? Rudbeckia nudicaulis Pers., Syn. Pl. (Persoon) 2: 477. 1806. Tipo: Uruguai. Hab. in Monte-Video (Herb. Juss.).

Figuras 2D e 28

Erva a subarbusto $25-60 \mathrm{~cm}$ alt., ramos aéreos flexíveis, cilíndricos, levemente canaliculados, esparsamente setosos, entrenós 1,5-5cm compr.; caule subterrâneo com algumas raízes adventícias com tuberosidade largamente fusiforme. Folhas verde-claras, opostas, decussadas, pecíolo 0,8-1,5mm compr., híspido, 1-2 pares inferiores reduzidos; lâmina das folhas medianas 2,5-6,5cm, elíptica a oval ou às vezes largamente oblonga ou levemente oboval, esparsa e longamente ciliada, base arredondada a atenuada, ápice agudo, arredondado ou às vezes truncado, mucronado, inteira ou esparsamente denteada na porção superior, cartácea, nervação acródroma suprabasal perfeita, uma nervura principal, híspida, tricomas tectores multicelulares, base cônica ereta, cercada por 3 séries de células. Inflorescência tirsóide, $10-28 \mathrm{~cm}$ alt. ou capítulos solitários, paracládios flexuosos, superiores terminando abaixo do capítulo terminal, 10-22cm compr., vináceos, canaliculados, setosos a estrigosos, com bractéolas foliáceas; pedúnculo terminal $4-28 \mathrm{~cm}$ compr.. Capítulos 4,5-5cm diâm., radiados, às vezes subtendidos por 1 bráctea linear 8-15mm; invólucro 11,2cm diâm., campanulado, brácteas involucrais levemente apressas na floração, em 2-3 séries, lanceoladas, oblongo-lanceoladas ou oblanceoladas, base caniculada, 3 nervuras destacadas, foliáceas em 1/2 a 2/3 superiores, cartáceas, face abaxial com base estrigosa, ápice agudo a acuminado, setoso a estrigoso, ciliadas, 1a série 8-12mm alt., cartáceas, face adaxial estrigilosa, 2a série 9$14 \mathrm{~mm}$ alt., cartáceas, face adaxial glabra, 3a série ca. $11 \mathrm{~mm}$ alt., escariosas; receptáculo convexo, páleas $6,5-7 \mathrm{~mm}$ alt., obovais ou oblongas, com carena estreita ou sem carena, ápice agudo a acuminado, 8 ou 10 nervuras, hialinas, glabras. Flores do raio 10-15, em 1 verticilo, corola 17-25x6-10mm, limbo oblongo a elíptico, ápice 3-partido, face abaxial esparsamente estrigilosa, 
nervuras 12-14, esparsamente estrigilosas, tubo ca. $1 \mathrm{~mm}$ alt., esparsamente estrigiloso; flores do disco 35-85, corola 4-5mm alt., tubo 0,5-1mm alt., limbo urceolado na base, lobos com altura igual ou maior que o dobro da largura, face externa com limbo e tubo estrigilosos, lobos esparsamente estrigilosos, antera de base auriculada, terminando acima da base do colar filetal, estilete com base cônica compactada, estilopódio 0,6-0,8x0,28-0,30mm. Cipselas 5-5,5mm alt., obovóides, comprimidas, levemente trígonas, estriadas, dourado-seríceas, carpopódio delgado, a médio, pápus estramíneo a amarelado, 2-aristado, aristas intramarginais 2,8-3mm alt., livres, porção basal oblonga, escariosa, alargada, ápice acuminado, nervura estrigosa, escamas ca. 3 pares, ca. 2,5mm alt., unidas até o ápice fimbriado.

Baker (1884), ao descrever a espécie, citou como duvidoso o material descrito por Persoon, inclusive designando outro material-tipo; o espécime examinado por Persoon não foi localizado no Herbário G (ex. Herb. Juss.) ou nas coleções Linneanas dos herbários BM e P; a observação da microficha correspondente ao material da coleção de Jussieu no herbário K indica que, provavelmente, a planta descrita como Rudbeckia nudicaulis pertence ao gênero Acmella Rich. ex Pers. A espécie aqui aceita como V. nudicaulis corresponde à que Baker descreveu com base no tipo citado acima.

Planta rara descrita para o Uruguai, onde só é conhecida pelo materialtipo e citada pela primeira vez para o Brasil por Mondin (2004), onde é encontrada no sul e sudeste do Rio Grande do Sul (fig. 42A). Floresce e frutifica de na primavera e no verão.

A espécie é confundida nos herbários com Aspilia montevidensis (Spreng.) Kuntz, com a qual é simpátrida e extremamente semelhante, com ligeira variação na cor das flores do raio, sendo necessária a observação atenta de características como a presença ou ausência de alargamento basal do estilete, ou de cicatriz na base do fruto, característica de Aspilia, para distingui-las. Aproxima-se morfologicamente de $V$. paranensis, da qual se diferencia pelas flores do disco com base urceolada e tubo menor, variando de 0,5 a 1mm, além de anteras terminando acima da base do colar filetal e estilete com base cônica; 


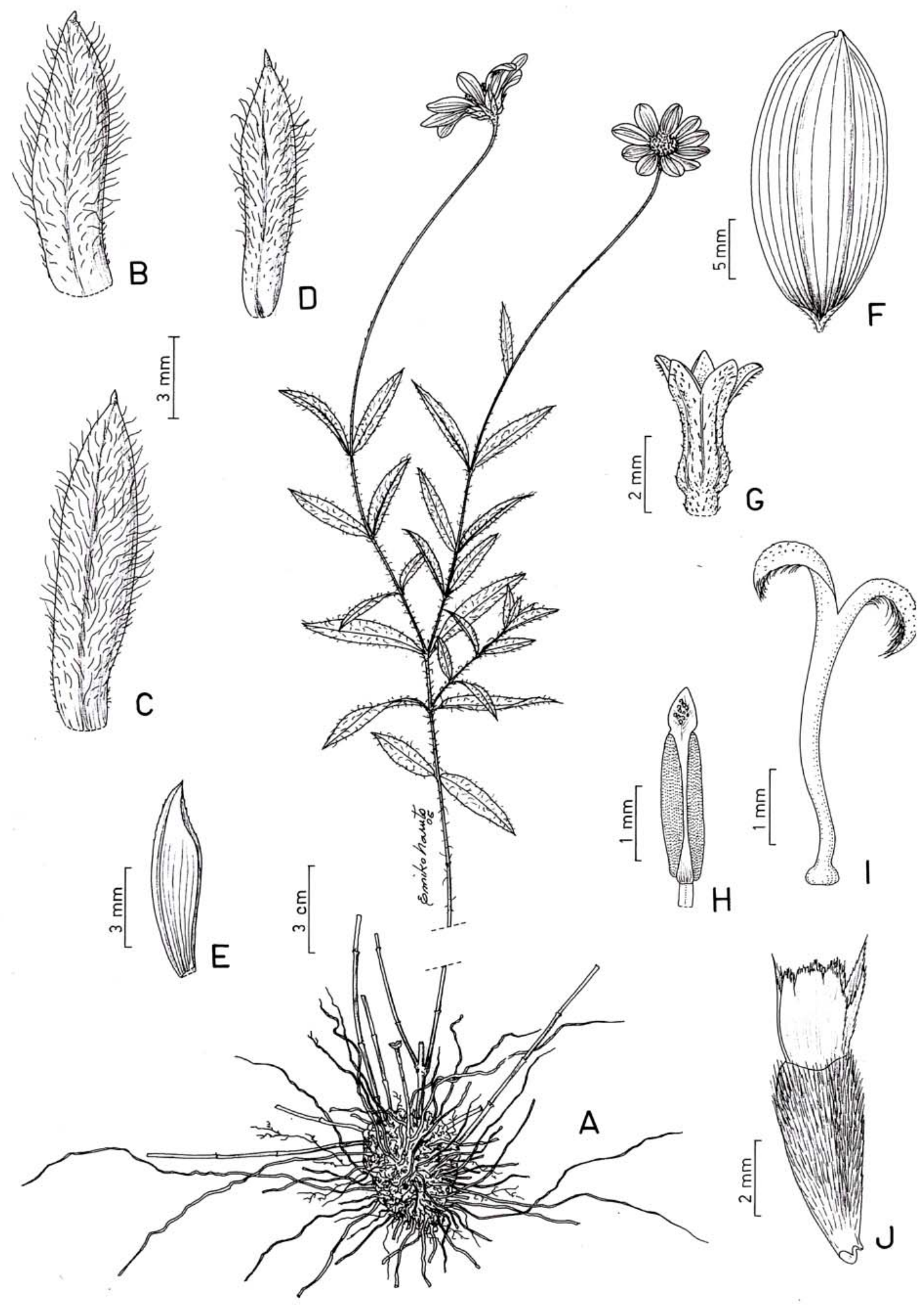

Fig. 28: V. nudicaulis A. Hábito, B-D. Brácteas involucrais, E. Pálea do receptáculo, F. Corola do raio, G. Corola do disco com base levemente urceolada. H. Antera com tecas de base auriculada, terminando acima do colar filetal, I. Estilete com alargamento basal cônico compactado, J. Cipsela com escamas do pápus unidas. A-J. M. Magenta \& C. Mondin 503 (SPF). 
$V$. paranensis possui flores do disco com limbo uniforme e tubo com cerca de 1,5mm, além de anteras terminando na base do colar filetal e estilete com alargamento basal cônico. Alguns espécimes apresentam semelhanças com $V$. aspilioides, da qual se diferencia pelo receptáculo convexo na maturidade e pelas flores do disco com base do limbo levemente urceolada; nesta última, o receptáculo se torna fortemente convexo ou cônico na maturidade, e a base do limbo das flores do disco é tubulosa.

Material examinado: BRASIL: Rio Grande do Sul: Caçapava do Sul, rodovia Caçapava - Bagé, 8 km de Caçapava, 15.X.1979 (fl), J.R. Mattos \& N.F. Mattos 19718 (HAS); Guaíba, Fazenda Maximiano, Rodovia BR 116 km 308, 16.IX.2001 (fl), N.I. Matzenbacher s.n. (ICN 122115); Fazenda São Maximiniano, 27.X.2001 (fr), C. Mondin 2386 (HASU, SPF); idem, Rodovia BR 116 km 308, 4.XI.2001 (fl), N.I. Matzenbacher s.n. (ICN 123298); Itapoã, Viamão, XI.1982 (fl), M. Sobral 1189 (ICN); idem, XII.1986 (fl, fr), M. Sobral \& Esposito 5408, 5412 (ICN); Minas do Leão, estrada para o Cerro do Roque, 29.IX.2001 (fl), C. Mondin \& A. Iob 2251 (HASU, SPF); idem, a 10,2 km da BR $290 \mathrm{~km} \mathrm{189,} \mathrm{30¹3`11,2”S,}$ 52 $2^{\circ} 04^{\prime} 46,2^{\prime}{ }^{\prime}$ W, 230 m.a.m., 21.I.2003 (fl, fr), M. Magenta \& C. Mondin 503 (SPF); Pelotas, Instituto Agronomico do Sul, 14.XI.1955 (fl), J.C. Sacco 406 (PEL); Pinheiro Machado, rodovia Pinheiro Machado - Bagé, a $3 \mathrm{~km}$ de Pinhiro Machado, 18.I.1979 (fl), J.R. Mattos \& E. Assis 19213 (HAS); Porto Alegre, Morro de Santa Teresa, próximo Menino Deus, 24.X.1958 (fl), G.F.J. Pabst 4570 (HB, LP); Morro Santana, no topo, 20.V.1980 (fl), O. Bueno 2503 (HAS, RB); Parque Municipal do Morro do Osso, 7.XII.2003 (fl, fr), M. Magenta \& C. Mondin 698 (SPF); Quaraí, Morro Maximiniano, Rodovia BR 116 km 308, 30¹0`38,9'`S, 51²2 55,1`W, 192 m.a.m., 14.IV.2003 (fl), M. Magenta \& L.R. Lima 615 (SPF);

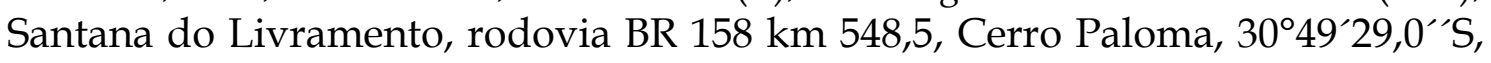
55²0`54,0`W, 132 m.a.m., 24.I.2003 (fl), M. Magenta \& C. Mondin 517 (SPF); Cerro Paloma, acesso pela Rodovia BR 158 km 458,5, 3049'29,0“'s, 55²0`54,0`W, 132 m.a.m., 13.IV.2003 (fl), M. Magenta et al. 605 (SPF); Viamão, Parque Estadual de Itapoã, 24.XII.2002 (fl, fr), C. Mondin 2840 (HASU, SPF).

23. Viguiera oblongifolia Gardner, London J. Bot. 7: 402. 1848. Rhysolepis oblongifolia (Gardner) H. Rob. \& A.J. Moore, Proc. Biol. Washington 117(7): 430. 2004. Tipo: Brasil, dry upland Campos, Mission of Duro, Province of Goyaz, Oct. 1839, Gardner 3291 [3291 e 3293 (K)] (lectótipo aqui designado: K! ex Herb. Hookerianum; fotografia do lectótipo: K!, SPF!; isolectótipos: BM!, G, GH frag., K! ex Herb. Trinity College, P!; fotografia do isolectótipo de G: F!).

V. nervosa Gardner, London J. Bot. 7: 403. 1848. Rhysolepis nervosa (Gardner) H. Rob. \& A.J. Moore, Proc. Biol. Washington 117(7): 429. 2004. Tipo: 
BRAZIL. GOYAZ: Bushy places in upland Campos near Villa de Natividade, Province of Goyaz, Jan. 1840. [Dec. 1839 (BM!, K!), na realidade, out.1839, D.J.N. Hind com. pess., segundo Gardner 1846], Gardner 3290 (lectótipo aqui designado: K!; fotografia do lectótipo: K!, SPF; isolectótipos: BM!, G, GH - frag., $\mathrm{NY}^{*} 2 \mathrm{x}$; fotografia do isolectótipo de G: F!). syn. nov.

Figuras 2C e 29

Erva a arbusto 0,5-1,5m alt., ramos aéreos eretos, cilíndricos ou levemente tetragonais, canaliculados, setosos a estrigosos, entrenós (0,5-)1-4(7,5)cm compr.; caule subterrâneo levemente espessado, raízes adventícias com tuberosidade fusiforme na porção mediana. Folhas verde-claras, inferiores opostas, superiores alternas; pecíolo 1-6,5mm compr., expandido na base, estrigoso a viloso; lâmina 4,5-10x0,9-2,5cm, estreita a largamente oblonga, estreita a largamente elíptica ou raramente oval, ciliada, base arredondada a obtusa, levemente cuneada, ápice obtuso a agudo, mucronado, inteira ou esparsamente denticulada, cartácea; nervação acródroma suprabasal imperfeita, 3 nervuras principais, face adaxial estrigilosa a estrigosa ou raramente setosa, face abaxial estrigilosa a estrigosa, setosa ou híspida, ambas com tricomas 3celulares com bossas inconspícuas, base cônica ereta cercada por 1-2 séries de células. Inflorescência botrióide ou tirsóide laxa, (20-)30-40cm alt., paracládios flexuosos, superiores terminando acima do capítulo terminal, canaliculados, hispídulos, bractéolas esparsas oblongas ou sem bractéolas, 1a ordem (20-)30$40 \mathrm{~cm}$ compr. 2a ordem $8-10 \mathrm{~cm}$ compr.; pedúnculo terminal $20-35 \mathrm{~cm}$ compr. Capítulos 3-3,5 cm diâm., radiados, subtendidos por 1-2 bractéolas 3-4mm compr. lineares, invólucro 8-10mm diâm., campanulado; brácteas involucrais apressas ou raramente reflexas na floração, 4 séries, ovais, oval-lanceoladas ou oboval-lanceoladas, base fortemente caniculada, foliáceas em $1 / 3$ a 1/2 superiores, ápice vináceo, 5-8 nervuras destacadas, ápice agudo a acuminado, cilioladas, coriáceas, face abaxial glabra ou com porção superior estrigilosa, 1a série $4,5-5 \mathrm{~mm}$, 2a série 5,5-11mm, 3a série 9-12mm alt., 4a séries $11-12 \mathrm{~mm}$ alt; receptáculo levemente convexo, páleas $12-15 \mathrm{~mm}$ alt., oblanceoladas a estreitamente oblanceoladas, ápice acuminado mucronado, carena estreita, 8 ou 10 nervuras, densamente estrigilosas. Flores do raio 8, em 1 verticilo, 16-18x5- 
7,5mm, tubo ca. 1,8mm alt., limbo elíptico, ápice obtuso, curtamente 3-partido, face adaxial glabra, face abaxial com 12-16 nervuras pubescentes, tubo hispídulo; flores do disco 35-40, corola 4,8-5mm alt., tubo 1,2-1,3mm alt., lobos com altura igual ou maior que o dobro da largura, face externa com tubo, base do limbo e margem dos lobos estrigilosos; antera de base curtamente sagitada, terminando acima da base do colar filetal; estilete com alargamento basal semigloboso a cônico, estilopódio 0,14-0,20x0,22-0,24mm. Cipselas 5-6mm alt., obovóides, comprimidas, levemente tetragonais, estriadas, hispídulas próximo ao ápice, carpopódio delgado, pápus estramíneo a amarelado, (1-)2-aristado, aristas livres, levemente intramarginais iguais ou desiguais 2,5-4mm alt., estreitamente triangulares, acuminadas, híspidas, laceradas; escamas ca. 3 pares 0,8-1,2mm alt., unidas até o meio ou até próximo ao ápice lacerado.

Ocorre em cerrados abertos e campos, no sudoeste do Ceará, Goiás, Minas Gerais, sudeste e norte de Tocantins, sudoeste do Maranhão, sudeste e nordeste de Mato Grosso e no Pará (fig. 46A), em local indefinido. Floresce e frutifica na primavera e no verão. As observações de campe dos espécimes herborizados indicam que frutificação, não ocorre com freqüência e a espécie provavelmente se propaga habitualmente por meio do sistema subterrâneo.

A espécie é facilmente reconhecida pelos longos paracládios flexuosos, invólucro com quatro séries de brácteas ovais a oval-lanceoladas que, na maioria das vezes, se mantêm apressas na floração e pelas cipselas muito grandes em relação ao tamanho das flores do disco. A variação na largura das folhas, principal caráter utilizado por Gardner para descrever $V$. nervosa, ocorre constantemente na mesma população, como observado em campo, e até no mesmo espécime.

O material depositado no herbário $K$, originário do herbário Hookerianum, foi selecionado como lectótipo de $V$. oblongifolia por possui a etiqueta manuscrita por Gardner com detalhes do protólogo da espécie. Na exsicata desse lectótipo está fixada ainda uma segunda etiqueta, com o número 3093, um erro provavelmente cometido pela pessoa responsável pela montagem do material. Gardner 3093 é, na verdade, Wedelia goyazensis Gardner, também 
depositada no herbário K. A seleção do lectótipo de $V$. nervosa foi efetuada com base nos mesmos critérios.

Material examinado: BRASIL: Ceará: Santana do Cairiri, Tabuleiro, 9.III.1860 (fl), F. Allemão 864 (R). Goiás: Caiapônia, rodovia BR 158 km 180, entre

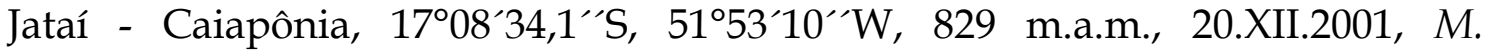
Magenta et al. 355 (SPF); Cercadinho, rodovia Belém - Brasília, Fazenda Americana, próximo a Cercadinho, 9.I.1961 (fl), L. Emygdio 1896 (R); Colinas do Sul, a 1 km do Rio do Peixe, Hidroéletrica Serra da Mesa, 1409`S, 4804`W, 450 m.a.m., 24.XI.1992 (fl, fr), R.F. Vieira et al. 1408 (CEN, SPF); Goiânia, XII.1936, A.C. Brade 15398 (RB); Iaciara, 15 km estrada Iaciara - Nova Rova, 5.II.1981 (fl), R.M. King \& L.E. Bishop 8801 (K, UB); Iporá, rodovia GO 060 km 224, sentido

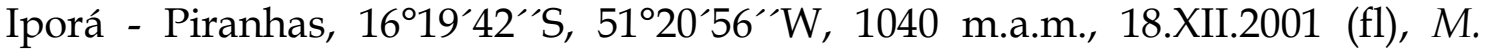
Magenta et al. 339 (SPF); Juscelino Kubtschek, vale do Paranã, Rodovia JK 60, 6.II.1967 (fl), A.P. Duarte 10333 (RB); Minaçu, em frente viveiro antigo da UHE Serra da Mesa, $5 \mathrm{~km}$ da entrada N do canteiro de obras, $13^{\circ} 48^{\prime} \mathrm{S}, 48^{\circ} 17^{\prime} \mathrm{W}, 500$ m.a.m., 9.XII.1991 (fl), B.M.T. Walter et al. 867 (CEN, K, SPF, UEC); Mossâmedes, Serra Dourada, 13.XII.1951 (fl), A. Macedo 3464 (RB); Niquelândia, ca. 17 km Sul Niquelândia, 750 m.a.m., 23.I.1972 (fl), H.S. Irwin et al. 34906 (NY, RB); Piranhas, rodovia BR $158 \mathrm{~km}$ 93, sentido Bom Jardim - Piranhas, 16²3'24,6"'S, 5149`59,6“'W, 370 m.a.m., 20.XII.2001, M. Magenta et al. 349 (SPF); rodovia BR 158, sentido Piranhas - Caiapônia, $1^{\circ} 28^{\prime} 0,8^{\prime \prime} \mathrm{S}, 5^{\circ} 47^{\prime 2} 23,5^{\prime \prime} \mathrm{W}, 390$ m.a.m., 20.XII.2001 (fl), M. Magenta et al. 350 (SPF); idem, 16³9`14,4”S, 5142`29,4”W, 660 m.a.m., 20.XII.2001 (fl), M. Magenta et al. 352 (K, SPF); Uruaçu, estrada de terra da BR 153, passando pela Vila Água Branca, $14^{\circ} 23^{\prime} \mathrm{S}, 4^{\circ} 00^{\prime} \mathrm{W}, 400$ m.a.m., 7.II.1996 (fl), B.M.T. Walter et al. 3084 (CEN); município indefinido, Projeto RADAMBRASIL, ponto 07, 10³0`S, 5003`W, 1.XII.1977 (fl, fr), E. Mileski \& C.T. Falcão 5142 (HRB, RB, UEC). Maranhão: Balsas, estrada para Alto Parnaíba, a 6 km de Balsas, 7.XII.1980, P. Martins e E. Nunes 9462, 9464 (RB); Fazenda do Sr. Damião, ca. $25 \mathrm{~km} \mathrm{~W}$ de Balsas, ao longo da rodovia, 3.XII.1981 (fl), M.J. Balick et al. 1328 (RB). Mato Grosso: Barra do Garças, Crest of Serra do Roncador, along new road , $209 \mathrm{~km}$ NNE of village de Xavantina, 9.XI.1969 (fl), G. Eiten \& L.T. Eiten 9818 (K); rodovia BR 158, sentido Barra do Garça - Nova Xavantina, 1551'25,1”S, 52¹8`32,3”W, 382 m.a.m., 18.XII.2001 (fl, fr), M. Magenta et al. 340 (HUFU, K, SPF, SPSF, TEX); Luciára, rodovia BR $1581-5 \mathrm{~km} \mathrm{~W}, 43 \mathrm{~km} \mathrm{~S}$ de

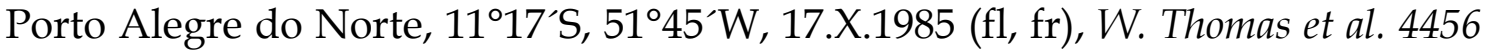
(K, SPF); Tapirapuã, III.1909 (fl), F.C. Hoehne 1611, 1689 (R); Xavantina, Rio dos Mortos, II.1947 (fl), H. Sick B.241 (RB); estrada Xavantina - Cachimbo, km 244, 1249’S, 51ํ6W, 5.XII.1967 (fl), D. Philcox et al. 3390 (P, RB, UB); estrada Xavantina - São Felix, 240 km N de Xavantina, Córrego do Porco, 13.VI.1968, R.R. Santos et al. 1786 (K, UB). Minas Gerais: Barrocão, 56 km NE da estrada Barrocão - Porteirinha, 21.I.1981 (fl), R.M. King \& L.E. Bishop 8585 (K, M, UB). Pará: município indefinido, Projeto RADAMBRASIL, ponto 02A, Rio Xingu,

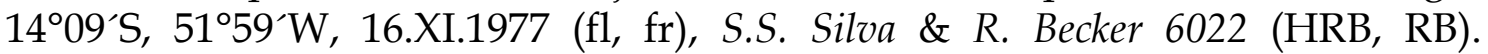
Tocantins: Araguaína, ponto 17, RADAMBRASIL, 07²5'S, 48²2'W, 28.XI.1983 (fl), E. Mileski 407 (HRB); Dianópolis, X.1939 (fl, fr), G. Gardner 3291 (BM, K, P); Natividade, Serra de Natividade, ca. 20 km de Natividade, 8.XII.1973 (fl), J.A. 


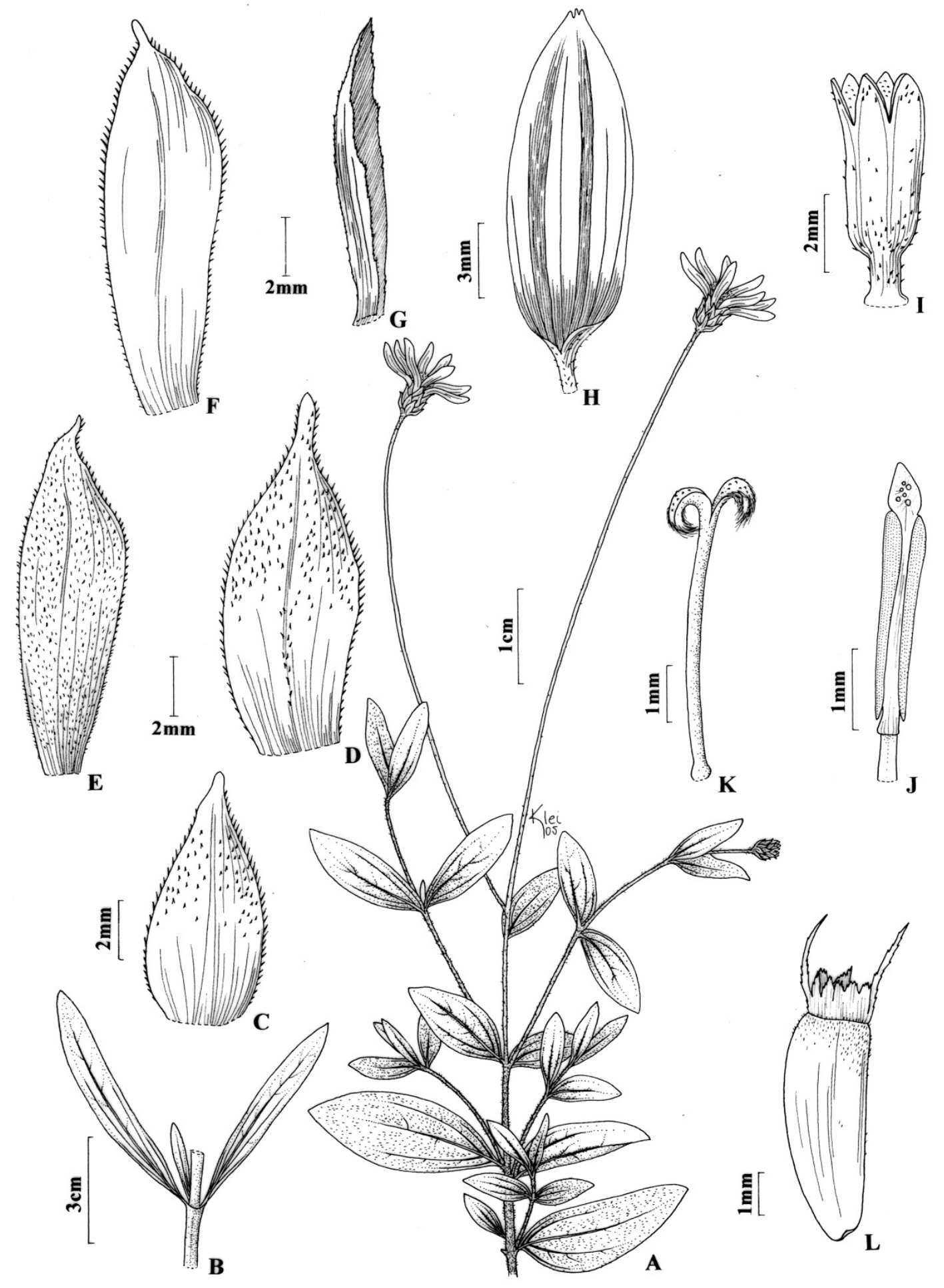

Fig 29: V. oblongifolia: A. Ramo com inflorescência (notar paracládios opostos e altenos), B. Folhas estreitas, C-F. Brácteas involucrais, G. Pálea do receptáculo, H. Flor do raio, I. flor do disco. J. Antera com tecas terminando muito acima do colar filetal, K. Estilete com alargamento basal semi-globoso, L. Cipsela. A-L. M. Magenta et al. 355 (SPF). 
Rizzo 9471 (UFG); Ponte Alta do Tocantins, $20 \mathrm{~km}$ de Ponte Alta, sentido Porto Nacional para Ponte Alta, 7.XII.1973 (fl), J.A. Rizzo 9453 (UFG). Sem indicação de estado, at Goyáz, about the S. eastern entrance to the town, 9.I.1828 (fl, fr), W.J. Burchell 6535 (K, P); at Cánga, 5.XI.1828 (fl), W.J. Burchell 8294 (K).

24. Viguiera paranensis (Malme) Santos, Rodriguésia 42/44 (68/70): 47. 1992. Aspilia paranensis Malme Kong. Swensk. Vetensk Akad. Handl. 3a sér. 12 (2): 88. 1933. Wedelia paranensis (Malme) B. Turner. Phytologia 72(5): 393. 1992. Tipo: [Brazil,] Paraná, 19.10. 1914, Turma 23 n.15646 [Paraná: 23 Turma, in Campo, Dusén 15646 (BM!, S*)] (lectótipo aqui designado: S*; fotografia do lectótipo: K!, SPF!; isolectótipos: BM!, G).

Figura 30.

Subarbusto ou erva cespitosa $30-40 \mathrm{~cm}$ alt., ramos aéreos fortemente decumbentes, cilíndricos, canaliculados, híspidos, entrenós 1-4,5cm compr.; caule subterrâneo levemente espessado, raízes adventícias sem tuberosidades. Folhas verde-claras, alternas ou basais opostas e geralmente adensadas, pecíolo 1-2mm compr., lâmina 1-5x1-2,5cm, obtriangular, oboval ou oblonga, base atenuada, ápice truncado ou abruptamente agudo, 3-7-denticulado, inteira ou com 1-2 pares de dentes próximo ao ápice , cartácea, nervação acródroma basal perfeita, híspida, tricomas tectores 2-7-celulares, células inferiores com bossas, base cilíndrica a estreitamente cônica, adpressa, cercada por uma série de células, face abaxial com glândulas esparsas. Capítulos 3,5-4cm diâm., radiados, solitários, terminais, subtendidos ou não por uma bractéola ca. 10mm compr., pedúnculos 15-27cm compr., eretos, canaliculados, híspidos, com 1-2 bractéolas 40x5mm, lineares, ou sem bractéolas; invólucro 0,8-10 mm diâm., campanulado, brácteas involucrais levemente apressas ciliadas, 2 séries, cartáceas ou internas com ápice estramíneo, ápice agudo ou acuminado 8-15mm alt., 1a série ovallanceoladas, oboval-lanceoladas ou linear-lanceoladas, base estriada, foliáceas em 2/3 superiores, ápice acuminado, face abaxial setosa, 2a série obovallanceoladas, face abaxial setosa a híspida; receptáculo convexo, páleas ca. $7 \mathrm{~mm}$ alt., oblongas, ápice agudo, mucronado a arredondado, 3-denteado, carena estreita estrigilosa, 8 ou 10 nervuras,. Flores do raio 12-14, em 1 verticilo, corola 13-20x5-6mm, tubo ca. 2mm alt., limbo oblongo ou ligeiramente oboval, ápice 
arredondado, 2-3-partido, face abaxial com ca. 14 nervuras esparsamente hispídulas; flores do disco com corola $4-4,5 \mathrm{~mm}$ alt., tubo ca. 1,5mm alt., limbo com face externa glabra, tubo hispídulo, anteras de base curtamente sagitada, terminando na base do colar filetal ou um pouco abaixo, estilete com alargamento basal cônico, estilopódio 0,10-0,12x0,24-0,26mm. Cipselas ca. 4mm alt., obovais, estriadas, levemente seríceas ou com porção superior hispídula, carpopódio delgado, pápus estramíneo 2-aristado, aristas intramarginais 22,5mm alt., oblongas, aristado, nervura hispídula, escamas 3-4 pares, 1,5-2mm alt., unidas até o ápice denteado.

Aparentemente endêmica dos arenitos da formação Furnas no Parque Estadual de Vila Velha, na depressão da Lagoa Dourada, situada na borda oriental da bacia do Paraná, no flanco sudoeste do Arco de Ponta Grossa (fig. 42B), onde coexistem campos limpos, mata de araucária e cerrado. Coletada com flores em outubro e novembro.

No aspecto vegetativo, é semelhante a $V$. nudicaulis (ver comentários da espécie) e a alguns espécimes de $V$. anchusifolia que crescem em regiões úmidas, diferenciando-se desta última por apresentar capítulos solitários e escamas do pápus totalmente unidas.

Nota nomenclatual: Santos (1992) se referiu ao material de Estocolmo como holótipo, sem discriminar os materiais; portanto, houve a necessidade de lectotipificação.

Material examinado: BRASIL: Paraná: Ponta Grossa, 850 m.a.m., 28.XI.1946 (fl), Maack s.n. (MBM, RB 74710); IX.1950 (fl), J. Vidal \& Araújo III-228 (R); Lagoa Dourada - Furnas, 7.XI.1987 (fl), P.M. Araki s.n. (HUEPG 3498), P.M. Araki s.n. (HUEPG 3506); município indefinido, 19.X.1914 (fl), Dusén 15637 (K). 

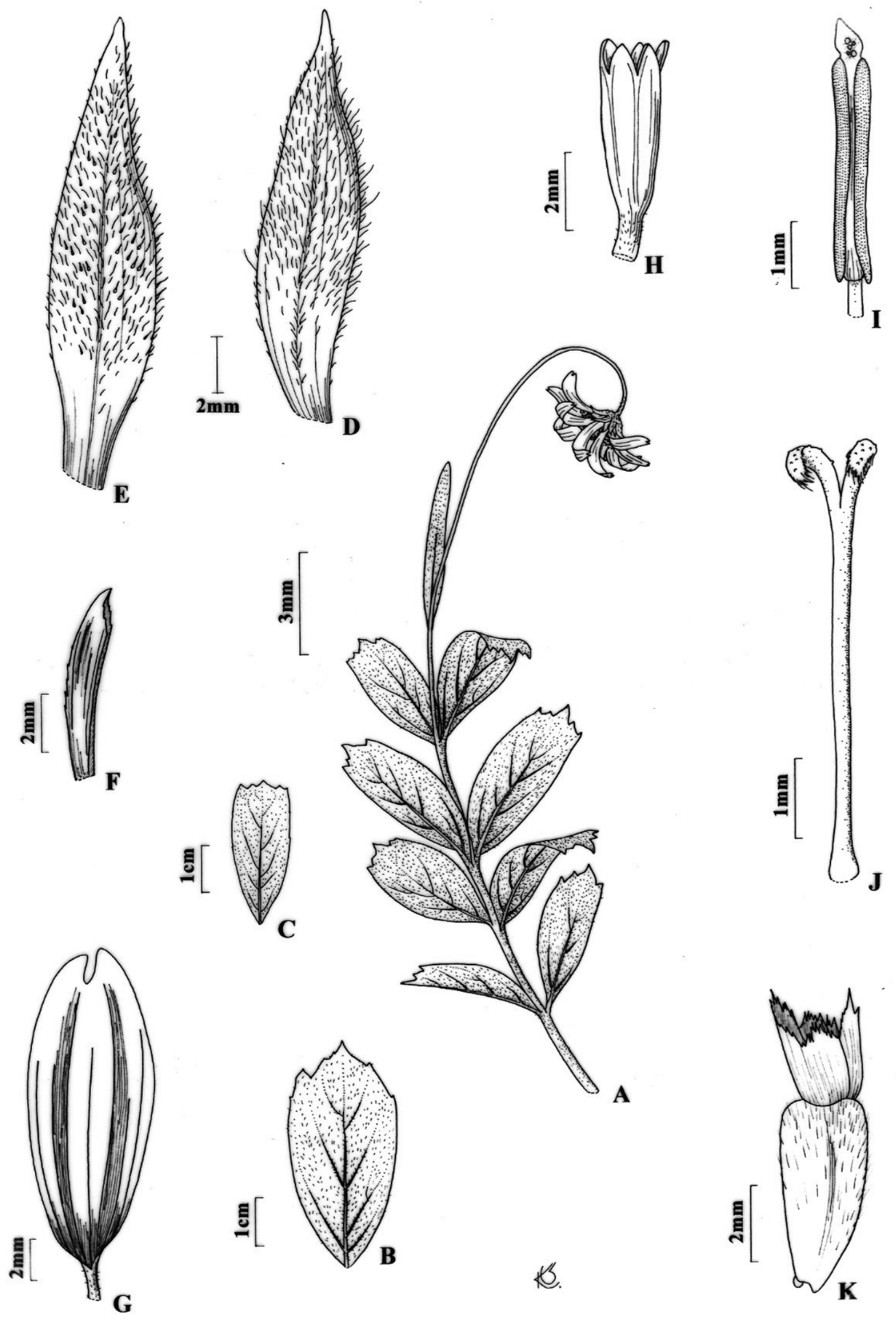

Fig. 30. V. paranensis A. Segmento de ramo com capítulo solitário, B-C. Folhas, variação da forma, D-E. Brácteas involucrais, F. Pálea do receptáculo, G. Corola do raio, H. Corola do disco. I. Antera com tecas de base auriculada, terminando um pouco abaixo da base do colar filetal, J. Estilete com alargamento basal cônico, K. Cipsela com escamas do pápus unidas . A. Araki 3498 (HUEPG). B-K. Vidal \& Araújo III.228 (R). 
25. Viguiera pilicaulis S.F. Blake, Contr. Gray Herbarium 54: 164. 1918. Viguiera robusta Gardner var. scaberrima Hassler, Repert. Nov. Regni. Veg. 14: 273. 1916. Rhisolepis pilicaulis (S.F. Blake) H. Rob. \& A.J. Moore, Proc. Biol. Soc. Wash. 117(3): 430. 2004. Tipo: Paraguai, Sierra de Amambay, II.1907-08, Rojas (distr. Hassler) 10757 (lectótipo aqui designado: BM!; fotografia do lectótipo: K!, SPF!; isolectótipos: GH - frag. , K!; fotografia de isolectótipo de B [destruído]: F!).

Viguiera robusta Gardner var. confusa Hassl. Repert. Nov. Regni. Veg. 14: 274. 1916. Tipo: Paraguai, Sierra de Amambay, II.1907-08, Rojas (distr. Hassler) $10757 a(\mathrm{G})$. syn. nov.

\section{Figura 31}

Erva ereta até $3 \mathrm{~m}$ alt., ramo aéreo ereto, cilíndrico, canaliculado, densamente híspido, entrenós 1,5-3cm compr.; sistema subterâneo desconhecido. Folhas alternas, verde-claras, pecíolo 2-3,5mm, viloso, lâmina $5,5-7 \times 3-5 \mathrm{~cm}$ oval a largamente oval ou às vezes levemente deltóide, base arredondada a levemente atenuada, ápice agudo, mucronado, esparsa e obscuramente serreada na porção superior; serrilhos mucronados, cartáceas, nervação acródroma suprabasal, 3 nervuras principais, face adaxial com nervuras emersas, híspida, tricomas tectores 3-celulares com bossas diminutas e base estreitamente cônica levemente apressa cercada por 3 séries de células, face abaxial densamente hirsuta, nervuras emersas, setosas, tricomas tectores 5celulares, a célula basal com bossas inconspícuas, base estreitamente cônica, ereta, cercada por uma série de células. Inflorescência botrióide ou tirsóide, ca. $30 \mathrm{~cm}$ alt., paracládios eretos, os superiores terminando acima do capítulo terminal, alternos, ou 2a ordem oposta, 1a ordem 4-20cm compr., 2a ordem 2,5-8cm compr., canaliculados, densamente estrigosos, eretos, bractéola linear ca. $5 \mathrm{~mm}$, ou sem bractéolas; pedúnculo terminal ca. 3,5cm. Capítulos 2,5-3cm diâm., radiados, invólucro 10-12mm diâm, campanulado; brácteas involucrais reflexas na floração, 3-4(-5) séries, base caniculada, 3 nervuras destacadas, foliáceas em $1 / 3$ a 1/2 superiores, ápice agudo mucronado, coriáceas, porção inferior ciliolada, porção superior ciliada ou internas sem cílios, 1a série oblongas, 5-7mm alt., face adaxial estrigosa, face abaxial híspida, demais oblongo-elípticas, glabras ou esparsamente hispídulas, centrais 7-8mm, internas 
9mm; receptáculo levemente convexo; páleas 6,5-7,5mm, estreitamente oblanceoladas, ápice obtuso a truncado, mucronado, estrigiloso, 8 ou 10 nervuras, carena estreita com porção apical curtamente lacerada, escariosas,. Flores do raio 10-12, 15-17×9-10mm, em 1 verticilo, corola ca. 4,5X2mm, tubo 1,2-1,6mm alt., limbo oblongo, curtamente 3-partido, glabro, tubo estrigiloso, nervuras ca. 12 com 2 destacadas, setulosas; flores do disco ca. 70, corola 5$5,5 \mathrm{~mm}$ alt., tubo 1-1,2mm alt., lobos com altura igual ou maior que o dobro da largura, tubo e parte central dos lobos estrigilosos; anteras de base sagitada, terminando bem abaixo da base cônica do colar filetal, estilete sem alargamento basal, estilopódio 0,10-0,12x0,13-0,18mm. Cipselas jovens ca. 3,5mm alt., estreitamente obovóides, acentuadamente trígonas, estriadas, porção inferior esparsamente setosa, ápice setoso, carpopódio delgado, pápus estramíneo, 2aristado, aristas levemente desiguais, unidas às escamas laterais, menor 1,5$2 \mathrm{~mm}$ alt., maior 2-2,5mm alt., estreitamente triangulares, margens profundamente laceradas, ápice acuminado, base setosa, escamas ca. 4 pares 11,5mm alt., livres, profundamente laceradas.

Espécie descrita para o Paraguai, possui até o presente um único registro em território brasileiro, no Mato Grosso do Sul (fig. 43B). Coletada com flores no mês de março.

Citada pela primeira vez para o Brazil por Robinson \& Moore (2004) como Rhysolepis pilicaulis. Os autores referem oito a nove flores do raio para a espécie; Blake (1918) contou 10 a 11 flores. Foi considerada por Hassler (1926) como variedade de $V$. robusta, mas desta se distingue pelas folhas verde-claras e cartáceas, por ter sempre brácteas involucrais em três séries, pelo pápus estramíneo com aristas unidas às escamas laterais; em $V$. robusta as folhas são discolores e coriáceas, o invólucro é, na grande maioria das vezes, formado por quatro a cinco séries de brácteas e o pápus é amarelado, com aristas livres.

Nota nomenclatual: A eleição do lectótipo se deu pelo fato de existir uma etiqueta com a incrição "type Coll." manuscrita por Blake, no material depositado no herbário BM. 
Material examinado: BRASIL: Mato Grosso do Sul: Guia Lopes da Laguna, rodovia BR $267 \mathrm{~km} \mathrm{447,} \mathrm{descida} \mathrm{da} \mathrm{chapada,} \mathrm{9.III.2003} \mathrm{(fl),} \mathrm{G.}$ Hatschbach et al. 74393 (MBM, SPF).
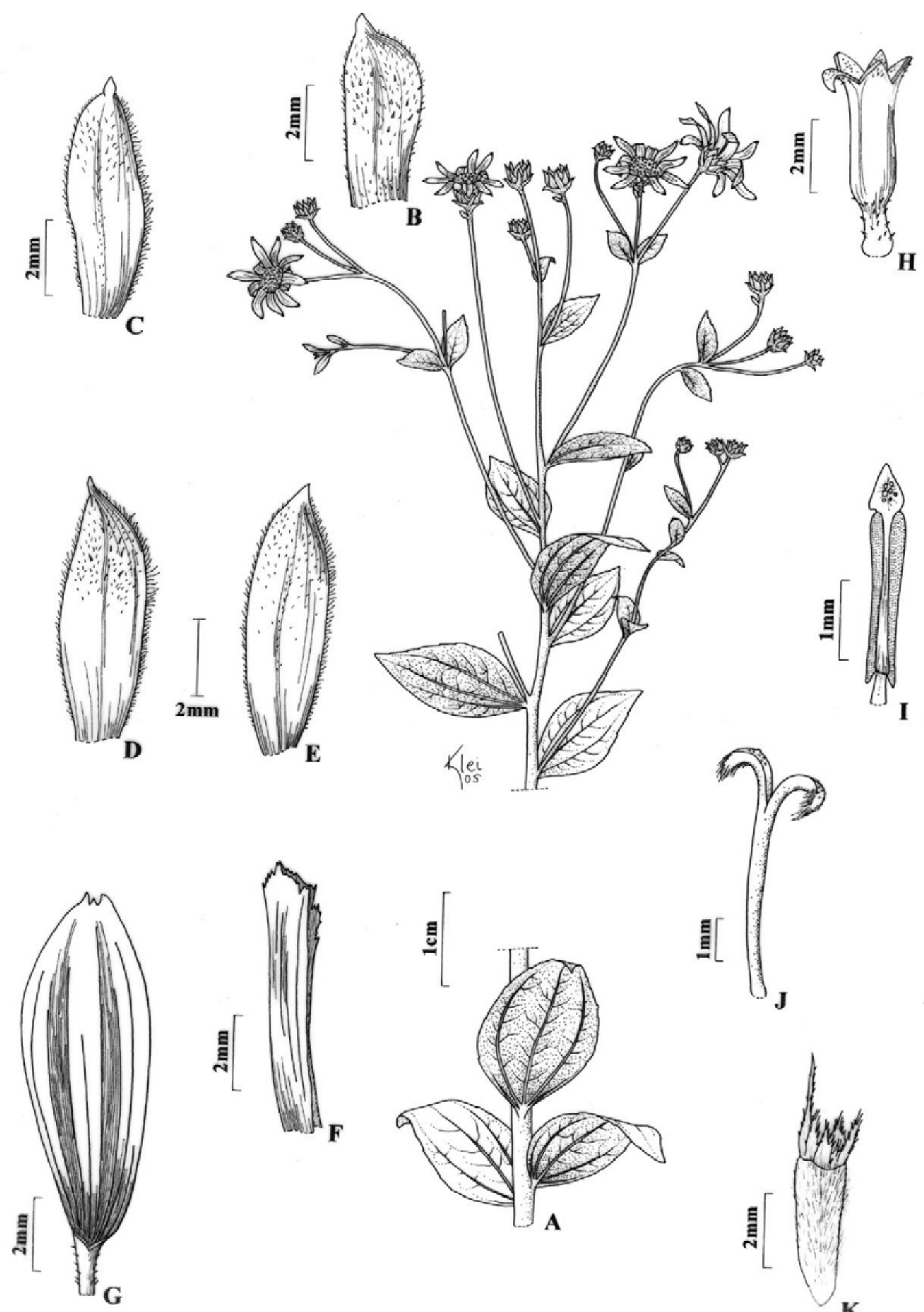

Fig. 31: V. pilicaulis. A. Segmento da sinflorescëncia (notar alguns paracládios de 2a ordem opostos), B-E. Brácteas involucrais, F. Pálea do receptáculo, G. Corola do raio, H. Corola do disco, I. Antera com tecas de base curtamente sagitada, terminando muito abaixo da base do colar filetal, J. Estilete com alargamento basal suave. K. Cipsela com pápus lacerado. A-K. G. Hatschbach et al. 74393 (SPF). 
26. Viguiera pilosa Baker in Martius, Fl. bras. 6(3): 223. 1884. Rhysolepis pilosa (Baker) H. Rob. \& A.J. Moore, Proc. Biol. Washington 117(7): 430. 2004. Tipos: 'Habitat in Brasilia, loco speciali ignoto, s.d., Sello 1028! (lectótipo aqui designado: K!; fotografia do lectótipo: K!, SPF!).

Viguiera malmei S.F. Blake, Contr. Gray Herbarium 54: 151. 1918. Tipo: Brazil, Rio Grande do Sul, rather moist pasture, near a wood, Rincão dos Valles, near Cruz Alta, 20 April 1893, Malme 794 (holótipo: BM!; fotografia do holótipo: $\mathrm{K}$ !, SPF!; isótipos: GH - frag. e esboço, R!, S* 2x, UPS).

Viguiera salicifolia Hassler, Repert. Spec. Nov. Regni. Veg. Beih 14: 274. 1916. Viguiera villaricensis S.F. Blake, Contr. Gray Herbarium 54: 152. 1918. Tipo: Paraguay. Ad margines silvarum pr. Villa Rica, flor et fruct. Mens. Jan., E. Hasller 8627 (lectótipo aqui designado: $\mathrm{G}^{*}$; fotografia do lectótipo: F; isolectótipos: GH, K!, ex herb. Hassleriano, $\mathrm{NY}^{*}$ ). syn. nov.

Figura 32

Subarbustos a arbustos 1-2(-3)m alt., ramos aéreos eretos, cilíndricos, canaliculados, setosos a vilosos, entrenós 1,5-5cm compr.; caule subterrâneo levemente espessado, raízes adventícias inteiramente tuberosas fusiformes. Folhas levemente discolores, alternas, pecíolo 3-10mm compr., estrigoso, lâmina 5-20x1-3cm, lanceolada a oval-lanceolada ou raramente oblonga, inteira a esparsamente serreada, base atenuada a arredondada ou levemente cordada, ápice agudo ou raramente obtuso, mucronado, nervação acródroma suprabasal perfeita; 3 nervuras principais, face adaxial setosa, face abaxial setosa a estrigosa e com glândulas, especialmente nas nervuras, tricomas tectores das duas faces com bossas, base cercada por 2-3 séries de células. Inflorescência botrióide ou tirsóide, $30-50 \mathrm{~cm}$ alt., paracládios flexuosos, superiores terminando acima do capítulo terminal, monocasiais ou dicasiais canaliculados, 1a ordem 9-22,5cm compr., 2a ordem 5,5-8,5cm compr.; pedúnculo terminal 2,5-16cm compr. Capítulos 3-5cm diâm., radiados, invólucro 1,2-2cm diâm.; brácteas em 3-4 séries, levemente desiguais, lanceoladas a oval-lanceoladas, base caniculada, 3 nervuras destacadas, foliáceas em 1/3 a 1/2 superiores, ápice agudo a acuminado ou cirroso, face adaxial com ápice estrigiloso, face abaxial com base glabra ou setosa, ápice setoso a estrigoso, cilioladas a ciliadas; externas 5-8mm, 
2a série 8-10mm alt., 3a e 4a séries 8-12 mm alt; receptáculo convexo, páleas 8$9 \mathrm{~mm}$ alt., obovais, ápice agudo a obtuso, mucronado, 8 ou 10 nervuras, carena e ápice estrigilosos. Flores do raio 10-14, corola 18-22x0,7-0,8mm, limbo oblongo, ápice obtuso, curtamente 3-partido, tubo ca. 1mm alt., esparsamente estrigiloso, nervuras ca. 15, face abaxial com nervuras estrigosas, limbo com muitas glândulas; flores do disco 50-85, corola 4,5-5mm alt., tubo ca. $1 \mathrm{~mm}$ alt., lobos com altura igual ou maior que o dobro da largura, tubo, base do limbo e lobos esparsamente estrigilosos; anteras de base curtamente sagitada, terminando na base do colar filetal ou um pouco abaixo; estilete com alargamento basal semi-globoso, estilopódio 0,20-0,24X0,08-0,10mm. Cipselas 4,5-5mm alt., levemente obovóides, comprimidas, levemente trígonas, estriadas, vináceo- setosas a seríceas, carpopódio médio, pápus geralmente vináceo ou às vezes amarelado, 2-aristadas; aristas intramarginais iguais ou levemente desiguais, 2,5-3mm alt., estreitamente triangulares, acuminadas, hispídulas, escamas 4-5 pares, 0,8-1,1mm alt., livres ou unidas até o meio, ápice eroso-lacerado.

Espécie comum na Formação Serra Geral (White 1908), nos Estados de Paraná, Santa Catarina e Rio Grande do Sul e também na Argentina e no Paraguai (fig. 42B), em bordas de mata, de mata ciliar, cerrados, beira de estrada e capoeiras. A espécie aparentemente forma híbridos com $V$. anchusifolia (ver material examinado antes das discussões). Em estado vegetativo é parecida com $V$. nudibasilaris e a indivíduos jovens de $V$. santacatarinensis (ver comentário das espécies).

Nota nomenclatual: No Herbário K há uma amostra de $V$. pilosa (da qual S.F. Blake obteve um fragmento) que possui uma etiqueta impressa 'Herb. Reg. Berolinense' com o número 1028 manuscrito. Nessa etiqueta consta a caligrafia de Baker grafando 'Viguiera pilosa Baker'. Porém, o espécime da amostra contém uma pequena etiqueta afixada com uma linha de algodão, com o número 4417. Apesar dessa pequena controvérsia numérica, os fatos de ambos números serem citados no protólogo e de que durante este trabalho não terem sido encontrados materiais (exsicatas, esboços ou fotografias) pertencentes ao 
terceiro número (2225) do protólogo, levam à adequada proposta de lectotipificação com base no espécime que tem as 2 etiquetas supracitado.

Obs.: Os isótipos de $V$. salicifolia depositados nos herbários K e NY trazem a inscrição "In regione collium: Cordillera de Villa-Rica".

Material examinado: ARGENTINA: Corrientes, Ituzaingó, 11.II.1971 (fl), A. Krapovickas et al. 18075 (CTES); San Ignácio, 12.III.1946 (fl), G.J. Sehwarz 2213 (R); Apóstoles, Ruta Nac. 110, 6.IV.1973 (fl), R. Carnevali 3368 (CTES); Apóstoles, de Azara a Concepión de La Sierra, $10 \mathrm{Km}$ de Azara, 1.V.1984 (fl, fr), F.O. Zuloaga et al. 1902 (RB, SI); [Misiones], Loreto, Misiones, 27.III.1930 (fl), G. Grüner 144 (LP). BRASIL: Paraná: Candói, Fazenda Coqueiro, 23.II.1996 (fl, fr), G. Hatschbach et al. 64453 (MBM); General Carneiro, Galinhas, 10.II.1966 (fl, fr), G. Hatschbach et al. 13845 (MBM); rodovia PR $170 \mathrm{~km} \mathrm{520,} \mathrm{entre} \mathrm{a} \mathrm{BR116} \mathrm{e}$ Bitiruna, 28 $11^{\prime} 17,7^{\prime \prime} \mathrm{S}, 5^{\circ} 31^{\prime} 13,1^{\prime \prime} \mathrm{W}, 895$ m.a.m., 29.III.2002 (fl, fr), M. Magenta \& J. Magenta 420 (HUFU, K, SPF, SPFR); Jangada, Rio Jangada, 900 m.a.m., 19.II.1992 (fl), G. Hatschbach, et al. 56384 (MBM); Turvo, Fazenda Rikli, 6.III.1991 (fl, fr), J.M. Silva \& S.D.P. Kricum 943 (MBM); União da Vitória, Rio Cotia, 15.II.1958 (fl, fr), G. Hatschbach 4529 (MBM, RB). Rio Grande do Sul: Arroio dos

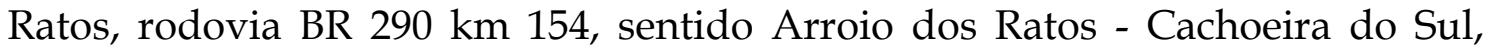
3006'19,2”S, 5145’07,7”W, 82 m.a.m., 21.I.2003 (fl), M. Magenta \& C. Mondin 500 (SPF); Augusto Pestana, sentido Pestana para Ijuí, 16.II.1956 (fl, fr), Pivetta 1174 (PACA); Bom Jesus, Fazenda Caraúna, III.1936 (fl, fr), Dutra 1280 (ICN); idem, 10.II.1937 (fl, fr), Dutra 1441 (ICN, LP); estrada Bom Jesus - Alziro Ramos km 11, 10.XII.2003 (fl, fr), M. Magenta \& J. Magenta 705 (SPF); Campestre da

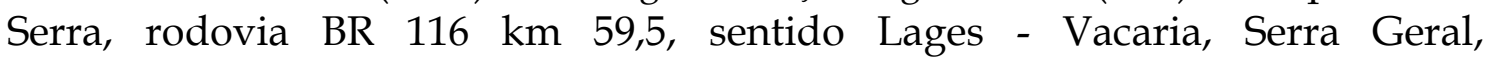
28³8`22,3”S, 5002`38,2”W, 839 m.a.m., 27.III.2002 (fl, fr), M. Magenta \& J. Magenta 406 (K, SPF, SPFR); Canela, arredores da cidade, II.1986 (fl, fr), M. Sobral \& R. Silva 4932 (ICN); Canoas, II.1944 (fl), Irm. Augusto 1524 (ICN); Carazinho, a $20 \mathrm{~km}$ sul de Sarandi, 10.IV.1986 (fl), M. Mattos \& N. Bassan 341 (HAS); Caxias do Sul, Mato Perso, 23.III.1986 (fl), R. Wasum et al. s.n. (HUCS 1375, MA); idem, VI.1986 (fl), R. Wasum et al. 1375 (BM); Ana Rech - Faxinal, 700 m.a.m., 17.III.1989 (fl), R. Wasum et al. s.n. (HUCS 5515); idem, 2.IV.1992 (fl), $R$. Wasum et al. s.n. (HUCS 8497, M); rodovia RST 453 km 160, $30 . X I .2002$ (fl, fr), C. Mondin 2845 (HASU, SPF); idem, km 159, 9.XII.2002 (fl), C. Mondin 2853 (HASU, $\mathrm{SPF}$ ); rodovia RS 453, Serra Geral, sentido Lageado Grande - Caxias do Sul,

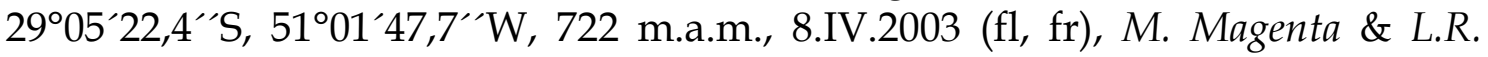
Lima 585, 586 (SPF); Cruz Alta, Rincão dos Vales, $20 . I V .1892$ (fl), G.O.A. Malme s.n. (R 156026); 26.II.1975 (fl, fr), L.A. Arzivenco s.n. (ICN 67746); rodovia BR 158 km 228, sentido Cruz Alta - Júlio de Castilhos, 2855’17,5”`S, 53³8`11,2”`W, 388 m.a.m., 25.I.2003 (fl), M. Magenta \& C. Mondin 531 (SPF); Ernestina, rodovia RST

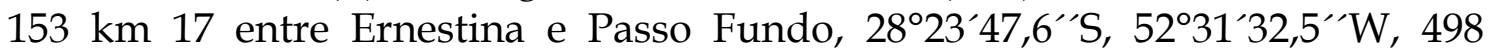
m.a.m., 25.I.2003 (fl), M. Magenta \& J. Magenta 535 (SPF); Esmeralda, Estação Ecológica de Esmeralda, 12.II.1979 (fl, fr), L.A. Arzivenco 566 (ICN); Ijuí, rodovia

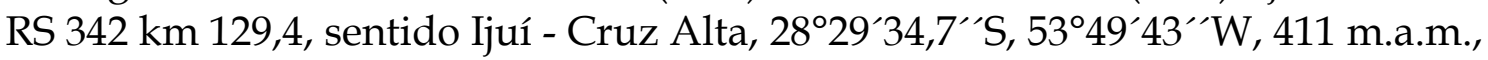
25.I.2003 (fl, fr), M. Magenta \& C. Mondin 529 (SPF); Júlio de Castilhos, Passo do Felício, ca. 15 km da cidade, 15.II.1994 (fl, fr), C. Mondin 847 (ICN); Lagoa 
Vermelha, 23.III.1951 (fl, fr), E. Maria, Irm. s.n. (ICN 31818); Mato Castelhano, rodovia BR 285 km 271, sentido Lagoa Vermelha - Passo Fundo, 28¹6 47"'S, 52¹0`57,5``W, 743 m.a.m., 28.III.2002 (fl, fr), M. Magenta \& J. Magenta 415 (SPF); Muito Capões, rodovia BR $285 \mathrm{~km} \mathrm{158,} \mathrm{sentido} \mathrm{Vacaria} \mathrm{-} \mathrm{Muitos} \mathrm{Capões,}$ 2820`2,1"S, 5109’22,4”W, 860 m.a.m., 28.III.2002 (fl, fr), M. Magenta \& J. Magenta 414 (SPF); Nonoai, Sarandi - Nonoaí para Uruguai, III.1945 (fl), B. Rambo s.n. (LP, PACA 28174); Nova Prata, Fazenda Tupy, 22.II.1985 (fl), R. Wasum et al. s.n. (HUCS 537); idem, 2.III.1989 (fl), R. Wasum et al. s.n. (HUCS 53470); Passo Fundo, rodovia RS 135 km 03, sentido Passo Fundo - Erechim, $28^{\circ} 12^{\prime} 39,9^{\prime \prime} \mathrm{S}, 52^{\circ} 21^{\prime} 21,9^{\prime \prime} \mathrm{W}, 740$ m.a.m., 28.III.2002 (fl), M. Magenta \& J. Magenta 416 (SPF); Porto Alegre, V.1898, E.M. Reineck \& J. Czermak $21 B$ (E); Montes de Paternom, XII.1898, E.M. Reineck s.n. (E 173864, E 173865); V.1899, E.M. Reineck \& J. Czermak 20B (S); Morro da Vila Manresa para Porto Alegre, X.1944 (fl), B. Rambo s.n. (PACA 27042); Santa Maria, Boca do Monte, III.1939 (fl), J. Vidal s.n. (R 39461); Santana do Livramento, Cerro Paloma, 21.I.1986 (fl), J.R. Mattos \& N.F. Mattos 28981 (HAS); Santo Antônio das Missões, estrada entre São Borja e

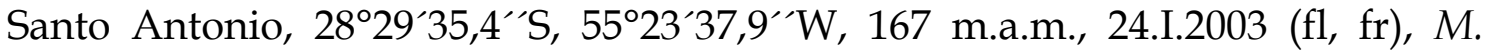
Magenta \& C. Mondin 526 (SPF); São Francisco de Paula, Fazenda Englert para São Francisco de Paula, 8.II.1941 (fl), B. Rambo s.n. (PACA 4446); São Leopoldo, 14.III.1989 (fl), R. Wasum s.n. (HUCS 5581, MA); São Marcos, rodovia BR 116 km 120,5, sentido São Marcos - Caxias do Sul, próximo ponte do Rio Redondo, 2900`17,4”S, 5104`13,4”W, 684 m.a.m., $27 . I I I .2002$ (fl, fr), M. Magenta \& J. Magenta 407 (SPF); Vacaria, Fazenda do Cedro, 450 m.a.m., 13.IV.1975 (fl, fr), A. Sehnem 14636 (HUCS, PACA); quase na descida para o vale do Rio Pelotas, 11.I.1978 (fl), J.R. Mattos \& N.F. Mattos 18263 (HAS); 6.XI.1985 (fl), N. Silveira et al. 2437 (HAS); Victor Graeff, rodovia BR $223 \mathrm{~km} \mathrm{7,6} \mathrm{sentido} \mathrm{para} \mathrm{Passo} \mathrm{Fundo,}$

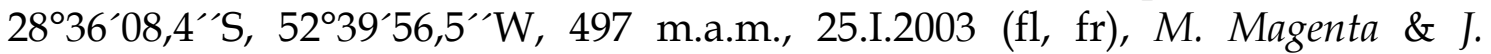
Magenta 534 (SPF). Santa Catarina: Água Doce, rodovia RS $153 \mathrm{~km} \mathrm{31,} \mathrm{sentido}$

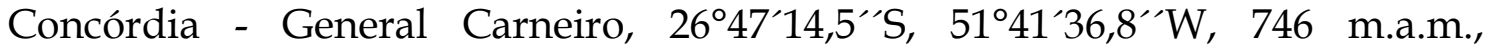
29.III.2002 (fl, fr), M. Magenta \& J. Magenta 417 (K, SPF); Caçador, sul de Ipoméia, 700 m.a.m., 5.I.1957 (fl, fr), L.B. Smith \& R. Reitz 9926 (R, RB); 11 km de Caçador na rodovia Lebon Regis Km 47, Curitibanos, 800 m.a.m., 8.II.1957 (fl), L.B. Smith \& R. Klein 11018 (RB); Taquara Verde, 800 m.a.m., 8.I.1962 (fl), R. Reitz \& R. Klein 11773 (LP, RB); Calmon, arredores da cidade, beira da estrada, 14.IV.2004 (fl, fr), L.R. Lima \& J.M. Silva 359 (SPF); Lages, rodovia BR 116 km 258, sentido Lages - Capão Alto, 2753`35,4`S, 50²5’23,4”W, 920 m.a.m., 27.III.2002 (fl, fr), M. Magenta \& J. Magenta 402 (SPF, SPFR); Lages, rodovia BR

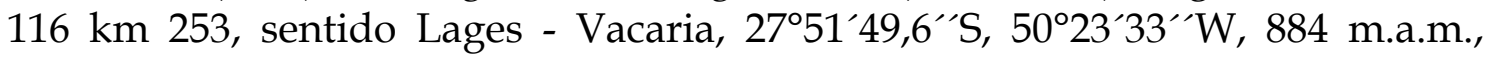
18.I.2003 (fl), M. Magenta \& J. Magenta 496 (SPF); Marombas, Campos Novos, 900 m.a.m., 11.IV.1963 (fl), R. Reitz \& R. Klein 14596 (RB); Santa Cecília, rodovia BR 116 km 131,5, Serra do Espigão, sentido São Cristovão do Sul - Ponte Alta do

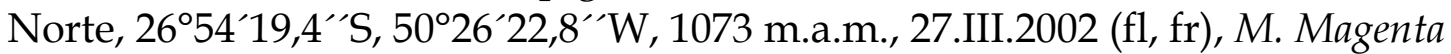




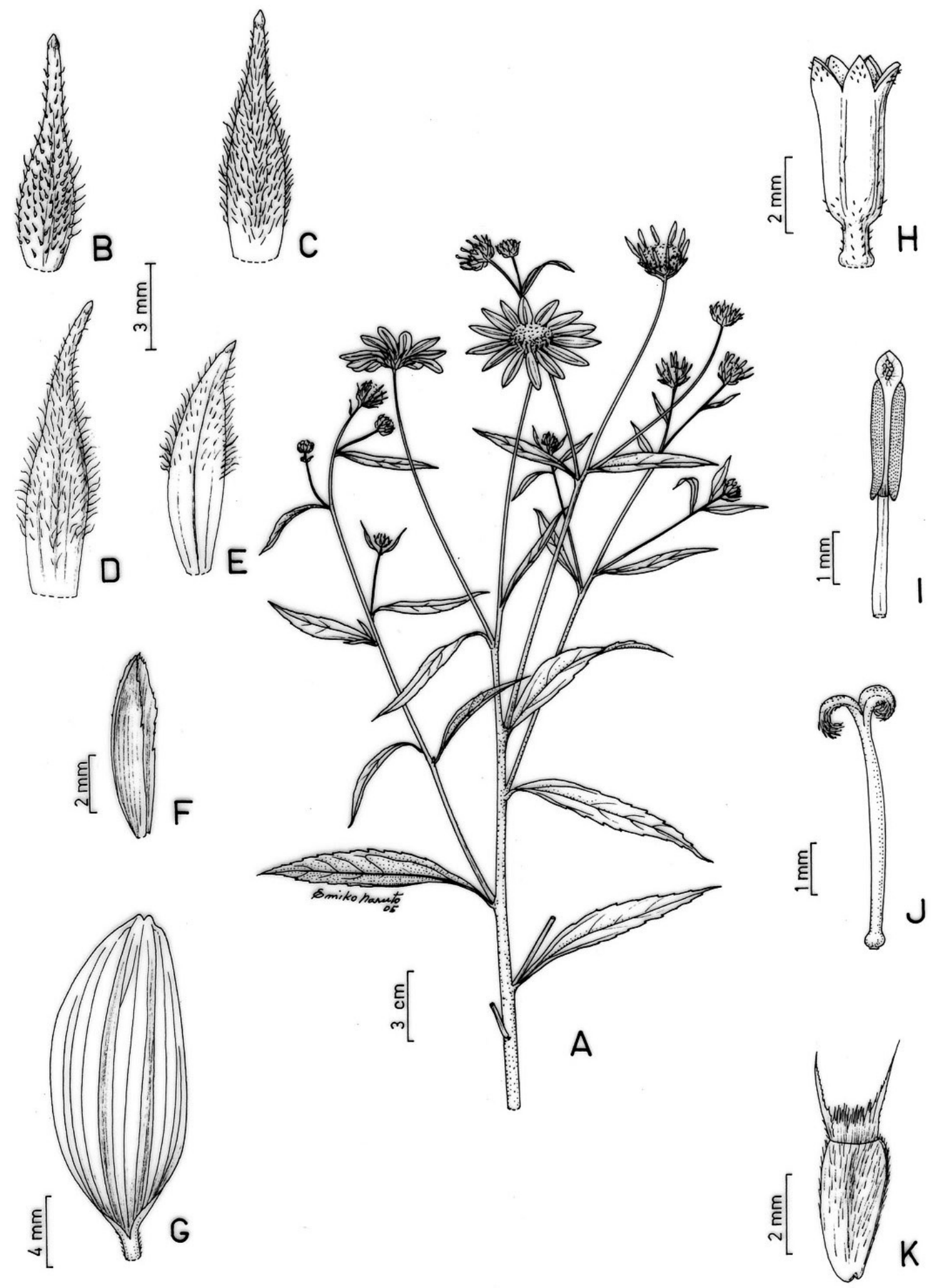

Fig. 32: $V$. pilosa A. Segmento da sinflorescência, B-E. Brácteas involucrais, F. Pálea do receptáculo, G. Corola do raio, H. Corola do disco, I. Antera com tecas de base curtamente sagitada, terminando abaixo da base do colar filetal, J. Estilete com alargamento basal semigloboso, K. Cipsela com aristas de tamanho maior que o dobro do das escamas. A-J. M. Magenta \& J. Magenta 406 (SPF). 
\& J. Magenta 393 (K, SPF); São Joaquim, perto de Passo do Pires, no Rio Rondnha, IV.1965 (fl), J.R. Mattos 12704 (HAS); São Miguel do Oeste, Rua das flores, 1.III.1964 (fl), A. Castellanos 24757 (RB); Rio das Flores, 700 m.a.m., 1.III.1964 (fl), R. Klein 5075 (RB); município indefinido, Estado de Sainte Catharina, em pendores de Capivare azima da Serra Geral, III.1891 (fl, fr), E. Ule 1790 (P), São Paulo: município indefinido, San-Paolo, s.d. (fl), C. Gaudichaud 411 (P). Sem indicação de estado, IX.1904 (fl), L. Netto 2289 (RB 156027).

27. Viguiera robusta Gardner in Hook, London J. Bot. 7: 403. 1848. Viguiera robusta Gardner var. genuina S.F. Blake, Contr. Gray Herb. 54: 171. 1918. Rhysolepis robusta (Gardner) H. Rob. \& A.J. Moore, Proc. Biol. Washington 117(7): 431. 2004. Tipo: Brasil, Goyaz: dry upland campos near San Domingos, May 1840, Gardner 4233 (lectótipo aqui designado: K! - ex Herb. Hookerianum; fotografia do lectótipo: K!, SPF!; isolectótipos: BM!, BR!, G, GH - 2x, K - 2x, NY* - 2x, P!, US*; fotografia do isolectótipo de G: F!).

Viguiera scabra Pohl ex Baker in Mart., Fl. bras. 6(3): 227. 1884, nom. nud. prosyn.

Viguiera ovatifolia (DC.) Baker in Mart., Fl. bras. 6(3): 226. 1884. Rhysolepis ovatifolia (Baker) H. Rob. \& A.J. Moore, Proc. Biol. Washington 117(7): 30. 2004. Tipo: Habitat in prov. S. Paulo in campis Herb. Imp. Bras. 410 (holótipo: P!, GH frag.; fotografia do holótipo: P!, SPF!). syn. nov.

Viguiera macrocalyx S.F. Blake, Contr. Gray Herb. 54: 171. 1918. Tipo: Brazil, without locality, Pohl 582 (holótipo: K!, G - frag.; fotografia do holótipo: $\mathrm{K}$ !, SPF!). syn. nov.

Viguiera robusta var. oxylepis S.F. Blake., Contr. Gray Herb. 54: 171. 1918. Tipo: Brasil, s.l., Riedel s.n. (lectótipo aqui designado: GH; isolectótipos: GH frag., K!, NY* - frag.). syn. nov.

Viguiera radula Baker in Mart., Fl. bras. 6 (3): 223. 1884. Rhysolepis radula (Baker) H. Rob. \& A.J. Moore, Proc. Biol. Washington 117(7): 431. 2004. Tipo: Brasil, Prov. Minas Gerais, locus minus editis in pascuis et capoeiras ad Caldas Abr. 1865, Regnell I. 190* (lectótipo aqui designado: BR!; fotografia do lectótipo: $\mathrm{K}$ !, SPF!; isolectótipos: S!, GH - frag.). syn. nov.

Figuras 4D, 5A, 6E e 33 
Ervas a subarbustos 0,8-2(-3)m alt., ramos aéreos eretos, cilíndricos a levemente tetragonais, estreitamente canaliculados, hirsutos ou raramente vilosos, entrenós(1)-2-4cm compr.; caule subterrâneo levemente espessado, raízes adventícias sem tuberosidade ou com leve espessamento uniforme. Folhas discolores a levemente discolores, alternas ou inferiores opostas e superiores alternas; sésseis ou pecíolo 1-2mm compr.; lâmina 1,8-7x1-4cm, oval a largamente oval, raramente estreitamente oval ou oblonga, base arredondada, levemente auriculada, geralmente cuneada, ápice agudo, porção superior esparsamente denteada, serreada ou crenada, coriácea, nervação acródroma basal imperfeita a perfeita, 3-5 nervuras principais, face adaxial estrigosa a setosa, tricomas tectores 3-celulares, base cônica a cilíndrica levemente apressa, cercada por uma série de células, face abaxial hirsuta a híspida ou raramente vilosa, tricomas tectores 4-5-celulares, base cilíndrica a estreitamente cônica, cercada por uma série de células, com tricomas glandulares. Inflorescência botrióide, $15-40 \mathrm{~cm}$ alt., paracládios eretos a flexuosos, superiores terminando acima do capítulo terminal, ou raramente próximo a ele, canaliculados, hirsutos ou raramente vilosos, bractéolas 7-10mm compr., foliáceas, esparsas ou raramente adensadas, 1a ordem $11-25 \mathrm{~cm}$ compr., 2a ordem 5-9cm compr.; pedúnculo terminal 1-5cm compr. Capítulos 2-2,5cm diâm., radiados, invólucro 1-1,5cm diâm., estreitamente campanulado, campanulado ou semigloboso, brácteas involucrais levemente apressas com ápice reflexo na floração, em (3-)45 séries, ovais a obovais, canaliculadas, foliáceas em $1 / 3$ a 1/2 superiores, ápice arredondado a agudo, mucronado, ou na $5^{\text {a }}$ série apiculado, margem longamente ciliada, coriáceas, face adaxial com ápice glabro a estrigiloso, face abaxial inteira ou parcialmente híspida ou às vezes estrigosa no ápice; nervura estrigosa; $1 \mathrm{a}$ série $4-6 \mathrm{~mm}$ alt., $2 \mathrm{a}$ série 6 a $8 \mathrm{~mm}$ alt., $3 \mathrm{a}$ a $5^{\mathrm{a}}$ séries $10-12 \mathrm{~mm}$ alt.; receptáculo levemente convexo a convexo, páleas 7-8mm alt., oblanceoladas, carenadas, ápice arredondado a truncado, mucronado, escariosas, 10 ou 12 nervuras, carena hispídula. Flores do raio 10-12(-14-24), em 1 verticilo, corola 8,5-12x2-4mm, tubo 0,8-1,5mm alt., limbo oblongo a levemente elíptico, ápice 2-partido, face adaxial glabra, face abaxial com glândulas, nervuras 10-12, esparsamente estrigilosas; flores o disco 80-120, 
corola 5-6mm alt., tubo 0,8-1,2mm alt., lobos com altura igual ou maior que o dobro da largura, face externa com tubo, base e lobos estrigilosos, antera de base curtamente sagitada, terminando acima do colar filetal; estilete com alargamento basal cônico a piriforme, estilopódio 0,14-0,20x0,26-0,30mm. Cipselas 4-5mm alt., obovóides a estreitamente obovóides, estreitamente estriadas, esparsa a densamente seríceas, tricomas adensados próximo ao ápice, carpopódio delgado, pápus amarelado, 2-aristado, aristas marginais desiguais, livres, menor 1-1,2mm alt., maior 1,5-2,5mm alt., lineares a triangulares, estrigilosas, margens com tricomas setulosos, firmes, antrorsos, escamas 4-6 pares, 0,2-18mm alt., unidas até o meio, até próximo ao ápice lacerado ou livres.

Espécie muito comum, ocorrendo no Distrito Federal, Goiás, Tocantins, Bahia, Minas Gerais, São Paulo e Paraná (fig. 44A), em campos e cerrados íntegros ou degradados, beira de estradas, rodovias e rios e córregos. Os registros de Glaziou, de ocorrência nas proximidades do Rio de Janeiro são imprecisos e provavelmente as plantas foram coletadas em Minas Gerais. Floresce e frutifica o ano todo, com picos nos meses de fevereiro a maio.

Os espécimes coletados em áreas sujeitas regularmente ao fogo no Distrito Federal e em Goiás, ou mais raramente em Minas Gerais, usualmente apresentam caule e pedúnculos tomentosos, robustos, brácteas involucrais coriáceas, aumento do número de flores do raio, pápus com escamas reduzidas ou sem escamas e tecas geralmente amarelas o que dificultou a delimitação da espécie. A observação de alguns materiais com várias duplicatas, apresentando características dos dois extremos fenotípicos permitiu sua circunscrição.

Notas nomenclatuais: $\mathrm{Na}$ escolha do lectótipo de $V$. robusta var. oxylepis, embora a etiqueta de identificação manuscrita pelo autor da variedade esteja presente nos materiais dos herbários $\mathrm{GH}$ e $\mathrm{K}$, o primeiro foi escolhido como depositário em virtude de ser onde Blake desenvolveu seus estudos com o gênero; para eleger o lectótipo de $V$. radula descrita por Baker (1884) considerou-se o herbário onde Regnell depositava suas coleta.

Material examinado: BRASIL: Bahia: Barreiras, perto do Rio Piaiui, 225 km S de Barreiras, 14.IV.1968, H.S. Irwin et al. 14787 (UB); São Desidério, área próxima a Roda Velho, após a entrada da Fazenda Pernambuco, 12³9`41'S, 45³7`59"W, 705 m.a.m., 24.IV.1998 (fl), R.C. Mendonça et al. 3427 (HEPH, IBGE, 
RB, US). Distrito Federal: Brasília, Imprensa Oficial, $11 . I V .1961$ (fl, fr), E.P. Heringer 8244 (HEPH, RB, SP, UB); Catetinho, 12.IV.1963 (fl), E. Santos 1656 (R); idem, 12.IV.1963 (fl, fr), J.M. Pires et al. 9037 (RB, UB); Universidade de Brasília, 2.IX.1964, H.S. Irwin \& T.R. Soderstrom 5851 (NY, UB); Chapada da Contagem, ca. 15 km NE de Brasília, 1000 m.a.m., 11.IX.1965 (fl, fr), H.S. Irwin et al. 8189 (NY, UB); 975 m.a.m., 8.XII.1965 (fl, fr), H.S. Irwin et al. 11106 (UB); 25 km E de Brasília, 28.I.1966 (fl), H.S. Irwin et al. 12073 (MBM, NY, UB); 975 m.a.m., 7.IV.1966 (fl), H.S. Irwin et al. 15311 (MBM, NY, R, UB); campo cerrado near British Embassy, 18.V.1966 (fl, fr), D.R. Hunt \& J.F. Ramos 5505 (K); área do zoobotânico, 31.I.1967 (fr), A.P. Duarte 10274 (RB, UB); campo experimental da Universidade de Brasília, 20.V.1967 (fl), E.P. Heringer 11487 (RB, UB); entre Universidade de Brasília e Lago Paranoá, 11.IV.1968 (fl, fr), D. Philcox \& E. Onishi 4794 (K, P, UB); Parque do Guará, 15.IV.1975 (fl, fr), E.P. Heringer 14539 (HEPH, IBGE, RB, UB, UEC); Fazenda Água Limpa, Estação Experimental da UNB, próximo a Vargem Bonita, ca. 18km SSW da torre de TV, 19.IV.1976 (fl, fr), J.A. Ratter \& S.G. Fonseca 2904 (CPAP, HMS, K, UB, UEC); Fazenda Água Limpa, 1557’S, 475`'W, 24.V.1979, H.L. Cesar 297 (UB); idem, 1557’S, 4756’W, 1.VI.1979 (fl), H.L. Cesar 283 (UB); Chapada da Contagem, 1250 m.a.m., 26.I.1980 (fl), R.M. King et al. 8325 (K, UB); rodovia BR 020, 5 km de

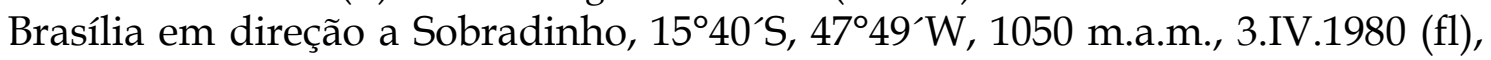
T. Plowman 9976 (CTES, MBM, UB); Cabeça de Veado, a $1 \mathrm{~km}$ da Escola Fazendeira, 1.V.1980 (fl), J.H. Kirkbride Jr. 3157 (K, MBM, UB); idem, 2 km da Escola Fazendária, 9.V.1980 (fl, fr), J.H. Kirkbride Jr. 1226 (SPF); Bacia do Rio Bartolomeu, 22.IV.1981 (fl), E.P. Heringer et al. 6837 (HEPH, IBGE, K, MO, NY, R, US); Fazenda Água Limpa, 15²13’S, 48¹9'W, 1080 m.a.m., 30.V.1981 (fl, fr), R.O. Leme 7 (MBM); Reserva Ecológica do IBGE, ao lado da estrada de acesso a sede da Recor, 24.III.1983 (fl, fr), E.P. Heringer et al. 7578 (HEPH, HRB, IBGE); Fazenda Água Limpa, IV.1983, M. Haridasan 251 (UB); Barragem do Paranoá, 15²5’S, 47²'W, 1000 m.a.m., 31.V.1983 (fl), M.M. Ouga 6 (UB); Bacia do Rio Bartolomeu, antes do Córrego Caruru, 25.IV.1984, B.A.S. Pereira 971 (HEPH); Reserva Ecológica do IBGE, 7.V.1984 (fl), B.A.S. Pereira 1016 (HEPH, UEC); Estação Florestal Cabeça de Veado, ca. $20 \mathrm{~km}$ SE de Brasília, área do atual Jardim Botânico de Brasília, 9.IV.1985 (fl, fr), A.E. Ramos 357 (HEPH); Chácara Tororó, 24.VI.1985 (fl), A. Martins dos Santos s.n. (UB 38-01-278); Centro Olímpico da Universidade de Brasília, 7.VI.1985 (fl), L. Branco s.n. (UB 38-01276); Fazenda Água Limpa, $18 \mathrm{~km} \mathrm{~S}$ do centro de Brasília, 7.V.1987 (fl, fr), A.D. Stevens 8 (UB); Reserva Ecológica do IBGE, 1557'04”S, 4752’38”W, 980 m.a.m., 18.IV.1988 (fl), M.A. Silva 664 (HEPH, IBGE); idem, 1557’03“'S,

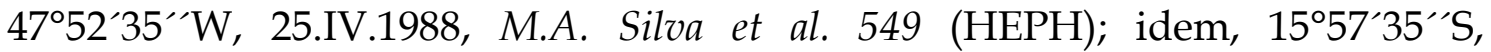
47052`35”W, 25.IV.1988 (fl, fr), M.A. Silva et al. 585, 587, 588 (HEPH, IBGE);

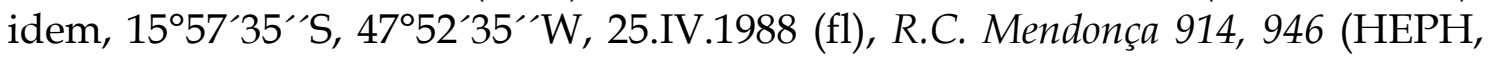

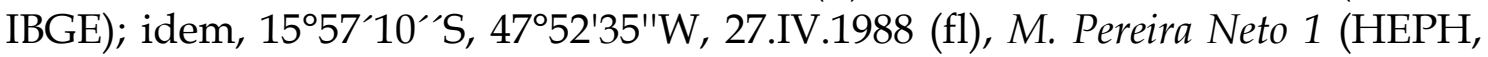
RB); Reserva Ecológica do IBGE, ao lado do laboratório da DIESA, 20.IV.1989 (fl), B.A.S. Pereira 1366 (HEPH, IBGE, RB); Parque Nacional de Brasília, portão do Matoso, 1553`0”S, 4756`0”W, 14.XII.1990, P.C.M. Ramos 443 (UB); Fazenda Água Limpa, FAL, Universidade de Brasília, próximo ao Olho D’agua da Onça, 30.IV.1991, P.S. Câmara 94 (HEPH); Reserva Ecológica do IBGE, área do projeto 
fogo, 14.V.1991, P.S. Câmara 127 (HEPH); estrada Brasília - Cocalzinho km 30, 1540’S, 48²0’W, 1225 m.a.m., 14.V.1991, R.F. Vieira \& B.M.T. Walter 754 (CEN, K); Reserva Ecológica do IBGE, projeto fogo, 25.II.1992, M.F. Landim de Souza 103 (HEPH, IBGE); Reserva Biológica do Jardim Botânico de Brasília, 1552’S, 4751’W, 16.IV.1993 (fl, fr), C. Proença 889 (UB); Fazenda Sucupira, logo após o açude da fazenda, 1555’S, 4801'W, 1080 m.a.m., 5.V.1994 (fl, fr), M.C. Assis et

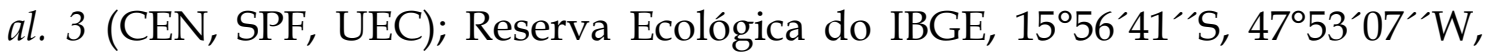
1100 m.a.m., 18.IV.1995 (fl), M.A. Silva et al. 2598 (HEPH, IBGE); Jardim Botânico de Brasília, 1552’S, 4751'W, 1025 m.a.m., 11.V.1995 (fl, fr), M. Boaventura 132 (HEPH, MBM, RB, SPF); Fazenda Sucupira, 1555’S, 4801'W, 1050 m.a.m., 11.IV.1996, S.M. Gomes 14 (CEN); rodovia DF 425, chácara FTRC Centro-Oeste, $1^{\circ} 41^{\prime} 0^{\prime \prime} \mathrm{S}, 47^{\circ} 52^{\prime} 0^{\prime \prime} \mathrm{W}, 1200$ m.a.m., $26 . I V .1996$ (fl, fr), C. Proença \& S.M.S. Almeida 1386 (UB); Jardim Botânico de Brasília, 1552’S, 4751`W, 1025 m.a.m., 6.V.1997, M. Boaventura 469 (CEN); Chapada da Contagem, 18.III.1998, K. Calago 88 (CEN, UEC); Jardim Botânico de Brasília, 23.IV.1998, F.B. Costa 75 (SPFR); Fazenda Água Limpa, 23.IV.1998 (fl, fr), F.B. Costa 76 (SPF, SPFR); Fazenda Sucupira, área no entorno do capril, 1555’S, 4801'W, 1070 m.a.m., 30.IV.1999, J.G. Faria et al. 37 (CEN); Gama, 19.V.1999 (fl, fr), K. Calago \& S. Silva 110, 114 (CEN, SPF); Fazenda Água Limpa, divisa com o Cristo Redentor (JBB) e

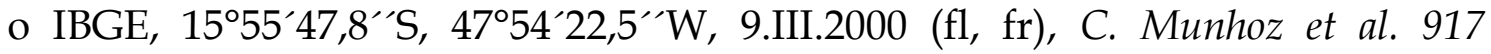

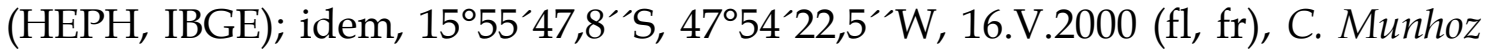
et al. 1385 (HEPH, IBGE); Lago Sul, próximo ao Jardim Botânico de Brasília, no Condomínio Ecológico Vilage III, 1552’02,2”S, 4748`53,2”W, 4.XI.2001 (fl, fr), M. Magenta \& J. Magenta 311 (SPF); Brazlândia, Fazenda Velho Barreiro, 24.VI.1985 (fl), H.B. Souza s.n. (UB 38-01-279); Planaltina, colégio agrícola, 5.III.1976 (fl, fr), E.P. Heringer 15410 (HEPH, IBGE, RB, UB); Brasília - Planaltina,

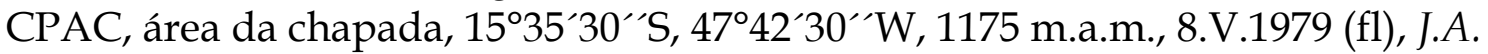
Silva et al. 314 (CEN); rodovia BR $020 \mathrm{~km} \mathrm{15,} \mathrm{Sobradinho} \mathrm{-} \mathrm{Planaltina,} \mathrm{CPAC}$ Embrapa, 4.III.1983 (fl, fr), J.A. Silva \& S.P. Almeida 11 (CPAC, UEC); rodovia GO 118, 45 km de São Gabriel de Goiás, 8.V.2000, G. Hatschbach et al. 71604 (MBM, UB); Samambaia, 1552`S, 4803`W, 1150 m.a.m., 29.IV.1997 (fl, fr), J.M. Rezende 436 (CEN, SPF); Sobradinho, ca. 3 km S de Sobradinho, 1000 m.a.m., 1.V.1966 (fl), H.S. Irwin et al. 15514 (IPA, NY); Tororó, 24.VI.1985 (fl), S.R.D. Passos s.n. (UB 38-01-277); município indefinido, lado norte do Ribeirão Bananal, 1542`S, 4754`W, 1060 m.a.m., 18.V.1980 (fl), J.H. Kirkbride Jr. 3182

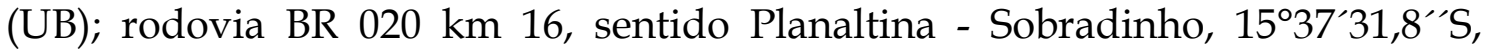
47²3`32,5``W, 1139 m.a.m., 16.XII.2001 (fr), M. Magenta et al. 336 (K, SPF). Goiás: Alto Paraíso de Goiás, Pontezinha, Parque Nacional do Tocantins, 3.VI.1965 (fl), F.R. Rosa 29 (RB); Anápolis, rodovia BR 153, $10 \mathrm{~km}$ Oeste de Anápolis, 22.V.1975 (fl, fr), G. Hatschbach 36676 (MBM, UEC); rodovia GO 330

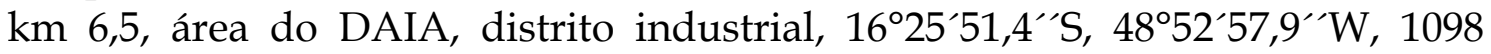
m.a.m., 25.I.2002 (fl, fr), M. Magenta \& J. Magenta 381 (K, SPF); Cocalzinho de Goiás, rodovia BR 070 km 61, sentido Águas Lindas - Cocalzinho, 15²46 1,3's, 4842’51,4”W, 1137 m.a.m., 7.V.2002 (fl, fr), M. Magenta et al. 459 (SPF); Corumbá de Goiás, ca. 15 km N de Corumbá, Serra dos Pirineus, 14.V.1973 (fl, fr), W.R. Anderson 10271 (NY, RB); 2.IV.1978 (fl), E.P. Heringer 17025 (HEPH, IBGE); Cristalina, Serra dos Cristais, 9 km estrada Cristalina - Catalão, 1170 
m.a.m., 4.IV.1973 (fl), W.R. Anderson 8115 (RB); $35 \mathrm{~km}$ by road E of Cristalina, 990 m.a.m., 6.IV.1973 (fl, fr), W.R. Anderson 8301, 8303 (K, NY, RB, UB); Serra dos Cristais, Rio das Perdizes, 10.II.1990 (fl), G. Hatschbach et al. 53783 (MBM); rodovia BR 040 km 72-73, Paracatu - Cristalina, IV.1998, F.B. Costa 115 (SPFR); rodovia BR 050 km 202-203, Cristalina - Catalão, IV.2000, F.B. Costa 117 (SPFR); Formosa, Rio Preto, 31.V.1960 (fl, fr), Gomes 1142 (RB); Rio Tiqueira, 18.IV.1967 (fl, fr), E.P. Heringer 11427 (RB, UB); Goiânia, estrada Goiânia - Guapó, 13.V.1968, J.A. Rizzo \& A. Barbosa 653 (UFG); junto ao Morro Santo Antonio, 7.VI.1968 (fl, fr), J.A. Rizzo \& A. Barbosa 1326 (UFG); rodovia GO 1, $9 \mathrm{~km}$ de Goiania para Leopoldo dos Bulhões, 14.V.1970 (fl), J.A. Rizzo 6784 (UFG); Goiás Velho ca. $15 \mathrm{Km}$ da cidade, 1000 m.a.m., 2.V.1973 (fl), W.R. Anderson 10033 (NY, RB); Luziânia, 4.V.1984 (fl), T. Naito 20981 (GHSP, SP); Mossâmedes, divisa Mossâmedes - Goiás , 1969, J.A. Rizzo 4056 (RB, UFG); Niquelândia, a 3 km da cidade, 29.IV.1988, R.R. Brooks et al. 238 (UFG); Southernmost ultramafic hill of Tocantine complex., 29.IV.1988 (fl, fr), R.D. Reeves et al. BRASPEX 238 (K); Planaltina de Goiás, Águas Emendadas, 22.IV.1972, M.B. Ferreira 1332-A, 1332-B (HEPH); Santo Antônio do Descoberto, Fazenda Boa Viagem, CPAC, 18.IV.1985, J.C.S. Silva 375 (CPAC, HEPH, IBGE); São Gabriel de Goiás, rodovia GO 118, sentido São João D’Aliança - São Gabriel, 1503`54”'S, 47³6`9,7”W, 1131 m.a.m., 7.V.2002 (fl, fr), M. Magenta et al. 454 (SPF); São João d'Aliança, 7 km sul da rodovia de São João, 1100 m.a.m., 22.III.1973, W.R. Anderson 7651 (NY, RB); rodovia GO 118, km 20-25, N de São João, 12.II.1990 (fl), G. Hatschbach et al. 53845 (MBM); município indefinido, Province de Goyaz, Sañ Domingos, V.1840 (fl, fr), G. Gardner 4233 (BM, K, P). Minas Gerais: Aiuruoca, Pico do Papagaio, 1520 m.a.m., 9.VI.1999 (fl, fr), M.F. de Vasconcelos s.n. (BHCB 47852); Araguari, rodovia BR 050, sentido Uberlândia - Araguari, $18^{\circ} 41^{\prime} 45,4^{\prime \prime} \mathrm{S}$, 48 ${ }^{\circ} 11^{\prime} 0,9^{\prime \prime} \mathrm{W}, 966$ m.a.m., 5.V.2002 (fl, fr), M. Magenta et al. 439 (HUFU, K, SPF); Araxá, rodovia BR 262 km 664, sentido Araxá - Belo Horizonte, 19³4³7,9”'S, 46²3'53,9”'W, 1090 m.a.m., 18.IV.2003 (fl, fr), M. Magenta \& J. Magenta 643 (SPF); Baependi, Toca dos Urubus, 3.V.2002 (fl, fr), F.M. Ferreira et al. 43 (CESJ, SPF); Barroso, Mata do Baú, 20.X.2001 (fl), R.C. Forzza et al. 1921 (CESJ, SPF); Belo Horizonte, Serra do Taquaril, 19.V.1933 (fl, fr), Mello-Barreto 4103 (BHCB, R); Barreiro, 19.IV.1935 (fl, fr), K.D. Barreto 1349 (RB); Serra do Curral, 17.IV.1955 (fl), L. Roth 1322 (CESJ, RB, SPF); Bento Pires 26.V.1945 (fl, fr), L.O. William \& V. Assis 7083 (RB); Brumadinho, fazenda da MBR, 15.VI.1989 (fl), A.M.G. Anjos et al. 97 (BHCB); Caeté, Serra da Piedade, base da serra, 10.IV.1996 (fl), J.A. Lombardi 1256 (BHCB); Caldas, s.d. (fl), A.F. Regnell 190 (R 156032); Camanducaia, estrada para Monte Verde a $19 \mathrm{~km}$ de Camanducaia, 2250'12,4”S, 4606'59”W, 1425 m.a.m., 6.IV.2002 (fl, fr), M. Magenta \& J. Magenta 428 (K, SPF); Capitólio, rodovia MG 050, Furnas - Capitólio após ponte Rio Turvo, 18.IV.1998, F.B. Costa 61 (SPFR); Carrancas, Cachoeira da Fumaça, 13.IV.1996 (fl, fr), F.R.S. Pires et al. 463 (CESJ, SPF); Caxambu, rodovia BR 58, entre Caxambu e Pouso Alto, 29.III.1964, Z.A. Trinta \& E. Fromm 687 (HB, K, R); Coromandel, Chapadão do Pau da Terra, Rodovia MG 040 km 289, entre

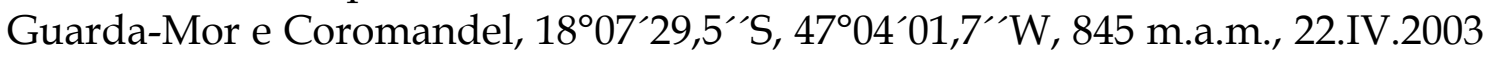
(fl, fr), M. Magenta \& J. Magenta 666 (SPF); Cruzília, Fazenda Iraituba, próximo Estação Experimental, 8.V.1979, M.L. Gavilanes 519 (UFLA); Furnas, rodovia MG 


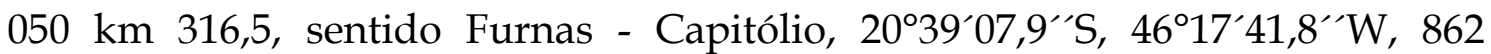
m.a.m., 17.IV.2003 (fl, fr), M. Magenta \& J. Magenta 625, 626 (SPF); Itabirito, Pico do Itabirito, 19.V.1994 (fl, fr), W.A. Teixeira s.n. (BHCB 24992, RB); Itumirim, 30.X.1983, M.L. Gavilanes 1020 (UFLA); Jaboticatubas, 30 km N de Lagoa Santa, km 72 da estrada Belo Horizonte - Conceição, 1940’S, 435``W, 900 m.a.m., 2.V.1952 (fl, fr), L.B. Smith 6797 (R); João Pinheiro, rodovia Brasília - Belo Horizonte, 3.VI.1960 (fl), E.P. Heringer 7526 (RB, UB); Joaquim Felício, Serra do Cabral, 15.IV.1996 (fl), G. Hatschbach et al. 64773 (MBM); Lagoa Dourada, 21.IV.1957 (fl, fr), E. Pereira \& Pabst 3124 (RB); Lagoa Santa, NE de Lagoa Santa, 1940’S, 435’W, 835 m.a.m., 30.IV.1852 (fl), L.B. Smith 6736 (R); Lavras, 10.X.1983, DAC et al. s.n. (UFLA 3011); 4.VIII.1984, E.C. Siqueira 5 (UFLA); Reserva Poço Bonito, 6.IV.1985, M.L. Gavilanes \& M. Brandão 1368 (UFLA); alto nova Lavras, 6.V.1985, A. Murad s.n. (UFLA 4459); serrinha, 1000 m.a.m., 10.V.1986, R. Leparizi s.n. (UFLA 6504); Campus da ESAL, próximo a carpintaria, 22.III.1987 (fl), M.L. Gavilanes \& M.B. Sanchez 2855 (UFLA); Poço Bonito, 26.IV.1987, H.H. Urano s.n. (UFLA 8059); Serra da Bocaína, antena, 1200 m.a.m., 15.V.1987, DAC et al. s.n. (UFLA 7135); idem, 1200 m.a.m., 10.VII.1987, DAC et al. s.n. (UFLA 8005); Serra do Campestre, 19.V.1990, M.L. Gavilanes 4589 (UFLA); Reserva Poço Bonito, 25.V.1991, M.L. Gavilanes \& S. D’Angelo 5142 (UFLA); cerrado da ESAL, s.d., A.P.O.M. Gieia s.n. (UFLA 5892); Machado, Alto da Lage, 26.IV.1943 (fl), Teodoro, Irm. 72M (RB); Montes Claros, rodovia BR 365 km 23, Serra dos Três Irmãos, 18.V.2000 (fl), G. Hatschbach et al. 71307 (MBM); Mutuca, IV.1932 (fl, fr), L.B. Smith 66 (BM); Nepomuceno, 24.IV.1987, M.L. Gavilanes 2966 (UFLA); Nova Lima, clube campestre, 29.IV.1979 (fr), E. Moreno 79/132 (CETEC); São Sebastião das Águas Claras V.1981 (fl), R.P. Martins et al. s.n. (BHCB 8438); Morro Velho, s.d. (fl, fr), L.B. Smith 18 (BM); Ouro Fino,

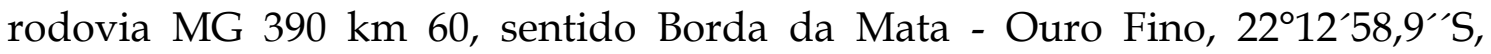
46²8’40,1”W, 1493 m.a.m., 6.IV.2002 (fl, fr), M. Magenta \& J. Magenta 431 (K, SPF); Ouro Preto, entre Engenheiro Correia e Ouro Preto, 19.IV.1957 (fl, fr), E. Pereira \& Pabst 3024 (RB); Paracatu, rodovia BR 040, Paracatu - Cristalina, 28 km de Paracatu, 1704’S, 4703'W, 21.IV.1998, F.B. Costa 66 (SPFR); Passos, Represa de Furnas, 10.II.1983, J.L.C. Lopes 17097 (UEC); Região de Furnas, Fazenda do Sr. José Caxeta, 2.III.1984 (fl), S.J. Sarti \& D. dos Santos F 15892 (UEC); Patrocínio, Serra do Salitre, 23.III.1994, G. Ceccantine 196 (SPF); Serra do Salitre, 24.III.1994 (fr), G. Ceccantine 263 (SPF); Perdizes, rodovia BR 452, 18 km leste de Santa Juliana, 20.III.1995 (fl), G. Hatschbach et al. 62070 (MBM); Poços de Caldas, Retiro Branco, 3.V.1966 (fl), A.R.A. Roppa 742 (RB); Presidente Olegário, Fazenda Vereda Grande, 1.V.1989 (fl), T.S.M. Grandi s.n. (BHCB 15747); São João Batista da Canastra, Serra da Canastra, estrada para Tapira, ca. $25 \mathrm{~km}$ de São João,

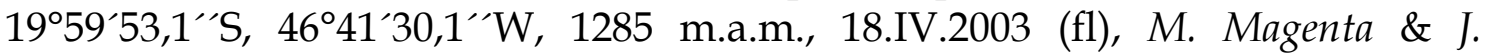
Magenta 634 (SPF); São João del Rey, Várzea do Marçal, Escola Padre Sacramento, 17.VII.1936 (fl, fr), Mello-Barreto 4649 (BHCB); São Roque de Minas, Serra da Canastra, próximo ao Curral das Pedras, estrada para Sacramento, 11 km da sede, 18.IV.1994, R. Romero et al. 934 (F, HUFU, UEC); idem, 19 km da sede administrativa, para Sacramento, 28.VI.1994 (fl), R. Romero \& J.N. Nakajima 1068 (HUFU, SPF); idem, Guarita do Sacramento, 9.V.1995, R. Romero et al. 2123 (HUFU); idem, estrada para Sacramento, após o Curral de pedras, 25.V.1996 (fl, 
fr), R. Romero \& J.N. Nakajima 3508 (HUFU, SPF); idem, estrada São Roque para Sacramento, $20^{\circ} 13^{\prime} 10,7^{\prime \prime} \mathrm{S}, 46^{\circ} 29^{\prime} 02,0^{\prime \prime} \mathrm{W}, 1448$ m.a.m., 16.III.2003 (fl), M. Magenta et al. 570 (SPF); idem, estrada para Cachoeira dos Rolinhos, $20^{\circ} 14^{\prime} 13,7^{\prime \prime} \mathrm{S}, 46^{\circ} 32^{\prime} 47,2^{\prime \prime} \mathrm{W}, 1427$ m.a.m., 16.III.2003 (fl, fr), M. Magenta et al. 576 (SPF); idem, estrada que liga São Roque a Sacramento $51 \mathrm{~km}$ da portaria de São Roque, $20^{\circ} 08^{\prime} 28,9^{\prime \prime} \mathrm{S}, 46^{\circ} 44^{\prime} 09,0^{\prime \prime} \mathrm{W}, 1405$ m.a.m., 17.III.2003, M. Magenta \& J. Magenta 581 (SPF); idem, estrada São Roque a Sacramento, a 21,5 Km portaria de São Roque, $20^{\circ} 14^{\prime} 45,6^{\prime \prime} \mathrm{S}, 46^{\circ} 32^{\prime} 54,8^{\prime \prime} \mathrm{W}, 1416$ m.a.m., 17.IV.2003 (fl, fr), M. Magenta \& J. Magenta 628, 629 (SPF); São Sebastião do Paraíso, Fazenda Fortaleza, 17.IV.1945 (fl), A.C. Brade \& E. Barbosa 17648 (RB); Tiradentes, Serra de São José, 1997 (fr), A.E. Brina s.n. (BHCB 39479); Uberaba, rodovia BR 050 km 118, 12.IV.1996 (fl), G. Hatschbach et al. 64552 (CTES, MBM); Uberlândia, Estação Ecológica do Panga, 22.V.1992 (fl, fr), G.M. Araújo et al. 146 (HUFU, RB, SPF, UEC); Unaí, Fazenda São Miguel, Grupo Votarantim, lado oeste da Campina Grande, 950 m.a.m., 23.IV.1992 (fl, fr), B.A.S. Pereira \& D. Alvarenga 2072 (HEPH, IBGE, RB, US); Vargem Grande, Serra Negra, 21.IV.1962, J.P. Lanna Sobrinho 602 (K); município indefinido, 1840 (fl, fr), P. Claussen 276 (BM, K, P); Minas Geraës, Brasilien, 1845 (fl), Widgren 164 (BR); Province Minas Gerais, 27.IV.1865 (fl, fr), A.F. Regnell I.190 (BR, K, M); IV.1896 (fl), A. Silveira 874 (R); Sete Montes, várzea do Rio Jacarés, 6.V.1946 (fl, fr), M. Kuhlmann \& P. Gonçalves 1369 (SP, SPF); 1952 (fl), s.c. s.n. (BHCB 46532, RB 97598); Capoeira do Campo, IV.s.d. (fl, fr), P. Claussen 56 (P); s.d. (fl, fr), A. Glaziou 17084 (K). Paraná: Arapoti, estrada para Ventania, $24^{\circ} 10^{\prime} 31,2^{\prime \prime} \mathrm{S}, 4^{\circ} 53^{\prime} 56,5^{\prime \prime} \mathrm{W}, 835$ m.a.m., 3.IV.2002 (fl, fr), M. Magenta \& J. Magenta 557 (SPF); Jaguariaíva, 19.IV.1910 (fl, fr), Dusén 9723 (K, M); $20 . I V .1911$ (fl, fr), Dusén 11663 (BM); Sengés, Rio Itararé, 15.VI.1971 (fl), G. Hatschbach 26735 (MBM); rodovia PR 11, próximo ao Rio Pelame, 20.IV.1989 (fl, fr), G. Hatschbach \& J. Cordeiro 52838 (MBM); Rio Pelame, 12.II.1997 (fl, fr), O.S. Ribas \& L.B.S. Pereira 1771 (MBM); rodovia PR 151 Km 53,5 sentido Sengés - Itararé, $24^{\circ} 06^{\prime} 54,7^{\prime \prime} \mathrm{S}, 49^{\circ} 23^{\prime} 34,2^{\prime \prime} \mathrm{W}$, 4.III.2003 (fl, fr), M. Magenta \& J. Magenta 562 (SPF). Rio de Janeiro: município indefinido, near Rio de Janeiro, XII.1878 (fl, fr), A. Glaziou 9490 (K); idem, XI. 1879 (fl, fr), A. Glaziou 11027 (K); idem, II.1882 (fl, fr), A. Glaziou 12880 (K). São Paulo: Altinópolis, rodovia Altinópolis - Batatais, $14 \mathrm{~km}$ de Batatais $13 \mathrm{~km}$ de Altinópolis, 19.IV.1996 (fl, fr), W. Vichnewski \& F.B. Costa 406 (K, SPF, SPFR); idem, 14.XI.1996, F.B. Costa \& W. Lopes 2 (SPFR); rodovia $351 \mathrm{~km} \mathrm{35,} \mathrm{Altinópolis} \mathrm{-}$ Batatais, margem direita, 18.IV.1998, F.B. Costa 60 (SPFR); rodovia $351 \mathrm{~km} \mathrm{35,}$ Altinópolis-Batatais, 8.IV.2000, F.B. Costa 105 (SPFR); rodovia SP 338 km 333,

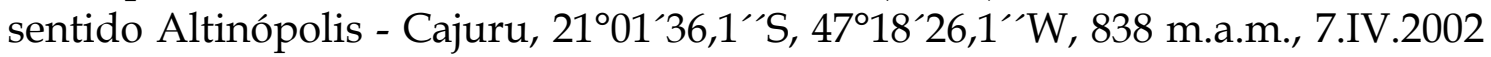
(fl, fr), M. Magenta \& J. Magenta 437 (K, SPF); Batatais, rodovia Batatais Alpinópolis km 34, 29.III.1978 (fl), s.c. s.n. (UEC 2624); Rodovia Altino Arantes

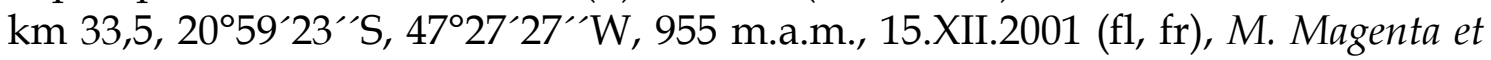
al. 327 (SPF); Bragança Paulista, s.d. (fl), G. Eiten \& L.T. Eiten 1881 (SP); Cabreúva, Jacaré, $23^{\circ} 14^{\prime} 13,6^{\prime \prime} \mathrm{S}, 47^{\circ} 02^{\prime} 34,1^{\prime \prime} \mathrm{W}$, 1.III.1994 (fl, fr), K.D. Barreto et al. 2034 (ESA); Caieiras, 4.V.1945 (fl, fr), W. Hoehne s.n. (ALCB, BHCB, ESA, F, HUEFS, IPA, K, MBM, MO, NY, RB 362733, SP, SPF 11487, UB, UEC 86864, US); Via Anhanguera km 30, 11.IV.1949 (fl, fr), W. Hoehne s.n. (K, SPF 12413, UB 86758, UEC); Campos de Jordão, IV.1937 (fr), L. Lanstryak s.n. (RB 33173); Capão 


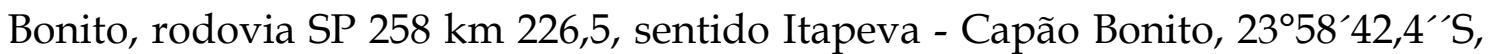
$48^{\circ} 21^{\prime} 39^{\prime \prime} \mathrm{W}, 665$ m.a.m., 5.III.2003 (fl, fr), M. Magenta \& J. Magenta 566 (SPF);

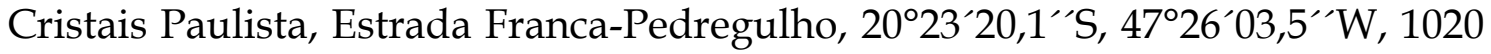
m.a.m., 1.XI.2001 (fl, fr), M. Magenta \& J. Magenta 296 (SPF); idem, 20²2`58,1”'S,

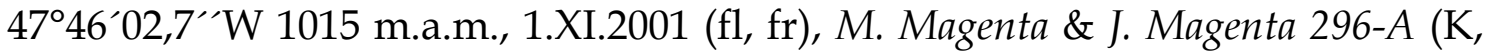
$\mathrm{SPF})$; Franco da Rocha, Parque Estadual do Juquery, trilha para o ovo da pata, 24.III.2002 (fl, fr), M.A. Farinaccio 493 (HRCB, SP, SPF); Parque Estadual do Juquery, $23^{\circ} 18^{\prime} \mathrm{S}, 46^{\circ} 48^{\prime} \mathrm{W}, 900$ m.a.m., 16.VI.2002 (fl), M. Groppo Jr. et al. 1102 (SPF); Itapetininga, 8.IV.1947 (fl), J.T. Lima s.n. (RB 60651); Itapeva, Fazenda das Plantar, V.1974 (fl), A. Clemente s.n. (RB 253269); Jundiaí, III.1915 (fl, fr), A.C. Brade s.n. (SP 6114); Estrada para Itu, 18.XII.1952 (fl), M. Kuhlmann 2883 (SP); cerrado ao lado da serra para Itu, 8.XII.1952, M. Kuhlmann 2886 (RB); Matão, 11.V.1949 (fl, fr), A. Corrêa 291 (RB); Mogi Guaçu, Reserva Biológica da Fazenda Campininha, perto de Pádua Sales, 18.IV.1955 (fl), O. Handro 476 (SP, SPF); Fazenda Campininha, 5.IV.1977 (fl, fr), P. Gibbs \& H.F. Leitão Filho 4680 (SP, UEC); Moji Mirim, 1.I.1958 (fl, fr), A.S. Grottas 223 (SPF); Aeroclube, 19.X.1983 (fl, fr), T. Nicci \& R. Rodrigues 15459 (UEC); Pedregulho, Rodovia Cândido Portinari, Pedregulho - Ribeirão Preto, $3 \mathrm{~km}$ de Pedregulho, margem direita, 20.IV.1998 (fl, fr), F.B. Costa \& G.H.B. Souza 84 (SPFR); idem, próximo km 417, sentido Cristais Paulista - Pedregulho, margem direita, 18.V.1999, F.B. Costa 94 (SPFR); Pirassununga, Cerrado de Emas, 27.III.1992 (fr), M.L.F. Salatino et al. 63 (SPF); Cachoeira de Emas, $30 . I V .1942$ (fl), s.c. s.n. (SPF 84384); São Carlos, Rodovia Washington Luiz, entre Itirapina - São Carlos, 7.III.1997 (fr), F.B. Costa et al. 5 (SPFR); São João da Boa Vista, Serra do Caracol, Pico do Gavião, 1666 m.a.m., 10.V.1995 (fl, fr), J.Y. Tamashiro et al. 1053 (SP, SPF, UEC); São José dos Campos, 28.IV.1909 (fl), A. Löfgren 289 (RB); estrada para Paraibuna, 7 km de São José dos Campos, 31.V.1961 (fl), G. Eiten \& T. Sendulski 2853 (SP); 5,5 km S da praça principal, estrada para Paraibuna, 31.V.1961 (fl, fr), G. Eiten \& T. Sendulski 2854 (K, SP, UB); encosta leste do vale do Córrego da Ressaca, 3.V.1962 (fl), M. Mimura 360 (K, SP, UB); ca. 7,6 km SSE, 7.VI.1962 (fl, fr), M. Mimura 418 (K, SP, UB); Sorocaba, Votorantim, 17.IV.1995 (fl, fr), M. Magenta et al. 10 (ESA, HRCB, SP, SPF, UEC); município indefinido, Province. Saint Paulo, s.d. (fl, fr), Riedel 338 (P). Tocantins: Mateiros, Região do Jalapão, proximidades do Riacho Formiga, fazenda do Sr. Vicente, $10^{\circ} 20^{\prime} \mathrm{S}, 46^{\circ} 29^{\prime} \mathrm{W}$, 6.V.2001 (fl, fr), P.L. Simpson \& A.B. Sampaio 56 (UB). Sem indicação de estado, 1950 (fl, fr), L. Roth 1332 (CESJ, SPF); s.d. (fl, fr), K.P. Martius, von 826 (K, M). 


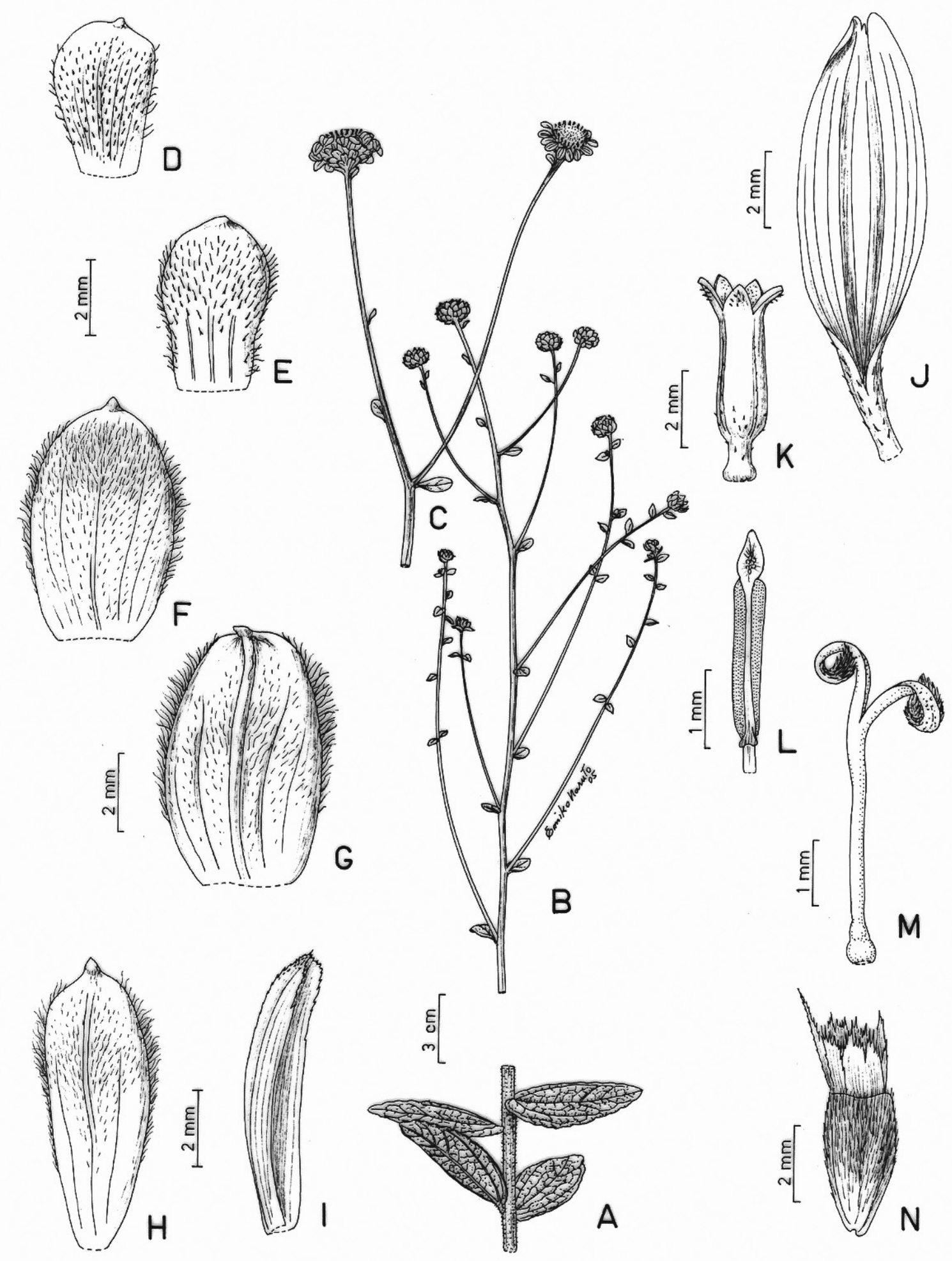

Fig 33: V. robusta. A. Segmento da base de ramo B-C. Segmentos da Sinflorescência, D-H. Brácteas involucrais, I. Pálea do receptáculo, J. Corola do raio, K. Corola do disco, L. Antera com tecas de base curtamente sagitada, terminando acima da base do colar filetal, M. Estilete com base piriforme. N. Cipsela A-N. M. Magenta \& J. Magenta 311 (SPF). 
28. Viguiera rubra Magenta, sp. nov. Tipo: Brasil. São Paulo. Pirassununga.

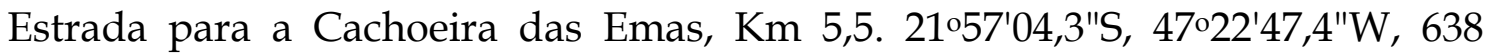
m.a.m, 17.III.2002, M. Magenta \& J. Magenta 388 (holótipo: SPF!; fotografia do holótipo: K!, SPF!; isótipos: GH, NY, K! ).

Figuras 4C, 6C e 34

Ervas a subarbustos 0,6-2m alt., ramos aéreos eretos, cilíndricos canaliculados, vilosos, entrenós 1,5-3,5cm compr.; caule subterrâneo levemente espessado, raízes adventícias sem espessamentos. Folhas discolores a levemente discolores, alternas ou inferiores raramente opostas, sésseis ou pecíolo 1-2mm compr.; lâmina 2-8x1,5-4,5cm, elíptica a largamente elíptica, oval ou raramente oval-lanceolada, base arredondada, levemente cordada ou atenuada, geralmente cuneada, ápice agudo a arredondado, porção superior esparsamente denteada, esparsamente estrigilosa, nervação acródroma basal ou suprabasal perfeita, face adaxial reluzente, com tricomas muito esparsos, 3celulares, sem bossas, base cônica a cilíndrica, cercada por uma série de células, face abaxial hirsuta a vilosa, com glândulas, tricomas tectores 4-5-celulares, sem bossas, base cilíndrica a estreitamente cônica, cercada por uma série de células. Inflorescência botrióide ou tirsóide, $15-50 \mathrm{~cm}$ alt., paracládios eretos, superiores terminando acima do capítulo terminal canaliculados, hirsutos a vilosos, bractéolas esparsas 7-10mm compr., alternas, foliáceas; 1 a ordem 7,5-50cm compr., 2a ordem 4-12cm compr. pedúnculo terminal 0,3-7cm compr. Capítulos discóides, 2-2,5cm diâm.; invólucro 8-10mm diâm., estreitamente campanulado a campanulado; brácteas involucrais reflexas na floração, 4-5 séries, oblongas a levemente ovais ou às vezes levemente obovais, base canaliculada, 3 nervuras evidentes, foliáceas em 1/2 superior, coriáceas ou da série interna às vezes escariosa, face adaxial glabra, face abaxial com nervuras esparsamente híspidas, porção apical às vezes hispídula ou estrigilosa, margem longamente ciliada, ao menos na porção superior, 1a série 4-6mm, ápice obtuso mucronado, demais com ápice obtuso a agudo, 2a série 6-8mm alt., 3a série 9$10 \mathrm{~mm}$ alt., $4 \mathrm{a}$ e 5a séries $9-12 \mathrm{~mm}$ alt.; receptáculo convexo, páleas 7-8mm alt., oblongas a oblanceoladas, ápice arredondado a truncado, mucronado, carena estrigosa, 12 ou 14 nervuras esparsamente estrigilosas. Flores do disco 40-75, 
porção superior vinácea, corola $5-5,5 \mathrm{~mm}$, tubo 1,2mm alt., lobos com altura igual ou maior que o dobro da largura, esparsamente setoso a setoso, lobos estrigilosos, antera de base curtamente sagitada, terminando abaixo da base do colar filetal, estilete com alargamento basal estreitamente cônico, espessado na base, estilopódio 0,10-0,12x0,30-0,54mm. Cipselas 3-5mm alt., obovóides a estreitamente obovóides, levemente trígonas, estreitamente estriadas, esparsamente seríceas a seríceas, tricomas dourados, carpopódio delgado médio, pápus amarelado com manchas vináceas, aristas marginais 2, desiguais, unidas às escamas laterais, menor 2-3mm alt., maior 3,5-4mm alt., triangulares a lanceoladas, base alargada, nervura e margem estrigilosas, escamas em 3-4 pares, 15-18mm alt., unidas até o ápice eroso.

Coletada nos Estados de Mato Grosso do Sul e São Paulo (fig. 44A), em duas regiões apenas, em cerrado ralo, com flores e frutos de março a maio.

Esta espécie de folhas com lâmina de face abaxial reluzente tem morfologia semelhante a $V$. robusta, mas apresenta capítulos discóides e mais estreitos, com flores do disco vináceas quando jovens. Além disso, as aristas são unidas às escamas laterais, que apresentam ápice eroso; em $V$. robusta as aristas são livres e as escamas têm ápice lacerado. Nas análises filogenéticas efetuadas no capítulo IV, $V$. rubra emergiu como espécie-irmã de $V$. vernonioides, do Mato Grosso do Sul, uma espécie com capítulos radiados com 3 séries de brácteas involucrais, pela semelhança na forma do ápice e indumento da face abaxial das brácteas involucrais.

Material examinado. Parátipos: BRASIL: Mato Grosso do Sul: Três Lagoas, Horto Santa Luzia, Reserva Florestal Três Lagoas, 2005’S, 515` W, 12.V.1993 (fl, fr), A.D. Caliente 298 (HISA, UEC). São Paulo: Matão, Rodovia Faria Lima km 01, 13.IV.1981 (fl, fr), H.F. Leitão Filho et al. 12470 (UEC); Mogi Guaçu, Reserva Biológica da Fazenda Campininha, 18.IV.1955 (fr), O. Handro 468 (SP); idem, 24.V.1965 (fl, fr), J.R. Mattos 12247 (SP, TENN); idem, 2.IX.1965 (fl, fr), J.R. Mattos 12502 (SP); idem, Bairro Pádua Sales, 8.IV.1980 (fl), W. Mantovani 519 (SP); idem, beira de estrada, 8.VI.1980 (fl), B.C. Lopes 11439 (UEC); IV.1982, H.C. Morais 13489 (UEC); Pirassununga, Cerrado de Emas, 25.IV.1992 (fl), M.L.F. Salatino et al. 89 (SPF); idem, 24.III.1993 (fl), M.L.F. Salatino et al. 220 (SPF); 2202’S, 47³0'W, 4.V.1994 (fl, fr), M. Batalha \& W. Mantovani 89 (SP); São Carlos [do Pinhal] 23.IV.1961 (fl, fr), A.P. Duarte 5604 (RB, SP). 


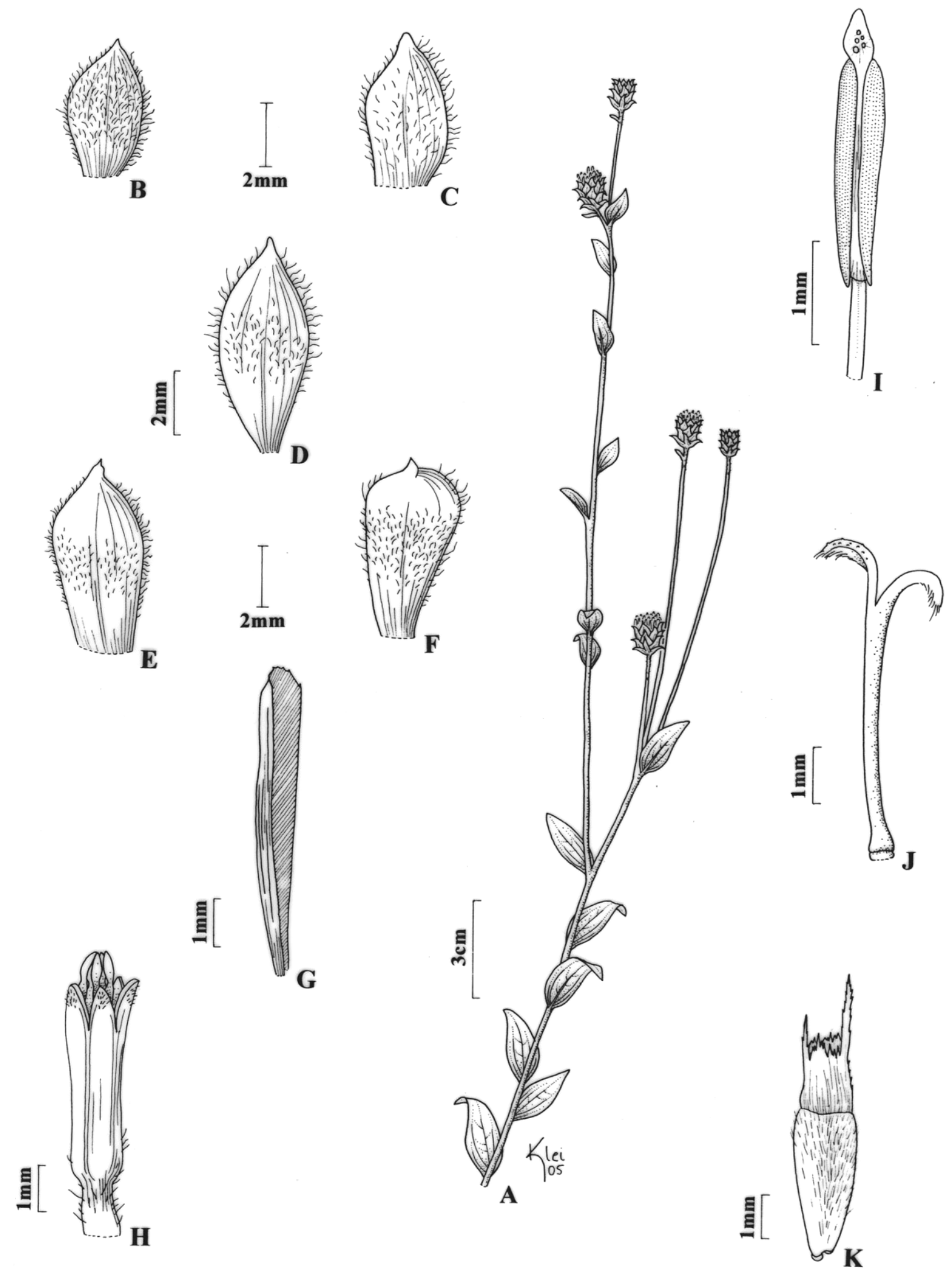

Fig 34: V. rubra. A. Segmento de ramo com sinflorescência, B-F. Brácteas involucrais longamente ciliadas, G. Pálea do receptáculo, H. Corola com tubo setoso, I. Antera com tecas de base curtamente sagitada, terminando abaixo da base do colar filetal, J. Estilete com alargamento basal estreitamente cônico. K. Cipsela com escamas do pápus unidas. A-K. M.Magenta \& J. Magenta 388 (SPF). 
29. Viguiera santacatarinensis (H. Rob. \& A.J. Moore) Magenta \& Mondin, comb. ined.

Rhysolepis santacatarinensis H. Robinson \& A.J. Moore, Proc. Biol. Soc. Wash. 117(3): 441. Tipo: Brasil. Santa Catarina. Serra do Faxinal (Mun. Praia Grande), paredões rochosos, 1200m, 15.abr.1993, G. Hatschbach et al. 59135 (holótipo: MBM!, isótipos: US*).

Figura 35

Subarbusto ereto, 0,5-2m alt., ramos aéreos eretos, cilíndricos, canescentes a albo-vilosos, entrenós 1-3cm compr.; caule subterrâneo levemente espessado, raízes adventícias inteiramente tuberosas fusiformes. Folhas alternas ou as inferiores opostas, discolores, sésseis ou pecíolo 1-2mm compr.; lâmina 10-26x1,5-5,5cm, lanceolada, base cuneada, ápice longamente acuminado, crenada a serreada, nervação acródroma suprabasal,perfeita a broquidódroma com uma nervura principal, face adaxial hirsuta a híspida, tricomas tectores 3-5celulares de base estreitamente cônica a cilíndrica, cercada por uma série de células, com bossas inconspícuas; face abaxial tomentosa, tricomas tectores 5celulares, com base cilíndrica e bossas inconspícuas; nervuras quaternárias repletas de glândulas. Inflorescência botrióide laxa ou capítulos solitários, paracládios $7-10 \mathrm{~cm}$ alt., eretos, superiores terminando abaixo do capítulo principal, canaliculados, densamente híspidos, bractéolas alternas foliáceas ou sem bractéolas; pedúnculo terminal 1-3cm compr. Capítulos 6-8(-10)cm diâm., radiados; brácteas involucrais reflexas na floração, 3-4(-5) séries, 12-30mm alt., lanceoladas, base canaliculada, foliáceas em 3/4 superiores ou totalmente foliáceas, ápice cirroso, cartáceas, margem longamente ciliada, face adaxial albo-tomentosa a albo-vilosa, face abaxial esparsamente estrigilosa a esparsamente setulosa; receptáculo convexo, páleas 7-12mm alt., oblongas a oblanceoladas, ápice agudo, geralmente denteado, mucronado, 8 ou 10 nervuras, hialinas, carena com ápice estrigiloso. Flores do raio 13-25(-35), em 12 verticilos, corola 20-40x7-10mm, tubo 1-3mm alt., limbo elíptico, ápice levemente 2-3 partido, estrigiloso, face externa com glândulas adensadas; nervuras 17-20, hispídulas a híspidas; flores do disco 150-220, corola 5-7mm alt., tubo 1-1,2mm alt.; tubo, base e nervuras estrigilosos, lobos esparsamente 
estrigilosos, com glândulas; antera de base curtamente sagitada, terminando na base do colar filetal ou levemente acima; estilete com alargamento basal semigloboso, estilopódio 0,1-0,15x0,3-0,4mm. Cipselas 4-4,5mm alt., obovóides, levemente tetragonais, estriadas, esparsamente setosas ou setosas próximo ao ápice, carpopódio médio, pápus estramíneo 2-3-aristado, aristas levemente intramarginais, desiguais, livres, menor 1,5-2,5mm alt., maior 2,5-4mm alt., lanceoladas, nervura e margem estrigilosas, escamas ca. 4 pares 0,2-0,8mm alt., unidas até o meio ou até próximo ao ápice lacerado.

Encontrada apenas nos Estados de Rio Grande do Sul e Santa Catarina (fig. 44B),, na região fisiogeográfica dos Campos de Cima da Serra.

Espécie vegetativamente semelhante a espécies do gênero Verbesina. As brácteas involucrais cirrosas são características do gênero Helianthus, do qual Viguiera é muito próximo. No entanto o hábito subarbustivo e o pápus persistente não deixam dúvidas quanto ao seu posicionamento neste último. Nas análises filogenéticas (capítulo IV) emergiu como espécie-irmã (análise com 68 terminais) ou no mesmo clado de $V$. nudibasilaris (análise com 106 terminais). Divide com ambas a presença de folhas lanceoladas e brácteas involucrais com formas diferentes; com $V$. nudibasilaris, compartilha mais duas sinapomorfias homoplásicas: brácteas involucrais fortemente reflexas na maturidade e folhas hipoestomáticas.

Material examinado: BRASIL: Rio Grande do Sul: Bom Jesus, Serra da Rocinha para Bom Jesus, 18.II.1955 (fl), B. Rambo s.n. (PACA 56807); Morrinhos do Sul, na subida da trilha Tajuva - Josafa, 450 m.a.m., XII.1995 (fl), M. Sobral \& J.A. Jarenkow 8014 (ICN); São José dos Ausentes, beira de estrada na Serra da Rocinha, 750 m.a.m., IV.1998 (fl, fr), M. Sobral \& S.B. Rech 8617, 8622, 8628 (ICN); na descida para Rocinha, 11.XI.2001, C. Mondin \& A. Iob 2466 (HASU, SPF); beira de estrada na Serra da Rocinha, I.2002 (fl), M. Sobral et al. 9495 (ICN, SPF); estrada São José - Timbé do Sul a 7 km da bifurcação Cambará - São José, 11.XII.2003 (fl, fr), M. Magenta \& J. Magenta 706, 707 (SPF). Santa Catarina: Bom Jardim da Serra, Serra do Rio do Rastro, 1400 m.a.m., 19.IV.1987 (fl, fr), G. Hashimoto 20980 (GHSP, SP); beira de estrada na Serra do Rio do Rastro, 700 m.a.m., I.2000 (fl), M. Sobral et al. 9008 (ICN); Lauro Muller, Serra do Rio do 

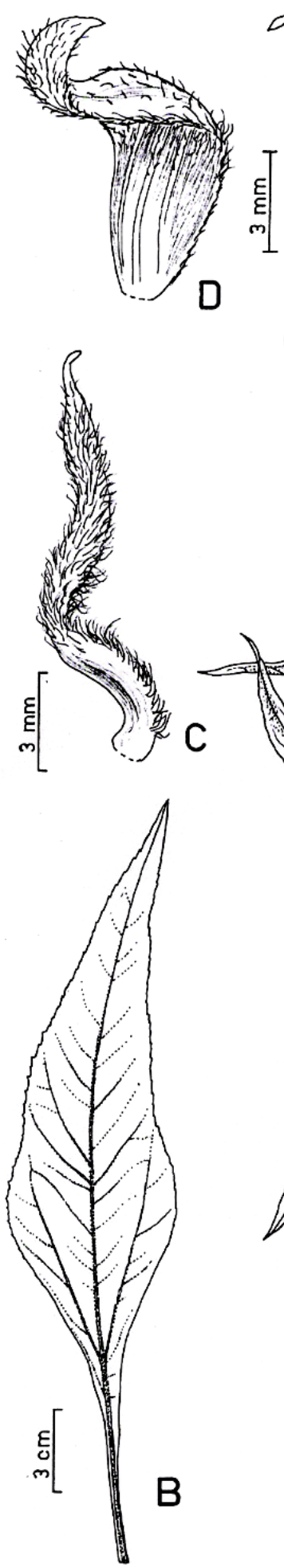
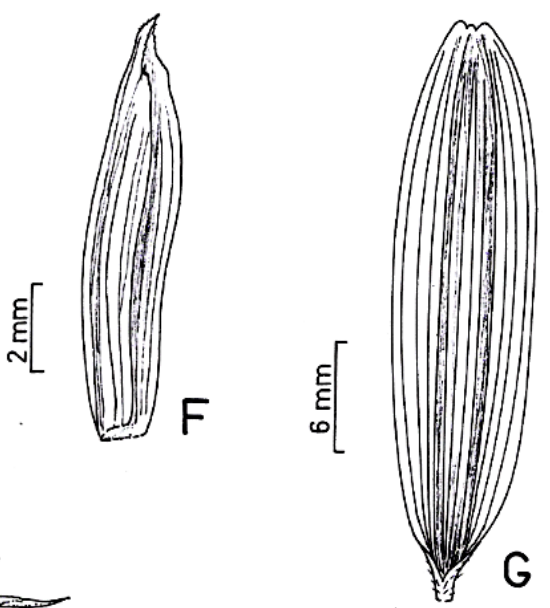

E
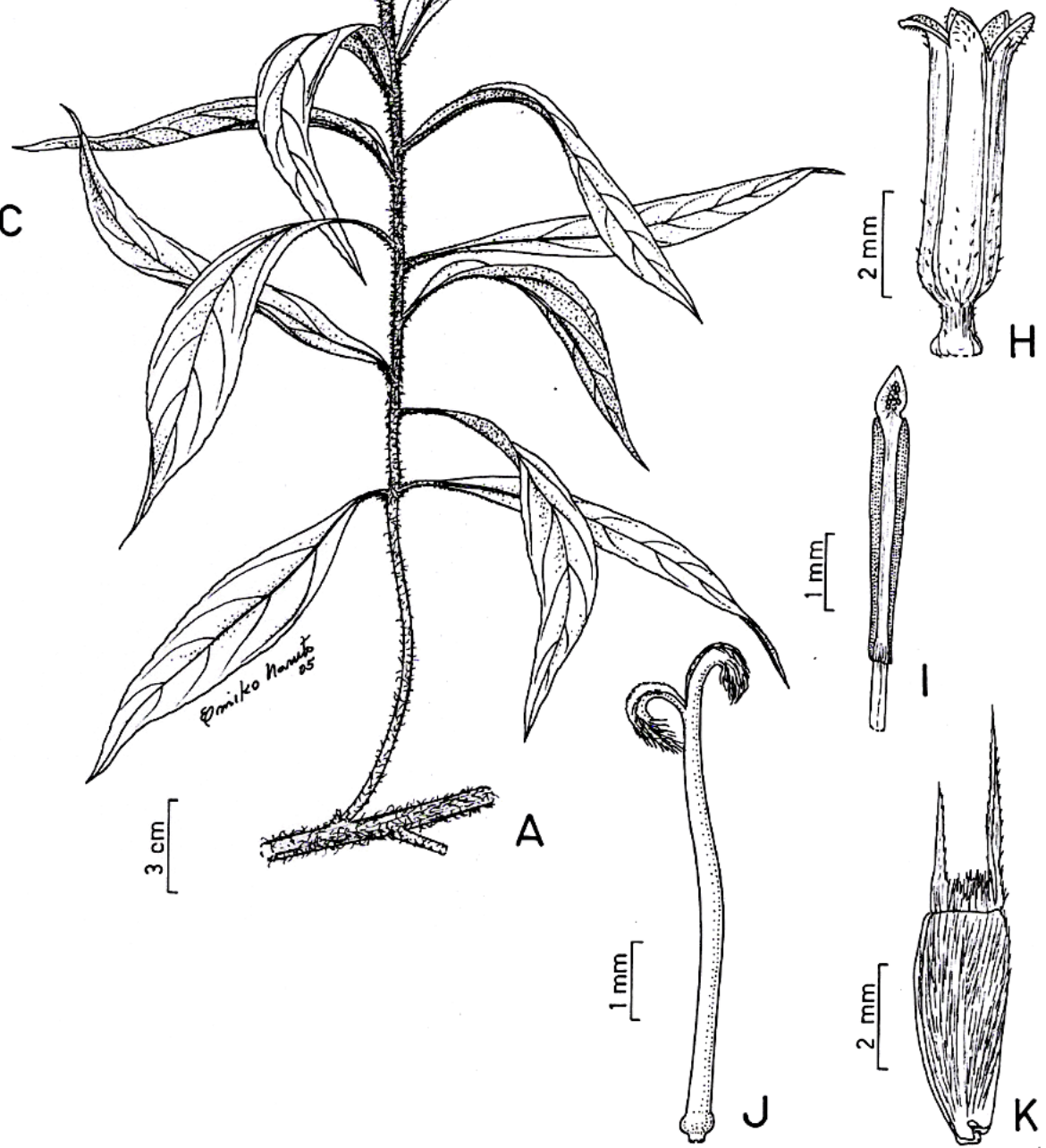

Fig. 35: V. santacatarinensis A. Paracládio densamente híspido com capítulo, B- Folha, detalhe com base do limbo longamente atenuada e pecíolo C-E. Brácteas involucrais, F. Pálea do receptáculo, G. Corola do raio, H. Corola do disco, I. Antera com tecas de base curtamente sagitada, terminando na base do colar filetal, J. Estilete com alargamento basal semigloboso, K. Cipsela com aristas longas e delicadas. A-K. M. Magenta \& J. Magenta 410 (SPF). 
Rastro, 700-1000 m.a.m., 3.IV.1957 (fl), L.B. Smith \& R. Klein 12339 (LP, US); Orleaes, Rio do Rastro para Orleaes, 29.XI.1950 (fl), R. Reitz 3339 (M, PACA); São Joaquim, Bom Jardim, na Serra do Oratório, 21.I.1959 (fl), J.R. Mattos 6543 (HAS); Timbé do Sul, Serra da Rocinha, III.2000 (fl, fr), M. Sobral \& C.B. Costa 8944 (SP, SPF); ídem 8948, 8950 (SPF); idem, sentido São José dos Ausentes -

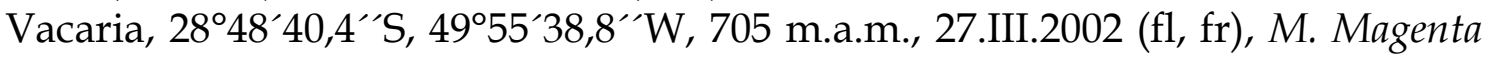
\& J. Magenta 410 (SPF).

30. Viguiera squalida Moore, J. Bot. 42: 37: 1904. Rhysolepis squalida (Spencer Le Marchant Moore) H. Rob. \& A.J. Moore, Proc. Biol. Washington 117(7): 431. 2004. Tipo: Brazil, Mato Grosso: S. Anna da Chapada 20.10.1902, A. Robert 640 (lectótipo aqui designado: BM!; fotografia do lectótipo: K!, SPF!; isolectótipos: $\mathrm{GH}$ - frag. e esboço, $\mathrm{K} !)$.

Viguiera wedellii Sch. Bip. ex S.F. Blake, Contr. Contr. Gray Herb. 54: 126. 1918. Rhysolepis weddelii (Sch. Bip. ex S.F. Blake) H. Robinson \& A.J. Moore, l.c.: 432. 2004. Tipo: Between Goyas and Cujaba, Nov.-Dez.1844, Wedell 2911 (holótipo: P!; fotografia do holótipo: F!, K!, SPF!). syn. nov.

Figura 36

Ervas a subarbustos 0,3-1m alt., ramos aéreos eretos, cilíndricos, canaliculados, hirsutos, entrenós 2,5-7(-10)cm compr.; caule subterrâneo fortemente espessado, raízes adventícias com tuberosidades alongadas na porção mediana. Folhas verde-claras, alternas e/ou opostas, sésseis, lâmina 4$17 \times 1-8 \mathrm{~cm}$, oval, elíptica ou raramente oboval ou orbicular, base obtusa, cuneada, ápice agudo ou raramente arredondado, às vezes mucronado, inteira ou crenada, denteada ou serreada na porção superior, membranácea ou raramente cartácea, nervação acródroma basal perfeita, 3-5 nervuras principais, glabra a estrigosa, hirsuta ou setosa, tricomas tectores levemente apressos, 2-3celulares, base cônica a cilíndrica, circundada por 2 séries de células. Inflorescência botrióide ou tirsóide laxa ou capítulos solitários, 9-35cm alt., paracládios ascendentes, superiores terminando próximo ao capítulo terminal, 7-25cm compr., canaliculados, esparsamente estrigosos, ebracteolados ou com 1 a 2 bractéolas; pedúnculo terminal 7,5-25cm compr. Capítulos 4-6cm diâm., radiados; invólucro 1,5-2cm diâm., campanulado; brácteas involucrais 
levemente apressas a levemente reflexas na floração, base canaliculada, 3 nervuras destacadas, foliáceas em 2/3 superiores ou totalmente foliáceas, 2(-3) séries, cartáceas; 1a e 2a séries 12-14mm alt., elíptico-lanceoladas a ovallanceoladas ou raramente oblongo-lanceoladas, ápice agudo a acuminado, margem estrigilosa, coriáceas, face adaxial com ápice estrigiloso, face abaxial esparsamente estrigilosa, 3a série $10-17 \mathrm{~mm}$ alt., oblongas a oval-lanceolada, ápice agudo, face abaxial glabra a esparsamente estrigilosa, margem estrigilosa; receptáculo levemente convexo, páleas $7-8 \mathrm{~mm}$ alt., oblanceoladas, carena estreita, estrigilosa, ápice obtuso a truncado, mucronado, 10 a 12 nervuras, esparsamente estrigilosas. Flores do raio 12-14(-18-20), em 1-2 verticilos, corola 20-40x4-9mm, tubo 1-1,2mm alt., limbo elíptico, oblongo ou oval, ápice curta ou profundamente 2-3-partido, face adaxial glabra, face abaxial com tricomas glandulares esparsos ou adensados, curtamente pedicelados; nervuras 13-18, muito esparsamente estrigilosa; flores do disco 45-120, corola 4-5,5mm alt., tubo 0,6-1mm alt., lobos com altura igual ou maior que o dobro da largura, lobos com face interna papilosa, face externa estrigilosa; tubo glabro a estrigiloso, anteras de base curtamente sagitada, terminando acima da base do colar filetal; estilete com alargamento basal semigloboso, estilopódio 0,12-0,14×0,38-0,30mm. Cipselas 5-6,5mm alt., obovóides a largamente obovóides, levemente tetragonais, estriadas, setulosas próximo ao ápice, carpopódio médio, pápus amarelado, 2-aristado, aristas marginais ou levemente intramarginais, unidas às escamas, iguais ou desiguais, menor 1,5-2,5mm alt., maior 2-5-3,5mm alt., largamente triangulares, agudas a acuminadas, ápice lacerado, porção basal gibosa, nervura estrigilosa, escamas 3-4 pares, 1-1,5mm alt., unidas até o ápice ou próximo a ele.

Ocorre no Paraguai e no Brasil nos estados de Goiás, Mato Grosso, Mato Grosso do Sul e Tocantins (fig. ???)," em matas, cerrados típicos com solo arenoso ou argiloso, campos e em afloramentos rochosos. Floresce e frutifica na primavera.

Espécie morfologicamente próxima de V. grandiflora e, assim como esta, tolera variações de luminosidade, com plantas ciófilas apresentando folhas de textura mais fina, formato alongado e cor mais escura, enquanto as heliófitas 
geralmente apresentam um maior número de folhas orbiculares mais espessas e mais claras. Diferencia-se de Viguiera grandiflora características do invólucro e do pápus (ver comentários da espécie). A cipsela se assemelha à de $V$. discolor, mas as aristas são geralmente intramarginais e o indumento do invólucro é diferente (ver comentários da espécie). As plantas coletadas em solos contendo grandes quantidades sedimentos ferríferos nas morrarias da Formação Santa Cruz, ao sul de Corumbá, apresentam-se menores e com folhas mais rígidas. Por outro lado, as plantas da Chapada dos Guimarães em Mato Grosso, podem apresentar folhas muito estreitas (J.U. Santos \& C.S. Rosário 360 e G.T. Prance et al. 18957 (INPA); contudo, no herbário RB, há uma duplicata deste último espécime com folhas da forma mais comum na espécie.

Material examinado: BRASIL: Goiás: Amorinópolis, Serra de Carapós, a 40 km de Amarinópolis para Rio Verde, 16.X.1971, J.A. Rizzo 7118 (UFG); idem, 16.X.1971, J.A. Rizzo \& A. Barbosa 5589 (UFG); Chapadão do Céu, Parque Nacional de Emas, $17^{\circ} 49^{\prime} \mathrm{S}-1^{\circ} 28^{\prime} \mathrm{S}, 5^{\circ} 39^{\prime} \mathrm{W}-5^{\circ} 10^{\prime} \mathrm{W}, 10 . X \mathrm{XI} .1998$ (fl, fr), M.A.

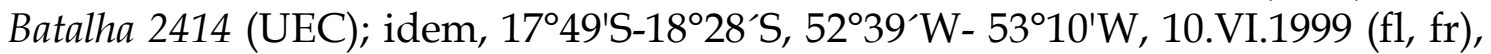
M.A. Batalha 3518 (UEC); 13.X.2000 (fl, fr), L.Y.S. Aona \& L. Baungartem 773, 774 (UEC); Goiânia, à direita da GO-7, Goiânia - Guapó, 10 km de Goiânia, 15.V.1968, J.A. Rizzo \& A. Barbosa 680 (UFG); rodovia Goiania - São Paulo, 9.IX.1968 (fl), J.A. Rizzo 2300 (UFG); Goianira, a 2 km do Rio Meia Ponte, Fazenda Louzandira, 17.X.1970 (fl), J.A. Rizzo \& A. Barbosa 5589 (UFG); idem, 21.XI.1970 (fl, fr), J.A. Rizzo 5727 (UFG); Itumbiara, rodovia BR $153 \mathrm{~km} \mathrm{637,}$

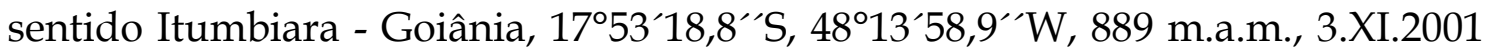
(fl, fr), M. Magenta \& J. Magenta 308 (HUFU, K, SPF, TEX); Mineiros, Morro Vermelho, ca. 10 km Parque Nacional das Emas, 25.XI.1997 (fl, fr), R.C. Forzza et al. 411 (SPF); Mossâmedes, divisa Mossâmedes - Goiás, área da Universidade Federal de Goiás, Serra Dourada, 8.XI.1969 (fl), J.A. Rizzo 4546, 4586 (UFG). Mato Grosso: Alto Paraguai, Serra das Araras - Vão Grande, ca. $27 \mathrm{~km}$ S of MT246, 23.X.1995 (fl, fr), B. Dubs 1892 (K, UFMT); Barra do Garças, pé da serra, 4.X.1968 (fl), D. Andrade-Lima 271-68 (IPA); idem, 4.X.1968 (fl), Sidney \& E. Onish

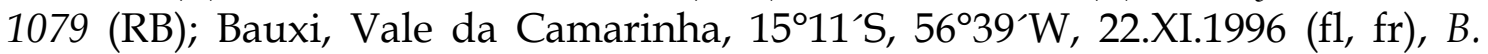
Dubs 2248 (K, MBM, S, UFMT, Z); Cáceres, Jacobina, IX.1908, Comissão Rondon 529 (R); entre Cachoerinha e Novo Oriente, Rodovia MT 343, 27.X.1983 (fl, fr), A. Mattos Filho \& N. Saddi 3657 (RB, UFMT); Chapada dos Guimarães, estrada para o Véu de Noiva, 720 m.a.m., 14.X.1973 (fl, fr), G.T. Prance et al. 18957 (IPA, NY, RB, UFMT); 9.IX.1981 (fl, fr), L.D.F. Mathes et al. 12995 (UEC); próximo ao Véu de Noiva, 18.XI.1982 (fl), J.U. Santos \& C.S. Rosário 360 (MG, UFMT); Cuiabá, rodovia Cuiabá - Santarém, ponto 06, RADAMBRASIL, 14³6'S, 56²13'W, 12.XI.1977 (fl, fr), J.M. Lumes et al. 4098 (HRB, RB); rodovia Cuiabá Porto Velho km 99, 24.XI.1982 (fl), J.U. Santos \& C.S. Rosário 494 (IPA, UFMT); Jacobina, Cáceres, IX.1908 (fl, fr), F.C. Hoehne 328, 329 (R); rodovia BR 070, Serra do Mangabal, 7.XI.1996 (fl, fr), G. Hatschbach et al. 65374 (MBM, SPF); Poxoréo, 
estrada Poxoréu - Sangradouro km 25, 30.X.1976 (fl), M. Macedo et al. 254 (IPA); Rondonópolis, Rodovia BR 364, entre kms 348 e 358, Rondonópolis - Alto das Garças, 24.X.1999, F.B. Costa 98 (SPFR); Xavantina, ca. 75 km N of Xavantina, 9.X.1964 (fl, fr), H.S. Irwin \& T.R. Soderstrom 6687 (K); município indefinido,

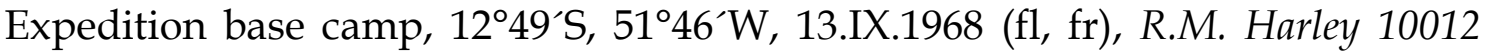
$(\mathrm{K}, \mathrm{P})$; Lago Leo, acampamento da Expedição Inglesa, 11.X.1968 (fr), Sidney \& E. Onish 1440 (RB). Mato Grosso do Sul: Aquidauana, Morro do Paxixi, 26.X.1986, S.T. Vasconcelos et al. 25 (CGMS, COR); Comissão, alto da serra, subida para torre da Embratel, Morro do Paxixi, 20²6`31,3“'S, 55³8’01,2”W, 617 m.a.m., 18.XI.2003 (fl, fr), M. Magenta \& J. Magenta 683 (SPF); Bandeirantes, rodovia BR $163 \mathrm{~km} \mathrm{568,} \mathrm{sentido} \mathrm{Cuiabá} \mathrm{-} \mathrm{Bandeirante,} \mathrm{entrada} \mathrm{fazenda} \mathrm{Talismã,}$ $19^{\circ} 43^{\prime} 16,9^{\prime \prime} \mathrm{S}, 5^{\circ} 21^{\prime} 03,8^{\prime \prime} \mathrm{W}, 705$ m.a.m., 16.XI.2003 (fl), M. Magenta \& T.U.

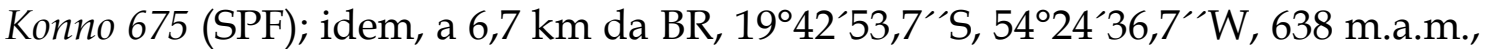
16.XI.2003 (fl, fr), M. Magenta \& T.U. Konno 676 (SPF); rodovia BR 163 km 555,7,

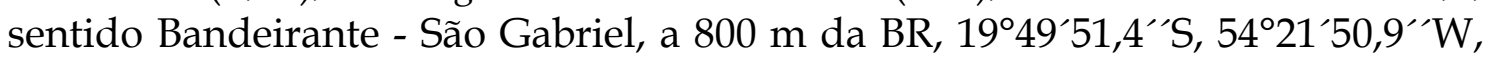
622 m.a.m., 17.XI.2003 (fl, fr), M. Magenta \& T.U. Konno 680 (SPF); idem, a 1 km da BR, 1949`46,2”S, 5421`45,4”W, 626 m.a.m., 17.XI.2003 (fl, fr), M. Magenta \& T.U. Konno 681, 682 (SPF); Campo Grande, Lagoa Rica, próximo ao balneário, 25.IX.1976 (fr), A. Oliveira s.n. (CGMS 2824); Parque dos Poderes, 26.X.1985, C.A. Conceição 1803 (CGMS, RB); Fazenda Santa Inês, 15.X.1989 (fl), A.M. Resende et al. 66 (CGMS); Rancho Dalenomás, 1.XI.1990, A. Oliveira s.n. (CGMS 3358, CGMS 3372); 20²7’S, 5326’W, 9.IX.1994 (fl, fr), B. Dubs 1755 (E, ESA, K, S, Z); Cerrado da Universidade Federal de Mato Grosso do Sul, 25.X.1997, L. Kokobum et al. s.n. (CGMS 10007); Chácara Cambará, s.d. (fl), R. Farias s.n. (CGMS 4885); Corumbá, Morro do Urucum, 19³5’S, 57³4`W, 1000 m.a.m., 4.X.1984 (fl), A. Pott et al. 1578 (CPAP, SPF); idem, 960 m.a.m., 4.X.1984 (fl, fr), C.A. Conceição 1612 (CGMS, COR, RB, SPF); Morro do Urucum, estrada para torre da Embratel, 1901'S, 57³9'W, 850 m.a.m., 18.XI.1987, A. Pott et al. 425 (CPAP); idem, 1060 m.a.m., 20.XI.1988 (fl, fr), s.c. s.n. (COR 1745); Morro do Urucum, 19¹1'40,2”S, 57³6'32,4"W, 900 m.a.m., 26.IX.1995, I.M. Bortolotto et al. 43 (COR,

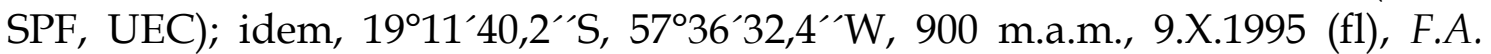
Damasceno Jr. et al. 932 (COR, SPF, UEC); idem, 19¹1'02”'S, 57³6,3'24"W, 900 m.a.m., 10.XI.1995, I.M. Bortolotto \& D.P. Rodriguez 101 (COR); idem, 16.X.1996 (fl, fr), C.S. Gonçalves 4 (COR, SPF); idem, 16.X.1996 (fl, fr), I.M. Bortolotto et al. 381 (COR); idem, 940 m.a.m., 16.X.1996, L.L. Pinto 4 (COR); idem, 18.IX.1996 (fr),

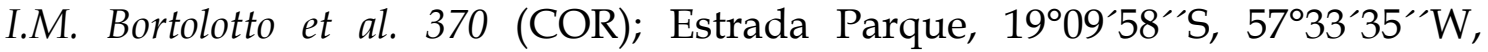
6.I.2001, E.A. Rodrigues et al. 7 (COR); Morro do Urucum, 2.II.2002, F. Mendes 6 (COR); Morraria Santa Cruz, Rodovia BR 262 km 743,5, Menck, antena da

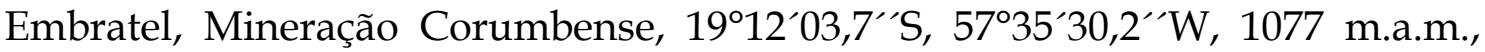
20.XI.2003 (fr), M. Magenta \& J. Magenta 686 (SPF); idem, 19¹2`06,2”S, 57³5`30,5``W, 1070 m.a.m., 20.XI.2003 (fl, fr), M. Magenta \& J. Magenta 687

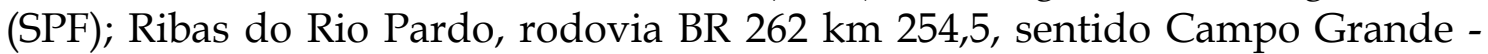
Ribas do Rio Pardo, 20²4`00,8“S, 5354’23,9”'W, 474 m.a.m., 22.XI.2003 (fl, fr), M. Magenta \& J. Magenta 695 (SPF); rodovia BR $262 \mathrm{~km} \mathrm{236,5,} \mathrm{sentido} \mathrm{Ribas} \mathrm{do}$

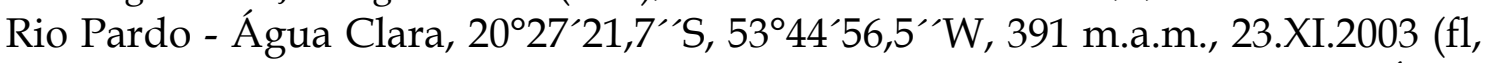
fr), M. Magenta \& J. Magenta 696 (SPF);rodovia BR 262 km 202,8, sentido Água Clara - Ribas do Rio Pardo, 20²8’00,2”'S, 53²5’55,2”W, 475 m.a.m., 23.XI.2003 
(fl, fr), M. Magenta \& J. Magenta 697 (SPF); Rio Brilhante, rodovia BR 267, entroncamento, 22.X.1970 (fl, fr), G. Hatschbach 25020, 25040 (MBM, RB); Rio Anhandui, 23.X.1970 (fl, fr), G. Hatschbach 25147 (MBM, RB); Rio Verde de Mato Grosso, Fazenda Capão da Taquara, 29.VIII.1973 (fl), G. Hatschbach 32470 (MBM, RB); $11 \mathrm{~km} \mathrm{~W}$ de Rio Verde, estrada para Pimenteira, $18^{\circ} 57^{\prime} \mathrm{S}, 54^{\circ} 55^{\prime} \mathrm{W}$, 470 m.a.m., 14.X.1993 (fl, fr), A. Pott et al. 6522 (CPAP, SPF); São Gabriel do Oeste, rodovia BR $163 \mathrm{~km} \mathrm{601,5,} \mathrm{sentido} \mathrm{Bandeirante} \mathrm{-} \mathrm{São} \mathrm{Gabriel,}$ $19^{\circ} 28^{\prime} 22,3^{\prime \prime S}, 54^{\circ} 29^{\prime} 47,3^{\prime \prime} \mathrm{W}, 720$ m.a.m., 16.XI.2003 (fl, fr), M. Magenta \& T.U. Konno 678 (SPF); município indefinido, Rio Correntes, V.1911 (fl), F.C. Hoehne 2317 (R); Lago Leo, arredores do acampamento da Royal Society, 11.X.1960 (fl, fr), D. Andrade-Lima 461-68 (IPA); Base Camp square, "terra Preta Camp", 1249’S, 5146`W, 19.VIII.1968 (fl, fr), G.C.G. Argent 6727 (K, RB). Paraná: Laranjeiras do Sul, 7.XI.1963 (fl, fr), E. Perreira \& G. Hatschbach 7737-A (HB, LP, M, MBM, PEL, RB). Tocantins: município indefinido, próximo ao Rio Lontra, na Fazenda Baixa, 9.XI.1973 (fl), J.A. Rizzo 9410 (UFG). Sem indicação de estado, Rio Pardo, s.d. (fl, fr), Riedel 476 (P). 

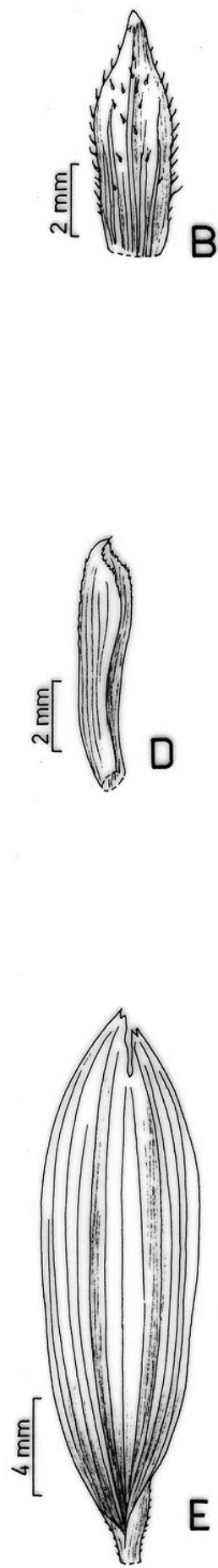
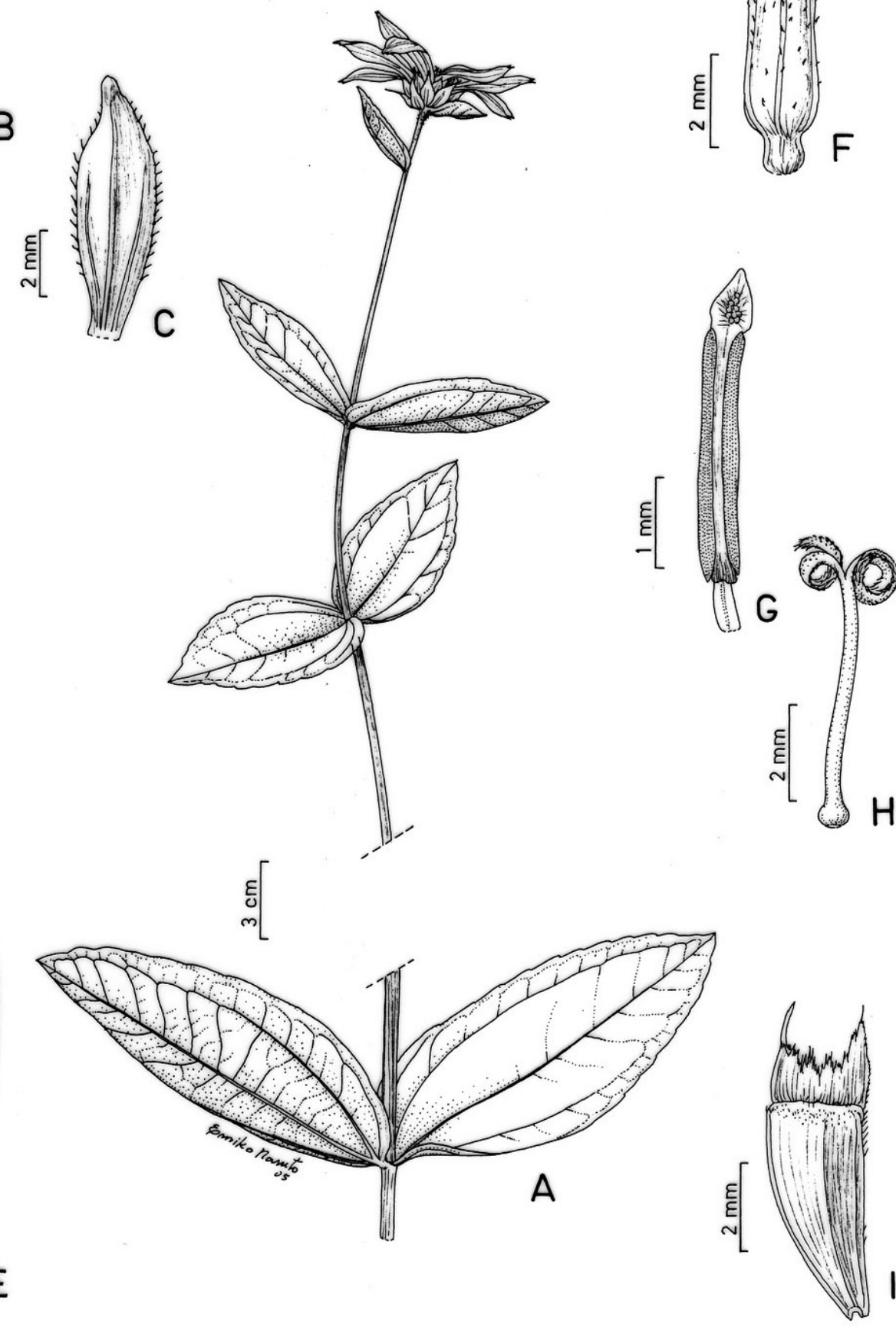

Fig. 36: V. squalida A. Segmento do ramo com capítulo solitário, B-C. Brácteas involucrais; D. Pálea do receptáculo, E. Corola do raio, F. Corola do disco estrigilosa, G. Antera com tecas de base levemente auriculada, terminando acima da base do colar filetal, I. Estilete com alargamento basal semigloboso; J. Cipsela com aristas unidas às escamas laterais. A-J. M. Magenta \& J. Magenta 696 (SPF). 
31. Viguiera tenuifolia Gardner, London J. Bot. 7: 400. 1848. Rhysolepis tenuifolia (Gardner) H. Rob. \& A.J. Moore, Proc. Biol. Washington 117(7): 432. 2004. Tipo: Brasil, Minas Gerais, Serra de Curral d'll Rey, Sept. 1840, Gardner 4927 bis (holótipo*: BM!; fotografia do holótipo: P!, SPF!; isótipo: GH - esboço).

Figuras 2E, 3B, 4F-G e 37

Erva cespitosa a subarbusto 0,6-1,5m alt., ramos aéreos eretos, cilíndricos, canaliculados, setosos, entrenós 2-13cm compr.; caule subterrâneo fortemente espessado, raízes adventícias tuberosas fusifomes em toda a extensão ou somente próximo à base. Folhas verde-claras, inferiores opostas, superiores alternas, sésseis, lâmina do par inferior reduzida, lâmina das medianas 50-200x3-2(-16)mm, ligeiramente amplexicaule, estreitamente oblonga, lanceolada, linear ou raramente elíptica, base atenuada, ápice agudo, mucronado, inteira ou esparsamente denteada, cartácea, nervação acródroma basal imperfeita, 3 nervuras principais, esparsamente estrigosa, estrigosa ou híspida, tricomas tectores 3-celulares, com bossas nas células basal e central, base cilíndrica levemente apressa, cercada por uma série de células, face abaxial com glândulas esparsas; às vezes com folhas jovens nas axilas. Inflorescência botrióide ou tirsóide laxa ou capítulos solitários, 15-30(70)cm alt., paracládios eretos, superiores terminando próximo ao capítulo terminal, 15-25cm compr., estreitamente canaliculados, esparsamente híspidos, com bractéolas foliáceas ou ebracteolados; pedúnculo terminal 8-30(55)cm compr. Capítulos 5,5-8cm diâm., radiados, invólucro 1,2-2cm diâm, campanulado, brácteas involucrais apressas a levemente apressas na floração, 2-3 séries, ciliadas, com glândulas esparsas; centrais geralmente maiores, face abaxial setosa a estrigosa; 1a série 7-16mm alt., estreitamente lanceoladas a lanceoladas, cartáceas, totalmente foliáceas ou foliáceas em 1/3 superior, às vezes 1-3 nervuras levemente destacadas até o ápice agudo a acuminado, mucronado, face adaxial estrigilosa, 2a série 8-20mm alt., lanceoladas, cartáceas, ápice agudo a acuminado, longamente mucronado, face adaxial grabra, 3a série 9-17mm alt., lanceoladas, membranáceas, porção superior estramínea, ápice agudo a acuminado, longamente mucronado, face adaxial glabra; receptáculo levemente convexo, páleas 5,5-6,5mm, oblongas a estreitamente oblongas, ápice agudo, geralmente mucronado, 8 ou 10 nervuras, 
carena estreita hispídula. Flores do raio 10-20, em 1(-2) verticilos, corola 2050x5-7mm, tubo ca. $1 \mathrm{~mm}$ alt., limbo oblongo, ápice agudo curtamente 2-3partido, face adaxial glabra, face abaxial ca. 12 nervuras hispídulas, 3 levemente destacadas; flores do disco 50-70, corola $4-5 \mathrm{~mm}$ alt., tubo ca. $1 \mathrm{~mm}$ alt.; limbo e tubo esparsamente estrigilosos, lobos estrigilosos, com glândulas; antera de base curtamente sagitada, terminando na base do colar filetal; estilete sem alargamento ou com alargamento levemente semigloboso, estilopódio 0,100,12×0,24-0,30 mm. Cipselas 4-5mm alt., estreitamente obovóides a elipsóides, estriadas, seríceas, carpopódio médio, pápus amarelado com manchas vináceas, 2-aristadas, aristas intramarginais iguais ou quase iguais 1,8-2mm alt., delgadas, livres ou unidas às escamas laterais, estreitamente triangulares, estrigilosas, escamas 4-5 pares, 1-1,2mm alt., unidas até o ápice fimbriado.

Ocorre em muitas áeras de Minas Gerais e possui um único registro recente oriundo de São Paulo (fig. 45A), da região de Pedregulho na divisa com MG. É encontrada em variados tipos de campo, em altitudes superiores a 900m. Floresce e frutifica na primavera e no verão, ou raramente no inverno.

Na análise filogenética efetuada com 106 terminais (capítulo IV) a espécie está inserida num clado que abrange as espécies de folhas estreitas e escamas do pápus unidas. Ela se diferencia de $V$. aspilioides e $V$. kunthiana, com as quais mais se assemelha, por características do invólucro e do receptáculo (ver comentários das espécies). Alguns espécimes coletados na Serra da Canastra apresentam capítulos muito grandes, de até $10 \mathrm{~cm}$ de diâmetro, e folhas mais largas e firmes, de até $1,6 \mathrm{~cm}$ de largura.

Nota nomenclatual: A identificação do material como holótipo levou em consideração o fato de no protólogo da espécie Gardner ter citado que sua amostra (referindo-se a uma única amostra) tinha poucas flores bem desenvolvidas, devido ao ataque de herbívoros; assim o material que está no $\mathrm{BM}$, foi a única amostra utilizada pelo autor para descrever a espécie.

Material examinado: BRASIL: Minas Gerais: Alpinópolis, próximo a barragem de Furnas, 18.IX.1977 (fl, fr), H.F. Leitão Filho \& F.R. Martins 5957 (UEC); Araxá, 24.XI.1948 (fl), J.E. Oliveira s.n. (BHCB 48541, RB 97599); 28.XI.1948 (fr), J.E. Oliveira s.n. (BHCB 48541, RB 97599); Belo Horizonte, Jardim 


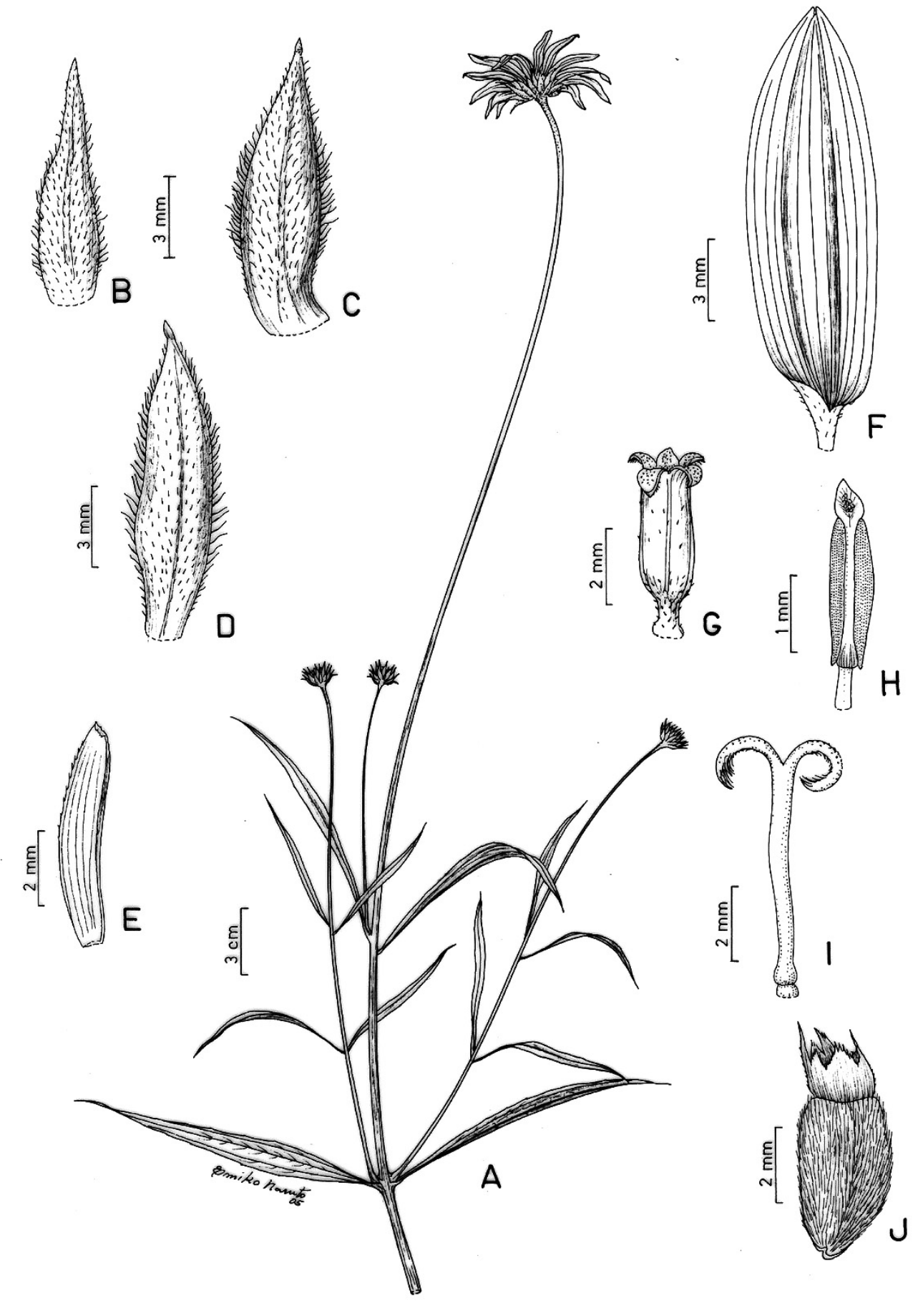

Fig. 37: $V$. tenuifolia. A. Segmento da sinflorescência (as bractéolas repetem o padrão das folhas caulinares), B-D. Brácteas involucrais, E. Pálea do receptáculo, F. Corola do raio, G. Corola do disco, H. Antera com tecas de base curtamente sagitada, terminando na base do colar filetal, I. Estilete com alargamento basal semigloboso, J. Cipsela (A-J. A-J. M. Magenta \& J. Magenta 481 (SPF). 
Botânico, 22.VIII.1932 (fl), K.D. Barreto 393 (RB); Serra do Taquaril, 25.VIII.1932 (fl), Mello-Barreto 4111 (BHCB); idem, 22.VII.1933 (fl), Mello-Barreto 4115 (BHCB, R); Serra do Curral, 6.XI.1933 (fl, fr), Mello-Barreto 4143 (BHCB); Parque das Mangabeiras, 25.X.1995 (fl, fr), F.A. Silveira 10 (BHCB); Brumadinho, Retiro das Pedras, 15.IX.1997 (fl, fr), J.R. Stehmann 2306 (BHCB); Serra da Moeda, 2006’S, 4359'W, 1400 m.a.m., 23.VIII.1998 (fl), V. Madsen \& F. Silveira 75 (BHCB); Capitólio, caminho para o Morro do Chapéu, 24.VII.1993 (fl), R.S. Bianchini \& S. Bianchini 420 (SP, SPF); rodovia BR 050 km 280, estrada Passos - Capitólio, 16.X.1997 (fl, fr), F.B. Costa et al. 26 (SPFR); rodovia MG 050, Furnas - Capitólio, X.1997, F.B. Costa 39 (SPFR); Morro do Chapéu, estrada da TELEMIG,

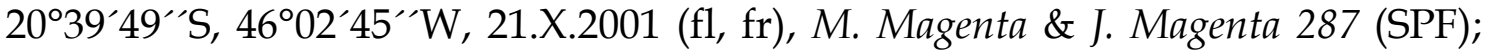
Carmo do Rio Claro, Serra da Tormenta, 3.XI.1990 (fl), M.J.O. Campos s.n. (HRCB 13362); Curvelo, rodovia BR 135 km 15, sentido Paraopeba, 1853`S, 44²8`W, 580 m.a.m., 11.X.1988 (fl, fr), R.M. Harley et al. 24818 (NY, SPF); estrada de terra entre Babilônia - Delfinópolis, 11.IX.1998 (fl, fr), F.B. Costa \& N.L. Lopes 90 (SPF, SPFR); Serra da Canastra, estrada para Serra Negra, 20²1 $45,8^{\prime}$ S, 465 $4555,2^{`}$ W, 1012 m.a.m., 19.X.2002 (fl), M. Magenta \& J. Magenta 482 (SPF); Furnas, 100 m após a barragem, entrada para Fazenda Salto, 17.X.1997 (fl), F.B. Costa et al. 31 (SPFR); Barragem de Furnas, IX.1998, F.B. Costa 89 (SPFR); idem, ca. $200 \mathrm{~m}$ após a barragem, 6.IX.2000 (fl), F.B. Costa \& O. Spring 121 (SPFR);

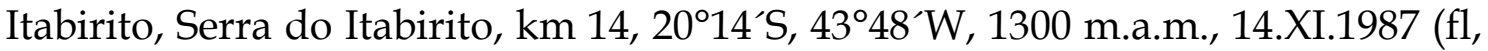
fr), R.F. Pinto s.n. (BHCB 11673); Serra do Itabirito, rodovia Belo Horizonte Itabirito km 14, 20² $14^{\prime} \mathrm{S}, 43^{\circ} 48^{\prime} \mathrm{W}$, 1300 m.a.m., 14.XI.1987 (fl), R.W. Kfuri s.n. (BHCB 11710); Itabirito, rodovia BR $040 \mathrm{~km} \mathrm{469,} \mathrm{sentido} \mathrm{Belo} \mathrm{Horizonte} \mathrm{-} \mathrm{Rio} \mathrm{de}$ Janeiro, 21.X.2002 (fl), M. Magenta \& J. Magenta 491 (SPF); Joaquim Felício, Serra do Cabral, 5.X.1995 (fl, fr), F.R.S. Pires et al. 515 (CESJ, SPF); Moeda, Serra da Moeda, 5.X.1985 (fl), M. Rezende \& T.S.M. Grandi 2140 (BHCB); idem, 5.VI.1988 (fl), A. Souza s.n. (BHCB 16059); Serra da Moeda, estrada que liga BR 040 a Moeda, ca. 2 km da BR, 12.X.1992 (fl), V.C. Souza \& C.M. Sakuragui 2062 (ESA); Nova Lima, Serra do Curral, no pico, 12.VIII.1955 (fl), L. Roth 1376 (CESJ, RB, SPF, UEC); estrada para Nova Lima, 18.XI.1980 (fl, fr), M. Imaculada et al. 483 
(BHCB); Morro do Chapéu, 22.VIII.1982 (fl), P.M. Andrade \& T.S.M. Grandi 1124

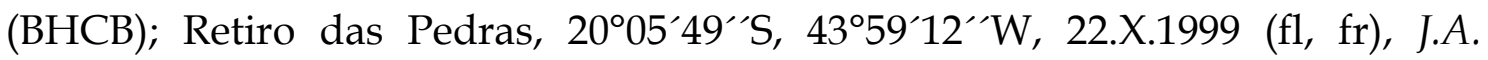
Lombardi 3324, 3332 (BHCB); Ouro Preto, rodovia BR 03, perto do desvio para Ouro Preto, 14.X.1962 (fl, fr), G.F.J. Pabst 7127 (RB); Passos, Rodovia Altino Arantes SP 351 km 318, sentido Passos - Capitólio, 20³907”'S, 46¹8`43”“W, 834 m.a.m., 20.X.2001 (fl, fr), M. Magenta \& J. Magenta 280 (K, SPF); Sacramento, Guarita de Sacramento, caminho para o Parque Nacional da Serra da Canastra, Córrego dos Coelhos, 23.IX.1996 (fl), R. Romero \& J.N. Nakajima 3655 (HUFU, SPF); São Roque de Minas, Parque Nacional da Serra da Canastra, 3 km da sede administrativa, topo do morro estrada para Sacramento, 16.IV.1994 (fl, fr), R. Romero et al. 900 (HUFU, SPF); idem, próximo à sede administrativa, 15.X.1994 (fl), J.N. Nakajima et al. 460 (F, HUFU, US); idem, Morro atrás do centro de visitantes, 25.IX.1995 (fl), J.N. Nakajima et al. 1340 (HUFU, SPF); estrada para a Cachoeira Casca D’Anta, 28.IX.1995 (fl), R. Romero et al. 2953 (HUFU, UEC); Parque Nacional da Serra Canastra, Cachoeira dos Rolinhos, 21.IX.1996 (fl), J.N. Nakajima \& R. Romero 2048 (HUFU); estrada São Roque - Sacramento, morro após a nascente do São Francisco, 20.VIII.1997 (fl, fr), J.N. Nakajima et al. 2678 (HUFU, SPF); Parque Nacional da Serra da Canastra, 6.IX.1997 (fl), F.B. Costa 21 (SPFR); idem, 6.IX.1997 (fl), F.B. Costa 23 (SPF, SPFR); Chapadão do Diamante, final da estrada para o parque, 15.X.1997 (fl, fr), J.N. Nakajima et al. 2849 (HUFU, SPF); Parque Nacional da Serra da Canastra, Cachoeira do Rolinho, 9.XI.2002 (fl, fr), A.F. Pontes et al. 559 (BHCB, CEN, NY, SPF,); idem, estrada que liga São Roque a Sacramento 2,5 km da portaria de São Roque, 20¹5`18,9`S, 46²5’01,4``W, 1305 m.a.m., 17.III.2003 (fl), M. Magenta \& J. Magenta 584 (SPF); São Sebastião do Paraíso, estrada Itamogi - São Sebastião km 10,5, 2058`53“S, 4658`52`W, 1000 m.a.m., 20.X.2001 (fl, fr), M. Magenta \& J. Magenta 277 (K, SPF); estrada que liga Monte Santo de Minas a Rodovia MG 050 km 11, 20²8`53,4`S, 4658`52,2`W, 997 m.a.m., 19.X.2002 (fl, fr), M. Magenta \& J. Magenta 481 (SPF); município indefinido, 1844 (fl), M. Weddell 1413, 1641 (P); Serra D'Ouro Branco, environs of Rio de Janeiro et D'Ouro Preto, $14^{\circ} 21^{\prime} \mathrm{S}$, 48²4`W, 1000 m.a.m., 11.XI.1884 (fl), A. Glaziou 15074 (K, P); Serra do Taboão, 2.XI.1981 (fl), A.B. Rocha 122 (RB); Serra da Moeda, 28.XI.1987 (fl), J.L.M. Wykrota 
\& J.M.P. Faria 72 (BHCB); Brésil, s.d. (fl, fr), A. Glaziou 19533 (P); Serra de Chrystaes, s.d. (fl), Pohl 576 d (P). São Paulo: Estreito, perto do Rio grande, Usina de Furnas, 6.XI.1997 (fl), W. Marcondes-Ferreira et al. 1509 (SP, UEC).

32. Viguiera trichophylla Dusén, Ark. Bot. 9(15): 30. 1910. Tipo: Im Camposgebiet, stets geselling wachsend, aber verhältnismässing selten; die Pflanze wurde in der Umgegend von Paraná, Ponta Grossa, [07.I.1904, Dusén] Nr. 3488, bei Serrinha und Guajuvira, in der Nähe von Curityba und zwischen Pinhaes und Piraquara gefunden. (holótipo: S!; fotografia do holótipo: F!, P!, SPF!; isótipos: BM!, K!, GH - frag., R!).

Figuras 3F, 6F e 38

Erva 1,2-2m alt., resinífera, ramos aéreos flexíveis, cilíndricos, estreitamente canaliculados, esparsamente setosos a estrigosos, entrenós 110mm compr.; caule subterrâneo fortemente espessado, raízes adventícias com tuberosidade fusiforme próximo a extremidade e às vezes também na porção central. Folhas alternas, ou basais às vezes aparentemente verticiladas, sésseis, lâminas inferiores $8-12 \times 0,5-0,8 \mathrm{~mm}$, lâminas superiores $50-85 \times 0,5-6 \mathrm{~mm}$, filiforme, inteira, uninervurada, fortemente revoluta, glabras. Inflorescência botrióide ou tirsóide laxa, 6-30cm alt., paracládios mais congestos próximo ao ápice, superiores terminando acima do capítulo terminal, terminais às vezes concrescidos em diferentes níveis, 1a ordem 2-35cm compr., 2a ordem raros, 47cm compr., cilíndricos a levemente tetragonais, canaliculados, glabros a esparsamente hispídulos, bracteolados, bractéolas foliáceas, sésseis, 2-5cm, pedúnculo terminal $7-15 \mathrm{~cm}$ compr. Capítulos 2,5-3,5cm diâm., radiados invólucro 8-12mm diâm., campanulado; brácteas involucrais levemente apressas na floração, 4 séries, linear a oval-lanceoladas, base canaliculada, 3 nervuras destacadas, foliáceas em $2 / 3$ superiores ou externas totalmente foliáceas, coriáceas, face adaxial glabra, face abaxial glabra a estrigilosa, esparsamente cilioladas, externas 4,5-5,5mm alt., reflexas na maturidade, 2a série 5-6,5 $\mathrm{mm}$ alt., 3a série 6-7 $\mathrm{mm}$ alt., e internas 5,5-9mm alt.,; receptáculo plano, páleas 4-5,5mm alt., oblongas a oval-oblongas, ápice arredondado a truncado, mucronado, 8 ou 10 nervuras, carena estrigosa na porção superior. 
Flores do raio (13-)18-20, em 1 verticilo, corola 12-20x-2,5-3,5mm, tubo 1-1,5mm alt., limbo estreitamente oblongo, estreitamente elíptico ou elíptico, ápice obtuso curtamente 2-partido, face adaxial glabra, nervuras 9-10, duas fracamente destacadas, esparsamente estrigosas na face abaxial tubo esparsamente estrigiloso; flores do disco 50-80, corola 4-4,2mm alt., tubo 0,5$0,9 \mathrm{~mm}$ alt., lobos com altura igual ou maior que o dobro da largura, face externa com base do limbo e tubo esparsamente estrigilosos, lobos glabros; anteras de base curtamente sagitada, terminando abaixo da base do colar filetal; base do estilete com alargamento semigloboso a cônico, estilopódio (0,10-)0,120,16x0,20-0,24mm. Cipselas 3,5-4mm alt., obovóides, levemente trígonas, às vezes comprimidas, estriadas, híspidas, carpopódio médio, pápus amarelado, 2-aristado, aristas levemente intramarginais, desiguais, unidas às escamas laterais, menor 1,5-2 mm alt., maior 2-3mm, triangulares, base muito alargada, páleas do pappus 3-4 pares, 0,4-0,6mm alt., unidas até a metade, ápice lacerado, ou sem escamas.

Viguiera trichophylla é uma planta resinífera que ocorre em campos e bordas de capões preferencialmente úmidos, do estado do Paraná, apenas na região de Curitiba (fig. 43A). Floresce e frutifica de fevereiro a março ou raramente até junho.

Espécie muito semelhante a $V$. filifolia, uma espécie de Minas Gerais e Goiás, da qual se diferencia por apresentar receptáculo plano, corolas tubulosas com lobos glabros e cipselas com 2 aristas de base alargada e escamas com 0,40,6mm. $V$. filifolia possui receptáculo levemente convexo, lobos das corolas do disco estrigilosos, cipselas com até 4 aristas estreitamente triangulares e escamas 1,5-2mm. Robinson \& Moore (2004) consideraram-na conspecífica com $V$. linearifolia sob o nome de Rhysolepis linearifolia (Cav.) H. Rob \& A.J. Moore, uma espécie sem dúvida proximamente relacionada, como visto no capítulo IV, mas com indumento lanoso na face abaxial foliar, nas brácteas involucrais e nas flores, quando em pré-antese. 


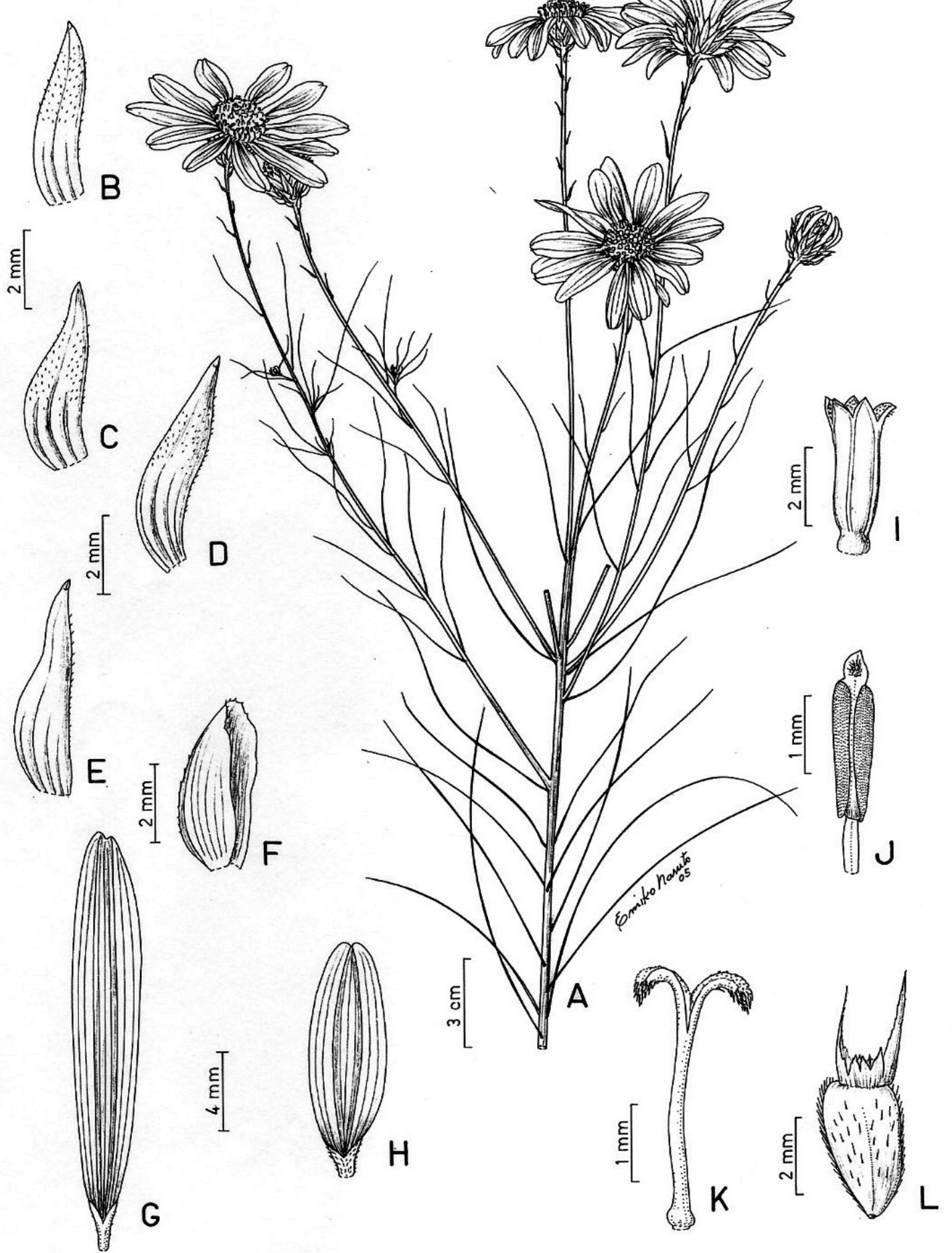

Fig. 38: V. trichophylla A. Segmento do ramo, B-E. Brácteas involucrais, E-F. Páleas do receptáculo, G-H. Corolas do raio, I. Corola do disco (notar lobos glabros), J. Antera com tecas de base curtamente sagitada, terminando levemente abaixo do colar filetal, K. Estilete com alargamento basal semigloboso, L. Cipsela. A-L. M. Magenta \& J. Magenta 424 (SPF). 
Material examinado: BRASIL: Paraná: Campo do Tenente, Ribeirão da Fazenda, 25.I.1968 (fl), G. Hatschbach 18445 (MBM); 14.III.1971 (fl), G. Hatschbach 26558 (MBM); Rio da Várzea, 20.IV.2000 (fl), E. Barbosa et al. 462 (MBM); rodovia BR 116 entre o Campo do Tenente e Quitandinha, 14.IV.2003 (fl, fr), M. Magenta \& L.R. Lima 623, 624 (SPF); Candói, município de Guarapuava, 25.II.1982 (fl), $R$. Kummrow \& J.G. Stuts 1818 (RB); Castro, Carambeí, Rio São João, 15.I.1965 (fl), G. Hatschbach et al. 12141 (K, MBM); Curitiba, 8.II.1946 (fl), F. Rawitscher s.n. (SPF 17033); 12.III.1947, E.A. Machado s.n. (RB 60199); Vale do Iguaçu, $15 \mathrm{~km}$ da cidade, 13.IV.1950 (fl, fr), G. Tessmann s.n. (MBM 5179, RB 70351); Rio Atuba, 30.I.1974 (fl), R. Kummrow 209 (MBM); Centro Politécnico, 8.IV.1981 (fl), N. Imaguire 5541 (MBM); setor de Ciências Biológicas da Universidade Federal do Paraná, 18.III.1982 (fl), N. Imaguire 5693 (MBM); Recanto das Araucárias, 9.XI.1987 (fl), J.M. Silva \& J. Cordeiro 416 (MBM); Recanto das Araucárias, 7.III.1991 (fl, fr), J. Cordeiro \& E. Barbosa 743 (HUEFS, CETEC, MBM); entre o

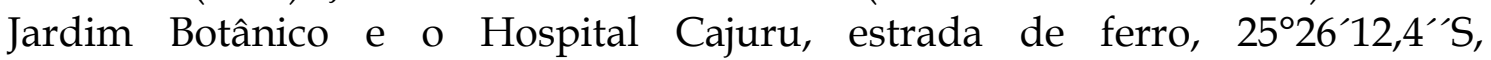

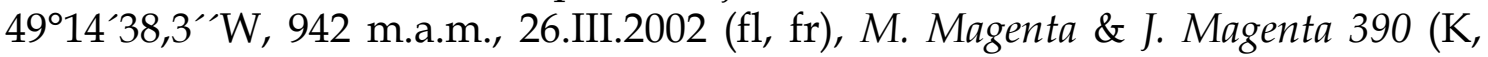
SPF, SPFR); Fazenda Rio Grande, rodovia BR116 km 121, Fazenda Rio Grande,

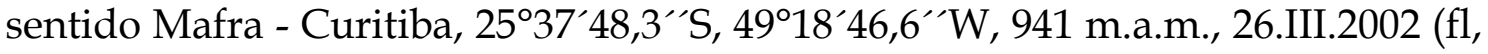
fr), M. Magenta \& J. Magenta 391 (SPF); rodovia BR $116 \mathrm{~km} \mathrm{125}$, sentido Curititba

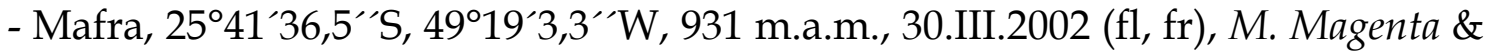
J. Magenta 424 (SPF); Jaguariaíva, 27.III.1974 (fl), R. Kummrow 445 (M, MBM); rodovia BR 151, próximo ao Rio Lambari, 24.IV.1988 (fl), G. Hatschbach \& J.M. Silva 51955 (MBM); Recanto Prainha, 10.II.1997 (fl), O.S. Ribas \& L.B.S. Pereira 1704 (MBM, PEL); 16.III.2000 (fl), M.D. Moraes 438 (SPF, UEC); rodovia PR 151 sentido Jaguaiaíva - Sengés, $24^{\circ} 12^{\prime} 07,4^{\prime \prime} \mathrm{S} 49^{\circ} 38^{\prime} 13^{\prime \prime} \mathrm{W}, 876$ m.a.m., 4.III.2003 (fl, fr), M. Magenta \& J. Magenta 561 (SPF); Lapa, Santa Bernardete, 5.III.1960 (fl), $R$. Braga \& R. Lange 253 (FUEL, HUEPG, HUM, RB); rodovia BR $476 \mathrm{~km}$ 214,

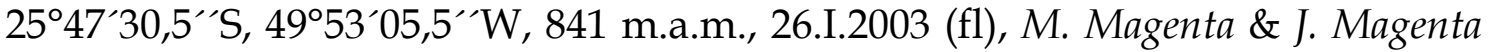
537 (SPF); Mandirituba, Rio Maurício, 23.II.1978 (fl), G. Hatschbach 41431 (CTES, MBM, UEC); Palmeira, 13.I.1988 (fl), L.T.H. Dombrowski 9399 (CTES, PKDC); Colonia Witmarsun, 20.IV.1994 (fl), A.C. Cervi et al. 4289 (MBM, UPCB); Córrego da Anta, 26.III.1984 (fl, fr), G. Hatschbach 47648 (CGMS, IPA, MBM, RB, UFMS); Piraquara, Barro Vermelho, 28.II.1946 (fl), G. Hatschbach 68 (MBM); Fazenda Experimental de Agronomia, Capão Gaiola, 17.III.1971 (fl), N. Imaguire 2587 (MBM); São Roque, 19.III.1985 (fl), J. Cordeiro \& P.I. Oliveira 11 (HRB, MBM); Piraí do Sul, Joaquim Murtinho, 21.III.1968 (fl), G. Hatschbach 18779 (MBM); idem, 8.III.1990 (fl), G. Hatschbach \& O.S. Ribas 54079 (K, MBM); Ponta Grossa, Vila Velha, 10.II.1960 (fl, fr), E. Pereira 5283 (RB); Parque Vila Velha, Arroio Quebra Perna, 805 m.a.m., 2.III.1962 (fl), G. Hatschbach 9024 (MBM); Vila Velha, 12.VI.1975, L.A. Arzivenco s.n. (ICN 42748); Buraco do Padre, 19.II.1995 (fl), H.F. de Oliveira s.n. (HUEPG 6535); Vila Velha, 31.I.1999 (fl, fr), I.J.M Takeda s.n. (HUEPG 9743); Porto Amazonas, 3.II.1982 (fl), P.I. Oliveira 344 (MA, MBM, UB); Rio Branco do Sul, Itapuruçu, 4.III.1959 (fl), G. Hatschbach 5533 (MBM); São José dos Pinhais, Rio Guamirim, 11.II.1978 (fl, fr), G. Hatschbach \& E. Zardini 40965 (MBM). Santa Catarina: Canoinhas, Três Barras, REGESA, 750 m.a.m., 5.I.1962 (fl), R. Reitz \& R. Klein 11535 (RB). São Paulo: município indefinido, Saint-Paul province, 1816-1821 (fl), A. St.-Hil. 1144 (P). 
33. Viguiera tuberosa Griseb. (Abh. Kön. Ges. Wiss. Gött. Phys. Cl. 24 (1): 192. 1879. (= Symb. Fl. Arg.: 192. 1879). Tipo: citado sob a var. tuberosa.

Figura 39

Ervas cespitosas a subarbustos, eretos a decumbentes, 0,4-1,5m alt., ramos aéreos cilíndricos, canaliculados, glabros ou com tricomas esparsos, entrenós 3-12cm compr.; caule subterrâneo levemente espessado, raízes tuberosidades globosas próximo à extremidade. Folhas discolores ou verdeclaras, medianas opostas, superiores e inferiores alternas, sésseis ou pecíolo 12mm compr.; lâmina 4-12x0,25-1,5cm, oblonga, estreitamente oblonga a oblongo-lanceolada ou elíptica a estreitamente elíptica, inteira, revoluta, base longamente atenuada, se peciolada decorrente, ápice agudo a acuminado, membranáceas, nervação imperfeita a perfeita, uma nervura principal, face adaxial estrigosa, tricomas tectores 2-celulares com bossas conspícuas, base estreitamente cilíndrica, leve a fortemente apressa, cercada por uma série de células, face abaxial serícea, tricomas tectores, 3-celulares, com bossas, base cilíndrica leve a fortemente apressa, cercada por uma série de células. Inflorescência botrióides ou capítulos solitários, paracládios delgados, os superiores terminando abaixo do capítulo terminal, $15-50 \mathrm{~cm}$ alt., canaliculados, com tricomas esparsos, bractéolas foliáceas; pedúnculo terminal $12-50 \mathrm{~cm}$ compr. Capítulos 3,5-4cm diâm., radiados, invólucro 9-10mm diâm., campanulado, brácteas involucrais levemente apressas na floração, 2-3 séries, estreitamente oval-lanceoladas a estreitamente lanceoladas, base fortemente canaliculada, 2 nervuras destacadas, foliáceas em 4/5 superiores, face adaxial com ápice esparsamente estrigiloso, face abaxial com base esparsamente estrigilosa, ápice foliáceo estrigoso, cilioladas, coriáceas, 1a série 4,5-10mm alt., 2a série 9-13mm alt., 3a série $8-15 \mathrm{~mm}$ alt.; receptáculo levemente convexo, páleas 7-9mm alt., estreitamente oblongas, ápice agudo, mucronulado, 8 ou 10 nervuras, estrigilosas, carena conspícua densamente estrigilosa. Flores do raio 10-14, em 1 verticilo, corola 12-25x3-4mm, tubo 1,8-2mm alt., limbo elíptico a oblongo, ápice obtuso, curtamente 2-3-partido, nervuras 10-12, esparsamente estrigilosas a esparsamente hispídulas, glândulas esparsas; flores do disco 5060, corola $5-6 \mathrm{~mm}$ alt., tubo ca. $1,2 \mathrm{~mm}$ alt., base do limbo e nervuras 
esparsamente estrigilosos, lobos densamente estrigilosos, tubo glabro ou com tricomas esparsos, antera de base sagitada terminando na base do colar filetal; estilete com alargamento basal semigloboso, estilopódio 0,12-0,18x0,25-0,20mm. Cipselas 5,5-7,5mm alt., estreitamente obovóides, trigonais, estreitamente estriadas, setosas a albo-seríceas, carpopódio médio, pápus amarelado, 2aristado, aristas intramarginais levemente desiguais, menor 2-2,5mm, maior 3$3,5 \mathrm{~mm}$ alt., estreitamente lanceoladas, base levemente alargada, ápice acuminado, nervura estrigilosa, escamas ca. 4 pares, 1,5-2mm alt., unidas até o ápice eroso.

Ocorre na Argentina, no Paraguai, no Uruguai e foi citada para o Brasil pela primeira vez por Mondin (2004) com base em coleta do Rio Grande do Sul e, neste trabalho, para os estados de Mato Grosso do Sul, Paraná e Santa Catarina.

Tradicionalmente eram consideradas duas espécies, mas Hassler (1916) percebeu que $V$. guaranitica distinguia-se apenas por uma variação morfológica das folhas; a observação de vários espécimes herborizados confirmou esta condição, que será adotada nestre trabalho. Divide várias características morfológicas (folhas de base atenuada, brácteas involucrais em duas a três séries, de formas similares e tamanhos diferentes e pápus com escamas totalmente unidas, entre outras) com V. aspilioides do Paraná, da qual emergiu como espécie-irmã nas 3 análises filogenéticas realizadas (capítulo IV) .

Nota nomenclatual: Os lectótipos foram eleitos com base na observação de imagens digitalizadas de exsicatas contendo etiquetas manuscritas pelos autores e provindas do herbário no qual eles tradicionalmente depositavam seu material, já que não há citação de herbário no protólogo dos táxons.

\section{Chave para as variedades de $V$. tuberosa}

1. Plantas com folhas oblongas a estreitamente oblongas

V. tuberosa var. tuberosa

1. Plantas com folhas elípticas estreitamente elípticas.

V. tuberosa var. guaranitica 
33.1. Viguiera tuberosa Griseb. var. tuberosa Hassler. Rhysolepis tuberosa (G Griseb.) H. Rob. \& A.J. Moore, Proc. Biol. Washington 117(7): 425. 2004. Tipo: [Argentina] E: en Concepción Del Uruguay [Quinta Del Colegio (BAF)\}, IV.1876 Lorentz 591 (lectótipo aqui designado: GOET* [312]; fotografia do lectótipo: F!, SPF!; isolectótipos: $\left.\mathrm{BAF}^{*}, \mathrm{GOET}^{*} 2 \mathrm{x}\right)$.

Viguiera tuberosa f. breviaristata Hassler, Repert. Sp. Nov. Regni Veg. 14: 275. 1916. Tipo: 'Paraguay: Hassler 4295*, Pl. Hassl. T. 164' (lectótipo aqui designado: $\mathrm{G}^{*}$; fotografia do lectótipo: SPF!; isolectótipo: $\mathrm{NY}^{*}$ ).

Viguiera tuberosa (Chodat) Hassler var. maxima Hassler, Repert. Sp. Nov. Regni Veg. 14: 275. 1916. Tipo: In campis rupestris Cordillera de Altos, Hassler 2080 (holótipo: $\mathrm{G}^{*}$; fotografia do holótipo: SPF!; isótipo: BM!).

Viguiera tuberosa (Chodat) Hassler var. maxima f. calvata Hassler, Repert. Sp. Nov. Regni Veg. 14: 275. 1916. Tipo: In campis rupestris Cordillera de Altos, 2080a (holótipo: G*; fotografia do holótipo: SPF!).

Figura 40

Material examinado: ARGENTINA: Chaco, Colonia Beniteg, II.1931 (fl), A.G. Schultz 188 (CTES, LP); Corrientes, Mburucuyá, Estancia Santa Tereza, 19.IV.1952 (fl), T.M. Petersen 1681 (P); Santo Tomé, 14.XI.1974 (fl), A. Schinini \& R. Carnevali 10457 (CTES, MBM); s.d. (fl), M.A. Bonpland 382 (P); Entre Rios, El Buete, próx. Paraná, 11.X.1927 (fl), J. Fuenguelli 26 (LP), idem, Concepción Del Uruguay. Quinta de Sagastume haufig Aug-Juni 1877, Lorentz 1027 (remanescente do síntipo original: GOET*); ídem, 10.1878, Lorentz 480 (remanescente do síntipo origina: K!). Paraná, verano,1929 (fl), J.F. Salellas 848 (LP); Federación Santa Ana, rio Uruguai, 24.IX.1961 (fl), A. Burkart 22775 (LP); La Paz, Santa Elena, Barranca del Paraná, 14.III.1962 (fl), A. Burkart et al. 23520 (LP); Paraná, Hernandarias, 17.V.1964 (fl), A. Burkart et al. 25543 (LP); [Entre Rios], [San Antonio de Padua de la] Concordia, IV.1908 (fl), Guiseb 16483 (LP); Santa Fe, 1905 (fl), Guiseb 16480 (LP). BRASIL: Mato Grosso do Sul: Aquidauana, km 48 da estrada de ferro, $5 . X I .1987$ (fl, fr), M. Sugiyama \& D.S. Pinto 139 (CGMS). Município indefinido, ponto 7, projeto RADAMBRASIL, Fazenda Congonha, 22.X.1980 (fl, fr), J.M. Pires \& P.P. Furtado 17241 (HRB, INPA, MG, RB). Paraná: Chopinzinho, Rio Iguaçu, Salto Santiago, 11.IV.1975 (fl, fr), G. Hatschbach 36635 (MBM). Rio Grande do Sul: Quaraí, Cerro do Jarau, 30¹1'22,5”S, 56²9’39,4”W, 247 m.a.m., 12.IV.2003 (fl, fr), M. Magenta et al. 600, 603 (SPF). PARAGUAI: [Alto Paraguai], Vista Alegre, I.1922 (fl), E. Rojas 4226

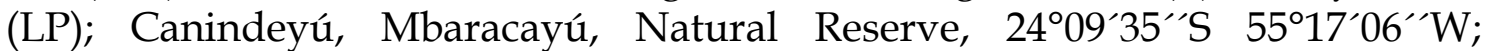
24.IX.1999 (fl, fr), E.M. Zardini \& S.R. Benitez 51429 (AS, K, MO, SPF); Concepcíon, próx. Sarg. José E. Lopes (Pirentecino), 22²2`58“S 5653`50”W; 16.I.2000, E.M. Zardini \& L. Guerrero 53982 (AS, K, MO, SPF); departamento

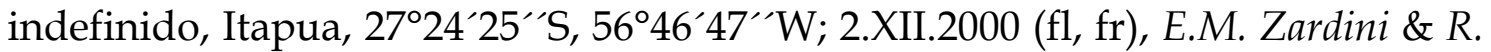


Gamarra 55618 (AS, K, MO, SPF); in campo, in regionis fluminis Tapiraguay, s.d. (fl), E. Hassler 4295 (P), E. Hassler 5459 (remanescente do sintipo original de $V$. tuberosa f. breviaristata: G, NY). URUGUAI: departamento indefinido, Concepción del Uruguay, X.1878 (fl), P. Lorentz 581 (M).

33.2 Viguiera tuberosa var. guaranitica (Chodat) Hassler. Viguiera guaranitica Chodat, Bull. Herb. Boissier ser. 2 (3): 724. 1903. Tipo: Paraguai, ad marginem silvae in regione cursus superioreis fluminis Apa, 1901-02, Hassler 7667 (lectótipo aqui designado: $\mathrm{G}^{*}$; isolectótipos: : BM!, frag. GH).

Viguiera tuberosa var. guaranitica (Chodat) Hassler f. angustifolia Hassler, Repert. Sp. Nov. Regni Veg. 14: 275. 1916. Tipo: Paraguay: Hassler 8349 1.c. [lectótipo aqui designado: $\mathrm{G}^{*}$; isolectótipos: $\mathrm{BM} !, \mathrm{NY}$ ].

Viguiera tuberosa var. guaranitica (Chodat) Hassler f. major Hassler, Repert. Sp. Nov. Regni Veg. 14: 275. 1916: 276. Tipo: 'Paraguay: Hassler 7667 (lectótipo aqui designado: $\mathrm{G}^{*}$; isolectótipo: BM!)

Viguiera tuberosa var. guaranitica (Chodat) Hassler f. scaberula Hassler, Repert. Sp. Nov. Regni Veg. 14: 275. 1916: 276. Tipo: 'Paraguay: Caballero cué, Fiebrig no 4844' (holótipo: $\mathrm{G}^{*}$ ).

Material examinado: ARGENTINA: Chaco, El Guayule, 28.X.1959 (fl), A.G. Schultz 10741 (CTES); Corrientes, Santo Tomé, Estancia Garruchos, 6.II.1972 (fl), A. Krapovickas et al. 21089 (CTES); Formosa, Patinõ, Ruta 81, 15 Km NW de Las Lomitas, 26.XI.1994 (fl), A. Krapovickas \& C.L. Cristóbal 46413 (CTES); Misiones, Canonelaria, Picda San Martin, 16.IV.1947, G.J. Sehwarz 4492 (R); San Ignácio, Santo Pipo, 4.XI.1947 (fl), G.J. Sehwarz 5100 (LP). BRASIL: Rio Grande do Sul: Manoel Viana, Cerro do Negro, 16.XI.2002 (fl), C. Mondin \& A. Iob 2825 (HASU, SPF); Santana do Livramento, Cerro Paloma, 2.III.2002 (fl), C. Mondin \& A. Iob

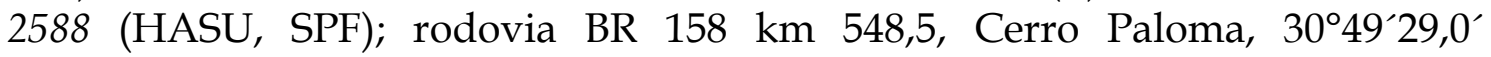
55²0`54,0`W, 132 m.a.m., 23.I.2003 (fl), M. Magenta \& C. Mondin 512 (SPF); Cerro Paloma, acesso pela Rodovia BR 158 km 458,5, 3049'29,0“'s, 55²0`54,0`W, 132 m.a.m., 13.IV.2003 (fl, fr), M. Magenta et al. 604, 606 (SPF). Santa Catarina: Capinzal, estrada de Capinzal, 700 m.a.m., 30.X.1963 (fl), R. Klein 4297 (RB). PARAGUAI: San Pedro, Primavera, Alto Paraguai, 10.XII.1956 (fl), A.L. Woclston 766 (SP, SPF), Hassler 6970 (remanescente do sintipo de V. tuberosa var. guaranitica (Chodat) Hassler f. major: $\mathrm{G}^{*}$ ); Gran Chaco: In campis siccis pr. Santa Rita, Hassler no 2652 [remanescente do sintipo de $V$. tuberosa var. guaranitica (Chodat) Hassler f. major: $\mathrm{G}^{*}$ ]; ídem, cum $2552 a$ lecta' [remanescente do sintipo de $V$. tuberosa var. guaranitica (Chodat) Hassler f. major: G*]. [PARAGUAI] In campo pr. Valenzuela, Jan. Hassler 8970 (remanescente do sintipo original de V. guaranitica: $\mathrm{G}^{*}$ ) ; idem, jan. 1902, Hassler 8349 (remanescente do sintipo de V. guaranitica : BM!, G*); Fiebrig sine scheda S. 55 in Herb. Hassler [remanescente do sintipo original de $V$. tuberosa var. guaranítica $\mathrm{f}$. angustifolia: G*]. Gran Chaco: Hassler $2652 a$ (remanescente do sintipo original de $V$. tuberosa var. guaranítica f. angustifolia: $\mathrm{G}^{*}$ ). Chaco austral. Flossdorf $\mathrm{n}^{\circ} 151$ remanescente do sintipo original de $V$. tuberosa var. guaranítica $\mathrm{f}$. angustifolia: $\mathrm{G}^{*}$ ). departamento indefinido, 1897 (fl, fr), E. Hassler 2080 (BM); Santa Elisa, 23이'S; 1903 (fl), E. Hassler 2652 (BM). 


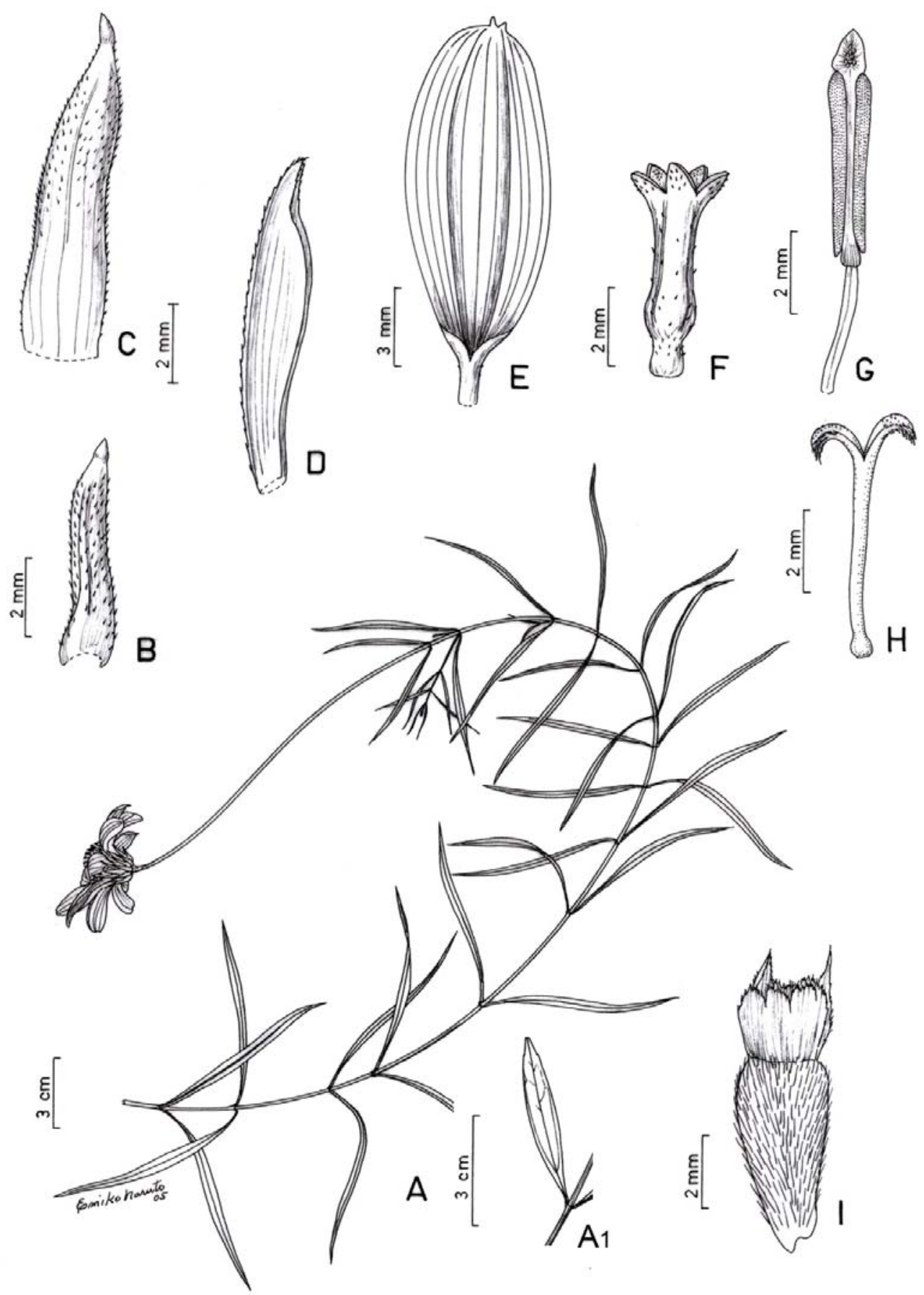

Fig. 39: V. tuberosa. A. Ramo com capítulo solitário, A1. Variedade guaranítica, segmento do ramo B-C. Brácteas involucrais, D. Pálea do receptáculo, E. Corola do raio, F. Corola do disco, G. Antera com tecas de base curtamente sagitada, terminando acima da base do colar filetal, H. Estilete com alargamento basal semigloboso, I. Cipsela com escamas do pápus unidas. A. M. Magenta et al. 600 (SPF), A1. Idem 604 (SPF). 
34. Viguiera veredensis Magenta, sp. nov. Tipo: Brasil. Minas Gerais. Chapada Gaúcha. Parque Nacional Grande Sertão Veredas, estrada que liga Chapada Gaúcha a Formoso, 15²2`49,9`S, 4556’18,1“W, 879 m.a.m., 21.IV.2003, M. Magenta \& J. Magenta 664 (holótipo: SPF!; isótipo: K!).

Figuras 3D, 6D e 40

Erva a subarbusto $1-1,5 \mathrm{~mm}$ alt., ramos aéreos levemente vináceos, eretos, cilíndricos, canaliculados, densamente híspidos, entrenós 1,5-3,5cm compr.; caule subterrâneo pouco espessado, raízes adventícias sem tuberosidade ou com leve espessamento uniforme. Folhas levemente discolores, basais e superiores alternas, medianas opostas, sésseis ou pecíolo 1-2mm compr.; lâmina 2,5-10x1-3cm, oblonga a oval, base levemente arredondada, ápice agudo, mucronulado, esparsamente denteada ou serreada na porção superior, cartáceas, nervação acródroma basal a suprabasal perfeita, 3 nervuras principais, face adaxial híspida, tricomas tectores 3-celulares sem bossas ou com bossas inconspícuas, base cilíndrica a levemente cônica, às vezes levemente adpressa, cercada por 2-3 séries de células, face abaxial vilosa e com tricomas glandulares diminutos na nervação terciária, tricomas tectores 3-celulares, com bossas inconspícuas, base cônica, cercada por 2-3 séries de células. Inflorescência botrióide ou tirsóide, $25-55 \mathrm{~cm}$ alt., paracládios eretos, superiores terminando acima do capítulo terminal, 13-22 cm compr., poligonais, canaliculados, esparsamente hirsutos, bractéolas opostas foliáceas esparsas; pedúnculo terminal 9-25cm compr.; Capítulos 1,5-2cm diâm., radiados, invólucro 10-12mm diâm., largamente campanulado a semigloboso, brácteas involucrais apressas na floração, 3 séries, base canaliculada com 3 nervuras destacadas, imersas, ápice obtuso, conspicuamente mucronado, inteiramente foliáceas, cartáceas, duas séries externas com porção inferior ciliolada e porção superior ciliada, face adaxial com ápice esparsamente estrigiloso, face abaxial albo-estrigosa, especialmente na porção superior, 1a série 3-5mm alt., oblongas a ovais, 2a série $4-6 \mathrm{~mm}$ alt., ovais a largamente ovais, 3a série $4-8 \mathrm{~mm}$ alt., obovais a ovais, cilioladas, porção superior estrigosa; receptáculo convexo; páleas 6-7mm alt., oblongas, hialina, ápice truncado, eroso, 6 ou 8 nervuras, 
escariosas, carena estreita e porção superior estrigilosas. Flores do raio 11-12, em 1 verticilo, tubo ca. $1 \mathrm{~mm}$ alt., corola $6-7 \times 2,8-3 \mathrm{~mm}$, limbo oblongo, ápice arredondado, emarginado, face adaxial glabra, face abaxial com glândulas, ca. 10 nervuras hispídulas; flores do disco ca. 70 , corola $4,5-5 \mathrm{~mm}$ alt., tubo ca. $1 \mathrm{~mm}$ alt., face externa com lobos esparsamente hispídulos; antera de base curtamente sagitada, terminando acima da base do colar filetal; estilete sem alargamento, estilopódio ca. 0,1mmx0,36mm. Cipselas jovens 3,5-5mm alt., obovóides, estriadas, dourado-seríceas, carpopódio médio, pápus estramíneo 2-aristado, aristas marginais levemente desiguais, 1,3-1,4mm, livres, margem e nervura estrigosas, escamas 6-7 pares, 0,5-1mm alt., unidas até próximo ao ápice lacerado.

Aparentemente rara, é encontrada de forma isolada no norte de Minas Gerais e no Sul da Bahia (fig. 46 B), em cerrado típico com solo arenoso, com flores em abril e maio e frutos em maio.

Espécie morfologicamente próxima de $V$. robusta, mas dela se diferencia pelas folhas cartáceas com face adaxial híspida, pelo pedúnculo terminal da inflorescência alongado, com $9-25 \mathrm{~cm}$, brácteas involucrais com indumento esbranquiçado e flores menores, do raio com corola de $6-7 \mathrm{~mm}$ de comprimento. $V$. robusta possui folhas coriáceas com face adaxial estrigosa ou raramente setosa, pedúnculo terminal com $1-5 \mathrm{~cm}$, brácteas involucrais com indumento cinéreo e flores do raio com 8,5-12mm de comprimento.

Material examinado: BRASIL: Bahia: Cocos, Fazenda Trijunção, próximo ao Lago Grande, $14^{\circ} 46^{\prime} 37^{\prime \prime} \mathrm{S}, 45^{\circ} 56^{\prime} 45^{\prime \prime} \mathrm{W}, 830$ m.a.m., 15.V.2001 (fl, fr), R.C. Mendonça et al. 4277 (HEPH, IBGE, US); Cocos, idem, área de Santa Luzia,

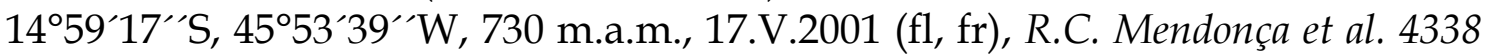
(HEPH, IBGE, RB, US). Minas Gerais: Chapada Gaúcha, Parque Nacional Grande Sertão Veredas, 15¹9`56“'S, 4559'00"W, 29.IV.1999 (fl), R. Rodrigues-daSilva et al. 243 (parátipo: HEPH, IBGE, US); idem, estrada que liga Chapada

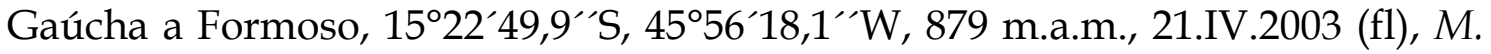
Magenta \& J. Magenta 665 (parátipo: SPF). 

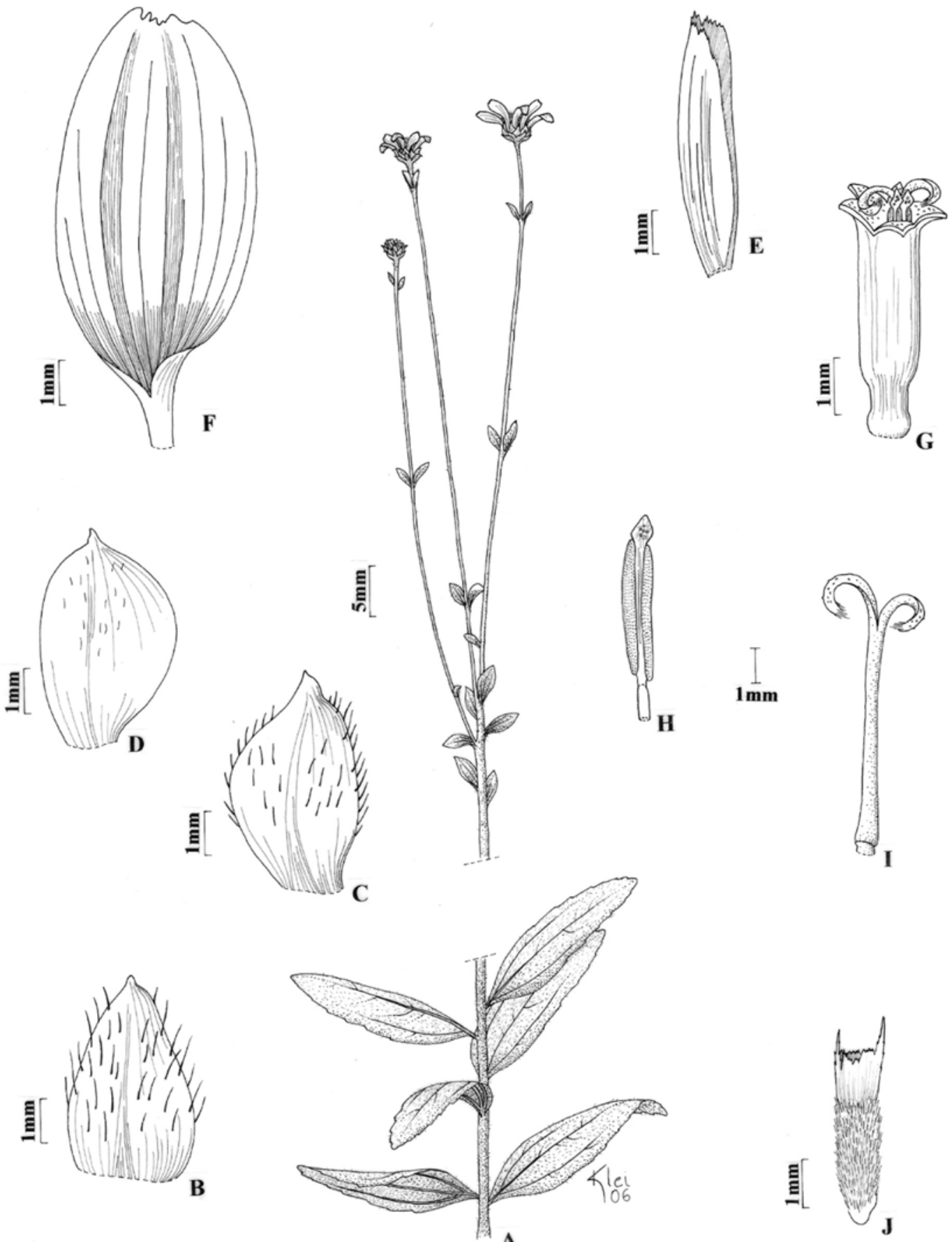

Fig 40: V. veredensis. A. Segmentos de ramo e inflorescência, B- D. Brácteas involucrais', E. Pálea do receptáculo, F. Corola do raio, H. Corola do disco, H. Antera com tecas de base curtamente sagitada, terminando acima da base do colar filetal, I. Estilete com base sem alargamento basal. J. Cipsela serícea A-J. M. Magenta \& J. Magenta 664 (SPF). 
35. Viguiera vernonioides Baker in Mart. Fl. bras. 6(3): 223.1884. Tipo: Habitat in Prov. Mato Grosso, Prope Pouso Alto in via ad urben Cuyabá, s.d., Manso n. 216 (holótipo: BR!; fotografia do holótipo: K!, SPF!).

Viguiera hypoleuca S.F. Blake, Contr. Gray Herb. 54: 165.1918. Tipo: Brasil,

Matto Grosso, sandy rather grassy open place, Buriti, near Santa Anna da Chapada, sandy rather grassy open places 3.June.1884, Malme 1658 (lectótipo aqui designado: BM!; fotografia do lectótipo: K!, SPF!, US!; isolectótipos: GH frag., R!), syn. nov.

\section{Figura 41}

Arbusto resinífero 0,5-2m alt., ramos aéreos eretos, cilíndricos, estreitamente canaliculados, setosos; entrenós 1-3cm; caule subterrâneo levemente espessado, raízes adventícias sem tuberosidades ou com tuberosidade suave uniforme. Folhas geralmente discolores, às vezes verde-claras, alternas, pecíolo 1-2mm compr., lâmina 3-9x0,7-2cm, oblonga, largamente oblonga, oblongo-lanceolada ou oval-lanceolada, base arredondada a obtusa; às vezes levemente auriculada; ápice agudo ou raramente obtuso, mucronado; inteira ou raramente esparsamente denteada na porção superior, nervação acródoma basal perfeita, 3-5 nervuras principais, cartácea; face adaxial com nervuras imersas, esparsamente estrigilosa a estrigosa ou esparsamente híspida, tricomas tectores 3-celulares, com bossas inconspícuas, base cônica ou cilíndrica, cercada por 1-2 séries de células; face abaxial com nervuras proeminentes, vilosa, tricomas tectores 5-celulares, base cilíndrica e tricomas glandulares. Inflorescência botrióide, 4-42 $\mathrm{cm}$ alt., paracládios eretos, superiores terminando acima do capítulo terminal, ou raramente próximo a ele, canaliculados, híspidos, com bractéolas foliáceas esparsas, tomentosos próximo ao capítulo; 1a ordem 8$30 \mathrm{~cm}$ compr.; 2a ordem 2-12cm compr.; 3a ordem 0,5-12cm compr.; pedúnculo terminal 0,5-7cm compr. Capítulos 1,5-2cm diâm., radiados, invólucro 7-12mm diâm., campanulado, subtendido por 1-2 bractéolas foliáceas 5-10mm; brácteas involucrais levemente apressas na floração, 3(-4) séries, oblongas a lanceoladas, base canaliculada, 3 nervuras destacadas, foliáceas em 1/3 superior, ápice agudo mucronado, esparsamente ciliadas, coriáceas, 1a série 4-5mm, face abaxial com ápice glabro a tomentoso; demais com ápice esparsamente 
estrigoso a estrigoso, 2a série 5-8mm, 3a e 4a séries 6-9mm; receptáculo levemente convexo, páleas 6-6,5mm, obovais, parte superior geralmente expandida, ápice truncado, arredondado ou agudo, denteado, mucronado, 8, 10 ou 12 nervuras, às vezes vináceas, estrigilosas,. Flores do raio ca. 8, em 1 verticilo, corola 6-10×2-2,5mm, tubo $0,6-0,8 \mathrm{~mm}$ alt., limbo oblongo, ápice inteiro a emarginado, ca. 2mm, face adaxial glabra, face abaxial com 10-11 nervuras pubescentes, 2 destacadas; tubo ca. 0,8mm alt., esparsamente pubescente; flores do disco 45-85, corola 4-4,5mm alt., tubo 0,8-1mm alt., limbo campanulado, lobos com altura igual ou maior que o dobro da largura, face externa com tubo e nervuras glabros a pubescentes, lobos glabros; antera de base curtamente sagitada, terminando na base do colar filetal ou abaixo, estilete com alargamento basal levemente cônico, estilopódio 0,12-0,16x0,30-0,36mm. Cipselas ca. 3,5mm alt., estreitamente obovóides, estreitamente estriadas, parcial ou totalmente seríceas, carpopódio médio, pápus vináceo na maturidade, aristas marginais (1-)2, desiguais, menor 2-2,5mm alt., maior 2,5-3mm alt., livres, firmes, triangulares, base geralmente expandida, porção superior estreita, margem e ápice hispídulos, escamas ca. 3 pares, 0,6-11mm alt. alt., unidas até o ápice lacerado ou próximo dele.

Planta resinífera que ocorre apenas no sul do Mato Grosso, na Chapada dos Guimarães e suas proximidades (fig. 44A). Coletada com flores e frutos em maio e junho.

Espécie muito semelhante a $V$. gardneri, difere desta por apresentar folhas geralmente oblongo-lanceoladas e inteiras, a maioria dos capítulos com apenas três séries de brácteas involucrais, flores menores e em menor número (ver comentários de $V$. gardneri), ausência de tricomas nos lobos das flores, anteras terminando na base do colar filetal ou abaixo e pelas raízes adventícias sem tuberosidade.

O material depositado no $\mathrm{BM}$ foi escolhido como lectótipo de $V$. hypoleuca por conter a etiqueta manuscrita por Blake. 

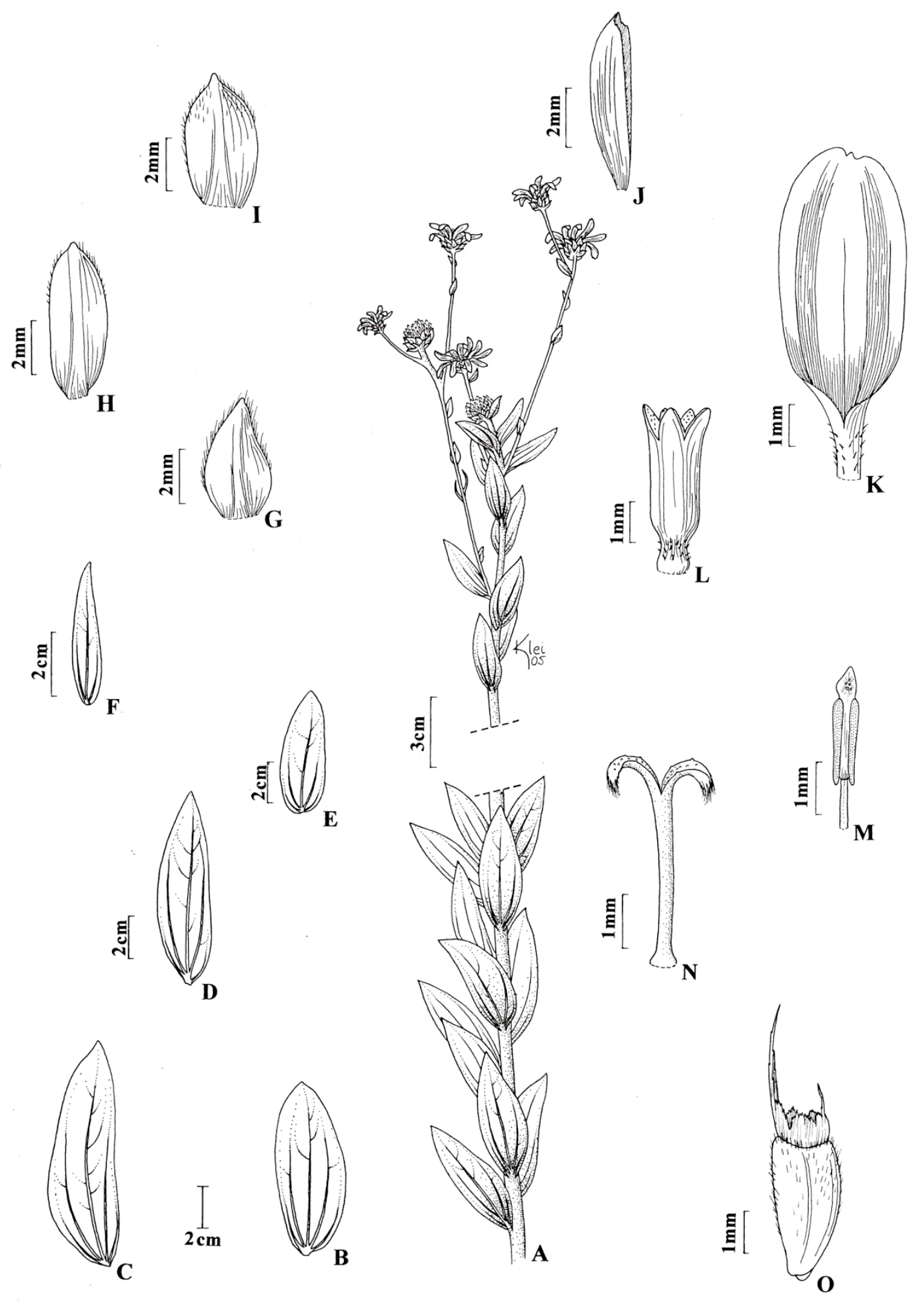

Fig. 41: V. vernonioides. A. Segmento de ramo com sinflorescência, B-F. Folhas, variação da forma. G-I. Brácteas involucrais, J. Pálea do receptáculo, K. Corola do raio, L. Corola do disco (notar lobos glabros), M. Antera com tecas de base curtamente sagitada, terminando abaixo da base do colar filetal, N. Estilete com alargamento basal cônico, O. Cipsela com escamas do pápus unidas. A. G. Hatscbach 62800 (MBM), B-O. M. Magenta \& J. Magenta 690 (SPF). 
Material examinado: BRASIL: Mato Grosso: Buriti, Province Santa Anna da Chapada, 3.VI.1894 (fl, fr), G.O.A. Malme 1658 (BM, R); Chapada dos Guimarães, Santa Ana da Chapada, 8.VI.1903, G.O.A. Malme 3325-A (R, UFMT); Cachoeira Véu de Noiva, 15.V.1997, F.E.F. de Souza 4 (UFMT); Diamantino, 42 km de Diamantino, em direção a Nobres, Serra do Tombador, $14^{\circ} 37^{\prime} \mathrm{S}, 5^{\circ} 15^{\prime} \mathrm{W}$, 400 m.a.m., 17.V.1997 (fr), V.C. Souza et al. 16024 (ESA); 20 km S de Diamantino, 14³2’S, 56¹8’W, 23.V.1997 (fl, fr), V.C. Souza et al. 16999 (ESA); Jaciara, rodovia BR 163 km 319, 15.V.1995 (fl, fr), G. Hatschbach et al. 62800 (K, MBM); São Vicente, São José da Serra, rodovia BR 364 km 319, entre Jaciara e São Vicente,

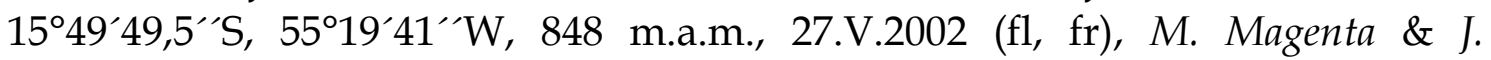
Magenta 460 (SPF).

\section{Informações adicionais}

Possíveis híbridos entre $V$. anchusifolia e $V$. pilosa

Dois diferentes fenótipos apresentando características intermediárias entre $V$. anchusifolia (DC.) Baker e V.pilosa Baker foram detectados e deverão ser analisados futuramente, à luz de evidências citogenéticas e por meio de experimentos de hibridação induzida, com uso métodos estatísticos. Morfologicamente diferenciam-se pela forma das folhas e os espécimes são listados abaixo:

\section{Provável híbrido 1}

Plantas com menos de 1m; folhas oblongas com até $10 \mathrm{~cm}$ compr.

Material examinado: BRASIL: Rio Grande do Sul: Caçapava do Sul, rodovia BR 290, sentido Caçapava do Sul - Santana do Livramento, 30²1`46,9”S, 5326’27,3”W, 239 m.a.m., 23.I.2003 (fl, fr), M. Magenta \& C. Mondin 506 (SPF); rodovia BR $290 \mathrm{~km} \mathrm{327,7,} \mathrm{sentido} \mathrm{Caçapava} \mathrm{do} \mathrm{Sul} \mathrm{-} \mathrm{Santana}$

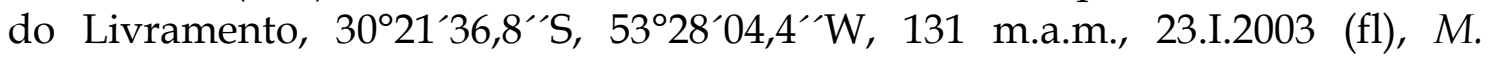
Magenta \& C. Mondin 507 (SPF); Eldorado do Sul, rodovia BR 290, sentido Eldorado do Sul - Arroio dos Ratos, 3004`43,2”S, 51³5’51,6”W, 82 m.a.m., 21.I.2003 (fl, fr), M. Magenta \& C. Mondin 499 (SPF); Osório, rodovia BR 101 km 90 sentido Osório - Capão da Canoa, região da Lagoa dos Quadros,

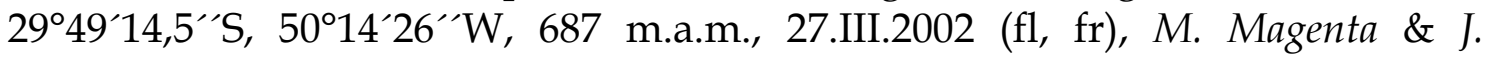
Magenta 409 (K, SPF); Santo Antônio da Patrulha, na saída da cidade, 1.XII.2002 (fl), C. Mondin 2852 (HASU, SPF).

\section{Provável híbrido 2}

Plantas com 1-2,5m; folhas deltóides com até 6cm compr.

Material examinado: BRASIL: Rio Grande do Sul: Alegrete, Durasnal, rodovia BR 290 km 214, 25.III.1976 (fl), N.I. Matzenbacher 480 (ICN); Cachoeira 
do Sul, rodovia BR 290, 13.XII.2002 (fl), C. Mondin 2860 (HASU, SPF); rodovia BR 290 km 159,5, sentido Arroio dos Ratos - Caçapava do Sul, 30²0`11,1”S, 53¹8`35,2`W, 208 m.a.m., 12.IV.2003 (fl, fr), M. Magenta et al. 598 (K, SPF); Pelotas, Instituto Agronomico do Sul, 24.III.1955 (fl, fr), J.C. Sacco 348 (PACA, PEL, R, RB); Encruzilhada, 9.III.1956 (fl), J.C. Sacco 590 (PACA, PEL); Porto Alegre, Bairro Boa Vista, 14.IV.2002 (fl, fr), C. Mondin 2646 (HASU, SPF); Santana do Livramento, 26.III.1976 (fl, fr), N.I. Matzenbacher s.n. (RB 174261); Cerro Armour, 2.III.2002 (fl), C. Mondin \& A. Iob 2568 (HASU, SPF); rodovia BR 158 km 548,5, Cerro Paloma, 3053`27,0”`S, 55²8`47,0”W, 90 m.a.m., 23.I.2003 (fl, fr), M. Magenta \& C. Mondin 514 (SPF); Cerro Armour, 3053’29,1”S, 55²8`36,1”W, 217 m.a.m., 23.I.2003 (fl), M. Magenta \& C. Mondin 515 (SPF).

Embora o contingente de espécimes examinados aqui especulativamente tratados como híbridos possa parecer grande, não se considerou a hipótese de sinonimizar $V$. anchusifolia e $V$. pilosa pelas seguintes razões:

a) o volume de espécimes claramente atribuíveis a cada uma das 2 espécies aqui aceitas é muito superior, e procedente de áreas diversas, denotando populações bem estabelecidas por área geográfica mais ampla.

b) as plantas híbridas são todas oriundas de uma área mais restrita, onde o contato das 2 espécies pode ser mais próximo.

c) esse fato mais pontual acima (b) não justificaria a fusão dos fenótipos bem caracterizados; ao contrário, essa conduta representaria perda de informação morfológica e geográfica (conhecimento bem estabelecido, expresso nas duas espécies distintas).

\section{$\underline{\text { Táxons duvidosos }}$}

$V$. coraniana Sáenz: provavelmente $V$. fusiformis S.F. Blake.

$V$. dillonorum H. Rob.: provavelmente $V$. szyszylowiczii Hieron.

V. emaciata H. Rob \& A.J. More: provavelmente $V$. fusiformis S.F. Blake.

V. macbridei S.F Blake : provavelmente V. atacamensis Phil.

V. bishopii H. Rob.: provavelmente V. lanceolata Britton.

$V$. misionensis Saénz: citada por Robinson \& Moore (2004) como sinônimo de $V$. pilosa; não foi possível observar o material tipo dessa espécie e a ilustração de Saénz (1979) parece representar um dos possíveis híbridos entre $V$. anchusifolia e V. pilosa. 
V. pusilla (Gray) A. F. Blake: provavelmente V. simsioides S.F. Blake.

\section{Esclarecimento}

Dois espécimes do Brasil foram tratados erroneamente por Glaziou como Viguiera (e descritos em obra inválida) e estão depositados no herbário P:

1. V. angustifolia Glaziou, Bull. Soc. Bot. Fr. 47. Mém. 3n . 412: 1910. nom. nud. (Glaziou 21603). Trata-se de um representante do gênero Vernonia Schreb.

2. V. glaucescens Glaziou, Bull. Soc. Bot. Fr. 47. Mém. 3. 412: 1910. nom. nud. (Glaziou 21562): Esta planta pertence ao gênero Calea L.

\section{$\underline{\text { Discussão e conclusões }}$}

As investigações sobre a morfologia do gênero Viguiera efetuadas neste capítulo e nos estudos filogenéticos (capítulo IV) apontam para provável polifiletismo do gênero. A espécie típica, V. dentata (Cav.) Spreng., mostra-se proximamente relacionada aos demais representantes da série Dentatae (Bahiopsis e V. potosina), diferenciando-se das espécies do Hemisfério Sul principalmente pela presença indumento denso-viloso na base do limbo da corola das flores do disco e de longos tricomas da face posterior da porção apical do filete da antera. $\mathrm{O}$ estudo proveu a identificação de várias similaridades entre as espécies sul-americanas e alguns representantes da seção Leighia e das séries mexicanas Grammatoglossae (exceto V. grammatoglossa) e Brevifoliae ( $V$. bicolor e $V$. brevifolia), esta já elevada ao gênero Calanticaria (Schilling \& Panero 2002), e constituída por arbustos muito ramificados, com paracládios lenhosos, característica por sua vez encontrada em Pappobolus, um gênero endêmico dos Andes, que possui cipselas com pápus decíduo, e que foi excluído de Helianthus (Panero 1992) por apresentar hábito lenhoso, chegando a arborescente. Pappobolus compartilha com V. grammatoglossa e espécies relacionadas (todas com hábito lenhoso e folhas opostas de base cordada) a posse de pilosidade densamente velutino-serícea nos órgãos vegetativos e, com 
as espécies andinas de Viguiera, o pápus decíduo. Segundo Panero (1992), é o único gênero da subtribo Helianthinae a alcançar regiões acima de 3000 metros de altitude. Durante o levantamento efetuado nos herbários para este trabalho, no entanto, foram encontrados registros de ocorrência de $V$. fusiformis, $V$. lanceolata, $V$. revoluta, $V$. procumbens e $V$. szyszylowiczii em altitudes que ultrapassam $3500 \mathrm{~m}$. Schilling (com pess.) aventou a possibilidade de uma relação mais próxima entre o gênero Pappobolus e as Viguiera da América do Sul do que entre estas e as do Hemisfério Norte. Numa análise filogenética com base em cpDNA, de Schilling e Panero (1996) representantes de Viguiera sect. Leighia e sér. Grammatoglossae emergiram, juntamente com Tithonia, como irmãos da seção Paradosa, à qual pertence a maioria das espécies sul-americanas; um resultado semelhante foi obtido a partir da análise de seqüências de ITS, incluindo espécies de Simsia e Pappobolus (Schilling et al. 2000) na qual V. flava (subg. Amphilepis), uma espécie herbácea epaposa despontou junto às plantas andinas, num clado-irmão do clado das espécies da Região Neotropical. A correlação entre as plantas dos dois Hemisférios implica uma distribuição disjunta, já que não ocorrem numa faixa que se estende da Nicarágua à Colômbia, onde só é encontrado o gênero Hymenostephium, antes pertencente à seção Diplostichis, e que tem folhas membranáceas com ápice acuminado, sem glândulas, receptáculo com páleas de ápice pungente ou com acúmen e cipselas com indumento hialino, além de números de cromossomos n= 12, 21 e 42 (Watanabe 2005), características não encontradas em Viguiera da América do Sul. Assim como esses trabalhos anteriores, os presentes estudos morfológicos não ofereceram suporte para o tratamento de Blake (1918) que inclui as espécies brasileiras nas seções Trichophylla e Paradosa ou para sua divisão em séries. A única delimitação possível parece ser condicionada pela distribuição geográfica, de acordo com o sistema de Morrone (1999) e existe entre as espécies da Região Andina, distribuídas nas sub-regiões Páramo-punenha, Chilena Central e Patagônica, que apresentam flores do disco tubulosas, cipselas com pápus facilmente destacável e das espécies enquadradas na Região Neotropical, das Subregiões Amazônica (Províncias de Yungas e do Pantanal), Chaquenha 
(Províncias Chaquenha, do Monte, Pampeana e do Cerrado) e Paranaense (Província Paranense), com flores tubuloso-campanuladase pápus persistente.

Tampouco houve respaldo para a decisão de Robinson \& Moore (2004), de transferir as espécies sul-americanas para o gênero da América Central Rhysolepis S.F. Blake, que exibe páleas do receptáculo (ao menos as periféricas das flores do disco) largamente bojosas e transversalmente corrugadas e cipselas das flores da periferia do disco fortemente assimétricas com carpopódio unilateral e pápus facilmente destacável, características compartilhadas com Aldama, também da América Central e aparentemente conspecífico. Visto que as diferenças entre $V$. dentata, Aldama (incluindo Rhysolepis) e as espécies sul-americanas também foram evidenciadas por trabalhos com sítios de restrição de cpDNA (Schilling \& Panero 1996) e que as espécies neotropicais apresentam um um baixo nível de variação nas seqüências de ITS (Schilling et al. 2000), fica justificada a decisão de manter atualmente o nome Viguiera Kunth, até que estudos moleculares, incluindo outros marcadores, sejam desenvolvidos. O Dr. Edward Schilling, da Universidade do Texas, tem efetuado com sucesso análises filogenéticas em Eupatorieae, usando o espaçador externo transcrito (ETS), e existe a possibilidade de um estágio, em futuro próximo, para dar continuidade às investigações naquela Universidade.

Como já comentado, flores tubuloso-campanuladas e pápus persistente são características distintivas entre as espécies que ocorrem na Região Neotropical e as andinas, que apresentam flores tubulosas e pápus facilmente destacável destacável; estas últimas são características compartilhadas com os componentes da série Dentatae, incluindo $V$. dentata, sugerindo uma possível origem do grupo a partir de plantas do Hemisfério Norte, hipótese já lançada por Schilling \& Panero (1996) que também sugeriram uma evolução, em Helianthinae, no número básico de cromossomos a partir de $\mathrm{n}=18$ (Encelia, Flourensia e Viguiera ser. Dentatae); grande parte da subtribo, incluindo a $V$. dentata e as espécies sul-americanas, apresentam $n=17$. Outro aspecto morfológico que parece corroborar esta hipótese concerne às escamas do pápus que, nas espécies da Região Neotropical, são unidas em algum grau; escamas 
livres são observadas em grupos mexicanos - $V$. dentata, subgênero Amphilepis (V. angustifolia, V. budleiaformis, V. flava, V. excelsa var. pachycephalla), seção Maculatae, série Gramatoglossae (V. rhombifolia, V. seemanii, V. sessifolia) e em muitas espécies andinas ( $V$. australis, $V$. chimboensis, $V$. britonii, V. lanceolata, $V$. media, $V$. mollis e $V$. peruviana). No hemisfério Norte, escamas totalmente unidas somente são encontradas em $V$. bicolor e $V$. brevifolia, dois dos três representantes da série Brevifolieae (Calanticaria); no Brasil, dezenove espécies apresentam esta característica, nove das quais emergiram em dois cladosirmãos nas análises filogenéticas ( $V$. anchusifolia, $V$. aspilioides, $V$. filifolia, $V$. kunthiana, V. linearifolia, V. macrorhiza, V. nudicaulis, V. tenuifolia, V. tuberosa).

Os resultados indicam na América do Sul existem cerca de 61 espécies; para a Região Andina são conhecidas 17 espécies exclusivas ausentes somente na Província Patagônica Fueguina de Morrone (1999), além de 6 com transgressões para a região Neotropical; as outras 38 estão na Região Neotropical, com 35 ocorrendo no Brasil, das quais 27 são exclusivamente brasileiras. Na revisão das espécies brasileiras, são propostas como novas: três espécies, uma variedade, três combinações; em acréscimo, são efetuadas 32 lectotipificações e 18 sinonimizações.

Em suma, como se pode observar na chave de identificação apresentada neste capítulo, as espécies da América do Sul podem ser divididas em dois grandes grupos: o que contém as espécies andinas e o das espécies neotropicais. O segundo pode sofrer subdivisões, de acordo com características relacionadas ao hábito, às brácteas involucrais, aos capítulos e ao pápus. Tais características foram utilizadas por Blake (1918), para delimitar os táxons infra-genéricos, mas o autor deixou de perceber várias nuances, levando-o a estabelecer grupos muito artificiais e a deixar de reconhecer a diferença crucial entre as plantas dos Andes e as demais.

Em vista do grave problema nomenclatural pendente, não é possível, no momento, propor uma re-delimitação dos táxons infragenéricos, mas as informações aqui obtidas deverão servir como subsídios para isso no futuro. 


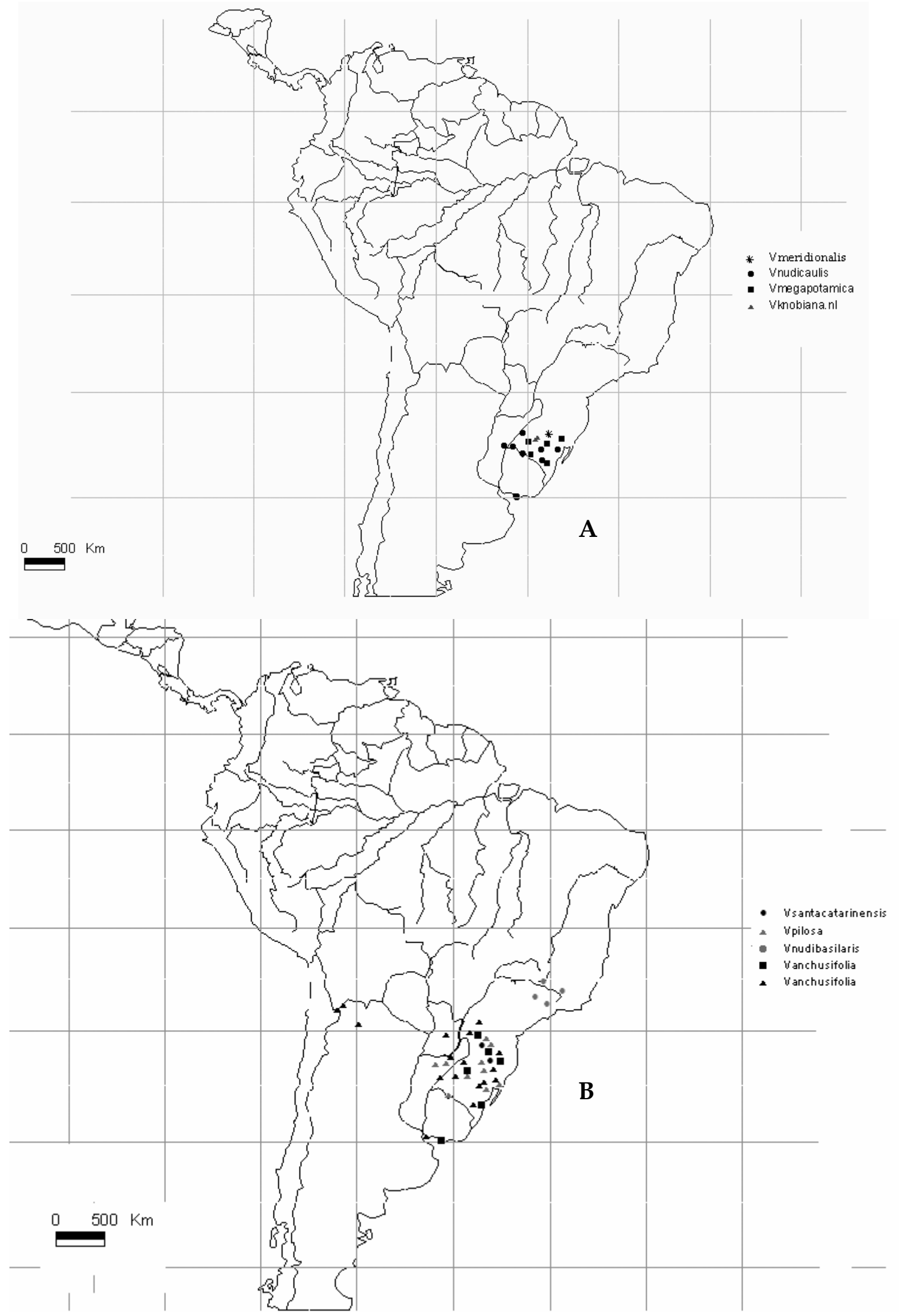

Fig. 42: Mapas de distribuição geográfica de espécies de Viguiera no Brasil (legenda das espécies ao lado dos mapas). 


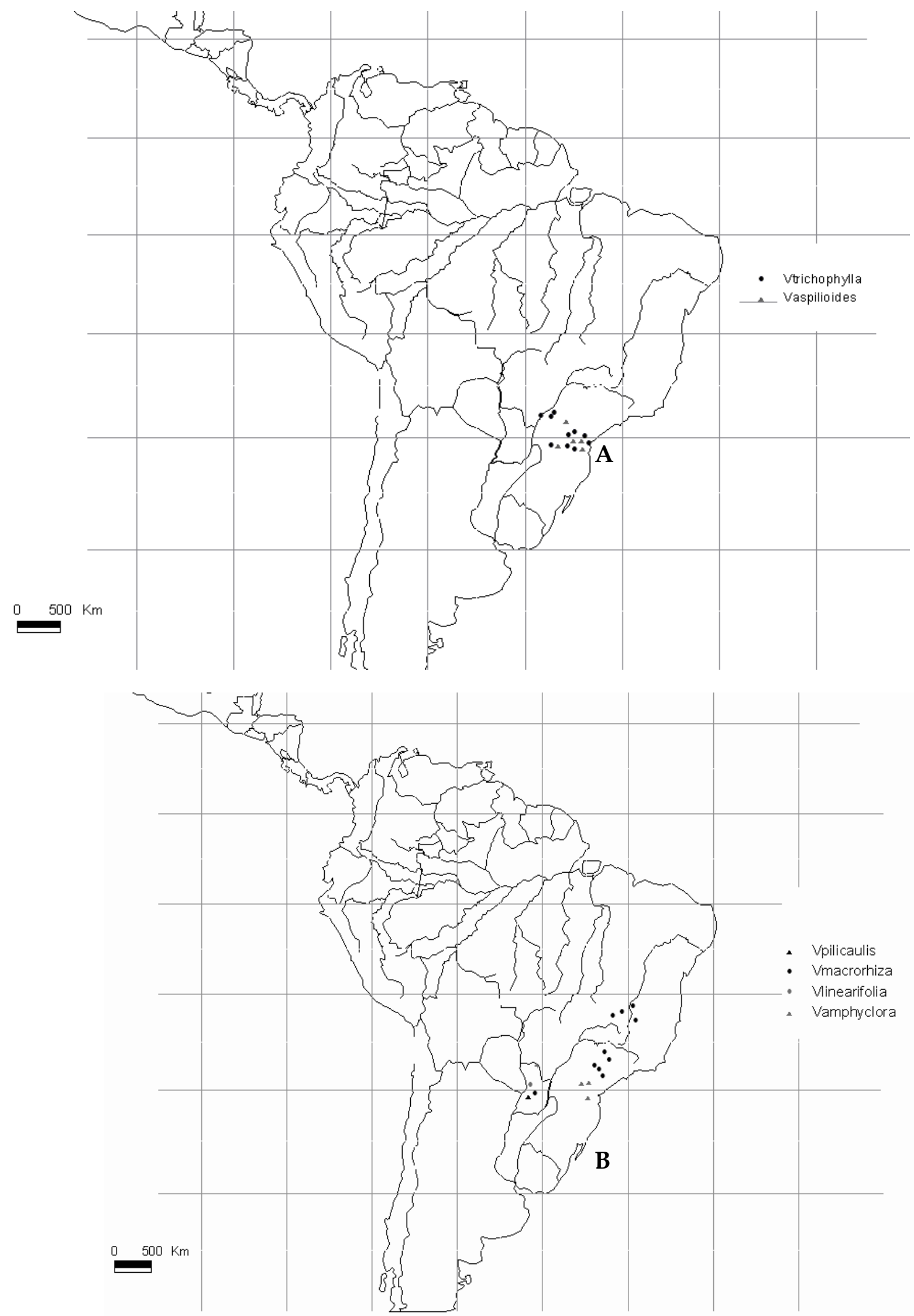

Fig. 43: Mapas de distribuição geográfica de espécies de Viguiera no Brasil (legenda das espécies ao lado dos mapas). 


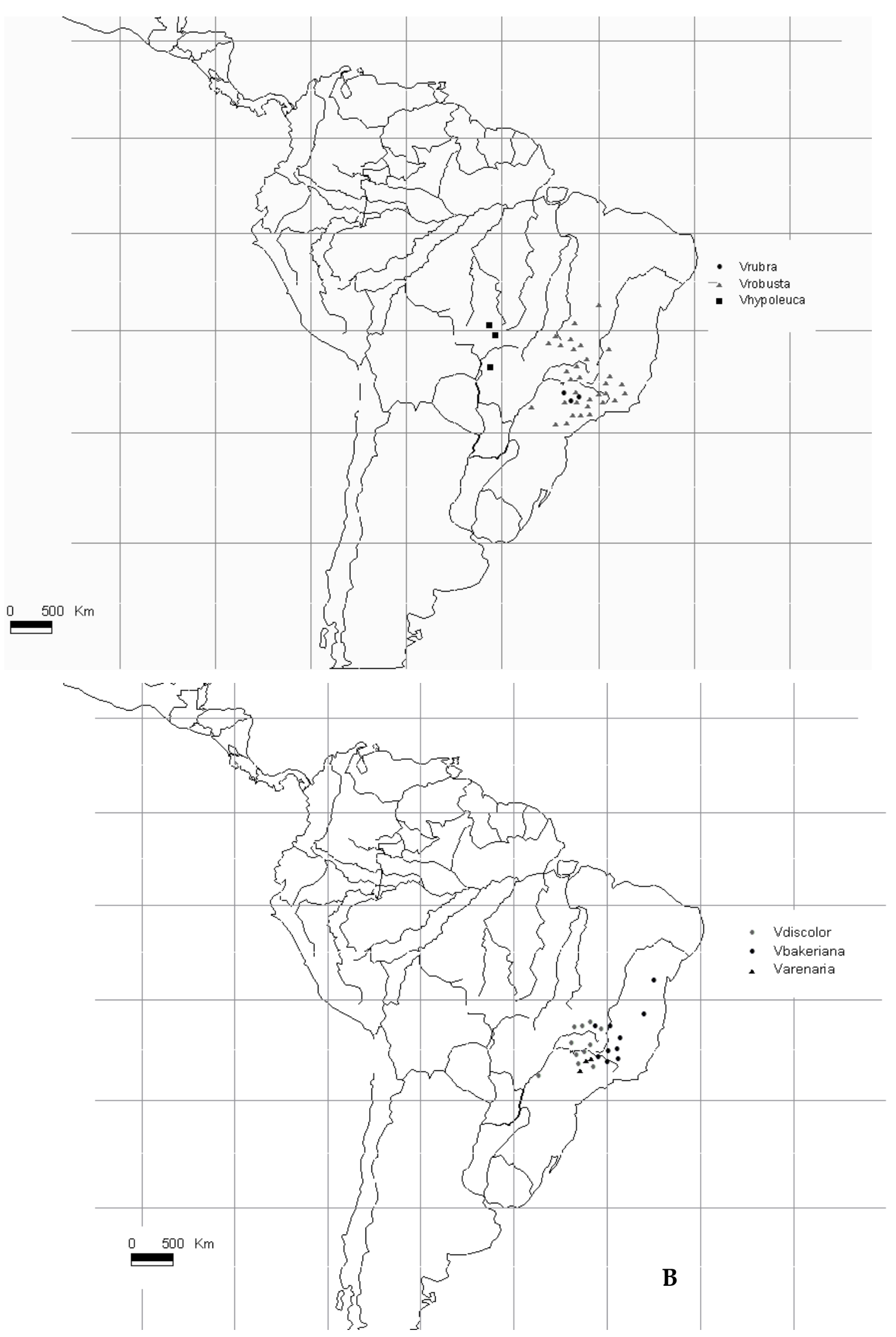

Fig. 44. Mapas de distribuição geográfica de espécies de Viguiera no Brasil (legenda das espécies ao lado dos mapas). 


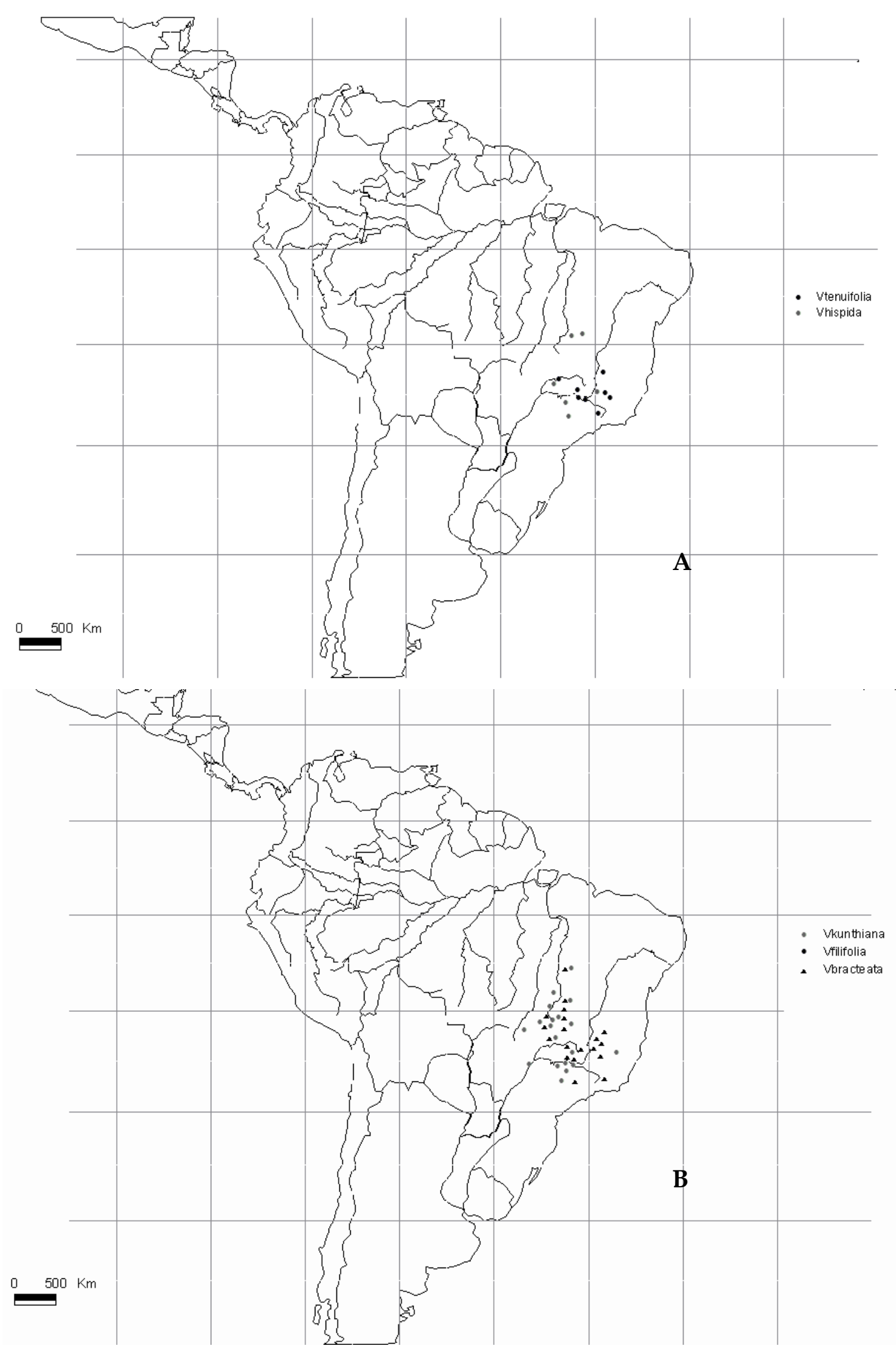

Fig. 45. Mapas de distribuição geográfica de espécies de Viguiera no Brasil (legenda das espécies ao lado dos mapas). 


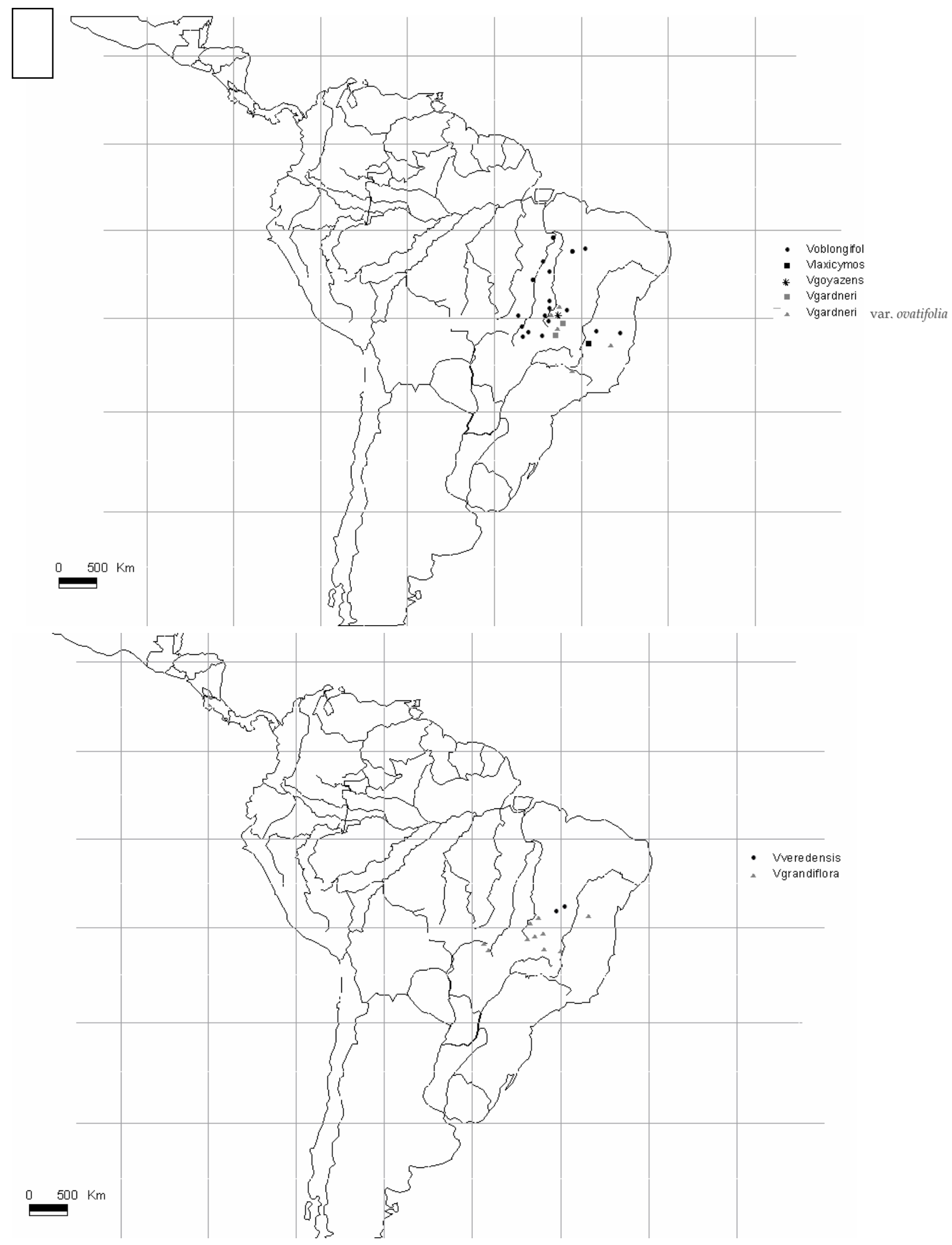

Fig. 46. Mapas de distribuição geográfica de espécies de Viguiera no Brasil (legenda das espécies ao lado dos mapas). 


\section{$\underline{\text { Referências bibliográficas }}$}

APEZZATO-DA-GLÓRIA, B. 2003. Morfologia de Sistemas subterrâneos - histórico e evolução do conhecimento no Brasil. A. S. Pinto, Ribeirão Preto.

BAILLON, H.E. 1886[1985]. Viguiera. In H.E. Baillon (ed.). Histoire des Plants vol. 8. Hachette \& Cie, Paris, London, Leipzig, p 46-201.

BAKER, J.G. 1884. Compositae IV: Helianthoideae. In C.F.P. Martius \& A.W. Eichler (eds) Flora brasiliensis Monachii. Typografia Regia vol. 6, pars 3, p. 135-268.

BENTHAM, G. 1873. Compositae. In G. Bentham . \& W.J. Hooker (eds) Genera plantarum. Reeve \& Co., London, vol. 2, pl. 1, p. 163-533.

BICUDO, C.E.M. \& BICUDO, R.M.T. 1970. Algas de águas continentais brasileiras: chave ilustrada para identificação de gêneros. EDUSP, São Paulo.

BLAKE, S.F. 1917. New and noteworth Compositae, chiefly Mexican. Contr. Gray Herb. 52: 16-39.

BLAKE, S.F. 1918. A revision of the genus Viguiera. Contr. Gray Herb. 54: 1-205.

BREMER, K. 1994. Asteraceae: cladistics and classification. Timber Press, Portland, Oregon.

BRIDSON, G.D.R. \& SMITH, E.R. (eds) 1991. B-P-H/S. Botanico-PeriodicumHuntianum/Supplementum. Hunt Institute for Botanical Documentation. Pittsburgh, Pennsylvania.

BROOKS, D.R. \& MCLENNAN, D.A. 1999. Species: turning a conundrum unto a research program. J. Nematol. 31: 117-133.

BRUMMIT, R.K. \& C.E. POWELL (eds.) 1992. Authors of Plant Names. Royal Botanic Gardens, Kew.

BRUNDIN, L. 1972. Evolution, casual biology, and classification. Zoologica Scripta 1: 107-120.

CABRERA, A.L. \& WILLINK, A. 1973. Biogeografia de América Latina. Monografias de la O.E.A. serie Biologia 13. Washington, D.C.

CARR, G.D., KING, R.M., POWELL, A.M. \& ROBINSON, H. 1999. Chromosome numbers in Compositae, XVIII. Amer. J. Bot. 86 (7): 1003-1013.

CASSINI, H. 1818. Aperçu des genres nouvex formes par M. Henri Cassini dans la famille dês Synanthérées. Bull. Soc. Philom. Paris: 139-142. 1821. Hélianthées. In G. Cuvier (ed.). Dictionaire Sciences Naturelles. Paris. 
CASSINI, H., 1825. Harpalium. In Cuvier (ed.). Dictionaire Sciences Naturelles. Paris v. 38, p. 17.

CAVANILLES, A.J. 1794. Icones vol. 3 pars 10, p. 354-385.

CRACRAFT, J. 1983. Species concepts and speciation analysis. Current Ornithology 1: 159-187.

DA COSTA, F.B., ALBUQUERQUE, S. \& VICHNEWSKI, W. 1996a. Diterpenes and synthetic derivatives from Viguiera aspilioides with tripanomicidal activity. Planta Medica 62: 577-579.

DA COSTA, F.B., ITO, Y.I., ANDRE, R.F.G. VICHNEWSKI, W., HERZ, W. 1998. Constituents of Viguiera species with antibacterial activity. Fitoterapia 69: 86-87.

DA COSTA, F.B., SCHORR, K., ARAKAWA SCHILLING, E.E., SPRING, O. 2001. Infraspecific variation in the chemistry of glandular trichomes of two Brazilian Viguiera species (Heliantheae; Asteraceae). J. Braz. Chem. Soc. 12: 403-407.

DA COSTA, F.B., VICHNEWSKI, W. \& HERZ, W. 1996b. Constituents of Viguiera aspillioides and V. robusta. Biochem. Syst. Ecol. 24: 585-587.

D’ARCY, W.G. 1975. Viguiera. In W.G. D’Arcy (ed) Flora do Panama. Ann. Missouri Bot. Gard. 62: 1156-1161.

DAVIS, J.I. 1997. Evolution, evidence, and the role of species concepts in phylogenetics. Syst. Bot. 22(2): 373-403.

DAVIS, J.I. \& NIXON, K.C. 1992. Populations, genetic variation, and the delimitation of phylogenetic species concepts. Bioscience 46: 502-511.

DE CANDOLLE, A.P. 1836. Compositae, part I. In A.P. De Candolle (ed.). Prodromus systematis regni vegetabilis v. 5. Treuttel \& Würtz., Paris, p. 4-706.

DE QUEIROZ, A. \& DONOGUE, M.J. 1988. Phylogenetic systematics or Nelson’s version cladistics? Cladistics 6: 61-75.

DIAS, P. 2004. NL. (finding localities in Neotropics), version 0.9, distributed by the author. São Paulo.

DONOGUE, M.J. 1985. A critique of the biological species concept and recommendations for a phylogenetic alternative. Bryologist 88: 401-418.

FORSKÅL, P. 1775. Kahiria. In N. Carsten (ed.). Flora aegyptiaco-arabica. Sive descriptiones plantarum, quas per aegyptum inferiorem et arabiam felicem. Hauniae ex officia Möller, Copenhagen, p 73. 
GARDNER, G. 1848. Contributions towards a Flora of Brazil, being the distinctive characters of some new species of Compositae, belonging to the tribe Senecionedeae. Lond. J. Bot. 7 (2): 395-405.

HEMSLEY, W.B. 1881. Phanerogamia. Dicotyledones. Gamopetalae. Series I. Inferae. Compositae. Tribe V. Helianthoideae. In W.B. Hemsley (ed) Biologia CentraliAmericana. Ser. Botanica, p. 166-189. Disponível em <www.sil.si.edu/web4/ bca/bca>. Acesso em 20 fevereiro 2006.

HENDERSON, A. 2005. The methods of herbarium taxonomy. Syst. Bot. 30(2): 456-469.

HERTER, W.G. \& RAMBO, B. 1953. Nas pegadas dos Naturalistas Sellow \& SaintHillaire (Itinera Sellowio-Hilariana). R. S. Am. Bot. 10 (3): 61-100.

ISEJIMA, E.M. \& FIGUEIREDO-RIBEIRO, R.C.L. 1993. Dynamics of fructans in tuberous roots of Viguiera discolor Baker (Asteraceae) as influenced by phenology. Plant Cell Physiol. 34: 723-727.

ISEJIMA, E.M. \& FIGUEIREDO-RIBEIRO, R.C.L. \& ZAIDAN, L.B.P. 1991. Fructan composition in adventitious tuberous roots of Viguiera discolor Baker (Asteraceae) as influenced by day length. New Phytologist 119: 149-154.

ITAYA, N.M., BUCKERIDGE, M.S. \& FIGUEIREDO-RIBEIRO, R.C.L. 1997. Biosynthesis in vitro of high-molecular-mass fructan by cell-free extracts from tuberous roots of Viguiera discolor (Asteraceae). New Phytologist 136:53-60.

ITAYA, N.M., FIGUEIREDO-RIBEIRO, R.C.L. \& BUCKERIDGE, M.S. 1999. Synthesis of fructans by fructosyltransferase from the tuberous roots of Viguiera discolor (Asteraceae). Braz. J. Med. Biol. Res. 32:435-442.

KARIS, P.O. 1993. The Heliantheae sensu latu (Asteraceae), clades and classification. Pl. Syst. Evol. 186: 139-195.

KORNET, D. 1993. Permanent splits as speciation events: a formal reconstruction of internodal species concept. J. Theor. Biol. 164: 407-435.

KUNTH, A. 1820. Compositae. In Humboldt, Bonpland \& Kunth (eds.). Voyage de Humboldt et Bompland. Sixième Partie. Botanique. Nova Genera et Species Plantarum vol. 4.. Edifolio, Mazi, Paris, p. 279-283.

KUSCHEL, G. 1963 [1964]. Problems concerning an Austral region. In: J.L. Gressit, C.H. Lindroth, F.R. Fosberg, C.A. Fleming \& E.G. Turbott (eds.). Pacific basin biogeography: a symposium. Honolulu: Bishop Museum Press. Pp 443-449.

LA LAVE, 1824. Aldama. In La Llave \& Lex (eds) Nov. Veg. Desc. Fasc. 1. p. 14. 
LESSING, C.F. 1832. Synopsis Generum Compositarum, earunque dispositionis novae tentamen monographus multarum capensium interjectis. Sumtibus Dunckri et Humblotii, Berolini.

LINNAEUS, C. 1754. Helianthus. In C. Linnaeus, Species Plantarum 5.

LINNAEUS f., C. 1762. Ethulia. In C. Linnaeus, Decas Prima Plantarum Rariorum. Horti Upsaliensis. Sumtu \& Literis Direct. !. Aurentii Salvii, Stocholmiae. p. 99.

LINDMAN, C.A.M. 1906. A vegetação do Rio Grande do Sul. Tradução de A. Löfgren, 1974. Itatiaia /EDUSP, Belo Horizonte. 377 p.

MACHADO, S.R., OLIVEIRA, D.M.T., DIP, M.R. \& MENEZES, N.L. 2004. Morphology and anatomy of the underground system of Smallanthus sonchifolius (Poepp. \& Endl.) H. Robinson (Asteraceae). Rev. bras. Bot. 27(1): 115-123.

MALLET, J. 1995. A species definition for the modern synthesis. Trends in Ecol. Evol. 10: 294-299.

MALLET, J. 1998. Species concepts. In P. Calow (ed. ). Encyclopaedia of Ecology and Environmental Management. Blackwell Press, Oxford, p. 709-711.

MAYR, E. 1942. Systematics and the Origin of Species. Columbia University Press, New York.

MONDIN, C. 2004. Levantamento da tribo Heliantheae Cass. (Asteraceae), sensu stricto, no Rio Grande do Sul, Brasil. Tese de doutorado. Universidade Federal do Rio Grande do Sul. $349 \mathrm{f}$.

MORRONE, J.J. 1999. Presentación preliminar de un nuevo esquema biogeográfico de América del Sur. 75(1): 1-16.

NAKAJIMA, J.N. 2000. A família Asteraceae no Parque Estadual da Serra da Canastra, Brasil. Tese de doutoramento. Universidade Federal de Uberlândia. 404f.

NELSON, G.J. \& PLATINICK, N.I. 1981. Systematic and Biogeography: cladistics and vicariance. Columbia University Press, New York.

NIXON, K. C. \& WHEELER, Q. . 1990. An amplification of the phylogenetic species concept. Cladistics 6: 211-223.

PANERO, J.L. \& SCHILLING, E.E. 1988. Revision of Viguiera sect. Maculatae (Asteraceae-Heliantheae). Syst. Bot. 13: 371-406.

PATERSON, H.E.H. 1986. The recognition concept of species. In E. S. Vrba (ed.), Species and Speciation. Transvaal Museum Monograph Number 4. South Africa,Pretoria: p. 21-29.

PAYNE, W.W. 1978. A glossary of plant hair terminology. Brittonia 30 (2): 239-255. 
PUORTO, G., DA GRAÇA, S.M., THEAKSTON, R.D.G., WARREL, D.A. \& WÜSTER, W. 2001. Combining mitochondrial DNA sequences and morphological data to infer species boundaries: phylogeography of lancehead pitvipers in the Brazilian Atlantic forest, and the status of Bothrorps pradoi (Squamata: Serpentes: Viperidae). J. Evol. Biol. 14: 527-538.

RAPINI, A. 2000. Sistemática: Estudos em Asclepiadoideae (Apocynaceae) da Cadeia do Espinhaço de Minas Gerais. Tese de Doutoramento. Universidade de São Paulo. 283 f.

RADFORD, A. E., DICKSON, W. C., MASSEY J. R. \& BELL, C.R. 1974. Vascular plants systematics. Harper \& Row, New York.

REZNICEK, A. \& CATLING, P. 1986. Vegetative shoots in taxonomy of sedges (Carex, Cyperaceae). Taxon 35(3): 495-501.

RIDLEY, M. 1989. The cladistic solution to the species problem. Biol. Phil. 4: 1-16.

RIESEBERG, L.H. 1991. Homoploid reticulate evolution in Helianthus (Asteraceae): Evidence from Ribossomal genes. Amer. J. Bot. 78(9): 1218-1237.

RIESEBERG, L.H. 1995. The hole of hybridization in evolution: old wine in new skins. Amer. J. Bot. 82(7): 944-953.

RIESEBERG, L.H. 2000. Crossing relationships among ancient and experimental sunflower hybrid lineages. Evolution 54 (3): 859-865.

RIVAS-MARTÍNEZ, S. \& TOVAR, O. 1983. Vegetatio Andinae, I. Datos sobre las comunidades vegetales altoandinas de los Andes Centrales del Perú. Lazaroa 4: 167-187.

ROBINSON, H. 1977. Studies in Heliantheae (Asteraceae) VIII. Notes on genus and species limits in the genus Viguiera. Phytologia 36(3): 201-215.

ROBINSON, H. 1981. A revision of the tribal and subtribal limits of the Heliantheae (Asteraceae). Smith. Contr. Bot. 51: 1-102.

ROBINSON, H. 1992. New combination in Elaphandra Strother (Ecliptinae: Helianthinae-Asteraceae). Phytologia 72(2): 144-151.

ROBINSON, H. \& MOORE, A.J. 2004. New species and new combinations in Rhysolepis (Heliantheae - Asteraceae). Proc. Biol. Soc. Washington 117(3): 423-446.

ROSEN, D.E. 1979. Fishes from the uplands and intermontane basins of Guatemala: revisionary studies and comparative biogeography. Bull. Am. Mus. Nat. Hist. 162: 267-376. 
RUGGIERO, P.G. \& ZAIDAN, L.B. 1997. Estudos de desenvolvimento de Viguiera robusta Gardn., uma Asteraceae do cerrado. Rev. Bras. Bot. 20: 1-9.

SAJO, M.G. \& MENEZES, N.L. 1986a. Anatomia do rizóforo de espécies de Vernonia Screb. (Compositae) da Serra do Cipó, MG. Rev. Bras. Biol. 46: 189-196.

SAJO, M.G. \& MENEZES, N.L.. 1986b. Origem e crescimento do rizóforo em espécies de Vernonia Screb. (Compositae), da Serra do Cipó, MG. Rev. Bras. Biol. 46:197-202.

SALGADO-LABOURIAU, M.L. 1964. Pollen Grains of Plants of the "Cerrado" VI Compositae - Tribus Heliantheae. Anais Acad. Brasil. Ci. 36(1): 85-100.

SALGADO-LABOURIAU, M.L. 1971. Contribuição à palinologia dos cerrados. Anais Acad. Brasil. Ci. 5: 67-75.

SANTOS, J.U.M. 2001. O gênero Aspilia Thou. no Brasil. FUNTEC. Museu Paraense Emilio Goeldi, Belém.

SCHILLING, E.E., DA COSTA, F.B., LOPES, N.P. \& HEISE, P.J. 2000. Brazilian species of Viguiera (Asteraceae) exhibit low levels of ITS sequence variation. Edinburgh J. Bot. 57(3): 323-332.

SCHILLING, E.E. \& JANSEN, R.K. 1989. Restriction fragment analysis of chloroplast DNA and the systematics of Viguiera and related genera (AsteraceaeHeliantheae). Amer. J. Bot. 76(12): 1769-1778.

SCHILLING, E.E. 1990. Taxonomic revision of Viguiera subg. Bahiopsis (Asteraceae Heliantheae). Madroño 37: 149-170.

SCHILLING, E.E. \& PANERO, J.L. 1991. Evidence for a close relationship between Iostephane and Viguiera (Asteraceae-Heliantheae). Amer. J. Bot. 78(8): 1054-1062.

SCHILLING, E.E. \& PANERO, J.L. 1996a. Relationships in Heliantheae subtribe Helianthinae based on chloroplast DNA restriction site analysis. In D.J. Hind \& H.J. Beentje, (eds.). Compositae: systematics proceedings of the international Compositae conference, vol. 1. Royal Botanic Gardens, Kew, p. 361-376.

SCHILLING, E.E. \& PANERO, J.L. 1996b. Phylogenetic reticulation in subtribe Helianthinae. Amer. J. Bot. 83(7): 939-948.

SCHILLING, E.E. \& PANERO, J.L. 2002. A revised classification of subtribe Helianthinae (Asteraceae-Heliantheae). I. Basal lineages. Bot. J. Linn. Soc. 140: 6576.

SCHILLING, E.E., PANERO, J.L. \& ELIASSON, U.H. 1994. Evidence from chloroplast DNA restriction site analysis on the relationships of Scalesia (AsteraceaeHeliantheae). Amer. J. Bot. 81(2): 248-254. 
SCHORR, K., GARCIA-PIÑERES, A.J.; SIEDLE, B., MERFOT, I. \& DA COSTA, F.B. 2002. Guaianolides from Viguiera gardneri inhibit the transcription factor NF-kB. Phytochemistry 60: 733-740.

SCHWARZBACH, A.E., DONOVAN, L.A. \& RIESEBERG, L.H. 2001. transgressive character expression in a hybrid sunflower species. Amer. J. Bot. 88: 270-277.

SCOPOLI, G.A. 1777. Leighia. In G.A. Scopolli (ed.), Introductio ad Historiam naturalem systems genera lapidum, plantarum et animalium. Wolfgangurn Gerle, Prague, p. 128.

SKVARLA, J.J.\& LARSON, D.A. 1965a. An electron microscopy study of pollen morphology in the Compositae with special reference to Ambrosiinae. Grana Palinologica 9: 50-62.

SITES, J.W., JR. \& MARSHALL, J.C. 2004. Operational Criteria for delimiting species. Annu. Rev. Evol. Syst. 35: 199-227.

SKÁLA, Z. \& ZRZAVÝ, J. 1994. Phylogenetic reticulation and cladistics: discussion of methodological concepts. Cladistics 10: 305-313.

SKVARLA, J.J. \& LARSON, D.A. 1965. An electron microscopy study of pollen morphology in the Compositae with special reference to Ambrosiinae. Grana Palinologica 9: 50-62.

SNAYDON, R.W. 1984. Infraespecifc variation and its taxonomic implications. In V.H.

Heywood \& D.M. Moore (eds.). Current concepts in plant taxonomy. Academic Press, London, p. 203-218.

SOSEF, M.S.M. 1997. Hierarchical models, reticulate evolution and the inevitability of paraphyletic supraspecific taxa. Taxon 46: 75-85.

SOSSEY-ALAOUI, K., SERIEYS, H., TERSAC, M.P., LAMBERT, P. SCHILLING, E. GRIVEAU, Y., KAAN, F \& BERVILLE, A. 1998. Evidence for several genomes in Helianthus. Theor. Appl. Genet. 97: 422-430.

SPRING, O., ZIPPER, R., REEB, S. VOGLER, B. \& DA COSTA, F.B. 2001. Sesquiterpene lactones and a myoinositol from the glandular trichomes of Viguiera quinqueremis (Heliantheae; Asteraceae). Phytochemistry 57: 267-272.

SPRING, O., ZIPPER, R., CONRAD VOGLER, B., KLAIBER, I. \& DA COSTA, F.B. 2003. Sesquiterpene lactones from glandular trichomes of Viguiera radula (Heliantheae; Asteraceae). Phytochemistry 62: 1185-1189.

STACE, C.A. 1980. Plant taxonomy and biosystematics. Edward Arnold, London. 279 p.

STAFLEU, F.A. \& COWAN, R.S. (eds.). 1976-1988. Taxonomic literature vol. 1-7, 2nd. Bohn, Scheltema \& Holkema, Utrecht. 
STUESSY, T.T. 1977. Heliantheae-Systematic review. In V.H. Heywood, J.B. Harborne, and B. L. Turner (eds.). The biology and chemistry of the Compositae. Academic Press, London, p. 621-671.

TEMPLETON, A.R. 1989. The meaning of species and speciation: a genetic perspective. In D. Otte and J.A. Endler (eds) Speciation and Its Consequences. Sinauer Associates, Sunderland, p. 3-27.

TEMPLETON, A.R. 2001. Using phylogeographic analyses of gene trees to test species status and boundaries. Mol. Ecol. 13: 789-809.

TURNER, B.L., BACON, J., URBATSCH, L. \& SIMPSON, B. 1979. Chromosome numbers in South American Compositae. Amer. J. Bot. 66: 173-178.

UNGERER, M.C., BAIRD, S.J.E., PAN, J. \& RIESEBERG, L.H. 1998. Rapid hybrid speciation in wild sunflowers. Proc. Natl. Acad. Sci. India, B. 95: 11757-11762.

VALEN, L. VAN. 1976. Ecological species, multispecies and oaks. Taxon 25: 233-239.

WATANABE, K. 2005. Index to Chromosome numbers in asteraceae. Disponível em <http://www-asteraceae.cla.kobe-u.ac.jp/index>. Acesso em 20.fevereiro.2006.

WEBERLING F. (1989) Morphology of Flowers and Inflorescences. Cambridge University Press, Cambridge.

WHITE, I.C. 1908. Relatório Final da Comissão de Estudos das Minas de Carvão de Pedra do Brasil. DNPM. Rio de Janeiro, 1988. Parte II (ed. Fac-similar), p. 301617.

YATES, W.F. \& HEISER, C.B. 1979. Synopsis of Heliomeris (Compositae). Proc. Indiana Acad. Sci. 88: 364-372.

WEBERLING F. 1989. Morphology of Flowers and Inflorescences. Cambridge University Press, Cambridge. 


\section{CAPÍTULO VI}

\section{BIOGEOGRAFIA DE VIGUIERA DA AMÉRICA DO SUL ${ }^{1}$}

\section{$\underline{\text { Abstract }}$}

The South American species of Viguiera originated from groups of the northern hemisphere (possibly related to the subg. Amphilepis, sects. Leighia and Hypargyrea or ser. Grammatoglossae) which, from the end of the Cretaceous period, migrated to the southern hemisphere, through the arc of volcanic islands formed between the Americas. Even though there is not a single and only explanation for the current floristic disjunction between Mexico and Ecuador, the similarities between the first one and the South American countries with the Andean regions are by far well known. The results indicate that the Andes Mountain range was a site for the spread of the distribution of the genus and established limits for the distribution of certain species. On the other hand, the regions of Yungas and Puna seem to have contributed to the infiltration of the genus in the continental area; 13 species are found only in the Andean Region, 38 in the Neotropical Region and 27 are exclusive Brazilians. The high number of distribution patterns found (19) corroborates other authors' opinions about the recent origin of Viguiera in South America. In Brazil, the most favorable condition for the population diversity and density always occur in areas with megathermic and mesothermic climates of the types Cwa e Aw of Köpen, which provide the Cerrado landscape.

\section{$\underline{\text { Resumo }}$}

As espécies sul-americanas de Viguiera originaram-se aparentemente de certos grupos do Hemisfério Norte (provavelmente relacionados ao subg. Amphilepis, sects. Leighia ou Hypargyrea ou ser. Grammatoglossae) que, a partir do final do Cretáceo, migraram para o Hemisfério Sul, através do arco de ilhas vulcânicas formado entre as Américas. Apesar de não haver uma única

\footnotetext{
${ }^{1}$ Manuscrito a ser submetido à Revista Brasileira de Botânica.
} 
explicação para a atual disjunção florística entre o México e o Equador, as similaridades entre o primeiro e países sul-americanos com regiões andinas são, há muito, conhecidas. Os resultados indicam que a Cordilheira dos Andes serviu para a extensão da distribuição do gênero e impõe limites para a distribuição de certas espécies; por outro lado, as regiões de Yungas e Puna parecem ter colaborado para a penetração do gênero na área continental; 13 espécies ocorrem apenas na Região Andina e 38 na Região Neotropical, com 27 exclusivas do Brasil. O elevado número de padrões de distribuição encontrado (19) corrobora a opinião de outros autores e.g. Schilling et al. 2000), sobre a recente origem de Viguiera na América do Sul. No Brasil, as condições mais favoráveis à diversidade e densidade populacional ocorrem sempre em áreas com climas megatérmicos ou mesotérmicos dos tipos Cwa e Aw de Köpen, que condicionam a paisagem dos cerrados.

\section{Introdução}

Viguiera sensu lato é um gênero do continente americano, encontrado entre as latitudes de aproximadamente $40^{\circ} \mathrm{N}$ e $36^{\circ} \mathrm{S}$, preferencialmente em regiões montanhosas, cuja revisão tradicional foi feita por Blake (1918). Existem sérios problemas de delimitação genérica e infragenérica e trabalhos com base em estudos moleculares efetuados a partir do final da década de 1990 (Schilling \& Jansen 1989; Schilling et al. 2000, Schilling \& Panero 1991 1996a 1996b 2002) deram início à sua re-delimitação. A exclusão das seções Diplostichis (gênero Hymenostephium) e Heliomeris (gênero Heliomeris) permitiu uma caracterização morfológica mais consistente das espécies sul-americanas que, nesse contexto, são ervas geralmente perenes, com sistema subterrâneo espessado, sinflorescências com paracládios quase sempre alternos, cipselas simétricas ou levemente assimétricas, levemente compressas, com pápus 2-aristado e escamas entre as aristas. Somam cerca de 61 espécies, com 13 exclusivamente andinas e 38 ocorrendo exclusivamente na Região Neotropical, das quais 35 ocorrem no Brasil e 27 são exclusivamente brasileiras. Em relação às espécies do Hemisfério Norte, as plantas da América do Sul apresentam similaridades morfológicas 
com algumas mexicanas, principalmente pertencentes ao subgênero Amphilepis, à seção Leighia à série Grammatoglossae.

Os aspectos biogeográficos do gênero são pouco estudados e foram abordados apenas superficialmente pelos autores citados acima. Este trabalho objetivou detectar possíveis padrões de distribuição geográfica de Viguiera da América do Sul e contribuir com hipóteses sobre a história de ocupação das áreas que habita neste continente.

\section{Material e métodos}

Os dados de distribuição geográfica foram obtidos a partir de literatura especializada e dos materiais procedentes dos seguintes herbários: $\mathrm{BHCB}$; $\mathrm{BM}$; BOTU; BR; CEN; CESJ; CETEC; CTES; CGMS; COR; CPAP; ESA; E; FUEL; HAS; HASU; HEPH; HRB; HRCB; HUCS; HUEFS; HUEPG; HUFU; IBGE; ICN; IPA; K; LP; LPB; M; MBM; P; PACA; PEL; R; RB; SGO; SP; SPF; SPFR; UB; UEC; UFG; UFLA; UFMT; VEN.

A classificação das regiões biogeográficas da América do Sul utilizada para o estabelecimento dos padrões fitogeográficos de Viguiera foi a de Morrone (1999). Com base na flagrante restrição da distribuição das espécies estudadas em habitats abertos, foi feita uma análise relacionada com a classificação de Burkart (1975) para Poaceae, que estabelece três Domínios sul-americanos de acordo com suas exigências de temperatura das gramíneas. Para elaboração dos mapas, informações contidas nas etiquetas do material herborizado foram registradas no banco de dados do programa de georeferências NL (Dias 2004) e transferidas para o mapa de fundo do programa Arcview 3.3.

Ressalte-se que os padrões ora detectados poderão representar artefatos a serem futuramente corrigidos, devido ao fato da iminente possibilidade de alguns nomes em Viguiera serem sinônimos; em virtude do número de baixo número de espécimes examinados (cerca de 350) dos países sul -americanos, que não o Brasil, decidiu-se por adiar algumas decisões de sinonimização. Assim, estudos futuros poderão reduzir consideravelmente o número de 
padrões de distribuição de Viguiera na América do Sul, especialmente o das espécies andinas.

\section{$\underline{\text { Resultados e discussão }}$}

\section{Distribuição e fatores relacionados}

A correlação encontrada neste trabalho e naqueles realizados com dados moleculares, entre as espécies sul-americanas de Viguiera e alguns grupos relacionados do Hemisfério Norte, implica uma distribuição claramente disjunta, já que não há ocorrência registrada de táxons como circunscritos acima numa área que vai da Nicarágua à Colômbia.

As disjunções de táxons diversos entre as Américas do Sul e do Norte são, há muito tempo, objeto de interesse dos pesquisadores (Bray 1900; Campbell 1944; Raven 1963, 1972; Solbrig 1972a e 1972b; Thorne 1972; Hunziker et al. 1972 e Sarmiento 1975).

Raven (1963) dividiu as disjunções anfitropicais em três categorias: bipolar ou de altas latitudes, temperada e de deserto, esta última com número substancial de espécies; o autor afirmou que a maioria das bipolares e temperadas veio do norte e as do deserto aparentemente se originaram no sul ou divergiram de um ancestral tropical em comum. Solbrig (1972a) observou que essas plantas são, quase sem exceção, auto-compatíveis ou autógamas, que crescem quase que exclusivamente em comunidades abertas, que não há casos de correspondências entre sua ocorrência e a de vertebrados terrestres, que existem poucas entre elas e os insetos, e que as floras das duas áreas são distintas no mínimo a partir do Cretáceo médio; o autor sugeriu que a única explicação plausível, ao se considerar estes fatores, parece ser que a grande maioria das plantas alcançou as áreas disjuntas por eventos relativamente recentes de dispersão à longa distância. Recentemente, Peterson \& Ortiz-Diaz (1998) demonstraram por inferência de distância genética entre populações de Muehlenbergia torreyi (Poaceae) que ao menos uma das populações norteamericanas estudadas ficava mais próxima do grupo de populações sul- 
americanas do que das demais da América do Norte. Segundo eles, isso constituiria forte corroboração a favor de dispersão recente como responsável pela disjunção anfitropical em pauta.

As análises morfológicas em Viguiera (capítulos IV e V) indicam uma estreita relação entre as plantas andinas e as mexicanas do subgênero Amphilepis das seções Leighia e Hypargyrea e algumas da série Grammatoglossae e, em menor grau, da série Brevifoliae (Calanticaria); são plantas com sinflorescências apresentando paracládios ebracteolados ou com 1-2 bractéolas, brácteas involucrais hirsutas a híspidas ou raramente estrigilosas. Dentro desses táxons, as espécies aparentemente relacionadas às sul-americanas, assim como essas, não possuem páleas do receptáculo com ápice pungente; por outro lado, as demais, com esse tipo de ápice nas páleas emergem, nas análises do capítulo IV, junto a Rhysolepis, um gênero para o qual Robinson \& Moore (2004) sugeriram a transferência das plantas da América do Sul.

Comparando as baixas taxas de divergência nas seqüências de ITS em amostras de Viguiera (ca. de 3,4\% entre as sul-americanas e as mexicanas, com uma única maior, ca. de 4,5\%, em relação a $V$. flava, uma espécie do subg. Amphilepis) e de outros grupos de Asteraceae como espécies eurasianas e norteamericanas de Eupatorium (taxas de 3 a 7 \%, Schimit 1988 in Schilling et al. 2000), para as quais foi inferida uma origem no Plioceno, Schilling et al. (2000) levantaram a hipótese de que a divergência entre as espécies sul-americanas data de menos de três milhões de anos. Neste caso, é possível admitir, a partir do final do Cretáceo, a migração de espécies relacionadas através do arco de ilhas vulcânicas formado entre as Américas (Salgado-Labouriau 1994) que viria a formar a América Central.

O único registro fóssil de grupos relacionados está na Coleção Paleobotânica do New York Botanical Garden; trata-se de Viguiera cronquistii Becker, um megafóssil carbonizado do Terciário (Oligoceno-Mioceno), encontrado ao sudoeste de Montana (mais de $45^{\circ} \mathrm{N}$ ), nos Estados Unidos, com aparência de um capítulo radiado inteiro, cujas brácteas involucrais são superpostas e aparentemente apresentam uma nervura central e cujo 
receptáculo é levemente cônico, características encontradas em Viguiera sensu lato. Crept \& Stuessy (1978) ressaltam sua semelhança com V. laciniata que, segundo resultados dos trabalhos com os dados moleculares mencionados na introdução os morfológicos encontrados no capítulo de filogenia (IV) desta tese, pertence a um grupo da Baixa Califórnia, aparentemente diverso daquele das espécies sul-americanas (Bahiopsis).

Considerando-se a ampla existência de Viguiera nas montanhas mexicanas e sul-americanas do extremo-oeste dos continentes, é plausível inferir que elas migraram do Norte para o Sul, através dos Andes. Raven (1972) compartilha esta opinião, em relação a outros grupos de plantas, conjecturando que as áreas secas nos trópicos devem ter provido rotas de passagem pelas quais as plantas se dispersaram no Terciário, mas alerta que devem ter havido múltiplos eventos, já que "menos de $2 \%$ das floras dos desertos da Argentina e sudoeste dos Estados Unidos e México adjacente são comuns a ambas as áreas e seria impossível imaginar um caminho direto e simples através dos trópicos". Solbrig (1972) ressaltou que seria impossível a dispersão de diáspororos pelo vento, devido ao forte fluxo de ar em certas épocas do ano e que, embora alguns pássaros norte-americanos migrem para a América do sul, nenhum deles pertence a áreas desérticas; aliás, as cipselas de Viguiera não parecem ser adaptadas à anemocoria, já que o pápus não é plumoso ou à ornitocoria, já que os frutos são secos; pode-se imaginar que o carpopódio ofereça algum tipo de recompensa às formigas, por exemplo. Gentry (1978) comentou as similaridades florísticas entre a Região Tropical da Bacia do Pacífico, composta por todos os países da América Central e as terras baixas do Equador e regiões adjacentes do Peru; em sua definição, mapeou uma faixa contínua de matas secas ao longo do lado Pacífico da América Central que se interrompe ao longo do Panamá, para depois se conectar a uma área também seca no Norte da América do Sul. Destacou também a existência de uma área isolada de mata seca que abrange o Sul do Equador e Noroeste do Peru e a existência desse tipo de vegetação nos vales dos principais rios. Segundo ele, os Andes e as cordilheiras da América Central podem ser vistos como um único sistema de montanhas interrompidas, 
com suas maiores quebras no vale Trato (Colômbia), Panamá central e através da maior parte da Nicarágua, justamente onde não são encontrados espécimes afins de Viguiera sul-americanas.

Em relação à polinização cabe citar que, durante as coletas efetuadas para este trabalho, foi observada a visitação constante de abelhas, vespas e borboletas nos capítulos das plantas, um indício claro de entomofilia.

Quanto aos Lepidoptera, pode-se mencionar as borboletas-monarcas (Danaus plexippus) que são nativas das Américas do Norte e do Sul; segundo Oberhauser \& Solensky (2005) existem, no hemisfério ocidental, duas subespécies da borboleta-monarca: a (1) Danaus plexippus plexippus presente no sul do Canadá, Estados Unidos, México e na maioria das Ilhas do Caribe, América Central e norte da América do Sul, e a (2) Danaus plexippus erippus ocorrendo no Peru, Bolívia, Chile, Argentina, Uruguai, Paraguai e Sul e Leste do Brasil (nenhuma subespécie foi registrada na região noroeste do Brasil). Suas larvas são herbívoras especialistas de Asclepias (o consumo do néctar torna as borboletas impalatáveis aos pássaros), mas o alimento para a população adulta consiste basicamente de néctar, sem seletividade do tipo; visitam constantemente plantas da família Asteraceae, especialmente dos gêneros Erigeron, Aster e Helianthus (Collicutt 2005). As monarcas são borboletas migratórias que, durante o inverno, trocam a região onde habitam por outras com temperaturas amenas; as maiores migrações ocorrerem na população do leste da América do Norte que vão para México e retornam na primavera. Um possível movimento migratório da subespécie da América do Sul poderia levála da Região Andina para as fronteiras da Região Neotropical, ampliando a área de atuação desses insetos na polinização.

A informação disponível mais interessante, no entanto, é sobre a distribuição dos Hymenoptera no continente Americano. Michener (1979) apresentou alguns padrões de disjunção na ocorrência de abelhas, entre os quais o denominado "Oeste do Hemisfério Anfitropical", aplicado a algumas abelhas que ocorrem em áreas secas temperadas das duas Américas, mas não nos trópicos intermediários. O autor observou que há algumas evidências de 
que a dispersão norte-sul é mais antiga que a sul-norte e procura explicar tal ocorrência pelo fato de que a maioria das abelhas e vespas estocam o perecível alimento de suas larvas (no caso das abelhas, pólen misturado ao néctar) em células escavadas no solo e que, em solos úmidos, o ataque de fungos a esse alimento e às abelhas jovens é catastrófico. Por outro lado, comentou que as savanas do Panamá e da Venezuela têm uma fauna pobre e que as áreas secas tropicais são savanas depauperadas e que os coletores de abelhas percebem que, nessa região, há uma floração muito menor durante o ano do que aquela observada nas zonas quentes e secas temperadas que, como conseqüência, apresentam uma fauna de abelhas muito maior. As pradarias apresentam estações de floração conspícuas e, segundo ele, os cerrados que se estendem de forma relativamente contínua do Brasil Central até os Pampas na Argentina têm uma fauna apícola crescente à medida que progride para o sul e provavelmente se tornando mais enriquecida nas partes desérticas da Argentina, as quais se assemelham a Região de Sonora no aspecto vegetacional; essa fauna mésica temperada também se estende ao Paraguai e Uruguai; todos os grupos de abelhas neotropicais possuem gêneros ou subgêneros adicionais nessas áreas e, entre o Sul do Brasil e a Argentina, está uma das mais ricas faunas apícolas do mundo (Michener 1979) e é fácil imaginar sua atuação positiva na expansão geográfica das Viguiera na América do Sul.

Morrone (1994, 1996) propôs a distinção de duas grandes regiões Biogeográficas na América do Sul, considerando as afinidades de sua biota com elementos de fora da América do Sul e critérios ecológicos. A Região Neotropical, restrita a uma parte da Região Neotropical de outros autores, como Cabrera \& Willink (1973), é incluída no Reino Holotropical e a Região Andina equivale ao sub-reino Andino de Rivas-Martinez \& Tovar (1983) unido ao domínio subantártico de Cabrera \& Willink (1973) e está associada ao Reino Austral, sensu Kuschel 1964 (Figura 1). 


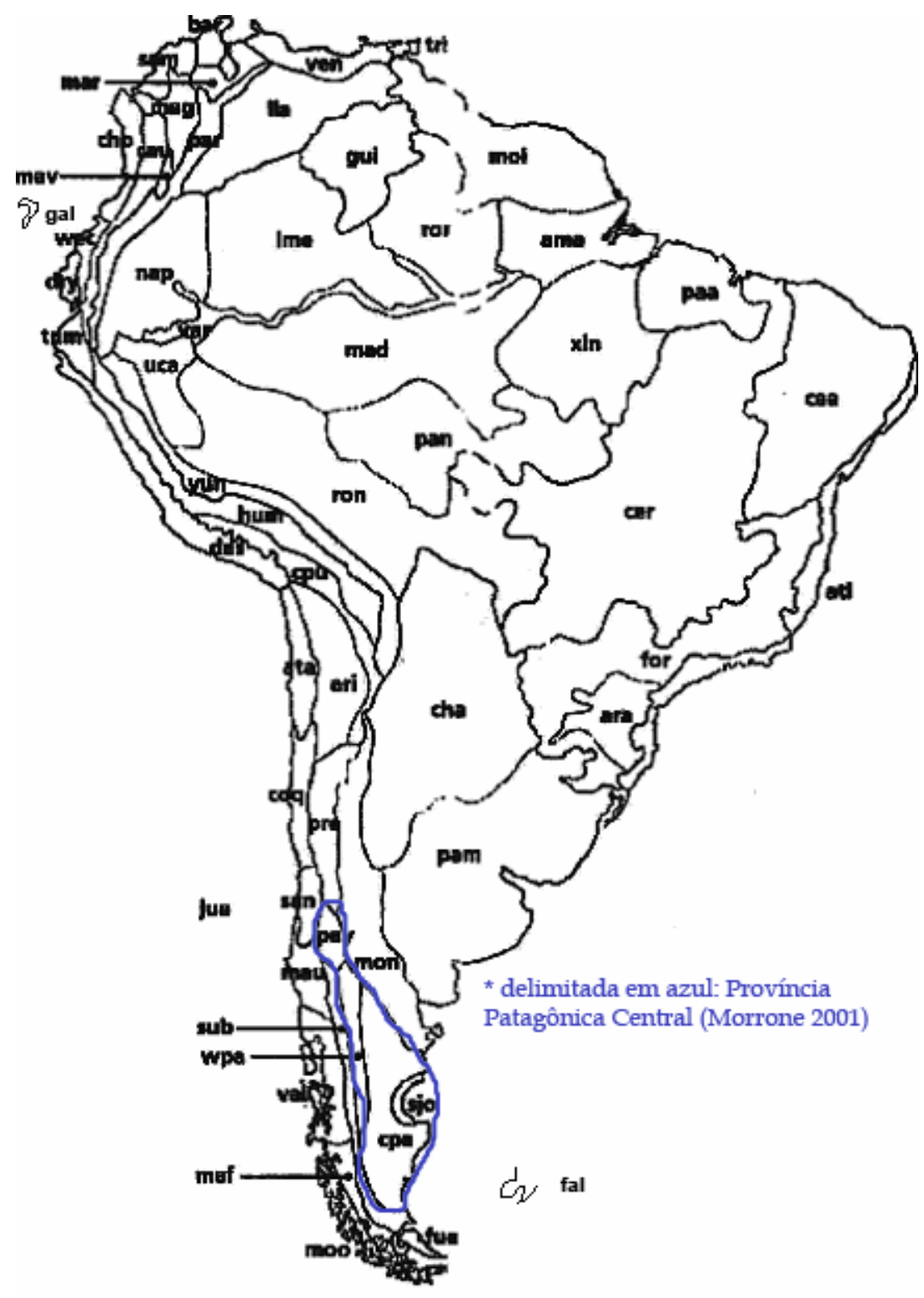

Fig. 1. Províncias biogeográficas de América do Sul. Referências = ama: Amapá, ara: dos Pinhais, ata: Atacama, atl: Atlântica, ari: Puna Árida, bar: Barranquilla, caa: Caatinga, cau: Cauca, cer: Cerrado, cha: Chaquenha, cho: Chocó, coq: Coquimbo, cpa: Patagônica central, cpu: Puna Central, des: Deserto, dry: Equatoriana Seca, fal: Ilhas Malvinas, for: de Ias Selvas, fue: Patagônica Fueguina, gal: Ilhas Galápagos, gui: Guiana, hum: Puna Úmida, ime: Imerí, jua: Ilhas Juan Fernández, lia: Llanos, mad: Madeira, maf: Bosque Magallânico, mag: Magdalena, mar: Maracaibo, mau: Maule, mav: Valle de Magdalena, moi: Guiana Úmida, mon: Monte, moo: Páramo Magallânico, nap: Napo, paa: Pará, pam: Pampeana, pan: Pantanal, par: Páramo, pay: Payunia, pre: Prepuna, ron: Rondônia, ror: Roraima, sam: Santa Marta, san: Santiago, sjo: Golfo de San Jorge, sub: Patagônica Subandina, tri: Trinidad y Tobago, tum: Tumbes-Piura. uca: Ucayali. vai: Valdiviana. var: Varzea, ven: , Venezolana Costcira, wec: Equatoriana Ocidcntal, wpa: Patagónica Ocidental, xin: Xingu- Tapajós, yun: Yungas (modificado de Morrone 1999).

Na Região Neotropical ocorre a maioria das espécies, concentradas principalmente na província do Cerrado, da Sub-região Chaquenha, (Tabela 1). 
Algumas espécies que aparentemente são originadas na região Andina, eventualmente são encontradas na Região Neotropical (V. australis, V. fusiformis, $V$. lanceolata, $V$. procumbens, $V$. retroreflexa e $V$. tucumanensis). Duas espécies alcançam o limite sul (ca. $38^{\circ} \mathrm{S}$ ), na Província Patagônica Central, localizada no Cone Sul da América do Sul: $V$. gilliesiii e $V$. revoluta, encontradas em elevações entre 1500 e 3000 m.s.m., aonde as temperaturas mínimas anuais chegam a $4^{\circ} \mathrm{C}$ (CONAMA 1999).

A interação entre grandes altitudes e cordilheiras latitudinais produziu vários tipos de ambientes alpinos especializados, referidos como páramos (Cuatrecassas 1968, Luteyn 1999). As espécies do Equador (V. incana, V. media e V. soridoi) são endêmicas das chamadas Terras Frias (2 a 3 mil metros, com temperaturas entre 12 e $18^{\circ} \mathrm{C}$ ) e desses ambientes (acima de 3 mil m.s.m. e temperaturas médias abaixo de $12^{\circ} \mathrm{C}$ ); assim, são mesotérmicas ou microtérmicas. Na porção setentrional do Peru, entre os Páramos ao norte e a Puna ao sul existem, acima de 3000m, comunidades alpinas transicionais conhecidas localmente como formações Jalca (Webebauer 1936) e limitadas bruscamente por $4,5-8^{\circ} \mathrm{S}$ e $77-80^{\circ} \mathrm{W}$ (Dillon 2005). São locais mais secos que os páramos e mais úmidos que a puna; Luteyn (1999) sugeriu que essa formação é similar aos Páramos do Sul do Equador, mas a região parece representar uma barreira para a migração entre espécies do Equador e Peru, superada apenas por $V$. procumbens, espécie com alta capacidade de adaptação e encontrada também em várias províncias da Região Neotropical. Entre 4-6 $\mathrm{S}$ existe uma descontinuidade nos Andes atravessando, no sentido noroeste-nordeste, os Departamentos de Piura e Cajamarca com as montanhas se tornando fragmentadas, o que resulta numa passagem de baixa altitude (menos de 3 mil metros) para a biota; é a Depressão de Huancabamba, uma região geograficamente complexa, com vales entre as montanhas, onde corre um intrincado sistema fluvial que alcança o Equador. Nessa região, em altitudes inferiores a 500 m.s.m., se encontram $V$. brittonii e $V$. truxilensis, que podem ser classificadas como megatérmicas. Deve-se aqui ressaltar que durante este trabalho foi notada uma grande semelhança entre $V$. truxilensis e $V$. incana, do 
Equador; estudos futuros poderão levar a sinonimização desses táxons.Os desertos Peruviano e do Atacama formam um cinturão que ocupa cerca de um terço da costa oeste da América do Sul e estão entre os mais secos da terra; a flora local é megatérmica e dependente da neblina (formação Lomas, 0-1000 m.s.m.) e está estimada em mais de 1100 espécies de fanerógamas (Dillon 2005). A aridez dos diversos pontos é controlada por fatores como a existência de breves períodos de chuva associados a eventos raros, mas recorrentes, de "El Niño" (Dillon \& Vision 2005) e pela estabilidade nos padrões de temperatura ao longo do ano, devido à relação entre a superfície fria do mar e correntes de Humboldt (Peruvianas), com a formação de estratos de nuvens abaixo de 1000 m.s.m., durante os meses de inverno (Proraska 1973). A formação Lomas ocorre como comunidades discretas ou ilhas de vegetação separadas por habitats extremamente áridos, destituídos de vida vegetal. O grau de endemismo é alto (40\%); vários gêneros primariamente do Hemisfério Norte têm espécies endêmicas nos desertos costeiros; é o caso de Viguiera weberbaueri, do Peru. Apesar da continuidade do deserto, entre Peru e Chile, a ausência de uma condição topográfica que provenha neblina entre Arica e Anfogasta (norte do Chile) resulta no fato de menos de $7 \%$ das espécies serem encontradas dos dois lados dessa região (Dillon \& Vision 2005) que, no entanto, abriga V. atacamensis e V. revoluta. Embora V. peruviana tenha sido coletada em Arica, junto ao Peru, não há registros desta espécie no restante do Chile. Neste país, aparentemente, a região de maior concentração em número de indivíduos é a Província de Coquimbo, onde ocorrem $V$. adenotricha, $V$. gayana e $V$. revoluta, esta última alcançando a Província Patagônica Central, na Sub-região Patagônica (de Morrone 2001). Nesta região, V. revoluta é encontrada nas Lomas, a cerca de 800 m.s.m. ou segue cruzando os Andes, do Chile à Argentina, em altitudes que chegam a 3500 m.s.m; de acordo com as evidências, $V$. revoluta pode ser classificada como mega ou mesotérmica. Outra espécie a alcançar a Província Patagônica é $V$. gilliesii, melhor representada na Argentina, na Província de Prepuna; é uma espécie primariamente mesotérmica e ocasionalmente microtérmica. 
Na Província de Prepuna ocorrem também $V$. procumbens, e $V$. tucumanensis, cuja distribuição se estende à outras Províncias.

Na Puna Árida, uma extensa área do tamanho do Novo México e caracterizada pelo clima seco e pelos campos de altitude (onde a temperatura média anual varia entre 3 e $10^{\circ} \mathrm{C}$ ), são encontradas $V$. australis, $V$. fusiformis, $V$. lanceolata, $V$. procumbens, $V$. retroreflexa, $V$ truxilensis $(=V$. incana?) e $V$. tucumanensis. Ocorrem como mesotérmicas ou microtérmicas, com $V$. fusiformis, $V$. lanceolata, $V$. procumbens e $V$. tucumanensis também são encontradas na Província de Puna Central, juntamente com $V$. peruviana que, por sua vez, tem sua distribuição estendida à Puna úmida, em simpatria com $V$. britonii.

As Yungas (Bosque Tucumano-Boliviano), com altitudes entre 800 e 3900 m.s.m. e temperaturas médias anuais entre 5 a $23^{\circ} \mathrm{C}$ recebem ventos frios do Sul. Aí são encontradas $V$. australis, $V$. fusiformis, $V$. lanceolata, $V$. procumbens, $V$. retroreflexa e $V$. tucumanensis; ocorrendo como mesotérmicas ou microtérmicas.

Nos Pampas, onde se distribuem principalmente os grupos de gramíneas mesotérmicos (os microtérmicos representam transgressões) da Região Neotropical, é encontrada, em profusão, V. anchusifolia, que chega às províncias biogeográficas do Cerrado e das Selvas, o que também ocorre $V$. pilosa, com número de bem menor de espécimes. Exclusivas da Província Pampeana são $V$. breviflosculosa, V. fabrisii, V.knobiana, V. megapotamica, V. nudicaulis e $V$. meridionalis, todas mesotérmicas.

As espécies exclusivamente brasileiras são classificadas como megatérmicas e a maioria é encontrada na Província do Cerrado, acima dos 500 m.s.m. Por outro lado, $V$. corumbensis está restrita à Província do Pantanal e $V$. trichophylla à Província dos Pinhais. As espécies encontradas também acima de 1500 m.s.m. são V. bracteata, V. filifolia, V. gardneri, V. grandiflora e V. robusta, em locais com temperatura média anual em torno dos $20^{\circ} \mathrm{C}$ (Alto Paraíso de Goiás, Rio de Contas e Airuoca).

Tabela 1. Eco-regiões de ocorrência das espécies da América do Sul, segundo a divisão de Morrone (1999). Abreviatura do nome das províncias biogeográficas. Yun $=$ Yungas, Pan $=$ Pantanal, Cha $=$ Chaquenha, Mon $=$ Monte, Pam $=$ Pampeana, Cer $=$ Cerrado, Ara $=$ Pinhais, Atl $=$ Atântica, For $=$ Selva, Pre $=$ Prepuna, $\mathrm{Cpu}=$ Puna Central, Hum = 
Puna Úmida, Ari $=$ Puna Árida, Des $=$ Deserto, Ata $=$ Atacama, Par $=$ Páramo, Coq $=$ Coquimbo, San = Santiaguina, $\mathrm{Mau}=$ Maule, $\mathrm{Cpa}=$ Patagônica Central.

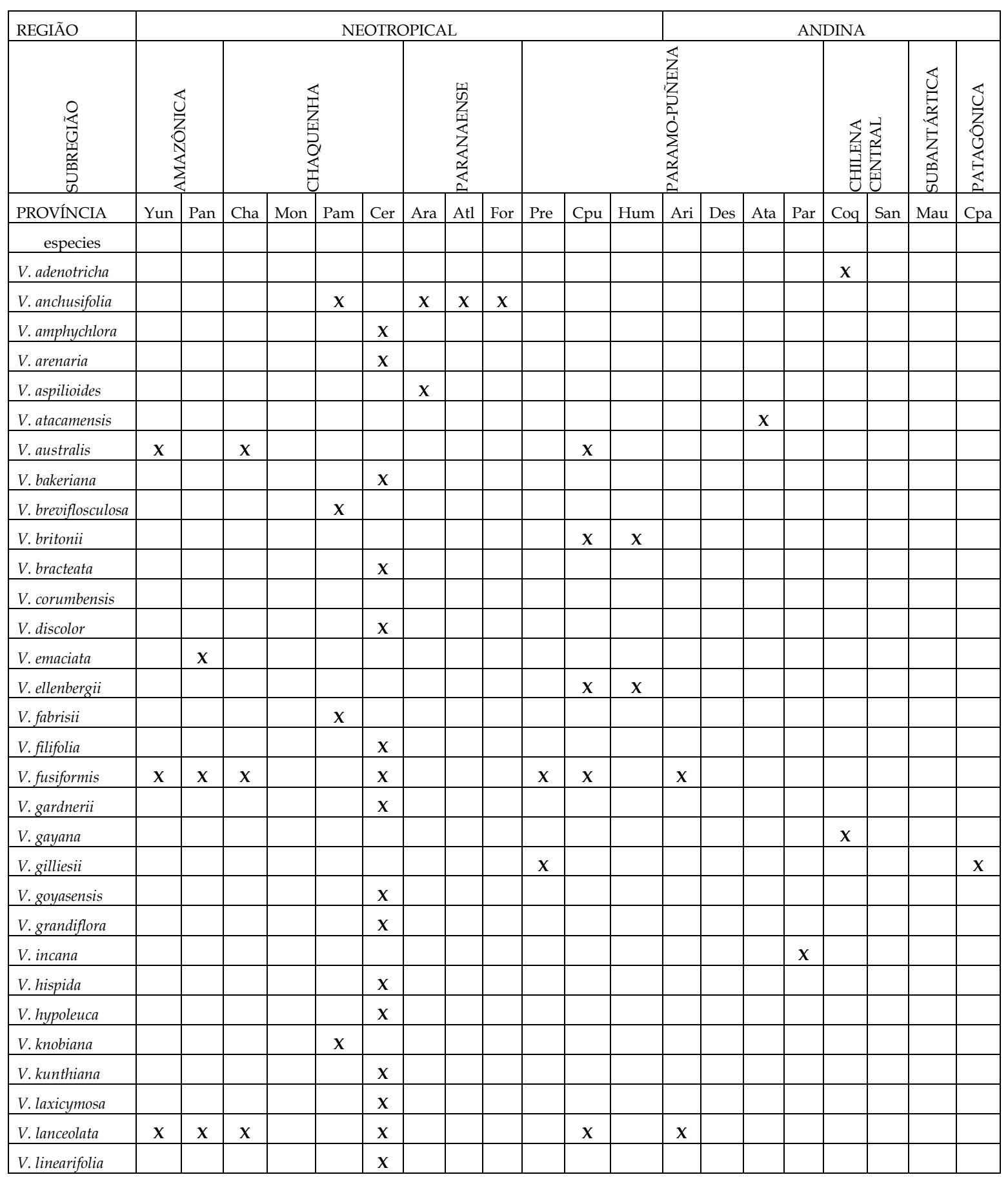


Tabela 1 (continuação). Eco-regiões de ocorrência das espécies da América do Sul, segundo a divisão de Morrone (1999). Abreviatura do nome das províncias biogeográficas. Yun $=$ Yungas, Pan $=$ Pantanal, Cha $=$ Chaquenha, Mon $=$ Monte, Pam $=$ Pampeana, Cer $=$ Cerrado, Ara $=$ Pinhais, Atl $=$ Atântica, For $=$ Selva, Pre $=$ Prepuna, $\mathrm{Cpu}=$ Puna Central, Hum $=$ Puna Úmida, Ari $=$ Puna Árida, Des $=$ Deserto, Ata $=$ Atacama, Par $=$ Páramo, $\mathrm{Coq}=$ Coquimbo, San $=$ Santiaguina, $\mathrm{Mau}=$ Maule, $\mathrm{Cpa}=$ Patagônica Central.

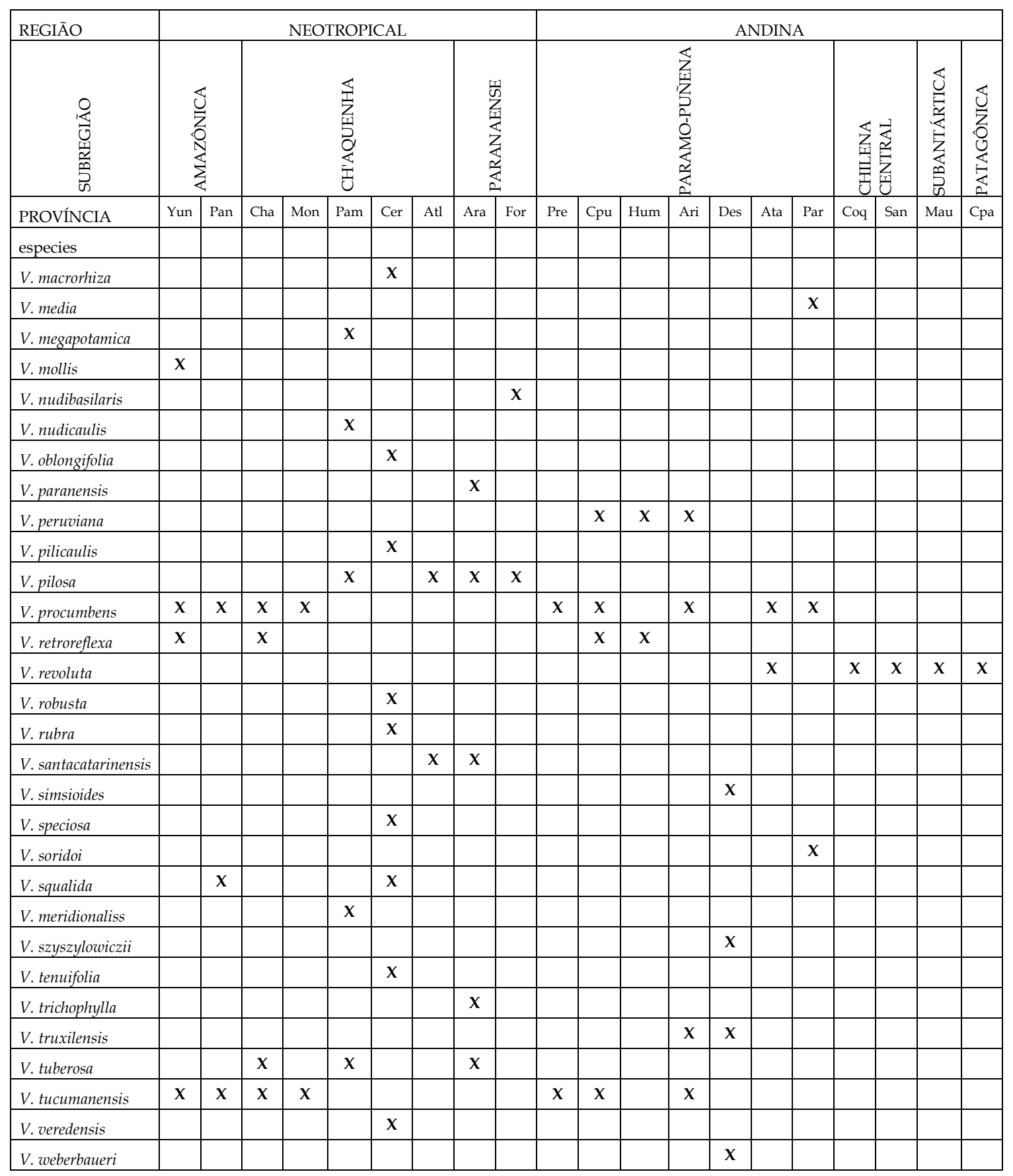


Padrões de distribuição, com base no Sistema de Morrone (1999).

A análise aqui apresentada não pretende ser definitiva para as espécies sul-americanas, já que apenas para as espécies ocorrentes no Brasil foi obtida uma amostragem confiável, incluindo observações de campo. Para as demais, contou-se com observação de materiais dos herbários sul-americanos citados e dos materiais-tipo, nos herbários europeus e uns poucos dados existentes de literatura. Devido à distribuição aparentemente restrita das espécies, optou-se por estabelecer padrões baseados nas Províncias de ocorrência e não nas Subregiões (Morrone 1999). O estudo das espécies brasileiras apontou para uma grande variação fenotípica em nível específico, o que provavelmente é verdadeiro para as demais e estudos futuros deverão alterar os padrões detectados que, no atual nível de conhecimento estão divididos em três grupos e, são os seguintes:

GRUPO 1: ESPÉCIES ANDINAS: Espécies exclusivas da Região Andina (de Morrone 1999).

1. Padrão Paramense: Local de endemismo das espécies do Equador: $V$. incana, $V$. media, e $V$. soridoi. Além dessas, somente é encontrada $V$. procumbens, distribuída nas duas grandes Regiões da América do Sul.

2. Padrão Desértico: Espécies encontradas apenas na Província do Deserto, endêmicas do Peru: $V$. simsioides, $V$. szyszylowisczii e $V$. weberbaueri.

3. Padrão Desértico - Árido - Punense: Apenas V. truxillensis, coletada no deserto, próximo ao mar e em Cachapoyas (em caso de sinonimização com $V$. incana este padrão dará lugar a outro, Páramo - Punense).

4. Padrão Atacamense: Uma espécie endêmica do deserto de Atacama, no Chile: V. atacamensis.

5. Padrão Coquimbense: Espécies chilenas exclusivas da Província de Coquimbo: $V$. adenotricha e $V$. gayana.

6. Padrão Yunguense: $V$. mollis (Há indícios de ser sinônimo de $V$. tucumanensis; neste caso, este padrão desaparece e a espécie se enquadra no padrão 11, Contínuo Yunguense - Chaquense). 
7. Padrão Punense Central - Úmido: Ambiente de V. britonii, V. ellenbergii e $V$. peruviana.

8. Padrão Atacamense - Patagônico Central: V. revoluta .

9. Padrão Patagônico Central - Prepunense: padrão de distribuição V. gilliesii) que cruzam os Andes, entre Argentina e Chile.

GRUPO 2: ESPÉCIES ANDINO-NEOTROPICAIS: Espécies primariamente andinas, com intrusões neotropicais.

10. Padrão Contínuo Paramense - Chaquense: Uma espécie, V. procumbens, encontrada desde os Páramos equatoriais até os Chacos bolivianos; seu centro de diversidade encontra-se, aparentemente, nas Yungas bolivianas, de onde se estende para o Norte, alcançando os Páramos e para o Sul, através das três Províncias de Punas, Província do Monte e chega à Província do Chaco.

11. Padrão Contínuo Yunguense - Chaquense: Espécies que ocorrem de forma contínua ou quase contínua, entre as Yungas e o Chaco; com $V$. australis, $V$. fusiformis e $V$. lanceolata, dispersas através das Punas e Pantanal e $V$. retroreflexa e $V$. tucumanensis, atravessando as Punas e chegando ao Chaco.

GRUPO 3: ESPÉCIES NEOTROPICAIS: Espécies exclusivas da Região neotropical (de Morrone 1975).

12. Padrão Pampeano: espécies mesotérmicas, exclusivas dos Pampas do Uruguai (V. breviflosculosa), da Argentina (V. fabrisii) e Brasil (V.knobiana, $V$. megapotamica, V. nudicaulis e $V$. meridionalis). Foram encontrados poucos exemplares destas plantas nos herbários (V. breviflosculosa, V. knobiana e $V$. meridionalis são conhecidas apenas pelo tipo).

13. Padrão Pampeano - Paranaense: compreendendo uma grande região que abrange os Pampas e as três Províncias da Sub-região Paranaense (da Selva, dos Pinhais e Atlântica) está a distribuição de duas espécies, $V$. anchusifolia com limite Sul nos Pampas Uruguaios e V. pilosa, encontrada a partir dos pampas Argentinos. 
14. Padrão Pampeano - Chaquense - Pinheirense: é o padrão de uma única espécie, $V$. tuberosa, encontrada em barrancos de rios da Argentina, Uruguai e no Brasil, em ocorrências esparsas no Rio Grande do Sul, Paraná e Mato Grosso do Sul.

15. Padrão Pantaneiro: $V$. corumbensis e $V$. emaciata (há evidências de que a segunda é sinônimo de $V$. fusiformis) são exclusivas desse ambiente, a primeira conhecida apenas pelo material tipo, de Cochabamba na Bolívia, e a segunda encontrada entre Miranda e Corumbá, no Mato Grosso do Sul.

16. Padrão Pantaneiro - Cerradense: V. squalida apresenta grandes variações fenotípicas, atingindo mais de $2 \mathrm{~m}$ de alt. e apresentando folhas ovallanceoladas membranáceas na região do Pantanal ou com menos de 0,5 m e folhas orbiculares cartáceas no alto de morrarias com sedimentos ferríferos; Robinson \& Moore (2004) se referiram a plantas do Brasil Central como pertencendo a esta espécie mas, de fato, aquelas são $V$. grandiflora.

17. Padrão Pinheirense: Espécies da Província dos Pinhais: duas exclusivamente brasileiras ocorrendo no Paraná, nas regiões de Curitiba e Ponta Grossa (V. aspilioides e V. trichophylla).

18. Padrão Pinheirense - Atlântico: V. santacatarinensis, nas encostas de Mata Atlântica e na região dos Aparados da Serra do Rio Grande do Sul.

19. Padrão Cerradense: Espécies encontradas unicamente no cerrado; abarca a maioria das espécies brasileiras: $V$. speciosa, do Paraguai, tem afinidades morfológicas com V. squalida do cerrado e Pantanal. Apenas o materialtipo da primeira foi examinado; estudos futuros poderão mostrar que se trata de uma única espécie, com variações na cipsela. Quatro espécies foram inicialmente descritas exclusivamente do Paraguai - V. amphychlora, $V$. linearifolia, $V$. macrorhiza e $V$. pilicaulis - das regiões de Savana das Serras de Maracayú, Caaguazuú e Amambay e encontradas no Brasil durante este trabalho, a primeira no Estado do Paraná e região circunvizinha de São Paulo, a segunda em Ponta Porã (MS), na divisa com o Paraguai, a terceira em pequenas populações, nos Estados de Mato Grosso do Sul, São 
Paulo e Minas Gerais e a última na região central do Mato Grosso do Sul, ocorrência já registrada por Robinson \& Moore (2004), como Rhysolepis pilicaulis; com exceção de $V$. macrorhiza, as demais apresentam ocorrência muito restrita, o que indica sua existência recente no País; tais espécies são as únicas restritas ao clima que Köpen classifica como mesotérmico sempre -úmido com verão quente (Cfa de Köpen). As demais são exclusivamente brasileiras, com $V$. robusta apresentando uma distribuição contínua em toda a Província do Cerrado. Das outras 16 espécies exclusivas do cerrado, 6 têm como limite Sul o Estado de São Paulo, derivando geralmente para o sentido Nordeste ou às vezes Norte (Minas Gerais e Goiás): V. arenaria, V. bakeriana, $V$. discolor, $V$. hispida, $V$. rubra e $V$. tenuifolia; essas espécies parecem estar restritas ao clima mesotérmico de inverno seco e verão quente (Cwa de Köpen). As outras, com limite Sul a partir de Minas Gerais (V. bracteata, V. filifolia, V. gardneri, V. goyasensis, V. grandiflora, V. kunthiana $V$. laxicymosa e V. veredensis) ou Mato Grosso ( . hypoleuca e V. oblongifolia), parecem apresentar preferência pelo clima megatérmico de inverno seco (Aw de Köpen) e sua área-core (área nuclear) é, provavelmente, a região dos Estado de Goiás e do Nordeste de Minas Gerais, com extensões para o Norte, até o Tocantins e para o Oeste, no Mato Grosso. De acordo com os dados disponíveis, o limite de distribuição das espécies ao Norte é em torno de $11^{\circ} \mathrm{S}$, mas $V$. oblongifolia apresenta poucas ocorrências em latitudes ente 7 e $8^{\circ}$ S. Uma espécie chega ao extremo Oeste do País ( $V$. squalida) e não há registros pra longitudes menores que $40^{\circ} \mathrm{W}$ (para a comparação com os padrões e tipos climáticos ver figura 2).

20. Padrão Cerradense - Silvestre: Apenas V. nudibasilaris transita entre a Região de Selva (sempre nas bordas) e o cerrado. 


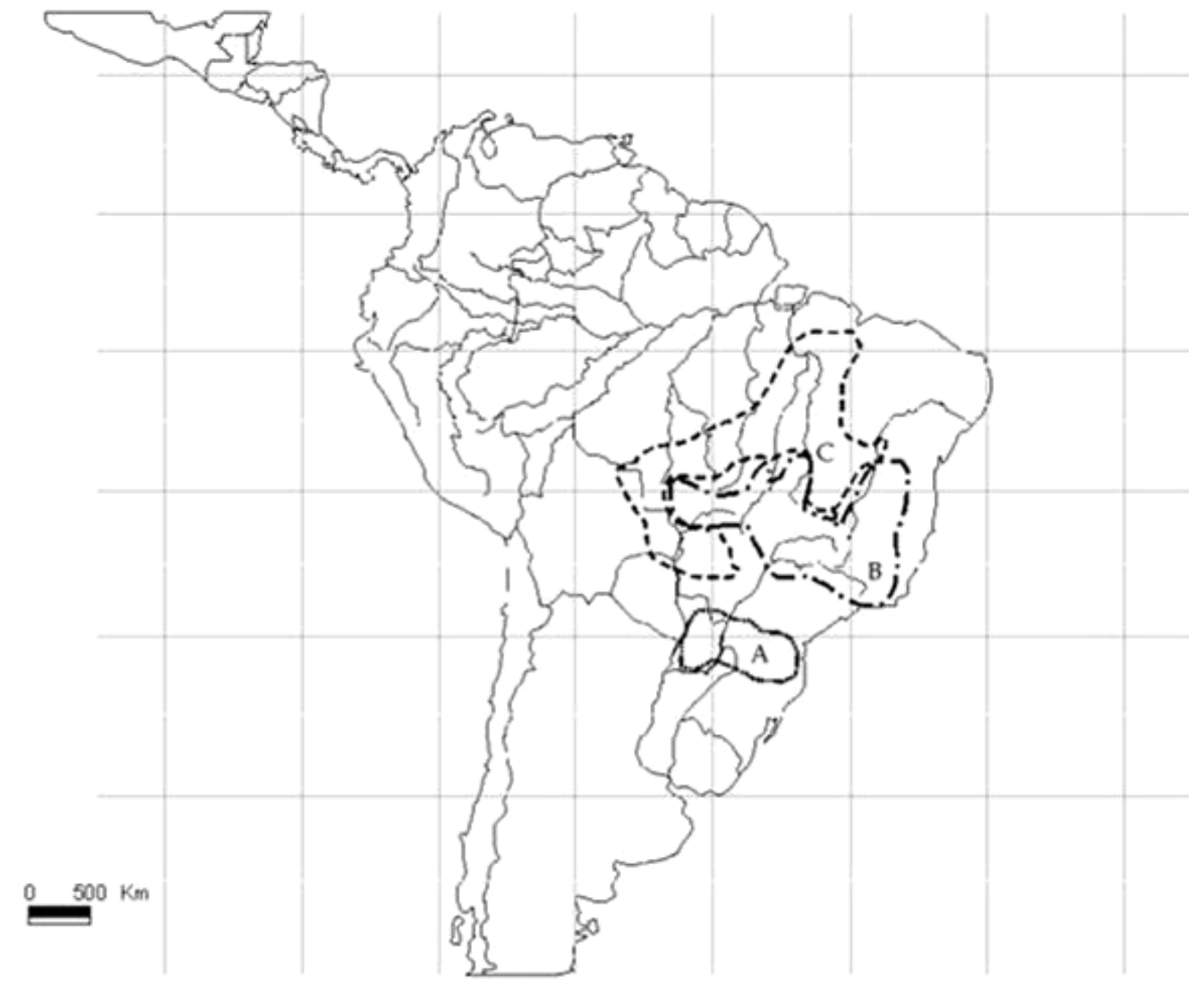

Fig. 2. Correlação entre os sub-padrões do Padrão Cerradense e o clima, segundo a classificação de Köpen A. Cfa ( $V$. amphychlora, $V$. linearifolia, $V$. macrorhiza e $V$. pilicaulis), B. Cwa (V. arenaria, $V$. bakeriana, $V$. discolor, $V$. hispida, $V$. rubra e $V$. tenuifolia), C. Aw V. bracteata, V. filifolia, V. gardneri, V. goyasensis, V. grandiflora, V. kunthiana $V$. laxicymosa e $V$. veredensis $V$. hypoleuca e $V$. oblongifolia).

\section{Domínios de Burkart}

Burkart (1975) propôs a seguinte classificação das gramíneas sulamericanas em três grupos (Figura 3):

1. Grupos megatérmicos: constituídos pelas gramíneas de áreas equatoriais e tropicais com temperatura média anual de $20^{\circ} \mathrm{C}$ ou mais e $15^{\circ} \mathrm{C}$ ou mais de temperatura invernal; na América do Sul, tais condições são encontradas nos planaltos, e serras baixas, entre cerca de $13^{\circ} \mathrm{N}$ e $28^{\circ} \mathrm{S}$. É 
feita uma ressalva para a Cordilheira dos Andes, que funciona como uma barreira que altera o clima, em função da altitude. Nos Andes tropicais as gramíneas megatérmicas alcançam até $150 \mathrm{~m}$, as mesotérmicas entre 1500 - $3000 \mathrm{~m}$ e as microtérmicas acima de 3500m.

2. Grupos mesotérmicos: englobam as gramíneas que requerem temperaturas médias anuais entre 10 e $20^{\circ} \mathrm{C}$ e invernais de 5 a $15^{\circ} \mathrm{C}$; essas condições prevalecem nas regiões temperadas da América do Sul (Argentina central, Uruguai e Sul do Brasil), entre 28 e $40^{\circ} \mathrm{S}$; o fator temperatura é menos importante e as condições hídricas controlam as fases da vegetação; assim, há um gradiente de leste a oeste, de condições úmidas a xéricas, com pampas e campos no Uruguai, Brasil e Mesopotâmia e vegetação xerófila de monte, a oeste da Argentina, com uma variada composição florística intermediária (Zucol 2000) .

3. Grupos microtérmicos: aqui se enquadram as gramíneas de áreas com climas temperados frios ou frios, com menos de $10^{\circ} \mathrm{C}$ de temperatura média anual e menos de $5^{\circ} \mathrm{C}$ de temperatura média invernal.Tais condições se apresentam em elevadas latitudes ou em altitudes extremas ao longo da Cordilheira dos Andes.

Com base nessas exigências térmicas, o autor agrupa em três Domínios:

1. Campestre Tropical e Subtropical: com vegetação de cerrado e dominado por grupos megatérmicos, abrange os Llanos de Orinoco, na Colômbia e Venezuela, os Campos Cerrados do Brasil Central, os pântanos como o Pantanal brasileiro, as partes ao Norte dos campos do Sul do Brasil e as formações campestres tropicais e subtropicais do leste dos Andes, que se estende numa estreita extensão, até o sopé dos Andes, da Venezuela, Colômbia à Bolívia e noroeste da Argentina.

2. Campestre Temperado: Composto pelas regiões dos Pampas, Campos do Uruguai e sul do Rio Grande do Sul.

3. Campestre de Países Frios: Região de gramíneas microtérmicas, que abarca os Páramos da Venezuela, Colômbia e Equador, as estepes 
andinas do Peru, Bolívia e noroeste da Argentina e as estepes da Patagônia.

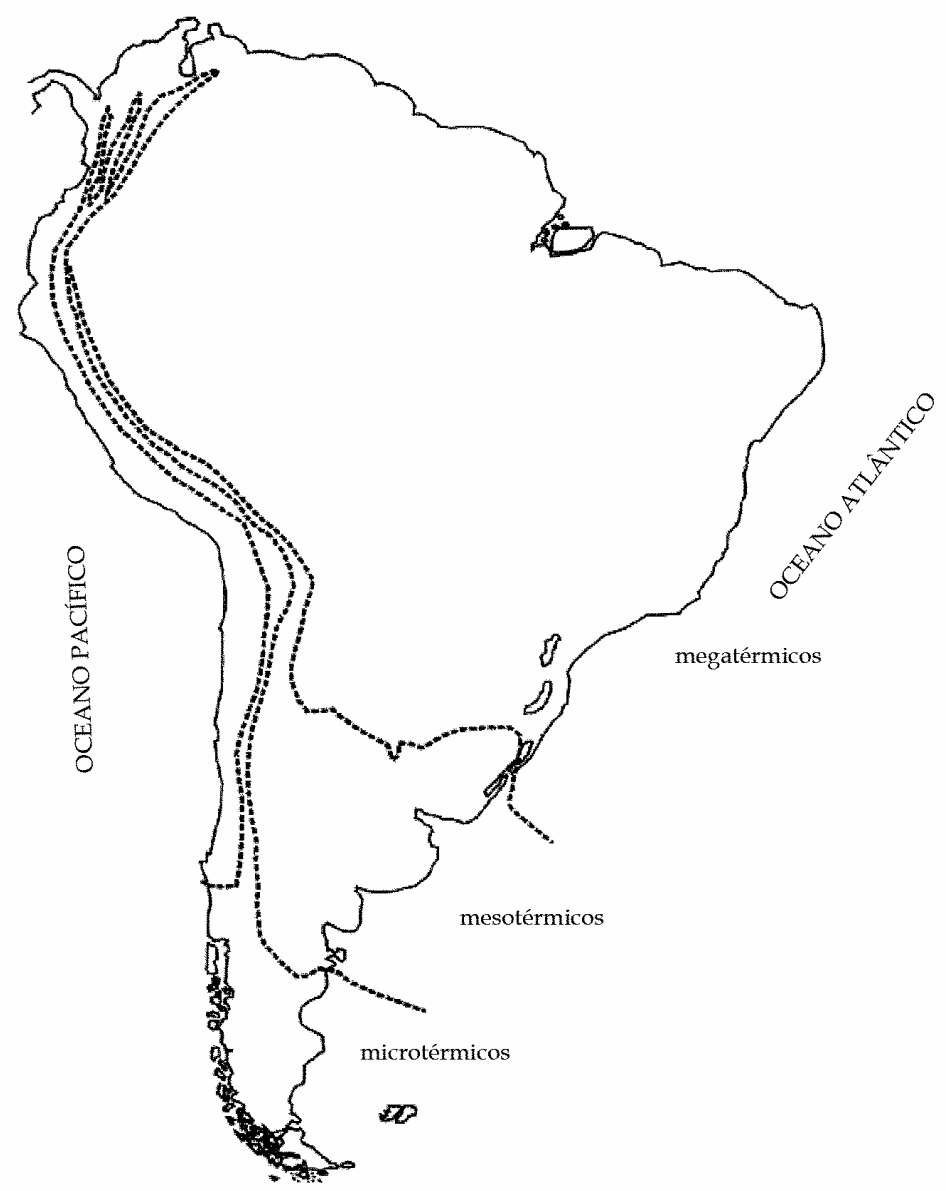

Fig. 3 Domínios dos Campos de Gramíneas da América do Sul (Burkart 1975, modificado de Zucol 2000).

De acordo com os resultados do presente trabalho, os padrões de distribuição de Viguiera na América do Sul podem ser considerados como um subconjunto dos domínios de campos de gramíneas especificados por Burkart; o gênero ocorre nos três domínios estabelecidos pelo autor, com maior representatividade no Domínio dos Campos Tropicais e Subtropicais; nele, somente os Llanos não possuem representantes de Viguiera. Nos Campos Temperados (zonas centrais da Argentina, Uruguai e Sul do Brasil) ocorrem poucas espécies e, nos Campos Frios esse número é ainda mais reduzido; não há representantes nos Páramos colombianos e venezuelanos e na Patagônia Fueguina. 


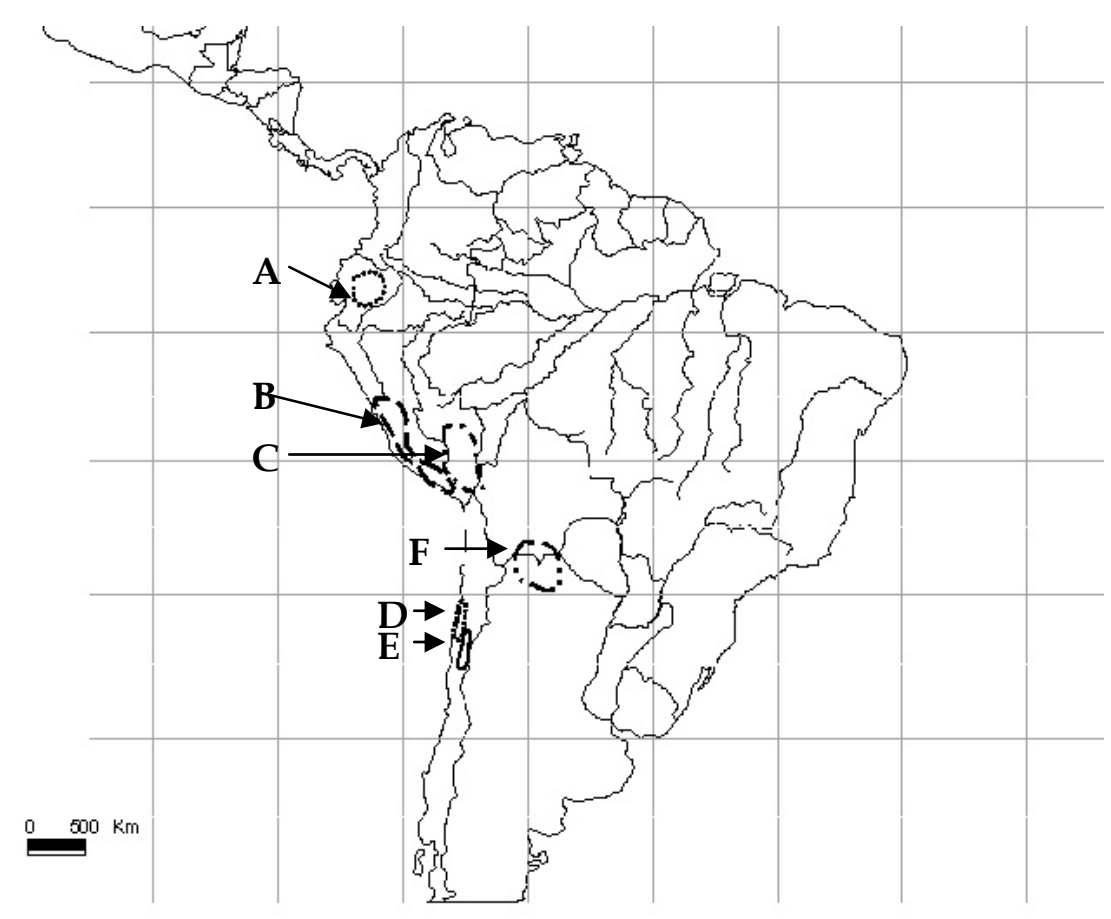

Fig. 4: Padrões de distribuição do grupo 1 (espécies andinas): A. Paramense (....................), B. Desértico(--_-), C. Desértico - Árido - Punense (---_-), D. Atacamense

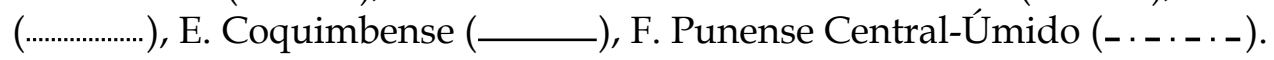

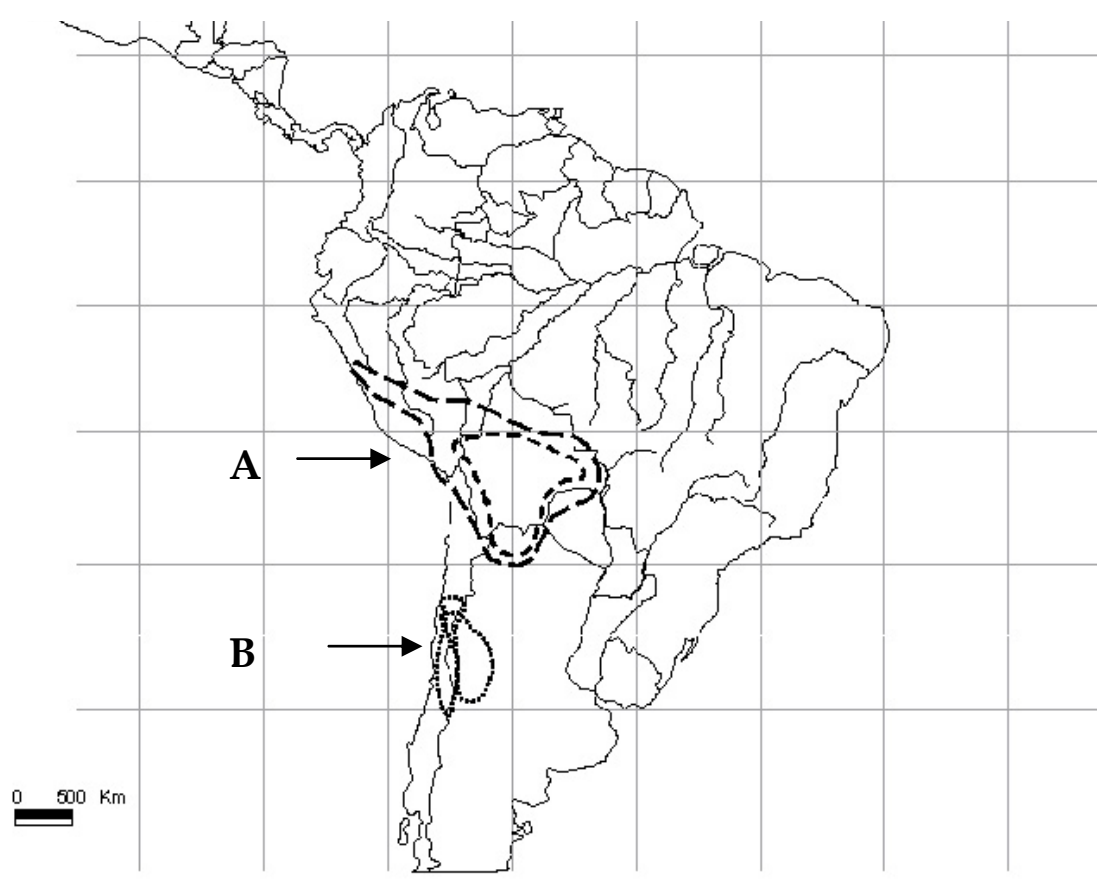

Fig. 5. Padrões de distribuição andinos: A. Atacamense-Patagônico (...............) e Patagônico Central - Prepunense (.................), B. Padrão contínuo Paramense - Chaquense (_- - -) e Padrão contínuo Yunguense - Chaquense (- - - - -). 


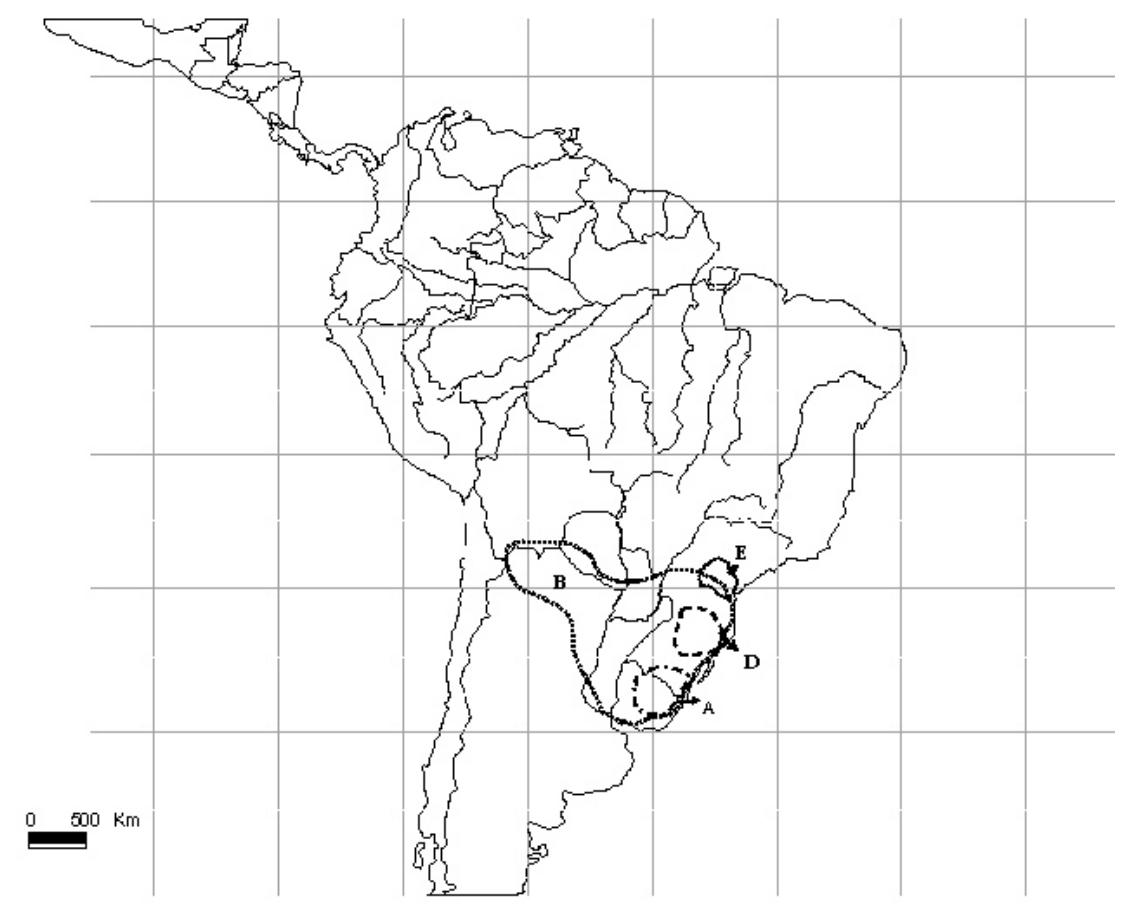

Fig. 6: Padrões do grupo Neotropical. A. Pampeano (_.....- ), B. Pampeano Paranense (...............), C. Pinheirense (..................), D. Pinheirense - Atlântico (—

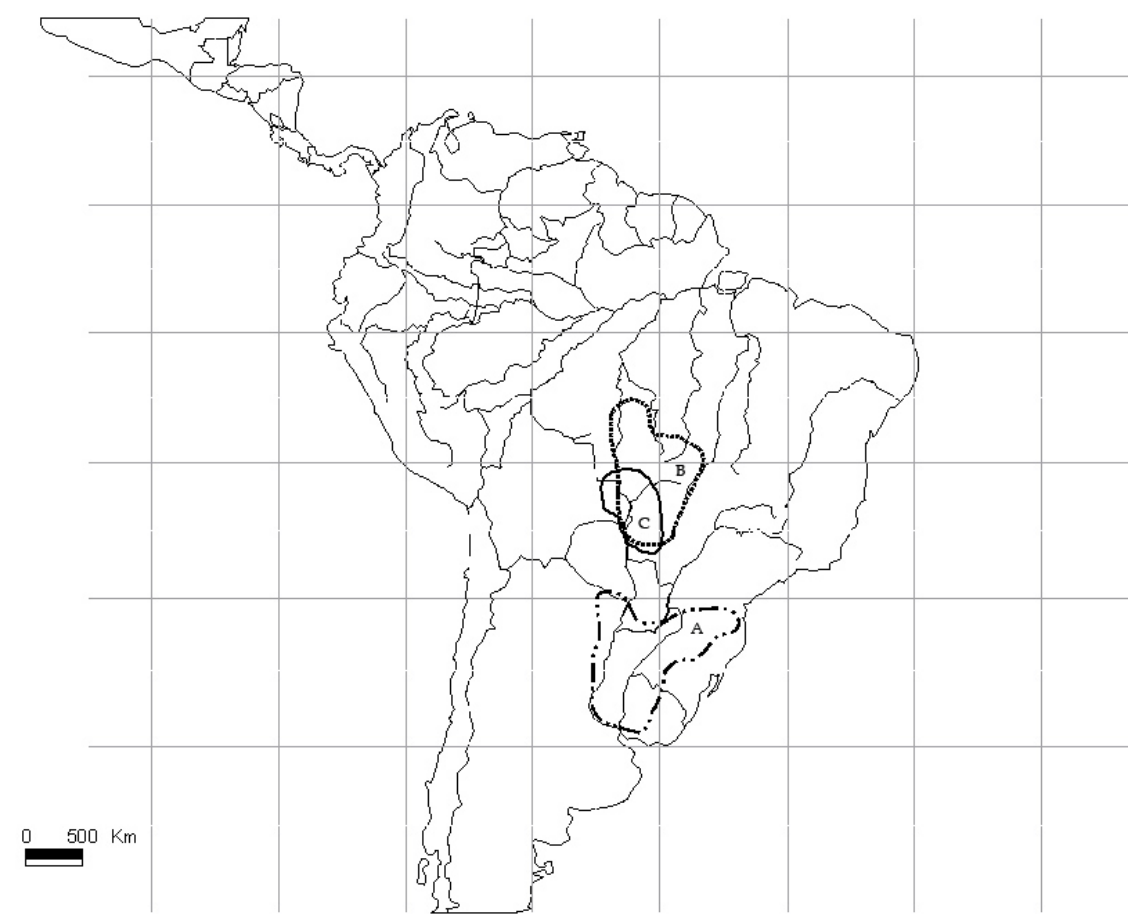

Fig. 7: Padrões do grupo Neotropical. A. Pampeano - Chaquense $(-\cdots-.$.$) , B.$ Pantaneiro ), C. Pantaneiro - Cerradense (... ...). 


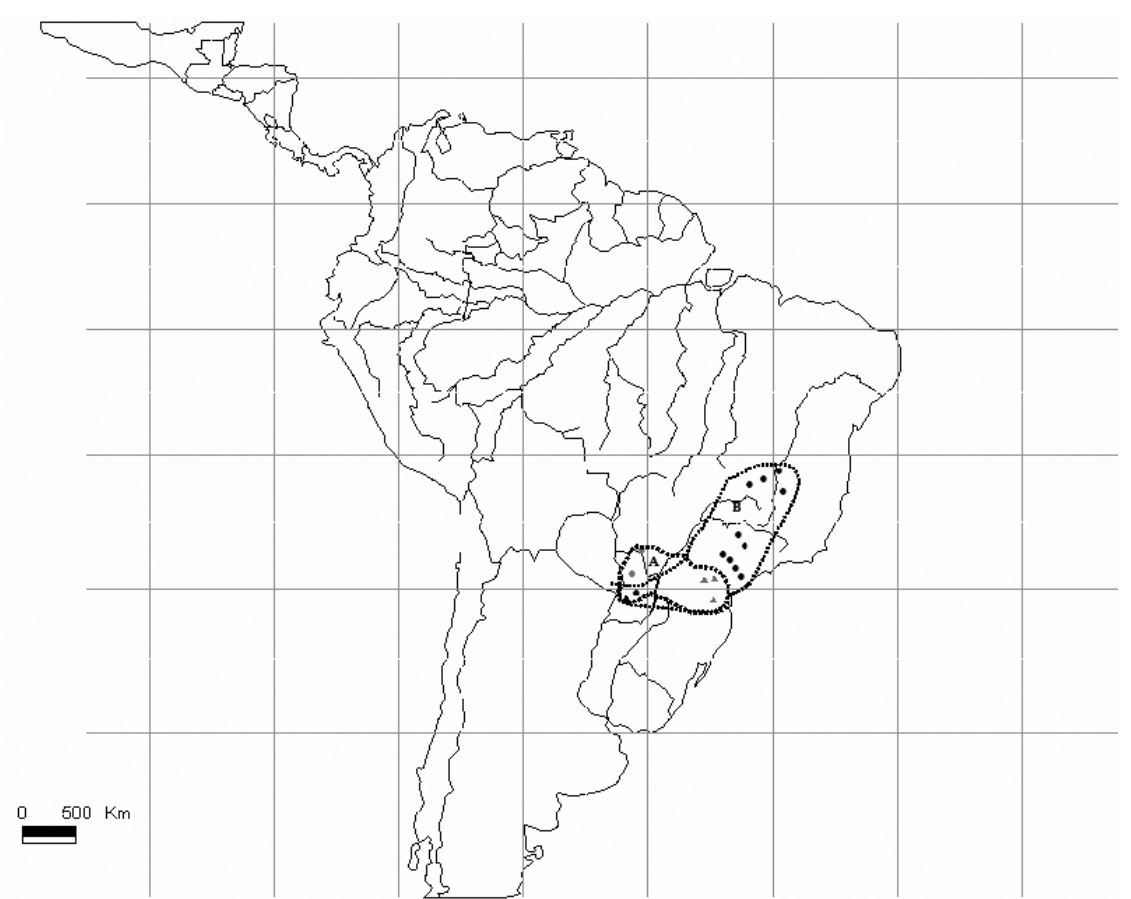

Fig. 8: Padrão Cerradense do grupo Neotropical. Espécies brasileiras não - exclusivas. A. V. amphychlora, V. linearifolia e V. pilicaulis, B. V. macrorhiza (clima Cfa de Köpen).

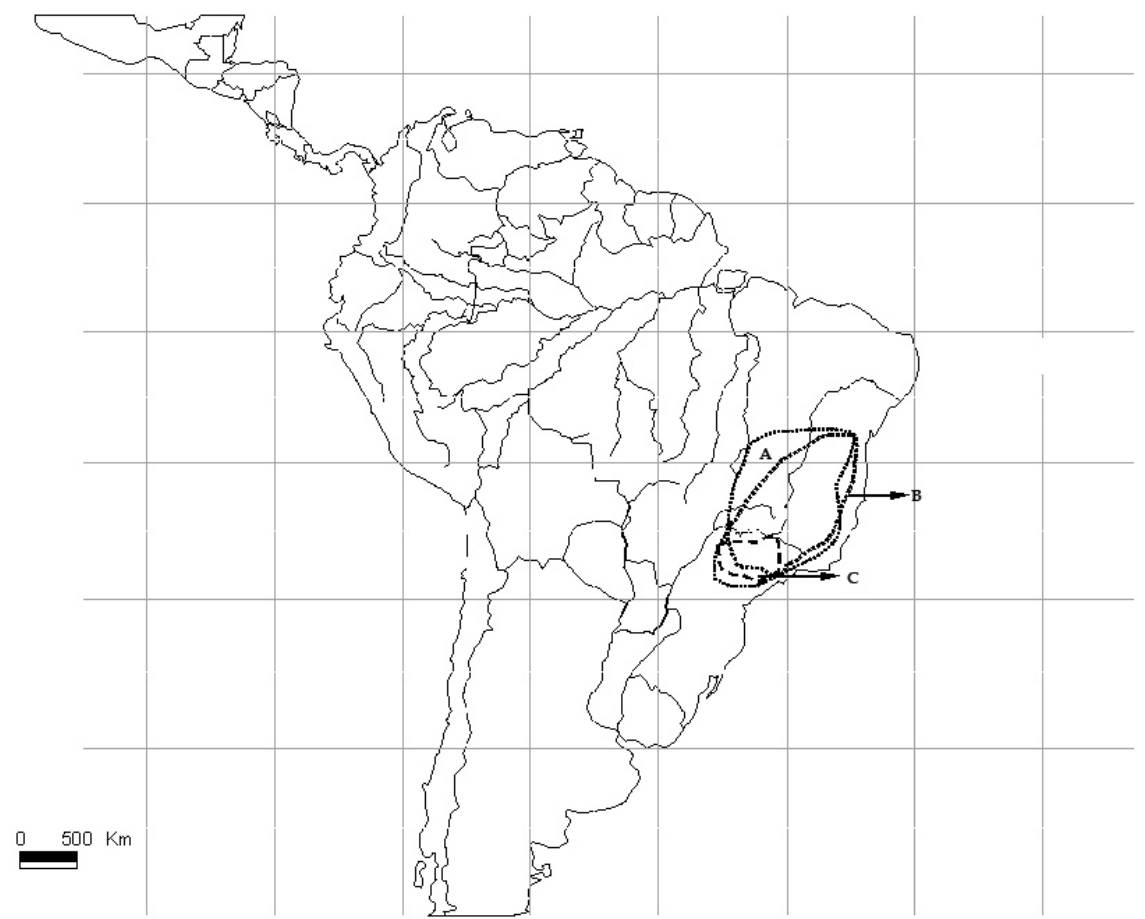

Fig. 9: Padrão Cerradense do grupo Neotropical. Espécies brasileiras exclusivas. A. $V$. robusta, B. V. bakeriana, C. V. arenaria (clima Cwa de Köpen). 


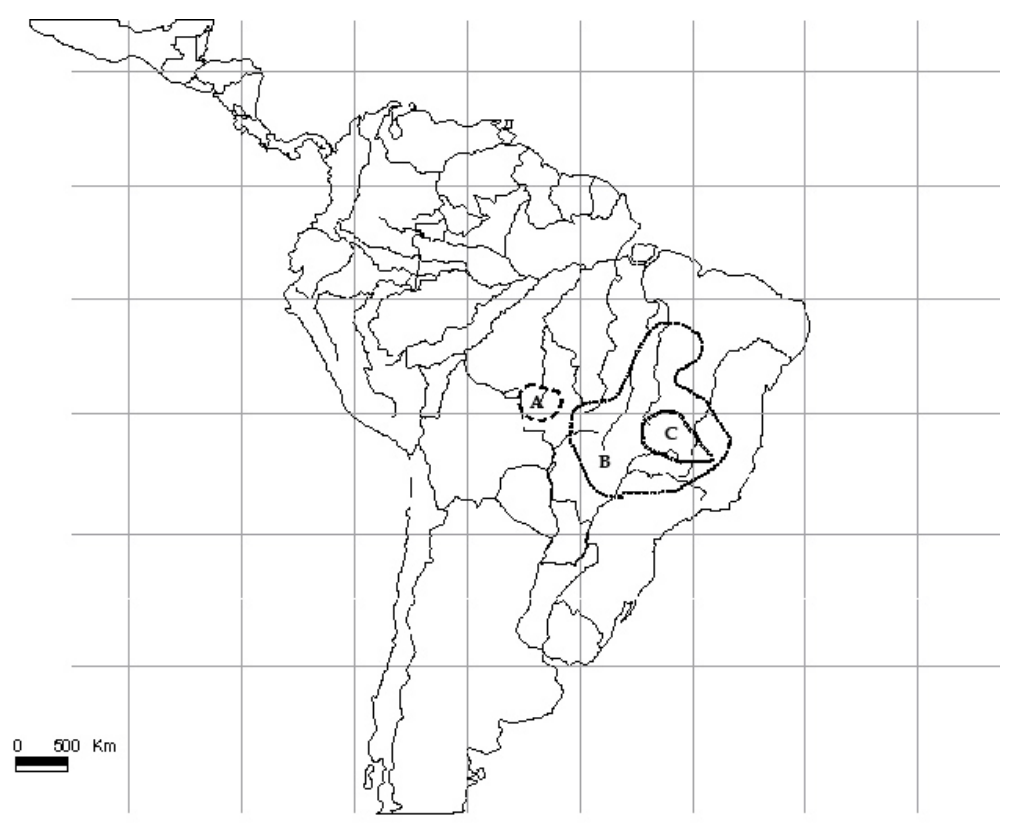

Fig. 10: Padrão Cerradense do grupo Neotropical. Espécies brasileiras exclusivas. A. V. hypoleuca, B. V. oblongifolia, C. V. gardneri, V. goyazensis e V. laxicymosa (clima Aw de Köpen).

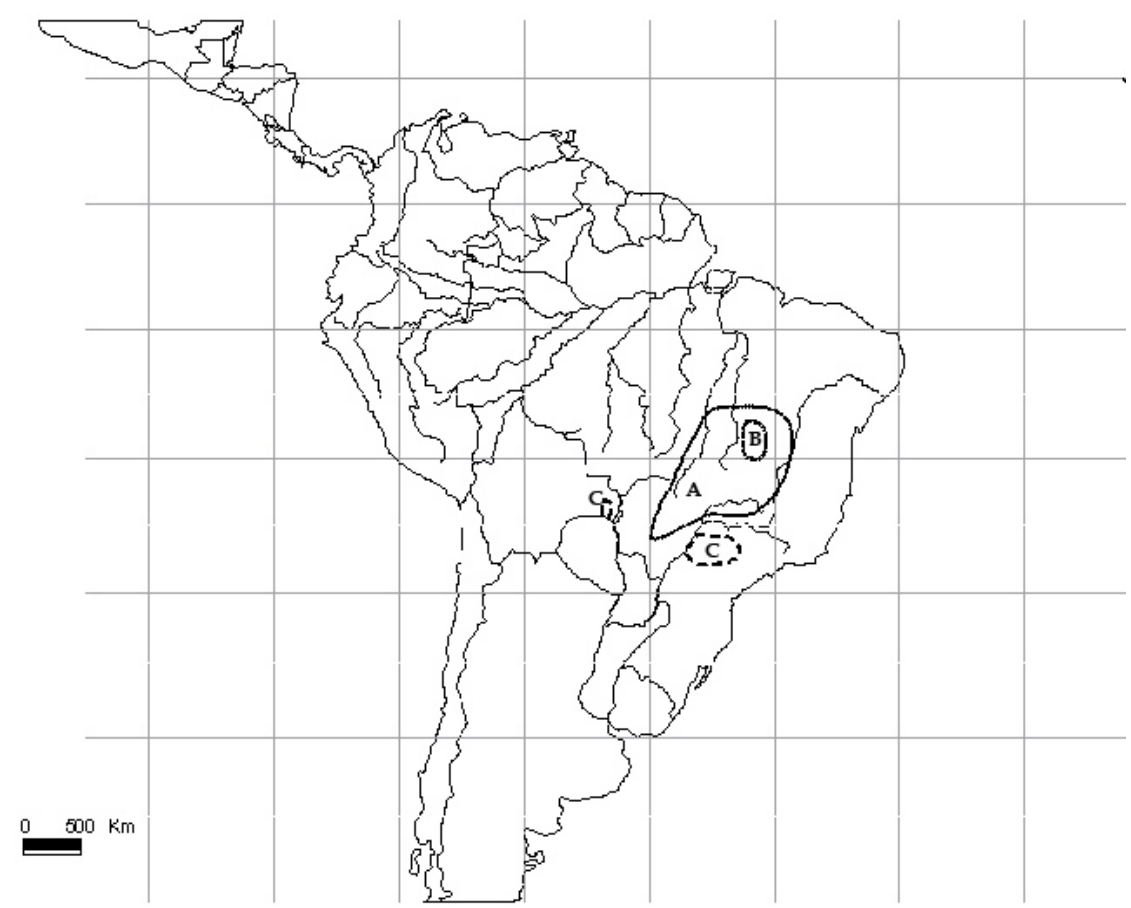

Fig. 11: Padrão Cerradense do grupo Neotropical. Espécies brasileiras exclusivas. A. V. grandiflora, B. V. veredensis, C. V. rubra (clima Aw de Köpen). 


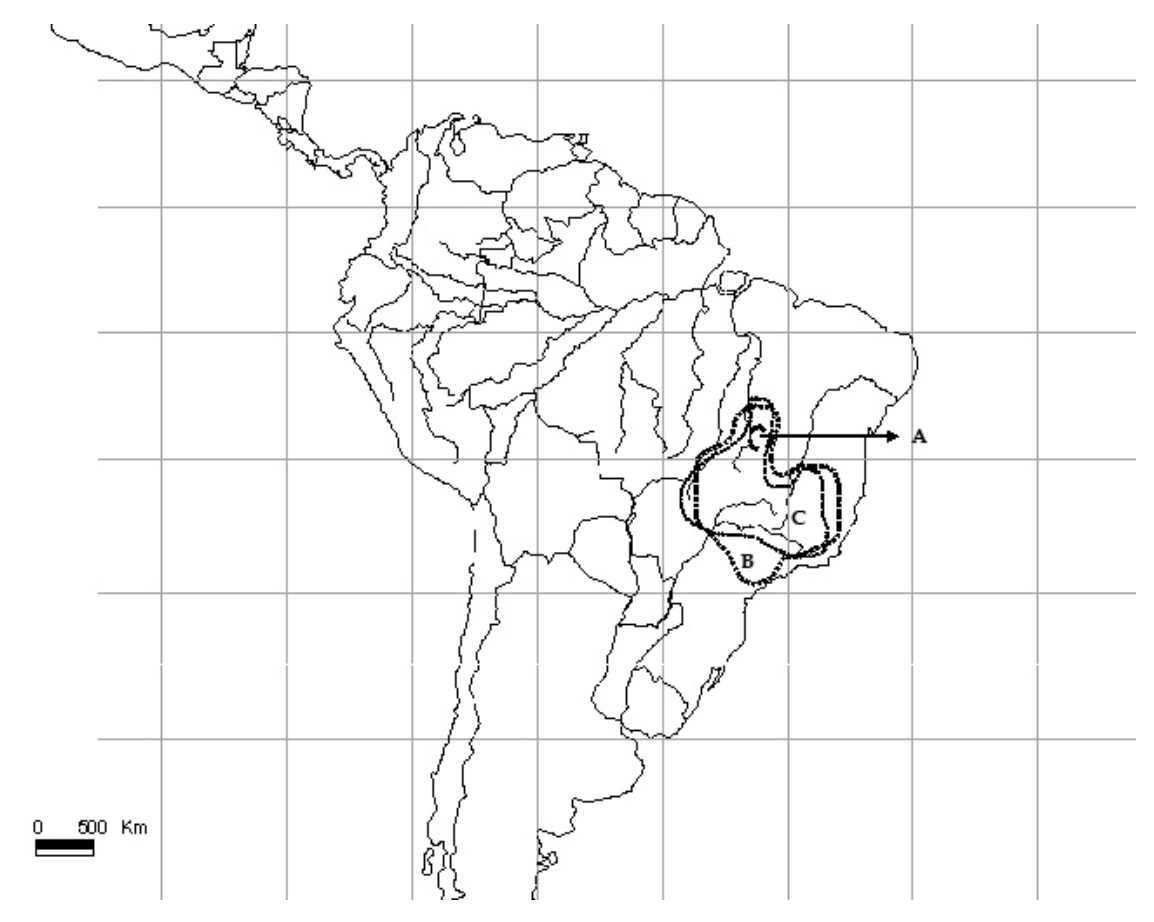

Fig. 12: Padrão Cerradense do grupo Neotropical. Espécies brasileiras exclusivas. A. V. filifolia, B. V. kunthiana, C. V. bracteata (clima Aw de Köpen).

\section{Discussão e conclusões}

Embora não haja uma explicação definitiva para a disjunção entre certos grupos do Hemisfério Norte e as espécies sul-americanas de Viguiera, estas aparentemente descendem das primeiras e migraram para áreas continentais através dos Andes. Os resultados indicam que as Yungas e Punas são os ecossistemas que mais podem ter colaborado nessa migração. $O$ elevado número de padrões de distribuição encontrado pode ser explicado pela origem relativamente recente do gênero no Hemisfério Sul; assim, o processo de dispersão das espécies estaria ainda em fase inicial.

No Brasil, há claramente uma maior ocorrência de espécies sob climas que apresentam inverno seco (Cwa e Aw de Köpen), que condicionam a paisagem de Cerrado, no Domínio Campestre Tropical e Subtropical (Burkart 1975). A adaptação a esses ambientes parece estar ligada ao tipo de sistema subterrâneo espessado, que certamente provê as necessidades hídricas da planta na fase de dormência, cuja importância na regeneração das partes vegetativas foi percebida pela primeira vez por Lindman (1906). 


\section{Referências bibliográficas}

BLAKE, S.F. 1918. A revision of the genus Viguiera. Contr. Gray Herb. 54: 1-205.

BRAY, W.L. 1900. The relation of the North American flora to that of South America. Science 12: 709-716.

BURKART, A. 1975. Evolution of grasses and grasslands in South America. Taxon 24(1): 53-66.

CABRERA, A.L. \& WILLINK, A. 1973. Biogeografia de América Latina. Monografias de la O.E.A. serie Biologia 13. Washington, D.C. 117p.

CAMPBELL, D.H. 1944. Relations of the temperate floras of North and South America. Proc. California Acad. Sci. Ser. 4: 25.

COLLICUTT, D. 2005. Biology of the Monarch butterfly. Disponível em < http:/ / www.naturenorth.com/summer/monarch/mnrchtx2.html>.

CONAMA. 1999. Estatísticas del Medio Ambiente 1994 - 1998. Santiago, Chile, Instituto Nacional de Estatísticas.

CREPT, W.L. \& STUESSY, T.F. 1978. A reinvestigation of the fossil Viguiera cronquistii (Compositae). Brittonia 30(4): 483-491.

CUATRECASAS, J. 1968. Paramo vegetation and its life forms. In C. Troll (ed.). Geo-ecology of the mountainous regions of the tropical Americas. Coll. Geogr. 9. Pp. 163-186.

DIAS, P. 2004. NL. (finding localities in Neotropics), version 0.9, distributed by the author. São Paulo.

DILLON, M.O. 2005. Jalca Formations of Northern Peru. Disponível em <www.sacha.org/envir/alpine/Jalca_webpage.htm>.

\& VISION, T. 2005. The biogeography and evolution of the Asteraceae in the Atacama and Peruvian deserts. Disponível em $<$ www.sacha.org/ famil/ lomaster. htm>.

GENTRY, A.H. 1978. Floristic knowledge and needs in Pacific Tropical America. Brittonia 30 (2): 134-153.

HUNZIKER, J.H., PALACIOS; R.A., VALESI; A.G. et al. 1972. Species disjunctions in Larrea: evidence from morphology, cytogenetics, phenolic coumpounds, and seed albumns. Ann. Missouri. Bot. Gard. 59: 224-233.

KUSCHEL, G. 1963 [1964]. Problems concerning an Austral region. In: J.L. Gressit, C.H. Lindroth, F.R. Fosberg, C.A. Fleming \& E.G. Turbott (eds.). Pacific basin biogeography: a symposium. Honolulu: Bishop Museum Press. Pp 443-449.

LINDMAN, C.A.M. 1906. A vegetação do Rio Grande do Sul. Tradução de A. Löfgren, 1974. Brasil, Belo Horizonte, Itatiaia/ EDUSP. 377 p.

LUTEYN, J. 1999. Páramos: a checklist of plant diversity, geographical distribution, and botanical literature. New York: The New York Botanical Garden Press. 278 p.

MICHENER, C.D. 1979. Biogeography of the bees. Ann. Missouri Bot. Gard. 66 (3): 277-347.

MORRONE, J.J. 1994. Distributional patterns of species or Rhytirrhinini (Coleoptera: Curculionidade) and the historical relationships of the Andean provinces. Global Ecol. Biogeogr. Lett., 4: 188-194.

1996. The biological Andean subregion: a proposal 
exemplified by arthropod taxa (Arachnida, Crustacea and Hexapoda). Neotropica 42: 103-114.

1999. Presentación preliminar de un nuevo esquema biogeográfico de América del Sur. Biogeographica 75(1): 1-16.

2001. Review of the biogeographic provinces of Patagonian Subregión. Rev. Soc. Entomol. Argent. 60 (1-4): 1-8.

OBERHAUSER K.S. \& SOLENSKY M.J. 2005. Ecologia da Borboleta-Monarca. Ecologia.Info 28. Disponível em <http://www.ecologia.info/borboletamonarca.htm>.

PETERSON, P. M. \& J. J. ORTÍZ-DIAZ. 1998. Allelic variation in the amphitropical disjunct Muhlenbergia torreyi (Poaceae: Muhlenbergiinae). Brittonia 50: 381-391.

PROHASKA, F. 1973. New evidence on the climatic controls along the Peruvian coast. In D.H.K. Amiran, \& A.W. Wilson (eds.). Coastal deserts, their natural and human environments. Tucson: University Arizona Press. Pp. 91-107.

RAVEN, P. H. 1963. Amphitropical relationships in the flora of North and South America. Quart. Rev. Biol. 38: 151-177.

1972. Plant species disjunctions: a summary. Ann. Missouri Bot. Gard. 59: 234-246.

RIVAS MARTÍNEZ, S. \& TOVAR, O. 1983. Vegetatio Andinae, I. Datos sobre las comunidades vegetales altoandinas de los Andes Centrales del Perú. Lazaroa 4: 167-187.

ROBINSON, H. \& MOORE, A.J. 2004. New species and new combinations in Rhysolepis (Heliantheae: Asteraceae). Proc. Biol. Soc. Wash. 117(3): 423-446.

SALGADO-LABOURIAU, M.L. 1994. História Ecológica da Terra. São Paulo: Edgard Blücher Ltda. 307 p.

SARMIENTO, G. 1975. The dry formation of South America and their floristic connections. J. Biog. 2(4): 233-251.

SCHILLING, E.E. \& JANSEN, R.K. 1989. Restriction fragment analysis of chloroplast DNA and the systematics of Viguiera and related genera (Asteraceae-Heliantheae). Amer. J. Bot. 76(12): 1769-1778.

DA COSTA, F.B.; LOPES, N.P., et al. 2000. Brazilian species of Viguiera (Asteraceae) exhibit low levels of ITS sequence variation. Edinburgh J. Bot. 57(3): 323-332.

SCHILLING, E.E. \& PANERO, J.L. 1991. Evidence for a close relationship between Iostephane and Viguiera (Asteraceae-Heliantheae). Amer. J. Bot. 78(8): 1054- 1062.

1996a. Relationships in Heliantheae subtribe Helianthinae based on chloroplast DNA restriction site analysis. In Hind, D.J., Beentje, H.J. (eds.). Compositae: systematics proceedings of the international Compositae conference, vol. 1. Kew: Royal Botanic Gardens. Pp. 361-376.

1996b. Phylogenetic reticulation in subtribe Helianthinae. Amer. J. Bot. 83(7): 939-948.

2002. A revised classification of subtribe 
Helianthinae (Asteraceae-Heliantheae). I. Basal lineages. Bot. J. Linn. Soc. 140: 65-76.

SOLBRIG, O.T. 1972a. Disjunctions in plants: A symposium. Ann. Missouri Bot. Gard. 59: 105-106.

b. The floristic disjunctions between the "Monte" in Argentina and the "Sonoram Desert" in Mexico and the United States. Ann. Missouri Bot. Gard. 59: 218-223.

THORNE, R.F. 1972. Major disjunctions in the geographic ranges of seed plants. The Quart. Rev. Biol. 47 (2): 365-411.

WEBERBAUER, A. 1936. Phytogeography of the Peruvian Andes. Field Mus. Nat. Hist., Bot. Ser. 15: 1-587.

ZUCOL, A.F. 2000. Pastizales sudamericanos. Cartilla de difusión de ciências naturares 2. Entre Rios, Argentina, Matteri y España. Disponível em $<$ http://cicyttp.org.ar/car2.pdf>. 


\section{CAPÍTULO VII CONSIDERAÇÕES FINAIS}

Os resultados das análises filogenética e sistemática confirmaram que o grupo não é monofilético, e que as espécies sul-americanas aparentemente devem ser transferidas para outro gênero, juntamente com alguns representantes de táxons infra-genéricos (de Blake 1918) do subg. Amphilepis, das sect. Leighia e Hypargyrea e da ser. Grammatoglossae. No entanto, não houve corroboração para a transferência das espécies sul-americanas ao gênero Rhysolepis, como propuseram Robinson \& Moore (2004).

Embora os conhecimentos obtidos até o presente momento não permitam o estabelecimento da filogenia, foi possível verificar que existem dois grandes grupos morfológicos de Viguiera na América do Sul, distribuídos nas duas regiões ecológicas estabelecidas por Morrone (1999) para a América do Sul: o primeiro com flores cilíndrico-tubulosas e pápus facilmente destacável ou persistente, da Região Andina e o segundo com flores cilíndrico-campanuladas, e pápus persistente firme, da Região Neotropical.

Em relação aos caracteres anatômicos das folhas, mostraram-se úteis para a delimitação em nível específico (e.g. $V$. bakeriana e $V$. discolor; $V$. trichophylla e $V$. filifolia) o número de séries de células que circundam a base dos tricomas e a distribuição das bossas que geralmente adornam tais tricomas. A delimitação de grupos de espécies é possível através da análise de certos conjuntos de caracteres foliares, como o tipo de clorênquima e a distribuição de seus tecidos, a disposição dos estômatos e a espessura da cutícula (e.g. $V$. bakeriana, V. discolor, V. grandiflora e V. squalida).

A análise conjunta de atributos dos grãos de pólen como classes de tamanho do intervalo de confiança do diâmetro polar e do tipo de área polar e caracteres como a forma e dimensões das aberturas forneceu subsídios à delimitação de espécies com fenótipo muito semelhante, como $V$. discolor e $V$. bakeriana; V. grandiflora e V. squalida; V. trichophylla e V. filifolia; $V$. tenuifolia e $V$. kunthiana; $V$. megapotamica e $V$. anchusifolia; $V$. aspilioides e $V$. tuberosa. 
No Brasil, o gênero Viguiera pode ser definido por apresentar sistema subterrâneo espessado com raízes adventícias geralmente tuberosas em diferentes níveis, folhas alternas na porção superior e geralmente opostas na porção inferior, sinflorescências com paracládios geralmente alternos e cipselas com pápus persistes 2-aristado e com escamas intermediárias.

Viguiera está representado na América do sul por cerca de 61 espécies, das quais 35 ocorrem no Brasil e 27 são exclusivamente brasileiras. A variação fenotípica das espécies levou à descrição de várias espécies, e muitos nomes foram aqui sinonimizados (capítulo V). Frise-se que estudos futuros deverão prover novas sinonimização entre espécies sul-americanas que não ocorrem no Brasil.

Em nosso País, as maiores diversidade e densidade de espécies ocorrem na região ecológica do cerrado, especialmente a noroeste do Estado de Minas Gerais e em todo o Estado de Goiás. O gênero se distribui principalmente por regiões que apresentam inverno seco (Cwa e Aw de Köpen), que condicionam a paisagem de Cerrado, no Domínio Campestre Tropical e Subtropical (Burkart 1975); tal situação divide as espécies em dois grupos distintos, e são raras as que suportam os dois tipos de clima.

Os elevado número de padrões de distribuição encontrados no capítulo VI deste trabalho, provavelmente reflete a origem recente do gênero na América do Sul, corroborando a opinião de outros especialistas, como Schilling \& Panero (1996a 1996b, Schilling et al. 2000).

\section{$\underline{\text { Referências bibliográficas }}$}

BLAKE, S.F. 1918. A revision of the genus Viguiera. Contr. Gray Herb. 54: 1-205.

BURKART, A. 1975. Evolution of grasses and grasslands in South America. Taxon 24(1): 53-66.

DA COSTA, F.B. \& LOPES, N.P. et al. 2000. Brazilian species of Viguiera (Asteraceae) exhibit low levels of ITS sequence variation. Edinburg J. Bot. 57(3): 323-332.

MORRONE, J.J. 1999. Presentación preliminar de un nuevo esquema biogeográfico de América del Sur. Biogeographica 75(1): 1-16.

ROBINSON, H. \& MOORE, A.J. 2004. New species and new combinations in Rhysolepis (Heliantheae: Asteraceae). Proc. Biol. Soc. Wash. 117(3): 423-446. 
SCHILLING, E.E. \& DA COSTA, F.B. \& LOPES, N.P., et al. 2000. Brazilian species of Viguiera (Asteraceae) exhibit low levels of ITS sequence variation. Edinburgh J. Bot. 57(3): 323-332.

\& PANERO, J.L. 1996a. Relationships in Heliantheae subtribe Helianthinae based on chloroplast DNA restriction site analysis. In Hind, D.J., Beentje, H.J. (eds.). Compositae: systematics proceedings of the international Compositae conference, vol. 1. Kew: Royal Botanic Gardens. Pp. 361-376.

1996b. Phylogenetic reticulation in subtribe Helianthinae. Amer. J. Bot. 83(7): 939-948. 


\section{APÊNDICE A}

$\underline{\text { Índice de coletores e exsicatas }}$

A. Plantas analisadas para a revisão das espécies brasileiras (O número entre parênteses corresponde à numeração do táxon no texto de revisão taxonômica das espécies do Brasil, no capítulo V).

Allem, A. 287 (12).

Allemão, F. 864 (23).

Alvarenga, D. 24 (6).

Anderson, W.R. 6594 (6), 7644 (6), 7651

(27), 8047 (6), 8115 (27), 8301 (27), 8303 (27), 10033 (27), 10271 (27).

Andrade, P.M. 1124 (32).

Andrade-Lima, D. 271-68 (30), 461-68 (30).

Anjos, A.M.G. 97 (27).

Anjos, V.C. 11 (12).

Aona, L.Y.S. 773 (30), 774 (30).

Aparecida da Silva, M.:549 (27), 585 (27), 587 (27), 588 (27), 664 (27), 687 (10.1), 707

(6), 1005 (16), 1008 (3), 1009 (12), 1688 (16), 1691 (16), 1694 (12), 2457 (12), 2598 (27), 4986 (6).

Aragaki, S. 174 (19).

Araki, P.M. s.n. (HUEPG 3506, HUEPG 3498) (24)

Arantes, A.A. 445 (8) 446 (8)

Araújo, G.M. 146 (27), 313 (8), 383 (8)

Argent, G.C.G. 6727 (30)

Arzivenco, L.A. 566 (26), s.n. (ICN 67746)

(26), s.n. (ICN 42748) (33)

Assis, M.C. 3 (27), 11657 (19)

Assis, V. 24 (5), 153 (5)

Atta, A.L.V. 16 (16)

Augusto, Irm. 1524 (26), s.n. (ICN 19236) (2.1)

Azevedo, A.A. 176 (19)

Azevedo, M.L.M. 180 (12), 548 (10.1), 966

(6) 1123 (16)

Balick, M.J. 1328 (23)

Barbosa, E. 462 (33)

Barbosa, S.B. 361 (4)

Barreto, K.D. 393 (32), 1349 (27), 2034 (27), 3362 (3)

Barros, F. 2521 (3)

Barros, M.A.G. 92 (12)
Barroso, G.M. 519 (16), 549 (9), 599 (16), s.n. (PEL 5138, RB 117480, SPF) (7), s.n. (RB 124550) (12)

Batalha, M. 89 (28)

Batalha, M.A. 1571 (3), 2414 (30), 3518 (30)

Batista, M.L. 17 (16)

Bautista, H.P. 2791 (12)

Belém, R.P. 3917 (16)

Beltrati, C.M. 4 (3)

Bianchini, R.S. 420 (32)

Black, G. 472 B2 (5)

Boaventura, M. 132 (27), 469 (27)

Borba, E.L. 564 (6)

Bortolotto, I.M. 43 (30), 101 (30), 370 (30), $381(30)$

Brade, A.C. 15398 (23), 17648 (27), s.n. (SP 6114) (27)

Braga, R. 253 (33)

Branco, L. s.n. (UB 38-01-276) (27)

Bridgewater, S. S-204 (9), S-206 (9)

Brina, A.E. s.n. (BHCB 39479) (27)

Brito, L. 51 (8)

Brochado, A.L. 59 (12), 70 (12)

Brooks, R.R. 238 (27), TMEX 652 (16)

Bueno, O. 1376 (2.1), 2214 (2.1), 2289 (2.2), 2409 (2.1), 2422 (2.1), 2493 (2.2), 2503 (22), Burchell, W.J. 5887 (8), 6083 (12), 6311 (16), 6418 (12), 6535 (23), 7519 (16), 8294 (23)

Calago, K. 88 (27), 110 (27), 114 (27) 313

(12)

Caliente, A.D. 298 (28)

Câmara, P.S. 94 (27), 127 (27)

Camargo, O. 18 (2.1), 125 (20), 92 (20)

Campos, M.J.O. s.n. (HRCB 13362) (32)

Carnielli, V. 4 (19), 6526 (19)

Carvalho, R.C.F. 92 (5)

Castellanos, A. 24757 (26)

Ceccantine, G. 196 (27), 263 (27)

Cervi, A.C. 4289 (33) 
Cesar, H.L. 283 (27), 297 (27)

Cestaro, L.A. s.n. (HAS 28492) (2.1)

Chini, E.R. 17 (2.2)

Claussen, P. 56 (27), 276 (27), 576 (16)

Clemente, A. s.n. (RB 253269) (27)

Cobra, L.Q. 227-A (12), 227-B (12)

Comissão Rondon. 529 (30)

Conceição, C.A. 1612 (30) 1803 (30)

Cordeiro, I. CFSC 7549 (5), 11 (33), 743 (33)

Cordovil, S.P. 50 (16)

Corrêa, A. 291 (27)

Costa, E.A. 21 (16)

Costa, F.B. 1 (3), 2 (27), 5 (27), 6 (8), 7 (3), 21 (32), 23 (32), 24 (19), 25 (8), 26 (32), 27 (5), 28 (5), 31 (32), 32 (16), 35 (12), 39 (32), 40 (12), 41 (12), 42 (12), 43 (16), 47 (16), 48 (8), 57 (3), 60 (27), 61 (27), 63 (6), 64 (6), 65 (6), 66 (27), 67 (6), 68 (6), 70 (9), 71 (6), 72 (10.1), 75 (27), 76 (27), 81 (10.2), 82 (10.1), 84 (27), 88 (8), 89 (32), 90 (32), 91 (8), 92 (5), 93 (3), 94 (27), 98 (30), 100 (8), 103 (3), 105 (27), 108 (6), 109 (6), 110 (6), 111 (6), 112 (6), 113 (6), 114 (6), 115 (27), 116 (6), 117 (27), 121 (32)

Costa, F.N. 694 (6)

Costa, L.V. s.n. (BHCB 52511) (21)

Custódio Filho, A. 441 (19)

DAC et al. s.n. (UFLA 3011) (27), s.n. (UFLA 7135) (27), s.n. (UFLA 8005) (27)

Damasceno, F.A. 932 (30)

Davidse, G. 11114 (2.2), 11136 (2.2)

Davis, P.H. 2784 (4), D.60081 (6)

Dombrowski, L.T.H. 9399 (33)

Duarte, A.P. 692 (5), 715 (5), 958 (16), 2615

(6), 5604 (28), 7424 (5), 8711 (5), 9402 (12), 9955 (8), 9966 (12), 9967 (16), 10274 (27), 10313 (12), 10333 (23), 9274-A (8), 9327-A (16), s.n. (RB 85092) (5)

Dubs, B. 1755 (30), 1892 (30), 2248 (30)

Dusén. 9723 (27), 11663 (27), 15637 (24), 15646 (24), 16875 (1)

Dutra. 1280 (26), 1281 (2.2), 1441 (26), 1442 (2.1), 1562 (2.1)

Edwall, G. s.n. (SP 16811) (13)

Eiten, G. 1881 (27), 2393 (19), 2395 (19), 2853 (27), 2854 (27), 3528 (19), 9818 (23), 16000A3527 (12), 16002A3529 (16)

Emmerich, W. s.n. (ICN 32125) (2.1)
Emygdio, L. 1896 (23)

Equipe do JBB. 895 (6)

Eugênio, S.J.J. 108 (2.1), 2620 (2.1)

Faria, J.G. 17 (6), 37 (27), 98 (6), 51, 93 (6)

Farias, R. s.n. (CGMS 4885) (30)

Farinaccio, M.A. 486 (3), 487 (3), 493 (27)

Felippe, G.M. 170 (3)

Ferreira, F.M. 43 (27)

Ferreira, M.B. 1193 (6), 1237 (6), 1331 (10.1), 1334 (6), 1417 (6), 1332-A (27), 1332B (27)

Filgueiras, T.S. 1150 (12), 1266 (6)

Fonseca, M.L. 1220 (16), 1240 (16), 1565 (16), 1629 (12), 2106 (12), 2114 (16), 5124 (6)

Fontella, J. 2855 (12)

Forzza, R.C. 411 (30), 892 (10.1), 1921 (27), 2457 (16)

Freitas Campos, J.M. 29-A (8)

Gardner, G. 3284 (16), 3285 (16), 3288 (12), 3291 (23), 3858 (12), 4233 (27), 4234 (6), 2133bis (10.1), 3288 (bis) (12), 4233,bis (10.1)

Gaudichaud, C. 411 (26)

Gavilanes, M.L. 519 (27), 1020 (27), 1368 (27), 2855 (27), 2966 (27), 4589 (27), 5142 (27)

Gehrt, A. s.n. (SP 3654) (8)

Gentry, A. 21415 (6)

Gibbs, P. 4680 (27), 5147 (6)

Gieia, A.P.O.M. s.n. (UFLA 5892) (27)

Glaziou, A. 27 (8), 1499 (2.1), 9490 (27), 11027 (27), 12806 (5), 12880 (27), 14006 (5), 15074 (32), 15080 (21), 16164 (21), 16170 (2.1), 17084 (27), 19533 (32), 21536 (12)

Godoy, S.A.P. 793 (3), 1263 (3)

Gomes, J.C. 2397 (19)

Gomes, S.M. 14 (27)

Gomes. 1142 (27)

Gonçalves, C.S. 4 (30)

Gottsberger, I.S. 128-19974 (19), 24-31872 (19)

Grandi, T.S.M. s.n. (BHCB 18394) (6), s.n. (BHCB 15747) (27)

Groppo Jr., M. 1102 (27)

Grottas, A.S. 223 (27), 289 (3)

Guillaumon, J.R. s.n. (SPSF 16084) (8), s.n. (SPSF 18022) (8)

Hagelund. s.n. (ICN 124881) (31) 
Handro, O. 356 (8), 468 (28), 476 (27)

Haridasan, M. 251 (27)

Harley, R.M. 4296 (12), 10012 (30), 11384

(9), 24818 (32)

Hashimoto, G. 20980 (29)

Hatschbach, G. 68 (33), 2693 (4), 2997 (1), 4529 (26), 5533 (33), 7769 (1), 9024 (33), 12141 (33), 12847 (4), 13009 (2.1), 13845 (26), 17257 (4), 18445 (33), 18779 (33), 18882 (1), 25020 (30), 25040 (30), 25147 (30), 26558 (33), 26735 (27), 32470 (30), 32583 (4), 35138 (2.1), 36225 (6), 36635 (34.1), 36676 (27), 37174 (12), 38227 (6), 38943 (16), 40965 (33), 41431 (33), 41675 (19), 43717 (6), 45454 (4), 47648 (33), 51955 (33), 52838 (27), 53753 (6), 53783 (27), 53845 (27), 54079 (33), 54358 (8), 55800 (8), 56012 (12), 56100 (16), 56384 (26), 58730 (18), 60230 (11), 62070 (27), 62800 (14), 64453 (26), 64509 (4), 64552 (27), 64675 (6), 64761 (6), 64773 (27), 65352 (12), 65374 (30), 70471 (11), 70586 (6), 70640 (6), 70682 (9), 70725 (10.1), 71307 (27), 71604 (27), 74393 (25), 74900 (7), 76929 (18)

Heringer, E.P. 249 (12), 1248 (6), 2015 (12), 4083 (6), 4228 (6), 4385 (16), 4387 (10.1), 4978 (12), 5461 (5), 6700 (6), 6820 (6), 6837 (27), 7287 (5), 7526 (27), 7578 (27), 8244 (27), 11205 (6), 11407 (6), 11427 (27), 11448 (12), 11487 (27), 13077 (6), 13092 (6), 13150 (10.2), 14539 (27), 15410 (27), 15803 (6), 17025 (27), 17150 (12), 17691 (10.2), 17807 (6), 17810 (12), 17886 (12), 17938 (16), $8084 / 278$ (6), 8365/559 (6), 8619/813 (6), $8703 / 897$ (12), 9223/1436 (6)

Hiltll, G. 1410 (2.2)

Hoehne, F.C. 328 (30), 329 (30), 1611 (23), 1689 (23), 2317 (30), 2914 (8), 6480 (5), s.n. (SP 2942) (21)

Hoehne, W. s.n. (ALCB, BHCB, ESA, F, HUEFS, IPA, K, MBM, MO, NY, RB 362733, SP, SPF 11487, UB, UEC 86864, US) (27, s.n. (K, SPF 12413, UB 86758, UEC) (27)

Hunt, D.R. 5505 (27)

Imaculada, M. 483 (32)

Imaguire, N. 2587 (33) 5541 (33) 5693 (33). Irwin, H.S. 5851 (27), 6687 (30), 7239 (16), 7805 (12), 8189 (27), 8676 (16), 9553 (16),
11106 (27), 12073 (27), 13564 (6), 14787 (27),15311 (27), 15401 (6), 15514 (27), 24403 (9), 24696 (6), 24761 (9), 28414 (6), 31826 (6), 32791 (9), 34712 (12), 34906 (23) s.n. (RB 177404) (9).

Joly, A.B. 1432 (6) 1526 (6).

Kfuri, R.W. s.n. (BHCB 11710) (32),King, R.M. 8277 (9), 8325 (27), 8585 (23), 8801 (23). Kirkbride Jr., J.H. 22 (16), 1226 (27), 3157 (27) ,3182 (27), 3716 (16), 5210a (6),Klein, R. $4297 \quad$ (34.2), 5075 (26),Kokobum, L. s.n. (CGMS 10007), (30) Krapovickas, A. 34175 (2.1), 39702 (2.1)

Krieger, L. Pe. 7412 (5)

Kuhlmann, M. 1369 (27), 2883 (27), 2886 (27), 3692 (19), 3695 (13), 4100 (3)

Kummrow, R. 209 (33), 445 (33), 1818 (33)

Landim de Souza, M.F. 83 (12), 103 (27)

Lanna Sobrinho, J.P. 602 (27)Lanstryak, L.

s.n. (RB 33173) (27)

Laueo, F. s.n. (R 35073) (21)

Leitão Filho, H.F. 48 (8), 1358 (8), 1819 (21), 1853 (21), 1930 (8), 2049 (8), 2149 (19), 5957 (32), 12470 (28), 13264 (3), 14447 (3), 15422 (5), 20187 (21)

Leme, R.O. 7 (27)

Leparizi, R. s.n. (UFLA 6504) (27)

Lima, J.T. s.n. (RB 60651) (27)

Lima, L.R. 359 (26)

Lindberg 4, 5 (21)

Lindeman, J.C. 2672 (4), 3637 (2.1), 4807 (2.2)

Löfgren, A. 289 (27), 329 (19)

Lombardi, J.A. 1256 (27), 3324 (32), 3332 (32)

Lopes, B.C. 11439 (28)

Lopes, J.L.C. 17097 (27)

Lumes, J.M. 4098 (30)

Lutz, A. 1572 (5)

1678 (5)

Luz, M.F. 12 (16)

Maack. s.n. (MBM, RB 74710) (24)

Macedo, A. 109 (13), 1344 (13), 1354 (13), 1365 (13), 1378 (8), 3464 (23), 3533 (16), 4248 (6)

Macedo, E.E. 55 (8)

Macedo, M. 254 (30)

Machado, E.A. s.n. (RB 60199) (33)

Madsen, V. 75 (32) 
Magenta, M. 10 (27), 269 (12), 271 (12), 272 (16), 274 (3), 275 (3), 277 (32), 279 (8), 280 (32), 287 (32), 291 (5), 294 (8), 295 (8), 296 (27), 299 (8), 300 (8), 304 (8), 306 (8), 307 (8), 308 (30), 309 (16), 310 (12), 311 (27), 312 (6), 315 (8), 316 (16), 319 (8), 320 (8), 321 (16), 322 (8), $324(8), 327$ (27), 330 (8), 333 (6), 336 (27), 339 (23), 340 (23), 349 (23), 350 (23), 352 (23), 355 (23), 358 (6), 363 (6), 366 (6), 371 (12), 376 (9), 378 (6), 381 (27), 383 (3), 384 (3), 386 (3), 387 (3), 388 (28), 390 (33), 391 (33), 393 (26), 394 (2.1), 397 (2.1), 398 (2.1), 401 (2.1), 402 (26), 403 (2.1), 404 (2.1), 405 (2.1), 406 (26), 407 (26), 409,410 (29), 412 (2.1), 413 (2.1), 414 (26), 415 (26), 416 (26), 417 (26), 420 (26), 421 (2.1), 422 (2.1), 423 (2.1), 424 (33), 426 (21), 428 (27), 430 (21), 431 (27), 437 (27), 439 (27), 440 (6), 441 (10.1), 442 (9), 443 (10.1), 444 (6), 445 (10.1), 446 (10.1), 447 (9), 452 (9), 453 (10.1), 454 (27), 455 (10.1), 456 (10.1), 457 (10.1), 459 (27), 460 (14), 476 (19), 477 (4), 478 (4), 479 (4), 481 (32), 482 (32), 483 (5), 484 (5), 485 (5), 487 (5), 488 (5), 490 (5), 491 (32), 492 (5), 493 (5), 494 (5), 495 (2.1), 496 (26), 499 , 500 (26), 502 (20), 503 (22), 504 (2.1), $506,507,508$ (2.1), $511(2.1), 512(34.2), 514,515,517$ (22), 526 (26), 527 (2.1), 528 (2.1), 529 (26), 530 (2.1), 531 (26), 532 (2.1), 533 (2.2), 534 (26), 535 (26), 537 (33), 557 (27), 561 (33), 562 (27), 566 (27), 570 (27), 575 (6), 576 (27), 577 (6), 578 (6), 580 (6), 581 (27), 584 (32), 585 (26), 586 (26), 587 (2.2), 588 (2.1), 589 (2.1), 590 (2.1), 591 (2.1), 592 (2.1), 595 (20), 596 (20), $597(2.1), 598$, 600 (34.1), 603 (34.1), 604 (34.2), 605 (22), 606 (34.2), 615 (22), 621 (2.1), 622 (2.1), 623 (33), 625 (27), $626(27), 628(27), 629(27), 630(6)$, $631(6), 632(3), 634(27), 637$ (6), 640 (6), 641 (6), 642 (6), $643(27), 644$ (6), 645 (6), $646(6), 647(6), 648$ (6), 649 (6), 650 (6), 651 (6), 655 (10.1), 656 (10.1), 657 (6), 658 (6), 660 (6), $661(6), 664(35), 665(35), 666(27)$, 667 (6), 668 (6), 669 (6), 670 (6), 671 (6), 675 (30), $676(30), 678(30), 680(30), 681(30)$, $682(30), 683(30), 686(30), 687(30), 690$ (18), 691 (18), 692 (18), 693 (18), 695 (30), 696 (30), 697 (30), 698 (22), 700 (2.1), 702 (2.1), 703 (2.1), 704 (2.1), 705 (26), 706 (29), 707 (29), 708 (2.1), 713 (8), 715 (8), 716 (13),
717 (8), 718 (8), 720 (13), 722 (13), 723 (8), 725 (8), 726 (8), 727 (8), 296-A (27), 300-A (8), 319-A (8), 623, 624 (33)

Magnago, W. 27 (6)

Malme, G.O.A. 922 (20), 1502 (2.1), 1503 (2.1), 1517 (2.1), 1658 (14), 3325-A (14), 794B (2.1), s.n. (R 156026) (26)

Mantovani, W. 267 (19), 465 (19), 519 (28), 961 (19), 1094 (19)

Marcondes-Ferreira, W. 507 (8), 529 (3), 530 (3), 541 (3), 585 (3), 586 (3), 745 (3), 990 (8), 1447 (8), 1509 (32), 1682 (8)

Maria E, Irm. s.n. (ICN 31818) (26)

Marquete, R. 2656 (16)

Martinelli, G. 265 (6), 7528 (12), 11261 (10.1)

Martins dos Santos, A. s.n. (UB 38-01-278) (27)

Martins, F.R. 228 (8), 16316 (8)

Martins, P. 9462 (23), 9464 (23)

Martins, R.P. s.n. (BHCB 8438) (27)

Martius, K.P. von 826 (27)

Mathes, L.D.F. 12995 (30)

Mattos Filho, A. 441 (21), 449 (21), 3657 (30)

Mattos, J.R. 1297 (2.2), 5470 (2.2), 6543 (29), 8371 (19), 8534 (13), 12247 (28), 12502 (28), 12704 (26), 16652 (2.2), 16690 (2.2), 16794 (2.2), 17731 (2.2), 18263 (26), 19213 (22), 19718 (22), 28981 (26), 30968 (2.1), 31004 (2.1), 31561 (2.2), s.n. (HAS 65070) (2.2)

Mattos, M. 341 (26)

Matzenbacher, N.I. 480 , s.n. (ICN 106400) (2.1), s.n. (PACA 40655) (2.2), s.n. (ICN 106240) (2.2), s.n. (ICN 59662A) (4), s.n. (ICN 122115) (22), s.n. (ICN 123298) (22), s.n. (RB 174261)

Maury, C.M. 126 (6), 242 (16)

Mechi, M.R. 173 (3)

Meira Neto, J.A.A. 669 (19)

Mello-Barreto 4103 (27), 4111 (32), 4115 (32), 4138 (5), 4140 (5), 4143 (32), 4649 (27)

Mendes, F. 6 (30)

Mendes, J.R.S. 13 (16)

Mendonça, R.C. 682 (16), 914 (27), 946 (27), 2478 (10.1), 3427 (27), 4277 (35), 4338 (35), $5514(10.1)$

Mexia, Y. 5840 (6)

Mileski, E. 407 (23), 5142 (23)

Mimura, M. 360 (27), 418 (27) 
Miranda, C.A. 194 (10.1)

Mondin, C. 743 (2.1), 830 (2.2), 847 (26), 2251 (22), 2386 (22), 2466 (29), 2508 (2.1), 2554 (2.1), 2568 , 2586 (2.1), 2588 (34.2), 2595 (2.1), 2610 (2.1), 2611 (20), 2646,2812 (2.1), 2825 (34.2), 2840 (22), 2845 (26), 2849 (2.1), 2852,2853 (26), 2856 (2.1), 2857 (2.1), 2859 (2.1), 2860 ( ) ), 2870 (20), 2959 (2.2)

Monteiro, C.H. 66 (16)

Moraes, M.D. 438 (33, 532 (16), 558 (7), 568 (6), 646 (6)

Morais, H.C. 13489 (28)

Moreno, E. 79/132 (27)

Mota, R.C. 77 (8)

Motta, J. s.n. (R 155997) (8)

Munhoz, C. 718 (9), 917 (27), 1016 (6), 1385 (27)

Murad, A. s.n. (UFLA 4459) (27)

Naito, T. 20981 (27)

Nakajima, J.N. 460 (32), 886 (6), 1340 (32), 1889 (6), 2048 (32), 2378 (6), 2678 (32), 2849 (32)

Nascimento, E.A. 108 (16)

Netto, L. 2289 (26)

Nicci, T. 15459 (27)

Oldenburguer, F.H.F. 1792 (16)

Oliveira, A. s.n. (CGMS 2824) (30), s.n. (CGMS 3358) (30), s.n. (CGMS 3372) (30)

Oliveira, F.C.A. 28 (16)

Oliveira, F.N. 151 (5)

Oliveira, H.F. s.n. (HUEPG 6535) (33)

Oliveira, J.E. s.n. (BHCB 48541, RB 97599) (32)

Oliveira, P.I. 344 (33), 965 (4)

Oliveira, R.P. 71 (12)

Onishi, E. 132 (6)

Ouga, M.M. 6 (27)

Pabst, G.F.J. 4570 (22), 7127 (32)

Pagano, S.N. 582 (8)

Palacios. 3691 (5), 3733 (5)

Palacios-Cuezzo. 1151 (20)

Passos, S.R.D. s.n. (UB 38-01-277) (27)

Pedersolli, J.L. 95 (5)

Pereira da Silva, G. 896 (12), 1725 (16), 1935 (8)

Pereira Neto, M. 1 (27)

Pereira, B.A.S. 227 (6), 816 (12), 971 (27), 994 (10.2), 1016 (27), 1366 (27), 2072 (27)

Pereira, E. 3024 (27), 3124 (27), 4688 (16), 4746 (12), 5283 (33), 8697 (2.2), 10184 (8),
10200 (12), 7737-A (30), 9290-A (12)

Philcox, D. 3390 (23), 4794 (27)

Pinto, L.L. 4 (30)

Pinto, R.F. s.n. (BHCB 11673) (32

Pirani, J.R. 4056 (6), 4377 (6), 4653 (6)

Pires, F.R.S. 463 (27), 515 (32)

Pires, J.M. 9037 (27), 9222 (16), 9365 (10.1), 17241 (34.1), 56977 (12), 57085 (16)

Pivetta. 1174 (26)

Plowman, T. 9976 (27)

Pohl. 578 (13), 670 (8), $576 \mathrm{~d}(32)$

Pontes, A.F. 559 (32)

Pott, A. 67 (2.2), 425 (30), 1578 (30), 6522 (30), 7026 (7), 8137 (12)

Prance, G.T. 18957 (30)

Proença, C. 461 (6), 889 (27), 1386 (27)

Rambo, B. s.n. (PACA 46631) (2.1), s.n. (PACA 36529) (2.1), s.n. (PACA 4670) (2.1), s.n. (PACA 28329) (2.1), s.n. (ICN, PACA 46991) (2.1), s.n. (PACA 51953, S) (2.1), s.n. (LP, PACA 27042) (2.1), s.n. (PACA 39171) (2.1), s.n. (PACA 39148) (2.1), s.n. (PACA 39214) (2.1), s.n. (PACA 40527) (2.1), s.n. (LP, PACA 26110) (2.1), s.n. (PACA 549) (2.1), s.n. (PACA 1962) (2.1), s.n. (PACA 32359) (2.1), s.n. (PACA 46888) (2.1), s.n. (PACA 46578) (2.1), s.n. (PACA 8793) (2.2), s.n. (PACA 9008) (2.2), s.n. (PACA 10036) (2.2), s.n. (PACA 10056) (2.2), s.n. (PACA 50062) (2.2), s.n. (PACA 37406) (2.2), s.n. (PACA 40655) (2.2), s.n. (PACA 53004) (2.2), s.n. (PACA 25775) (2.2), s.n. (PACA 9794) (2.2), s.n. (PACA 32238) (2.2), s.n. (LP, PACA) 28174) (26), s.n. (PACA 27042) (26), s.n. (PACA 4446) (26), s.n. (PACA 56807) (29)

Ramos, A.E. 357 (27)

Ramos, P.C.M. 289 (16), 443 (27)

Rampin, V.T. 834 (3)

Ratter, J.A. 2857 (6), 2904 (27), 3032 (6), 3496 (12), 4266 (16), 4912 (19), R.427 (12)

Rawitscher, F. s.n. (SPF 17033) (33)

Recena, F. s.n. (ICN 50223) (2.1)

Reeves, R.D. BRASPEX 238 (27)

Regnell, A.F. 190 (27), I.190 (27), III.771x (3), III.772 (21), III.773 (13)

Reineck, E.M. 20B (26), 21B (26), s.n. (E 173864, E 173865) (26)

Reitz, R. 3339 (29), 11535 (33), 11773 (26), 14596 (26), C890 (2.1)

Resende, A.M. 66 (30) 
Rezende, J.M. 192 (16), 436 (27)

Rezende, M. 2140 (32)

Ribas, O.S. 1704 (33), 1771 (27)

Riedel. 338 (27), 476 (30), 733 (5)

Rizzo, J.A. 445 (16), 653 (27), 680 (30), 1326

(27), 2300 (30), 2972 (12), 4056 (27), 4536

(16), 4539 (16), 4546 (30), 4586 (30), 5232

(6), 5589 (30), 5589 (30), 5602 (16), 5711 (6),

5727 (30), 6784 (27), 7048 (16), 7118 (30),

7570 (9), 7900 (10.1), 7918 (9), 8036 (10.1),

8926 (6), 9410 (30), 9453 (23), 9471 (23)

Robim, M.J. 256 (21), 443 (21)

Rocha, A.B. 122 (32)

Rocha, D.S. 10565 (5)

Rodrigues Jr., C.E. 1423 (12)

Rodrigues, E.A. 7 (30)

Rodrigues, R.S. 56 (2.2)

Rodrigues-da-Silva, R. 243 (35)

Romero, R. 900 (32), 934 (27), 1068 (27), 1550 (8), 2123 (27), 2953 (32), 3508 (27),

3655 (32), 4603 (12)

Roppa, A.R.A. 285 (8), 742 (27), 1027 (21)

Roque, N. 15192 (6)

Rosa, F.R. 29 (27)

Rossato, M. 99 (2.2)

Rossi, L. 1031 (6)

Rossi, M.S. 4 (16)

Roth, L. 1322 (27), 1332 (27), 1376 (32)

Sem nome de coletor. (RB 4848) (5), (RB

96544) (8), (R 156023) (20), (BHCB 46532,

RB 97598) (27), (UEC 2624) (27), (SPF

84384) (27), (COR 1745) (30)

Sacco, J.C. 348 , 406 (22), 590

Saint-Hilaire, A. 1144 (33), 1216 (6), 1282

(5), 1283 (5), 1790 (5)

Salatino, M.L.F. 63 (27), 89 (28), 220 (28)

Salgado, O.A. 239 (12)

Salles, A.E.H. 134 (10.1), 160 (10.2), 1276 (30)

Sampaio, A.J. 260 (5), 275 (16), 6148 (21)

Santos, E. 1656 (27), 2111 (4), 2124 (4)

Santos, J.U. 360 (30), 494 (30)

Santos, N. s.n. (R 36962) (19)

Santos, R.R. 1786 (23)

Saraiva, L.C. 44 (3)

Sarti, S.J. 8481 (5), 15892 (27)

Sartori, W. 28 (3)

Schultz. 534 (2.1)

Sciamarelli, A. 312 (8), 313 (8)

Sehnem, A. 14636 (26)

Sello. 2509 (2.1)
Semir, J. 11560 (3), 20506 (16)

s.n. (K, UEC 2827) (6)

s.n. (HEPH 40373, IBGE, UEC 2628) (9)

Sick, W. B.241 (23)

Sidney. 1015 (13), 1079 (30), 1440 (30)

Silva, J.A. 11 (27), 314 (27)

Silva, J.C.S. 375 (27)

Silva, J.M. 416 (33), 943 (26), 3485 (4)

Silva, S.S. 6022 (23)

Silveira, A. 205 (5)

Silveira, A. 874 (27)

Silveira, F.A. 10 (32)

Silveira, N. 595 (2.2), 2437 (26), 4019 (2.2),

6645 (2.1), 7064 (2.2), 9786 (1)

Simpson, P.L. 56 (27)

Siqueira, E.C. 5 (27)

Smith, L.B. 18 (27), 66 (27), 6736 (27), 6797

(27), 7009 (6), 9926 (26), 11018 (26), 11128

(2.2), 12199 (20), 12339 (29)

Soares, M.V.L. 14 (6)

Sobral, M. 1189 (22), 3787 (2.1), 4932 (26),

5063 (2.2), 5408 (22), 5412 (22), 5700 (2.1),

7874 (20), 8014 (29), 8228 (2.2), 8617 (29),

8622 (29), 8628 (29), 8944 (29, 8948 (29),

8950 (29), 9008 (29), 9495 (29)

Sonoda, F. 20 (12)

Souza, A. s.n. (BHCB 16059) (32)

Souza, F.E.F. 4 (14)

Souza, H.B. s.n. (UB 38-01-279) (27)

Souza, V.C. 2062 (32), 2592 (3), 3400 (6),

5788 (3), 16024 (14), 16999 (14)

Stehmann, J.R. 593 (2.2), 2306 (32)

Stevens, A.D. $8(27)$

Sucre, D. 298 (6), 873 (16)

Sugiyama, M. 139 (34.1)

Takeda, I.J.M. s.n. (HUEPG 9743) (33)

Tamashiro, J.Y. 1053 (27)

Tameirão Neto, E. 1294 (6)

2163 (30)

Teixeira, W.A. s.n. (BHCB 24992, RB) (27)

Tenório, E.C. 78-1535 (6)

Teodoro, Irm. 72M (27)

Tertuliano, M.F. 36 (3)

Tessmann, G. s.n. (MBM 5179, RB 70351)

(33)

Thomas, W. 4456 (23)

Toledo, J.C. 10 (3)

Tosta, C.D. 35 (12)

Trinta, Z.A. 687 (27)

Trovó, M.L.O. 121 (2.2)

Ule, E. 1790 (26) 
Urano, H.H. s.n. (UFLA 8059) (27)

Vasconcelos, M.F. s.n. (BHCB 47852) (27)

Vasconcelos, S.T. 25 (30)

Vichnewski, W. 406 (27), 31638 (3), 31639

(3), 31640 (3), 31649 (3)

Vidal, J. I-731 (3), III-228 (24), III-5 (8,),

s.n. (R 75773) (2.1), s.n. (R 39461) (26)

Vieira, R.F. 754 (27), 1408 (23), 1679 (16)

Walter, B.M.T. 781 (16), 867 (23), 1394

(10.1), 3084 (23)

Wanderley, M.G. 1764 (13)

Wasicky, R. s.n. (SPF 15244) (3)
Wasum, R. 524 (2.2), 1375 (26), s.n. (HUCS 12386, MBM) (2.2), s.n. (HUCS 1375, MA) (26), s.n. (HUCS 5515) (26), s.n. (HUCS 8497, M) (26), s.n. (HUCS 537) (26), s.n. (HUCS 53470) (26), s.n. (HUCS 5581, MA) (26)

Weddell, M. 1413 (32), 1573 (5), 1641 (32)

Weiser, V.L. 16, 17 (3)

Widgren. 164 (27), 229 (21)

William, L.O. 7083 (27)

Wykrota, J.L.M. 72 (32)

\section{B. Plantas analisadas para a elaboração da filogenia ou determinação dos padrões de distribuição geográfica}

\section{B.1. Viguiera sensu lato - América do Sul}

Bahiopsis tomentosa

México: Purpus, C.A. 491 (K); Xanthus, L.J. $61(\mathrm{~K})$.

Bahiopsis deltoidea

México: Carter, A. 1901 (K), 2652 (K); Constance, L. 3190 (K); Gray, A. 4369 (K); Kaune, S.M. 673 (K); Moran, V. 7024 (K); Xanthus, L.J. 60 (K).

Bahiopsis deltoidea var. chenopodina

México: Carter, A. 2480 (K); Constance, L. 3156 (K); Johnston, I.M. 3826 (K).

Bahiopsis deltoidea var. nesiotica

México: Johnston, I.M. 3127 (K), 3141 (K).

Bahiopsis deltoidea var. parishii

México: Carter, A. 3143 (K); Palmer, E. 530 (K).

Bahiopsis deltoidea var. tastensis

México: Carter, A. 3508 (K); Gentry, S. $4018(\mathrm{~K}), 4100$ (K).

Bahiopsis laciniata

EUA: Brandegge, T.S. 1614 (K, M); Carter, A. 3172 (M, R); Vasey, G.R. 289 (K).

México: Carter, A. 2542 (K); Purpus, C.A. 218 (K); Wiggins, I.L. $18186(\mathrm{~K})$.

Bahiopsis lanata

México: Anthony, A.W. 279 (K); Palmer, E. $943(\mathrm{~K})$.

Bahiopsis reticulata

EUA: Purpus, C.A. 3018 (M); 5321 (K, M); Charlton, D. 2043 (K); Huie, G. NV052-0115 (K).
EUA: White $753(\mathrm{~K})$.

\section{Bahiopsis tomentosa}

México: Carter, A. 2244 (K), 3470 (K); Constance, L. 3161 (K); Moran, V. 7128 (K); Rieseberg, L. 83-11 (LP, TENN); Wiggins, I.L. 15256 (K).

Calanticaria bicolor

México: Rzedowski, J. 19526 (LP).

Heliomeris ciliata

EUA: Wright, C. 1222 (K), 1222a (K).

México: Lloyd, C.E. 411 (K).

Heliomeris longifolia

EUA: Peebles, R.H. 3169 (M); Wright, C. 328 (K).

México: Gentry, S. 2735 (K); Hartman, C.V. 777 (K); King, R.M. 9814 (K), 9834 (K), 9891 (K); Palmer, E. 1102 (K).

Heliomeris longifolia var. annua

EUA: Blumer, J.C. 1755 (K); Nelson, A. 1924 (K); Wright, C. 334 (K), 1220 (K).

México: Pringle, C.G. 9921 (K).

Heliomeris multiflora var. brevifolia

EUA: Metcalfe, O.B. $511(\mathrm{~K})$.

Heliomeris multiflora var. nevadensis

EUA: Blumer, J.C. 1361 (K); Chandler, H.P. 6988 (K); Clokey, I.W. 7747 (ICN, K, LP); Lee, A. 46178 (K); Purpus, C.A. 5025 (K); Baker, C.F. 684 (K), 700 (K), 944 (K); Doppelbaur, H. 901 (M); Jones, G.N. 19726 (K); Metcalfe, O.B. 436 (K); Worthington, R.D. 18339 (M). 
Heliomeris obscura

México: Kerber, E. 211 (K).

Hymenostephium angustifolium

Venezuela: Aristeguieta, L. 2567 (VEN).

Hymenostephium debile

Argentina: Schinini, A. 22443 (CTES).

Bolívia: Gutte, P. G516 (LPB); Herzog, B. H448 (LPB); Mostacedo, B. 390 (LPB); Solomon, J.C. 10220 (IPA, LPB, MO); Zabala, R. 186 (CTES).

Hymenostephium goebelii

Venezuela: Schultz, J.P. 304 (VEN);

Vareschi, L. 6080 (VEN).

Hymenostephium guatemalense

Venezuela: Steyermark, J.A. 111051 (VEN). Hymenostephium meridense

Venezuela: Aristeguieta, L. 3436 (VEN); Badillo, V.M. 493 (VEN).

Hymenostephium mexicanum

México: Bourgeau, E. 1565 (K); 1932 (K). Orcut, C.R. 3369 (K).

Hymenostephium mucronatum

Colômbia: Smith, H.H. 517 (MBM).

Venezuela: Aristeguieta, L. 6858 (VEN); Davidse, G. 4181 (VEN); Fendler, A. 1962 (K); Guevara, L.C. 1968 (VEN); King, R.M. 10405 (K), 10457 (K); Panero, J.L. 2628 (CTES, TEX); Smith, H.H. 1976 (K), 2619 (K).

Hymenostephium quitensis

Colômbia: Haught, O. 1530 (LP, SI).

Hymenostephium serratum

Colômbia: Rusby, H.H. 516 (P).

Venezuela: Steyermark, J.A. 108752 (VEN). Hymenostephium tenuis

México: Palmer, E. 657 (síntipo de V. tenuis: K!), 1151 (K); Panero, J.L. 6224 (K, TEX); Pringle, C.G. 1725 (M), 11612 (K); Stuessy, T.F. 3717 (LP).

Hymenostephium viride

Venezuela: Badillo, V.M. 1008 (VEN);

Steyermark, J.A. 56209 (VEN).

Hymenostephium ? leptodonta

Venezuela: Aristeguieta, L. 2528 (VEN), 4825 (VEN); Oberwinkler, B. 14230 (VEN); Steyermark, J.A. 121894 (VEN).

Pappobolus

Bolívia: Arroyo, L. 896 (LPB, USZ); Jiménez, R.P.A. 51 (LP).

Peru: Martineb 10 (LP).
Viguiera adenotricha

Chile: Barros, E. 2064 LP).

Viguiera adenophylla

México: Parry, C. 467 (síntipo: K!).

Viguiera amphychlora

Paraguai: Hassler, E. 5160 (BM).

Viguiera angustifólia

México: Ortega, J.G. 4970 (K); Pringle, C.G. 4546 (K); Sinclair, D. 1844 (K).

Viguiera australis

Bolívia: Beck, St.G. 875 (LPB), 4482 (LPB, SPF), 7993 (LPB, SPF), 8383 (LPB, SPF); Cordech, T.M.R. 52 (LPB); Dios, R.C.J. 112 (LPB, SPF); Ehrich, R. 464 (LPB, US); Feuerer, T. 5474 (LPB); Lewis, M. 35360 (LPB); Steinbach, J. 9703 (K); Torrico, G. 465 (LPB, SPF).

Viguiera bishopii

Bolívia R.M. King \& L.E. Bishop7574 (fotografia do holótipo: M!).

Viguiera brevifolia (foto)

México: Palmer, E. 527 (síntipo: K!).

Viguiera brittonii

Peru: Ângulo, N. 2597 (LP); Cabrera, A.L. 13518 (LP). Matthews s.n. (síntipo: K!)

Viguiera budleiaeformis

México: Arsène 8741 (K), 8742 (K); Bourgeau, E. 965 (K, M).

Viguiera cabrerae

Argentina: Venturi, S. 3675 (fotografia do holótipo: M!).

Viguiera chenopodina

México: Palmer, E. 807 (K).

Viguiera cordata

Costa Rica: Estrada, A. 2692 (K).

Viguiera cordifolia

México: Townsend, H. 300 (K).

EUA: Blumer, J.C. 1412 (K); Greene, E.L. can4/81 (K); Kearney, T.H. 9880 (K); Metcalfe, O.B. 130 (K); Palmer, E. 593 (K); Rusby, H.H. 170 (K); Wooton, E.O. 365 (K); Wright, C. $272(\mathrm{~K}), 332(\mathrm{~K}), 1226(\mathrm{~K})$.

Viguiera cordifolia var. genuina

USA: Wright, C. 332 (síntipo: K!!).

Viguiera cordifolia var. latisquama

México: King, R.M. 9937 (K); Palmer, E. 667 (síntipo: K!), 747 (síntipo: K!).

Viguiera decurrens

México: King, R.M. 9815 (K); Nelson, E.W. 4981 (K), 6287 (K); Pringle, C.G. 676 (K) 
Viguiera deltoidea var. genuina

México: Xanthus, L.J. 60 (isolectotipo: K!)

Viguiera deltoidea var. parishii

EUA: Parishii, W.F. 963 (isótipo: M!).

Viguiera deltoidea var nesiotica

USA: Johnston, I.M. 3127 (síntipo: K!)

Viguiera densifolia

Paraguai: Hassler, E. 9075 (BM, K);

Zardini, E.M. 49127 (K); Balansa, B. 858

(sintipos: K!, P!).

Viguiera dentata

México: Landon, K. 780 (LP); Berlandier 827

(síntipo: P!), 1905 (K, P), 2558 (P);

Bourgeau, M. 961 (K), 1222 (K).

Cuba: de La Sagra 62 (síntipo: P!)

Viguiera dentata var. brevipes

México: Berlandier 2258 (síntipo: K!), 1905 (síntipo: P!); Bourgeau, M. 960 (M); Mckee, H.S. 11040 (K); Nee, M. 26620 (K); Ocampo, L.A. WS017 (K); Orcut, C.R. 4237 (K); Ortega, J.G. 5002 (K); Palmer, E. 456 (K), $472(\mathrm{~K})$.

EUA: Bush, B.F. 1208 (K); Drummond 194 (síntipo de $V$. texana: K!); Lindheimer, $F$. 434 (K, M), 973 (K, M), 974 (K, M); Metcalfe, O.B. 883 (K); Palmer, E. $604(\mathrm{~K})$; Wooton, E.O. 190 (K); Wright, C. 270 (K), 333 (BM, K).

Viguiera dentata var. canescens

México: Goulay, O.B. 30 (K); Palmer, E. 674 (K).

Viguiera dentata var. helianthoides

Cuba: Curtiss, A.H. 595 (K, M); Hermann, H.A.V. 437 (K); Rugel, F. 2 (K); Sagra, de La. 62 (P); Wilson, P. 9481 (K); Wright, C. 2853 (BM, K).

México: Gaumer, G.F. 502 (K); Gentle, P 121 (K); Valdez, P. 71 (K); Way, M.J. MJW149 (K).

EUA: Tharp, B.C. $16 \mathrm{~T} 206$ (K), 45-61 (K); Warnock, B.H. 45-62 (K), W1068 (K).

Viguiera dentata var. lancifolia

México: Gentry, S. 2937 (K); s.c. 11301 (K).

EUA: Kearney, T.H. 10454 (K).

Viguiera ellenbergii

Peru: Vargas, C. 2601 (LP), 12492 (LP 909605).

Viguiera ensifolia

México: Seemann 2007 (K).
Viguiera eriophora

México: Spooner, D.M. 2836A (LP, TENN). Viguiera excelsa

México: Balls, E.K. 5564 (K); Berlandier 1265 (K); Bourgeau, E. 599 (K), 843 (BR, P); Nicollas s.n. (R 1561018); Spooner, D.M. 2520 (LP, TENN).

Viguiera flava

México: Arsène 5322 (K); Baldo, N.E.K. B5199 (K); Ghiesbrreght, M. 416 (K); Pringle, C.G. 3263 (TIPO BR, K), 9918 (K).

Viguiera fusiformis

Bolívia: Baar, R. 202A (LPB), 281 (LPB); Balls, E.K. B6180 (K); Beck, St.G. 14774 (LPB, SPF), 27754 (LPB, SPF); Buchtien, O. 808 (BM, K, No M entre os tipo - não é $\mathrm{M}$ ); Dios, R.C.J. 30 (LPB, SPF); Hensen, I. 319 (LPB, SPF); King, R.M. 7553 (K); Mandon, G 49. (síntipo: BM!)Sigle, M. 232 (LPB); Solomon, J.C. 13716 (CTES, K, MBM), 17802 (LPB, MO); Vargas, I.G. 909 (CTES, USZ).

Viguiera funkiae

México: Hartman, R.L. 4153 (fotografia do holótipo: K!, M!).

Viguiera gayana

Chile: Barros, E. 9926 (LP); Brinck, A. s.n. (SGO 122909); Cabrera, A.L. 3497 (LP); Geisse, G. s.n. (SGO 72188); Jiles, C. 1238 (M); Marticorena, C. 1074 (CONC, CTES); Pettersson, J. JJ4 (SGO); Teillier, S. 2557 (SGO).

Viguiera gilliesii

Argentina: Araque, J. 19Ar953 (LP); Barkley, F.A. 20Mz128 (LP); Boelcke, O. 10275 (CTES); Burkart, A. 14352 (K); Cabrera, A.L. 24308 (MBM), 24432 (MBM); Dawson, G. 1054 (LP, M); Fabris, H.A. 8539 (LP); Gillies 67 (BM), 68 (BM), 140 (K); Haene, E. 1609 (LP); Meglioli, C. 49 (CTES); Moreau, R.P. 28 (LP); Paci, O. 751 (LP); Prina, A. 1862 (CTES)

Chile: Cabrera, A.L. 12617 (LP, M); Gillies $81(\mathrm{~K})$.

Viguiera gramatoglossa

México: Calzada, J.I. 23206 (K); Panero, J.L. 6143 (K), 6782 (K); Pringle, C.G. 6142 síntipo de Encelia hypargyrea: K!, M!). 
Viguiera gregii

México: Delevoyas, D. 404 (K), 405a (K); Gregg 3821 (isótipo: K!).

Viguiera hemsleyana

México: Conzatti, C. 4046 (M).

Viguiera hypargyrea

México: Palmer, E. 816 (síntipo: K!).

Viguiera hypochlora

México: Panero, J.L. 6843 (K); Pringle, C.G. 11537 (K); Sanders, A.C. 11960 (K).

Viguiera incana

Equador: Asplund, E. 16684 (K, R); Haught, O. 3316 (BM); Jameson 15 (K); Lehmann 7965 (síntipo de V. lehmanii: K); Spruce, R. 5974 (K); Stuessy, T.F. 5929 (LP), 5936 (CTES, US), 5937 (LP).

Viguiera insignis

México: Calzada, J.I. 24248 (K).

Viguiera lanata

México: Haines, A.L. s.n. ( K)

Viguiera lanceolada

Bolívia: Bang, A.M. 382 (BR, K, M); Beck, St.G. 6122 (LPB); Brandbyge, J. 649 (LPB); Caning 90 (P, RB); Chauviere, G. GC81 (LPB); Eyerdam, W.J. 24668 (K); Guillés, R. 375 (LPB); Hensen, I. 360 (LPB); Ibisch, P. 1151 (LPB); Mandon, G, 35. (síntipos de $V$. mandoni - nom. nud. : BR, K,) Michel, R. 126 (LPB); Müller, J. 9379 (LPB, M); Pardo, R.C. 49 (BOLV, CTES, LPB, US); Solomon, J.C. 14282 (LPB, MO).

Viguiera latibracteata

México: Ortega, J.G. 1539 (K), 1571 (K); Seemann 1485 (K).

Viguiera linearis

México: Arsène $1325(\mathrm{~K}), 5321$ (K, M); Balls, E.K. 5570 (K); Bourgeau, E. 708 (K); King, R.M. 9908 (K), 9933 (K); Lyonnet, E. 138 (K); Nelson, E.W. 4980 (K); Parry, C. 454 (P), 455 (K); Pringle, C.G. 645 (K), 756 $(\mathrm{K}, \mathrm{P}), 13090$ (K); Ross, H. $92(\mathrm{M})$; Schaffner, J.G. 339 (M), 864 (P).

Viguiera linearis var. acutior

México: Pringle, C.G. 9995 (síntipo: K).

Viguiera linearis var. genuine forma latiorifolia

México: Pringle, C.G. 756 (síntipos: K! e P!)

Viguiera media

Equador: Seemann 710 (síntipo: K!)
Viguiera microphylla

México: Palmer, E. 802 (síntipo: K).

Viguiera molinae (= Aldama dentata var. dentata Feddema)

Nicarágua: Williams, L.O. 42374 (fotografia do holótipo de $V$. molinae: M!).

Viguiera mollis

Argentina: Burkart, A. 11807 (LP); Cabrera, A.L. 12885 (LP, M), 16807 (K), 18282 (LP), 19934 (K), 24906 (MBM); Fabris, H.A. 5883 (LP); López, A.M. 609 (LP); Novara, L. 9667 (M); Spegazzini, C. s.n. (LP 16744); Venturi, S. 9353 (LP), 1563 (LP), 1785 (LP).

Viguiera montana

México: Ortega, J.G. 5270 (K); Palmer, E. $340(\mathrm{~K})$.

Viguiera ovata

México: Méndez, A. 8459 (K).

Viguiera pachycephala

México: De Candolle (P) Palmer, E. 532 (K);

Pringle, C.G. 2484 (K), 11609 (K); Rose, J.N. 2740 (K).

Viguiera parkinsonii

México: Palmer, E. 531 (sintipo de Gymnolomia rudis: K!); Parkinson, W. 5 (K); Pringle, C.G. 2460 (M), 4584 (sintipo de Gymnolomia rudis: var. minor: M!).

Viguiera pinnatilobata

México: Calzada, J.I. 23084 (K), 23205 (K), 24247 (K); Pringle, C.G. 6252 (K, M); s.c. $384(\mathrm{~K})$.

Viguiera peruviana

Peru: Hutchison, P.C. 7137 (K, M); Leckler 2760 (K); Leiva, S. 2204 (M); Cuming, H. $941(\mathrm{~K})$.

Viguiera potosina

México: Pringle, C.G. 3763 SINTIPO (síntipo: K!)

Viguiera pringlei

México: Pringle, C.G. 4365 (síntipos: $\mathrm{M} !, \mathrm{P} !), 8496$ (K, M, P).

Viguiera procumbens

Argentina: Hurrell, J.A. 677 (LP), 797 (LP); Stuessy, T.F. 12949 (LP).

Bolívia: Avila, M.V. 338 (LP, LPB, SI); Bang, A.M. 44 (K, M); Barco, R. 869 (CTES); Beck, St.G. 26392 (LPB, SPF); 3573, 3574 (LPB, SPF), 7503 (CUZ, F, LPB, S, SI, US), 11706 (LPB, SPF), 18186 (LPB, SPF) 
11816 (G, LPB, MO, QCNE, S, SI, US), 27194 (LPB, SPF); Buchtien, O. 8360 (M), 8575 (M); C.A.G. 27PA (LPB); Cabrera, A.L. 33783 (LPB, SI); Coimbra, G. 220 (LPB); Coro, M. 19 (LPB); Cruz, L.F 73 (LPB); Ehrich, R. 197 (LPB); Garcia, E. 153 (LPB); Gentry, A. 44365 (LPB, MO); Hensen, I. 2419 (LPB); King, R.M. 9636 (LPB);Lara, D. 364 (LPB); Lewis, M. 35454 (LPB, MBM, MO); Mandon, G. 35 (K), 36 (BM, K); Meyer, T. 20868 (LP); Navarro, G. GN70 (LPB); Novara, L. 8744 (M); Perry, A. 661 (LPB); Romero, J.D. 118 (LPB); Seidel, R. 970 (CTES, LPB, MO); Solomon, J.C. 6663 (CTES, MBM, M), 7182 (MBM, M, MO), 7221 (K, LPB, MO), 15099 (CTES, M, MO), 15252 (IPA, MO), 16337 (M); Spooner, D.M. 6740 (LPB, TEX, WIS); Tate, G.H.H. 881 (LPB); Torrico, G. 261 (LPB, SPF); Troll, C. 1636 (M).

Chile: Muñoz, A. s.n. (SGO 149087); Sudzuki, F. 432 (SGO).

Equador: Mandon, G. 36 (BM);

Peru: King, R.M. 9004 (K); Sandernan, C. $5381(\mathrm{~K})$.

Viguiera purissimae

EUA: Gentry, S. 4043 (K); Nixon, K.C. 931 (M); Palmer, E. 773 (K); Purpus, C.A. 220 (K); Wiggins, I.L. 15042 (K).

Viguiera quinqueradiata

México: Panero, J.L. 7 (LP); Pringle, C.G. 1794 (K); Reveal, J.L. 4089 (K).

Viguiera revoluta

Argentina: Cabrera, A.L. 22860 (LP); Ifisser, A. 645 (LP).

Chile: Arroyo, L. 994966 (SGO); Barros, E. 2056 (LP); Bridges 1165 (K); Crisci, J.V. 427 (LP); Grau, J. 1587 (M); Landrum, L.R. 8220 (CTES, SGO); Muñoz, M. 3685 (SGO); Niemeyer, H. $\mathrm{F}^{\circ}$. s.n. (SGO 128300); Pöppig III.222 (M); Ruiz, F. s.n. (LP 70963); Werdermann, E. 556 (K), 882 (BM); Worth, C.R. 16204 (K), 16489 (K), 16517 (K); s.c. s.n. (LP 10146).

Viguiera retroreflexa

Argentina: Krapovickas. A. 47481 (CTES); Bolívia: Krapovickas. A. 18757 (CTES, LP); Lewis, M. 88378 (CTES, MO); Solomon, J.C. 16076 (MBM, MO). Viguiera rhombifolia
México: Pringle, C.G. 4813 (K, M); Salinas, A. 6203 (K); Spooner, D.M. 2826 (LP).

Viguiera rosei

México: Rose, J.N. 2710 SINTIPO (síntipo: $\mathrm{K} !)$.

Viguiera schultzii

México: Oliva, L. s.n. ISÓTIPO (P); Palmer, E. 486 (K); Pringle, C.G. 2474 (K), 11540 (K).

Viguiera seemanii

México: Hooker 1861 (K); Seemann 2005 (K, P).

Viguiera sessifolia

México: Graham 78 (K); Pringle, C.G. 8677 (M).

Viguiera serrata

Colombia: Rusby 516 (isótipo: P!)

Viguiera sphaerocephala

México: Hinton, G.B. 9815 (K, M); Panero, J.L. 527 (LP); Pringle, C.G. 8390 (síntipo: $\mathrm{K} !)$.

Viguiera stenoloba

EUA: Shiller, I. 657 (LP).

México: Johnston, I.M. 7322 (LP); Nee, M. 25354 (K); Palmer, E. 621 (K); Stuessy, T.F. 4012 (LP); Butterwick, M. B-532 (K); Mueler, C.H 2314 (P); Palmer, E. 174 (K); Pringle, C.G. 9922 (K); Wynd, L. $730(\mathrm{~K}), 756(\mathrm{~K})$.

Viguiera stenoloba var. chihuahuensis

México: Worthington, R.D. 22151 (M).

Viguiera subcanescens

México: Ghiesbrreght, M. 383 (isótopo: P!). Viguiera subincisa

México: Masoon, H.L. 1933 (K).

Viguiera szyszylowiczii

Peru: Ângulo, N. 1677 (LP); Cerrate, E. 1678 (LP); Johnston, I.M. 3544 (K); King, R.M. 9026, 9023 (K); Rojas, E. 7 (LP); Sagastegui, A. 7549 (LP); Stafford, D. 286 (K), K.7 (K); Worth, C.R. 15723 (K).

Viguiera sylvatica

Costa Rica: Estrada, A. 3197 (K), 3203 (K).

Viguiera trachyphylla

México: Cronquist, A. 9628 (LP); Pringle, C.G. 8248 (K, M).

Viguiera trachyphylla

México: Pringle, C.G. 8248 (síntipos: K!, M!)

Viguiera truxillensis

Peru: Matthews 565 (K). 
Viguiera tucumanensis

Argentina: Beck, St.G. 26673 (LPB, SPF); Cabrera, A.L. 3054 (LP), 8016 (LP), 8616 (LP), 19972 (K); Cialdella, A.M. 395 (LP); Fabris, H.A. 4241 (LP), 4241 (LP), 6028 (LP); Galván, C. 12 (CTES); Hawkes, J.G. 3834 (K); Krapovickas. A. 37364 (CTES, IPA); Leal, R. 19419 (LP); Novara, L. 7900 (M), 9710 (M); Okada, K. 2962 (LP); Schreiter 4148 (BM); Scolnik, R. 143 (LP); Sello 227 (P); Toledo, C.S. 13381 (K, MBM); Zardini, E.M. 1342 (LP).

Bolívia: Beck, St.G. 26164 (LPB, SPF); Ehrich, R. 455 (LPB, SPF).

Viguiera tucumanensis var. discoidea
Argentina: Cabrera, A.L. 19882 (K);

Krapovickas. A. 30751 (CTES, MBM), 46623 (CTES, K, MBM); Novara, L. 8709 (M); Xifreda, C.C. 690 (MBM, SI);

Bolívia: Bastián, E. 1123 (LPB).

Viguiera tucumanensis var. Oligodonta

Argentina: Cuaglianone, E.R. 741 (SP); Krapovickas. A. 30567 (MBM); Venturi, S. 4162 (LP).

Viguiera weberbaueri

Peru: Asplund, E. 10883 (K); Goodspeed, T.H. 11304 (K); Guillen, J.L. 46 (LP); King, R.M. 9014 (K); Matthews 1043 (K).

Viguiera urticiformis

México De Candolle (P)

\section{B.2 Espécies de outros gêneros}

Aldama dentata

México: Palmer, E. 582 (holótipo de Gymnolomia acuminata: NY).

Aldama mesoamericana

Nicarágua: Stevens, W.D. 15555 (Isótipo: NY).

Encelia farinosa:

EUA, Rawitcher, A. 3695 (SPF)

Flourensia blakeana

Argentina, Farinaccio, M.A. 661 (SPF).

Flourensia fiebrigii

Bolívia, Beck, St.G. 23836 (SPF)

Flourensia riparia

Argentina, M.A. Farinaccio , M.A. 660 (SPF)
Helianthus annus

Brasil, São Paulo, Hoehne, W. s.n. (SPF 15424)

Helianthus decapetalus

EUA, Moldenke, H.N. 20379 (SPF)

Helianthus divaricatus

EUA, Moldenke, H.N. 20380 (SPF)

Rhysolepis morelensis

México: Hinton, G.B. 2463 (K); Pringle, C.G. 11295 (síntipo: K!)

Rhysolepis palmeri

México: Palmer, E. 738 (isótipos: K, P); Pringle, C.G. 2314 (K, M, P), 8621 (K), 8631 (P), $11610(\mathrm{~K})$. 


\section{APÊNDICE B}

Lista dos herbários de origem das coleções examinadas (acrônimos segundo

$\underline{\text { Holmgreen et al. 1990; * herbários não indexados) }}$

\begin{tabular}{|c|c|}
\hline BHCB & Universidade Federal de Minas Gerais; \\
\hline $\mathrm{BM}$ & British Museum Natural History; \\
\hline BOTU & Universidade Estadual Paulista, Botucatu; \\
\hline $\mathrm{BR}$ & Jardin Botanique National de Belgique; \\
\hline CEN & Embrapa, Centro Nacional de Pesquisas e Recursos Genéticos; \\
\hline CESJ & Universidade Estadual de Juiz de Fora, MG; \\
\hline CETEC & Fundação Centro Tecnológico de Minas Gerais; \\
\hline CTES & Instituto de Botánica del Nordeste; \\
\hline CGMS & Universidade Federal de Mato Grosso do Sul, Campo Grande; \\
\hline COR & Universidade Federal de Mato Grosso do Sul, Corumbá; \\
\hline CPAP & Embrapa, Centro de Pesquisas Agropecuárias do Pantanal, Corumbá; \\
\hline ESA & Universidade de São Paulo, Escola Superior de Agricultura Luiz de Queiroz; \\
\hline $\mathrm{E}$ & Royal Botanic Gardens, Edinburgh; \\
\hline FUEL & Universidade Estadual de Londrina; Depto. De biologia animal e vegetal; \\
\hline HAS & Fundação Zoobotânica do Rio Grande do Sul, Porto Alegre; \\
\hline HASU & Universidade do Vale do Rio dos Sinos CCS/ Centro 2, São Leopoldo; \\
\hline $\mathrm{HEPH}$ & Herbário E. P. Heringer, Jardim Botânico de Brasília; \\
\hline HRB & Herbário Radambrasil, Instituto Brasileiro de Geografia e Estatística; \\
\hline HRCB & Universidade Estadual Paulista, Rio Claro; \\
\hline HUCS & Universidade de Caxias do Sul; \\
\hline HUEFS & Universidade Estadual de Feira de Santana; \\
\hline HUEPG & Universidade Estadual de Ponta Grossa; \\
\hline HUFU & Universidade Federal de Uberlândia, Instituto de Biologia; \\
\hline IBGE & Herbário do Instituto Brasileiro de Geografia e Estatística \\
\hline $\mathrm{ICN}$ & Universidade Federal do Rio Grande do Sul, Instituto de Biociências; \\
\hline IPA & Empresa de Pesquisas Agropecuárias, Recife; \\
\hline K & Royal Botanic Gardens; \\
\hline LP & Universidad Nacional de La Plata, Museo de História Natural; \\
\hline LPB & Herbario Nacional de Bolívia; \\
\hline M & Botanische Staatssammlung Manchen; \\
\hline MBM & Museu Botânico Municipal, Curitiba; \\
\hline NY & New York Botanical Garden \\
\hline $\mathrm{P}$ & Muséum National d’Histoire Naturele; \\
\hline PACA & Instituto Anchietano de Pesquisas/UNISINOS, São Leopoldo; \\
\hline PEL & Universidade Federal de Pelotas, RS; \\
\hline $\mathrm{R}$ & Universidade Federal do Rio de Janeiro, Museu Nacional; \\
\hline $\mathrm{RB}$ & Jardim Botânico do Rio de Janeiro; \\
\hline SGO & Museo Nacional de Historia Natural; \\
\hline SP & Instituto de Botânica, São Paulo; \\
\hline SPF & Universidade de São Paulo, Instituto de Biociências; \\
\hline SPFR & Universidade de São Paulo, Depto. de Biologia, Ribeirão Preto; \\
\hline UB & Fundação Universidade de Brasília; \\
\hline UEC & Universidade Estadual de Campinas; \\
\hline UFG & Universidade Federal de Goiás, Goiânia; \\
\hline UFLA & Universidade Federal de Lavras; \\
\hline UFMT & Universidade Federal de Mato Grosso, Cuiabá. \\
\hline VEN & Fundación Instituto Botánico de Venezuela Dr. Tobías Lasser. \\
\hline
\end{tabular}




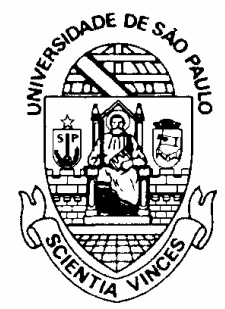

Universidade de São Paulo

Instituto de Biociências

Botânica 